


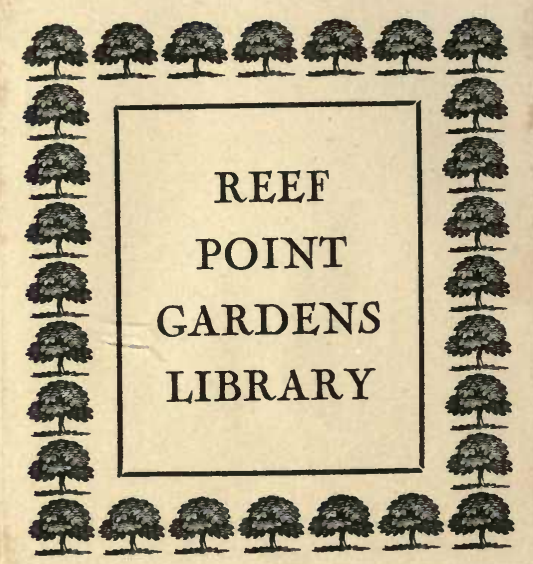

\section{The Gift of Beatrix Farrand} to the General Library University of California, Berkeley 



\section{AUDUBON THE NATURALIST}




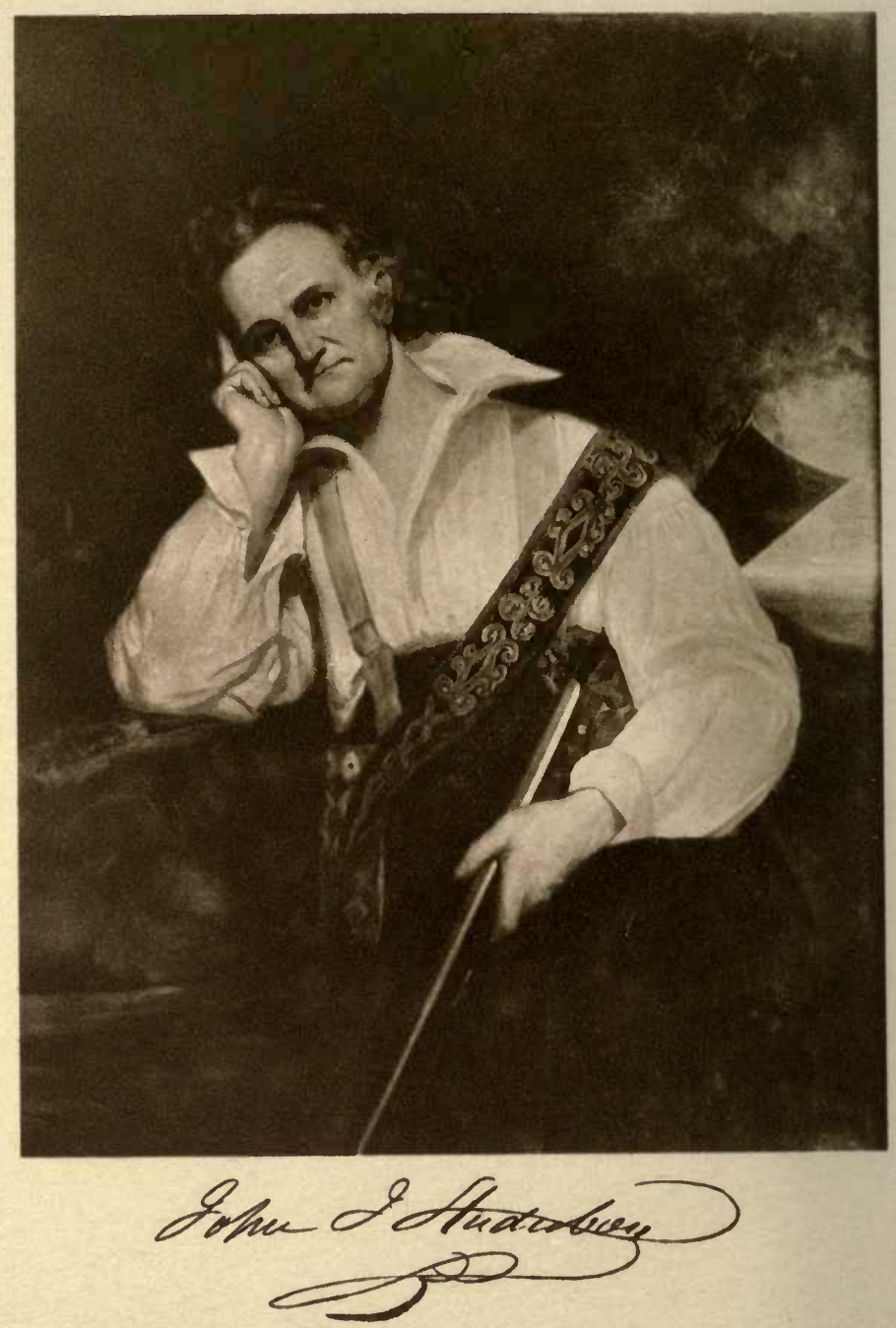

AFTER PORTRAIT BY GEORGE P. A. HEALY, 1838; ORIGINAL IN POSSESSION OF THE BOSTON SOCIETY OF NATURAL HISTORY. 


\section{AUDUBON THE}

NATURALIST A HISTORY OF HIS LIFE AND TIME

\section{BY \\ FRANCIS HOBART HERRICK, Ph.D., Sc.D. \\ PROFESSOR OF BIOLOGY IN WESTERN RESERVE UNIVERSITY; \\ $\triangle$ UTHOB OF "THE HOME LIFE OF WILD BIRDS," ETC.}

IN TWO VOLUMES

ILLUSTRATED

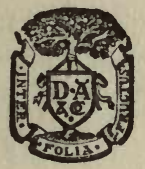

VOLUME II

D. APPLETON AND COMPANY NEW YORK LONDON 
Coprright, 1917, BY

D. APPLETON AND COMPANY

Printed in the United States of America

\section{มสก प \\ LANDSCAPE} ARCHITECTURE 


\section{QL 31 \\ $\mathrm{A} 9 \mathrm{H} 4$ \\ CONTENTS OF VOLUME II $\vee .2$ \\ CHAPTER XXVI

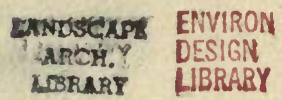

\section{Explorations in Florida and the South Atlantic}

Obituary published in London on day of his arrival in New York-Assistance from the Government-John Bachman becomes his friend -Winter in Charleston-His folios as gifts-To Florida with two assistants-Letters to Featherstonhaugh-St. Augustine-Misadventures in the mud of East Florida-Audubon on Florida's future-At the sources of the St. John's-Aboard the MarionReturn from Key West-A merchant of Savannah-Disbanding of party at Charleston . • • . • • • • • • •

\section{CHAPTER XXVII}

\section{Eastern Visit and Explorations in the North Atlantic}

Bachman's success as a canvasser-Boston visit-Journey to PortlandAscent of the St. John's-Return overland-Victor Audubon becomes his father's agent-Winter in Boston-The Golden EagleStricken with illness-Expedition to Labrador planned-American support-Sails from Eastport with five assistants-Discoveries and adventures on the Labrador-Safe return-Another winter in Charleston-Sued for old debts-Experience with vultures-Advice and instruction to a son-Working habits-Return to England .

\section{CHAPTER XXVIII}

\section{Thorns on the Rose}

Contributions to magazines-Attacked in Philadelphia-Statement to Sully-The rattlesnake episode-Behavior of a Philadelphia editor - Mistaken identity in account of the reptile-Lesson of the serpent's tooth-Audubon's long lost lily rediscovered-"Nosarians and Anti-Nosarians"-Bachman and Audubon on vultures-Aim of the critics-Authorship in the Biography-His most persistent heckler-Pitfall of analogy . 


\section{vi AUDUBON THE NATURALIST}

\section{CHAPTER XXIX}

\section{Sidelights on Audubon and His Contemporaries}

What was a Quinarian?-Controversy over the authorship of the Ornithological Biography-Audubon's quaint proposal-Swainson's reply-Friendship suffers a check-Species-mongers-Hitting at one over the shoulders of another-Swainson as a biographer-His career-Bonaparte's grievance-A fortune in ornithology-Labors of John Gould and his relations with Audubon-The freemasonry of naturalists .

\section{CHAPTER XXX}

\section{Audubon and MacGillivray}

In London once more-MacGillivray's assistance continued-Return to Edinburgh-MacGillivray's character and accomplishments-Audubon's acknowledgments-Tributes of "Christopher North"-Results of overwork-Fusillades from "Walton Hall"-Progress of the large plates

\section{CHAPTER XXXI}

\section{Third American Tour, 1836-1837}

In New York harbor-Collections from the Far West-Audubon's efforts to secure them-Return to Boston-Friendship of Daniel Webster-Renewed efforts to obtain the Nuttall-Townsend collections-Expedition to the west coast of Florida-Deferred governmental aid-Another winter with Bachman-Overland journey to New Orleans-On board the Crusader-Mistaken for pirates-With Harris and his son explores the Gulf coast-The Republic of Texas -Visit to its capital and president-Meeting in Charleston-Marriage of his son-Their return to England . . . . . 146

\section{CHAPTER XXXII}

\section{- Audubon's Greatest Triumph}

Extension of his work-Financial panic and revolt of patrons-New western collections-His "book of Nature" completed-Work on the letterpress in Edinburgh-Vacation in the Highlands-Commissions 


\section{CONTENTS}

to Harris-Parting address to the reader-Dissolution of the Havell engraving establishment-The residuum of The Birds of America-Robert Havell, engraver, and his family-Lizars' first edition and the Havell reissues of plates-Brief manual for collectors-Appreciations-Total edition of The Birds of AmericaPast and oresent prices-The Rothschild incident . . . . 168

\section{CHAPTER XXXIII}

\section{New Enterprises and Life at "Minnie's Land"}

Settlement in New York-The Birds in miniature, and work on the Quadrupeds-Marriage of Victor Audubon-Coöperation of Bachman in the Quadrupeds secured-Prospectuses-History of the octavo edition of the Birds-Baird's enthusiasm and efficient aidParkman's Wren-Baird's visit to Audubon in New York-"Look out for Martens," and wildcats-New home on the Hudson-God-" win's pilgrimage to "Minnie's Land" in 1842 . . . . . 208

\section{CHAPTER XXXIV}

\section{Expedition to the Upper Missouri}

Ambitions at fifty-seven-Plans his last expedition in the rôle of naturalist-Credentials from public men-Canvassing tour in Canada described-Baird's plans to accompany Audubon west frustratedWestern expedition begun-Ascent of the Missouri and Yellowstone -Discoveries of new birds-A wilderness that howls-Buffalo hunting-Passing of the great herds-Return from Fort Union-Incident on the canal boat-Completion of the octavo edition of the Birds.

\section{CHAPTER XXXV}

\section{Final Work Days}

Painting the Quadrupeds-Assistance of Bachman and Audubon's sons - Copper plates of the Birds go through the fire in New YorkAudubon a spectator at the ruins-Bachman's ultimatum-Success of the illustrations of the Quadrupeds-Bachman's letterpressRecommendation of Baird-J. W. Audubon in London-Bachman's assistants-His life and labors-Decline of Audubon's powers-Dr. Brewer's visit-Audubon's last letters-His death at "Minnie's Land" . . . . . . . . . . . . . 261 


\section{CHAPTER XXXVI}

\section{Afterword : Audubon's Family in America}

Bachman completes his text on the Quadruped8-Victor Audubon's success in canvassing-John Woodhouse Audubon's family-New houses at "Minnie's Land"-Second octavo edition of the BirdsVictor Audubon's illness and death-Attempt to reissue The Birds of America in America-The residual stock of this imperfect edition-Death of John Woodhouse Audubon-His career and work as an artist and field collector-Mrs. Audubon resumes her old vocation-Fate of "Minnie's Land"-Death of Mrs. Audubon-Her share in her husband's fame-Story written on Audubon's original drawings-Fate of the original copper plates of the Birds-A boy comes to the rescue-"Minnie's Land" today-The "Cave"-A real "Audubon Park"

\section{APPENDIX I}

\section{Original Documents}

1. Copy of the original bill rendered by Doctor Sanson, physician at Les Cayes, Santo Domingo, to Jean Audubon, containing the only existing record of the birth of his son, Jean Jacques Fougère Audubon, on April 26, 1785; Les Cayes, December 29, 1783October 19, 1785 . . . . . . . . . . . 314

1a. Translation of the Sanson Bill . . . . . . . . 315

2. Copy of the Act of Adoption of Fougère (John James Audubon) and Muguet (Rosa Audubon), Nantes, March 7, 1794 . 328

3. Copy of the Act of Baptism of Jean Jacques Fougère Audubon, Nantes, October 23, 1800 . . . . . . . . . . 329

4. Copy of a bill of sale of Negroes rendered by Monsieur Ollivier to Monsieur Audubon, Les Cayes, Santo Domingo, 1785 • . 330

5. Statement of Accounts of Messrs. Audubon, Lacroix, Formon \& Jacques in the purchase of Negroes from M. Th. Johnston, Les Cayes, Santo Domingo, 1785 • • • • • • • . 331

6. Copy of bill of sale of Negroes to Monsieur Audubon, and a statement of his account with Messrs. Lucas Brothers \& Constant, Les Cayes, Santo Domingo, August 7, 1785-June 9, 1788334

7. Accounts of William Bakewell of "Fatland Ford" as protégé of his future son-in-law, and as attorney or agent for Audubon \& Rozier, giving certain exact indications of the naturalist's early movements and personal relations, before and after finally leaving "Mill Grove," January 4, 1805-April 9, 1810 • . . . 336

8. Concerning a Power of Attorney issued by Lieutenant Audubon and Anne Moynet Audubon to Ferdinand Rozier and John Au- 


\section{CONTENTS}

dubon, the Younger, at Couëron, France, in 1805; parts in French translated by a Philadelphia notary; signatures of original document authenticated by the Mayor of Couëron, October 21, 1805; his attest of the legality of Anne Moynet Audubon's signature at Couëron, October 27, 1805; authentication of the signature of the Mayor of Couëron by the Subprefect of Savenay, November 27, 1805; attest of the Subprefect's signature by the Prefect.

9. Articles of Association of Jean Audubon and Ferdinand Rozier to govern their partnership in business; drawn up at Nantes, March 23, 1806 . . . • • • • • . • . .

9a. Translation of the Articles of Association of Jean Audubon and Ferdinand Rozier . . . . . . . . . . . 345

10. Power of Attorney issued by Lieutenant Jean Audubon, Anne Moynet Audubon and Claude François Rozier, to their respective sons, Jean Audubon and Ferdinand Rozier, at Nantes, France, April 4, 1806, eight days before the latter embarked to America to enter upon their partnership in business . . . . 350

10a. Translation of the Power of Attorney issued by Jean Audubon, Anne Moynet Audubon, and Claude François Rozier to Jean Audubon and Ferdinand Rozier, April 4, 1806 . . . . 35

11. Account current of John Audubon and Ferdinand Rozier with the estate of Benjamin Bakewell, late commission merchant in New York, showing their dealings and standing with this house during the first sixteen months of their business experience in the West. Covers the period August 1, 1807, to December 13, 1808 . 354

11a. Final Account of Francis Dacosta, rendered July 25, 1807, to Lieutenant Jean Audubon, his partner in the unfortunate mining enterprise at "Mill Grove"; later contested and settled by arbitration

12. Quit Claim or Release given by John James Audubon to Ferdinand Rozier on the Dissolution of their Partnership in Business, at Sainte Geneviève, Upper Louisiana (Missouri), April 6, 1811359

13. Copy of a portion of the first Will of Lieutenant Jean Audubon, Couëron, May 20, 1812 . . . . . . . 360

14. Copy of the second and last Will of Lieutenant Jean Audubon, March 15, 1816 . . . . . . . . . . . 361

15. Copy of a portion of the first Will of Madame Anne Moynet, wife of Lieutenant Audubon, December 4, 1814 . . . . 363

16. Copy of a portion of the second Will of Madame Jean Audubon, May 10, 1816 . . . . . . . . . . . 364

17. Copy of the third Will, "No. 169, of Madame Anne Moynet, widow of M. Jean Audubon, living at his house called "La Gerbetière," and situated near the village of Port-Launay, not far from Couëron," December 26, 1819 . . . . . . 366

18. Copy of a portion of the fourth and last will of Madame Jean Audubon, living at the house of "The Turtle Doves" ("Les Tourterelles"), at Couëron, July 16, 1821 
19. Notice of the death of Lieutenant Jean Audubon, from the official registry of Nantes, Nantes, February 19, $1818 \quad$ • $\quad . \quad 369$

20. Letter of Lieutenant Jean Audubon to Francis Dacosta, his American agent and attorney, relating to the conduct of his son, and to the lead mine at "Mill Grove" farm, transliterated from photographic copy of duplicate (Letter No. 4) in Jean Audubon's letter-book. Nantes, March 10, 1805 . . . . 370

21. Letters of John James Audubon to Claude François Rozier, father, and to Ferdinand Rozier, son, immediately preceding and following his active partnership in business with the latter, 1807 and 1812

\section{APPENDIX II}

Audubon's Early Dated Drawings Made in France and America

Drawings now in the collections of Mr. Joseph Y. Jeanes of Philadelphia, and formerly belonging to Mr. Edward Harris, of Moorestown, New Jersey; of Mr. John E. Thayer, Lancaster, Massachusetts, and of Harvard University .

\section{APPENDIX III}

\section{"The Birds of America"}

1. Final Lists of Subscribers to The Birds of America, folio edition, as published by Audubon in 1839 . . . . . 380

2. Prospectus of The Birds of America, as issued in 1828, when ten Numbers of the original folio were engraved . . . 386

3. Prospectus of the Second (partial) Edition of The Birds of America, issued by John Woodhouse Audubon, through Messrs. Trubner \& Company, London, 1859

\section{APPENDIX IV}

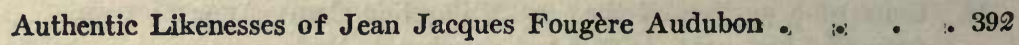

\section{APPENDIX V}

\section{Bibliography}

Containing a fully annotated list of Audubon's writings, biographies, criticism, and Auduboniana .. . . . . . . 401 


\section{ILLUSTRATIONS IN VOLUME II}

Audubon. After a portrait by George P. A. Healy, 1838. Photogravure

"Beechgrove," William Garrett Johnson's plantation house near St. Francisville, West Feliciana Parish, Louisiana, where Mrs. Audubon lived and taught from 1827 to 1829 . . . Facing 6

John Bachman's house in Charleston, South Carolina . . Facing 6

Early drawing in water color of the Carolina Parrot on branch of the hickory, 1811, hitherto unpublished . . . . Facing 20

John Bachman at thirty-two. After an engraving by Charles C. Wright of a portrait by A. Fisher . . . . . . Facing 32

Robert Havell at eighty-five. After a photograph taken shortly before his death in 1878 . . . . . . . Facing

Letter of Dr. George Parkman to Audubon, May 25, 1833 • . . 43

Pileated Woodpeckers on the "Raccoon Grape," The Birds of America, Plate CXI. After the original engraving by Robert Havell, 1831. Color Facing 46

Letter of Robert Havell to Audubon, June 15, 1833 . _ . . . 51

John George Children .

Edward Harris

John Bachman . . . . . . . Facing 72

George Ord . . . . . . . . . Facing 72

Samuel Latham Mitchell . . . . . . Facing 72

Charles Waterton . • . . . . . . . . Facing 72

Dr. Thomas Cooper, President of South Carolina College. After a contemporary silhouette . . . . . . . . 78

Vindication of Audubon's representation of the fangs of the southern rattlesnake as recurved at their tips. Detail from The Birds of America, Plate XXI, and photograph of the skull of a recent Florida specimen . • • • . . - . • Facing

Bluebirds on a stalk of the "great Mullein," The Birds of America, Plate CXIII. After the original engraving by Robert Havell, 1831. Color 
Thomas Nuttall • • • • • • • • • • Facing 118

Charles Lucien Bonaparte . . . . . . . . Facing 118

Constantine Samuel Rafinesque . • • • . . Facing 118

Audubon. After an engraving by H. B. Hall of a portrait painted by Henry Inman in 1833 • • • . . . . . Facing 126

Letter of William MacGillivray to Audubon, October 22, 1834 . 131

Part of the original draft of Audubon's manuscript for the Introduction to Volume II of the Ornithological Biography, giving list of names of persons to whom Audubon carried credentials on his first visit to London in 1827 . . . . . . Facing 133

Audubon's inscription in a copy of the Ornithological Biography, which he presented to William MacGillivray in 1839 . 138

Early drawings of American birds, 1807-12, hitherto unpublished: the Whippoorwill and the American Robin, with details . - Facing 144

Bust of Audubon by William Couper, in front and profile views. After the original in the American Museum of Natural History, New York . . . . . . . . . . Facing 160

Life mask of Audubon, hitherto unpublished, in front and profile views. After the original made by Robert Havell in London, now in possession of the Museum of Comparative Zoölogy of Harvard University . . . . . . . . . . . . . Facing 178

Canvas-backed Ducks, with distant view of the city of Baltimore, Maryland, The Birds of America, Plate CCCI. After the original engraving by Robert Havell, 1836. Color • • • . Facing 196

Victor Gifford Audubon . . . . . . . Facing 210

John Woodhouse Audubon. . . . . . . . Facing 210

Title page of the paper covers in which parts of the first American (octavo) edition of The Birds of America were originally issued . 213

Audubon. After a portrait painted by John Woodhouse and Victor Gifford Audubon about 1841 • • • • . Facing 226

"Minnie's Land," Audubon's home on the Hudson River, as it appeared in 1865. After a lithograph in Valentine's Manual . • Facing 236

"Minnie's Land," as it appears to-day from the river front protected by the retaining wall of Riverside Drive . . . . . Facing 236

Audubon, with gun, horse, and dog. After a painting by John Woodhouse Audubon about 1841 . . . . . . . Facing 244

Letter of Edward Harris to Audubon, January.31, 1843 . . . . 251 
Drawings for The Viviparous Quadrupeds of North America: the American or Canada porcupine and rabbits. After the originals in water color in the American Museum of Natural History, New York .

Title page of Volume I of the English edition of the text of The Viviparous Quadrupeds of North America . . . . . . . 275

John W. Audubon's inscription in a copy of Volume I of the text of the Quadrupeds (English edition), presented to John Edward Gray 280

Audubon. After an engraving by Nordheim of a daguerreotype possibly earlier than 1849 . . . . . . . Facing 280

Audubon. After his last portrait, a daguerreotype made in New York about 1850 . . . . . . . Facing 280

Letter of John Bachman to George Oates, November 7, 1846 . $\quad$ • 282

Audubon's last (?) letter to Edward Harris, February 22, 1847 • . 287

House formerly belonging to Victor Gifford Audubon, east front, as it appears to-day . . . . . . . Facing 294

House formerly belonging to John Woodhouse Audubon, south front, as it appears to-day . . . . . . Facing 294

Lucy Bakewell Audubon. After a miniature painted by Frederick Cruikshank in London, about 1831 . . . . Facing 304

Lucy Bakewell Audubon. After an unpublished photograph of 1871 . 



\section{AUDUBON}

\section{THE}

NATURALIST 


\section{SONNET}

TO J. J. AUDUBON, ESQ., ON BEHOLDING HIS DRAWINGS.

Is there delight in Nature's solitudes,

Her dark green woods, and fragrant wilderness,

In scenes, where seldom human step intrudes,

And she is in her wildest, loveliest dress?

Is there delight in her uncultured flowers,

Each ripened bloom or bright unfolding dye,

Or in the tribes which animate her bowers,

And through her groves in living beauty fly?

Then, on thy canvas as they move and live,

While taste and genius guide the fair design, And all the charms which Nature's works can give

With equal radiance in thy colours shine;

Amidst the praise thy country's sons extend,

The stranger's voice its warm applause shall blend.

J. E. R. [J Jne Elizabeth Roscoe].

The Winter's Wreath, 1832. 


\section{AUDUBON \\ THE \\ NATURALIST}

\section{CHAPTER XXVI}

\section{EXPLORATIONS IN FLORIDA AND THE SOUTH ATLANTIC}

Obituary published in London on day of his arrival in New York-Assistance from the Government-John Bachman becomes his friendWinter in Charleston-His folios as gifts-To Florida with two assistants-Letters to Featherstonhaugh-St. Augustine-Misadventures in the mud of East Florida-Audubon on Florida's future-At the sources of the St. John's-Aboard the Marion-Return from Key West-A merchant of Savannah-Disbanding of party at Charleston.

In the summer of 1831 Audubon felt that he must again return to America and extend his researches to the north, south and west, as well as begin a campaign for subscribers in the United States. His large folio was now running into its second volume, and the first installment of his text had been published; the time was favorable to his plans, and he hoped to remain in the country two or three years.

For the second time the publication of his plates was entrusted to friend Children, and with Mrs. Audubon he set sail for New York on August 2, 1831. From the American metropolis he wrote to Joseph B. Kidd on September 7 as follows: ${ }^{1}$

${ }^{1}$ Quoted by Captain Thomas Brown (Bibl. No. 163) in the Edinburgh Caledonian Mercury, November 3, 1831. 
We landed on the $3 \mathrm{~d} \ldots$. [of September] after a remarkably fine passage of 33 days. In two days more I proceed to the woods, and away from white man's tracks and manners. I hope you are going on well with your work. . . . I have a new subscriber here. The papers and scientific journals (we have not many,) are singing the praises of my work, and, God willing, I may yet come out at the broad end of the horn; at all events, I will either break it or make a spoon! I shot sixteen birds on the passage, which I got through the kind attention of our commander. I killed fifty more, when the "Columbia" was going too fast to stop for the purpose of picking them up. My young man is now busily engaged in skinning, and killed a bag-full of warblers yesterday ... prices of peaches, first quality, 75 cents per bushel,-_apples, half that price;-water melons are dull of sale, as also cantelopes and nutmeg melons. Fish alive in the markets, and, vive la joie, no taxes on shooting or fishing."

What Audubon actually did was to proceed to Philadelphia, where Mrs. Audubon left him to visit her sons in Louisville, and where he laid his plans for exploring the Southern States, especially the islands and eastern coast of the Florida peninsula. For this expedition he engaged two assistants, one of whom was Henry Ward, the "young man" mentioned above, an Englishman who had come with him to America as taxidermist, while the other was George Lehman, a Swiss landscape painter whom he seems to have found at Philadelphia. With them he soon started for Washington to obtain assistance from the Government.

On the very day that Audubon landed in New York, there appeared in the London Literary Gazette a seriocomic notice under the title of "Wilson the Ornithologist," who, it may be remembered, had died in Philadelphia eighteen years before. Said the editor of the Gazette: 
We observe with sorrow an account of the death and burial of poor Wilson, somewhere in the state of Philadelphia, even while the Edinburgh journals are anticipating his return, laden with scientific treasures. We have now before us No. 1 of his Illustrations of American Ornithology, on a reduced scale, to sort with Professor Jameson's edition-a pretty and attractive publication. The coloured prints are extremely correct and well done.

When on September 8 the Edinburgh Caledonian Mercury had called attention to this egregious blunder regarding Wilson, the Gazette explained that his name had been confused with that of Audubon, whose obituary presently appeared in its issue of October 29, the editor remarking that this naturalist's death was equally, if not more, to be deplored than that of Wilson. Captain Brown then sent to the Caledonian Mercury Audubon's letter to Kidd, quoted above, which was written from New York four days after the naturalist's death was announced in England. "What is the editor of the Literary Gazette about," exclaimed a writer in the Edinburgh paper; "he first resuscitates a man who has been dead 18 years, only to kill him again, and then, by way of correcting his error, kills another, who is now clearly proved to have been alive and well several days after the date of his obituary in London."

As was often the case, Audubon's ambitious hopes for exploring the continent far outran his means and powers of accomplishment. Colonel John James Abert, whose counsel he sought in Washington at this time, said:" "His plan is first to examine the peninsula

${ }^{2}$ Extract of letter of Colonel Abert. See G. W. Featherstonhaugh (Bibl. No. 164), Monthly American Journal of Geology and Natural Science, vol. i, p. 229 (1831).

John James Abert (1788-1863), long associated with the Bureau of Topographical Engineers of the United States Army, became brevet 
of Florida; then the regions west of the Mississippi, Mexico, and if possible penetrate into California. He also contemplates crossing the Rocky Mountains and pursuing the Columbia River to its mouth, and thinks that he will be absent from us about two years." In November G. W. Featherstonhaugh, the geologist, also made this announcement in his Monthly American Journal of Geology and Natural Science:

We are authorized to state that information of the progress of Mr. Audubon will be given, from time to time, to the scientific world, in the pages of this journal.

We are gratified in being able to state, that he was received in the most cordial manner, at Washington, and that the distinguished gentlemen in authority there, have given him such letters to the military posts on the frontiers, as will assure him the aid and protection his personal safety may require. We anticipate the most interesting reconnaisances, both geological and zoölogical, from this enterprising naturalist, who is accompanied by Mr. Lehman, as an assistant draftsman, and by an assistant collector who came with him from Europe.

The "distinguished gentlemen" at Washington who particularly aided Audubon at this time, besides Colonel

lieutenant-colonel in charge of that office in 1837; according to Ruthven Deane (see Bibliography, No. 216), he was an organizer of the National Institute of Science, afterwards merged with the Smithsonian Institution at Washington; an ardent friend of Audubon, he assisted him in many ways, and, as Dr. Richard Harlan affirmed, paid dearly for his support by being rejected for membership in the American Philosophical Society at Philadelphia. Harlan wrote to Audubon on January 27, 1832, that out of twenty-five members present on the occasion referred to, five, led by Mr. George Ord, Mr. Isaac Lea, and Dr. Hays, had voted against him: in his opinion no possible grounds could be found for opposing so desirable a member excepting his friendship for Audubon and his support of the snake "Episode" (see Chapter XXVIII). In 1832 Abert's paper on the "Habits of Climbing of the Rattlesnake," which was written. in the previous year, had appeared in a Philadelphia journal (see Bibliography, No. 107). To this friend Abert's Squirrel, Sciurus aberti, was later dedicated; see Audubon, The Viviparous Quadrupeds of North America (Bibl. No. 6), plate 153. 
Abert, were Edward Everett, Levi Woodbury, Secretary of the Navy, and Lewis McLane, Secretary of the Treasury. He was particularly anxious to obtain accommodation for his party aboard a government vessel, but it was some time before a suitable one was available. They left Washington about October 15, 1831, and went by steamer to Norfolk and Richmond, Virginia, where the Governor, John Floyd, whom Audubon had known in his Kentucky days, gave him numerous letters of introduction. At Charleston, their next stopping-place, he had hardly begun work in the field when he was sought out by the Rev. John Bachman, by inclination a naturalist of the old school and by profession a Lutheran minister, who at once took the whole party under his hospitable roof, where they remained a month. Thus began a life-long and almost ideal friendship between these two men, so unlike in character, in temperament and in training, which was quite as important to the modest German-American divine as to the impulsive Franco-American painter and student of birds. It was Audubon's infectious enthusiasm which kindled to an ardent flame that love of nature which was innate in Bachman, and which eventually brought his name and work to the attention of the scientific world.

Audubon remained at Charleston with the Bachmans until November 15, when the opportunity which they had awaited came suddenly, and they sailed for St. Augustine, Florida, on the government schooner Agnes. On that day Bachman wrote to Mrs. Audubon, in compliance "with a request of your kind and worthy husband, who laid an injunction on me this morning": ${ }^{3}$

${ }^{3}$ C. L. Bachman, John Bachman, D.D., LL.D., Ph.D. (Bibl. No. 191), to which work I am indebted for numerous extracts from Bachman's letters to Audubon and for various incidents relating to the different members of both families. 
The last has been one of the happiest months of my life. I was an enthusiastic admirer of nature from my boyhood, and fond of every branch of Natural History. Ornithology is, as a science, pursued by very few persons-and by none in this city. How gratifying was it, then, to become acquainted with a man, who knew more about birds than any man now livingand who, at the same time, was communicative, intelligent, and amiable, to an extent seldom found associated in the same individual. He has convinced me that I was but a novice in the study; and besides receiving many lessons from him in Ornithology, he has taught me how much can be accomplished by a single individual, who will unite enthusiasm with industry. For the short month he remained with my family, we were inseparable. We were engaged in talking about Ornithologyin collecting birds - in seeing them prepared, and in laying plans for the accomplishment of that great work which he has undertaken. Time passed rapidly away, and it seems but as yesterday since we met, and now, alas! he is already separated from me-and in all human probability we shall never meet again.... I need not inform you that Mr. Audubon was a general favorite in our city. His gentlemanly deportment, his travels and experience, his information and general talents, caused him to be sought after by all. But your husband knew that the great objects before him required his unremitted attention, and he was obliged to deny himself to his friends, on many occasions, and devoted to them only his evenings.

There seems quite a blank, in my house, since he has gone, for we looked on him as one of our family. He taught my sister, Maria, to draw birds; and she has now such a passion for it, that whilst I am writing, she is drawing a Bittern, put up for her at daylight by Mr. Audubon.

On December 23 Bachman wrote to Audubon: "Your visit to me gave me new life, induced me to go carefully over my favorite study, and made me and my family happy." His sister-in-law, Miss Maria Martin, 


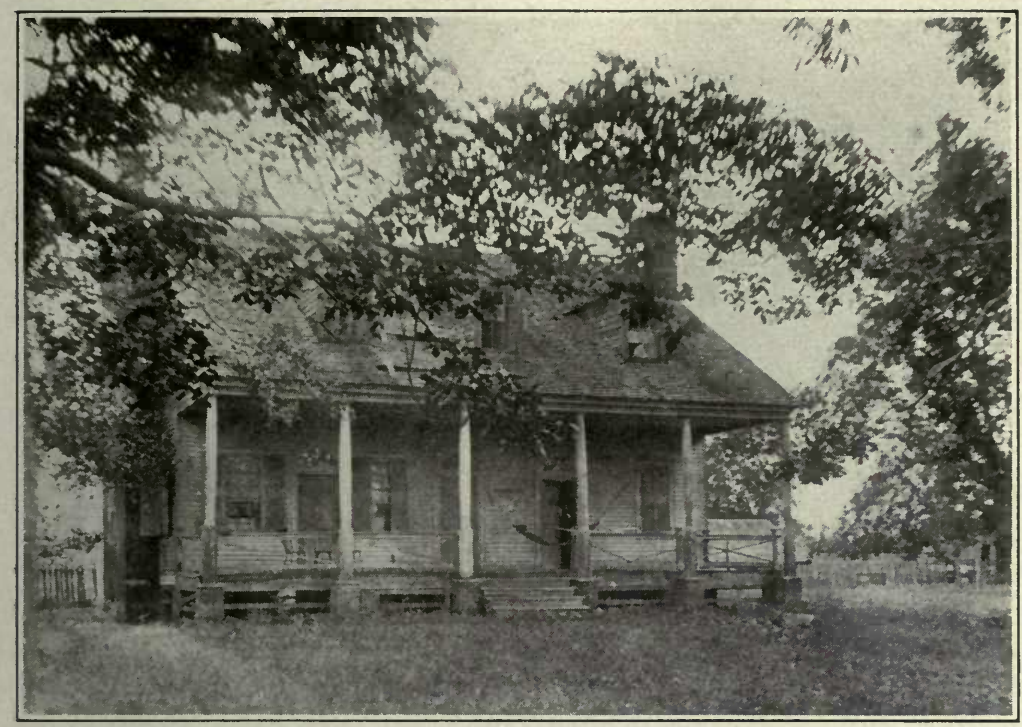

"BEECHGROVE," WILLIAM GARRETT JOHNSON'S PLANTATION HOUSE IN WEST FEL1CIANA PARISH, LOUISIANA, WIIERE MRS. AUDUBON LIVED AND TAUGHT FOR TWO YEARS, 1827-1829.

After a photograph by Mr. Stanley Clisby Arthur, 1916.

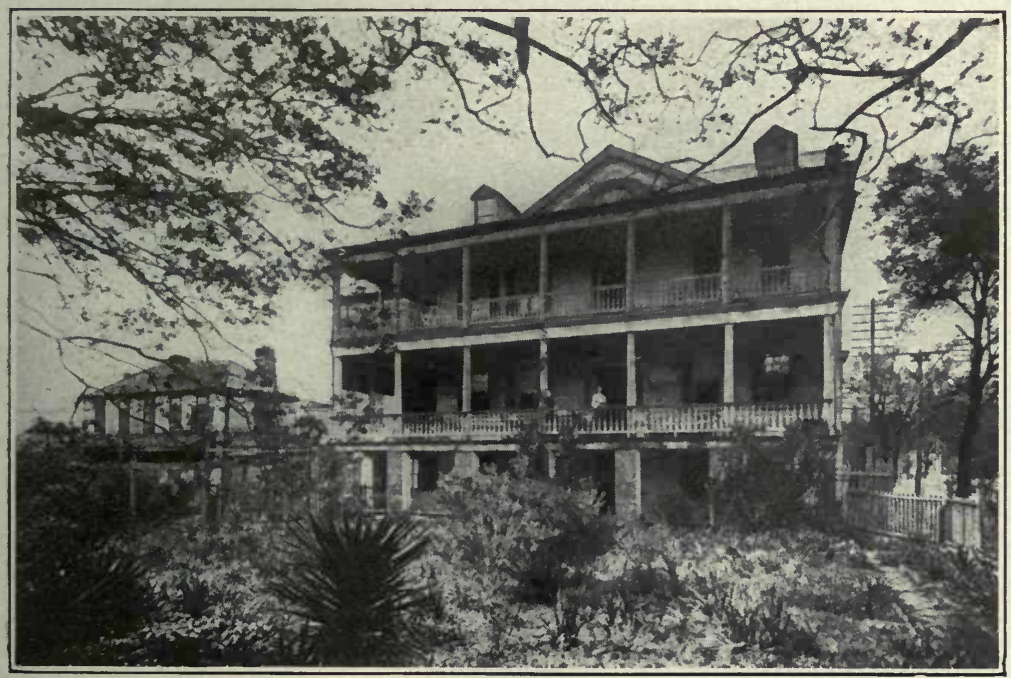

JOHN BACIMAN'S HOUSE IN CHARTESTON, SOUTH CAROLINA.

After a photograph in possession of Mr. Ruthven Deane. 

who possessed considerable artistic talent, became one of Audubon's enthusiastic helpers, and not only drew birds for him but painted many of the flowers and insects which were later used for the embellishment of his plates. John Bachman's serious contributions to natural history also date from this visit. To repay him and his family for their hospitality, Audubon presented them with the first volume of The Birds of America, but the folio was not received until some time later; he was referring to this when he wrote to Bachman, just before sailing from New York, on April 5, 1834, and asked him to accept "the superbly bound book" from "your old Friend, in part atonement for the troubles I have given you, and the leatherings you may yet receive at my hands at chess." In a letter to Miss Martin, written also from New York on the following day, he said: "The Great Volume which Maj. Glassel did fortunately return into your hands, I give with all my heart to my valued friends, the Bachmans, and shall try to furnish them the sequel in like binding." 4

Audubon scattered detached plates and numbers of his large work freely among his friends, and sometimes spoke of a gift of the whole. The costly nature of such a present in most cases, no doubt, led to a change of mind if not of heart, but not in all, for a number of his presentation copies still exist. One was given to David Eckley ${ }^{5}$ of Boston, a noted sportsman who had aided

"This "Great Volume," bound in fine Russia leather, was still in possession of the Bachman family in 1888, and is said to represent one of the earliest impressions of the plates, which Audubon had selected and used for exhibition purposes. See C. L. Bachman, op. cit., p. 101.

'This unique copy of The Birds of America bears the inscription: To my worthy Friend

D d. Eckley, Esq., of [Boston]

this volume is given with

his sincere and good wishes.

JoHN J. AUdubor. 
Audubon in collecting materials for his work. In a letter written at Charleston, January 1, 1837, to young Thomas M. Brewer, Audubon said: "Please to call on my good friend David Eckley, Esq., present to him and to his family my very best regards, and ask of him whether he has collected any hawks or owls for me. If so, take them from him, and place them in the general receptacle of 'pale-faced rum.'" Another copy is said to be in possession of the Public Library of Manchester, England, and to have been bequeathed to that institution by the Earl of Crawford. A complete set of the Birds was also presented to his friends, the Rathbones of Liverpool, and is still in possession of the family.

We shall now return to our narrative and fulfill our promise of reproducing Audubon's own account of his journey from Richmond to Florida: ${ }^{6}$

\section{Audubon to G. W. Featherstonhaugh}

I am now seated in earnest to give you an unceremonious summary of my proceedings up to this time, since we left Richmond, in Virginia. As a geologist, I venture to suppose you would have been but indifferently amused, if you had been with us in our journey from this latter place to Charleston, in South Carolina; and as an ornithologist, I cannot boast of the

The plates thus dedicated were unbound, and apparently in their original covers, which consisted of plain brown sheets. They passed through the hands of Messrs. Burrows Brothers' Company, Cleveland, to Mr. Robert H. Sayre of South Bethlehem, Pennsylvania, and were originally received by the American dealers from the Messrs. Sotheran \& Company of London. Possibly this was the set mentioned by Coues, who says "Truibner... quotes the work with plain plates. I have never seen one in that condition" (Birds of the Colorado Valley, p. 612; Bibl. No. 181). After Mr. Sayre's death, his library was dispersed by public auction at Philadelphia, when this complete set of Audubon plates, though in an uncolored state, brought $\$ 3,200$; see Public Ledger, November 9, 1907, and "Bohemian"•(Bibl. No. 207a), Black Diamond Express, vol. iv, p. 3.

- Letter (No. 1) from Audubon to the editor of the Monthly American Journal of Geology and Natural Science (Bibl. No. 34), published in vol. i, p. 358 (1832); dated "St. Augustine, East Florida, Dec. 7, 1831." 
enjoyment I found; poor coaches, dragged through immense, deserted pine forests, miserable fare, and neither birds nor quadrupeds to be seen. We at length approached Charleston, and the view of that city from across the bay was hailed by our party with unfeigned delight. Charmed, as we were, with having terminated our dreary journey, it did not occur to us to anticipate the extraordinary hospitality which awaited us there, and which led to a residence of a few of the happiest weeks I ever passed.

I had passed but one night in the city, when I was presented to the Rev. Mr.—. This benevolent man, whom I am proud to call my friend would not suffer the "American Woodsman" to repose any where but under his roof; and not him alone-all his assistants too. When I tell you that he was an old friend of Alexander Wilson, that he shoots well, is an ornithologist, a philosophical naturalist, and that during the time we enjoyed his hospitality, he took us all over the country with his carriages and servants, in search of specimens, and that he was every thing a kind brother could be to me, you may suppose that it is with great sincerity I say, and ever shall say, God bless him! When I first saw this excellent man, he was on horseback, but upon my being named to him, he leaped from his saddle, suffered his horse to stand at liberty, and gave me his hand with a pressure of cordiality that electrified me. I saw in his eyes that all he said was good and true; and although he spoke of my labours in terms far exceeding what is due to them, I listened to him pretty well assured that he did not intend me to play the part of Gil Blas over again; for myself, my assistants, George Lehman and Henry Ward, were removed in a jiffy to his own mansion, introduced to the family, and at work the very next morning.

Although the weather was "shockingly hot," they prepared three hundred specimens, embracing about

These letters, which were hurriedly written in the field, appeared in a short-lived and forgotten publication; they are here given in part on account of the general interest of the narrative. 
sixty land and water birds, and sent all the "pickled specimens to our mutual friend $\mathrm{H} \longrightarrow$ _" [Dr. Harlan, of Philadelphia] for safe keeping until their return.

I jumped at once into my wood-hunting habits. All hands of us were up before day-break, and soon at work, either in the way of shooting, taking views, or drawing birds; after sunset-scribbling in our journals. .... In the early part of November the alligators had gone into their winter quarters; the migratory birds were passing swiftly on towards the south, although we had had no frost. The planters considered the country as still unhealthy, and resorted to the city at night. If I had been governed by the practice and advice of many, I should not have put a foot in the mud, either salted or fresh; but difficulties of this character must be disregarded by the American woodsman, while success, or the hope of it, is before him.

It is impossible to do justice to the generous feelings of the Charlestonians, or to their extreme kindness towards me. Many of the gentlemen took the greatest interest in my pursuits; one, Dr. — Foundland dog, and other valuable memorials of his regard. Another, Dr. — gave me a collection of shells, from the adjacent waters. The ladies presented me with a capital supply of snuff. 7 Desirous of going to Cole's Island, distant about 25 or 30 miles, to look after some marine birds, a boat, four hands and a pilot, were immediately offered to me, free of all expense, with the liberty to detain them as long as was agreeable to me. It is not possible for me to express properly the sense I feel of the kindness I received from that warm-hearted and intelligent people.

And now, as you have good naturedly listened to what I have felt bound to say on the score of gratitude, I will tell you what I know you are impatient to come to-something about my proceedings at Cole's Island. It lies south from Charleston about 25 or 30 miles; there we arrived and encamped for the

'See Audubon's New Year's resolution against snuff, Vol. I, p. 396. 
night: certain beef-steaks we brought with us we roasted upon sticks, and the adjacent shore provided us with excellent oysters : gaiety, good appetites, and our hearts all right, made the time pass pleasantly, and it was with some reluctance we spread our blankets, and arranged the fire preparatory to going to rest. Nothing is more valuable to a naturalist, and particularly to an ornithologist, than the first hours of the day; therefore, long ere the sun had glowed over the broad sea that lay before our camp, we had reached another island where birds resort to roost by thousands; but, notwithstanding these multitudes, not a new species did we procure. We, however, had the pleasure of observing two noble "birds of Washington," 8 sailing majestically over the broad watery face.

But it was necessary to bring my stay in Charleston to a close, and it was somewhat difficult too. My friends had increased in number; they were in the habit of accompanying me in my shooting excursions; I was becoming very much attached to them; invitations poured in from various parts of the country; and I really believe that had I been willing, we might have remained there and in the neighborhood, if not all our lives, at least as long as would have caused a rare scarcity of the feathered tribes, in that portion of the Carolinas. But my mind was among the birds farther south,- the Floridas, Red River, the Arkansas, that almost unknown country, California, and the Pacific ocean. I felt myself drawn to the untried scenes of those countries, and it was necessary to tear myself away from the kindest friends.

We embarked on the schooner Agnes; the wind was fair, and we hoisted all sails for the Floridas. Our passage was not short; the wind changed, and we put back into St. Simon's Island Bay. This was one of the few put backs in life of a fortunate kind for me. I made for the shore, met a gentleman on the beach, presented him my card, and was immediately invited to dinner. I visited his gardens, got into such agreeable conversation and quarters, that $I$ was fain to think that

${ }^{8}$ See Vol. I, p. 400. 
I had landed on some one of those fairy islands said to have existed in the golden age. But this was not all; the owner of this hospitable mansion pressed me to stay a month with him, and subscribed to my Birds of America in the most gentlemanly manner. This was T. B. K., Esq. ${ }^{9}$ But the wind shifted; I was sent for, and our voyage to St. Augustine resumed.

St. Augustine, whatever it may have been, is far from being a flourishing place now. It lies at the bottom of a bay, extremely difficult of access, even for vessels of light draft, which seldom reach the "city" in less than a day. I cannot say much for the market, nor for the circumjacent country. Oranges and plenty of good fish seem to contribute the wealth of the place. Sands, poor pine forests, and impenetrable thickets of cactus and palmettos form the undergrowth. Birds are rare, and very shy; and with all our exertions, we have not collected one hundred skins in a fortnight that we have been here. I have received many kind attentions, and numerous invitations to visit plantations, on our way to the south, where I shall direct my steps in a few days. I have drawn seventeen species, among which one mongrel vulture, which I think will prove new. You will see it, I hope, very soon.

I will give you a sketch of our manner of passing the time. We are up before day, and our toilette is soon made. If the day is to be spent at drawing, Lehman and I take a walk, and Ward, his gun, dog, and basket, returning when hungry or fatigued, or both. We draw uninterruptedly till dusk, after which, another walk, then write up journals, and retire to rest early. When we have nothing on hand to draw, the guns are cleaned over night, a basket of bread and cheese, a bottle with old whiskey, and some water, is prepared. We get into a boat, and after an hour of hard rowing, we find ourselves in the middle of most extensive marshes, as far as the eye can reach. The boat is anchored, and we go wading through mud and water, amid myriads of sand-flies and mosquitoes,

'Thomas Butler King, of St. Simon's Island, Georgia. 
shooting here and there a bird, or squatting down on our hams for half an hour, to observe the ways of the beautiful beings we are in pursuit of. This is the way in which we spend the day. At the approach of evening, the cranes, herons, pelicans, curlews, and the trains of blackbirds are passing high over our heads, to their roosting places; then we also return to ours. If some species are to draw the next day, and the weather is warm, they are outlined that same evening, to save them from incipient putridity. I have ascertained that feathers lose their brilliancy almost as rapidly as flesh or skin itself, and am of opinion that a bird alive is 75 per cent more rich in colours than twenty-four hours after its death; we therefore skin those first which have been first killed, and the same evening. All this, added to our other avocations, brings us into the night pretty well fatigued. Such, my dear friend, is the life of an active naturalist; and such, in my opinion, it ought to be. It is nonsense ever to hope to see in the closet what is only to be perceived-as far as the laws, arrangements and beauties of ornithological nature is concerned,- by that devotion of time, opportunities, and action, to which I have consecrated my life, not without hope that science may benefit by my labours.

As to geology, my dear Friend, you know as well as myself, that I am not in the country for that. The instructions you gave me are very valuable, and I shall be vigilant. The aspect of the country will soon begin to change, and as I proceed, I will write to you about all we see and do. . . . Do not be afraid of my safety; I take a reasonable care of my health and life. I know how to guard against real difficulties, and I have no time to attend to that worst of all kinds of difficulties,-imaginary ones. Circumstances never within my control, threw me upon my own resources, at a very early period of my life. I have grown up in the school of adversity, and am not an unprofitable scholar there, having learnt to be satisfied with providing for my family and myself by my own exertions. The life $I$ lead is my vocation, full of smooth and rough paths, like every vocation which men variously try. My physical constitution has always been good, and the fine flow of 
spirits I have, has often greatly assisted me in some of the most trying passages of my life. I know I am engaged in an arduous undertaking; but if I live to complete it, I will offer to my country a beautiful monument of the varied splendour of American nature, and of my devotion to American ornithology. John JaMes Audubon.

Ther., this day, at 2 p. m.,

$78^{\circ} \mathrm{Fahr}$.

On the following day, December 8, 1831, Audubon sent the following request to Dr. Harlan of Philadelphia: "I wish you also to send me-to Key West-, 20 more pounds of powdered arsenic from Friend Wetherell's shop, ${ }^{10}$ and also a double barelled gun of usual length, as good as you can procure for $\mathbf{3 0}$ dollars; probably a second hand one may be procured; it must be percussion and, if possible, back action." Dr. Richard Harlan, who often transmitted to Mrs. Audubon any news which came direct from her husband, wrote to her on December 10, 1831, as follows: ${ }^{11}$

I have just rec ${ }^{d}$ a letter from $\mathrm{Mr}$ Aud-dated St. Augustine Nov. $24^{\text {th }}$ they enjoy health amidst their fatiguing avocations-has obtained another subscriber, living on St. Simons island named Tho. Butler King - to whom I am to send the work as soon as the Copies exported arrive from London-he has good expectations of adding some new birds to his listhave you seen the Sonnet addressed to $\mathrm{M}^{\mathrm{r}}$ Aud. in the "Wreath" a London annual for 1832? - under the signature of J. E. R? - our newspapers announce the arrival, departure \& progress of $\mathrm{M}^{\mathrm{r}}$ Audubon, as if he was an Embassador-and so he is, one of Natures-

${ }^{10}$ Then belonging to the four sons of Samuel Wetherill, who succeeded to the white lead and drugs industry after his death in 1829 .

${ }^{11}$ For the favor of reproducing this and another letter by Dr. Harlan given in Chapter XXVII, as well as the sonnet referred to, which will be found facing page $I$ of this volume, I am indebted to Mr. Ruthven Deane. 
The winter season at St. Augustine proved unfavorable for the naturalist's work, and he anxiously awaited the coming of the government vessel, the Spark, to the commander of which he bore letters from Washington. After spending about three weeks in the neighborhood of the city, the party proceeded through the inlet which divides Anastasia Island from the mainland, to the plantation of General Hernandez, thirty-five miles distant, where they were entertained for ten days. On Christmas morning they set out afoot for the plantation of John Bulow, of Bulowville, fifteen miles away. To follow the naturalist's account:

A wagon was sent for our baggage and horses for ourselves were offered at the same time, but it was not my desire to give unnecessary trouble, and above all upon an occasion when I was glad to see the country in as much detail as possible, and anxious to avail myself of every occasion to get new birds.

During the whole long stay with Mr. Bulow, there was no abatement of his kindness, or his unremitted efforts to make me comfortable, and to promote my researches. I shall ever feel grateful to one of the most deserving and generous of men.

On December 28 their host proposed that they should descend the Halifax River in search of new and valuable birds to a point about forty miles from that place and eighty miles from St. Augustine. ${ }^{12}$

Accordingly, the boat, six hands, and "three white men," with some provisions, put off with a fair wind, and a pure sky. ....We meandered down a creek for about eleven miles-the water torpid yet clear-the shore lined with thousands of acres covered by fall grapes, marshes, and high palm trees,

12 The following account is quoted from Audubon's second letter to G. W. Featherstonhaugh (Bibl. No. 35), dated "Bulowville, East Florida, December 31, 1831 ;" published, loc. cit., vol. i, p. 407 (1832). 
rendering the shore quite novel to my anxious eye. Some birds were shot, and secured so as to be brought back, in order to undergo the skinning operation. Before long we entered the Halifax river, an inland arm of the sea, measuring in breadth from a quarter to nearly a mile.

They reached a spot, called "Live Oak Landing," where a schooner from New York was then anchored, and there passed the night.

At sunrise the next morning, I and four negro servants proceeded in search of birds and adventures. The fact is, that I was anxious to kill some 25 brown Pelicans... to enable me to make a new drawing of an adult male bird, and to procure the dresses of the others. I proceeded along a narrow, shallow bay, where the fish were truly abundant. Would you believe it, if I were to say, that the fish nearly obstructed our head-way? Believe it, or not, so it was; the waters were filled with them, large and small. I shot some rare birds, and putting along the shore, passed a point, when lo, I came in sight of several hundred pelicans, perched on the branches of mangrove trees, seated in comfortable harmony, as near each other as the strength of the boughs would allow. I ordered to back water gently; the hands backed water. I waded to the shore under cover of the rushes along it, saw the pelecans fast asleep, examined their countenances and deportment well and leisurely, and after all, levelled, fired my piece, and dropped two of the finest specimens I ever saw. I really believe I would have shot one hundred of these reverend sirs, had not a mistake taken place in the reloading of my gun. A mistake, however, did take place, and to my utmost disappointment, I saw each pelecan, old and young, leave his perch, and take to wing, soaring off, well pleased, I dare say, at making so good an escape from so dangerous a foe.

After shooting more birds, and pushing or pulling their boat "over oyster banks sharp as razors," they 
made the schooner at the landing again. "The birds, generally speaking," he continues, "appeared wild and few-you must be aware that I call birds few, when I shoot less than one hundred per day."

Such remarks as we have just quoted might convey the impression that the American woodsman, with whose name the cause of bird protection is now associated in this country, was a reckless destroyer of all bird life, but this was far from the case. It must be remembered that this was over eighty years ago, when the unrivaled abundance of our birds was such that the necessity of their conservation had hardly entered the dreams of the most discerning. Audubon no doubt had gradually yielded to the prevalent mania for describing and figuring new species, and to make out all the minute specific differences a large series of specimens was necessary; still more were needed for the detection of individual variation, which did not escape him, and much less his assistant, William MacGillivray, who demanded large numbers for his anatomical studies. Furthermore, Audubon counted upon defraying a part of his expenses by collections of skins of American birds, which were then desiderata among the museums of Europe. ${ }^{13}$

When it was proposed that they should return,

preparations were accordingly made, and we left the schooner, with tide and wind in our teeth, and with the prospect of a severe, cold night. Our hands pulled well, and our bark was as light as our hearts. All went on merrily until dark night came on. The wind freshening, the cold augmenting, the provisions diminishing, the waters lowering, all-all depreciating except our enterprising dispositions. We found ourselves fast in the mud about 300 yards from a marshy shore, without the least hope of being able to raise a fire, for no trees except palm

${ }^{12}$ See Vol. II, p. 129. 
trees were near, and the grand diable himself could not burn one of them. Our minds were soon made up to do-what? Why, to roll ourselves in our cloaks, and lay down, the best way we could, at the bottom of our light and beautiful barque. Good God, what a night! To sleep was impossible; the cold increased with the breeze, and every moment seemed an hour, from the time we stretched ourselves down until the first glimpse of the morn; but the morn came, clear as ever morn was, and the north-easter as cold as ever wind blew in this latitude. All hands half dead, and masters as nearly exhausted as the hands -stiffened with cold, light-clothed, and but slight hope of our nearing any shore; our only resort was, to leap into the mire, waste-deep, and to push the barque to a point, some five hundred or six hundred yards, where a few scrubby trees seem to have grown to save our lives on this occasion. "Push, boys, push! Push for your lives!", cry the generous Bulow, and the poor Audubon.- "All hands push!" Aye and well might we push: the mire was up to our breasts, our limbs becoming stiffened at every step we took. Our progress was slowly performed as if we had been clogged with heavy chains. It took us two and a half hours to reach the point, where the few trees of which I have spoken were; but, thank God, we did get there.

We landed . . . and well it was that we did; for on reaching the margin of the marsh, two of the negroes fell down in the marsh, as senseless as torpidity ever rendered an alligator, or a snake; and had we, the white men, not been there, they certainly would have died. We had carried them into the little grove, to which, I believe, all of us owe our lives. I struck a fire in a crack; and, in five minutes, I saw, with indescribable pleasure, the bright, warming blaze in a log pile in the center of our shivering party. We wrapped the negroes in their blankets-boiled some water, and soon had some tea-made them swallow it, and with care revived them into animation. May God preserve you from being ever in the condition of our party at this juncture; scarcely a man able to stand, and the cold wind blowing as keenly as ever. Our men, however, gradu- 
ally revived-the trees, one after another, fell under the hatchet, and increased our fire-and in two hours I had the pleasure of seeing cheerful faces again.

Their predicament, however, was still serious, for, to continue the narrative, they were

confined in a large salt marsh, with rushes head high, and miry; no provisions left, and fifteen miles from the house of their host.

Not a moment was to be lost, for I foresaw that the next night would prove much colder still. The boat was manned once more, and off through the mud we moved to double the point, and enter the creek, of which I have spoken, with the hope that in it we should find water enough to float her. It did happen so, thank God! As we once more saw our barque afloat, our spirits rose, - and rose to such a pitch that we in fun set fire to the whole marsh: crack, crack, crack! went the reeds, with a rapid blaze. We saw the marsh rabbits, scampering from the fire by the thousands, as we pulled our oars.

Their pleasure in being afloat was short-lived, for "the northeaster had well nigh emptied the creek of its usual quantum of water," and they were again obliged to wade to effect a landing, their object being to gain the east Florida coast and thus make their escape. This was finally attained after abandoning their boat, when began a long tramp on the beach, in the teeth of the wind,

through sand that sent our feet back six inches at every step of two feet that we made. Well, through this sand we all roaded, for many a long mile, picking up here and there a shell that is nowhere else to be found, until we reached the landing place of J. J. Bulow. Now, my heart, cheer up once more, for the sake of my most kind host. . . . I assure you, I was glad to see him nearing his own comfortable roof; and as we saw 
the large house opening to view, across his immense plantation, I anticipated a good dinner with as much pleasure as I ever experienced.

All hands returned alive; refreshments and good care have made us all well again, unless it be the stiffness occasioned in my left leg, by nearly six weeks of daily wading through swamps and salt marshes, or scrambling through the vilest thickets of scrubly live oaks and palmitoes that appear to have been created for no other purpose but to punish us for our sins.

Readers of the following account who have visited eastern Florida may conclude that Audubon was not a good prophet, but probably at that early day no one could have made a better forecast of the future:

The land, if land it can be called, is generally so very sandy that nothing can be raised upon it. The swamps are the only spots that afford a fair chance for cultivation; the swamps, then, are positively the only places where plantations are to be found. These plantations are even few in number; along the coast from St. Augustine to Cape Carnaveral, there are about a dozen. These, with the exception of two or three, are yet young plantations. General Hernandez's, J. J. Bulow's, and Mr. Durham's are the strongest, and perhaps the best. Sugar cane will prosper, and doubtless do well; but the labour necessary to produce a good crop, is great! great!! great!!! Between the swamps of which I now speak, and which are found along the margin laying west of the sea inlet, that divides the main land from the Atlantic, to the river St. John of the interior of the peninsula, nothing exists but barren pine lands of poor timber, and immense savannas, mostly overflowed, and all unfit for cultivation. That growth, which in any other country is called underwood, scarcely exists; the land being covered with low palmitoes, or very low, thickly branched dwarf oaks, almost impenetrable to man. The climate is of a most unsettled nature, at least at this season. The thermom- 


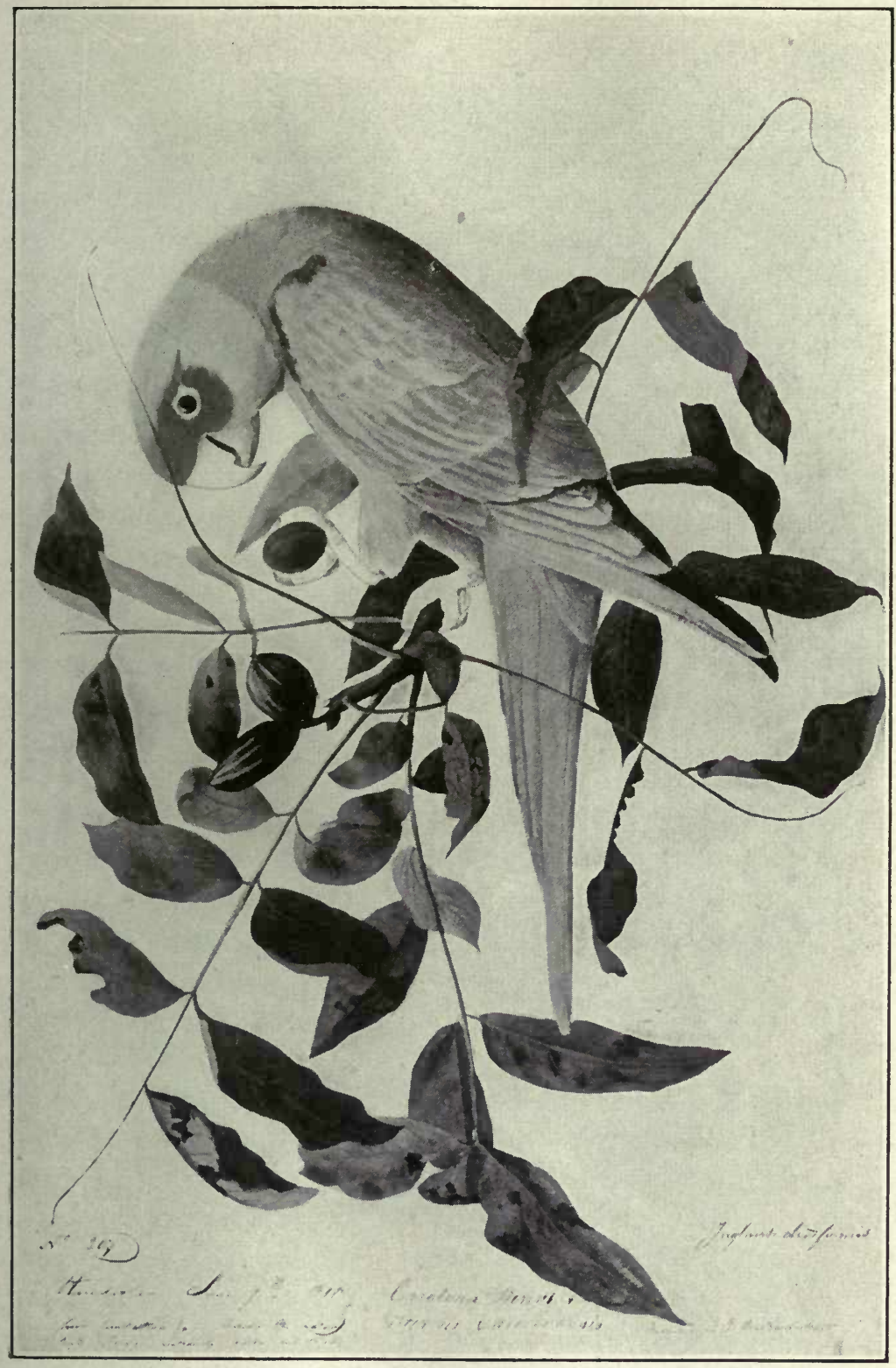

EARLY UNPUBIISIIED DRAWING IN WATER-COLOR OF THE CAROIINA PARROT, ON BRANCH OF THE HICKORY, DATED "HENDERSON, JUNE 9TH, 1811." TIHE ORIGINAL BEARS THE NOTE: "POOR IMITATION OF COLOR, THE NATURAL BIRD BEING EXTREMELY GLOSSY

$$
\text { AND RICH." }
$$

Published by courtesy of Mr. Joseph Y. Jeanes. 

eter has made leaps from 30 to 89 degrees in 24 hours, cold, warm, sandy, muddy, watery, -all these varieties may be seen in one day's travelling. . . . Game and fish, it is true, are abundant; but the body of valuable tillable land is too small to enable the peninsula ever to become a rich state.

On January 6, 1832, the party started to visit a famous spring near the sources of the St. John's River, which was described in his third letter to Featherstonhaugh as well as in a later "Episode." ${ }^{14}$ There his host, Colonel Rees, who utilized the abundant flow from this curious spring for grinding the whole of his sugar cane, took them down the Spring Garden Creek to a series of muddy lakes which emptied into the St. John's. The mud on this occasion was the cause of great disappointment to the naturalist, for it made it impossible for him to recover what he believed to represent a new species of Ibis, which was shot in one of those bottomless pits. "Being only a few yards distant from us," to quote from Audubon's third letter, ${ }^{15}$ "and quite near enough to ascertain the extent of my loss, I submitted to lose a fine pair of a new species, the which if $I$ ever fall in with it again, I shall call Tantalus fuscus."

When they had reached the borders of Woodruff's Lake, after noon, fatigued and hungry, he continued:

We landed on a small island of a few acres, covered with a grove of sour orange trees, intermixed with not a few live oaks. The oranges were in great profusion on the trees-everything about us was calm and beautiful and motionless, as if it had just come from the hand of the Creator. It would have been a perfect Paradise for a poet, but I was not fit to be in

${ }^{14}$ See following Note; and "Spring Garden," Ornithological Biography (Bibl. No. 2), vol. ii, p. 263.

${ }^{15}$ See Bibliography, No. 36 ; undated; published, loc. cit., vol. i, p. 529 (1832). 
Paradise; the loss of my ibis made me as sour as the oranges that hung about me. I felt unquiet, too, in this singular scene, as if I were almost upon the verge of creation, where realities were tapering off into nothing. The general wildness the eternal labyrinths of waters and marshes, interlocked, and apparently never ending; the whole surrounded by interminable swampsall these things had a tendency to depress my spirits, notwithstanding some beautiful flowers, rich looking fruits, a pure sky, and ample sheets of water at my feet. Here I am in the Floridas, thought $I$, a country that received its name from the odours wafted from the orange groves, to the boats of the first discoverers, and which from my childhood I have consecrated in my imagination as the garden of the United States. A garden, where all that is not mud, mud, mud, is sand, sand, sand; where the fruit is so sour that it is not eatable, and where in place of singing birds and golden fishes, you have a species of ibis that you cannot get when you have shot it, and alligators, snakes, and scorpions.

Mr. Bartram was the first to call this a garden, but he is to be forgiven; he was an enthusiastic botanist, and rare plants, in the eyes of such a man, convert a wilderness at once into a garden.

When we had eaten our humble repast at the sweet little Orange Grove Island, we left it "alone with its glory," but not without a name. It was determined, nolens volens, that it should be called Audubon's Island, on the St. John's river. Lat. $29^{\circ} 42^{\prime}$.

Early in February, 1832, Lieutenant Piercy took Audubon and his assistants aboard the government schooner Spark at St. Augustine, and sailed for the mouth of the St. John's River, which he had orders to ascend in the interests of the Revenue Service. On February 12 , when they had reached a point one hundred miles from the mouth of the river, the vessel, being in need of repairs, was suddenly recalled. Audubon, with 
two men, thereupon engaged a boat and attempted to return to St. Augustine across country, by a short cut to the eastward. They were soon stranded and the party divided. Audubon with his dog and one companion then endeavored to make their way by land to the town, eighteen miles distant, but they were overtaken by a terrific gale and thunder-storm, and in order to keep to the trails were often obliged to grope their way on hands and knees. ${ }^{16}$

At about this time the publishers of the Journal of Geology and Natural Science, from which we have quoted, failed, and Featherstonhaugh, who assumed their debts to all subscribers, was obliged to bring it to a close with the completion of the first volume; Audubon's third and last letter appeared in the valedictory number for June, 1832.

Again the naturalist applied to the government officials at Washington for assistance, and, as the following letter shows, Edward Everett again came to his aid, as did also Levi Woodbury, Secretary of the Navy, to whom Audubon later received a personal introduction from Chief Justice Taney of the Supreme Court:

\section{Levi Woodbury to Louis McLane}

Navy Department

February 241832

Sir,

The letter of the Honorable Mr. Everett of the 18 th. inst. relating to Mr. Audubon \&c and referred by you to this Department, has been received.

I regret that the impaired condition of the Spark made it necessary some weeks ago, to order that vessel to Norfolk to be refitted.

${ }^{16}$ See "St. John's River in Florida," Ornithological Biography, vol. ii, p. 291. 
I have heretofore taken much pleasure in furnishing $\mathrm{Mr}$. Audubon with credentials to the officers of the Navy, and requesting [them] to furnish every aid, in the prosecution of [his] scientific researches: and shall be happy to afford any further facilities within the power of the Department.

I am very respectfully

$\& c \& c$

Levi Woodbury

Honorable. L. Mc Lane

Secy of the Treasury

Finally, on April 15, 1832, Audubon and his party were able to board the revenue cutter Marion, commanded by Robert Day, and the opportunity thus afforded for exploring the dangerous east Florida coast amply repaid them for their long and vexatious delays. They visited the islands from St. Augustine to Key West, and examined every part of the shore which it was the duty of the Marion to approach. At Indian Key the deputy collector, Mr. Thurston, gave Audubon the services of his pilot, a veteran sailor and hunter, who accompanied him on the Marion for a number of weeks and led many boat journeys to lonely islands, where vast colonies of sea fowl then dwelt in undisputed possession. The leisurely movements of the vessel also enabled the naturalist to produce many finished drawings, and to obtain materials for fresh "Episodes." 17 At Key West Audubon was hospitably received by Major Classel, ${ }^{18}$ and by Dr. Strobel, who was of great assistance both to him and to Bachman in procuring new birds from that little known point.

The unexpected delays experienced in Florida, and the expense which the presence of his assistants neces-

"See "The Florida Keys," Ornithological Biography, vol. i, pp. 312 and 345, and "The Turtlers," ibid., vol. ii, p. 370 .

${ }^{18}$ See Vol. II, p. 7. 
sarily entailed, in all probability, deterred the naturalist from the more hazardous and uncertain enterprise of attempting to reach the Rocky Mountains and the Pacific Coast, which for years had been the great object of his ambition. At all events, after their work was finished at Key West, the party returned to St. Augustine, and on the fifth day of March again boarded the packet schooner Agnes, which was to bear them with their collections to Charleston. Audubon, however, left the vessel at Savannah, in order to deliver letters from the Rathbones of Liverpool to a number of their rich merchant friends in the former city. One of these, named William Gaston, ${ }^{19}$ at first declined to subscribe to The Birds of America, on the ground of its great expense and the demands made upon his purse by charity, but his indifference was quickly overcome: not only did he write his name on Audubon's list, but he immediately went out and obtained three other subscribers; he even insisted on becoming Audubon's agent at Savannah, and saw to it that none of those subscriptions was ever allowed to lapse in after years. Savannah eventually gave him six subscribers, which was more than were credited to either Philadelphia or Baltimore.

At Charleston the party disbanded. Lehman returned to Philadelphia, whither Audubon later followed him, but Henry Ward obtained a position with the Museum of Natural History, in which Bachman was interested, and he appears to have been of much assistance both to Bachman and to his friend in procuring for them specimens of new or desirable birds and mammals; at a later day, however, he seems to have fallen into disesteem on account of unpaid debts.

${ }^{10}$ See "A Merchant of Savannah," Ornithological Biography (Bibl. No. 2), vol. ii, p. 549 . 


\section{CHAPTER XXVII}

\section{EASTERN VISIT AND EXPLORATIONS IN THE NORTH ATLANTIC}

Bachman's success as a canvasser-Boston visit-Journey to PortlandAscent of the St. John's-Return overland-Victor Audubon becomes his father's agent-Winter in Boston-The Golden Eagle-Stricken with illness-Expedition to Labrador planned-American supportSails from Eastport with five assistants-Discoveries and adventures on the Labrador-Safe return-Another winter at Charleston-Sued for old debts-Experience with vultures-Advice and instruction to a son-Working habits-Return to England.

Foiled in his attempt to see the Florida coast at the season best suited to his purposes, and disappointed in his ambition to penetrate to the Far West, Audubon now turned his attention to the East and determined to follow the migratory birds to their summer homes in the North Atlantic. He left Charleston in early June, 1832, and went to Philadelphia, ${ }^{1}$ where he remained about a month, waiting, it seems, for his wife and two sons to join him. In a letter to Edward Harris, dated at Philadelphia, June 9, 1832, he said that he had left the "National hotel, on account of the too high price, I found I would have to pay there, and removed to Camden, at a Mr.

${ }^{1}$ It was possibly during his visit to this city that an experiment was made in bringing out some of his plates by lithography. Two copies of a large plate, possibly the only one produced, lithographed without colors, were shown to me by Mr. Goodspeed, of Boston, in the summer of 1910; these represented the "Rallus crepitans-Marsh Hen," and bore the following legends: "By John J. Audubon, F.R.S., \&c., \&c.," and "Drawn \& Printed by Childs \& Inman, Philadelphia, 1832." Three birds are here figured in place of the two which appear in the plate of this species which Havell later engraved, and in composition the two publications are quite distinct. 
Armstrong's, where I formerly boarded"; he asked Harris to send him "a pair of fine woodchucks," as he wished to secure a drawing of those animals.

It is interesting to notice that while Audubon had been absent in Florida, his friend Bachman had busied himself in his behalf and eventually succeeded in placing three copies of The Birds of America in public institutions in Charleston. On December 23, 1831, he wrote to Audubon, who was then at St. Augustine:

I arrived in Columbia, S. C., almost too late, for the "House" had just resolved that the State was too poor to subscribe for Audubon's work. I felt that it would be a disgrace to the State; and, for the first time in my life, I turned to electioneering. And now, behold me among the back countrymen, spinning long yarns. The thing however, took, and your book is subscribed for. . . I I read what was said in your favor with regard to the "Rattlesnake Story," and thus far, they have not found a wrong twist in your yarn; but be careful in describing the wonders of the South and West.

Audubon wrote to Bachman from Philadelphia, July 1, 1832: "G. Ord has caused a most violent attack on my veracity to be inserted in a London journal; how will he stand mine eye, on Tuesday next at the Society, is more than I can at present tell. . . . Mr. Berthoud will ship you 3 volumes of the Birds of America, and the succeeding numbers; he will send a bill of sale of those."

His plan was now to visit Boston and Maine, and he left Philadelphia with his family in early August; they traveled by stage to New York, but upon finding that the city was then suffering from a periodic scourge of the cholera, tarried but a day and hastened on. The following letter which Richard Harlan sent after his 
friend in August of this year shows that his own city did not escape the pest:

\section{Richard Harlan to Auidubon}

[Addressed] J. J. Audubon Esqr.

No Pearle st.

Boston

DeAr Sir-

[PhiLAdelphta, August, 1832.]

I have just rec ${ }^{\text {d. }}$ your favour of the $5^{\text {th }}$ inst-by which I perceive you are not in possession of the letter I addressed you to the care of $M^{r}$ Berthoud, the day after your departure. I have since forwarded two others one from N. Orleans, also to care of $\mathrm{M}^{\mathrm{r}}$. Berthoud-The Cholera has raged dreadfully in some localities here-I was engaged on Monday superintending the removal of the sick prisoners from the jail in arch $\mathrm{S}^{\mathrm{t}}$. at the request of the City authorities-I was there three times during the day -60 were sick at one time, the suffering, and agony of the dying wretches, was an awful sight to witness, 26 died there that day, and about as many more who were removed to the various local Hospitals - I have treated altogether up to present date 35- of whom 18 from prison. 16 have diedand only one remains today-my success is rather encouraging considering the habits of the poor wretches whose cases fell under my care-most of the fatal cases were in a dying state when admitted-I would not have rec ${ }^{\mathrm{d}}$. them, but for the wish to alleviate suffering and scatter the tenants of the infected rooms of the jail-The Newspapers do not give an accurate account, because numbers are cured in the early stages whose cases are never reported - the statements of deaths are more accurate-and I suppose the greatest mortality has not exceeded 100 per diem-today only 26 deaths reported, there will probably be more tomorrow-I am happy to hear of yr. safe arrival and reception in Boston, in $\mathbf{M}^{\mathbf{r}}$ Perkins you will find an aimable, liberal, and efficient patron, $\mathrm{M}^{\mathrm{r}}$ Featherston [Featherstonhaugh] has been in town, but is at present at 
Braddywine springs - his may $\mathrm{N}^{0}$ has just appeared-he told me it would be in time to strike out Vignolas name-in the next $\mathrm{N}^{\mathrm{O}} \mathrm{My}$ term of duty as Surgeon to the alms House commenced at the $1^{\text {st }}$ of August-the sik for the surgical wards have also suffered, but not so much as the poor tenants of the cells, it has nearly cleaned them out-some respectable, but weakly families in the city have already suffered-My time is usefully, at least, if not profitably employed, night and day. cholera, cholera, cholera! ! ! !-Tho' I may have no time to write much-I always think of absent frd - Remember to Nuttall, and all yr. family,

Most truly yrs ,

\section{R HARLAN}

Audubon's visit to Boston in the summer of 1832 was a red-letter period in his career. So warmly was he then welcomed by the leading public and professional men of the city that he could never say enough in praise of the Bostonians. Dr. George Parkman, Dr. George C. Shattuck, and Col. Thomas H. Perkins, ${ }^{2}$ who was already one of his subscribers, were among his most enthusiastic supporters. Of Parkman Audubon said: "He it is, whose memory is most dear to me." It was doubtless Parkman, then a professor in the Medical School, who introduced Audubon to the president of Harvard University, Josiah Quincy, whose name was added to his list.

On August 14, shortly after reaching Boston, Audubon wrote to his friend Harris:

${ }^{2}$ In a letter written to Audubon by his engraver, January 20, 1831, Havell said: "Since writing my last, I have a new subscriber from America, the Honble. T. H. Perkins, Boston Athenæum. I packed it in a tin case, and a wooden one; for the whole I am paid thro. the banking house of the Baring Brothers, \& Co., Bishopsgate St."

The copy of The Birds of America in possession of the Boston Society of Natural History bears the following in autographic inscription on the fly-leaf of the first volume:

Cost $\$ 1125-$

T. H. Perkins

1837. 
We left Camden, pushed by the season, and the desire I have to fulfil towards my subscribers, the world, and indeed myself, the task allotted me by nature, - the completion of my work. ... Allow me to say that with my work, as in the days of 'r6, the Bostonians have proved themselves the best supporters of a good cause in the country. We expect the support of the Cambridge University, that of the Natural History Society, \& again of the State! (Pray remember how anxious we are to have all the States.)

I made drawings of 3 rare species; one is the Marsh Wren, for which I searched in vain when near Salem; the $2 \mathrm{~d}$. is a Flycatcher, described by Mr. Nuttall, and the last a Thrush.

We leave tomorrow for Portland, in Maine, through which we will merely pass, and ere one week expires, expect to be at the Bay of Fundy.

The Audubon family now traveled by carriage and mail-coach along the entire coast of Maine, but made no prolonged stay until they reached Eastport, where excursions were taken into the surrounding country, and the woods and shores were thoroughly ransacked. At Dennisville they made the acquaintance of Judge Lincoln's family, which rendered their stay of a number of weeks "exceedingly agreeable"; as will appear later, ${ }^{3}$ it was this agreeable family that furnished Audubon with a valuable recruit for his expedition to Labrador. Towards the end of September they entered New Brunswick and began to ascend the St. John's River. A week was passed at Fredericton, where they were hospitably received by Sir Archibald Campbell. Thence they continued in a small boat, which was towed upstream by mules, to Woodstock, Maine. There a cart was procured, in which they proceeded overland to Houlton, in Aroostook County, then "A neat village,

${ }^{3}$ See Vol. II, p. 43. 
consisting of some fifty houses," and after a few days passed at this garrison town in looking for new birds, they started for Bangor, following the old military road which led along the Penobscot River to Old Town. Said the ornithologist of this journey:

Autumn, with her mellow tints, her glowing fruits, and her rich fields of corn, smiled in placid beauty. Many of the fields had not been reaped; the fruits of the forests and orchards hung clustering around us, and as we came in view of the Penebscot river, our hearts thrilled with joy. ...

The road which we followed from Old Town to Bangor was literally covered with Penobscot Indians, returning from market. On reaching the latter beautiful town, we found very comfortable lodgings in an excellent hotel; and the next day we proceeded by the mail to Boston. ${ }^{4}$

Audubon felt that he ought to remain in America for at least another year, and decided to send his son, Victor, to England to take charge of his publication. This work had now become a paramount family interest, and for the nineteen years of life that remained to the elder Audubon, his two sons virtually became his assistants, John as an active collector and companion in the field, and Victor as his business agent and secretary. In writing again to Edward Harris, from Boston, November 1, 1832, Audubon noted that they had found the Canada Grouse in abundance, and that he was assured of its breeding commonly within the Union; Victor, he added, had sailed to England, "on the tenth of last month" on the packet ship South America.

The autumn of 1832 and the following winter were spent in Boston, where the naturalist was busily engaged in drawing and in laying plans for the now famous ex-

"See "Journey in New Brunswick and Maine," Ornithological Biography (Bibl. No. 2), vol. ii, p. 467. 
pedition to the coast of Labrador. Meantime Bachman, who was keenly interested in his success, was urging him to return to Charleston; on October 20, 1832, he wrote: "A month in your society would afford me greater pleasure than the highest prize in a lottery. I cannot, I find, feel myself at home with new birds without having the skins to refer to. My cabinet is enlarging every day. Henry Ward now prepares the skins-a pair of each. ... What ducks, that are not likely to be obtained for you in Boston, would you like Maria to draw for you?" Writing again on the 26th of October, he said: ${ }^{5}$

I wish to know what you are doing-what progress your work is making; and, whilst I feel deeply interested for your fame. ... I feel also a particular interest in your personal welfare, and that of all that belongs to you; . . . Besides, I want to see you once more to ascertain whether you have stuck to your good resolutions, viz., never to swear (which is a vulgar practice for one who is conversant with the most beautiful of God's works, the feathered race), and never to work on Sundays. However, you are now under the tutorage of your good wife, and, I doubt not, you are as obedient to her in these things, as you ought to be. ... Y You say new birds are scarce. So they are, and yet, in my opinion, we will occasionally find them for half a century to come. (November 11) Maria has figured for you the "White Hibiscus," and, also, a red one, both natives and beautiful; a Euonymus in seed, in which our Sylvia is placed; the white Nondescript Rose; the Gordonica, a Begonia. .... She is prepared to send them to you; shall she ship them at once to Boston? ... Y Your resolution to publish the $3 \mathrm{rd}$. Vol. of Water Birds, you will recollect was partly entered into here, and from that moment, my mind was at ease. It will give you four or five years in advance, and will enable you, in a 5th. Vol., to add all recent

'C. L. Bachman, John Bachman, D.D., LL.D., Ph.D. (Bibl. No. 191). 


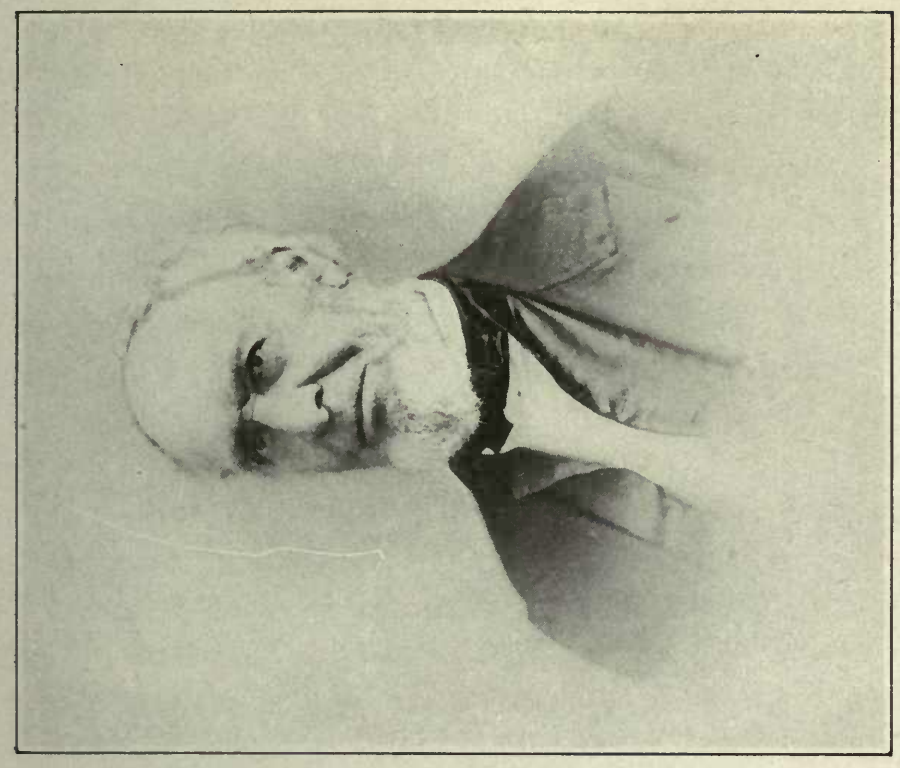

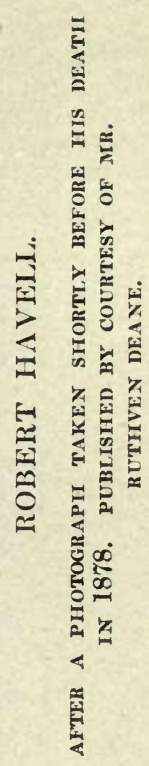
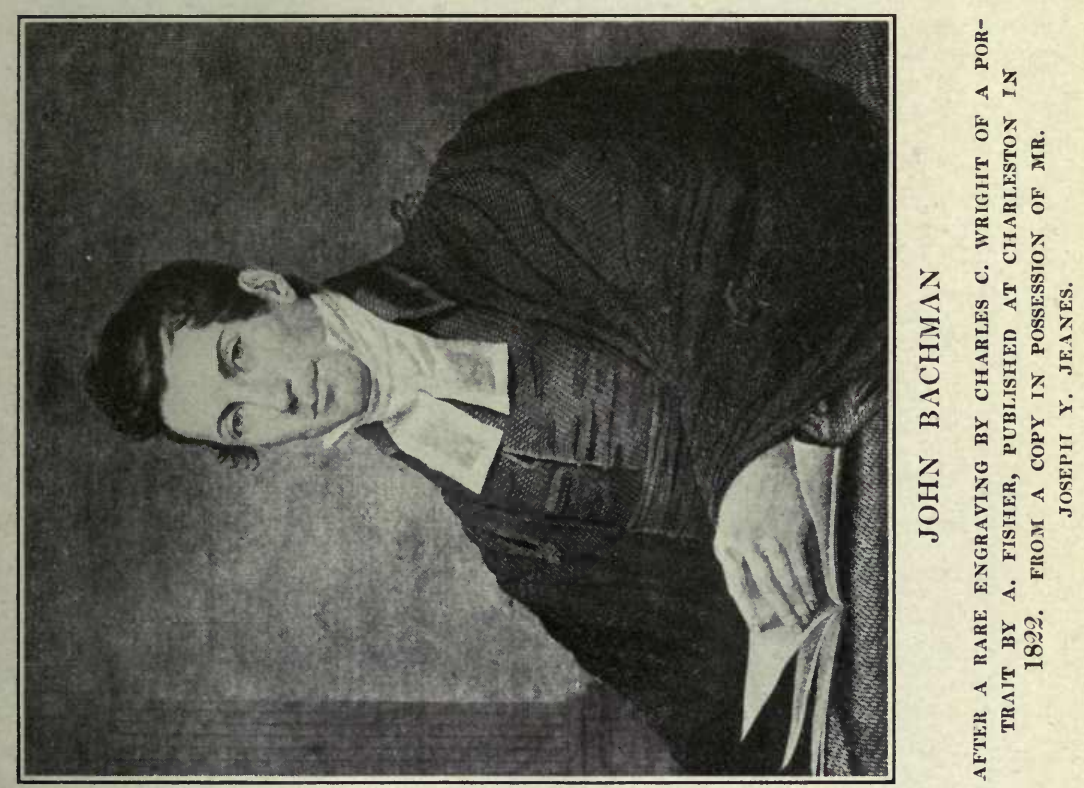

discoveries of Land and Water Birds. Should you, yet be able to go to Florida and the Pacific, I apprehend that you will extend our American Ornithology to 460 or 470 species, perhaps more. Your sons being able to skin birds and paint them, is a great desideratum; it should be mentioned in the preface to your next volume. The talents of the family combined. . . will now place the work beyond the fear of falling through, even in case of your death, and the public ought to know it. But you must push for subscribers. If your son Victor can do nothing in Europe, you must go there yourself, and sooner than let the work suffer, you must go on a pilgrimage throughout all the great cities of our Union. Should God spare your life, I want to hear of you enjoying, in your old age "Otium cum dignitate," and to see your children reaping some of your recompense.

Under date of December 20, 1832, his friend "had nothing to write but bad news," and hoped "to see our political atmosphere a little brighter. Do not ask me about birds; I do not know a Buzzard from a King Bird. Oh, what an enjoyment it would be for me to escape, just for one week, from the hydra-headed 'Nullification,' and sit by your side and talk birds!"

Audubon was anticipating his third volume of plates, devoted mainly to water birds, which was begun with Number 45, in 1834, when the following letter was sent to his son in London:

\section{'Au'dubon to his Son, Victor}

Bostor, Jany, 17 th, 1833-

MY dear Victor-

The Columbia arrived yesterday at New York, and N [icholas]. B [erthoud]. has forwarded us Mr. Havell's letter and yours, both dated 30 th. of November last- I hope soon to see the drawings to work on them-. You give no 
account of that of The Bartram Sandpiper and of The Spotted Sandpiper-; probably they have escaped you-let me know so that I may renew these should they be missing-, but I think my Friend Children has them-enquire-

The Charlotte is not yet in. She had not left Deal on the 2\%th of Nov r.-

Your Dear Mother \& John wrote to you this morning and you will probably receive this, and that letter at the same moment-.

We will keep all the half Bound Copies of Volume 1st. in America where I hope soon to dispose of them-go on and push the Work with care and all will be well-give our best regards to Havell \& his wife \& family-I had expected the Death of his Father ${ }^{6}$ sometimes-remembrances to our good friend Children, Cuthbutton \&c., \&c. I will be able to arrange 100 Drawings of Water Birds, ready, and in that finest of style for Publication-Tell Havell I will write to him in a very few Days, and to keep up a good Heart-I hope we will all meet early in the Spring of 1834-

God bless you my Dear Victor: employ your time well and [you] cannot fail being as Happy, at least as it is possible to be, far away from your Dear Mother, John \& Your ever affectionate Father \& Friend,

John J. Audubon

Send the Gun \& Drawing Paper of N-Largest \& Middle Size as quick as possible-

[Addressed] Victor G. Audubon Esqr., Care of

Robt. Havell, Esqr.,

Engraver,

77 Oxford Street,

London.

While at Boston in the winter of 1833, Audubon obtained from the proprietor of the New England $\mathrm{Mu}$ -

- For notice of Robert Havell, Senior, who died in 1832, see Vol. I, p. 382. 
seum, in Court Street, a superb specimen of the Golden Eagle, which had been caught in the White Mountains in a trap set for foxes. Possessed with a desire to depict this noble bird, he worked so hard at the drawing that, as he said, it nearly cost him his life; he was suddenly seized with "a spasmodic affection," which prostrated him for a time and greatly alarmed his family, but thanks to a strong constitution and to the aid of his medical friends, Doctors Parkman, Warren and Shattuck, the crisis was averted, and he was soon able to continue his labors. "The drawing of this Eagle," said the naturalist, "took me fourteen days, and I had never before laboured so incessantly excepting at that of the Wild Turkey." He was at work on this painting when the following letter ${ }^{7}$ was dispatched to his eldest son:

\section{Audubon to his Son, Victor}

\section{Bostor.}

F'eb. 5 th 1833.

MY DEAR FRIENDS

I am just now quite fatigued by the drawing of a Golden Eagle which although it will make a splendid plate has cost me sixty hours of the severest labor I have experienced since I drew the Wild Turkey. You shall I hope see it through the care of Mr. Gordon. ${ }^{8}$ Do not ever ship any more Nos. to this port unless on vessels that are intended as packets. The Charlotte has not come and it will be a rubber if $\mathrm{I}$ can get enough cash to establish our going to Labrador until she does. Push Jos. B. Kidd of Edinburgh if he can be pushed to paint copies of our drawings. I look on that series as of great importance to us all. Havell's blunder in not having the num-

${ }^{7}$ Originally published by Ruthren Deane (Bibl. No. 48), The Auk, vol. xxii, 1905.

- Alexander Gordon, who married Ann Bakewell, youngest sister of Mrs. Audubon. For notice of Jos. B. Kidd, mentioned below, see Vol. I, p. 446. 
bers and paper on board the New York in time, is one which, with him I can never correct. If you can do more than I on this score of punctuality I will be gratified. I shall proceed to New York as soon as the weather moderates, on Sunday last the thermom. was 12 below zero. The work is now I am assured free of duty. When you write give a word of recollection to Dr. Parkman who is a most desirable and worthy friend.

God bless you, forever yours

\section{J. J. Audubon.}

In the spring of 1833 Audubon was determined to carry out a long cherished desire to explore the coast of Labrador, where he hoped not only to discover many new birds, but to ascertain the summer plumages and breeding habits of a host of water fowl that were known to resort in the milder season to that stern and rockbound shore. Accordingly, he set about with characteristic energy to organize and finance an expedition upon his own responsibility. The number of his American subscribers was steadily increasing, and at that moment he felt a degree of confidence in the future of his work to hazard almost any undertaking. In April, when his plans were fixed, he went to New York to consult with his wife's brother-in-law and agent, Nicholas $\mathbf{A}$. Berthoud, and to settle his business affairs before leaving the country. While there he wrote the following long letter ${ }^{9}$ to his son, Victor, filled, as usual, with careful instructions and interesting personal details. It will be noticed that when he took pen in hand the number of his American subscribers stood at 51, but before he laid it down it had risen to 54 ; his belief that his efforts in the cause of natural science would receive a hearty response in his own country was fully justified.

- Originally published by George Bird Grinnell (Bibl. No. 54), The Auk, vol. xxxiii, 1916. 


\section{Audubon to his Son, Victor}

New York April 28th 1833-

My deAR Victor-

On opening the box containing the numbers last sent to this place for distribution, we found the contents Wet and of course some of them damaged. We have however dried them and made of them that could be done and they will all go on Monday (tomorrow) to their Several destinations-In future I recommend that Each parcel of numbers for the different individuals are rolled up in separate Parcel, inclosed in good stout brown Paper, and each directed outside, enumerating the numbers therein contained-then put all the Rolls in a Boxin this manner they all will be less liable to Injury, will not need to be undone here for we have no trouble at all at the Custom House, and it will Save the handling of the Plates at the Compting House.-

N. Berthoud rendered me his account yesterday I send you inclose a Copy of it-and I also send you a Copy of a general \& particular memorandum left with him, by the assistance of which the Business is clearly exhibited, so that each Subscriber's Standing with the Work Shows at once.-

The Balance in our favor in N. Berthoud's hands is $\$ 1358.91-W e$ have due South of this $\$ 1834.48$. and at Boston \$1220.00-altogether \$4413.39.-The Boston amount will be ready for me when I reach there on Thursday next. - I take from N. B's hands here $\$ 800: 00 .-300 \$$ of which I give to your Dear Mother-when at Boston I will take $500 \$$ more and send the Balance to $\mathrm{N}$. Berthoud-he will then have about \$1278.91 of cash out of which he will send you $100 £$ say $480 \$$ leaving still with him about $\$ 798.91$. besides what he will collect from the South the amount which is mentioned above, all of which I hope will be collected ere I return to this Place, as early as I can without losing the opportunity of doing all that can be done.

You will easily perceive by all this that we have been extremely fortunate of late on this Side of the Water, and the 
$400 £$ forwarded to you will fully enable you to meet the demands of Havell $\&^{c}$ for the 20 Volumes you have to send here \& other emergencies.-We have at Present 51 Subscribers in the U. States, without the name of Doc ${ }^{\mathbf{r}}$ Croghan from whom not a word has been heard, and also without that of Baron Krudener who is now at Washington City, but who has not taken any cognisance of the letter I sent him. N. Berthoud is going to write to him and I hope the Baron will take the work. - he certainly ought.

I found the Plates sent here better coloured than usual and with your present assistance I greatly hope the goodness of the Work will still improve.-Nicholas will forward you Two very beautiful Numbers - the Plates are as follows,

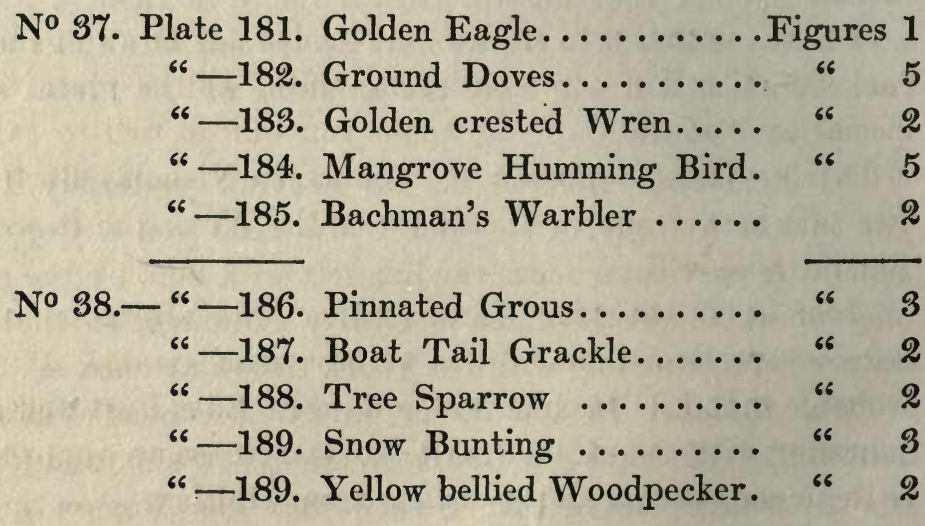

I should have sent you 2 more Numbers had I The Two large Plates for them, but hoping that I may meet with something Large \& perhaps New I Shall not do so, until I return which will be Still time enough.-I am very anxious to See the $2 \mathrm{~d}$ Volume finished and for this reason invite you to push the Work, as much as you can $\&$ have it very well executed meantime.

The State of Maryland is subscribed to by D. Ridgely M.D. Librarian of that State. he desires the $1^{\text {st }}$ Volume and the following numbers forwarded as soon as can be.-Send it here -as he has authorized N. B. to draw on him for Payment. - 
Miss Harriet Douglass also desires to have her Number sent here for the Future. I hope the Copies for $\mathrm{Co}^{\mathrm{l}}$ Perkins \& others at Boston \& vicinity, as well as for $\mathrm{W}^{\mathrm{m}}$ Oakes, \& John Neale will soon arrive.-

April $30^{\text {th }}$-Since the above, I have obtained Two more Subscribers - the names of whom are

1. Rich F. Carman. New York
1. L. Reed- Do Do.-

I was told last night that the State has also Subscribed, but cannot tell until I see this day's Paper-Whilst at the Lyceum of Natural History last evening, I was promised their Subscription on Monday next-being the Society's day of business.

I have concluded to send the 2 Numbers of Drawings by the Packett-The Tin case containing them, will be given to the special care of the $\mathrm{Cap}^{\mathrm{n}}$ on whom you will do well to call irhmediately. - I have given a $1^{\text {st }}$ Volume to Nicholas Berthoua ; there are many enquiries made to see the Work and it answers that purpose well.

John \& I leave for Boston either this afternoon or tomorrow-perhaps tomorrow as we have much to do.-It is not probable that Ed ${ }^{d}$ Harriss will join us at East Port and go to Labrador with us-I shall write to you at every opportunity as these may occur, and doubtless from Halifax.

$M^{r}$ Inman has painted my Portrait in Oil, and I say that it is a truer portrait of me than even the Miniature.-Now my Dear Victor exert yourself in the having all the Volumes compleated which I have written for-See that they are carefully packed with Paper between each $\&^{c} \&^{c} \&^{c}$ I shall not close this until I have given the Box to the $\mathrm{Cap}^{\mathrm{n}}$ and when I hope to add the Subscription of this State.-

2, o'clock-I have just returned from the bustle of the Lower part of the City-the State has Subscribed! Therefore add that valuable one. There is no Packet for London Tomorrow, therefore the Drawings will go off on the $10^{\text {th }}$ of May by the

$\operatorname{Cap}^{\mathrm{n}}$ in whose particular care they 
will be given. - These 10 Drawings have been insured this morning against all Risk, for $2,000 \$$ at $1 / 2$ per Centum-I hope you will receive them in perfect order; they are carefully packed by myself in a Tin Box securely sodered \&c $\&^{c}$.

We have now 54. Subscribers in America.

$M^{\mathbf{r}}$ Inman is going to Paint the Portrait of your Dear Mother, and I have not a doubt that it will be "good \& true." The Weather is extremely Warm-The Thermometer ranges at nearly 72. The Martins are flying over the City and Tomorrow I shall fly toward the Coast of Labrador-If fortunate I shall bring a load of Knowledge of the Water Birds which spend the Winter in our Country and May hope to Compete in the study of their Habits with any Man in the World.

My Good Friend Charles Bonaparte as (I am told) taken umbrage at a Passage in My Introduction (first Volume) ${ }^{10}$ Which proves how difficult it is to please every one-I am going to write to him by Duplicate to try to correct that Error of his-God ever bless You my Dear Son, and May We all meet Well \& Happy

Yours ever affectionately,

John J. Audubon.

Audubon was particularly anxious to enlist a number of enthusiastic young men in the Labrador enterprise, and had hoped that his friend, Edward Harris, would join the party. Upon his return to Boston he started at once for Eastport, Maine, where he expected to charter a vessel and complete his preparations. On May 9, 1833, he wrote to Harris from that point:

The more I approach the desired object of this voyage, the more bouyant my spirits, and the greater my hopes that when I return I will bring a cargo (not of codfish) but of most valuable information. Make up your mind; shoulder your firelock, and away to the fields where science awaits us with ample

${ }^{10}$ See Chapter XXIX, p. 118, and the letter which Audubon wrote to Bonaparte at this time. 
stores, the contents of which are the rarest materials ever employed by nature.

To this friend he wrote again from Eastport on the 14th of the same month:

As to my making use of your name in my letterpress, $I$ shall act as you desire, and yet I hope and fully expect no denial on your part, on such occasions as will grant me the pleasure of giving public notice of the treatment $I$ have received from you. I owe such a thing to you as a trifling, very trifling, mark of my gratitude towards one, whom I shall never cease to admire and esteem.

The National Gazette of Philadelphia for May 2, 1833, devoted an editorial to Audubon and his prospective Labrador journey, in which the writer said: "We wish him a degree of success and prolongation of vigor equal to his great merits: indeed, for the past at least, success is fully assured." He added that between fifty and sixty subscribers to The Birds of America had then been obtained in the United States; Boston had furnished eighteen; New York, eleven; Philadelphia, four; Baltimore, eight; Savannah, seven; Louisville, two, and New Orleans, three; moreover, the legislatures of Massachusetts, New York, Maryland and South Carolina and the Congressional Library were subscribers for one copy each. The writer continued:

A contribution to Mr. Audubon equal at least to that of Boston or New York, would seem due from Philadelphia. The subscription price may be considered as large $(\$ 1,000)$, but how rich, ornamental, instructive, and entertaining is the work, and how much preferable to the merely personal gewgaws or transitory gratifications, upon which greater sums are as frequently expended! There are few minds of any refinement or 
elevation, to which an act that rewards genius and fosters science, would not yield higher and more durable pleasure than any ordinary luxury.

We learn that Mr. Audubon will return to the United States next autumn, and make a short sojourn before his embarkation for Europe. Eight or nine more years, it is supposed, will yet be necessary for the consummation of his grand design. His constitution appears to be still vigorous; his zeal is unabated; his powers of graphic delineation have suffered no decay; we may, therefore, expect that he will realize all his own laudatory hopes and projects, and in so doing confer new obligations on the votaries of natural history, and reflect additional honor on his country.

While Audubon was still at Eastport, and looking anxiously for young recruits, the following letter was received from Dr. George Parkman: ${ }^{11}$

\section{Dr. George Parkman to Audubon}

\section{J. J. Audubon Esqr.}

Boston, May 25 th. 1833.

\section{Dear Sir}

Through the unceasing \& active good-will of our Friend, Dr. Shattuck, I present to you Mr. Ingalls, son of Dr. Ingalls, one of our senior physicians \& an experienced public teacher of Anat.y \& Surg y-

The son is the father's pupil; \& we have reason to expect that he will prove a satisfactory disciple to you.

The enclosed I claim for you the right to read, \& for myself to repossess, when we meet again.

$$
\text { respectfully }
$$

\section{G. Parkman.}

11 Most readers will doubtless recall that Dr. George Parkman was the victim of an almost unbelievable tragedy in 1849, when he met his death at the hands of a colleague; the entire country was then aroused as it seldom had been by an event in the annals of crime. 
Edward Harris was unable to accompany his friend, and the four young men eventually chosen were Joseph Coolidge, ${ }^{12}$ William Ingalls, of Boston, Thomas Lincoln, of Dennisville, Maine, and George Cheyne Shattuck, ${ }^{13}$ the son of Dr. George C. Shattuck of Boston; these, with John Woodhouse Audubon and the natural-

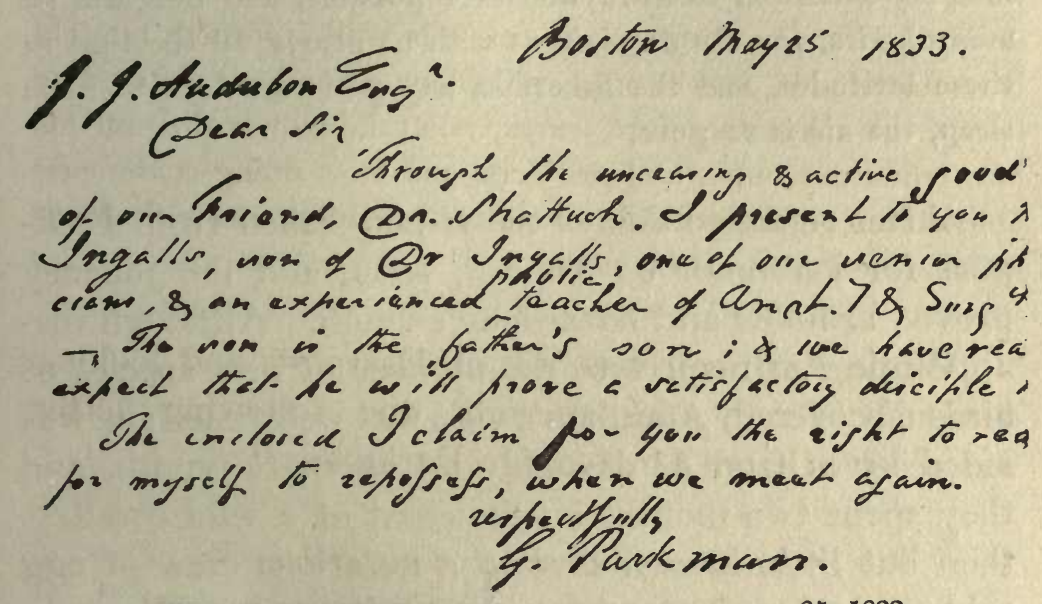

LETTER OF DR. GEORGE PARKMAN TO AUdUBON, MAY 25, 1833.

From the Howland MSS.

ist, made up the party. The schooner Ripley, a staunch new vessel of 106 tons, was chartered at Eastport, and the expedition was ready to start by the latter part of May. During his stay at Eastport Audubon visited Grand Manan Island, a favorite resort for sea birds in the Bay of Fundy, and cruised about the coast in a revenue cutter. On May 31, he wrote to Victor: ${ }^{14}$

${ }^{12}$ In $1897 \mathrm{Mr}$. Joseph Coolidge, who was then living in San Francisco, was the sole survivor of this expedition; see Maria R. Audubon, Audubon and his Journals (Bibl. No. 86), vol. i, p. 347.

${ }^{18}$ Dr. George Cheyne Shattuck, like his father a philanthropist, and an ardent patron of all good works, in 1855 planted a seed on the rocky soil of New Hampshire which has since shown a marvelous vitality; to him primarily, and to the revered schoolmasters, the fleverend Dr. Henry Augustus Coit and the Reverend Dr. Joseph Howland Coit, the world owes that great foundation, St. Paul's School.

${ }^{14}$ Maria R. Audubon, op. cit., vol. i, p. 346. 
I have been working hard at the Birds from Grand Menan, as well as John, who is overcoming his habit of sleeping late, as I call him every morning at four, and we have famous long days. ...

The hull of the vessel has been floored, and our great table solidly fixed in a tolerably good light under the main hatch; it is my intention to draw whenever possible, and that will be many hours, for the daylight is with us nearly all the time in those latitudes, and the fishermen say you can do with little sleep, the air is so pure.

After repeated delays the Ripley sailed from Eastport for Labrador on June 6, 1833, and the journey proved arduous and hazardous enough. Although disappointing in respect to the number of new species of birds discovered, Audubon's visit was well timed; he was aided by a band of devoted and energetic youth, and they spent two months on the coast of a wild country, then but little known save to a nefarious crew of egg robbers and a few enterprising fishermen. His published journal of the voyage shows that he worked to the full limit of his physical powers in studying and portraying the wonderful bird life which the party encountered. Despite the miseries of seasickness, an incompetent pilot, tempestuous weather, and the cramped quarters of a small schooner, where all his drawings had to be done under an open hatch, he accomplished wonders, considering the shortness of his stay. By rising at three o'clock in the morning and working for seventeen hours, he succeeded in completing many large drawings of birds, as well as studies of characteristic flowers; he also journalized voluminously and saw much of the coast and its adjacent islands.

From Eastport they passed through the Gut of Canso and steered for the Magdalen Islands, where they 
landed and made collections. On June 14 they approached the famous Bird Rock, which at a distance seemed to be covered with a mantle of new-fallen snow, an illusion soon dispelled as their vessel bore them nearer and a vast concourse of Gannets rose in great clouds from the rock; "all stood astonished and amazed," said Audubon, and he felt that such a sight had of itself fully repaid them for their journey. On June 17, the twelfth day out from Eastport, they passed Anticosti Island, and soon began to see what appeared like white sails on the horizon; these proved to be snow drifts on the Labrador, and on the 18th they landed at the mouth of the Natashquan River. Ducks, Geese, Auks and Guillemots were there in great multitudes, as well as Gulls and Terns; many were breeding, and all seemed wilder than at points farther south, a circumstance which was explained as soon as they discovered the astounding proportions which the traffic in eggs of sea fowl had attained even at that time. ${ }^{15}$

On June 27 they procured a new bird ${ }^{16}$ which Audubon named after his young companion, Thomas Lincoln of Dennisville, Maine, and which is still known as "Lincoln's Finch." This reference is found in his journal for the 4th of July: "I have drawn all day, and have finished the plate of the Fringilla lincolnii, to which I have put three plants of the country; to us they are very fitting to the purpose, for Lincoln gathered them."

The Ripley left its anchorage at American Harbor or Natashquan on June 28, and stood out to sea, their usual recourse to avoid the intricacies of the coast. After proceeding fifty miles or more they touched at numerous

${ }^{15}$ See "The Eggers of Labrador," Ornithological Biography (Bibl. No. 2), vol. iii, p. 82 .

${ }^{16}$ Lincoln's Finch, Fringella lincolnii, now Melospiza lincolni. 
islands, where Guillemots, Puffins, and Black-backed Gulls were breeding in vast numbers, and managed to anchor safely, in spite of that "ignorant ass" of a pilot, at a wild and desolate point which a recent traveler has identified as the harbor of Wapitagun. ${ }^{17}$ July the second was such a beautiful day for Labrador that Audubon went on shore, where he drew this vivid picture of that desolate land in sunshine: ${ }^{18}$

The country, so wild and grand, is of itself enough to in'terest any one in its wonderful dreariness. Its mossy, grayclothed rocks, heaped and thrown together as if by chance, in the most fantastical groups imaginable, huge masses hanging on minor ones as if about to roll themselves down from their doubtful-looking situations, into the depths of the sea beneath. Bays without end, sprinkled with rocky islands of all shapes and sizes, where in every fissure a Guillemot, a Cormorant, or some other wild bird retreats to secure its egg, and raise its young, or save itself from the hunter's pursuit. The peculiar cast of the sky, which never seems to be certain, butterflies flitting over snow-banks, probing beautiful dwarf flowerets of many hues [that are] pushing their tender stems from the thick bed of moss which everywhere covers the granite rocks. Then the morasses, wherein you plunge up to your knees, or the walking over the stubborn, dwarfish shrubbery, making one think that as he goes he treads down the forests of Labrador. The unexpected Bunting, or perhaps Sylvia, which perchance, and indeed as if by chance alone, you now and then see flying before you, or hear singing from the creeping plants of the ground. The beautiful fresh water lakes, on the ragged crests of greatly elevated islands, wherein the Red and Black-necked Divers swim as proudly as swans do in other latitudes, and where the fish appear to have been cast as 133 (1917).

${ }^{17}$ See Charles W. Townsend (Bibl. No. 234), The Auk, vol. xxxiv, p.

${ }^{18}$ Maria R. Audubon, op. cit., vol. i, p. 386. 


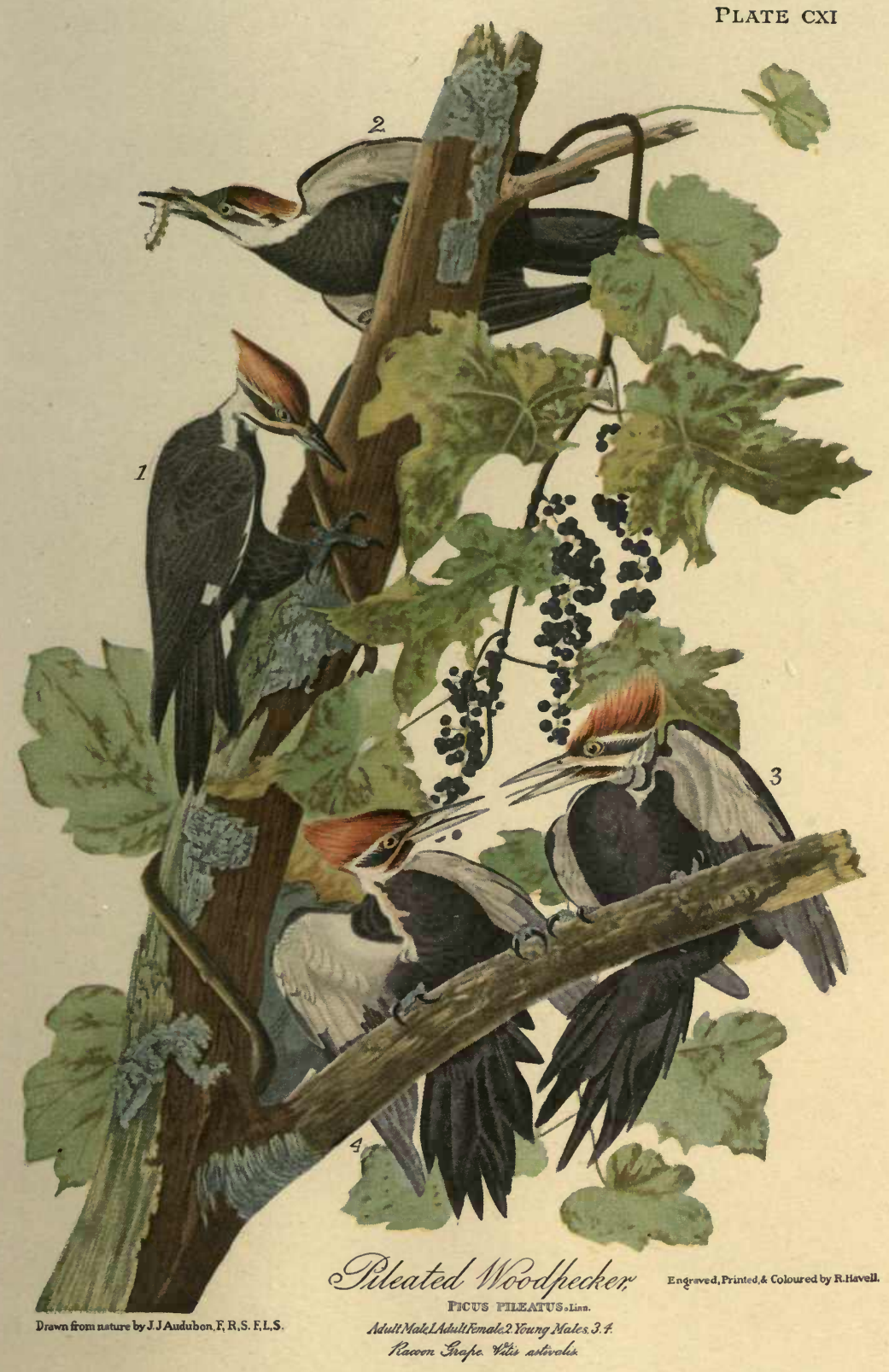



strayed beings from the surplus food of the ocean. All-all is wonderfully grand, wild-aye, and terrific. And yet how beautiful it is now, when one sees the wild bee, moving from one flower to another in search of food, which doubtless is as sweet to it, as the essence of the magnolia is to those of favored Louisiana. The little Ring Plover rearing its delicate and tender young, the Eider Duck swimming man-of-war-like amid her floating brood, like the guardship of a most valuable convoy; the White-crowned Bunting's sonorous note reaching the ear ever and anon; the crowds of sea-birds in search of places wherein to repose or to feed: how beautiful is all this in this wonderful rocky desert at this season, the beginning of July, compared with the horrid blasts of winter which here predominate by the will of God, when every rock is rendered smooth with snows so deep that every step the traveller takes is as if entering into his grave; for even should he escape an avalanche, his eye dreads to search the horizon, for full well does he know that snow,- - snow, is all that can be seen. I watched the Ring Plover for some time; the parents were so intent on saving their young that they both lay on the rocks as if shot, quivering their wings and dragging their bodies as if quite disabled. We left them and their young to the care of the Creator. I would not have shot one of the old ones, or taken one of the young for any consideration, and I was glad my young men were as forbearing.

On the 6 th of July he wrote: ${ }^{19}$

By dint of hard work and rising at three, I have drawn a Colymbus septemtrionalis [Great Northern Diver] and a young one, and nearly finished a Ptarmigan; this afternoon, however, at half-past five, my fingers could no longer hold my pencil, and I was forced to abandon my work and go ashore for exercise. The fact is that I am growing old too fast; alas! I feel it,-and yet work I will, and may God grant me life to see the last plate of my mammoth work finished.

${ }^{10}$ Ibid., p. 390. 
On the seventh there is this note:

Drawing all day; finished the female Grouse and five young, and prepared the male bird. The captain, John, and Lincoln, went off this afternoon with a view to camp on a bay about ten miles distant. Soon after, we had a change of weather, and, for a wonder, bright lightning and something like summer clouds. When fatigued with drawing I went on shore for exercise, and saw many pretty flowers, amongst them a flowering Sea-pea, quite rich in color. ... The mosquitoes quite as numerous as in Louisiana.

On July 14 the Ripley took the party forty-three miles farther east to Little Maccatina, or Hare Harbor, as it is called today, where they remained until July 21, proceeding thence to Baie de Portage. Here they were able to enter their small boats, and visited the captain of a whaling schooner from New Brunswick, a Canadian trapper, and a Scotchman, Samuel Robertson by name, who was engaged in the sealing industry at Sparr Point, all of whom Audubon pumped for information on the country and its products. On July 25, they started for "Chevalier's Settlement," but were caught in a storm, and came to in Bras d'Or (Bradore) Bay; there they found the Labrador Duck, which in 1875, but forty-two years later, had become totally extinct.

At the approach of August the brief Labrador summer, of barely one month, was drawing to a close, and Audubon was exerting his utmost efforts to accomplish his purposes. Under date of August 10 he wrote: ${ }^{20}$

My reason for not writing at night is that $I$ have been drawing so constantly, often seventeen hours a day, that the weariness of my body at night has been unprecedented, by such work at least. At times I felt as if my physical powers

${ }^{20}$ Ibid., p. 425. 
would abandon me; my neck, my shoulders, and, more than all, my fingers, were almost useless through actual fatigue at drawing. Who would believe this? Yet, nothing is more true. When at the return of dawn my spirits called me out of my berth, my body seemed to beg my mind to suffer it to rest a while longer; and as dark forced me to lay aside my brushes I immediately went to rest as if I had walked sixty-five miles that day, as I have done a fero times in my stronger days. Yesternight, when I rose from my little seat to contemplate my work and to judge of the effect of it compared with the nature which I had been attempting to copy, it was the affair of a moment; instead of waiting, as I always like to do, until the hazy darkness which is to me the best time to judge of the strength of light and shade, I went at once to rest as if delivered from the heaviest task $I$ ever performed. The young men think my fatigue is added to by the fact that I often work in wet clothes, but I have done that all my life with no ill effects. No! no! it is that I am no longer young. But I thank God that I did accomplish my task; my drawings are finished to the best of my ability, (and) the skins well prepared by John.

On the 11th of August all hands parted with Labrador without regret, and the captain of the Ripley steered for Newfoundland, where they landed in St. George's Harbor on the 13th. That region was searched for five days, when a fresh start was made for Pictou, Nova Scotia, but when they encountered head winds, Audubon and his party were landed on the nearest shore and made their way overland to the town. Thence they proceeded to Truro and Halifax, and after three days went on to Windsor, where they watched the famous tides in the Bay of Fundy-emptying and filling a broad river, and rising, in course, to a height of sixty-five feet. From that point a steamboat was taken to St. Johns, New Brunswick, where the faithful Harris awaited the naturalist with tidings of his wife and elder 
son; ${ }^{21}$ this intelligence induced him to abandon his contemplated course through the woods of Quebec and hasten back to the United States. The party finally reached Eastport on August 31, after being out nearly twelve weeks. When the Ripley had docked and their collections were securely packed, all but Coolidge and Lincoln returned to Boston, and on September 7 Audubon was again in New York.

The Labrador experience was in a measure disappointing, but the naturalist brought back twenty-three large drawings of birds, complete or nearly so, and seventy-three bird skins, as well as considerable collections of marine animals and plants. The expenses of the journey had been heavy, amounting, as he told his son, to "about $\$ 2,000$," but one fine morning when they had flushed a Black Poll Warbler from its nest, Audubon felt that he was amply "refunded in the sight," though this bird was later found to have a much wider breeding range than he then supposed.

The National Gazette of Philadelphia ${ }^{22}$ published a long editorial upon Audubon's return, as well as an extended account of his journey, extracted from the Boston Patriot. To quote the editor's comment:

The distinguished naturalist returned from his northeastern excursion to Boston Wednesday last. We believe that there is no one who will not be gratified to learn the progress of his arduous and unremitted labors in a branch of science, which he has made peculiarly his own; and he has kindly fa-

${ }^{21}$ As a memento of the Labrador experience, Audubon presented Harris with his pocket companion, The Genera of North American Birds and a Synopsis of the Species, by Charles Lucien Bonaparte (New York, 1828), and inscribed it as presented to his friend at "Eastport, Sept. 1, 1833." This volume, which saw much hard usage on this voyage and is filled with Audubon's manuscript notes, is now in possession of Mr. Joseph Y. Jeanes.

${ }^{22}$ For Tuesday, September 10, 1833. 
vored us with information on the subject of his recent tour, which we are glad to lay before our readers; regretting only that we are unable to present it in his own rich and animated language, and to invest it with the attractions which it would derive from his own descriptive powers.

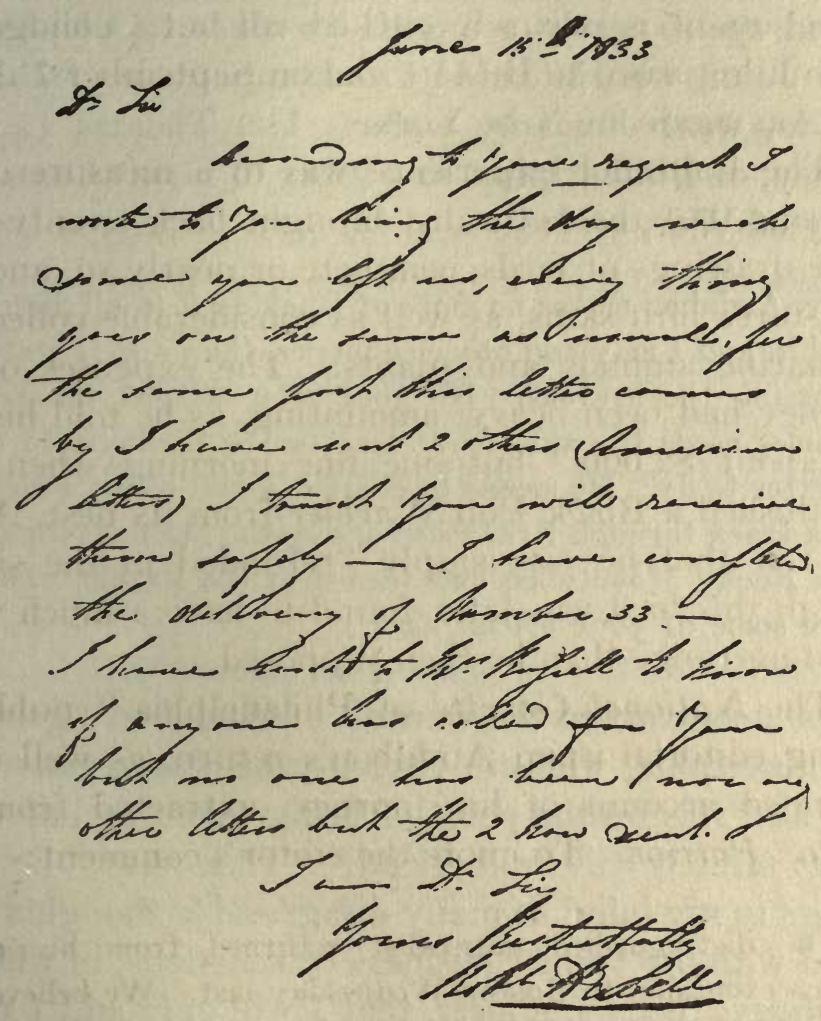

LETTER OF ROBERT HAVELL TO AUDUBON, JUNE 15, 1833.

From the Deane MSS.

While at Halifax Audubon received a congratulatory letter from Bachman, who urged him to visit Charleston and to bring his family. The invitation was accepted, and early in September Audubon returned to New York, where he immediately prepared the new drawings for dispatch to London; thirteen of the land 
birds were for the completion of his second volume, and seventeen, representing water fowl, were to form the initial series of the third; all, as usual, were heavily insured.

Audubon left New York with his wife on September 25 and spent nearly a month en route to Charleston, while John, who intended to accompany his father to Florida, went direct by water. Dr. Thomas L. McKenney, of Philadelphia, in a letter to Lewis Cass, Secretary of War, said: ${ }^{23}$

Mr. Audubon makes no more of tracking it in all directions over this, and I may add other countries, than a shot star does in crossing the heavens. He goes after winged things, but sometimes needs the aid of - at least a few feathers, to assist him better to fly. He means to coast it again round Floridamake a track through Arkansas-go up the Missouri-pass on to the Rocky Mountains, and thence to the Pacific. He will require some of your official aid.

As a contrast to the warmth of Audubon's greeting in Philadelphia, while in that city he was arrested for debt, and was on the point of being taken to jail when he was offered bail by a friend. "This event," he said, "brings to my mind so many disagreeable thoughts connected with my former business transactions, in which I was always the single loser, that I will only add I made all necessary arrangements to have it paid."

Four new subscribers were obtained at Baltimore, but when the naturalist applied to Secretary Cass at Washington for the privilege of accompanying an expedition to the Rocky Mountains under the patronage of the Government, he met with a cool reception, and

${ }^{23}$ Lucy Audubon, ed., Life of John James Audubon, the Naturalist (Bibl. No. 73), p. $37 \%$. 
though he had forgotten his letter from Dr. McKenney, he was resolved not to trouble that official further. At this juncture he met Washington Irving, who did his best to save the situation, and thought that Audubon had been mistaken in his judgment of the Secretary; "I might have been," he said, "but those eyes of mine have discovered more truth in men's eyes than their mouths were willing to acknowledge." Irving accompanied him to the offices of Mr. Taney, the Secretary of the Treasury, who at once gave the naturalist the privileges of the revenue cutter service on the southern coast.

At Richmond Audubon met Governor Floyd, who promised to try to induce the legislature of his State to subscribe for a copy of the Birds. From that point to Charleston we shall follow their itinerary as given in his journal under date of October 16: ${ }^{24}$

We left Richmond this morning in a stage well crammed with Italian musicians and southern merchants, arrived at Petersburg at a late hour, dined, and were again crammed in a car drawn by a locomotive, which dragged us twelve miles an hour, and sent out sparks of fire enough to keep us constantly busy in extinguishing them on our clothes. At Blakely we were again crammed into a stage, and dragged two miles an hour. We crossed the Roanoke River by torchlight in a flatboat, passed through Halifax, Raleigh, Fayetteville, and Columbia, where we spent the night. Here I met Dr. Gibbs, at whose house,we passed the evening, and who assisted me greatly; at his house I met President Thomas Cooper, who assured me he had seen a rattlesnake climb a five-rail fence on his land. I received from the treasury of the State four hundred and fifty dollars on account of its subscription for one copy of the "Birds of America."

24 Ibid., p. 379. 
For a number of years Audubon's snake stories had subjected him to no little ridicule in certain quarters, and this notice of a climbing rattlesnake pleased him so much that he asked the venerable president to put his statement in writing; he willingly complied, and his interesting letter on the subject will be given in a later chapter. ${ }^{25}$

When Audubon and his wife reached the Bachman home on October 24, he was prepared to push on to the South, but changed his plans, on account, he said, "of the removal of my good friend Captain Robert Day from his former station to New York, and I did not like to launch on the Florida reefs in the care of a young officer unknown to me." The winter of 1833-4 was passed under the hospitable rooftree of his friend, in the usual occupations of painting, writing and hunting birds. At this time an attachment sprang up between his younger son, John Woodhouse Audubon, and Maria Rebecca, the eldest daughter of the Bachman household. Here Audubon wrote the first drafts of many of the bird biographies contained in the second volume of his letterpress, and with Bachman conducted a series of careful experiments on the power of smell in vultures, in order to settle a question which had then become acute among naturalists. ${ }^{26}$ This subject is referred to in the following intimate letter, ${ }^{27}$ which reveals the confidence which Audubon felt in his sons and in their united ability to bring his great undertaking to a successful issue, as well as the infinite pains which he bestowed upon every part of it. Audubon, who was now in his fortyninth year, felt that he was aging very fast, and de-

${ }^{25}$ See Chapter XXVIII, p. 78.

${ }^{26}$ See ibid., p. 81. Audubon.

${ }^{27}$ Which I am able to reproduce through the kindness of Miss Maria $\mathbf{R}$. 
clared that one year then would be equal to three, three years from that time.

\section{Audubon to his Son, Victor}

Charleston, Dc., 24, 1833.

MY deAR BeLOVEd Victor:-

Your last letter to us is dated at London, 7 th. Octbr. It has given us all ample and sincere pleasure. The copy of your reply ${ }^{28}$ to Mons. Waterton is excellent; that from Swainson ought to prove a death-blow to the Demerara Gent! I hope that these letters are now before the world, for my mortification has been great enough respecting the blackguardism of G. Ord and others, and yet I am heartily glad that I never paid personally any attention to them through the press or otherwise. Here my friends are as much shocked as myself, and the moment is at hand when these T. . will be glad to find some hiding place to resort to, and wait for time to obliterate their obvious jealousy and falsehood.

John Bachman and myself have begun a second series of experiments, such as I made before, connected with the nosesmelling of Turkey Buzzards; as far as we have gone through them, these experiments have proved perfectly satisfactory to my good friend and myself, and depend [upon] it, from next Wednesday, the American World will know that Turkey Buzzards are first, Gregarious, as well as the Carrion Crow [Black Vulture], that they eat fresh meat in preference to putrid stuff; that they eat birds, fresh killed, either plucked or not, even of their oron species; that they suck birds' eggs, and devour their callow young; that they come to their food by their sense of sight, and not that of smell, and lastly that they cannot discover by any sense of smell the most putrid matter, even when this putrid stuff is within a few feet of them, out of sight of their eyes. Were Snakes as abundant near

${ }^{28}$ The reference is to Victor G. Audubon's second article in defense of his father, which appeared in Loudon's Magazine of Natural History (see Bibliography, No. 118). Swainson's paper, under the same title (see Bibliography, No. 117), was published in the same number. 
Charleston as Buzzards, that business would soon be also set at rest, but for this, however, time is required, and the time I think will come. The experiments we are making will be repeated in the presence of the faculty of this city, ${ }^{29}$ and their Certificates attached to the whole, and immediately published in the Annals of the Philosophical Society of Phila. ${ }^{30}$ those of the Lyceum of New York. A copy will be sent to be read at the Linnean, or Royal Society of London, and Royal Institute of France; then let those laugh who win. We have attracted Turkey Buzzards with pieces of fresh beef, not more than an inch square, and we have seen others pass unnoticed the body of a hare or fowl within 20 steps. We have now 3 fine birds of this species to experiment upon, and their olfactory nerves will be examined by the faculty here, where there are some highly talented men.

Our friend Bachman has written a very fine paper for Loudon's Mag. ${ }^{31}$ which will be forwarded to you in a few days by duplicate, and which I wish you to give to our friend J. G. Children, and ask him to have it read at the R. and L. Societies, and inserted in the above mentioned Mag. afterwards. We hope all this will be accomplished by the 1 st. March next.

Now to other subjects. We are deeply at work. John has drawn a few Birds, as good as any $I$ ever made, and in a few months I hope to give this department of my duty up to him

${ }^{20}$ For an account of this discussion see Chapter XXVIII, where the memorial drawn up and signed by the faculty of the Medical College of South Carolina is reproduced.

${ }^{30}$ When in New York, awaiting the sailing of his vessel, in April, 1834, Audubon referred to Bachman's paper on the Turkey Buzzard in writing to Miss Maria Martin, as follows: "At Phila., Mr. Lee and Docr. Hays managed to have it not read at Philosoph. Socy, but the Lyceum of New York, after reading it, have sent it to Professor Silliman, in whose Journal it will appear. John Bachman may consider himself a member of the Lyceum of New York, and 'mayhap,' a fellow of the Linnean Society of London." Bachman's paper was actually published in the Journal of the Boston Society of Natural History for 1834; see Bibliography, No. 125.

"This paper, entitled "Remarks in Defense of [Mr. Audubon] the author of the Birds of America," was published in volume vii of Loudon's Magazine of Natural History for 1834, and is dated "Charleston, Dec. 31, 1833"; see Bibliography, No. 124. 
altogether; his improvements on other subjects are equally pleasing. I write a [biography of a] Bird or so every evening, and our friend grants me all his knowledge of the habits of those with which he has become well acquainted, belonging to this part of the Union. I have nearly one 100 drawings of Water Birds ready for publication \& I pronounce them equal to any previous ones. I am much pleased at the news you give me respecting Havell; I hope he will continue with hand and heart to do all in his power for the fame of our work, and for himself. We have not seen Nos. 34, 35, tho. from your letter we suppose them to be in New York. Wm. Oakes, I have written you, has paid all, up to No. 33; Arnold, of New Bedford, for all he has had; John Neal has his copy, but I do not know if he has yet paid Dr. Parkman, who is our kind friend and agent in that part of the Country. I wish you had forwarded first volumes bound, as you had those on hand, as several would have been disposed of and paid for by this time; do send all, or whatever of them you have ready, as soon as possible. It will be well for you to have friend Bachm's. paper published in toto, in some good circulating paper in London \& Edinboro. Brushes! Brushes! Brushes! I am glad to hear of Kidd \& Co.'s publication of Parrots, but I regret that my face should have been there from Syme's picture, which in my estimation is none of the best. Push Kidd with the pictures; have them, and take care of them. Sell all the Shells you please; write to John Adamson, of New Castle, about them, but keep smug all the Bird Skins. I cannot do without them when I write my Synopsis, which will be when $I$ am with you. Our voyage round the Floridas, Gulph Mexico \&c. will begin about the 1st. February. This will be my last journey, after which John and I will hunt for Subscribers, procure a round number, and join you as soon as possible. Your dear Mama will in all probability join you in May or June next. In about a fortnight I shall send you more land Birds for the end of the $2 \mathrm{~d}$. volume, extra small plates, and several numbers of Water Birds. I am anxious to hear something about the little edition. Do not omit to let me know when you want money, for tho. our expenses are always 
great, the Work must not, and shall not suffer, as long as my eyes and hands can work.

Dec. $23 \mathrm{~d}$., last evening, we had the pleasure of yours of the 28 Oct, and one from Havell of the 9 th. Regarding Havell, we are glad that all is well with him, and hope he will not trouble us about extra prices, not even for the Water Birds. The safe arrival of my last drawings has relieved me of that anxiety. You are quite right on the score of advice. You in England, will do best to act as you may think proper. We, in America, are trying to do equally well, and our little Alliance is as efficient as the Holy one at least. That Subscribers should die is an event we cannot help; that such fellows as V. should act so cannot be controlled, but depend upon our industry, our truth, and the regular manner in which we publish our work; this will always prove to the world and to our Patrons that nothing more can be done than what we do; nay, I doubt if any family, with our pecuniary means, ever will raise for themselves such a monument as the "Birds of America" is, over their tomb.

How comes it that Harlan has not money enough to pay his expenses in Europe? I shall remember the $20 \mathrm{f}$, and the exchange. Chamley, of New Castle, was never prompt pay; indeed, my dear Victor, were you fully acquainted with the great difficulties which I had to surmount and did surmount, it would give you less fear than you now feel or experience. We shall be glad to receive the Brushes that are, I hope, now under way for us. Mr. Miesson resides [at] No. 2 Rue Pigalle, on the east side of the grand Boulevards. Present my regards to Mr. Yarrell, and thank him in my name for his kind offer of eggs, and add that I shall have it in my power to present him with many which I think he has not found, that our two collections will most likely comprise the whole of those published in my 4 volumes. I fear that to give the eggs in the $2 \mathrm{~d}$.' of Biography would render that volume too large, and again too costly, and that a few plates of eggs at the end of the large work will answer better. ${ }^{32}$ The plates ought to

${ }^{32}$ See Note, Vol. I, p. 426. 
be insured for at least 4 or 5 times the cost, for should they by an accident be destroyed, the amount of their cost would prove a poor remuneration, when compared with the time it would require to have them renewed. Attend to this as soon as you can. Henry Ward has rendered himself very obnoxious here. a letter came to Mr. B. on last evening from St. Augustine, to inquire how a certain amount left by him unpaid was to be settled. Mr. Bachman will inform you of the particulars.

Do forward the bound volumes as soon as possible, for with them I could at once make you a considerable remittance, which would enable you to prepare the Nos. of the 2d. Vol. for those who do not wish to have it complete. I am trying to receive some money on Act. of the $2 \mathrm{~d}$. Vol. through the mediums of Dr. Parkman, N. Berthoud, John Bellonis, Wm. Gaston, and will let you know the result. The Plate .... which you sent me is extremely well engraved, but let us keep to Havell as long as he behaves with propriety, and does good work.

I have now replied to your letter fully, except on what you say about my immediate return. The following are my views, but if after all, you say-come on, $I$ shall do so. Our country is becoming more wealthy every day. Science is looked upon with more congeniality every year. Subscribers in this Dear Country of ours do not drop off unless they die. They pay punctually on demand, and to have more of them in this land than in Europe is a thing that may prove of the greatest importance to us. When I visited our woods on my first return from England, I was absent about 12 months. The Rathbones and Mr. Children wrote to me many times to return, or expect the work to fall. I went back to Europe before I was ready to go, and on my arrival there, to my surprise and joy, I found everything going on as well as usual; but $I$ was again obliged to come to our Country to renew my researches, and improve my head, as well as my collection of drawings. I had then left no one like you in England. Now you, my Dear Son, are there; thank God for it! You prove to be a better man at carrying on the publication than myself, and to tell you 
more, I doubt if I could procure more subscribers there than yourself. I am truly desirous for your sake, and that of your dear Mother and Brother, to do all in my power for the completion of this great work. I wish to finish here all that is to be done both in the way of drawing, and increase of knowledge, in black and rehite, and also in Patrons, as much as possible, ere I return to Europe, where, when I do go, I must remain several years, if not until the completion of the engraving. I am growing old very fast; in 3 or 4 years my career as a traveller will be ended, and should I be obliged to renew my fieldlabours, it is doubtful if my constitution could bear it. One year now is equal to 3,3 years hence. I receive much assistance from the Government, and have John to accompany me. I am still able to undergo some fatigue, and, as I have said, I am anxious, very anxious, to do all that can be done ere I return to Europe. Now the whole time which I conceive necessary to enable me to perform these desideratums cannot exceed 12 or 15 months. What pleasure it would be to us all, when I take your hand and press you to my heart, I should also have a list of 100 new names from America!; all the drawings and the manuscripts ready for the completion of this our wonderful undertaking. I would advise you to address a circular letter to all those who may be concerned in Europe, to acquaint them with what $I$ call the necessity of my being in America, for the sole purpose of increasing the value of our publications, either Illustrative or graphical. This, and the constant improvement now exhibited to them with each new number of the work, could not fail, I think, to render them quiet, if not pleased, that I am now doing all I can for the advantage of the work. Tell them the facts, that $I$ have greatly added to the Ornithology of the United States since my absence from Europe, that the number of species which I now have, and that are not given by Wilson or Bonaparte, combined, amounts to nearly one hundred, and that the Water Birds will be fully equal in point of interest and beauty, to any of the land Birds that are published. And, not the least part of this, my remaining in America has already [given], and will con- 
tinue, to give me the power of portraying the habits of the Water Birds with more truth and completeness than has ever yet been done. Next, have extracts of my letter to you, before the world's eye, through the medium of Papers. Visit such of our friends, and ask them to say those things to their acquaintance; go on yourself, as you have done, and depend upon it, we shall all be greatly benefitted. In your most kind letter to John you mention with unexampled modesty what you are attempting to do in the way of self-improvement, but my Dear Victor, you cannot convey more thoroughly to us the march of your improvement than you have done by sending your letters, and the result of your actions, so well delineated as this is, and we all feel deeply gratified and most happy. Cruickshank is right; by drawing you are enabled to study the lights and shadows of bodies, again the beautiful mellowness with which, altho. all powerful in the effect, these blend themselves with each other. The reflective power of bodies will also strike your discerning attention, and when these combinations of the true Materia are well understood, the artist is a Master! Nature after all, has done all for us; she groups, and most beautifully, every thing that is presented to our eye or mind, so completely also, that if one observes a number of bodies, no matter what these bodies are, whether horses or apes, he sees at once the general elegance of their arrangement in contour, the force of the light and shadows, the mellowness existing between these, and as the eye passes on to the finishing of that natural picture, it at once pronounces it complete.

Do not forget to take from Kidd whatever pictures of ours he may have finished, and take good care of them. We have pretty nearly kilt G. Ord and Waterton with our Buzzard experiments. You say you wish you could see us at friend Bachman's; I assure you my pleasure at such an event would be equal to yours. We are indeed happy in having such a friend. Miss Martin, with her superior talents, assists us greatly in the way of drawing; the insects she has drawn are, perhaps, the best I've seen; at night we have some music and reading. 
When you receive Bird Skins, perhaps it would be as well to form a collection of each species in pairs, and variety of age or color.

24. Dec. We have just received yours of 18 th. October. You are, my Dear Son, too low spirited respecting my immediate appearance in England. Cheer up, my beloved Victor! Believe me, when I repeat that our own Dear Country will support the efforts of us all, and will grant us more Patrons than the whole of Europe together; by the way of a nightcap, let me give you the name of Wm. J. Rees, of Sumpter district, Statesbury, South Carolina, who put his name to my list this afternoon at the moment when the Vultures lost their olfactory powers, for I daubed the imitation of a sheep, and the very first one that passed over the picture rounded and came to it.

Respecting Kidd, and his prospectus, depend upon it, nothing is to be feared from that quarter; that work is dead at the moment I rorite, and as to his publishing the intention of the pictures, it signifies nothing. All you have to do is to take all the pictures from him, by goodwill or otherwise, and give him no more originals to copy.

If $I$ regret anything at this moment, it is that you should have kept the 20 volumes in London, when, if I had them in America, I should at once be enabled to make you a valuable remittance. Ship them, ensured, as fast as possible, and doubt not my disposing of them. Lewis Atterbury writes me to night that all the numbers 34,35 , which Havell has shipped, are injured greatly by salt water. I do not know yet if they were insured or not. I write to him this evening. Do not ship anything without insurance; it is better to lose time in this case than money. I will write again in a few days, and I shall forward you Water Birds in good time. God bless you, my dear fellow; keep up your spirits, and again may God bless you.

Ever your affectionate father,

$$
\text { J. J. Audubon. }
$$

Honest John Bachman, who had lived and worked 
with Audubon for months at a time, and who probably knew him better than did any one in America outside of the naturalist's own family, gave this account of his habits in 1834, when, at the age of forty-nine, he was still working at his best:

He rises at the earliest dawn, and devotes the whole of the day, in intense industry, to his favourite pursuit. The specimens from which he makes his drawings are all from nature; carefully noting the colors of the eye, bill, and legs; measuring, with great accuracy, every part of the bird. When differences exist, either in the sexes or young, several figures are given on the same plate; sparing no labour in retouching old drawings or in making new ones, in all cases where he conceives there may be a possibility of making an improvement. In this way, he has already succeeded in figuring nearly the whole of the birds necessary to complete his splendid and important work.

He keeps a journal, and regularly notes down every thing connected with natural history. This journal is always kept in English: a language which, it must be acknowledged he writes very correctly, when it is taken into consideration that he spent nearly the first seventeen years of his life in France. Besides this, he keeps separate journals, in which he notes every thing that he learns each day on the habits of every bird. In all his travels, he carries these journals with him; and he never suffers business, fatigue, or pleasure to prevent him each evening from noting down every interesting observation. In this way, a mass of information has been accumulated from year to year. When he sits down to write the history of a bird (which is usually in the evening), he first reads over all the memoranda which he has made with regard to its habits and he is generally able to write an interesting paper on the subject in the course of an evening. At some leisure moment this is again revised and corrected: the scientific details he leaves to the last. 
Early in March, 1834, Audubon left his friends in Charleston, and with his wife and son passed northward to Washington and Baltimore. From the latter city, on March 9, he wrote to Edward Harris, in part as follows:

Friends such as you have been, and are still, are the only recompense such poor individuals such as I am can enjoy in this world, and the more valued as they are so very rare.

We came from Charleston by land to Norfolk; thence to Washington City by steamer in 20 hours, and in 8 to the city here, well fatigued but safely. .... At Washington, where we remained only an hour, Col. J. Abert told me something connected with the climbing of Rattlesnakes upon trees \&c. that will make your mouth water, and your generous heart leap with joy, when you read [about] them, which you shall do ere long, I give you my word for it.

Audubon was still in Baltimore on March 15, for on that day he gave Harris a letter of introduction to Edward Everett. New York was reached in April, when he wrote to Bachman that they had secured berths in "that fine packet ship the North America," which was to sail on the tenth of that month.

Toward the close of Audubon's Charleston visit he had an unpleasant experience; he was sued for an old debt, which no doubt dated from his Henderson period and the failure of his mill in 1819. ${ }^{33}$ Apparently the case was carried into court, where the naturalist was defended by a lawyer named Dunkin, who, if my inference is correct, later became a distinguished judge and Chief Justice of the Supreme Court ${ }^{34}$ of South Carolina. The incident was referred to by Audubon in letters written from New York at this time; on

See Vol. I, p. 260.

see Audubon's statement of the case, given in Note 18, Vol. I, p. 260. 


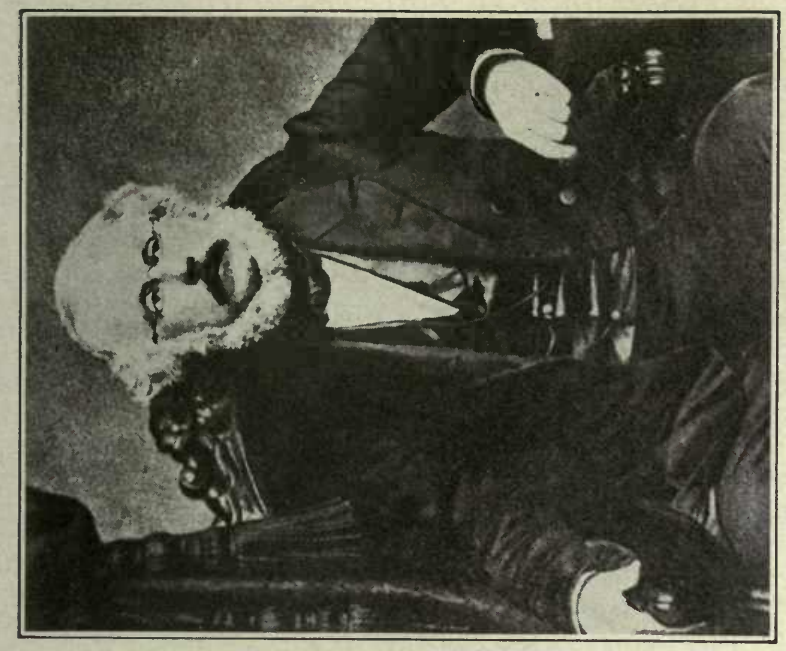

\}?

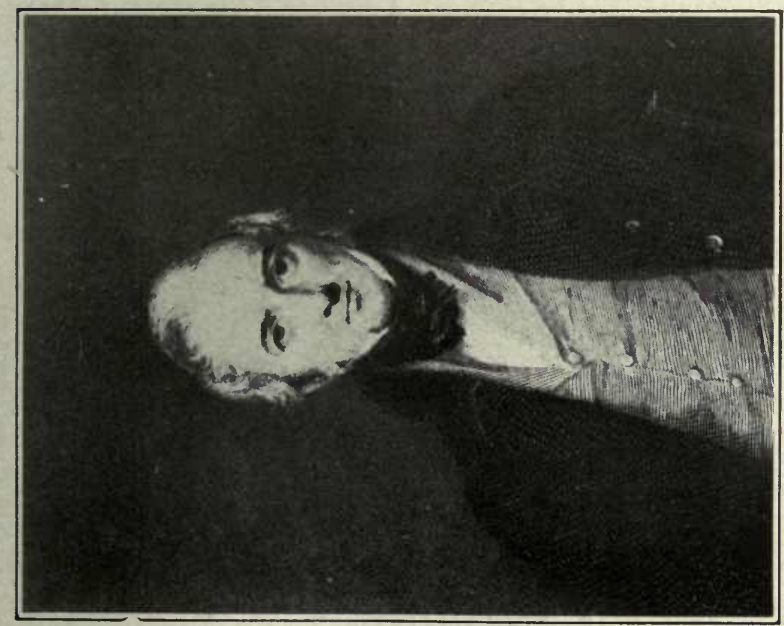

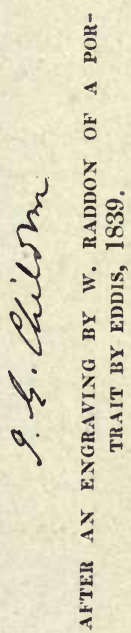



April 6, he wrote to Miss Maria Martin as follows:

I told friend Bach. in my letter of yesterday that I knew nothing of Mr. Pettigrue, connected with my business at Charleston, and that if that gentleman had presented himself before the court, it must have been for charity's sake; indeed, from the conversations that passed between Friend B. \& I respecting Mr. Dunker [Dunkin], it would have been absurd in me to think for a moment of employing any other person than Mr. D.

In the letter just quoted Audubon said also that he had spent all of the morning of the previous day in going from shop to shop with friend Harris to procure some models for "the dear girls," but in vain; New York with its two hundred and fifty thousand souls, possessed but two drawing masters; "these instruct in 3 months," he added, "and starve for the nine of the year." In reference to financial matters, he said that he had managed to collect about $£ 600$ sterling, and had sent 500 to Victor in bills of exchange, so that when they reached London, they would be tolerably well off, considering that they were "naturalists from the wilds of America." "Nothing starts the blues so effectually," he continued, as "constant unemployment; for myself who have done next to nothing since I left you, have had horrors all around me; dreams of sinking and burning ships at night, fears of lost drawings, \& failures of subscribers by day, have ever and anon been my companions." "Victor," he added, "has sent 6 boxes of pills, which will be divided into 3 parts, the largest for G. Ord."

The Audubons finally sailed from New York on April 16, 1834. On the preceding day the naturalist sent his friend, Edward Harris, a parting letter, in which he said: 
To tell you that I am surprised at your generous conduct in remitting to me Four hundred, Ninety dollars in advance, for all the numbers of my book, would be a poor gratification to me. I feel your generosity, and I cannot say any more. God bless you.

Nos. $36 \& 37$ have reached this place; my drawings shipped from Charleston are safely in the hands of Victor at London. I have been able to forward him $650 £$, and I have 30 sovereigns to defray our expenses from Liverpool to the Great Metropolis. In 1824, poor J. had dreams, but how far was I then from believing that I should ever have succeeded as I have; who will believe my story? Only one or two besides yourself, have an Idea of what I have undergone, but, if God grants me life, I shall publish that story, and send you the sheets thereof, as they are struck by the printer.

Audubon took with him to England all the collections which he had accumulated during nearly three years of travel and search in different parts of the United States and the British possessions. During this eventful period he had renewed one hundred of his older drawings, executed many new ones, discovered new birds, extended his acquaintance, and added sixty-two names to his list of patrons.

After they had reached Liverpool, he wrote to Bachman, May 8, 1834, that they had returned on the "superb packet of 650 tons, called the North America, commanded by an admirable gentleman, named Dixie of Philadelphia"; the voyage was made in not quite twenty days. A little later they joined their son, Victor, in London. 


\section{CHAPTER XXVIII}

\section{THORNS ON THE ROSE}

Contributions to magazines-Attacked in Philadelphia-Statement to Sully-The rattlesnake episode-Behavior of a Philadelphia editorMistaken identity in account of the reptile-Lesson of the serpent's tooth-Audubon's long lost lily rediscovered-"Nosarians and AntiNosarians"-Bachman and Audubon on vultures-Aim of the criticsAuthorship in the Biography-His most persistent heckler-Pitfall of analogy.

We have seen that John James Audubon had attended the school of adversity many years before he was known to the public in either America or Europe. The difficulties inseparable from such colossal undertakings as that in which he engaged were well nigh insuperable; but to these were added others which perhaps might have been avoided but which could hardly have been foreseen. From the moment he began to write for publication, he was bitterly and persistently assailed by a number of detractors, who seemed bent upon ruining his reputation and thus undermining the work to which he was devoting his life and upon which he depended as a means of support.

Were no worthy purpose to be served, it would be folly to resurrect the animosities of a past generation, but since a few "fed fat the ancient grudge they bore him," and since this hostility, handed down through the years, is occasionally echoed at the present day, the impartial historian is left no choice; he must weigh the merits of the case to the best of his ability. The reader, I think, will find that the law of compensation has 
worked fairly well in respect to all these matters, for if Audubon possessed faults, he was not lacking in merits; if he was assailed by a few bitter enemies, he was supported by a host of judicious friends.

As soon as Audubon became known in England, he was importuned to contribute to the scientific magazines, and in response to this demand wrote five articles, which were published in Edinburgh and London in 1827. Some of these papers, which dealt with the habits of the Turkey Vulture, the Alligator, the Carrion Crow or Black Vulture, the Wild Pigeon, and the Rattlesnake, ${ }^{1}$ were roundly scored in the Philadelphia press, and Audubon was called a romancer of the first order. Thomas Sully, the artist, who was then living in that city and who had taken a deep interest in the naturalist since their meeting in 1824, wrote in November, 1827, and told him what had occurred. Since Audubon's reply was practically the only answer which he ever made to attacks of this sort, and since his friend was given permission to make such use of it as he saw fit, we shall reproduce this letter nearly entire. ${ }^{2}$ In writing to his wife on the same day Audubon said: "Now my Lucy, I am going to answer Sully's letter; it is no difficult task, so far as truth be connected with my answer, but as regards my feelings it is perhaps the severest one I have had to encounter for many years."

\section{Audubon to Thomas Sully}

My dear Mr. Sully:-

LiverpooL, Decr 22, 1827.

I received from your truly friendly letter of the 7 th. of November the long wished for intelligence that you and your

${ }^{1}$ See Bibliography, Nos. 17-21.

${ }^{2}$ For this privilege I am indebted to Miss Maria R. Audubon. 
family were well. I am not much astonished that in Philadelphia, remarks such as you allude to, should have been made respecting some papers on the habits of objects of Natural History, read by me to different institutions in this country, but I am grieved at it.

The greatest portion of my life has been devotedly spent in the active investigation of Nature, her beauties \& her objects in granting to different individuals, classes, or species, such privileges as best suit their form, situation, or habits. This arduous task I have followed with unremitting diligence, and with a degree of industry that has caused to my family and to myself more troubles than any person in Philadelphia can be aware of. For more than 20 years $I$ have been in the regular habit of writing down every day all the incidents of which I have been an eye-roitness, on the spot, \& without confiding to my memory, as many travellers have done and still do. You have read some portion of this journal, and have also been an eye-witness of many of the occurrences, and to this I now owe the gratification of possessing your esteem, but, My dear Mr. Sully, you are not the only evidence. Mr. Joseph Mason, who is now, I believe, an artist in your city, accompanied me on a hunting excursion, beginning at Cincinati, and ending in the State of Louisiana, which lasted 18 months. He drew with me; he was my daily companion, and we both rolled ourseives together on bufaloe robes at night. James Cummings, Esq., past captain, the author of a treatise on the navigation of the rivers Ohio and Mississippi, was one of the party, and he saw me write in my Journal, and read it frequently. Every member of my family has seen the whole of those Diaries and could readily assert the truth of the whole of their contents, to many of which they were party, present and acting.

The papers alluded to in your estimable letter, are merely copies from those journals; they were transcribed in Edinburgh, and the style corrected by patrons, who saw the originals, nearly worn out by time and the casual dampness, which journals like mine must often be exposed to. I read these papers to the different societies, of which $I$ have the honor to 
be a member, and read them with a sensation of pleasure that nothing but a full persuasion of their truth could bestow.

Those persons in Philadelphia that have felt a desire to contradict my assertions cannot, without lowering themselves very much indeed affect to conceive that the members of the Wernerian Society would have listened to my "say so," without investigating the subject, even if they had not been well versed in the habits of the objects I treated of. Neither can they believe that all my acquaintance and particular friends would permit me to proceed in relating Tales of Wonder, which if untrue, would load me with disgrace, ruin my family, nay, prove me devoid of all honor! Could I suffer myself to be so blinded at the very moment when $I$ am engaged in the publication of a work of unparalled magnitude, of which the greatest naturalists and best judges both in America and in Europe have given the fullest praise and firmest support, \& from which my very means of pecuniary comfort are to be drawn? It would certainly be highly unfair to conceive $\&$ assert that at the time whilst I was portraying individuals, animal and vegetable, I should have rambled so wide and so far from facts in a portion of science so intimately connected with \& necessary to the support of those delineations, as well as to the general standing of my reputation! Mere interest would suggest a very contrary line of conduct, and I hope I am not so devoid of common sense as to lose sight of all that can render life desirable in this world or the world hereafter.

No, my dear Mr. Sully, I have written with care what I have seen, and have felt a great desire to spread the knowledge I have obtained in the great field of Science for the benefit of the world at large, and I rest content with this motto: "Le temps découvrira la vérité." To whom then, my dear Mr. Sully, can I ascribe the birth of the animadversions expressed in the papers of Philadelphia! Is their author one [who] comes avowedly forward with a life spent in the woods, loaded with facts differing in every respect from mine, one who like me can bring forth vouchers, and who can by respectable witnesses support what he says? Or, is he one, who, writing at 
random and without any knowledge of his subject, merely wishes to push himself into notice by a blunt denial of my veracity, and would edify \& please some of his friends, at the price of my reputation. I think, my dear Mr. Sully, the latter much more applicable, and must belong to the author of the report current in your city.

I have not read any of the Philadelphia papers since I came to England, and do not know the tone of the attacks upon me, but judging from your friendly letter, I feel assured that the pen that traced them must have been dipped in venom more noxious than that which flows from the jaws of the rattlesnake!

To you, my dear Friend, I solemly affirm that however unnatural my observations may appear, they are all facts, without a word of exaggeration. My fate in this instance differs not from that of many others, but believe me, will differ widely from that of the illustrious Bruce; those attacks will not make me die of sorrow!

With this, my dear Friend, I will close the subject, giving you meanwhile full liberty to use this letter in any manner that may best suit your feelings, and I will now pass on to other things.

My success in the mother country continues to augment apace. I have many most valuable friends and patrons, and discovered soon after my landing that Science has no particular country. The 5 th. number of my work is now published, \& completes my labor for 182\%. During my progress I have often received letters from highly distinguished characters, expressive of the highest approbation, \& I hope by regular industry to be able to go on with the performance, with credit to myself \& benefit to my family.

I shall leave this town for London in a few days, when I will convey your wishes to Robert Sully, \& [when] there I hope to see the picture which you have sent to the Marquis of Wellesley. ...

The attack referred to in the letter just quoted was called forth by Audubon's unfortunate paper on the 
Rattlesnake, ${ }^{3}$ which was read before the Wernerian Society of Edinburgh in the winter of 1827 and published by Robert Jameson in the Nere Philosophical Journal in April of that year. The controversy then started was long and bitter, while the merits of neither side were ever fully established; in the history which follows we shall see that the naturalist was, on the whole, more sinned against than sinning.

In July, 1828, Dr. Thomas P. Jones ${ }^{4}$ appropriated Audubon's Rattlesnake article, and published it without acknowledgment in the Franklin Journal and American Mechanics' Magazine at Philadelphia. It should be noticed that at the close of $\mathbf{1 8 2 7}$ Audubon's famous plate of the Mocking Birds defending their nest against the sinister designs of this formidable reptile had also been published in London. In this remarkable picture the rattlesnake was represented coiled about the nest, at the fatal moment when ready to strike its bold defenders, and in a tree. The anomaly was apparent, for the climbing habits of rattlesnakes were not then generally understood. This circumstance, together with some of Audubon's notes, repeated in certain cases from stories current in rural communities, furnished his detractors with a powerful lever, which they seized with avidity; snakes coiled in trees seemed suddenly to have produced a brood of another order which lurked in the grass, and it was many years before Audubon heard the last of his snake stories. The attack in the American press was laid to the door of George Ord, and it was not long before it was renewed with great vigor by his friend and corre-

See Bibliography, No. 21.

- At one time superintendent of the Patent Office at Washington, and professor in the medical department of Columbia College; he was later professor of mathematics in the Franklin Institute of Philadelphia and editor of the Franklin Journal, and American Mechanics' Magazine. 


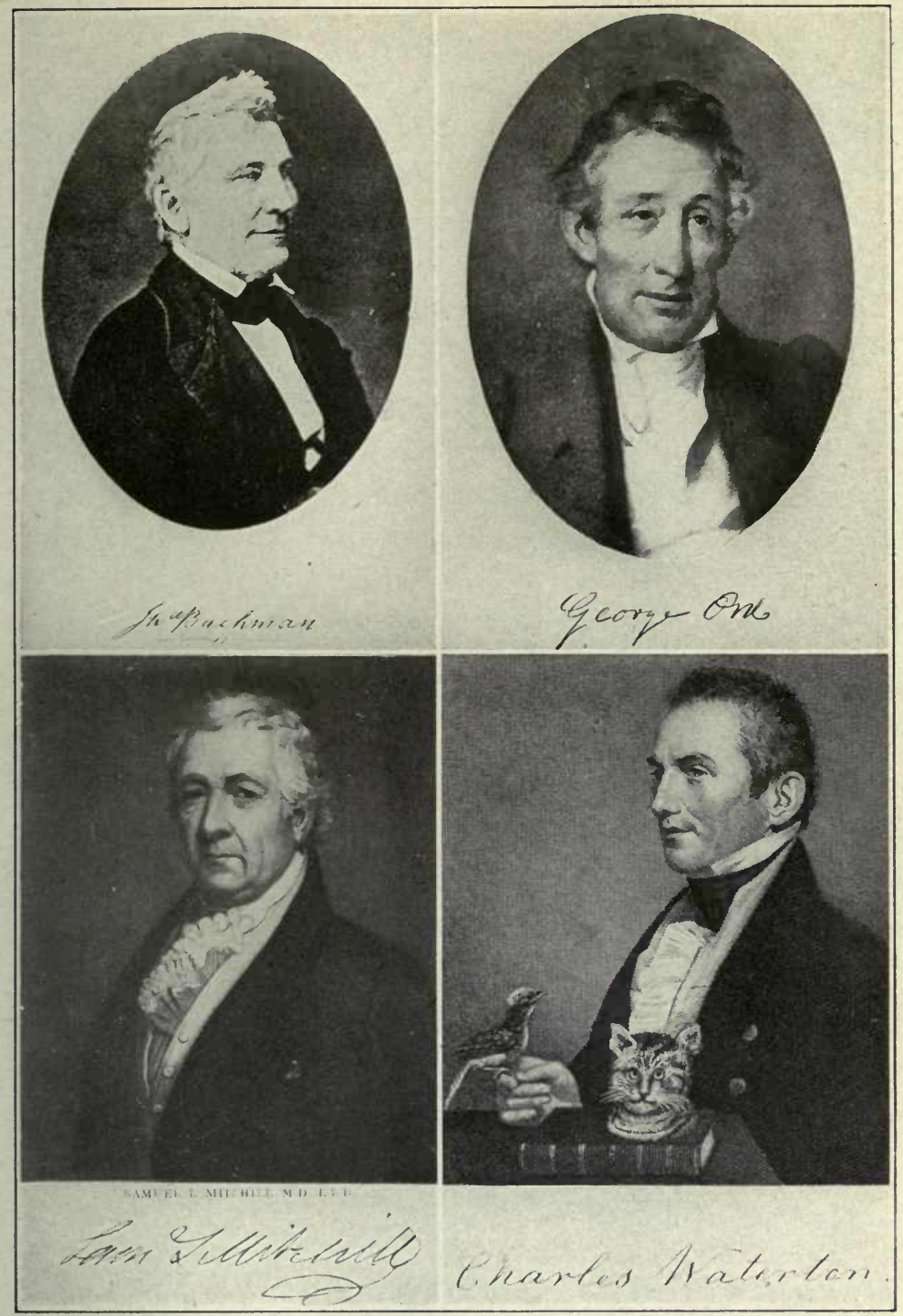

JOHN BACHMAN

SAMUEL LATHAM MITCHELL
GEORGE ORD CHARLES WATERTON

BACIIMAN FROM C. L. BACHMAN, "JOHN BACHMAN, D.D., LL.D." ; ORD FROM "CASSINIA" FOR 1908; MITCHELL AFTER AN ENGRAVING BY GAMBER AND DICK OF A PORTRAIT BY HENRY INMAN; WATERTON FROM MOORE'S EDTTION OF WATERTON's "ESSAYS," 

spondent in England, Charles Waterton, who proclaimed Audubon as a new and greater Münchhausen. ${ }^{5}$

Dr. Jones immediately repudiated the article which he had unceremoniously appropriated, and under the title of "The Romance of the Rattlesnake" inserted the following notice in the August number of his magazine: ${ }^{6}$

Just as the Editor was leaving Philadelphia for Washington, he was pressed for "more copy" by his printer, and hastily marked some articles for insertion, among which were "Notes on the Rattlesnake," by John James Audubon, F.R.S. E., M.W.S., \&c. Time did not admit of reading the article, but it was seen that the writer professed to offer the "fruits of many years' observation, in countries where snakes abound." This with his titles, and the bold and splendid assurances which we had seen respecting the publication of his works, served as a password to his tissues of falsehoods, which would have been expunged from the proof, but for absence from the press.

We had determined to publish a notice like the foregoing, when we received a note from a scientific friend, whose remarks are, at once, so pointed and correct, and so fully express our own ideas upon the subject, that we gladly adopt and insert them.

It is a tissue of the grossest falsehoods ever attempted to be palmed upon the credulity of mankind, and it is a pity that any thing like countenance should be given to it, by reproducing it in a respectable Journal. The romances of Audubon rival those of Münchausen, Mandeville, or even Mendez de Pinto, in the total want of truth, however short they may fall of them in the amusement they afford.

This was rather a stiff charge to be made flatly against the reputation of any one without the most

'See Bibliography, No. 115.

- See Bibliography, No. 93. 
careful investigation, even upon the authority of "a scientific friend." Let us see, then, what basis, if any, really existed for such sweeping charges. In the paper which caused the trouble Audubon had described in great detail how he had seen a large rattlesnake pursue, capture, kill by constriction, and devour a gray squirrel. Before quoting his description of this singular encounter, we shall recall a passage which Audubon wrote in his journal at the time when it occurred, ${ }^{7}$ when he was at "Oakley," the plantation of James Pirrie at St. Francisville, Bayou Sara, in the summer of 1821: "August 25. Finished drawing a very fine specimen of a rattlesnake, which measured five feet and seven inches, weighed six and a quarter pounds, and had ten rattles. Anxious to give it a position most interesting to a naturalist, I put it in that which the reptile commonly takes when on the point of striking madly with its fangs." After describing a rough dissection which he made of the rattlesnake's dental arsenal and poison apparatus, he added: "The heat of the weather was such that I could devote only sixteen hours to the drawing." The drawing thus referred to was undoubtedly used in the composition of his celebrated plate.

To revert now to a mooted passage in Audubon's published paper:

Rattlesnakes hunt and secure for their prey, with ease, grey squirrels that abound in our woods; therefore they must be possessed of swiftness to obtain them. Having enjoyed the pleasure of beholding such a chase in full view in the year 1821, I shall detail its circumstances. Whilst lying on the ground to watch the habits of a bird that was new to me, previous to shooting it, I heard a smart rustling not far from me, and turning my head that way, saw, at the same moment, a

7 This episode was referred to in Chapter XX, p. 316. 
grey squirrel full grown, issuing from a thicket, and bouncing off in a straight direction, in leaps of several feet at a time, and, not more than twenty feet behind, a rattlesnake of ordinary size, pursuing, drawn apparently out to its full length, and sliding over the ground so rapidly that, as they both moved away from me, I was at no loss to observe the snake gain upon the squirrel. The squirrel made for a tree, and ascended to its topmost branches as nimbly as squirrels are known to do. The snake performed the same task considerably more slowly, yet so fast that the squirrel never raised its tail nor barked, but eyed the enemy attentively as he mounted and approached. When within a few yards the squirrel leaped to another branch, and the snake followed by stretching full two-thirds of its body, whilst the remainder held it securely from falling. Passing thus from branch to branch, with a rapidity that astonished me, the squirrel went in and out of several holes, but remained in none, knowing well that, wherever its head could enter, the body of its antagonist would follow; and, at last, much exhausted and terrified, took a desperate leap, and came to the earth with legs and tail spread to the utmost to ease the fall. That instant the snake dropt also, and was within a few yards of the squirrel before it began making off. The chase on land again took place, and ere the squirrel could reach another tree, the snake had seized it by the back near the occiput, and soon rolled itself about it in such a way that, although I heard the cries of the victim, I scarcely saw any portion of its body. So full of its ultimate object was the snake, that it paid no attention to me, and I approached it to see in what manner it would dispose of its prey. A few minutes elapsed, and I saw the reptile loosening gradually and opening its folded coils, until the squirrel was left entirely disengaged, having been killed by suffocation. The snake then raised a few inches of its body from the ground, and passed its head over the dead animal in various ways to assure itself that life had departed; it then took the end of the squirrel's tail, swallowed it gradually, bringing first one and then the other of the hind legs parallel with it, and sucked with difficulty, and for some time, 
at them and the rump of the animal, until its jaws became so expanded, that, after this, it swallowed the whole remaining parts with apparent ease.

Audubon then described the appearance that the snake presently assumed, which suggested "a rouleau of money, brought from both ends of a purse towards its centre," and its ineffectual attempts to move off; "when having cut a twig," he continued, "I went up to it, and tapped it on the head, which it raised, as well as its tail, and began for the first time to rattle."

Now every careful reader of this remarkable story, provided he is at all conversant with the habits of snakes, will perceive that it could not possibly have been invented, for it is strictly and minutely in accord with facts, except in one important particular; the snake whose behavior Audubon watched and so accurately described was not the rattlesnake, but the blue racer or black snake (Bascanion constrictor) ; substitute "blue racer," for "rattlesnake," and this record is photographically correct. ${ }^{8}$ The black snake does all the things which are here so minutely described-pursuing its prey with astounding agility, constricting about it as a prelude to swallowing it, ascending trees readily, coiling when brought to bay as if about to strike, and even vibrating the tip of its tail on the ground or leaves, as if in emulation of the genuine rattler, a kind of behavior which was looked upon by Darwin as a case of protective mimicry. No one could have known the rattlesnake better than Audubon from his constant encounters with it in the field; he made drawings of it, dissected its poison apparatus, and had kept it for months in confinement in

${ }^{8}$ This was very clearly pointed out in 1908 in an excellent article by Mr. George W. Colles, entitled "A Defence of Audubon" (Bibl. No. 160), in Scientific American, vol. xcviii, p. 311. 
order to study its habits; but by some curious twist of his notes or his memory, or led astray by the record made of the rattling habit, the species became confused in his published account. His error was gross and he paid dearly for it, but it certainly does not prove him to be the king of nature fakirs.

Audubon's critics were probably right in affirming that the rattlesnake never ascends trees for the purpose of destroying birds, but some overshot the mark by denying that the reptile was able to climb at all. Nor could it have been said with greater justice that the brilliant but sluggish coral snake (Elaps fulvius), which Audubon had also placed in a tree, ${ }^{9}$ really never aspires to this distinction. When the snake controversy was waxing warm in America, a number of Audubon's friends, including Colonel John J. Abert ${ }^{10}$ and Richard C. Taylor, ${ }^{11}$ investigated the question and proved that the rattlesnake was a ready climber at certain times of the year and under certain conditions, a fact which is now better known. Mr. Taylor's party in the course of explorations in the Alleghanies killed forty-one large rattlesnakes during the month of August on a single ridge bordering the Lycoming Valley, and in rendering his report, this geologist said: "I have repeatedly endeavored to verify Mr. Audubon's account of the rattlesnake ascending trees, which has been confirmed."

We have already referred to Audubon's meeting with Thomas Cooper at Columbia, South Carolina, in October, 1833. This versatile man, sometime English lawyer, revolutionist in France, friend of Priestley, judge in the Court of Common Pleas of Pennsylvania,

- See Plate lii, of the Chuck-will's-widow.

${ }^{10}$ See Vol. II, p. 3; and Bibliography, No. 107.

${ }^{11}$ An English geologist, who made a survey of the bituminous coaldeposits of the Alleghany mountains in 1834. See Bibliography, No. 129. 
professor of chemistry in Dickinson College as well as in the University of Pennsylvania, and at this time president of South Carolina College at Columbia, was able to confirm Audubon's account of the climbing habit of the rattlesnake, and probably wrote this statement at his request:

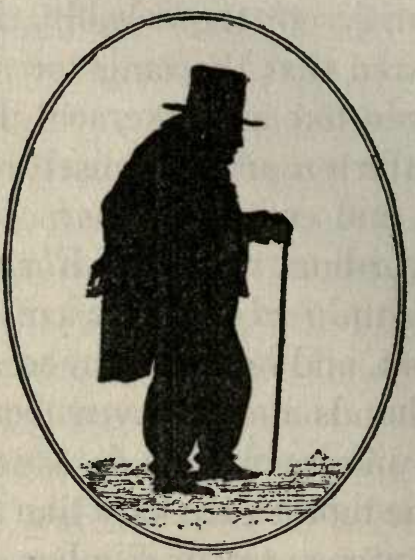

DR. THOMAS COOPER.

After a contemporary silhouette.

Thomas Cooper to Audubon

Columbia S. Carolina

Octr 21. 1833

Mr Audubon

Dear Sir

About three weeks ago, my son and two of my black servants, observed a very large rattle snake climbing up the fence that separates my garden from the road, at my country house. The snake put himself in the attitude of striking; whereupon one of the men ran for a gun, and shot the snake on the last rail but one of the fence. The snake was 4.3 long; as thick as my wrist, and had seven rattles.

I am Dear Sir

Your obedient servant

Thomas Cooper 
Waterton maintained that Audubon's drawing of the rattlesnake, to which we have referred, was a monstrosity, "a fabulous Hydra, with its eyes starting out of their sockets," and a point repeatedly ridiculed was his representation of the fangs as slightly recurved, or bent up at their tips. Who had ever heard of such an anomaly? Certainly not the doughty lord of "Walton Hall," who declared that the fangs of poisonous snakes were always curved like a scythe, with their points bent downwards. Waterton prided himself on his knowledge of these reptiles, and certainly was not lacking in selfconfidence. According to his own account, he went eleven months in the forests of Brazil without shoe or stocking to his foot, and on a certain occasion in London secured with his hands and removed from its cage a live rattlesnake; but, like so many sophisticated writers on natural history, he took to analogy like a duck to water.

Waterton's statement sounds plausible enough, but obviously could be proved only by extensive observations and comparisons. When Audubon was proceeding up Galveston Bay to Houston, Texas, in the spring of 1837, with his son, John, and Edward Harris, they stopped at the plantation of Colonel James Morgan, near Red Fish Bar. "There, among other rarities," said he, "we procured a fine specimen of the climbing rattlesnake with recurved fangs, which with several others of the same kind, is now in my possession." ${ }^{12}$ In writing to Thomas M. Brewer, from Charleston, on June 12 of this year, he alluded to this subject as follows: "I must not forget to say to you that I had the good fortune to procure specimens of my ' $\mathrm{Climb}$ ing $\mathbf{R}$ a t t l es n a k e with DOUBLE recurved fangs' which, I am told, will prove a new genus! and therefore the

${ }^{12}$ Ornithological Biography (Bibl. No. 2), vol. iv, p. xviii. 
Messrs. Ord and Waterton-good souls! -will be perfectly delighted at the sight of this strange reptile." 13 Unfortunately a large part of Audubon's collections made upon this expedition were lost. I have seen no other reference to this extraordinary peculiarity, and there the matter seems to have rested until the present time.

Audubon's judgment or memory might play him false, but his pencil, in such a matter, could be relied upon to tell the truth. It is therefore a pleasure to be able to confirm his accuracy in reference to the serpent's tooth, for the true representation of which he was roundly abused during his lifetime. The reader will perceive the point by examining the accompanying photograph, which represents the skull of a large diamond-backed specimen from Florida. ${ }^{14}$ In the prairie rattlesnake, and probably in some others, the fangs are sickle-shaped, as Waterton maintained, but upwards of eleven species of rattlesnakes have been found on the continent of North America, and, true to Audubon's disputed drawing and account, in this Florida specimen the fangs are slightly, but very distinctly, bent uproards at their tips! Let nature writers, inclined to the easy path of analogy, remember the rattlesnake's fang, for it teaches a salutary lesson.

As I have not hesitated to speak of Audubon's real or supposed mistakes, I will give another and more striking instance of his tardy vindication. In his plate of the American Swan (No. ccecxi), which was published in

${ }^{13}$ See Thomas M. Brewer, (Bibl. No. 79), Harper's New Monthly Magazine, vol. Ixi, p. 666 (1880).

${ }^{14}$ This specimen, which was presented to me by the late Dr. X. C. Scott of Cleveland, measured 6 feet, and showed eight rattles and a button; the skin and skeleton are preserved in the Biological Laboratory of Western Reserve University. 


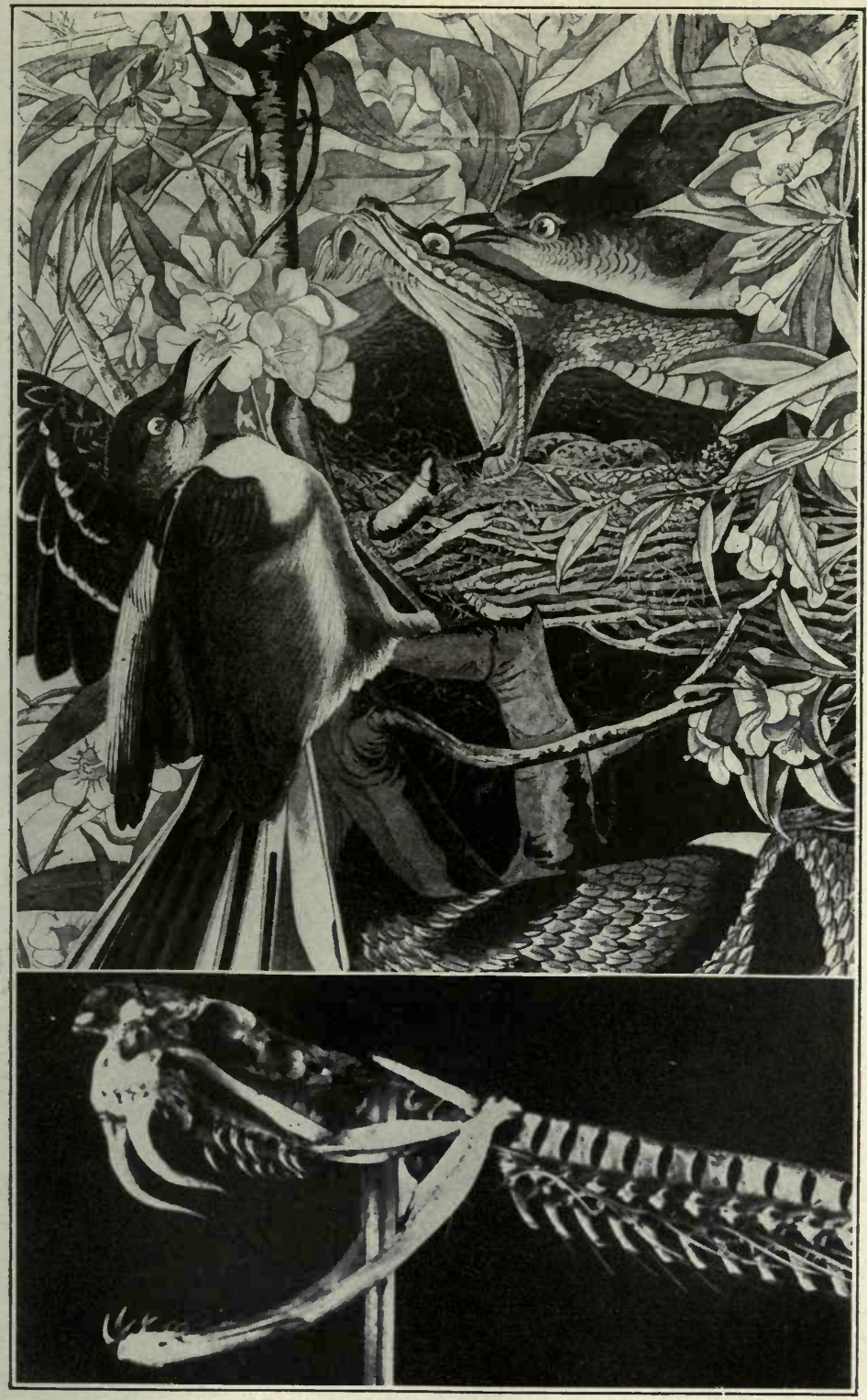

A VINDICATION OF AUDUBON'S REPRESENTATION OF THE FANGS OF THE SOUTHERY RATTIESNAKE: ABOVE, DFTAIL OF THE "MOCKING BIRDS," PLATE XXI (U NCOIORED) OF "THE BIRDS OF AMERICA"; BELOW, THE SKUI.L OF A RECENT FLORIDA SPECIMEN, SHOWING THF SAME RECURVATURE 

1838, there is represented a yellow water lily, under the name of Nymphaea lutea. Since this lily was then quite unknown to botanists, it was ignored and treated as a fable, or as an extravagant vagary of the naturalist's imagination, until the summer of 1876 , when it was rediscovered in Florida by Mrs. Mary Treat. Audubon's long lost lily was then identified and acknowledged by Professor Asa Gray, the botanist, who, with poetic justice, proposed to rename it after the discredited enthusiast, in view of the fact that it had been originally discovered and faithfully depicted by him a generation before.

While the snake controversy was acute in America, another of a purely academic character, which assumed even wider proportions, was started on the smelling powers of the vulture. We have already seen a reference to this in the naturalist's letter to his son, Victor, written at Charleston, where he was conducting with Bachman a new series of experiments to settle the question. ${ }^{15}$ The idea, commonly accepted, that the scavengers of the Southern States were possessed of a keenness of scent comparable with that of a beagle hound, had been vigorously combated by Audubon, who showed by numerous experiments ${ }^{16}$ that they were guided to their prey

${ }^{15}$ See Vol. II, p. 55.

${ }^{16}$ Bachman's account of these experiments is interesting: "A coarse painting," he'said, was made on canvas, "representing a sheep skinned and cut open. This proved very amusing-no sooner was this picture placed on the ground than the Vultures observed it, alighted near, walked over it, and some of them commenced tugging at the painting. They seemed much disappointed and surprised, and after having satisfied their curiosity, flew away. This experiment was repeated more than fifty times, with the same result. The painting was then placed within two feet of the place where the offal was deposited-they came as usual, walked around it, but in no instance evinced the slightest symptoms of their having scented the offal which was so near them.

"The most offensive portions of the offal were now placed on the earth; these were covered over by a canvass cloth-on this were strewn several pieces of fresh beef. The Vultures came, ate the flesh that was in sight, 
by the sense of sight only; thus it was found that they would come readily to the effigy of a calf or sheep painted on canvas and set up in plain view, or to a skin stuffed with straw, but failed to detect their quarry when the dead bodies of these animals were placed on the ground and screened from their eyes, if only by the thinnest cover, though the carrion was calling loudly to the nose but a fraction of an inch away. An attack by Waterton, ${ }^{17}$ who hurried to the fray whenever a statement in his jealously guarded Wanderings was called in question, led to a lively tilt, in which the advocates of the nose and the eyes were sometimes humorously referred to as the "Nosarians" and the "Anti-Nosarians," some of the most eminent anatomists of the day eventually taking part.

Bachman felt keenly the aspersions which were cast upon his friend, and in the winter of 1833 he undertook with Audubon the series of experiments to which we have referred. The tests which were then made supported Audubon's statements in every particular, and the faculty of the Medical College of South Carolina were invited as a body to witness them; this they did

and although they were standing on a quantity beneath them, and although their bills were frequently within the eighth of an inch of the putrid matter, they did not discover it. We made a small rent in the canvass, and they at once discovered the flesh and began to devour it. We drove them away, replaced the canvass with a piece that was entire; again they commenced eating the flesh exhibited to their view, without discovering the hidden food they were trampling upon.

"As it [the organ of smell] does however exist, (although in an inferior degree,) I am not disposed to deny to birds the power of smell altogether, nor would I wish to advance the opinion that the Vulture does not possess the power of smelling in the slightest degree, (although it has not been discovered by our experiments). All that I contend for is, that he is not assisted by this faculty in procuring his food-that he cannot smell better for instance, than Hawks or Owls, who it is known are indebted altogether to their sight, in discovering their prey."

${ }^{17}$ See Bibliography, No. 104, and Vol. II, p. 55; also Ornithological Biography, vol. ii, p. 46. 
willingly, and the following memorial signed by all the witnesses present was published by Bachman in $1834 .^{18}$

We, the subscribers, having witnessed several of the experiments made on the habits of the vultures of South Carolina (Cathartes aura and $C$. atratus), commonly called the turkey buzzard and the carrion crow, feel assured that these species respectively are gregarious, the individuals of each species associating and feeding together; that they devour fresh as well as putrid food of any kind, and that they are guided to their food altogether through their sense of sight, and not of smell.

In a letter written to Ord, on March 4, 1834, Waterton said:

You will see that the Charleston parson [Bachman], Doctors, Surgeons and Professors are up in arms against me and are determined to cut off the Vulture's nose. But do not be alarmed for me, I promise you that I will answer them to your heart's content and tomorrow I shall send up a paper to Loudon for his May number which will make your Philosophers appear very small and put Audubon's claim to literature and ornithology in so clear a light that no one will be in doubt hereafter. ... Audubon's gulled friends and supporters in London are in the highest spirits and feel sure that I cannot answer the Charleston letter. By the first of May next their crowing will cease.

When anatomists came to consider the question and found that well developed olfactory lobes and nerves were present in these birds, they favored the theory of smell, ${ }^{19}$ and Edinger has more recently expressed the opinion that this consideration renders the possession of

${ }^{18}$ See Bibliography, No. 125, and for the quotation to follow, Samuel N. Rhoads, "George Ord," Cassinia, No. xii (Philadelphia, 1908).

${ }^{10}$ See W. Sells (Bibl. No. 140), Proceedings of the Zoölogical Society of London, pt. $\nabla$, p. 33 (1837). 
an olfactory sense in such birds highly probable. His contention is weakened, however, by the fact that granivorous and insectivorous birds also possess true olfactory nerves, and yet are proved by experiment to have little or no effective sense of smell. It is a problem for students of behavior to solve, and so far as the American vultures are concerned, Audubon's and Bachman's experiments, I believe, have never been repeated or extended with sufficient care to settle the question. The little that has been done, however, suggests that while the vulture in its daily and never ending search for food is mainly guided by its keen eyes, the nose, possibly, may be a coöperating factor when the wind and other conditions are favorable.

While critics were driving the pen, Audubon was hard at work in the field, but his friends did not long remain silent. Favorable notices of his work, actual or prospective, had appeared in the scientific and literary press of England, by David Brewster, Robert Jameson, William Swainson, and "Christopher North" of Blackrwood's Magazine. The first American notice appeared in the American Journal of Science for 1829, and this was followed by G. W. Featherstonhaugh, the English geologist, in his recently established but shortlived Monthly American Journal of Geology and Natural Science, to which we have already referred..$^{20}$ A little later the London Athenceum gave the first of eleven extended articles on Audubon's work; in reviewing his second volume of letterpress, which appeared in 1834, the writer said: "There is amply sufficient remaining in Audubon's pages for fully a dozen more notices, were we disposed to follow the exhausting system. We have admired Audubon's gorgeous drawings, but our

${ }^{20}$ See Vol. II, pp. 4 and 23, and Bibliography, No. 106. 
interest in them has been increased a thousand fold, in knowing that they are the spoils of a life's campaign." ${ }^{21}$ Again a series of able articles was started by a just critic, W. B. O. Peabody, in the North American Revier for April, 1832. ${ }^{22}$ Featherstonhaugh deserves credit for having given Audubon a fair hearing at a critical time, when baiting the American Woodsman was a popular pastime in certain circles at Philadelphia; in reviewing the Ornithological Biography in 1832, this plain spokesman gave what he called "a true history of a conspiracy, got up to utterly break down and ruin the reputation of one of the most remarkable men America ever produced." ${ }^{23}$

Audubon's silence under fire of hostile criticism tempted someone in the capacity of a reporter to call on him in London to obtain, if possible, a personal statement, but his lips were then sealed and he would only say: "Had I wished to invent marvels, I need not have stirred from my garret in New York or London." However, in writing to Featherstonhaugh from Bulowville, East Florida, December 31, 1831, Audubon made this comment: ${ }^{24}$

If I did not believe the day to be gone by when it was necessary to defend my snake stories, I could send you many curious accounts of the habits of those reptiles; and I should do it, if it were not that I might be thought to enjoy-too much that triumph which the feeble hostility of three or four selfish individuals has forced upon me. I receive so many acts of real friendship and disinterested kindness, that, I thank God, there is no room left in my heart to cherish unkind feelings towards any one. Indeed, I am not now so much sur-

${ }^{21}$ See Bibliography, No. 136.

${ }^{22}$ See Bibliography, No. 105.

${ }^{23}$ See Bibliography, No. 106.

${ }^{24}$ See Bibliography, No. 35. 
prised at the incredulity of persons who do not leave cities, for I occasionally hear of things which even stagger me, who am so often a denizen of woods and swamps. What do you think of rattlesnakes taking to the water, and swimming across inlets and rivers? I have not seen this, but I believe it; since the most respectable individuals assure me they have frequently been eye-witnesses of this feat. I can conceive of inducements which reptiles may have for traversing sheets of water to gain dry land, especially in a country much intersected by streams, and subject to inundations, which compel them to be often in the water. In such countries, it is not an uncommon occurrence to find snakes afloat and at great distances from the shore. This appears, no doubt, surprising to those who live where there is almost nothing but dry land; still they ought to be good natured, and believe what others have seen. It has now been made notorious, that numerous respectable individuals, whom duty, or the love of adventure, have led into the woods of our country, have often seen snakes -and the rattlesnake too-in trees; the good people, therefore, who pass their lives in stores and counting houses, ought not to contradict these facts, because they do not meet with rattlesnakes, hissing and snapping at them from the paper mulberries, as they go home to their dinners. ...

Audubon's most persistent heckler was Charles Waterton, ${ }^{25}$ who during two of his most prolific years, 1833 and 1834, published no less than fourteen lucubrations against the "foreigner," and "stranger" as the American was called; all were characterized by quizzing interrogatories, shallow criticism and personal vituperation, for the most part unworthy of serious consideration. Long noted for his eccentricities, Waterton had little or no standing among English zoölogists, against many of whom, from time to time, he issued broadsides or breezy polemics, whenever their statements cast a

${ }^{25}$ See Bibliography, No. 104 et seq. 
shadow on his Wanderings. Some of these accusing articles were answered by Victor Audubon and other friends of the naturalist, but they never drew his own fire; probably they benefited him in the end, for when it appeared that the charges brought against him were in large measure the work of envious calumniators, a strong current set in his favor on both sides of the Atlantic.

When Audubon's name was first proposed for membership in the Academy of Natural Sciences at Philadelphia, it was rejected, according to report, through the influence of George Ord and a few of his partisans, while Waterton, who was Mr. Ord's close friend and correspondent, affirmed that Audubon was rejected by the Society on the strength of Alexander Wilson's personal diary, ${ }^{26}$ a statement which appears to be utterly incredible. ${ }^{27}$

In 1833, two years after the first volume of Audubon's "Biography of Birds" had made its appearance, Waterton raised another controversy, in this instance with ammunition supplied by his friend, George Ord of Philadelphia. He boldly proclaimed ${ }^{28}$ that Audubon was not the author of the work which bore his name, a charge similar to that which had been brought to the door of the French ornithologist, Le Vaillant, whose history resembled Audubon's in many ways. "I request the English reader," said Waterton, "to weigh well in his own mind what I have stated, and I flatter myself that he will agree with me, when I affirm that the cor-

${ }^{26}$ See Vol. I, p. 224.

27 "I myself, with mine own eyes, have seen Wilson's original diary, written by him at Louisville, and I have just now on the table before me the account of the Academy of Sciences indignantly rejecting Mr. Audubon as a member, on that diary having been produced to their view."

See Bibliography, No. 119.

${ }^{28}$ See Bibliography, No. 119. 
rect and elegant style of composition which appears through the whole of the Biography of Birds cannot possibly be that of him whose name it bears." Waterton maintained that, while Audubon's earlier papers were the work of an illiterate person, his Biography betrayed the hand of a finished scholar from beginning to end. In a reply to Victor Audubon, written July 6, 1833, ${ }^{29}$ Waterton declared, upon the authority of George Ord, whom he quoted, that William Swainson had been importuned to write Audubon's work for him, but declined when Audubon insisted upon his own name being given to the world as author. This direct accusation called forth an immediate explanation from Swainson, who said: ${ }^{30}$

In reply to that gentleman (G. Ord, Esq.), regarding the assistance it was expected I should have given my friend, Mr. Audubon, in the scientific details of his work, my reply was, that the negotiation had been broken off from an unwillingness that my name should be printed on the title-page. I was not asked to write the work, nor did Mr. Audubon "insist upon his own name being given to the world as the author" of such parts as he wished me to undertake. . . I have read Mr. Audubon's original manuscripts, and I have read Mr. Waterton's original manuscripts. I think the English of one is as good as the English of the other-but here the comparison ends."

The controversy thus started did not reflect much credit on Audubon's detractors, but reverberations of the charge were heard at a much later day.

Robert Bakewell, the geologist, who was a relative of Mrs. Audubon, then living at Hampstead, entered 
this controversy, and in June, 1833, replied ${ }^{31}$ to one of Waterton's fulminations, which he attributed to envy and jealousy, saying that posterity would regard Audubon as "the most distinguished ornithologist of the present age."

Charles Waterton began his travels at eighteen, but early settled down to a life of leisurely independence on his ancestral estate in Yorkshire, where he studied birds to little purpose and wrote extensively on natural-history subjects; he is best known for his Wanderings, ${ }^{32}$ which has passed through numerous editions and is still read. From youth Waterton enjoyed exceptional advantages, and according to one of his biographers, "lived to extreme old age without having wasted an hour or a shilling." He was the twenty-seventh "lord of Walton Hall," the manor house of the family, which stood on an island in a lake; the estate of 260 acres was mainly converted into a preserve for wild birds. His young wife died in 1829, after having given birth to a son, and he lived on his paternal acres in semi-retirement ever after. It was said that Waterton would never don evening clothes or a black coat, but insisted on wearing a blue frock with gold buttons until an anxious policeman in the neighboring village of Wakefield persuaded him to make a change; he told the Reverend J. G. Wood in 1863 that he had been bled 160 times, mostly by his own hand. When, in his sixty-ninth year, he had the misfortune to fall from a pear tree and break an elbow joint, the first remedy tried was the extraction of thirty ounces of blood; shortly after this a careless servant withdrew a chair as he was seating himself at table, and

${ }^{81}$ See Bibliography, No. 114.

${ }^{22}$ Wanderings in South America, the North-West of the United States, and the Antilles, in the years 1812, 1816, 1820, \& 1824. Originally in 4to., London, 1825. 
thirty more ounces were immediately required. The wage of one of his laborers is said to have sufficed for his personal needs, and his sleeping apartment had neither bed, chair, nor carpet; he lay on bare boards, wrapped in a blanket, with an oaken block for pillow; and he is said to have never tasted fermented liquor and to have eaten but sparingly of meat. His daily habit was to retire at eight and rise at three o'clock in the morning, and he was always dressed by four; an ardent Roman Catholic, he would spend an hour at devotion in his private chapel; he then read Latin and Spanish authors, wrote his polemics against Audubon or any others with whom he came in conflict, and received the reports of his bailiff, all before breakfast, which was at eight o'clock; the remainder of the day was mostly devoted to his birds and other animals, to preserve which he surrounded his entire estate with a high rampart of stone, said to have cost, all told, $\$ 50,000$.

Though a devout Romanist, as someone has remarked, Waterton never hesitated to adopt the same mode of reasoning which Hume had employed in his argument against miracles. Thus he rejected with scorn Edward Jenner's account of how the young parasitic Cuckoo, when but a day old and hardly able to stand, turned out of their nest its rightful occupants. This account, which was generally accepted then, and has been repeatedly verified and recorded by the camera since, "carries," said Waterton, "its own condemnation, no matter by whom related, or by whom received." Trusting to analogy again, he maintained that Audubon's description of the Ruby-throated Hummingbird gluing bits of lichen to the surface of its nest with saliva was false, because "the saliva of all birds immediately mixes with water," and the first shower of rain 
would immediately undo the work of the bird. No account was taken of the Chimney Swift, which not only glues together the twigs of its nest but secures the whole to a support through an abundant salivary secretion, although this habit had long been known. In the instance of this hummingbird, however, both Audubon and Waterton were partly right and partly wrong, as a careful examination of the nests of five species of hummingbirds, including the Ruby-throat, has clearly shown..$^{33}$ It proved that saliva was only casually used on the surface of the nest, the lichens in the case referred to being adherent by means of spiders' silk and fine vegetable fibers of various sorts; the saliva of the Rubythroat, when dry, moreover, was found to be practically insoluble in cold water, even after an immersion of several days; but more interesting than this is the fact that the nest itself is glued to its supporting twig by a large salivary rafer, which represents this hummingbird's first step in the work of nest construction.

Shortly after his arrival at Edinburgh, and before he had published anything, Audubon wrote in his journal on November 5, 1826: "I returned home early and found a note from Mr. John Gregg, who came himself later, bringing me a scrubby letter from Charles Waterton," so it would appear that the lord of "Walton Hall" had been warned to keep an eye on the dangerous American, and Waterton's American correspondent was Mr. Ord, of Philadelphia. Later on Waterton wrote to Swainson an extraordinary letter of some four thousand words, ${ }^{34}$ afterwards published in his Essays on Natural History, which for petty vanity and personal animosity

${ }^{23}$ See "Nests and Nest-Building in Birds," Pt. 2, Journal of Animal Behavior, vol. i (1911).

" See Bibliography, No. 138. 
has seldom been surpassed, but with this effort his ammunition seems to have been exhausted.

Charles Waterton, who lived to his eighty-third year, and who wrote nineteen polemics against Audubon and his friends, was probably sincere in his attacks upon the American Woodsman, whom he seems to have regarded as a dangerous charlatan. Waterton was a curious compound of fearless independence, kindness, credulity, pedantry, vanity, and intolerance. He should be given credit, however, for having done much to spread abroad a love of natural history and for his attitude towards an artificial system of classification, then much in vogue, which, though only an amateur, he had the good sense to reject. 


\section{CHAPTER XXIX}

\section{SIDELIGHTS ON AUDUBON AND HIS CONTEMPORARIES}

What was a Quinarian?-Controversy over the authorship of the Ornithological Biography-Audubon's quaint proposal-Swainson's reply-Friendship suffers a check-Species-mongers-Hitting at one over the shoulders of another-Swainson as a biographer-His careerBonaparte's grievance-A fortune in ornithology-Labors of John Gould and his relations with Audubon-The freemasonry of naturalists.

Few, probably, ever attain marked success in their chosen field without exciting jealous rivalry or misrepresentation on the part of some of their contemporaries. Audubon was no exception to the rule, but in this respect he has been subject to so much misunderstanding that the reader is entitled to know the truth, whenever it can be ascertained. An instance of this sort was furnished by the English naturalist, William Swainson, whose relations with Audubon have been touched upon in earlier chapters.

In April, 1828, Swainson published an eulogistic account of some of Audubon's plates, and shortly after they became good friends, as their familiar letters already reproduced amply testify; ${ }^{1}$ in the autumn of that year, as we have related, they visited Paris together, and they kept up a correspondence for a number of years. At this time Swainson was known as a systematic zoölogist of merit and an excellent draughtsman, hav-

${ }^{1}$ See Chapter XXIII. 
ing published a series of "Zoölogical Illustrations" that seem to have been well received. Moreover, as early as 1824, he had adopted the notorious "Circular System" of the classification of animals, and at this time was its most zealous advocate in England. The tenets of this curious doctrine, often called "Quinarianism" from the recurrence of the number 5 , was confused in a mystical jargon which conveys little meaning to a reader of today; it was derived from William Sharp MacLeay, who had advocated a similar system in his Horae Entomologicae, published in 1821. According to Swainson's creed, "all things that have life have been created upon one plan, and this plan is founded on the principle of a series of affinities returning into themselves; which can only be represented by a circle." "This sublime discovery," which, as Swainson thought, was sufficient "to immortalize a name," was duly attributed to his "illustrious countryman." 2

In the summer of 1830 , when Audubon was ready to prepare the letterpress of his mammoth plates and needed assistance in its technical details, he applied to his friend Swainson, who, as we have seen, was then living at a farmstead in the Hertfordshire country, not far from St. Albans. ${ }^{3}$ Some of the letters which passed between the two naturalists after the return of the former to England, in the spring of that year, will now be given, without amelioration or change of any sort. It should be remembered that Swainson at this time was in an overwrought state, since he was dependent mainly

${ }^{2}$ Swainson expounded the Quinarian or Circular System in the Fauna Boreali-Americana; or the zoölogy of the northern parts of British America, published in collaboration with John Richardson, and the first zoölogical publication issued by the British Government; but $A$ Treatise on the Geography and Classification of Animals contained his most authoritative thesis upon this grotesque concept.

See Vol. I, p. 403. 
upon his scientific writings for the support of a family of five children, oppressed by pecuniary difficulties, and, no doubt, irritated by lack of success and the rebuffs which a leading part in the Quinarian movement was certain to entail. Audubon's letter ${ }^{4}$ which follows served to answer that of Swainson, bearing date of January 30, 1830, ${ }^{5}$ which had been received in America but too late for the fulfillment of its commissions. References to Audubon's "book," which unfortunately proved a stumbling block in the path of friendship, are noticed here and in Swainson's reply for the first time.

\section{Audubon to William Sroainson}

My dear Mr. Swainson,

London, May 5th 1830.

You may be assured that nothing but an over [roord undecipherable] or [another similar word] has stopt me from writing to you sooner, Yet I would have had the pleasure of announcing you my return to good old England had I not been informed by Mr. Havell that you we apraised of it when last in town \& that more over you were quite well.-I hope that your kind wife and children are equally so and happy.-I brought my good wife with me to Liverpool where she is for a while with her sister Mrs. Gordon \& the family Rathbourn We had a rough voyage of 25 days \& glad to be back on this hospitable shore. I am sorry to say that your last letter to me (I presume) did not reach me in time to enable me to procure either squirrels or birds for you.-I have indeed brought about 150 birds and some of them good singers and beautifull but all are on Double Elephant Paper-they may and I hope they will please your eyes, when I have the satisfaction to shake you by the hand the first time you come to

'For the history of the Audubon-Swainson correspondence, see Note, Vol. I, p. 400. Swainson's letter which follows was first published by Ruthven Deane (Bibl. No. 218), The $A u k$, vol. xxii, p. 248 (1905).

${ }^{5}$ Reproduced in Vol. I, p. 430. 
town.-I called on Mr. Lea at Philadelphia, but he told me that you had countermanded your wishes to me $\&$ has given me a memorandum to that effect-Mr. Gilpin on whom I also called told me that your travelling boxes had forwardd. I saw Mr Ward at New York he is doing extremely well if what he told me is true. I saw M. le Comte also.-I have just taken the Reins of my Mammoth Publication which by the way I am glad to find in a good way of process or progress. I am greatly indebted to Mr. Children and grateful to him-Havell has done his part I think well and now I will set about procuring subscriptions with new ardour. Now in return of this packet of information I am very desirous to know what you are engaged at present in the way of science; I feel as if I had a world of talk for you.-Bonaparte's 4th volume is printing have you seen the third? I have it at Liverpool by this time.-I wrote to the author this morning.-I am well pleased with my voyage I think it will be of material advantage to my work my health \& my comfort-We have left our two sons quite well and doing well at the Falls of the Ohio where I killed a fine Turkey about forty days since. Those sent to the Zoological Gardens alive have had ill luck. They received only one and 3 Oppossums - The blue Gias [?] and Parakets are not yet arrived, and Mr. Rathbone as well as Mr. Shepherd told me (to my great sorrow) that the last shipment of 10,000 forest trees were all dead. How did those sent to you?-I have commenced the having a complete collection of the Birds of America in skins \& have instituted some agents in the U. S. to provide for me. So much have I seen of those dear creatures of the feathered creation that I feel even now as if I heard their notes and saw their all elegant movements.-I am going to write a book! but more of this when we meet.-do you know that the poor woodsman who now is scribling to you will take his seat at the Royal Society of London tomorrow-the very words make my head whirl and I will stand it I do not know-I will indeed be glad when I am seated.-Mrs A and myself had the pleasure of being very kindly received and treated by our President Jackson Congress subscribed, I procured there four 
more and an act will be passed to enter my works Paintings etc free of the customs. - It is past 5 and I have to pay a penny, I wish I were allowed to write untill time made it a shilling so much do I think I could still trouble you with. however as time and tide wait neither for me or others I must conclude by begging that you will remember me most kindly to your amiable wife-kiss your little Folk and believe me

sincerely your friend

John J. Audubon

\section{William Swainson to Audubon}

Saturday, 1[10?] May, 1830.

Welcome once more, my good friend to merry England:

I had indeed heard from Havell, with the greatest pleasure, that you had safely landed at Liverpool; and I regret very much that you did not reach London before I had left it; for I am now much seldomer in town than formerly, and I know not when I may have the power to do so again. My old and most valued friend Mr. Burchell has also, to my great delight, just returned to England after six years spent in wandering over the Forests and Andes of South America bringing with him collections, that will make everything else in this country sink into utter insignificance, he too, is longing to see me, and if I possibly can get away for a day next week, with two such desirable objects I will, but my literary engagements bind me, hand and foot.

You think that I do not know that you are an F. R. S.you are mistaken, furthermore, you will be surprised at knowing I have been fighting your battles against a rising opposition which originated among some of your Ornithological friends (at least so I strongly suspect) for the purpose of your name being blackballed. But more of this when we meet, such matters had better not be committed to paper.

The whole of your bundle of young trees reached me as withered sticks, not a spark of life in any one of them. 
So you are going to write a book 'tis a thing of little moment for one who is not known, because they have no reputation to loose, but much will be expected from you, and you must, therefore, as the saying is, put your best leg foremost. I am coming fast round to the prejudice, as you may think it, against the Americans.

Dr. Richardson's and my own volume on the Arctic Birds, is now in press. Not being able to refer to your plates, I have not had the power to quote your work, you know how repeatedly I have applied on this head, both to you and Mr. Havell in vain.

Prince C. Bonaparte has long promised me his second \& third volume but they have never come. Ward ${ }^{6}$ is a regular Scamp he has taught me a good lesson-fool that he isand that is, to steal my heart against distress such as his was, and to consult, like all the rest of the world, my own interest only. I am sick of the world and of mankind, and but for my family would end my days in my beloved forests of Brazil.

So Mr. Lea ${ }^{7}$ did not settle my account with you? I have found him out, also, to be no better than he should be. He also is one of your friends who would, if he could, cut your throat. Another friend of yours has been in England, Mr. Ord and has been doing you all the good he can: if these are samples of American Naturalists, defend me from ever coming in contact with any of their whole race.

Mrs. Swainson's health I am grieved to say, has suffered much the last twelve months, she is now at Birmingham with the children. I have not failed to mention your kind inquiries

- Possibly Henry Ward, who came to America with Audubon in 1831 as his assistant and taxidermist (see Vol. II, p. 2); a Frederick Ward is also mentioned in Audubon's letters.

Isaac Lea, naturalist and Philadelphia publisher; Mr. Lea was a member of the firm of Messrs. Carey \& Lea, at one time the principal proprietors of Wilson's American Ornithology, and it was thought that the prejudice which he manifested towards Audubon and his friends was traceable to his desire to maintain the sales of that work. His attitude was compared with that of Judge Hall, whose brother, Harrison, was also an interested publisher. See Vol. I, pp. 223 and 281. 
after both, whenever Havell has a parcel for me, I hope you will occasionally accompany it with a few lines.

\section{Yours my dear Sir very faith'ly}

W. Swainson

John J. AUdubon

at Mr. HAVELI's

79 Newman St.

Oxford St.

As already noticed, Audubon started on a canvassing tour late in July, 1830, as announced in the following letter to Swainson, but he changed his plans, and instead of returning to London, went to Edinburgh, and again settled there for the winter.

\section{Audubon to William Sroainson}

My dear Friend,

July 26 th 1830.

I was particularly pleased at receiving yours of the 22nd this morning, I cannot well say where it has rambled since it was dated, but certainly its migration has not been that of a Swallow for instance.-

Thank you about the Jay-It has been my misfortune to have been rather misunderstood by you respecting what you please to call "Poor Nomenclators" had I not some regard for you all of that nobler breed I would not borrow names in my work but would have like some others, made new ones right out.-If you have a new Woodpecker from the visited states, a new species, I will feel greatly honoured to have it dedicated to me, and the more so by you who first dared in good faith to write respecting an unknown woodsman-one of my case [s] is come to hand, I gave from it to the British Museum thirty skins several of which are very rare indeed and 3 of which I [here a roord is apparently omitted by the roriter] as 3 new [here another word is omitted] - I have males and females of the woodpecker you speak of quite at your service for a few 
weeks - and I have also a few duplicates for you altogether as I promised.-Say how I am to send them-I go to Bristol tomorrow in search of subscribers for ten days-To Paris on the 15th of August - have written to queen Adelaide this pleasant morning \& am glad to see that you are all well. Mr. A. joins in respects to you all \& I am as ever

your friend most truly

John J. Audubon

[The following note is written up the side of the page across the main letter:]

I cannot at present say When we can avail ourselves of your kind invitation but will let you know in good time should we but find it convenient to you when we return.-

It should be noticed that the revolution in France which upset the Bourbon dynasty occurred just as Audubon was leaving London, and that the House of Orleans, in the person of Louis Philippe, was seated on the throne the day the following letter ${ }^{8}$ was written; very likely Audubon was not reluctant to change his plan of visiting Paris after hearing of these events, although he had enjoyed an interview with the new king, who was his patron.

\section{William Sroainson to Audubon}

My dear Mr. Audubon

Saturday 7 August 1830.

as you was on the point of leaving London, when you wrote your last letter, I did not reply to it. This will probably find you returned from your excursion, and I hope with every success, on the score of increased subscribers, that you had anticipated, If you will be so good as send me your specimens of the Woodpeckers to Havell's, I shall be very glad to see them, and they shall be returned to you after examination with

\footnotetext{
${ }^{8}$ From the Howland MSS.
} 


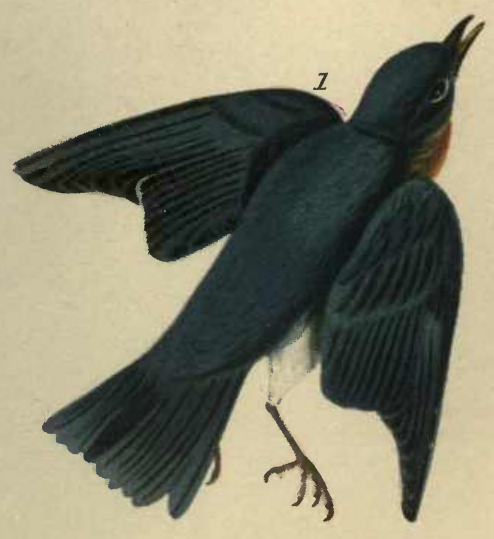

Plate CXü

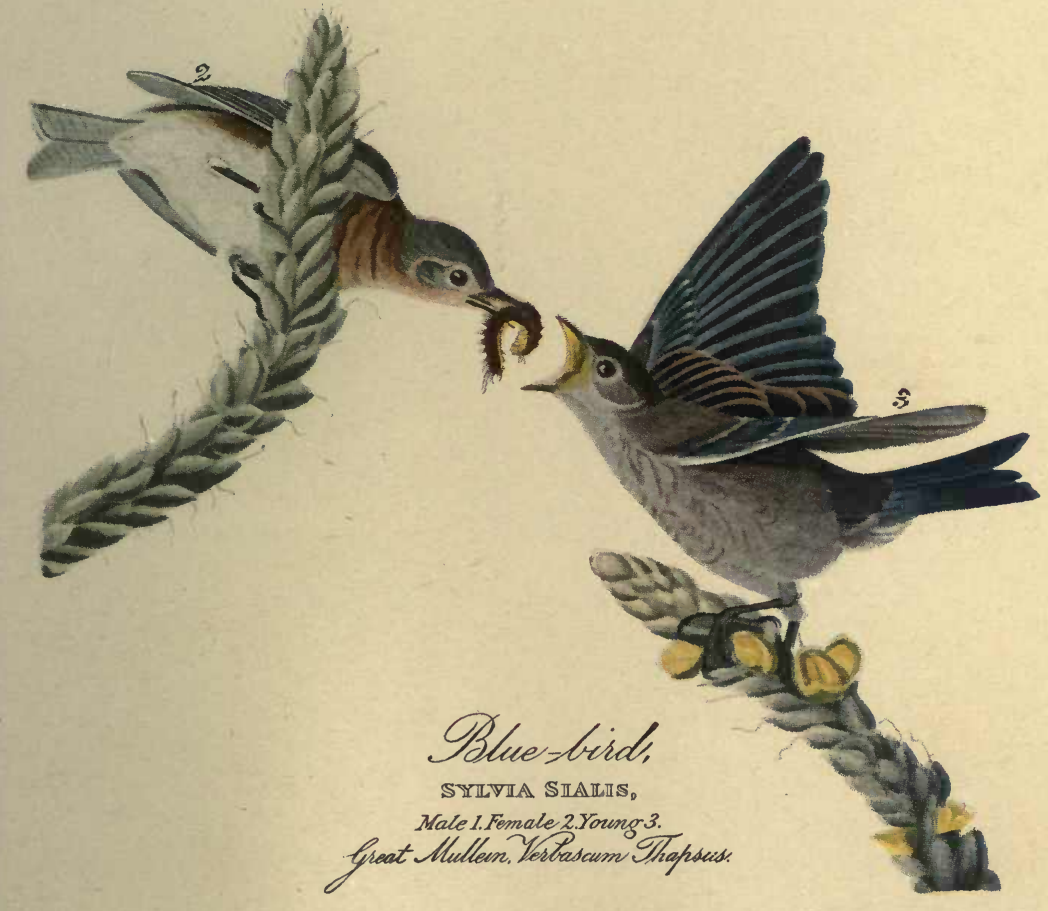

Drewn from nature by J.J Audubon F. R.S. F. L.S. 



\section{SIDELIGHTS ON CONTEMPORARIES 101}

the Arctic ones. You will assist me very much by any Duplicates you can spare me, I particularly want a pair of the Ivory billed Woodpecker. the No Am: Parrots. Summer red birds and the Painted Buntlings also the Pinecreeping Warbler. $\mathrm{m} \&$ fem.

I do not expect that these most wonderful events in France will deter you from going, seeing that everything is now quiet. The french are certainly a great nation. I never had such an opinion of them as I now have.

I suppose you will be at the Dinner to Cuvier on Tuesday, when you will no doubt hear complements passing about, and a long speech from Mr Vigors. I have neither time nor health for such things.

Our united true regards to Mrs Audubon In haste very faithfully yours

W Swarnson

J. J. Audubon Esq.

43 Great Russell Street,

Bloomsbury.

From Manchester Audubon sent Swainson this letter, in which he makes a quaint proposal regarding the text of his projected work, suggesting that they combine their resources and their families, he to provide the ideas, as well as his own wine or ale, while Swainson furnished the science.

\section{Audubon to William Sreainson}

Manchester 22nd August 1830.

My dear Mr. Swainson,-

At the time that I sent you the Woodpeckers skins, I had not a moment to spare or be assured $I$ would have answered your note-When I opened my boxes of skins I had the mortification to find most of them touched by insects-I felt a desire that those nondescribed specimen [s] which I had should go to a public institution \& I therefore presented them to the 
British Museum through my friend Children-I sent others to New Castle upon Tyne some to this place and some to our friends Selby \& Sir Wm Jardine.-respecting the Woodpeckers which you look upon as knew I will merely say that if for instance it differs from all others known by having the top of the head entirely red that it may be a young bird, I say this because $I$ do not know if you are acquainted with the fact that almost all the Woodpecker tribe have this in their youth more or less extended but after the first moult they assume the red in the form they are to wear it during life. I sent you a young of the Downy in that state-and if I recollect well also one of the Golden Winged-had you sent me your specimen, I think I could assisted you in determining if or no it is a new bird.should you become satisfied on that head, and I am honoured with its being named after me, I will feel gratified and thankful to you.-Mrs. Audubon is with me $\&$ we are bound to the Scotch Lakes \& will return in about 2 months.-I am desirous to hear from you if you can have the time to spare $\&$ the inclination to Bear a hand in the text of my work.-by my furnishing you with the ideas \& observations which $I$ have and you to add the science which I have not!-If it would suit you and Mrs Swainson to take us as borders for few months when being almost always together I could partake of your observations \& you of mine.-I would like to receive here your ideas on this subject \& if possible what amount you would expect from us as remuneration.- My first volume will comprise an introduction and one hundred letters addressed to the Reader referring to the 100 plates forming the first volume of my illustrations. - I will enter even on local descriptions of the country.-Adventures and anecdotes, speak of the trees \& the flowers the reptiles or the fishes or insects as far as I know-I wish if possible to make a pleasing book as well as an instruction one.-In the event of my living with you we will furnish our own wines, porter or ale.-

I hope you know me well enough to write to me your ideas without fearing any offence done us should you find it either disagreeable or inconvenient, indeed this is simply to know 


\section{SIDELIGHTS ON CONTEMPORARIES 103}

from you if such a thing is at all likely to be advantageous to all parties.-We leave this on Saturday for Leeds and I will be glad to hear from you then-I have a confounded steel pen that scratches abominably.-Present Mrs Audubon's kind regards to your good Lady \& accept Yourself our united good wishes,

your friend

John J. Audubon.

Address to the care of

Thos Fowler Esq.

Bookseller

Aug 22nd $1830 \quad$ Manchester.

[Superscribed] WM Swannson Esq.

Tittenhanger Green

$\mathrm{Nr}$

St Albans,

Herts.

In Swainson's clear and candid reply, ${ }^{9}$ which followed at once, all was figured "to a nicety"; he would supply his share of the matter at the rate of three dollars and seventy-eight cents per printed page, with an extra charge for corrections; he would follow his own ideas, but strive to avoid any conflict of opinion, and would expect his name to stand on the title.

\section{William Srainson to Audubon}

[between August 24 and 28, 1830]

My dear Mr. Audubon.

Thursday

I received your letter yesterday, and hasten to reply to it. By some mistake or other, of Havell's, he has not sent the birds to which you allude, and I did not of course know that you had left them with him, now to your two propositions.

'First published by Ruthven Deane (Bibl. No. 217), The Auk, vol. xxii, p. 31 (1905). 
First, as to boarding with us, you do not know probably, that this is never done in England, except as a matter of necessity or profession, in which case the domestic establishment is framed accordingly. But this consideration would have no influence with me, in your case did other circumstances allow of it. It would however be attended with so many changes in our every-day domestic arrangements, that it becomes impossible.

Secondly, as to the proposition I once made to you, I am fearful you have put it out of my power to do so much as I might have done, from your having distributed the very birds which would have been the materials I was to work upon; and upon which only, any scientific observations truly original, (\& therefore worth putting into your book), must be founded. Fortunately, however, my own collection is not poor in North American Specimens, and these would still furnish a mass of interesting information to the Scientific. It would be, however, highly advisable that all these species which I have not, but which you have brought home, and given away, should be borrowed back again, without delay.

Next as to plan. I have always told you that the plan you mention, so far as your own narrative goes, is the very best which could possibly be chosen. You have to speak of the birds as they are alive, $I$ to speak of their outward form, structure, and their place in the great System of their Creator, for the true system, if I have, or anybody else, has discovered is not a Human System. If my views are correct, every observation you make, plain, unvarnished, and strictly accurate, will fully and perfectly harmonize. Our parts are totally distinct, and we have no occasion to consult with each other what we should say at every page. Where our views may differ, I shall not, of course, say anything. My own remarks had better be kept distinct, in the form of "Scientific Notes" to each letter, at the end, and in this way you will make the work, the standard authority on American Ornithology, which without Science, it certainly would not be, however interesting or valuable in other respects. 


\section{SIDELIGHTS ON CONTEMPORARIES 105}

As to time, and remuneration, I shall have completed all my portion of Dr. Richardson's works in two months. I can then devote a portion of each day to yours. The terms of my remuneration will be those which $I$ always receive from the Booksellers, and which are fixed, worth twelve guineas a sheet of the same size and Type as the Zoölogical Journal, each sheet being 16 pages, and each page averages 390 words, the calculation is there brought to a nicety, and you may spend as much as you choose. If I have to revise and correct the proofs, make alterations etc. that will be something additional, I always charge this by the time each sheet takes me, and would come to from $5 /$ to $7 / 6$ a sheet but the booksellers generally give me a round sum, which I name after trying the three first sheets of a work, with Dr. Richardson's the case was different, I there had $300 £$ for my assistance and drawings. It would of course be understood that my name stands in the title page as responsible for such portion as concerns me.

Should we arrange this matter, it will be time enough to fix on other minor points. But I should like to know your decision soon, as $I$ have been applied to in another quarter. Indeed I am already so full of business, that I have two years active employment ahead of me. I go for two days to assist Burchell ${ }^{10}$ in the arrangement of his African Birds prior to publication, at the end of the month, I shall bear in mind what you say on the Woodpecker but I have peculiar notions on Species, which, as I believe them correct, so I do not suffer to be influenced by others, you will see more of this in my Book of American Birds. ${ }^{11}$ Our kindest remembrance to Mrs. Audubon, and always look upon me as your sincere, but very plain spoken friend,

W. Swainson.

${ }^{10}$ William John Burchell (1782?-1863), an indefatigable collector and explorer, especially in Africa and Brazil; the zebra, Equus burchelli, and many animals and plants which he discovered have been dedicated to him.

${ }^{11}$ Referring to the Fauna-Boreali Americana, the second part of which, on "Birds," published in 1831, was by Swainson; see Vol. I, p. 410. 
P. S. I had a long letter from Chas. Bonaparte the other day, Vigors is gone to Rome!!

[Addressed] J. J. Audubon

c/o Mr. Thomas Fowler, Bookseller,

Manchester.

[Endorsed by Audubon:] Answered 29th Aug. 1830. J. J. A.

Audubon's next letter, which was written from Manchester on August 29, must have been distinctly provocative, to judge from the following caustic reply ${ }^{12}$ which it drew forth; this is dated, "Tittenhanger Green, 2d October, 1830":

\section{William Swainson to Audubon}

MY DR Sir

I have refrained from replying to your letter until I thought you had returned to London.

Either you do not appear to have understood the nature of my proposition on supplying scientific information for your work, or you are very erroneously informed on the matter in which such assistance is usually given. Dr. Richardson, and a hundred others, similarly situated, might with equal justice say that no name should appear but their own; as it would rob them of their fame, because notes are furnished by one or two other persons, your friends would tell you, if you enquired of them, that even my name would add something to the value of the "The Birds of America" You pay me compliments on my scientific knowledge, and wished you possessed a portion; $\&$ you liken the acquisition of such a portion to purchasing the sketch of an eminent painter-the simile is good. but allow me to ask you, whether, after procuring the sketch, you would mix it up with your own, and pass it off to your friends as your production? I cannot possibly suppose that such would be your duplicity and I therefore must not suppose that you

12 First published by Elliott Coues (Bibl. No. 203), The Auk, vol. xv, p. 11 (1898); reproduced by Theodore Gill (Bibl. No. 205), The Osprey, vol. v, p. 23 (1900). 
intended that I should give all the scientific information I have laboured to acquire during twenty years on ornithologyconceal my name,-and transfer my fame to your pages \& to your reputation.

Few have enjoyed the opportunity of benefiting by the advice and assistance of a scientific friend so much as yourself; and no one, I must be allowed to say, has evinced so little inclination to profit by it. When I call to mind the repeated offers I have made you to correct the nomenclature of your birds, from the first time of our acquaintance, and recollect the dislike you appeared to have to receiving any such information or correction, I cannot but feel perfect surprize at you now wishing to profit by that aid, you have hitherto been so indifferent about.

Let me however urge upon you one advise which, for your own sake, I should be sorry you despised. It is to characterize yourself, or get some friend to do so for you, all your new species. The specimens, you tell me, are now in England, \& the task will be comparatively easy. I urge this, because you may not be aware that a new species, deposited in a museum, is of no authority whatsoever, until its name and its character are published. I have repeatedly set my face against such authorities, so has Mr. Vigors, so has Ch. Bonaparte, and on this head we are all perfectly unanimous. Unless, therefore, this is done, you will, I am fearful, loose the credit of discovering nearly all the new species you possess, and this I again repeat, for your own sake I should be sorry for. To me, individually, your not doing so, would rather be advantageous.

The more a book is quoted, the more is its merits admitted, and its authority established. it was on this account I so repeatedly requested the use only, of a copy of your book, that it might have been cited in "Northern Zoölogy" 13 not having it-I could not therefore mention it

I shall always be as thankful to you as formerly for any information on the habits, economy, and manners of birds;

${ }^{13}$ See Note, Vol. II, p. 105. 
but, as to species, I want not, nor do I ever ask, the opinions of any one. that is quite a different matter, and entertaining peculiar ideas on that subject, you must not feel surprised at my differing from you in almost every instance. My reasons will always be laid before the public. In the present case, we totally differ about species of Woodpeckers. I shall not, however propitiate a favourable opinion from you, or any one, by a compliment and therefore I will wait for some species which you yourself will admit, which I shall then give your name to, I am rather glad you did not accept my offer, for I am now assisting in bringing out an Octavo edition of Wilson, by Sir W Jardine which will be arranged according to my nomenclature.

$$
\begin{array}{r}
\text { Yours my dr Sir } \\
\text { Very faithy }
\end{array}
$$

W SwaInson

The letter just quoted naturally served as a check to their intimacy, but Audubon did not withdraw his friendly hand, as shown by his letters to follow later, though his answer to this has not been preserved. ${ }^{14}$

Audubon reached Edinburgh early in October, soon after receiving Swainson's decisive reply, and immediately made an arrangement with MacGillivray, as already related. ${ }^{15}$ It is evident from Swainson's letter that when Audubon called upon him for editorial aid,

14 But three other letters of Audubon to Swainson, after this date, are noted by Albert Günther (Bibl. No. 204) in the Proceedings of the Linncean Society, 112th session (1900): one of " 6 June, 1831," announces Audubon's prospective return to America in August of that year; another, dated "6 Dec. 1837," asks for the loan of some bird skins; and the last of "11 Jan. 1838," is reproduced in Chapter XXXII. Swainson is said to have been negotiating at this time with Charles L. Bonaparte in reference to a joint compilation for a work on the birds of the world; Bonaparte estimated that there were then between 7,000 and 8,000 known species to be characterized, but Swainson's terms were not satisfactory, and nothing came of the project. To the above list should be added the letter, evidently misdated, of "April 28 th. 1831," soon to follow.

${ }^{16}$ See Vol. I, p. 438. 
he was by no means ready to defer to him wholly in the matter of naming his birds, a subject in which Swainson regarded himself as the first of living authorities. Swainson's pride was also wounded at Audubon's apparent lack of appreciation of the weight which his name would carry if allowed to grace the title pages of his works, and he speaks of Audubon as if he were ready to bargain for scientific information but determined to withhold that credit which is every writer's just due. It is only fair to say that Swainson's vanity seems to have outrun his candor, for when the controversy over the authorship of Audubon's Biography of Birds was started in 1833, he publicly denied that any such proposal had been made. ${ }^{16}$ According to Swainson's own statement, quoted earlier, Audubon was ready to grant him whatever credit was due, but it is evident that he was not then disposed to adopt Swainson's peculiar ideas upon the classification of birds or to enter upon a thoroughgoing arrangement of joint authorship. Though no philosopher himself, it seems clear that the American woodsman was by no means disposed to swallow all the vagaries of the "Circular System" to which his friend was committed, and which was later held up to ridicule.

The craze for describing ncw species of animals was all too common in both England and America at the time of which we write; the chief aim of many naturalists seems to have been to attach their names to as many of nature's forms as possible. Swainson, who "never went to bed without describing a new species," as Audubon said at a later time, had admonished his friend above all else to hasten to publish descriptions of every new bird which he had obtained in America, lest he lose

${ }^{10}$ See Vol. II, p. 88. 
credit for the discovery; but Audubon, who had not hesitated to poke fun at the species-mongering Rafinesque, was still inclined to look with disdain upon work of this sort. He not only rejected Swainson's advice but answered it rather tartly in the first volume of his letterpress, which appeared in the following year. A passage which caused the naturalist no little annoyance on another score was as follows: ${ }^{17}$

Since I became acquainted with Mr. Alexander Wilson, the celebrated author of the well known and duly appreciated work on American Birds, and subsequently with my excellent friend, Charles Lucien Bonaparte, I have been aware of the keenness with which every student of Natural History presses forward to describe an object of his discovery, or that may have occurred to travellers in distant countries. There seems to be a pride, a glory in doing this, that thrusts aside every other consideration; and I really believe that the ties of friendship itself would not prevent some naturalists from even robbing an old acquaintance of the merit of first describing a previously unknown object. Although I have certainly felt very great pleasure, when, on picking up a bird, I discovered it to be new to me, yet I have never known the desire above alluded to. This feeling I still cherish; and in spite of the many injunctions which $I$ have received from naturalists far more eminent than I can ever expect to be, I have kept, and still keep, unknown to others, the species, which, not finding portrayed in any published work, I look upon as new, having only given in my Illustrations a number of them proportionate to the drawings of already known species that have been engraved. Attached to the descriptions of these, you will find the place and date of their discovery. I do not, however, intend to claim any merit for these discoveries, and should have liked as well that the objects of them had been previously known, as this would have saved some unbelievers the trouble of searching for

${ }^{17}$ Ornithological Biography (Bibl. No. 2), vol. i, p. xvii. 
them in books, and the disappointment of finding them actually new. I assure you, good reader, that, even at this moment, I should have less pleasure in presenting to the scientific world a new bird, the knowledge of whose habits I do not possess, than in describing the peculiarities of one long since discovered.

It is a pity that Audubon did not maintain so admirable an attitude towards the description of new species as was here expressed, but at the close of his career in England, when he desired to make his work on American ornithology as complete as possible, he appeared as keen to describe and publish new birds as any of his contemporaries.

Shortly after his return to London in the spring of 1831, Audubon sent Swainson the following letter with a copy of the first volume of his Biography of Birds, but his one-time friend was not the author of an extended and impartial review of the work, which appeared in the Edinburgh Nere Philosophical Journal in the same year. ${ }^{18}$

${ }^{18}$ Signed “Ornithophilus" (see Bibliography, No. 97), and attributed by Coues (see Bibliography, No. 181), with a question mark, to Swainson, but the internal evidence shows conclusively that he was not its author. The writer of this article said that it was not enough to state that Audubon "has invented a new style in the representation of natural objects; for so true are his pictures, that he who has once seen and examined them, can never again look with pleasure on the finest productions of other artists. To paint like Audubon, will henceforth mean to represent Nature as she is. ... To relieve, as Mr. Audubon says, the tedium of those who may have imposed upon themselves the task of following an author through the mazes of descriptive ornithology, he has interspersed descriptions of American scenery and manners, gloomy forests, tangled cane-brakes, dismal swamps, majestic rivers, floods, tornadoes, and earthquakes; the migration of the white man, the retreat of the red; the character and pursuits of the backwoodsman.... Much, therefore, is it to be wished that Mr. Audubon would undertake the delineation of the birds of Great Britain, which, with his matchless talents, aided by those of Mr. Havell, would eclipse, not only all other representations of these birds, but even the 'Birds of America,' unrivalled as that work now is." 


\section{Audubon to William Swainson}

My dear Mr Swainson,

Londow April 28th 1830 [1831]

We arrived here last evening \& I found your favour of the 17th instant for which I offer you my sincere thanks-I had began to think that I was erased from your list.-I have now the pleasure of sending you a copy of my first volume of ornithological biography which I hope you will accept as a small memento of the high regard I have for your self \& your talents.-My inserting your name was not a matter merely of duty but of great pleasure and believe when I say that I never will be ungrateful to anyone who has been kind to me.-

We are going to Paris on Friday week \& will be absent about a month-on the first day of August next we sail from Liverpool to America where I intend to beat the bushes once more-my peregrinations will extend in all probability \& God willing to the Pacific Ocean into California etc-After my return I wish to settle in England somewhere, but where is yet undetermined.-

I have felt much grieved at reading the article of yours respecting French Naturalists. I say grieved, because I am always so when I see men of superior talents employing their pen time and mind at sparring instead of peacably giving to the world those results of their investigations \& experience at all times so desired by everyone bent on studying the wonderful laws \& beauties of nature. I do not wish to read a lecture to you but from my heart I am sorry you should be à la joute [?] with any one $\&$ will conclude by sincerely hoping that you will have no more of this sort of warfare.-

I am over head in business as you may well suppose after an absence of 8 months but will be most happy to hear from you. Have you heard from C. Bonaparte lately? Is he still at Rome? it is now two months since I heard from him.-

Present our united kind respects to your good Lady, accept the same yourself \& believe me your friend

J. J. Audubon.

77 Oxford Street. 
It is interesting to notice that Swainson kept his promise about the woodpeckers, and in 1831 named one, which had been obtained from Louisiana, Picus auduboni; ${ }^{19}$ although Audubon later repudiated it, saying that he believed it to represent only an immature state of the common Downy Woodpecker, he returned the compliment by dedicating to Swainson one of his warblers, Sylvia, now Helinaria, srainsonii.

When William Swainson brought to a close his labors on the Cabinet Cyclopcedia in 1840, a part of the eleventh volume was devoted to a biography of naturalists. ${ }^{20}$ In this little work Audubon was accorded a page, Alexander Wilson received eight, while the author devoted fourteen pages to himself. The talented MacGillivray, whose memorable History of British Birds had then advanced to its third volume, was studiously ignored, and was referred to only in a footnote as "Mr. Gilvray"; but he was of necessity a sharer in the follow-

${ }^{10}$ See Ornithological Biography, vol. $\nabla$, p. 194; and Theodore Gill (Bibl. No. 206), The Osprey, vol. iv and $\nabla$. It seems that Dr. James Trudeau, out of ignorance or disregard for Swainson's designation, later named a woodpecker, obtained near New Orleans in 1837, Picus auduboni, and by a strange coincidence, as Dr. Gill has noticed, the same name was given by two different naturalists to the same bird, now regarded as a variety and known as Dryobates villosus auduboni.

${ }^{20}$ The Cabinet Cyclopadia was published by Messrs. Longman, Orme \& Company, and edited by Rev. Dionysius Lardner. Swainson wrote eleven of the twelve volumes devoted to natural history. The volume to which we refer is entitled Taxidermy, Bibliography, and Biography, by William Swainson, A. C. G. [Assistant Commissary-General], F. R. S. \& L. S., Hon. F. C. P. S. etc., and of several foreign societies (see Bibliography, No. 170). The Literary Gazette for August 8, 1840, in noticing this work, said: "Perhaps the amusing and frequent illustration of his character is to be found in the autobiographical sketch of himself, which he has not only included in this portion of his volume, but induced his publishers to forward on a separate sheet with the subjoined note:

" 'Messrs. Longman, Orme, \& Co., will feel particularly obliged if the Editor of the ..................... will permit the above Autobiography to appear in his columns at the first suitable opportunity.'

" '39 Paternoster Row, July 29, 1840." " (1900).

Quoted by Theodore Gill (Bibl. No. 206), The Osprey, vol. iv, p. 105 
ing criticism of Audubon's Biography of Birds: "a want of precision in his descriptions, and a general ignorance of modern ornithology sadly disappoint the scientific reader." The technical descriptions in that work were written, as Swainson must have known, by his young rival, William MacGillivray, then one of the ablest exponents of the anatomy of birds in Great Britain; but anatomy, the master key to relationship, Swainson affected to regard with contempt, though overzealous friends had compared him with Cuvier, one of the greatest masters of anatomy of all time. To follow the comment of a later critic, ${ }^{21}$ Swainson probably regarded the title of "the British Cuvier" as rather derogatory, since he had pronounced Cuvier to have been "totally unacquainted with the very first principles of the natural system." To Swainson, however, as the same commentator explains, "the natural system" implied the concept of a magical number and a circle, ideas which Cuvier would have been the first to repudiate or ignore.

The ardent MacGillivray was naturally scornful of Swainson's unscientific attitude, which he had roundly scored in the introduction to his History of British Birds that had begun to appear in 1837; he then said that Swainson could exclaim: "How superficially do we study nature," while in anatomy his own studies were a century behind the times and his opinions on the subject worthy of the Dark Ages.

In his biographical notice of Audubon, Swainson refers to their Paris experience in the following words:

It is singular how two minds, possessing the same tastes, can be so diversified, as to differ in toto respecting the very same objects. During the whole of Mr. Audubon's residence

"1 Theodore Gill, loc. cit. 
in Paris, he only visited the Ornithological Gallery twice, (where I was studying for hours, almost daily), for the purpose of calling upon me; and even then he merely bestowed that sort of passing glance at the magnificent cases of birds, which a careless observer would do while sauntering in the room.

Audubon, to be sure, was never much of a closet naturalist or an admirer of stuffed specimens; but in reading this criticism of an estranged friend, one wonders if the writer had really forgotten that while his own expressed desire in going to Paris in 1828 was to study in the Museum, Audubon's sole purpose was to extend his subscription list; that after innumerable interviews with ministers of state and running from post to pillar for two months, his friend was obliged to come away with but thirteen additional names or orders for his work. Had Swainson also forgotten that during all that time Audubon acted as his interpreter, assisting him in all his visits and purchases, and that but shortly after, when hard pressed for money, he had called on Audubon for a considerable sum?

As a parting shot to his former friend, Swainson also said:

He can shoot a bird, and make it live again, as it were, upon canvass ; but he cannot describe it in scientific, and therefore in perfectly intelligible terms. Hence he found it necessary, in this part of his work, to call in the aid of others; but being jealous that any other name should appear on the title page than his own, he was content with the assistance of some one who, very good naturedly, would fall in with his humour.

What was here said of Audubon might have been true in 1830, but it was not true in 1840. Swainson could never understand that his friend was a man who 
never stood still. Audubon drew heavily upon his more learned associates, and he could give as well as take. When working under the influence of a powerful motive, he improved as rapidly in his use of English words as he had in the finish and composition of his pictures; he soon came to write not only with fluency but at times with eloquence, and the technicalities of his science did not remain to him a sealed book, though for the drudgery of detailed description he had confessedly no stomach.

We have referred to William Swainson's advocacy of the "Circular" or "Quinarian" system of the classification of animals, with him amounting almost to a monomania, which was one of the most notorious examples of reasoning in a circle of which zoölogists have ever been guilty. It was a serious attempt to rationalize nature in a wholly irrational manner, and must be regarded as a curious by-product of minds fixed in the belief of a special creation,- to whom every form of evolutionary doctrine was sacrilegious and abhorrent. Its advocates, nevertheless, were sincere, and Swainson probably regarded himself as a martyr to the cause. As a later critic remarked, the system served him well by investing with a cloak of originality his treatises on those classes of animals with which he had little first-hand knowledge. His work on fishes is regarded as "a literary curiosity, the appearance of which was a misfortune to a man who, by his indefatigable industry under by no means favorable circumstances, had contributed as much as any of his contemporaries to the advancement of Zoölogy and its diffusion among the people." 22 This egregious doctrine, which its disciples called "the natural system" without grasping the true meaning of

${ }^{22}$ Albert Günther, loc. cit. 
"affinity," or "homology," to use the more modern word, vitiated most of their writings; abler men played with it for a time, only to cast it aside, and no one but a historian or a psychologist would now give it a passing thought. So far as Swainson was concerned, Audubon's conduct appears to have been above reproach, and it must be regarded as fortunate that this ardent "Quinarian" did not have a hand in the Biography of Birds, for if it were really true that Audubon could have brought himself to accept the artificial system then in vogue, American ornithology, as Elliott Coues remarked, escaped a great affliction.

Swainson's early life affords a striking illustration of nepotism, and his later years reflected some of its disastrous consequences. At fourteen he was appointed as a junior clerk in the Liverpool Customs House at a salary of eighty pounds a year, to service under his father, who had in turn succeeded his grandfather in the office of Collector. At eighteen he received an appointment in the commissary department of the English army and went to Sicily, where he remained eight years, during which he worked industriously at natural-history pursuits. Having attained the rank of Assistant Commissary-General, at twenty-six he was retired on halfpay because of ill health. Upon returning to England he became a member of the Linnæan Society, in 1816, before his departure for Brazil, where with Henry Koster he collected birds for nearly two years. Having settled again at Liverpool, he entered the Royal Society, on the recommendation of Sir Joseph Banks, in 1820, the year in which he began to publish the results of his studies. Swainson was married in 1825, but upon the death of his father in the following year, his income was so much reduced that he resorted to authorship as 
a profession; of course he found it a poor crutch, though he worked with indefatigable industry and produced from one to two illustrated volumes each year. Eventually he became embittered against Audubon and towards the world of men and things in general, especially after 1835, when domestic bereavement and trouble of many kinds pressed hard upon him. He repeatedly applied to the Zoölogical Department of the British Museum for a position which went to others; he tried to sell his collections to the Museum and failed; he applied for an appointment on the Civil List but was denied; then he decided to give up the struggle of authorship in England and leave the country.

In 1840 Swainson emigrated with his family to New Zealand, where he seems to have met with no better success, although his scientific activity did not wholly cease. Though four years younger than Audubon, he outlived him five years, dying in 1856. His excellent draughtsmanship, tireless industry, and punctilious habits were deserving of recognition, but he suffered from the lack of a liberal education, and was rather too vain, too inclined to jealousy and to quarrel with his contemporaries, to have achieved great success.

In a paragraph already quoted from the Ornithological Biography, in which Audubon portrayed the eagerness with which some naturalists pressed forward to describe new species of birds, too often forgetting every propriety in their eagerness to outstrip a rival, the name of his "excellent friend, Charles Lucien Bonaparte," ${ }^{23}$ had been indiscreetly mentioned. Though there was no evident intention of giving offense, this reference was keenly resented. Bonaparte, it may be recalled, was still engaged upon his American Orni-

${ }^{23}$ For notice of Bonaparte see Note, Vol. I, p. 329. 


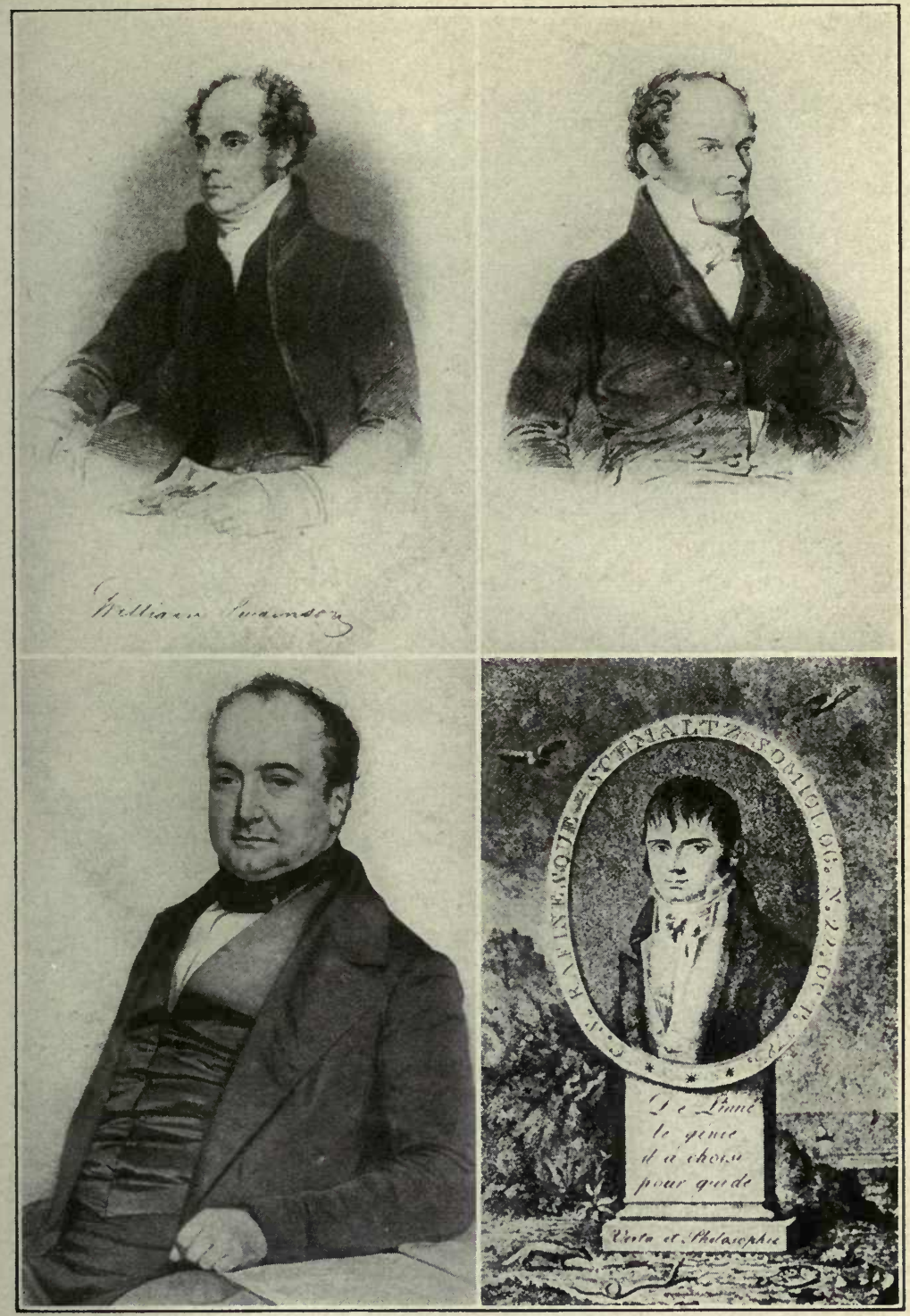

WILLIAM SWAINSON

THOMAS NUTTALL CHARLES L. BONAPARTE CONSTANTINE S. RAFINESQUE SWAINSON FROM HIS "BIOGRAPHY OF ZOÖLOGISTS"; NUTTALL FROM AN ENGRAVING AFTER DERBY, 1825; BONAPARTE FROM A PHOTOGRAPH IN POSSESSION OF MR. RUTHVEN DEA NE, FIRST PUBLISHED IN "CASSINIA"; AND RAFINESQUE FROM RICHARD ELLSWORTH CALL, "RAFINESQUE." 

thology, the last volume of which was not published until 1833, and was therefore, in a degree, a rival of Audubon in the ornithological field. Audubon did his best to smooth over the difficulty but with little success. In writing to his son, Victor, from New York in 1833, ${ }^{24}$ he referred to the following letter which he was about to send "by duplicate, to try to correct that error" of his early friend:

\section{Audubon to Charles Lucien Bonaparte}

To Charles Bonaparte,

Prince of Musignano, \&c., \&c., \&c.

My dear Sir:-

I am sadly grieved to hear through our friend, Wm. Cooper, of this city, that you have taken umbrage to a passage in the Introduction to my first volume of Ornithological Biographies.

To tell you that not even a thought of disparagement ever existed in my mind towards you, would not be enough. I have always repeated to all my Friends, nay, to all persons who have ever spoken of you, of the superior talents you possess, and of the Intrinsic value connected with all your ornithological or otherwise scientific productions.

I am a plain sailing man. You know full well that I derive no knowledge from classical education, and that being the case, connected with my being honest, I always try to say what I think truth, at once. Could I have praised you at one place, and attempted to lower you in the estimation of the Scientific World at another? If so-I would acknowledge myself unworthy the good wishes of any one, much less of the good wishes of Charles Bonaparte! the very being who brought me forward into worldly notice by his kind advice. Nay, Nay; take me for what $I$ am in truth

Your Friend \& ever your well wisher, as well as your obt. Sert.

John J. Audubon.

${ }^{24}$ See Vol. II, p. 40. 
Bonaparte was too much of a man of the world to permit such an incident to cause any sudden break in their relations. We know that they met in London in 1837, when, as Audubon said in a later letter to Harris ${ }^{25}$ he "pumped him sadly too much"; at his request Bonaparte then drew up a list of American birds, to the number of $425 .^{26}$ Although his subscription to The Birds of America was permitted to lapse, Bonaparte's name was retained on the list to the end. When the business was being closed up in London, however, Audubon wrote to Havell, from Edinburgh, under date of 15 May, 1839: "As respects my old Friend, C. Bonaparte, unless he pays the long standing balance which he owes me of £8.18.6, and also the price of the set of Nos. 81-87, on the nail, he is not to receive the latter." Again on the thirtieth of June he wrote: "I have no numbers for Charles Bonaparte, and no 5 th. vol. of Biog. for Mr. Gould; let the Gentlemen purchase or procure what they want where they can."

In 1838 Bonaparte published a paper ${ }^{27}$ in which appeared this comment:

Throughout the list I have quoted, as types of the species

${ }^{25}$ See Vol. II, p. 184.

${ }^{28}$ This manuscript list is preserved with the original drawings of The Birds of America, in possession of the Historical Society of New York, where I was permitted to examine it. It bears the following attests of both naturalists in autograph:

"The above list of the Birds of America was made at London on the 15 th. of December, 1837, when it was supposed to contain all the known species.

$$
\text { "Jomir J. Audubon, }
$$
of Louisiana."

"The above list of North American Birds was drawn up by myself to please Mr. J. J. Audubon.

"London, 15 December, 1837.

"Charles L. Bonaparte.

"The total number of good species, 460 ," has been added in pencil. London, 1838.

${ }^{27}$ Comparative List of the Birds of Europe and North America, 


\section{SIDELIGHTS ON CONTEMPORARIES 121}

under consideration, the figures of the great works of $\mathrm{Mr}$. John Gould and Mr. Audubon on the Ornithology of the two regions, as they must be considered the standard works of the subject. The merit of Mr. Audubon's work yields only to the size of his book; while Mr. Gould's work on the Birds of Europe though inferior in size to that of Mr. Audubon-is the most beautiful work that has ever appeared in this or any other country.

A reviewer in America, ${ }^{28}$ who could not repress his resentment at the last remark, said: "It would be invidious to make any comment on this-to even insinuate a wonder that a personage bearing this world renowned name would consent to resign his reputation as a man of science, through all time, to the doubtful association of such an expression of mere professional spite."

John Gould, to whom Bonaparte referred, was perhaps the only ornithologist who ever grew rich at his profession. He was the author of forty large, illustrated folios, produced at the rate of about one a year, on the birds of Great Britain, Europe, Asia, and Australia, as well as those of numerous families of the tropical Orient. Audubon, in response to Bachman, thus referred to him when writing in London, April 30, 1835: "Gould is a man of great industry and has the advantage of the Zoölogical Society, museums, gardens, \&c., and is in correspondence with Temminck, Jardine, Selby, James Wilson and the rest of the scientific gentry. His wife makes his drawings on stone. She is a plain, fine woman, and although their works are not quite up to nature, both deserve great credit."

Acting no doubt upon this expressed belief, Audubon became a subscriber to Gould's Century of Birds,

${ }^{28}$ See Note, Vol. II, p. 122. 
published in 1831, and also to his Birds of Europe (1832-37). In the preface to the latter work, "J. J. Audubon, Esq.," and twenty others are thanked "for the warm interest which they have at all times taken in the present work"; it was also said that the greater part of the plates of this series, those of his Century of Birds from the Himalaya Mountains and his Monograph on the Trogons, as well as three-quarters of those of the Monograph on the Toucans, "have been drawn and lithographed by Mrs. Gould, from sketches and designs by myself always taken from nature." It should be noticed also that Gould appeared as a subscriber to The Birds of America in 1838, but his name was soon dropped.

Gould was preëminently a museum naturalist, of strong commercial instincts, and spent but little time in the field. His books were mainly composed of illustrations made by artists from stuffed specimens, with a text of so thin a quality as to possess little scientific value; but, as Alfred Newton has remarked, a scientific character was so adroitly assumed that scientific men have often been deceived. In his best work, that on the Humming Birds, ${ }^{29}$ the plates are enlivened by numerous specimens of tropical flowers and fruits, an accessory not so noticeable in his early productions. It has been said that Gould sought and received Audubon's aid in the composition of some of his plates, and that thereafter his figures began to show more vitality. The over-zealous writer quoted above ${ }^{30}$ made the charge that Gould not only received much unacknowledged aid from Audubon, but copied his drawings; he mentioned five

20 A Monograph of the Trochilida, or Family of the Humming-Birds; 5 vols., fol., with Supplement by Bowlder Sharpe, London, 1861.

${ }^{30}$ Charles Winterfield, see Bibliography, No. 148. 
cases of what he called "picking and stealing," in one of which the Red-headed Pochard is declared to have been copied from Audubon's Scaup Duck: "here the trick is so shallow," he adds, "that detection cannot for a moment be at fault. You see that the Scaup Ducks have been accurately outlined, then lifted from the original 'grounding,' and let down upon a new one, by Gould, who found it safer for his pencil to adjust earth and water differently beneath them, than to tamper in the slightest degree with the proportions of the figures themselves." Suffice it to say that there is little or no substantial basis for such odious charges.

Gould is said to have possessed a kind heart under a rather gruff exterior. The following anecdote of his methods comes at second hand from his friend and collaborator, Mr. Bowlder Sharpe. Mr. Gould was invited to dine at a well known country estate, where were gathered numerous representatives of wealth and aristocracy. The attention of the ornithologist was soon directed from the guests to a bird on the lawn, which he was watching intently when dinner was announced; abruptly leaving the table with the remark that dinner was of no consequence to him when he could study a bird, he returned to the window and stood there munching a roll or piece of bread. Of course the seated guests began to inquire who the peculiar individual was, and were quietly informed by their host that it was "Mr. Gould, the famous ornithologist." The meal over, Gould selected a promising looking young nobleman and began to tell him about the habits of the bird which had so fascinated him; "that species," he said, "I have described in my Birds of Europe. Of course, you have seen my Birds of Europe." The nobleman was obliged to admit that he had not. "Why," said Mr. Gould, "you must 
have seen it; every country gentleman has it in his library. Won't you let me put you down for a copy?" Naturally he could not refuse a work which every country gentleman possessed, and down went his name on the list; later he received the volumes and also a bill for fifty pounds. John Gould is said to have left a fortune of eighty thousand pounds.

Probably no class of men with kindred tastes are bound together with stronger ties of good fellowship than the naturalists. Their free-masonry extends to every clime and race, and knows no distinction of language, class or station; but, as with all serious workers, occasional jealousies or disputes occur to ruffle the serenity of their lives. Though we have been obliged to touch upon some of these incidents, they are nevertheless quite exceptional. 


\section{CHAPTER XXX}

\section{AUDUBON AND MACGILLIVRAY}

In London once more-MacGillivray's assistance continued-Return to Edinburgh-MacGillivray's character and accomplishments-Audubon's acknowledgments-Tributes of "Christopher North"-Results of overwork-Fusilades from "Walton Hall"-Progress of the large plates.

Audubon's return voyage, begun in mid-April, lasted twenty days, and was one of the uneventful, "not unpleasant sort." Liverpool was reached in early May, and later in the month the Audubons were again settled in London, where on June 1, 1834, the naturalist wrote to Edward Harris:

We found Victor at home in the evening of our arrival; I thought that the very sight of him was a restoration of life to me, and our happiness was as complete as it may ever be expected on this Earth.

After all, I long to be in America again, nay, if I can go home to return no more to Europe, it seems to me that I shall ever enjoy more peace of mind, $\&$ even Physical comfort than I can meet with in any portion of the world beside. ${ }^{1}$

While at Charleston in the previous winter, Audubon had worked diligently at his letterpress, and no doubt, before returning to Europe had his "biographical" materials well in hand. We have seen that at Edinburgh in the autumn of $\mathbf{1 8 3 0}$ he entered upon a businesslike arrangement with William MacGillivray to as-

${ }^{1}$ From letter written at 73 Margaret Street, Cavendish Square, and sealed with turkey-cock seal. (Jeanes MSS.) 
sist him with the technical portions of the Ornithological Biography. The part which his young assistant played in this work was long a subject of dispute, until letters of both which showed the precise character of the relations between them were finally published.

Immediately upon his return to England Audubon again applied to his young friend, and received from him the following letter: ${ }^{2}$

\section{William MacGillivray to Audubon}

Edingurgh, 11 Gilmore Place.

Dear Sir, 28 th May 1834.

I am glad to hear of your safe arrival, which I did not expect so soon, and pleased to find you in good health and high spirits. As you have the kindness to inquire respecting myself and family, I am happy to inform you that we are all very well, contented and busy. My head and hands are quite full-abundance of work and sufficient pay-time to ramble now and then for the purpose of hammering rocks, pulling plants, and shooting birds.

You say you have accumulated a mass of materials which you are desirous of sening in print, and propose that $I$ should revise it as before. I shall be glad to do so, if you please, and willing that you confer the benefit on another, if you find it expedient. As to the terms, let them be such as you please with respect to money; but as time is valuable to me, I should like that arrangements be made so as to prevent unnecessary loss of it, by letting me have manuscripts, books, \&c. in due array.

The skins of which you speak I apprehend cannot be disposed of here to any great extent; but I believe shells might be sold to advantage, and bring higher prices than in London.

You ask if I draw Birds yet, with a view to publish. My

First published by Elliott Coues (Bibl. No. 43) in the Bulletin of the Nuttall Ornithological Club, vol. v (1880). 


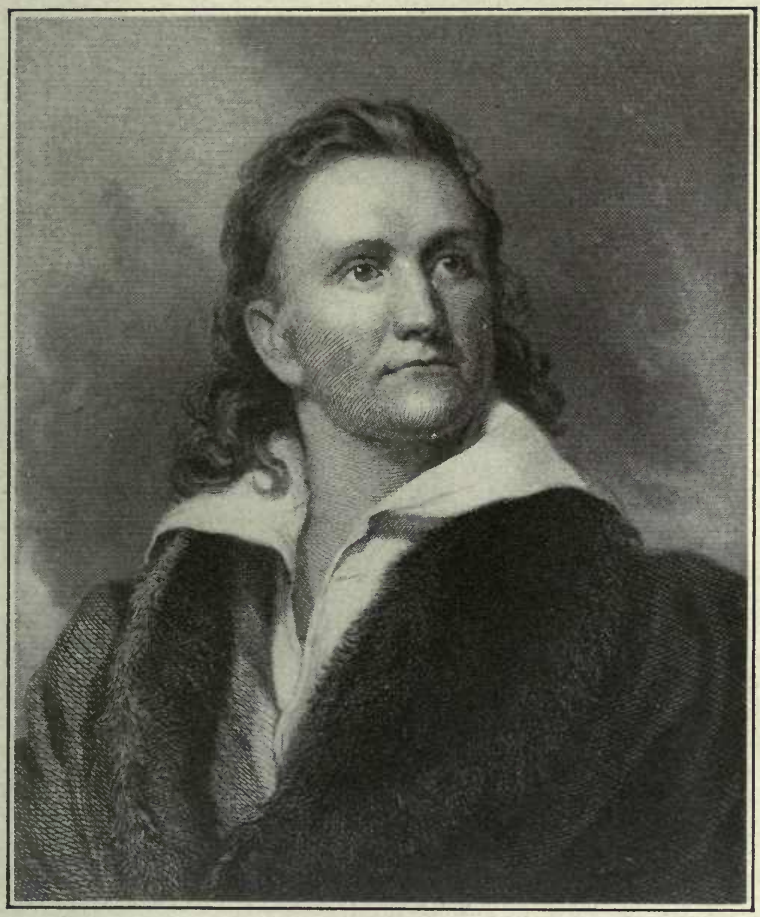

AUDUBON

AFTER TIIE ENGRAVIYG BY H. B. HAI.L OF TIIE PORTRAIT PAINTED BY IHENRY INMAN IN 1833. 

answer is that I dissect, describe, and draw Birds, Quadrupeds, whales, reptiles, and fishes, with view of astonishing the world, and bettering my condition. I have about a hundred drawings, all the size of life, excepting two dolphins. But I have determined nothing as yet respecting publication. Some time ago a friend of mine called on Mr. Havell with a letter in which I desired that person to engrave for me a few of my drawings, for the purpose of being exhibited at the meeting of naturalists. I had no answer, and so Mr. Havell may go to Jerico, or elsewhere, as he lists; but further your correspondent saith not.

I am decidedly of opinion that, although you should continue the publication of the Ornithological Biography, you might bring out various other works which could not fail to be popular; for example a biography of yourself, and sketches of American scenery. But of these matters it is impossible to speak to purpose unless I had the pleasure of seeing you, a pleasure which I hope I shall have at the time of the general assembly of the naturalists.

With best respects to Mrs. Audubon, and best wishes for the prosperity of all that bear that name, I have the honour to be, Dear Sir, yours in sincerity,

\section{W MacGillivray.}

[Superscribed] John J. Audubon, Esqr. Mr. Havell, 77 Oxford St. London.

A satisfactory arrangement was made and MacGillivray set to work on Audubon's second volume. On the 16th of June he wrote from Edinburgh:

If you send me twenty or twenty-five articles, I can revise them without the books to which you refer, and without your own presence, provided your descriptions be full, and the drawings or plates sent to me. The skins and books might be consulted afterwards, when we might go over the articles in company. Should you come here for the purpose, it.would not, I 
believe, be necessary for you to stay more than three weeks or so. . . . To be methodical I should like twenty-five birds, that is description of birds, by your first parcel; but I cannot state precisely at what time they might be revised, only I think were you to send them, you might make a trip to France and be back before I should be done. ${ }^{3}$

By the 9th of July MacGillivray had received the twenty-five descriptions of birds called for, and on the 18th of that month he wrote to report progress as follows:

I commenced my operations on the 1 st of July, and have transcribed and corrected eighteen articles, one for each day, but not one on each, the work of Sunday being transferred to Monday. This volume will certainly be much richer and more interesting. ... You wish to know my opinion as to the improvement of your style. It seems to me to be much the same as before, but the information which you give is more diversified \& more satisfactory.

On more than one occasion MacGillivray urged Audubon to reduce the size of his text, and in the letter just quoted he said: "Had it been of the post 8 vo size, in two volumes it would have gone off in style; but your imperial size and regal price do not answer for radicals, or republicans either. Could you sacrifice the first volume, reprint it of a small size and continue the series to the end?" He remarked that if twenty woodcuts or engravings were added to each volume, "it would spread over the land like a flock of migratory pigeons. Even without the embellishments it would fly, but were you to give it those additional wings, it would sweep along in beautiful curves, like the nighthawk or the

For this and extracts in the two following paragraphs, see Ruthven Deane (Bibl. No. 209), The $A u k$, vol. xviii (1901). 
purplebreasted swallow." "I have often thought," he continued, "that your stories would sell very well by themselves, and I am sure that with your celebrity, knowledge, and enthusiasm, you have it in your power to become more popular than your glorious pictures can ever make you of themselves, they being too aristocratic and exclusive."

Audubon kept MacGillivray supplied with materials, while he remained in London during the summer of 1834. On the 25th of August he wrote Bachman that he had sold bird skins to the British Museum to the amount of fifty-two pounds sterling, and again for twenty-five pounds, while Havell had disposed of a goodly number more, so that "he would not be a loser in that way"; he added: "My own double collection I have in drawers at home." Acting evidently upon Swainson's advice, Audubon began to accumulate a large and valuable collection of the skins of American birds, which he brought with him to America in 1839. Though rightly criticized for not having deposited in some museum a complete series of the forms which he described, Elliott Coues certainly was not justified in remarking that his interest in a bird ceased from the moment he had made a drawing of it; on the contrary, he spent no end of time and lavished large sums of money on collections to illustrate variation in every description, as well as for anatomical dissection.

A hint thrown out by MacGillivray seems to have been well taken, for in the letter just quoted Audubon said: "This coming winter I will spend at writing my oren Biography, to be published as soon as possible, and to be continued, as God may be pleased to grant me life." As already noticed, ${ }^{5}$ this effort resulted only in

' See Vol. II, p. 264.

${ }^{5}$ See Vol. I, p. 16. 
a fragmentary sketch, which was not published for over half a century.

Audubon started for Edinburgh in September of 1834. He wrote to Edward Harris from Liverpool, on the 15th of that month, to inquire into the truth of a report, which had circulated in London, of the failure of the house in New Orleans "in which our friend N. Berthoud is concerned." "I wish you would have the kindness to inform me," he adds, "if he is a sufferer by this mishap, and I wish you to keep this quite entre nous."

At a slightly earlier day Audubon had entertained the idea of illustrating the birds of Great Britain on a scale commensurate with his work on those of America, but on May 1, 1828, he wrote Swainson that no one favored the project, and it was quickly given up. The subject is referred to by MacGillivray, in a letter written from Edinburgh, May 7, 1831: "As I understand your proposals respecting the Birds of Britain to have ended in nothing, and as you do not allude to the subject, I shall suppose all your ideas to have dispersed, and shall think of the matter myself." The first volume of MacGillivray's History of British Birds appeared six years later. ${ }^{6}$ It is evident that he wished to obtain $\mathrm{Au}$ dubon's criticism of some of the drawings subsequently used in this work when he sent the following formal note $^{7}$ to his lodgings at Edinburgh:

\section{William MacGillivray to Audubon}

Dear Sir,

EDINBURgh, 22d. october, 1834.

I take the liberty of sending you a collection of drawings made by myself, and intended for a work on the vertebrate

- See Vol. II, p. 135.

This, and the letter of MacGillivray soon to follow, are from the Howland MSS. 
seae dri;

\section{Eduribugh, 22: oototex, 1834.}

State the libenty of rending your a edeection of trawnigs made by myreg, ano nitehdes for a work on the bectelvate ammoci of heat Pritout. He astimil. my ruceefs with whice you thave deficter awhole clap of

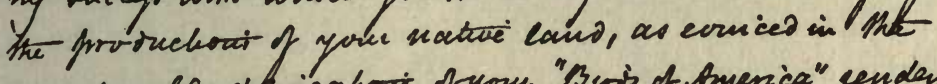
meonfrarabe detureahoir Ifyou "Buris of America", eenden

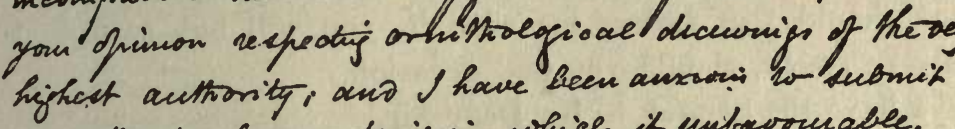

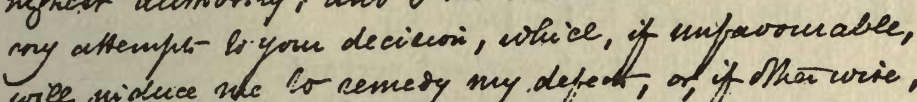

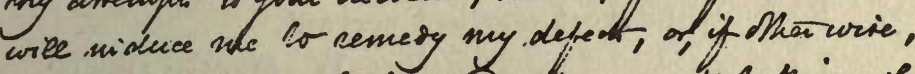

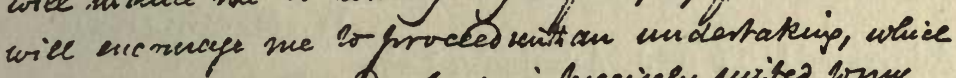

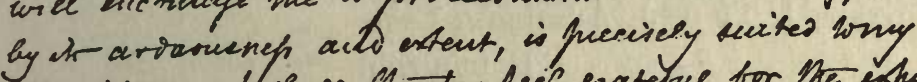

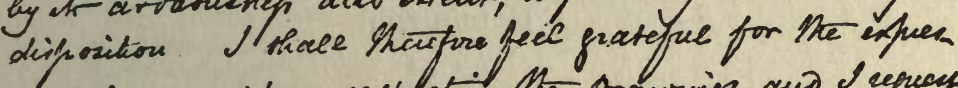

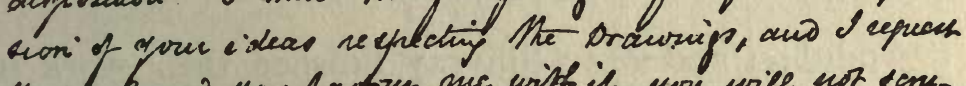
that shoued you facoren one with it, you will not serne. the so censure frely, oboucd you fino oceatcori. Ihave the honom Wobe, Deau Hir; you most oberient tervant, Hi: chachill wray.

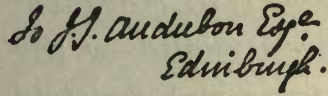

IETTER OF WILLIAM MACGILLIVRAY TO AUDUBON, OCTOBER 22. 1834. From the Howland MSS. 
animals of Great Britain. The astonishing success with which you have depicted a whole class of the productions of your native land, as evinced in the incomparable delineations of your "Birds of America," renders your opinions respecting ornithological drawings of the very highest authority; and I have been anxious to submit my attempts to your decision, which, if unfavourable, will induce me to remedy my defects, or, if otherwise, will encourage me to proceed with an undertaking, which by its arduousness and extent, is precisely suited to my disposition. I shall therefore feel grateful for the expression of your ideas respecting the Drawings, and I request that should you favour me with it, you will not scruple to censure freely, should you find occasion.

I have the honour to be, Dear Sir, your most obedient servant,

W. MacGilitiray.

[Addressed] To J. J. Audubon, Esqe.

Edinburgh.

Audubon and MacGillivray finished their work in November, and by the first of December the manuscript of the second volume of the Ornithological Biography was in the printer's hands. On the 10th of the latter month Audubon wrote to Bachman from Edinburgh: "I am quite sure I never have been half as anxious as I am at this moment to do all in my power to compleat my vast enterprise, and sorrowful indeed would be my dying moments if this book of mine were not finished ere my eyes are for ever closed." The naturalist was thinking of materials for new "Episodes" for the work when he added:

Try to study the habits of the alligator, the time of its propagation, number of eggs, form of the nest, \&c., \&c., \&c. I long to possess all respecting this reptile (amphibian) [sic] for my article of the Wood Ibis and Sand Hill Crane, for it 


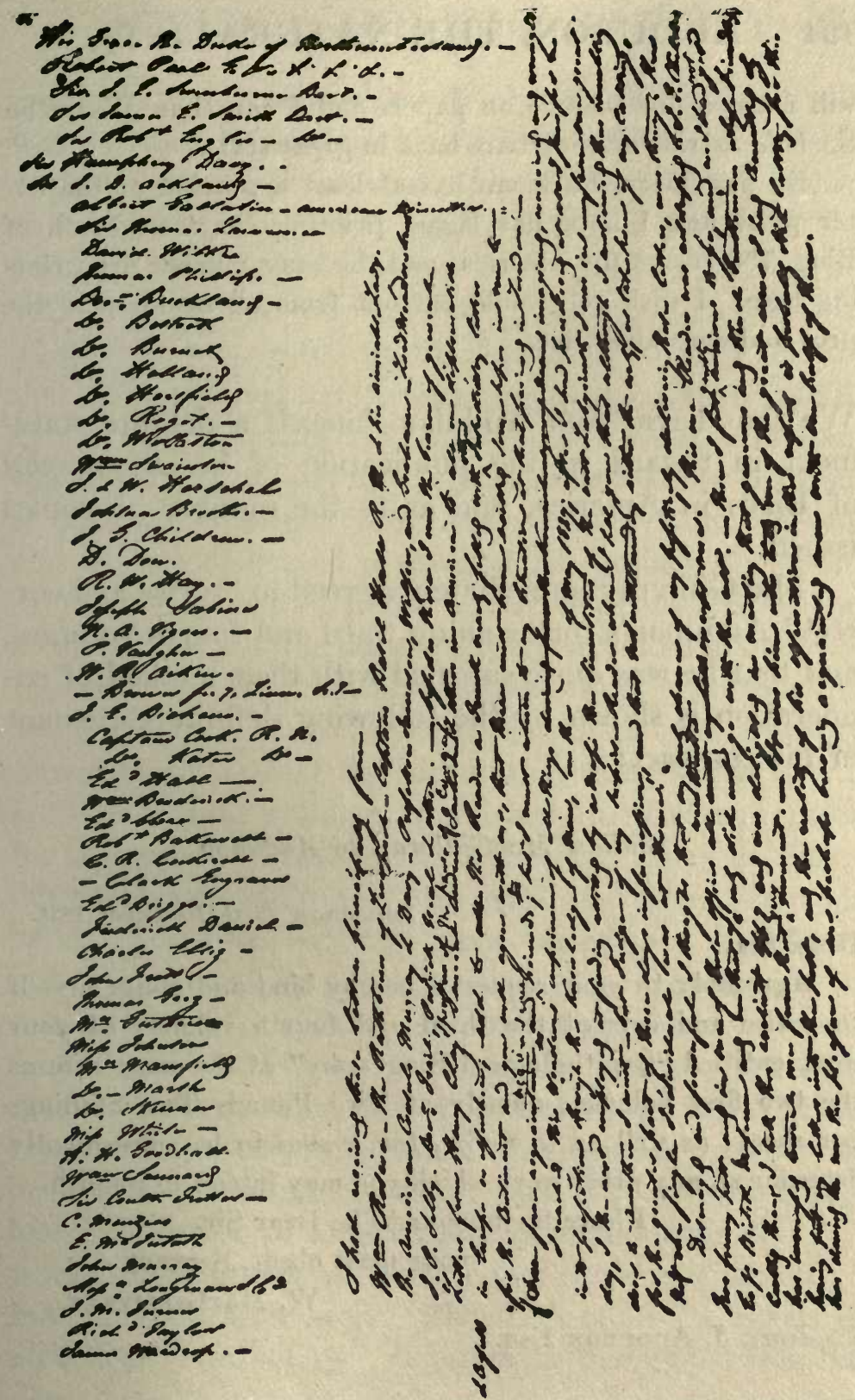

PART OF THE ORIGINAL DRAFT OF AUDUBON'S MANUSCRIPT FOR THE INTRODUCTION TO VOLUME II OF THE "ORNITHOLOGICAL BIOGRAPHY," GIVING NAMES OF PERSONS TO WHOM HE CARRIED LETTERS OF INTRODUCTION ON HIS FIRST VISIT TO LONDON IN 1827.

From the Howland MSS. 
will make a fine picture on paper, and I can show Waterton the bold astride of one's bare back in great style.

By now Docr. Parkman has at least a portion of the letter press and I hope has begun printing the second vol. of Biog. 750 copies for America, and the same number are printing here. I wish you would cut out from all newspapers the pros and cons about me.

We thus have from Audubon himself a definite statement in regard to the publication of his Biography of Birds in America, and as to the number of copies issued.

MacGillivray immediately agreed to "revise and correct" Audubon's forthcoming third and fourth volumes, and that he was quite satisfied with their method of cooperation is shown by the following definite statement of his contract:

\section{William MacGillivray to 'Audubon}

\section{Dear Sir,}

Edinburam 15 th December 1834.

Agreeably to your request I hereby bind and oblige myself to revise and correct the third and fourth volumes of your work entitled "Ornithological Biography" at the same rate as the two first volumes, namely at Two Pounds Two Shillings per sheet; as well as to revise, for a sum to be subsequently determined, any other work which you may intend to publish.

I have the honour to be Dear Sir, your most obedt. Servant

W. MacGillivray.

To John J. Audubon Esq.

When William MacGillivray first met Audubon, in the autumn of 1830, he was an enthusiastic naturalist of four and thirty, young, but, as we have seen, a thor- 
ough anatomist, who stood firmly on his own feet and was destined to advance his favorite study in a notable degree. Audubon at this time was forty-five, but in anatomy the older man gladly sat at the feet of the younger and acknowledged him master; while this young anatomist was dissecting, Audubon in the rôle of student was seated by his side, and we may be sure that little escaped his penetrating eye and keen intelligence. To MacGillivray, on the other hand, Audubon was master of his art, and to him he looked for criticism of his own artistic efforts; after him he named a son, and to him dedicated a child of his brain. ${ }^{8}$ In short, MacGillivray looked upon Audubon as his best friend in the world, and the latter fully appreciated his indebtedness to this able assistant. MacGillivray continued to aid Audubon with his letterpress, revising and probably contributing most of the technical details; in the fourth and concluding volumes, published in 1838 and 1839 , the large store of anatomical matter and many excellent drawings were duly acknowledged as coming from his hand. His own writings were varied and numerous, but were generally characterized by a high degree of excellence. His History of British Birds, in five volumes (1837-1852), was too extended and too technical ever to become popular, but in that work, for the first time in the history of science, classification was placed on a strictly anatomical basis. MacGillivray even followed Audubon to some extent by introducing into this work "delineations of British scenery and character," but under another head. The sixth of his "Lessons in Practical Ornithology" recounts in dialogue form the

${ }^{8}$ The Rapacious Birds of Great Britain, by William MacGillivray, was dedicated to Audubon "in admiration of his talents as an ornithologist, and in gratitude for many acts of friendship." 
experiences of two friends in tramping the Pentland Hills together; says "Physiophilus" [himself], "You must have many fine songsters in America"; to which "Ornithologus" [Audubon] replies:

That we have indeed. The Mocking Bird, of course, stands first in my opinion, and is unrivalled. Then, perhaps on account of my own sensitive nature, I would place next the Wood Thrush, although the Cat Bird is far its superior in many points, as is also the Turdus rufus. Think of our Rose-breasted Pine and Blue Grosbeaks, how mellow and sweet their continuous songs are, whether by day or during calm nights. Watch the varied ditties of the Orchard Oriole, and the loud and more musical notes of its brother, the Golden Hangnest. You have never heard the Tawny Thrush or the Hermit Thrush, otherwise, believe me, you would have enjoyed much delicious pleasure. ...

William MacGillivray was a man of the finest character and an honor to the best traditions of British scholarship; in his enthusiasm and indefatigable energy he was fully a match to Audubon. For nearly twelve years (1841-1852) he was an honored lecturer and professor in Marischal College and University, Aberdeen, where he died, probably as a result of overwork in the field, in 1852, thus outliving his older friend but one year. His last completed work, Natural History of Deeside and Braemar, was published under the patronage of Queen Victoria and by her command privately printed, under the editorship of E. Lancaster, in 1855. MacGillivray's surviving son, whose career as a field naturalist was also cut short by too strenuous work, accompanied Huxley, then an assistant surgeon in the Royal Navy, on the memorable voyage of the Rattlesnake under Captain Owen Stanley in 1842. MacGillivray was honored when 
alive, and though dead has not been forgotten; in $\mathbf{1 8 9 0}$ a beautiful tablet was dedicated to him in Aberdeen, and at the same time a worthy monument was raised to his memory at Edinburgh. ${ }^{9}$

In authorship the public is mainly interested in seeing merit duly acknowledged. Said Audubon, in the introductory address to his first volume:

There are persons whose desire of obtaining celebrity induces them to suppress the knowledge of the assistance which they have received in the composition of their works. In many cases, in fact, the real author of the drawings or the descriptions in books on Natural History is not so much as mentioned, while the pretended author assumes to himself all the merit which the world is willing to allow him. This want of candour I could never endure. On the contrary, I feel pleasure in here acknowledging the assistance which $I$ have received from a friend, Mr. William MacGillivray, who being possessed of a liberal education and a strong taste for the study of the Natural Sciences, has aided me, not in drawing the figures of my Illustrations, nor in writing the book now in your hand, although fully competent for both tasks, but in completing the scientific details, and in smoothing down the asperities of $\mathrm{my}$ Ornithological Biographies.

\section{In the introduction to Volume IV he added that the}

anatomical descriptions, as well as the sketches by which they are sometimes illustrated, have been executed by my learned friend, William MacGillivray, who in the most agreeable manner consented to undertake the labour, by no means small, of such a task, and to whom those who are interested in the progress of Ornithological science, as well as myself, must therefore feel indebted.

For an excellent account of the life of William MacGillivray and of his labors in natural science, see William MacGillivray, A Memorial Tribute to William MacGillivray (Bibl. No. 211). 
Audubon evidently believed that this printed acknowledgment was just; MacGillivray was as plainly satisfied, so that complaints which have been made against the naturalist on this score seem to have been rather groundless. It might be noticed that bookmaking at that time was regarded as more of a trade than at present; as Sir Walter Besant remarks, a traveler would often give his notes to a bookseller, who in turn would hand them over to a literary hack to be cast into suitable form.

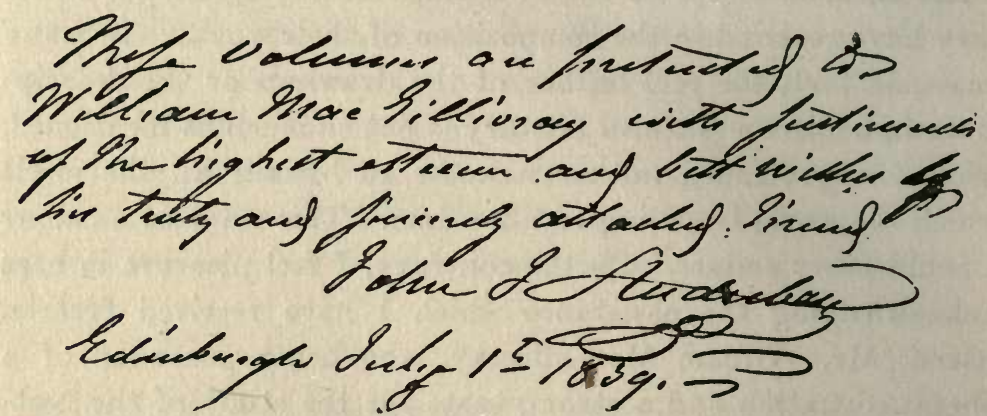

AUDUBON'S INSCRIPTION IN THE COPY OF THE "ORNITHOLOGICAL BIOGRAPHY" PRESENTED TO WILLIAM MACGILLIVRAY

A fine token of the friendship which existed between these two men was discovered in the summer of 1903 in a London bookshop, where it was found reflected in the pages of a handsomely bound copy of Audubon's Biography of Birds; on the title pages were inscribed the autographs of William MacGillivray, while on the first page of the introduction to the first volume the hand of Audubon had written this dedication:

These volumes are presented to

William MacGillivray with sentiments of the highest esteem and best wishes by his truly and sincerely attached friend John J. Audubon

Edinburgh July 1 t 1839. 
Professor John Wilson gave the third volume of the Ornithological Biography a very handsome notice in Blackwood's Magazine, and on New Year's Day, 1836, Audubon acknowledged the compliment in the following letter: ${ }^{10}$

\section{Audubon to John Wilson ("Christopher North")}

My Dear Friend :-

The first hour of this new year was ushered to me surrounded by my dear flock, all comfortably seated around a small table in middle-sized room, where I sincerely wished you had been also, to witness the flowing gladness of our senses, as from one of us "Audubon's Ornithological Biography" was read from your ever valuable Journal. I wished this because I felt assured that your noble heart would have received our most grateful thanks with pleasure, the instant our simple ideas had conveyed to you the grant of happiness we experienced at your hands. You were not with us, alas! but to make amends the best way we could, all of a common accord drank to the health, prosperity, and long life, of our generous, talented, and ever kind friend, Professor John Wilson, and all those amiable beings who cling around his heart! May those our sincerest wishes reach you soon, and may they be sealed by Him who granted us existence, and the joys heaped upon the "American woodsman" and his family, in your hospitable land, and may we deserve all the benefits we have received in your ever dear country, although it may prove impossible to us to do more than to be ever grateful to her worthy sons.

Accept our respectful united regards, and offer them to your family, whilst I remain, with highest esteem, your truly thankful friend and most obedient servant,

John J. Audubon.

Wilson had said in his earlier review:

${ }^{10}$ See Mrs. Gordon, "Christopher North:" A Memoir of John Wilson (Bibl. No. 44). 
We do not believe that till within these few years, he had any practice in composition. ... Yet Genius, if from circumstances behindhand in any common accomplishment, soon supplies it-soon makes up its lee-way-or rather, it has only to try to do what it has never done before, and it succeeds in it to admiration. Audubon, who had written but little even in his native tongue-French-under a powerful motive, took to writing English; and he was not long in learning to write it well, not only with fluency, but eloquence, as the fine extracts we have quoted show in unfading colours.

The following comment on Audubon's second volume of the Biography appeared in the Athencum for 1835:

If only considered as evidence that it is in the power of man to achieve whatever he reills, and that no obstacles are too great to be overcome by energy and devotion of purpose, it would claim our good will and best wishes.

He has told what he has seen and undergone, not perhaps in the smooth nicely balanced periods of a drawing-room writer ... but with unstudied freedom, rising at times to eloquence, nor been ashamed to utter the thousand affectionate and benevolent feelings which a close and enthusiastic communion with nature must nourish. The work is full of the man.

The winter and spring of 1835 were spent in London, and though suffering from the strain of overwork, Audubon kept doggedly at his tasks. On April 20 he wrote to Bachman:

Immediately on my arrival in London I set to writing, and finished in one month, one 4 th. of the Biographies of my $3 \mathrm{~d}$. vol. This rendering me puffy, I could scarcely breathe-my appetite was gone-my digestion bad-in other words I was attacked by Dyspepsia as bad as ever. Then I thought of a change of work-for in change of labour the body and the mind 
undergo sure and certain relief. I took to Drawing! and what do you think-I have positively finished 33 drawings of American birds in England. This has enabled me to swell my $3 \mathrm{~d}$. vol. of Illustrations with 57 species not given by Wilson and therefore forestalling my friend Charles Bonaparte.

On the 28th of April Audubon wrote to Edward Harris, begging him to send specimens of certain birds which he needed, as well as a circumstantial account of the shad fisheries of the Delaware River as material for an "Episode" for the third volume of his Biography; the fiftieth number of his illustrations was then in the hands of the colorist. He continued: ${ }^{11}$

I thought better to push my publication on account of the woeful dulling of the times in this country, where political strife engrosses the mind of every person so much that arts and sciences are, as it were, put on the shelves. Ministers are beings of six weeks lives now-a-days. The Reformers are struggling against the Tories, and vice versa. The Churchmen are aghast at the prospect of the future, and all this puts a complete stoppage to business, independent of such matters. Even since my return to England I have obtained only two or three subscribers, and have lost more than a dozen; nay, I may safely say, two dozen. In America, on the contrary, things appear to go on more prosperously. May God's will grant a long continuation of this to our only Land of Liberty. France, you will have heard, has at last passed an order for the payment of her debts to the citizens of the United States, and I hope that this may prove amply sufficient to save us from having a war with that powerful nation. ... I I wrote you that Dr. George Parkman, of Boston, would have my $2 \mathrm{~d}$. volume of Biographies reprinted in his city. I have seen 100 pages of this reprint here, but do not know if the Vol. (American Ed.) has appeared before the Public?

${ }^{11}$ This and extracts from letters which follow are from the Jeanes MSS. 
My-Friends-erton, Ord \& Co. keep up their curious animadversions against me still-methinks they must be shockingly mortified at my stubborn silence toward them. Some unknown friends now $\&$ then reply to their absurdities.

His persistent heckler, Charles Waterton, was quite busy at this time, four articles having been directed against Audubon or his friends in 1835, though this was not his most prolific year. A similar reference occurs in a letter written to Bachman from Edinburgh on the 20th of July: "As to the rage of Mr. Waterton, or the lucubrations of Mr. Neal, who by the bye is a subscriber to the Birds of America (bona fide), I really care not a fig-all such stuffs will soon evaporate, being mere smoke from a Dung Hill."

In the summer of 1835 Audubon was again established in Edinburgh and working with unremitting vigor at his Biography; some idea of the speed which he maintained when able to devote himself unreservedly to this task can be gathered from the fact that after the issue of his second volume, of 620 large pages, in December, 1834, the third, of 654 pages, was published in just a year from that time. He wrote to Edward Harris from Edinburgh on the 5th of July, when engaged in this work:

I intend to write a few ["Episodes"] of such extraordinary men, now deceased, with whom I have been acquainted-Thomas Bewick, and Baron Cuvier, for example.

We receive no new subscribers in Europe. The taste is passing for Birds like a flitting shadow-Insects, reptiles and fishes are now the rage, and these fly, swim or crawl on pages innumerable in every Bookseller's window. When this is also passed, naturalists will have to turn over a new leaf and commence afresh, or go to the antipodes in search of materials to 
please the taste for novelty's sake.-However my work will I hope be finished ere I leave this world, and must be appreciated in years to come, when perhaps my childrens' children will feel proud of their gone ancestor, "The American Woodsman." You see my Dear Friend how far enthusiasm and a portion of the like for standing fame carries even your humble servant a man with no other means than his industry and prudence as a means of support, and one with scarce the motive of education. There are moments, and they are not far between, when thinking of my present enormous undertaking, I wonder how I have been able to support the extraordinary amount of monies paid for the work alone, without taking cognizance of my family and $\mathrm{my}$ expeditions, which ever and anon travelling as we are from place to place and country to country are also very great. When I publish my Life and let the world know that Audubon like Wilson, was at Phila. without the half of a Dollar, and that had it not been for benevolent generosity of a certain Gentleman whose name is Edward Harris, Audubon must have walked off from one of the fairest of our Cities like a beggar does in poor Ireland, left destitute of all things save his humble talents, and his determination to produce something worthy of the soul of man: I say my dear Harris will not the world stare! Poor Wilson was only better off than I on account of his superior talents over me at driving the goose quill, but much similarity still seems to have [existed] in both of us, as I could drive the pencil, the brush, the Fiddle bow and even the "Fleuret" [better] than he.

Audubon wrote to Harris again from Edinburgh, on September 5, when he said:

Between you and I the measurements of different Birds given by Wilson are hardly to be depended upon, as I constantly discover a great deficiency in this part of his descriptions which indeed in some cases are otherwise slack, and given as if when fatigued or vexed. Nay I even think at times that he has copied Authors and not nature? as in the instance of the Oyster 
Catcher, which I fear he made \& figured from a European one in the Philadelphia museum, took the descriptions from Latham, and described the Habits of Palliartus which is our own Bird and it seems the only species to be met with in America, at least on our Atlantic coast. Wilson committed the same blunder with the Rallus elegans which he figured and described the habits of the $R$. capitans for it! I could enumerate more instances of carelessness, but poor Wilson is dead and may God bless his soul!

The third volume of his letterpress, ${ }^{12}$ which dealt with the water birds of America, made its appearance at the close of 1835 ; in the introduction he said:

I look forward to the summer of 1838 with an anxious hope that I may then be able to present you with the last plate of my Illustrations, and the concluding volume of my Biographies. To render these volumes as complete as possible, I intend to undertake a journey to the southern and western limits of the Union, with the view of obtaining a more accurate knowledge of the birds of those remote and scarcely inhabited regions. On this tour I shall be accompanied by my youngest son, while the rest of my family will remain in Britain to direct the progress of my publication.

Audubon returned to London with his family early in 1836, visiting Newcastle, York, Leeds, Manchester and Sheffield by the way, and took a house at Number 4, Wimpole Street, Cavendish Square. As Mrs. Audubon's health was anything but good, they were fortunate in having as a neighbor in this street an eminent surgeon, Benjamin Phillips, ${ }^{13}$ and this friend was also a subscriber to The Birds of America. "Were I to mention," said Audubon,

${ }^{12}$ See Bibliography No. 2.

${ }^{18}$ For letter written to Dr. Phillips in 1842, see Vol. II, p. 244. 


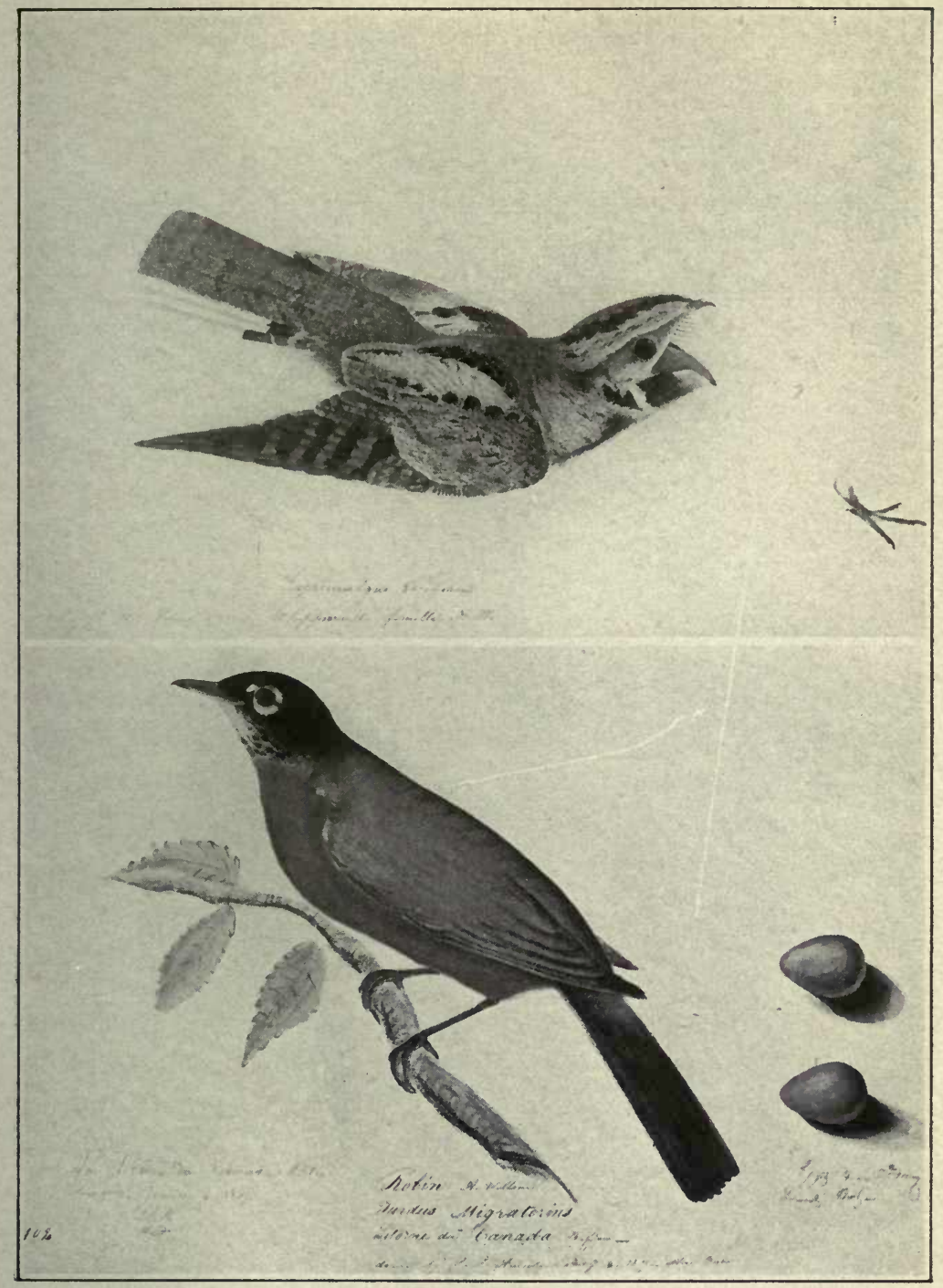

FARIY UNPUBLISHED DRAWINGS OF AMERTCAN BIRDS: ABOVE, "CAPRIMULGUS VOCIFERUS. WIIPPOORWILl FEMELLE. A. W. MAY 7TH, 1812. PEXNSA. No. 11"; BELOW, "ROBIN A. WILISON. TURDUS MIGRATORIUS. LITORNE DU CANADA-MAIE-BUFFON-DRAWY BY J. J. AUDUBON JANY. 4, 1807 - NEW YORK. No. 10?."

Published by courtesy of Mr. Joseph Y. Jeanes. 

the many occasions on which he has aided me by his advice and superior knowledge of the world, you would be pleased to find so much disinterestedness in human nature. His professional aid too, valuable as it has proved to us, and productive of much inconvenience to him, has been rendered without reward, for I could never succeed in inducing him to consider us his patients, although for upwards of two years he never passed a day without seeing my wife.

In the spring of 1836 Audubon's two sons made a tour of France and Italy; on the 9th of March he wrote to Harris that they expected to leave England in a week, be gone three and a half months, visit Paris, Rome and Messina, and return by way of Marseilles and Paris. With the passage of $\mathbf{1 8 3 6}$ he had completed $\mathbf{7 0}$ numbers, of 350 plates, of his larger work, leaving but 85 plates yet to be engraved. Though anxious to see this greatest of his tasks brought to an end, he still looked with longing eyes to the Rocky Mountains and the Pacific Coast, and began preparations for his last journey to obtain materials and subscribers in the United States. 


\section{CHAPTER XXXI}

\section{THIRD AMERICAN TOUR, 1836-1337}

In New York harbor-Collections from the Far West-Audubon's efforts to secure them-Return to Boston-Friendship of Daniel WebsterRenewed efforts to obtain the Nuttall-Townsend collection-Expedition to the west coast of Florida-Deferred governmental aid-Another winter with Bachman-Overland journey to New Orleans-On board the Crusader-Mistaken for pirates-With Harris and his son explores the Gulf Coast-The Republic of Texas-Visit to its capital and president-Meeting in Charleston-Marriage of his son-Their return to England.

Audubon left London with his son, John, July 30, 1836, and on the second day of August sailed from Portsmouth on the packet Gladiator, bound for New York. Two hundred and sixty live birds had preceded them to the ship, while three dogs came as a present from the Earl of Derby, and "a brace of tailless cats from our friend George Thackeray, D.D., provost of King's College": all had suffered somewhat from lack of care, but the dogs, one of which was sent to John Bachman of Charleston, and some of the birds crossed the Atlantic in safety. Five weeks were spent at sea; when the Navesink Highlands at last hove into view the welcome news spread rapidly over the ship; rockets were sent up later to attract a pilot, and when anchor was grounded on American soil, Audubon confessed that he cried like a child and devoutly thanked God for their preservation. He continued:

All was now bustle and mutual congratulations; our commander was praised for his skill by some, and others praised his whisky, which the waiters handed about, and the night was 
nearly spent in revelry; but John and myself retired at two o'clock. .... As a gleam of daylight appeared, my eyes searched through the hazy atmosphere to catch a glimpse of the land, and gradually Staten Island opened to my view; then the boat of the custom-house appeared, and soon he boarded us, arranged the sailors and passengers on deck, and called their names. Then followed breakfast, and soon another boat, with a yellow flag flying, landed the health officer, and there being no sickness on board, myself and John returned to Staten Island in the doctor's boat, and were taken by the steamer Hercules to the city. ${ }^{1}$

Audubon remained in New York from the 7 th to the 13th of September. On Sunday, the 12th, he wrote to Edward Harris, in part as follows: ${ }^{2}$

\section{Audubon to Edward Harris}

My dear Friend-

Whilst running over the interesting list of the Species of Birds procured by Nuttall \& Townsend in the Rocky Mountains, and the shores of the Pacific, I became so completely wrapt up with the desire to see these as soon as possible that I have concluded to go to Philadelphia tomorrow by the 10 o'clock boat. I will stay at Harlan's for two or three days and hope that you will meet me there, that I may have the pleasure of pressing your hand and talking to you.

You well know how anxious I am to make my work on the Birds of our Country as compleat as possible within my power: -you know that to reach this end I have spared neither time, labours or money: you are also aware that although this undertaking may never remunerate me, I am so enthusiastic as to indulge in the hope that God will grant me life to effect all this; but $\mathrm{I}$ am becoming old, and though very willing doubt whether

${ }^{1}$ Lucy B. Audubon, ed., Life of John James Audubon, the Naturalist (Bibl. No. 73), p. 385.

${ }^{2}$ The Jeanes MSS. 
I could support the fatigues connected with a journey of several years, and separated from my dear Family. Well the desiderata has come to Philadelphia at least in part, and if I could be allowed to pourtray the new species now there as an appendix to the Birds of America, I should be proud and happy to do so, but do you think that the Academy is likely to indulge me in this my wish? Do join me at Harlan's as soon as you can, and lend me a hand and try to promote my views through mutual Friends attatched to that Institution.

Audubon also communicated at once with John Bachman, whom he had planned to visit on his journey south, but soon learned that the cholera had broken out in Charleston and that the Seminoles were on the warpath in Florida. Said Bachman, writing on September 14:

With regard to Florida, nothing will be done by naturalists for at least two years. Your Indian friends, the cut-throats, have scalped almost every woman and child south of St. Augustine, save those on Key West. They have burnt and plundered every plantation; and although they will probably be, in a great measure, put down next winter, yet there will, undoubtedly, remain many small predatory bands that will make no bones of scalping at Ornithologist secundum artem; and would ask no questions whether he were the friend or enemy of William Penn. Of Texas, I think better, and thither, or along its borders, you may, I think, venture-for the Texans are our friends. I suppose Genl. Gaines will keep the Comanches quiet. ${ }^{3}$

Bachman kept his friends informed of the progress of the epidemic, which had placed an embargo over his city; at the same time he sent news of the Anhingas, Caracara Eagles and Cormorants, which had been successfully held in captivity for the naturalist, and added:

${ }^{8}$ C. L. Bachman, John Bachman, D.D., LL.D., Ph.D. (Bibl. No. 191). 
"These are awful times in money matters, but of this you will hear enough when we meet. Everyone nearly has failed, but the Parsons and Ornithologists."

On September 13 Audubon started for Philadelphia, anxious to see with his own eyes those western collections which had so stirred his curiosity. It seems that in 1834, Dr. Thomas Nuttall and Dr. John Kirk Townsend set out on a journey to the mouth of the Columbia River; Nuttall was first of all a botanist, and is said to have carried no gun, but Townsend was an experienced ornithologist and made extensive collections of birds, a part of which he sent in care of Nuttall to Philadelphia in 1835, although he himself did not return east until the close of 1837. One of Audubon's great ambitions had been to explore the regions which they had recently visited, and in the circumstances we can sympathize with his desire to acquire so valuable an acquisition for the work upon which he had been long engaged. The object of his immediate quest apparently had been entrusted to the Academy of Natural Sciences, an institution which had not always shown itself friendly to his claims, and which in this instance is said to have assisted the travelers with funds to prosecute their journey. The collection, said Audubon, contained "about forty new species of birds, and its value cannot be described." Balked in his initial efforts to obtain the coveted prize, after two days of fruitless efforts on the part of his Philadelphia friends, he returned to New York; Edward Harris then came forward with the offer of $\$ 500$ for the purchase of the collection outright, but negotiations were not immediately successful.

With his hunger still unappeased, Audubon now visited Boston on a canvassing tour, while his son remained with Nicholas Berthoud at New York. Setting 
out on the 20th of September, he traveled by the steamer Massachusetts and the Providence Railroad, paying seven dollars fare, "which included supper and breakfast"; the sail up Providence Bay in early morning was like a "fairy dream," and the locomotive in waiting then pulled the passengers from "Providence to Boston at the rate of fifteen miles an hour." We arrived, said he, at four in the afternoon: "a cart took my trunk, and placing myself by the side of the owner, we drove to the house of my friend, Dr. George C. Shattuck."

On the day after his arrival, Audubon visited Thomas M. Brewer, then a young ornithologist living at Roxbury, to examine his collection of bird skins and eggs, and upon his return called on David Eckley, "the great salmon fisher," to whom he later presented a copy of his folio plates of The Birds of America. ${ }^{4}$ Brewer, who later became a physician and distinguished ornithologist, for many years was one of Audubon's valued correspondents and supplied him with much interesting material. On the following day Audubon met Thomas Nuttall, ${ }^{5}$ who at once promised him duplicates of all the new birds which he had brought from the West. Colonel Thomas H. Perkins, an early subscriber, Edward Everett, who had befriended him in Washington, and who in 1836 became Governor of Massachusetts, Josiah Quincy, president of Harvard College, Dr. Bowditch, and

See Note, Vol. II, p. $\%$.

Thomas Nuttall (1786-1859), a native of Yorkshire, was brought up a printer; in 1807 he emigrated to the United States, and became noted for his wide botanical explorations, for his Journal of Travels in the Arkansas Territory in 1819, and for his excellent Manual of the Ornithology of the United States and Canada (1833-1834), which has had several editions. From 1822 to 1834 he was professor of Natural History and curator of the Botanical Gardens at Harvard University; in 1834 he crossed the Rocky Mountains along the sources of the Platte, explored Oregon and Upper California, and visited the Sandwich Islands. He returned to England, where he had inherited property, in 1842, and died at St. Helen's, Lancashire, September 10, 1859. 
other prominent characters, all extended a helping hand. He visited Salem to deliver his letters, and was successful in obtaining a number of subscribers; upon invitation of the curator of the Natural History Society there, he examined "the young collection of that newborn institution," and had "the good fortune to find one egg of the American bittern." On the 25th of September he wrote Harris: "Nuttall has arrived-he breakfasted with me the other day-gave me 6 new species of Birds and tells me that he will urge both Townsend and the Society at Philadelphia to allow me to portray all the species which they have procured within the limits of our Territories."

In Boston, September 27, 1836, Audubon made this note in his journal: ${ }^{6}$ "The citizens are all excitement; guns are firing, flags flying, and troops parading and John Quincy Adams is delivering a eulogy on the late President Madison. The mayor of Boston did me the honor to invite me to join in the procession, but I am no politician and declined." He noted on the same day also that Dr. Shattuck had completed the subscription list of the Boston Society of Natural History "by presenting me to his lady, who subscribed for one-tenth, and the Dr. then put down his son George's name for one-twentieth, making his own family one-fourth of the whole, or two hundred and twenty dollars, for which he gave me his cheque. Without the assistance of this generous man, it is more than probable that the Society never would have had a copy of "The Birds of America.'" Two days later he met Daniel Webster at the rooms of the Historical Society, and on the same evening at the home of Isaac P. Davis, where, said Audubon, "we took tea, talked on ornithology and orni-

- See Lucy B. Audubon, ed., op. cit.; and Note, Vol. II, p. 29. 
thologists; he promised to send me some specimens of birds, and finished by subscribing to my work." Webster also gave him a general note of recommendation, in which he said: ${ }^{7}$ "I take this mode of commending Mr. Audubon to any friends of mine he may meet in his journey to the west. I have not only great respect for Mr. Audubon's scientific pursuits, but entertain for him personally much esteem and hearty good wishes." Mr. Davis exerted his influence in other directions, and in this instance acted as agent for the transmission of Audubon's plates to their distinguished friend; on October 7 , he wrote: ${ }^{8}$ "I received the half Nos of the 'Birds of America' for the worthy and sublime Danl. Webster-they shall be delivered safely on his return." After urging Audubon to visit Buffalo, where Dr. Bowditch and his friends thought that a number of new subscribers might be procured, he appended a list of twelve likely names of residents of that city, and added: "Bowdoin College shall be remembered as the opportunity offers."

Webster, who was an ardent sportsman and well acquainted with the water fowl of the coast, had volunteered to procure for Audubon specimens of the Labrador Duck, which was even then extremely rare and has since become extinct, but was unable to fulfill his promise. Audubon had already found that many American birds, like the common crow, which had been regarded as identical with those of the Old World, were in reality distinct, and was now anxious, as he wrote to Thomas Brewer, "to compare the anatomy of all our birds with those of the same families in Europe." His letters

${ }^{7}$ See Lucy B. Audubon, ed., op. cit., p. 391.

8In a letter signed "I. P. Davis," and superscribed to "John J. Audubon Esqr at Mr. Berthoud's, 106 Broad Street New York." (Howland MSS.) 
to young Brewer at this time show how eager he was to secure the promised specimens. On October 23 he wrote from Philadelphia: "I hope you will not forget to call on our enlightened statesman D. Webster, and remind him of his kind promise to assist you in the procuring of specimens for me. This winter and next spring are my only chances, and I beg you to do all you can for me." He wrote again from Charleston, January 1, 1837: "I am sorry that the Hon. D. Webster has not attended to his promises, and will write to him; yet I would beg you, being on the spot, to trouble him a good deal." 9

After returning to New York, Audubon had a visitor for whom he expressed the greatest admiration, Washington Irving, who had aided him in 1833; he now received from his hands letters to Martin Van Buren, the President-elect, and Benjamin F. Butler, who then occupied the post of Attorney-General. Irving called attention in his letter to the national character of $\mathrm{Au}$ dubon's work, and warmly commended it to the patronage of the country at large. On October 8 Audubon wrote MacGillivray from New York that he had obtained twelve new subscribers, two at Salem, four at Boston, and six in New York, but a little later, through the aid of Nicholas Berthoud, in one week's time eighteen new naines were added to his subscription list in New York City alone.

Meanwhile Nuttall's and Townsend's birds had not been forgotten, and on October 15 he started with his son for Philadelphia, where he was again welcomed by Dr. Richard Harlan. No sooner, however, were efforts renewed to gain permission to study the desired objects

- See Thomas M. Brewer (Bibl. No. 79), Harper's New Monthly Magazine, vol. lxi, p. 666 (1880). 
than new obstacles were encountered. To quote the naturalist: ${ }^{10}$

Having obtained access to the collection sent by Dr. Townsend, I turned over and over the new and rare species, but he was absent at Fort Vancouver, on the shores of the Columbia River; Thomas Nuttall had not yet come from Boston, and loud murmurs were uttered by the soi-disant friends of science, who objected to my seeing, much less portraying and describing, those valuable relics of birds, many of which had not yet been introduced into our Fauna.

At length, "it was agreed," to continue his account of the transaction,

that I might purchase duplicates, provided the specific names agreed upon by Mr. Nuttall and myself were published in Dr. Townsend's name. This latter part of the affair was perfectly agreeable to my feelings, as I have seldom cared much about priority in the naming of species. I therefore paid for the skins which I received, and have now published such as proved to be new, according to my promise. But, let me assure you, Reader, that seldom, if ever in my life, have I felt more disgusted with the conduct of any opponents of mine, than I was with the unfriendly boasters of their zeal for the advancement of ornithological science, who at that time existed in the fair city of Philadelphia.

While still in Philadelphia, on October 23, Audubon wrote to Thomas Brewer that Dr. Morton, the corresponding secretary of the Academy, had not only permitted him to portray the new birds but had sold him "ninety odd of the skins, forming a portion of the collection," and added that with his other acquisitions they would swell his "catalogue to the number of 475 , all of which must be introduced in my fourth volume."

${ }^{10}$ Ornithologicai Biography (Bibl. No. 2), vol. iv, p. xi. 
For many years Audubon had expressed great contempt for all seekers after priority in the naming of new species of animals, but now he began to find the pressure from without too strong to be resisted. Rivalry in this field had become keen on both sides of the Atlantic, and in the commendable desire to render his work as complete as possible, he was inevitably drawn into a struggle in which the higher aspirations of scientific men are all too apt to be obscured by petty vanities, suspicions and disputes.

While at Philadelphia Audubon paid this fine tribute to the ornithologist whom he had met at Louisville twenty-six years before, and whose name had long been a cover for the jealousies and animosities of supposititious friends: "Passed poor Alexander Wilson's schoolhouse, and heaved a sigh. Alas, poor Wilson! Would that I could once more speak to thee, and listen to thy voice!"

Audubon was planning during the coming year to explore the west coast of Florida, in company with his son and Edward Harris, and to proceed as far as possible along the coast of Texas. From Philadelphia he went to Baltimore, and on November 8 he arrived at Washington. His steadfast friend and supporter, Colonel John James Abert, then at the head of the Topographical Bureau, took him to the White House to call on President Andrew Jackson and present his letters. The General, said Audubon, looked well and was smoking a pipe; after reading his letters attentively, he said at once: "Mr. Audubon, I will do all in my power to serve you, but the Seminole war, will, I fear, prevent you from having a cutter; however, as we shall have a committee at twelve o'clock, we will consider this, and give you an answer tomorrow." Levi Wood- 
bury, Secretary of the Treasury, was as friendly as ever, and offered the party passage to Charleston on the Campbell, a vessel of fifty-five tons carrying three guns' and twenty-one men, but Audubon, who was a poor sailor, preferred to travel by land and await the coming of this boat at the Bachman home. Before leaving the capital the naturalist and his son were invited to dine informally at the White House, and he had the opportunity of studying at close range "a man who had done much good and much evil to our country." Said Audubon of this dinner:

I sat close to him; we spoke of olden times, and touched slightly on politics, and I found him very averse to the cause of the Texans. ... The dinner was what might be called plain and substantial in England; I dined from a fine young turkey, shot within twenty miles of Washington. The general drank no wine, but his health was drunk by us more than once; and he ate very moderately, his last dish consisting of bread and milk. ${ }^{11}$

Audubon, with his son, John, left Washington on the 10th of November, and after traveling six days on one of "the most extraordinary railroads in the world," they reached the city of Charleston, where, under the hospitable roof of John Bachman, the party eventually passed the winter, though momentarily expecting their vessel, which did not arrive. During this long interval of waiting, Audubon made drawings of all the new birds in the Nuttall-Townsend collection, representing upwards of seventy figures, and Miss Maria Martin, Bachman's sister-in-law, again assisted him in drawing plants and insects.

${ }^{11}$ Lucy B. Audubon, ed., op. cit., p. 398. 
As spring approached and the long awaited Campbell had not arrived, Audubon, with Harris and John, started overland for New Orleans. After several days of hard traveling by coaches they reached Montgomery, and descended the Alabama River by steamboat to Mobile. When that district had been ransacked for birds, they went on to Pensacola, where they learned that the Government cutter would soon be at their service at New Orleans; accordingly they retraced their steps to Mobile, passed through the lakes, and entered the southern capital, the city in which the naturalist had nearly starved, a penniless stranger, sixteen years before, but which, less than three-quarters of a century later, was to raise a monument to his memory. He was still destined to a degree of disappointment, when it was learned that the Campbell could not be put in readiness before the last of March, but he was delighted to find that the old pilot of the Marion, Napoleon Coste, was to command this vessel. At New Orleans Audubon met for the last time "good M. Le Sueur," artist and naturalist, who had spent many years at New Harmony, Indiana, and whose acquaintance he had first made at Philadelphia in $\mathbf{1 8 2 4 .}$

Audubon and his party finally left New Orleans on the 1st of April and entered the Gulf by the Southwest Pass, where, on the 3rd of the month, they were joined by the Crusader, a schooner of twelve tons which was attached to the Revenue Service; on this journey she carried a crew of four, with as many guns, and acted as a tender to the larger vessel. The expedition was provisioned for two months, and aimed to explore the keys, bayous and shoreline from the Mississippi to the Bay of Galveston. Some of Audubon's experiences on this cruise were described in a letter to William Mac- 


\section{Gillivray," dated "Côte Blanche, 18 April, 1837," which we will now reproduce:}

\section{Audubon to William MacGillioray}

\section{My Dear Friend, -}

Being just now snugly anchored in a bay, the description of which may prove agreeable to you, I sit down to give you an account of what $I$ have been doing since $I$ last wrote to you.

After visiting "Rabbit Island," on which, as I have already told you, not a single Rabbit or Hare is to be seen, we made our way between it and Frisky Point, by a narrow and somewhat difficult channel leading to the bay in which I now write. The shores around us are entirely formed of a bank, from twenty to thirty feet high, and composed of concrete shells of various kinds, among which the Common Oyster, however, predominates. This bank, which at present looks as if bleached by the sunshine and rain of centuries, is so white that it well might form a guiding line to the vessels which navigate this bay even in the darkest nights. The bay, however, is so shallow, that it is rarely entered by vessels larger than schooners of about seventy tons burthen, which visit its shores to take in the sugars and cottons grown in the neighbouring country.

The "Crusader" is a somewhat curious craft, small, snug withal, and considerably roguish looking. She has not fewer than four "grunters" on her fore deck, her sails are of pure white cotton, and although she bears the lively flag of our country at the peak, her being painted purely black gives her the aspect, not merely of a smuggler, but of a pirate. But here she is, at the entrance of a canal of a sugar plantation, and close to another craft, much the worse for wear, and, for aught I know to the contrary, belonging to the captain alone, who, I would almost venture to assert, belongs to no country at all.

${ }^{12}$ Printed in the Edinburgh Journal of Natural History (Bibl. No. 37), vol. i, p. 17 (December, 1838). 
It is now four weeks since a razor came in contact with my chin. All my companions are equally hircine; or, if you please, hirsute. As to our clothing, were you to see us at this moment, you would be ready to exclaim, "What vagabonds these fellows are!" Coats and trousers plastered with mire, shirts no longer white, guns exhibiting the appearance of being in constant use, and all sorts of accoutrements that pertain to determined hunters, complete our tout ensemble. But, as I have said, here we are, and on shore must go. "Man the gig," quoth our captain. In a trice the gig is manned. One after another, for there are five or six of us, we swing ourselves into the aftersheets. The word is given, the oars are plied, and now we are once more on terra firma.

The crossing of large bays, cumbered with shallow bars and banks of oyster-shells, is always to me extremely disagreeable, and more especially when all these bars and banks do not contain a single living specimen of that most delectable shell-fish. Nay, I am assured by our pilot, who is no youngster, that ever since he first visited this extensive waste, not an oyster has been procured in these parts. But now, in single file, like culprits or hungry travellers, we proceed along the margin of the canal. Ah, my dear friend, would that you were here just now to see the Snipes innumerable, the Blackbirds, the Gallinules, and the Curlews that surround us; - that you could listen as I now do, to the delightful notes of the Mocking-bird, pouring forth his soul in melody as the glorious orb of day is fast descending towards the western horizon;- - that you could watch the light gambols of the Night Hawk, or gaze on the Great Herons, which, after spreading their broad wings, croak aloud as if doubtful regarding the purpose of our visit to these shores! Ah! how well do I know you would enjoy all this; but, alas! we are more than four thousand miles apart.

Hark! what's that? Nothing but a parcel of men coming to greet us. Here they are, seven or eight Negroes. Who lives here my good fellows? Major Gordy, massa. Well, now show us the way to the house. Yes, gentlemen, come along. So we follow our swarthy guides. 
The plantations here are of great value, both on account of their proximity to the Gulf of Mexico, and the excellence of the soil, which, as in other parts of Louisiana, is composed of a fat, black mould. The Indian corn was at least six feet high, and looked most beautiful. As we approached the mansion of Major Gordy, I observed that it has a pleasant aspect, and was furnished with a fine garden, and a yard well stocked with cattle, together with a good number of horses and mules, just let loose from labour. A mill for grinding corn and making sugar particularly drew our notice to it, as the Crusader happened just then to be destitute of both articles; and as I saw some women milking the cows, my heart fairly leaped with joy, and the hope that ere long we might procure a full bowl of the delightful and salubrious beverage. The short twilight of our southern latitudes had now almost involved every object in that dim obscurity so congenial to most living creatures after the toils of the day, as allowing them to enjoy that placid quiet which is required to restore their faded energies.

Near the entrance of the mansion stood an elderly man, of tall stature and firm aspect, leaning on what $I$ would call a desperate long gun. As I approached this Côte Blanche planter, I thought that something not so very friendly as I could have wished was expressed in his countenance. As he rested his heavy frame on his monstrous rifle, he neither moved his head, nor held out his hand to me, until I presented mine to him, saying, "My good sir, how do you do?" His answer was a rather suspicious look at me and my companions; but notwithstanding, and probably because he was on his own ground, he asked us what was our wish, and then desired us to walk in.

Côte Blanche Bay, you must be informed, has for a number of years been infested by a set of rascally piratical vagabonds, who have committed extensive depredations, in consequence of which, a few years ago, a United States' revenue cutter was sent to protect the coast. I have no doubt that the major took us, to a man, for members of the gang who had more than once visited, not his house, but his plantation, on 


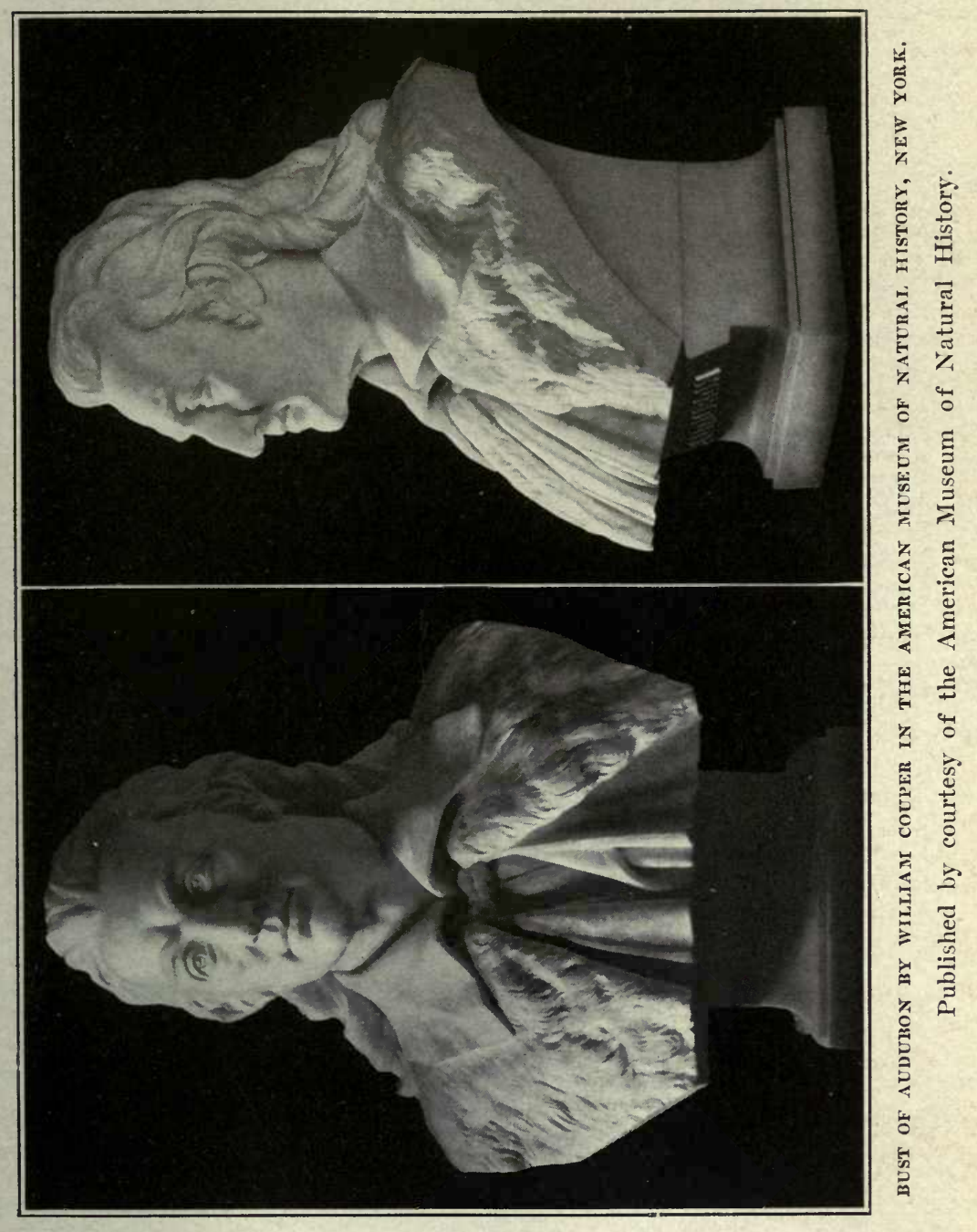



which they had played many wanton and atrocious freaks.

We now, however, had entered the house. Candles were lighted, and we at once came face to face, as it were. It curiously happened that our captain was without his uniform, and fully as rough looking otherwise as any of us. I was, however, much pleased to see that the major himself was not much superior to us in respect of apparel; nor had his razor been employed for many days. I happened to have about me some unequivocal credentials, from the head departments of the United States, which, on my observing that some degree of suspicion still remained, I placed in his hands. He read them, spoke kindly to us, promised to forward our letters to the nearest post-town, and invited us to consider his dwelling as our own. From that moment until we returned to our vessel, we were all as comfortable and merry as men can be when distant from their own dear homes.

Next morning we received from Major Gordy a barrel of sugar, another of corn meal, some pails of milk, and a quantity of newly made butter, together with potatoes and other needful articles - and all this without being allowed so much as to offer him the least recompense. The day after, we returned to breakfast by invitation, and found in the house several strangers armed with rifles and double-barrelled guns. After we had been introduced to all around, we seated ourselves, and made a vigorous attack upon our host's eggs and bacon, coffee, tea, and milk. As this important business was proceeding, I was delighted to hear the following anecdotes, which I hope you, my dear friend, will relish as much as I did.

"Gentlemen," said our host, straightening himself up in his chair, "I am considerably suspicious as regards the strangers who happen to anchor within the range of my dominions. Indeed, gentlemen, I must acknowledge that even after you returned on board last night, I sent off some of my men in various directions, to let my neighbours know that a strange craft had anchored near the landing-place; and here, gentlemen, are those neighbours of mine; but as it happens that the name of the gentleman who calls himself a 'Naturalist' is well known to some 
of them, I now feel quite satisfied as respects the purposes you have in view. But let me tell you what happened to me some years ago.

"Such a shark-looking craft as the one you call the Crusader happened to drop its anchor abreast of my landing-place, about dusk one evening, and as I guessed that the fellows on board were not better than they should be, I watched their motions for a while from my back piazza. But nothing happened that night. Next morning, however, I heard the firing of guns down the meadows where my cattle and hogs were in the habit of feeding. So I took my rifle, walked towards the spot, and soon found, sure enough, that the rascals had killed a fine ox and several hogs, which they were dragging to the shore. Indeed, gentlemen, I saw the yawl crammed with the spoils of my plantation. Well, I took as good an aim as I could at the nearest man, and cracked away, but without hitting. At the report of my gun the fellows all took to their heels, and getting on board hoisted sail and went off. I have never heard of them since. Well, gentlemen, about the same hour next morning, a black-looking barge, hardly as large as your Crusader, came to, off the very same spot, and although I watched it and every one on board nearly the whole night, and it was a beautiful moon-shining one, not a soul of them came on shore until morning. Then, however, I saw some bustle on board. Several men got off in a very small affair, which was fastened astern of the large boat. I saw them land, and deliberately walk towards the meadows. No sooner had they reached the wettest part, and that is where my hogs generally root for food, than crack, crack, crack, went off their guns in all directions. You may well suppose how vexed I was at all this, and conceive how soon I mustered my men with clubs, and armed myself with my rifle. On reaching the ground, think, gentlemen, what were my thoughts, when I saw the fellows all advancing towards me and my people, as if they were the honestest men in the world. I was so mad when they came close up, that I had a mind to shoot the one in front, for he looked for all the world as if he cared not a pin for any one. However, I did 
not shoot, but asked him why he was shooting my hogs? 'Hogs! good man, you are quite mistaken; we are shooting snipes until we come in contact with the rascally pirates who infest the coast, and lay waste your plantations. My name, my good sir, is Captain —, of the United States Navy; and these are some of my men. Will you come on board, and breakfast with us on your own snipes?" No wonder that the major, having been subject to the visits of these marauders, should have taken us in the dusk, armed as we were, and withal not having precisely the aspect of sober citizens, for persons not quite as good as we should be. But I must now conclude, and in my next you shall hear something of the result of my expedition into the marshes.

After wading through mud for whole days, exposed to scorching heat, and constantly annoyed by myriads of insects in the course of their numerous excursions on shore, they reached Galveston Bay on the 24th of April. The fort of Galveston returned their salute of " 26 fires," given by the big gun on the Campbell, and shortly after they received a visit from the Secretary of the Navy of the Republic of Texas, which under Sam Houston had declared its independence but a few weeks before their arrival, and were invited to proceed to the seat of government, at Houston, eighty miles distant, in the interior. They landed on the 26th of April, and after three weeks had been spent in exploring Galveston Island and its adjacent shores for birds and animals of all sorts, they started for Houston on the 8th of May. After making about twelve miles, their vessel grounded on Red Fish Bar, and the party then took to tender and gig, reaching their destination on the 15th; wild turkeys, ibises, and ducks of many kinds were seen in great numbers along their course.

${ }^{13}$ See Lucy B. Audubon, ed., op. cit., p. 411. 
Audubon has left a graphic account ${ }^{13}$ of what he then saw at the capital of this short-lived infant Republic, including its picturesque President, the mêlée of dejected Mexican prisoners then gathered there, and its drunken Indians, "halooing and stumbling about in the mud in every direction." Houston's abode was a small log house, "consisting of two rooms, with a passage through, after the Southern fashion."

The moment we stepped over the threshold, on the right hand of the passage, we found ourselves ushered into what in other countries would be called the ante-chamber; the ground floor, however, was muddy and filthy; a large fire was burning; a small table, covered with paper and writing materials, was in the centre; camp-beds, trunks, and different materials were strewn around the room. We were at once presented to several members of the cabinet, some of whom bore the stamp of intellectual ability, simple though bold, in their general appearance. ...

The President was engaged in the opposite room on national business, and we could not see him for some time. Meanwhile we amused ourselves by walking to the capitol, which was yet without a roof, and the floors, benches and tables of both houses of Congress were as well saturated with water as our clothes had been in the morning. Being invited by one of the great men of the place to enter a booth to take a drink of grog with him, we did so; but I was rather surprised that he off ered his name, instead of the cash, to the bar-keeper.

We first caught sight of President Houston as he walked from one of the grog-shops, where he had been to prevent the sale of ardent spirits. He was on his way to his house, and wore a large gray coarse hat, and the bulk of his figure reminded me of the appearance of General Hopkins of Virginia, for like him he is upwards of six feet high, and strong in proportion. But I observed a scowl in the expression of his eyes, that was forbidding and disagreeable. We reached his abode 
before him, but he soon came, and we were presented to his excellency. He was dressed in a fancy velvet coat, and trowsers trimmed with broad gold-lace; around his neck was tied a cravat somewhat in the style of seventy-six. He received us kindly, was desirous of retaining us for awhile, and offered us every facility within his power. He at once removed us from the anteroom to his private chamber, which by the way was not much cleaner than the former. We were severally introduced by him to the different members of his cabinet and staff, and at once asked to drink grog with him, which we did, wishing success to his new republic. Our talk was short; but the impression which was made on my mind at the time by himself, his officers, and his place of abode, can never be forgotten.

The party left Texas on the 18th of May, and on the 27 th reached New Orleans, which was then oppressively hot and nearly deserted. Here Audubon's collections and equipment were packed to be sent north; his dog was given to his brother-in-law, William Bakewell, and on the last day of the month the party began to retrace their steps of the previous March. After more hard traveling by car, coach and railroad, Charleston was reached in eight and a half days, on June 10, 183\%. Edward Harris, who ascended the Mississippi from New Orleans for the purpose of making further collections, later rejoined the party at Bachman's home in Charleston. Audubon said that he lost twelve pounds in weight during this journey, which proved exceedingly trying, and the hardships encountered were hardly commensurate with the returns in bird and animal lore; yet Audubon was by no means dissatisfied at the results, as shown by the following account which he gave Thomas Brewer two days after his return: ${ }^{14}$

The weather during the principal portion of our absence

${ }^{14}$ Thomas M. Brewer (Bibl. No. 79), loc. cit. 
was unusually cold, even for the season, and this gave us, perhaps, the very best opportunities ever afforded to any student of nature to observe the inward migrations of myriads of the birds that visit us from the south and west when the imperative laws of nature force them from their winter retreats towards other countries to multiply. To tell you all regarding this would be more by a thousand times than can be given in a letter written in haste, and I will therefore at once touch the spring with whose sound you are most in harmony. We procured many eggs for you - ay, a great number-and as soon as we reach New York I will make up a large box, and take it to you myself. ... One thing that will interest you most, as it did me, is that we found west of the Mississippi many species of ducks breeding as contented as if in latitude $68^{\circ}$ north. There is, after all, nothing like seeing things or countries to enable one to judge of their peculiarities, and I now feel satisfied that through the want of these means many erroneous notions remain in scientific works that can not otherwise be eradicated. We found not one new species, but the mass of observations that we have gathered connected with the ornithology of our country, has, I think, never been surpassed. I feel myself now tolerably competent to give an essay on the geographical distribution of the feathered tribes of our dear country, and I promise that I will do so, with naught but facts and notes made on the very spot, and at the fitting time.

Maria Rebecca Bachman, eldest of the nine Bachman children, was married at this time to John Woodhouse Audubon, and the entire party started north before the end of June. They went by steamer to Norfolk, and thence to Washington, where Audubon presented his letters to President Van Buren and tendered his thanks in person to the various officers of the Grovernment and friends who had aided his expedition; they passed rapidly through Baltimore and Philadelphia, to New York, where Audubon remained a fortnight, while 


\section{THIRD AMERICAN TOUR}

his son and daughter-in-law were enjoying a honeymoon at Niagara Falls. All sailed from New York on the packet England, and landed at Liverpool on the $2 \mathrm{~d}$ of August. Five days later the family was united in London. 


\section{CHAPTER XXXII}

\section{AUDUBON'S GREATEST TRIUMPH}

Extension of his work-Financial panic and revolt of patrons-New western collections-His "Book of Nature" completed-Work on the letterpress in Edinburgh-Vacation in the Highlands-Commissions to Harris-Parting address to the reader-Dissolution of the Havell engraving establishment-The residuum of The Birds of AmericaRobert Havell, engraver, and his family-Lizars' first edition and the Havell reissues of plates-Brief manual for collectors-AppreciationsTotal edition of The Birds of America-Past and present prices-The Rothschild incident.

After Audubon's return to England in the summer of 1837, the completion of his magnum opus occupied but two years. Certain now of the ultimate success which would crown his efforts, he worked with a furious ardor, determined not only to execute his original plans, but to extend them, if necessary, to include every bird which had been discovered in America, or, at least, in the United States.

Audubon wrote Thomas Brewer in September that, for some unexplained cause, a large part of his collections made in Texas had probably been lost; when writing on October 29, the box containing all the eggs collected on the Gulf of Mexico had not come to hand. He continued: ${ }^{1}$

I authorize you to offer and to pay as much as five dollars. for an old raven, in the flesh, and perfect as far as internals

${ }^{1}$ For this and the quotations in the following paragraph, see Thomas M. Brewer (Bibl. No. 79), Harper's New Monthly Magazine, vol. Ixi, p. 666 (1880). 
are concerned. European writers who a few years since were all agog to prove that our apparently analogous species were identical with those of Europe have suddenly "faced about," and pronounce our birds to be quite distinct species, and of course now say that our raven is indeed our raven! and all this because I proved that the Corvus corone of Europe existed not in America. All this induces the present natural student of nature to have his eyes and all his senses fully open, and to see into things further than we can into grindstones. ...

Charles Bonaparte, who has just this moment left me, has kindly proffered me his new North American species, and I hope to figure them all, thereby rendering my work the more complete, if not quite perfect, as far as truly well-known species are now thought to exist in the limits of our country, or indeed those of North America.

When writing his young friend again, on November 18, he implored him to proceed

with all possible industry, in procuring the birds of my list, in rum. I hope you will have a pair of pied ducks (Fuligula labradora) for me. Send me all the drawings of eggs you can so that they reach me here by the 1st to 10 th of March next. If the birds arrive in London by the middle of April, it will do. ... I send you inclosed the copy of an advertisement of my work, which I wish you to hand over to our most generous friend George Parkman, Esq., M. D., and ask him to have it inserted in one or more of the Boston newspapers as soon as convenient.

Again, on the 22nd, he admonished his friend not to send his "drawings of eggs by letter," but to forward all such to $\mathbf{N}$. Berthoud, "and ask him to send them by captains of London packets. The postages are very heavy these hard times, and I am not a prince."

Although Audubon's "Prospectus" called for only 
eighty parts of 400 plates, by 1837 the number of new discoveries had multiplied to such an extent that he faced the dilemma of either enlarging his work or issuing it in an incomplete state. In the summer of that year large numbers of his British patrons discontinued their subscriptions, a result, no doubt, of the disastrous panic which had driven many into bankruptcy, and still more refused to take any plates in excess of the stipulated number. To alleviate this anticipated difficulty, he had already begun to admit composite plates, on which from two to six different kinds of birds were grouped together, much in the older style which he abhorred; but, in spite of this concession and omission of the eggs, colored figures of which he had hoped to give at the end, he was obliged to add seven parts, thus swelling the total number of large plates to 435 , which represented 489 supposedly distinct species of American birds.

When Audubon was facing such protests in England, Dr. J. K. Townsend ${ }^{2}$ returned to Philadelphia with a second great collection from the Far West. How eager he was, at this psychological moment, to gain access to these ornithological treasures is clearly shown in the following letter ${ }^{3}$ to Edward Harris:

\section{Audubon to Edward Harris}

[Outside address] To $\mathrm{ED}^{\mathrm{D}} \mathrm{H}_{\mathrm{ARRIS}} \mathrm{Esq}^{\mathrm{r}}$.

Moorestown New Jersey

9 miles from Philadelphia Pennsylvania

$$
\text { U. S. A. }
$$

Duplicate

Londos, Oct. 26 th., 1837.

I have this moment received your dear letter of the 4 . instant, for the contents of which, I do indeed most truly thank

2 See Vol. II, p. 149.

${ }^{3}$ See S. N. Rhoads (Bibl. No. 46), The $A u k$, vol. $\mathrm{xx}$, p. 377 (1903). 
you, but the most important point contained in it, Dr. Spencer is now at Paris quite well and happy. I have not heard of his supposed intentions to visit Russia, at least not until you have shown yourself in Europe for awhile. When will you come? I have not received one single letter from Dr. Morton since my return to England, and have been the more surprised at this, because I look upon him as a worthy good man and as one whom, since my last visit to him, I cannot but consider as my friend.

The return of Dr. Townsend to our happy land has filled me with joy, and trebly so when you tell me that he is as friendly disposed to me as I ever have been towards him. I congratulate you my dear friend, in the step which you have so kindly taken in my favour, by first selecting all such Birdskins as you or Townsend have considered as new, and also in having given freedom to Dr. Morton to pay Dr. Townsend Fifty Dollars for the skins selected by you, under the prudent considerations or restrictions talked of in your letter. May I receive all the Bird skins very soon, for depend upon it, now or never is for me the period to push on my publication. If I have any regret to express it is, that Townsend or Dr. Morton or yourself did not at once forward to me the whole of the Bird skins brought latterly by Townsend, for I can assure you that it has become a matter of the greatest niceity to distinguish the slight though positive species lines of demarkation between our species of Birds - and if on this reaching you, the least doubt exists amongst yourselves respecting any one, why send it to me at once by the very earliest conveyance. If by New York, with letter to $\mathrm{N}$. Berthoud to lose not a day, provided a packet, either to Liverpool or London, is ready to sail! Had Townsend sent me the rohole of his disposible birds, I might now have perhaps been able to have mad[e] him a remittance in cash, which the single arrival of the German Naturalists, who are now in California may hereafter put an end to. Mention this to him, nay, shew him this letter if you please and assure him that I am willing to exert myself in his behalf. Indeed, I wish you to urge him in forwarding me either his own manuscripts or a copy 
of all such parts as appertain to Birds, as soon as possible, knowing ( $\mathrm{I}$ think) that he will not undertake to publish them himself under his present (I am sorry to say) embarrassed pecuniary circumstances. Tell him that I want all about the habits of any Birds which he has written upon, especially, however, those found from the beginning of his journeys until his return, and appertaining to species belonging to our fauna or otherwise. Their exact measurements, dates, localities, migratories or vice versa inclinations, descriptions of nests, eggs \&c. periods of breeding; in a word all that he can, or will be pleased to send me-and you may assure Townsend, that all he will confide to me will be published as coming from him, although I may think fit to alter the phraseology in some instances. Tell him to be extremely careful in naming his new species, and that [if] he thinks of difficulties in this matter, to leave it to me, as here I am able to see all the late published works (and they are not a few) and work out the species with more advantage than any one can at present in Philadelphia. Do not take this as egotism far from it, it is in friendship and for his sake that $I$ venture on undertaking such an arduous task. I am exceedingly [anxious] to receive a letter from him (for Nuttall, though an excellent friend of mine and a most worthy man, will not answer me in time on this subject) of all the birds contained in the plates now at the Academy of Natural Sciences in Philada., which he saw on the Rocky Mountains, over those mountains, on the Columbia River and off the coast of our Western boundaries. This I want much, and if he would simply dictate to you plate 1 , not there, plate 2 , there, plate 3 there \&c. \&c. this would amply answer my purpose, and this I wish you not to neglect to forward me as soon as possible by duplicate! Of course I cannot speak upon any one of the new species of which you speak until I have examined them all. To talk of new species in London is a matter not now understood in any part of America, and sorry will you be as well as himself, when I assure you that out of the twelve supposed to be, and published by Dr. Morton, from Townsend's first cargo, not more than six are actually undescribed, although $I$ have taken 
upon myself the risk of publishing his names to the Birds on my plate, but which of course I am obliged to correct in my letter press. The little beautiful owt, I would venture to say has been described by Vigors at least ten years ago, \&c. \&c. Swainson never goes to bed without describing some new species, and Charles Bonaparte, during his late visit to London, has published as many as 20 of a night at the Museum of the Zoological Society Insects \&c. \&c. Stir, work hard, [be] prompt in every thing. My work must soon be finished, and unless all is received here by the month of May next, why I shall have to abandon to others what I might myself have accomplished. God bless you, many happy years. We are all well, thank God, just now. Remember me and us kindly to all around and every friend and believe me ever your most truly and sincerely attached friend,

\section{John J. Audubon.}

To Edward Harris, Esqre.

Addressed, care "Messrs. Rathbone, Brothers \& Co. When you send to Liverpool. Liverpool."

If Townsend has brought Birds Eggs, ask him to send them me. I will return all to him that he may want. I greatly regret that you did not find me the water Birds of which you speak, as I might have perchance found something new or curious among them. The Golden Eye Duck especially, if any be had?

In reference to the new species of birds which had come into his hands, Audubon said:

What was I to do? Why, to publish them, to be sure; for this I should have done, to the best of my power, even if every subscriber in Europe had refused to take them. What! said I, shall the last volume of the "Birds of America" be now closed, at a time when new species are in my hands? No! And in spite of threats from this quarter and that, that such and such persons would discontinue their subscriptions (which indeed 
they have done), and refuse to take the few numbers that would have rendered their copies complete, my wish to do all that was in my power has been accomplished.

Doubtless we should hesitate to blame many of Audubon's subscribers for wishing to be relieved from an obligation which for a period of ten years had cost them from $\$ 50$ to $\$ 100$ per annum, not to speak of any who had met financial disaster in the panic of that day, but at this juncture he really had no choice. When his eightieth Number, originally intended to be the last, appeared in 1837, many important kinds of birds, including ducks, swan, tern, and the Flamingo, as well as grouse, warblers and woodpeckers, were still calling loud for recognition. So generous of space had he been in the earlier phase of his undertaking that twenty species were each shown on two distinct plates, while in the end the need of compression compelled him to introduce thirtyfive composite plates.

Subscribers to The Birds of America at the beginning had been permitted to take a part or the whole, and many incomplete sets were circulated, upwards of 120 , as Audubon declared in 1839, having then discontinued their subscriptions. Towards the end of his undertaking, owing to the great expense and uncertainty involved, he was disinclined to supply any but regular subscribers, as shown by the following letter written from London, May 25, 1838, to William A. Colman of New York: ${ }^{4}$

... We find that six of the plates you want are not only. largest figs, but some of them extremely full and difficult to colour, and he [Mr. Havell] says that our Printers and our Colourers would not undertake to go throu them without charg-

- From MS. in the Public Library, New York. 
ing a most extravagant price. I have no extra plates whatever on hand, and in consequence of this must be obliged to decline furnishing you with them.

If at the conclusion of my publication I find any of the plates you want they will be sent to you forthwith, but I wish you not to calculate upon this until you hear again from me, or from my sons on this subject.

My work will [be] entirely finished by the end of next month, when our engraving and Printing establishment will be broken up, and few will indeed there be copies to be had by any one, who has not subscribed to the "Birds of America."

Should you see any of my American subscribers who have not as yet seen any portion of the work, please to assure them that as soon as the fourth volume is quite finished, and bound according to their desires, their copies will be forwarded at once to their respective homes, or to whomsoever they have directed me to send their copies.

On May 26 Audubon wrote Thomas M. Brewer that "Edward Harris, one of the best men of this world," had reached his house "yesterday at noon, after a pleasant passage of fourteen days and a few hours." "My illustrations," he said, "will be finished on the 20th of next month, and the fourth volume of text shortly afterward"; at the end he added: "When I return to our beloved land, I intend to spend a full season about the lakes in Northern Vermont, for, from what I hear, much knowledge is to be acquired there and thereabouts." After returning to New York in September of the following year, he again alluded to the ramble he would like to take "along the borders of the famous lakes of New Hampshire and Vermont," but was unable to bring it to pass at that time.

To depart but slightly from the chronological sequence, the last to be preserved of Audubon's letters to 
William Swainson, ${ }^{5}$ written at a time when his great work was drawing to a close, will be given at this point:

\section{Audubon to William Srainson}

My dear Mr Swatnson,

Lospos 11th Jan 1838

The severe indisposition of my good wife which has continued almost unabated now since $I$ had the pleasure of seeing you, is my excuse for not having ere this answered your two notes, especially the last of the 8th instant.-

Your box \& contents came perfectly safe to hand, and I think will soon again be in your possession in like good order. I certainly should like to see the Buteo [?] vulgaris to compare it with mine (that at the mouth of the Columbia) and the one described by Nuttall before the return from America of D. [Dr. John] Richardson \& of which it seems you were not aware.I am glad nevertheless that if differing from the European bird of that name the Transatlantic bird will be honoured by your own name.

Charles Bonaparte is at Paris \& is to remain there. I am well informed for about a fortnight.-He left London in great haste and I assure you has left no parcels or letters for you or anybody else either with us or with Havell.-I am sorry that he should have disapointed you \& your dear Children but- -

I cannot say just now whether I have a specimen of Muscicapa Trailli "the Prince" having two of my giving, if however, I have another I will send it to you with great good will \& pleasure- As regards your queries respecting several species of quiscalus or Crow black birds You are correct for I have myself discovered two in America one in the Floridas the other in the Arkansaw River, both of which will be given in my work. - That more exist I have no doubt especially further South and West.

You have described a swan in the Fauna Boriali Americana

${ }^{5}$ The Linnæan Society's MSS. See Chapter XXIII, Note 13. 
under the name of the Cygnus Bewicki, but as your measurements there and then given are very far from those of the swan now known under the name of Old Bewick I should feel obliged to you to let me know whether the specimen you described from was the identical bird procured by Captain Lyons, and of which that gentleman described the nest? And again I should like you to tell me whether you have seen the Clangula vulgaris of Linn. that in the months of April \& May?

Many thanks for all your kind wishes \& may you and yours enjoy the like return of many many new \& happy years.-Call upon us when you come to Town and believe me my dear $\mathbf{M r}$ Swainson ever sincerily

yours attached friend

JoHn J. Audubon

I have had the jawache for nearly one week \& have not been out of the house

\section{Wimpole Street}

Audubon's day of greatest triumph came on June 20,1838 , when he had the supreme satisfaction of seeing the last plate of his "Book of Nature," The Birds of America, completed. Having been begun virtually in the autumn of 1826, it was in press nearly twelve years. The sumptuous character of this work, its commanding beauty, as well as its surprising accuracy, considering all the obstacles of time and circumstance, mark it, when combined with its letterpress, as one of the most remarkable and interesting undertakings in the history of literature and science in the nineteenth century. Unique as it was in every detail of its workmanship, it will. remain for centuries a shining example of the triumph of human endeavor and of the spirit and will of man. This is true in spite of any errors it may disclose, and even if it be conceded that bare bones and plain photographs are more valuable for elucidating the technicali- 
ties of science than the most artistic productions of the pen, pencil or brush.

Audubon's labors in England, however, did not end with the completion of his plates, for two volumes of his "Biographies" still remained to be published. He was in London during the early summer of 1838, when he recorded a visit from John Bachman, who had come to Europe for the recuperation of his health. He was then obliged to hasten to Edinburgh, where he was soon joined by both Bachman and Victor Audubon and later by other members of his family. For the convenience of work he took rooms near the museums, on the south side of the city, not far from Lauriston Place and within easy reach of "The Meadows," a well known recreation ground.

The following letter, ${ }^{6}$ sent to his son John soon after his arrival at the Scottish capital, and addressed "No. 4 Wimpole Street, London," abounds in interesting personal details, but the student of birds would find more significant its clear statement of his relations with MacGillivray; it shows us the anatomist at work, and Audubon as his student and "secretary." "Under his kind tuition," he said, when writing at a little later time, "I think I have learned something of anatomy, which may enable me, at some future period, to produce observations that may prove interesting ..."

\section{Audubon to his Son, John}

Edrisurgh, July 1 st, 1838, Sunday.

MY DEAREST FRIENDS

Your joint letter of the 27 th Wednesday, did not reach me until yesterday afternoon, probably because the steamer

- First published by R. W. Shufeldt (Bibl. No. 4.5), in The Auk, xi (1894); see also Maria R. Audubon, Audubon and his Journals (Bibl. No. 86). 


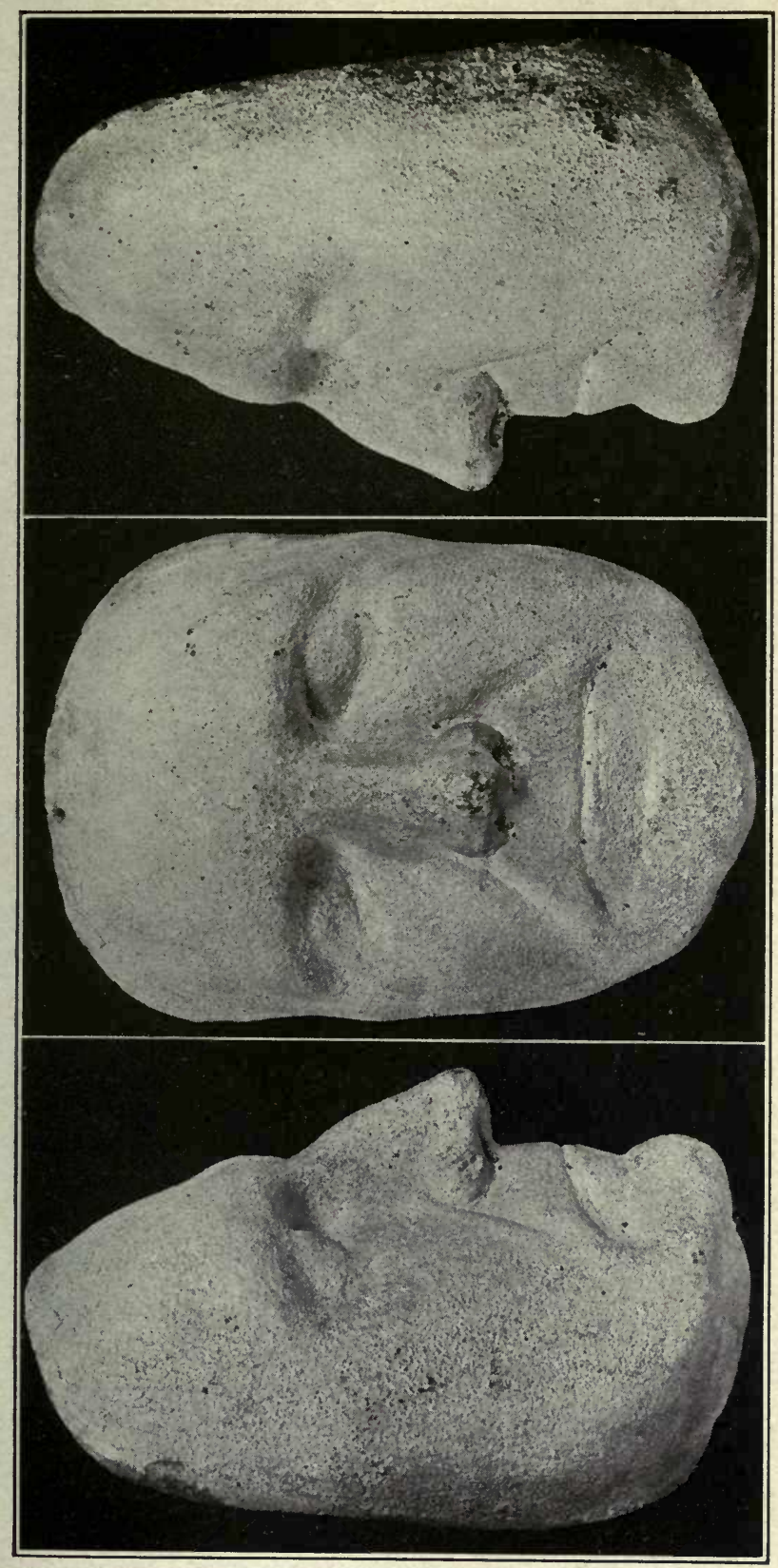

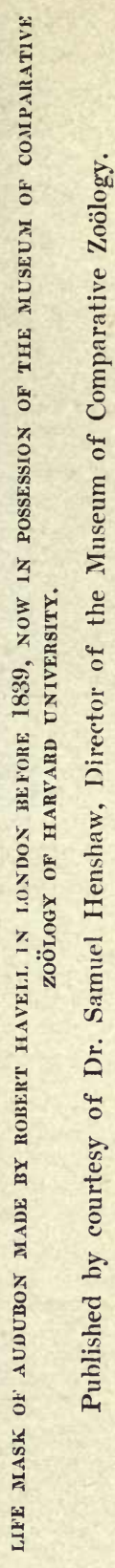



which brought it did not leave London on that evening on a/c of the coronation etc., Here the festivals were poor beyond description, and although scarcely anything was to be seen, the whole population was on foot the entire day, and nearly the whole night, gazing at each other like lost sheep.-No illuminations except at two shops, Mr. Henderson's and another close by him.-The fireworks at the castle consisted merely of about one hundred rockets, not a gun was fired from the batteries. MacGillivray \& I went to see the fireworks at 10 p.m, and soon returned disgusted.-His museum (College of Surgeons) and the Edinburgh Museum were thrown open gratis, and were thronged to excess Upwards of 20000 in the first, and about 25000 in the other; all was however quite orderly. The day was showery; cloudy and dismal at times, but the evening was clear and fine.-Mr. Hill's father died on the morning of the 27th and I have not seen Alexander H., since. Many thanks to Maria for her bunch of letters, and the few lines of her own to me, I hope that everything will go on well with you all.

We begin printing tomorrow $2 d$ of July, 1838!! remember that Mesdames et Messieurs! and I intend to proceed with all possible despatch and care. All the birds in rum will be inspected as far as internal or digestive organs, trachea \&c are concerned, and as I am constantly present in the dissecting room, I think I shall know something about the matter anon.I am almost in hopes to see Victor tomorrow night but cannot be sure. There are somewhere at home the nests of the birds found on the Columbia by Nuttall and Townsend, I believe that of Bewick's Wren is among them; send them all, very carefully packed. I want the journal of my first trip to the Floridas, which was cut out of my large leather journal, previous to going to Labrador, also a letter on the habits of the Yellow${ }^{2}$ bellied Cuckoo, by a gentleman at Charleston. If it cannot be found perhaps Maria will recollect his name, being a friend of John Bachman, if so send me that, in full if possible. It is the gentleman in whose garden I procured the small and large cuckoos in the same nest.-

I have written fortyfour articles for my appendix and 
will continue whenever I am not otherwise engaged, so as to save time at last.- I am sorry for the death of poor Wickliffe but glad that his brother was with him at New York previously, and that we, at least, have done all that we could for him. MacGillivray is quite well, and works very hard, poor fellowI am glad of John's repainting the head by VanDyke, two copies of such heads are valuable to him, besides his improving by so working-When Victor has left for this place, John must pay much attention to the colourers and cxll also at the bookbinder. Havell ought to exert himself in having some 4th vols; delivered as soon as possible.

My last letter which was written last Sunday, was put too late in the office, which closed on that day at two o'clock, and did not therefore leave this till four o'clock on Monday afternoon; this one will have a better chance, for I will take it myself to the general office. I have seen no one hardly since my last, I am indeed as busily engaged as ever, and rarely go to bed before eleven-being with Mr. MacGillivray until generally past ten, describing etc., I rise at four or earlier, he at ten; but I go to bed at eleven, he at two. I discovered that he was adverse to the examination of the intestinal canals etc., because many of my birds which are common to both countries will be published before his $2 \mathrm{~d}$ vol., can now possibly be; but as soon as I told him that I had already said in my introduction, that the anatomical structure was declared to be his, he was much pleased and began on the instant.

Today is very dismal, and it will rain probably until night; I wish we had here some of the warm weather of which dearest Mamma speaks. I have had but one walk to Arthur's Seat, but now and then I stroll to the meadows which are close to me, and now look well.-From the window of my sitting room I overlook the garden of Mr. Frazer our printer, and now and then speak to him there, I have not yet however visited him.-I will recollect the Queen's farthing when next I see Professor Wilson, but doubt much if he will recollect the least idea of it. Has Charley written or said anything to Victor about the review of the work; remember me to Healey.- 


\section{AUDUBON'S GREATEST TRIUMPH 181}

I suppose that the crown of England sits very quietly down, and that all was very superfine. I have not so much as seen a paper since I left you.

God bless you all, dearest friends, and take good care of Mamma and Maria,

Ever your firmly attached father and friend

J. J. Audubon.

No. 7 Archibald Place,

Lauriston.

Audubon's fourth volume, the printing of which was announced in this letter, was published in November, and at the conclusion of the introduction he said:

I believe the time to be fast approaching when much of the results obtained from the inspection of the exterior alone will be laid aside; when museums filled with the stuffed skins will be considered insufficient to afford a knowledge of birds; and when the student will go forth not only to observe the habits and haunts of animals, but to procure specimens of them to be carefully dissected.

These prophetic remarks, which were no doubt inspired by the studies of MacGillivray, have found ample justification in the later history of ornithology; to give a single illustration, it was through the aid of anatomy only, in this instance, of the vocal organs, that modern students have been able to define the true Passerine or Oscine birds, as distinguished from all others, and as the highest representatives of the avian class.

In the autumn of 1838, when Mrs. Audubon was still suffering from impaired health, the naturalist paused in his work to indulge in a short vacation, the first in many years. On September 14, he wrote to Edward Harris, who was then in Scotland: ?

? See S. N. Rhoads (Bibl. No. 46), loc. cit. 


\section{Audubon to Edrard Harris}

Edinburgir, 14 Sep', 1838.

\section{My Dear Friend:}

Not having hecrd anything from you in answer to my last, I suppose that you may yet be away from Glasgow, but as we ourselves are going off tomorrow to the "Highlands," with a view to be at Glasgow on Thursday next, I write to you now, with the hope of meeting you then. Nothing of importance has occurred here since my last, but the book has considerably swollen in its progress towards completion.

We all unite in best wishes to you and I remain as ever your most truly attached and sincere friend,

\section{John J. Audubon}

We intend being home again on Saturday next.

[Addressed] To Edward Harris Esq ${ }^{\mathrm{r}}$.

Comrie's Royal Hotel,

Glasgow.

With MacGillivray as guide, Audubon and his family visited Stirling, Doun and Callander, where they "marched in a body to the Falls of Bracklin, guided by a rosy-cheeked Highland lassie, stopping now and then by the way to pick up a wild flower, - a blue-bell, a 'gowan,' or a dog-rose, or to listen to the magpies and titmice." From Callander they ascended to Loch Katrine, and explored the Trossachs, "admired by many, chiefly or entirely on account of Scott's description of them"; at the tavern there, said Audubon, "with that most curious innate desire which there is in us of becoming older, for the purpose of enjoying the morrow, I went to rest, anxious to see the morn, and discover what existed beyond the crags that had bounded my view."

From the wild and beautiful scenes about Loch Katrine, which stirred the naturalist's emotions and 


\section{AUDUBON'S GREATEST TRIUMPH 183}

evoked the desire to remain until the curtain of night had gradually and peacefully closed the landscape from their view, they proceeded to the rocky shores of Loch Lomond, where they found "a few small stone cabins, some fat bairns, abundance of ale, and a sufficiency of capital whisky." After crossing to Tarbet and examining both the head and the foot of the lake, they went on from Balloch to Dumbarton by stage, and thence by steamer to Glasgow; there they spent a few days, and returned to Edinburgh by way of Dunbarton and Lanark. Steamers and coaches, slow as they then were, were all too fast for Audubon on this journey, and he declared that if ever again he visited the Highlands, it should be on foot, "for no man, with nerve and will, and an admirer of the beauties of nature, can ever truly enjoy the pleasures of travelling, unless he proceed in this manner."

Mrs. Audubon's health had not improved by the journey, for shortly after their return she was again taken ill; she was placed in the care of Dr. John Argyle Robertson, for whose efficient aid and "kind and gentle treatment," said Audubon, "we can never cease to cherish the most lively feelings of affection." "It is a curious part of my history," he continues, "that during the whole of my sojourn in Britain, none of the principal medical advisers whom we had occasion to employ would receive any recompense from us."

By the 5 th of November, 1838, but a few days after the issue of the fourth volume of his "Biographies," the printing of the fifth and last had already begun. The following letter ${ }^{8}$ is interesting for its personal details, and in showing that his confidence in the existence of the "bird of Washington" " had not been shaken:

${ }^{8}$ See ibid.

'See Vol. I, p. 241. 


\section{Audubon to Edreard Harris}

Edrmburar December 19th., 1838.

My dear Friend:

Your letter of the 13 th. instant to Victor reached us this morning, and glad were we all to hear from you.

My object in writing to you is, for the purpose of assuring you that I feel great [pleasure] in preparing a box of bird skins for you according to your desire. It is true, however, that I am now on the eve of commencing my synoptical arrangement of our birds, I shall not be able to show you as many of my specimens [as] I could otherwise have done, but you must take the will for the deed. The Box will be taken as far as London by Victor, who will leave us on the first of January. You will find in it a list of the contents, and I trust such bird skins as may answer your purpose well. Besides these Victor will also attend to your request as soon as in New York and will ship to you by way of Havre as you direct.

I am glad that you should have seen what you conceive to be the great rara avis $\mathbf{F}$. Washingtonii. I am sorry you could not have pocketed it, but who knows if it is not left yet in store for you - and I to shoot a pair of these noble birds at The West, and that, after having satisfactorily examined its habits, its eggs, or its young! Bonaparte, between you and I, is exceedingly ignorant as regards our birds, as I found to my cost when he was in London, and where he pumped me sadly too much, but it is now over and I forgive him as I do all others who have or who may try to injure me.

John Bachman wrote to me that he had left in commission to Trudeau, the purchase for me of a copy of Vieillot's Oiseaux de l'Amérique Septentrionale, and also a copy of Boié or Bojé work ${ }^{10}$ on birds generally, but I have received neither books or

${ }^{10}$ Voyage Autour du Monde, exécuté par ordre de sa Majesté l'Emperenr Nicholas ler, sur la Corvette Le Séniavine, 1826-1829. Par Fréderic Lutké, Capitaine de vaisseau. Partie Historique, avec un atlas, lithographié, d'après les dessins originaux d'Alexandrie Postels et du Baron Kittlitz. Traduit du Russe sur le manuscrit original, sur les yeux de l'auteur, par Le Conseiller D'Etat F. Boyé. Text in 3 vols. 8vo. Paris, 1835-36. The first two volumes are historical, and the third, entitled "Travels of the 
promises of them from Trudeau as yet, perhaps you would undertake the task yourself, and show to Havell as soon as possible, for I shall be sadly in want of them in a few weeks more. I should also like you to try to find Mr. Augustus Thorndike of Boston, to whom Victor wrote a few days ago, with the view to inquire from that Gentleman when he wished his copy of the Birds of America to be delivered. Victor addressed his letter to "his Hotel" or to the care of the "American Embassy." We are not sure, however, whether he is in Paris at present, and let me know what discoveries you have made as regards this.-Victor will remain ten days in London and wishes you, should you write to him there, to put your letter under cover to Havell and request him to keep it. Victor will write you from thence,

I cannot account why Trudeau has not written to me in answer to my last, now full two months old? Should you perchance discover a specimen of the Bird of Washington in Paris and purchase the same, I should like you to send it to me on loan to enable me to compare it with mine, and the Immature of the F. Albicilla of Europe!

I have got twelve sheets of the 5 th. Vol. of Biographies already printed, and I expect to have quite finished by the 1st. of April next. I have decided on the Trichas resembling Sylvia Philadelphia of Wilson. It is a distinct species, but what will probably surprise you more, the $S$. Agilis of the same author is also perfectly distinct from either. All this you will plainly see when you read their separate descriptions and compare the three species.

I wish you would ask Trudeau whether he recollects the specimen of an Eagle send by Townsend in his first collection, numbering 54 and which the latter has lost, though he considered it as a new species. It was procured in California. Townsend speaks sorrowfully of the loss of this specimen. It never came under my eye, did it come under yours? Ask Tru-

Naturalists," is translated by Alexandre Postels. The expedition traversed the Behring Sea, touched at some of the Aleutian Islands, and then explored South America as far as the coast of Chili. 
deau whether he ever saw my Hirundo Serripennis in America. Bachman wrote to me that Trudeau thought he had in the skins of Frederick Ward. I think Trudeau will be pleased with the anatomy of our birds, as it opens misteries hitherto unknown in connection with the relative affinities of some species toward others and assists in the formation of groups \&c., in what some day or other, will be called a Natural arrangement!

I wish I could have spent a few weeks in Paris with you and Trudeau, as I readily imagine that some new species of North American birds, may yet be found there unknown to the World of Science. I have written to Mr. Chevalier and to Townsend, but will not, I dare say, hear anything more of the former until through Victor, who intends to see him very shortly after his arrival in America.

My Dear Wife is much better than when you saw her, and I hope that when once again she has been safely landed on our shores and enjoyed the warmth of our own Summers, her health will be quite restored.

The Little Lucy has grown as fat as butter, and the rest of us are well.

We all unite in kindest best wishes to you and to Trudeau, and I remain as ever, my Dear Friend,

Yours,

John J. Audubon.

6 Alva Street.

In May, 1839, Audubon's fifth and last volume of the Ornithological Biography, consisting of 704 pages, was issued. It was followed almost immediately by $A$ Synopsis of the Birds of North America, in which the efficient aid of MacGillivray was again enlisted. On May 4 Audubon wrote to Havell that this work was. in press and would be ready in about a month's time; again, on the 30th of June he announced that it was finished and in the hands of the binder. With this methodical catalogue of the birds of North America 
then known and described, to the number of 491, fiftytwo of which were new, Audubon's life and labors in England were brought to a close.

The introduction to the last volume of his "Biographies" begins as follows:

How often, Good Reader, I have longed to see the day on which my labours should be brought to an end! Many times, when I had laid myself down in the deepest recesses of the western forests, have I been suddenly awakened by the apparition of dismal prospects that have presented themselves to my mind. Now, sickness, methought, had seized me with burning hand, and hurried me away, in spite of all my fond wishes, from those wild woods in which $I$ had so long lingered, to increase my knowledge of the objects which they offered to my view. Poverty, too, at times walked hand in hand with me, and on more than one occasion urged me to cast away my pencils, destroy my drawings, abandon my journals, change my ideas, and return to the world.

Later on he says: "You may well imagine how happy I am at this moment, when ... I I find my journeys all finished, my anxieties vanished, my mission accomplished"; and he concludes: "I have pleasure in saying that my enemies have been few, and my friends numerous. May the God who granted me life, industry, and perseverance to accomplish my task, forgive the former, and forever bless the latter!"

Audubon's introductions to the five volumes of his "Biographies," from which we have frequently quoted, are characteristic; in them he cheers his subscribers, calls all his helpers and correspondents by name, and takes the public into his confidence by recording the acts which marked the steady progress of his work. Frequent appeals to the "good" and "gentle reader" have gone out of fashion, but in this instance they seem in keeping with 
the style and character of the man, and they were not made in vain. Audubon's belief in his mission was so plainly sincere, his power so manifest and his enthusiasm so ardent, that there were few who did not gladly acclaim the extraordinary success of the man who twelve years before had landed in Liverpool poor and unknown.

In the winter and spring of 1839, while Audubon was engaged in Edinburgh and Victor was in America, the settlement of his business affairs in London was entrusted mainly to Robert Havell, his engraver. At that time Havell was also pulling up roots, for he had caught the spirit of his patron and had decided to emigrate with his family to the United States; this involved disposing of his stock and breaking up his engraving and printing establishment at 77 Oxford Street. Havell had acquired distinction as well as a competence through his long engagement with Audubon, and being then in his forty-sixth year, he doubtless looked to America as a field for the fuller expression of his artistic aspirations and talents. How anxious Audubon was at this juncture regarding the disposition of the residual stock of his plates, his drawings, and his books, then in Havell's hands, is seen by the following letter, ${ }^{11}$ written at Edinburgh, in the winter of this year.

\section{Audubon to Robert Havell}

Edinburgh, Feb. 20th, Monday, 1839.

My dear Mr. HaVeli

I perceive by the date of your letter of the 16th instant that you must have been some days beyond my expectations,

"First published by Ruthven Deane (Bibl. No. 225), in The Auk, vol. $\operatorname{xxv}(1908)$. Mr. Deane writes me that he has a copy of a receipt from William MacGillivray to Audubon for the final amount due him for work on the technical parts of Volume V of the Ornithological Biography; at the bottom of this paper Audubon made a memorandum, under date of November 21, 1838, to the effect that the total amount which he had paid MacGillivray for his work upon this volume was $\$ 47-11-1$. 
in the receiving of my parcel to you, and that on that account my letter of Saturday last crossed yours of the same date. I thank you for what you say as regards the balance in my favor at Wright and Co.

Does Henry sail from London Docks or from Portsmouth? and pray what is the name of the Captain of the "Wellington"? I do not precisely understand what you mean by the loose sets which you desire to know how they should be packed? let me hear what they are and how many of them by return of mail. The five perfect sets I think might all go into one case, tinned as usual and insured of course to the full amount of their value, as well as all others and to which I pray you to attend as if for your own self. It is impossible for me to go to London at present and indeed I cannot exactly tell when I will, and I trust to you entirely for the seeing that all the volumes are fair and good and passed through your oron inspection of them before they are packed. No volumes of Biographies must be put in the same boxes.

When you have disposed of your business, what will you do with what you have on hand belonging to us? This requires an answer from you at once. You have a great number of volumes of Biographies, Pictures, \&c. \&c., a regular list of which you ought to send me. I cannot yet say when the 5th vol. of Biographies will be finished, but will let you know as soon as I can. I received yesterday morning a letter from a gentleman who has procured a copy of the work through Mr. Eame the bookseller, he says that he has called upon you to say that he is missing one plate and begs to have a copy of the plate struck and remitted to Mr. Eame who will pay you whatever price the extra trouble on this account may amount to, but he does not say what plate it is, and I therefor suppose that you do? If so as he is the brother-in-law of Mr. Walker of Ravensfield Park, one of our good subscribers I would say do it for him! My wife begs of you to save all the loose prints which were returned to you by our son Victor, as well as any others whatever, perhaps among them you might find one to send Mr. Eame's subscriber? 
On the 4th of this month the 'Great Western' was nearly half way across the Atlantic!! Sir William Jardine has published a capital review of the work! What a strange world we do learn in! Be sure to let me know about the original drawings at Henry's, if he has finished them, where they are \&c. \&c. We all remain as usual with kind good wishes to you all,

Your friend

John J. Audubon.

[Superscribed] 6 Alva St.

Robert Haveli Esq.

Engraver.

77 Oxford st

London.

How fully Audubon's injunctions in regard to his residual stock, and particularly to scattered plates of the Birds, were followed, is not known, but it is certain that a part of this residuum remained in England, where it is occasionally turned up even at the present day. In a considerable number of the original plates which were found in a bookshop in New Oxford Street in August, 1912, twelve were in the uncolored state, and several had the appearance of rejects; moreover, in a collection of these plates received from England in 1910, there were nine copies of the same subject, the Painted Bunting (No. 11, Plate 53). Though a complete set of the plain plates is known, ${ }^{12}$ and a considerable number were probably dispersed in America, they are very rare.

Audubon wrote to Havell again on the 13th of March, when he complained of the gross mistakes made

${ }^{12}$ See Note 5, Vol. II, p. 7. Mr. John Hardin (see Vol. II, p. 295) showed me an uncolored print of the Hen Turkey which John W. Audubon had given him, and a correspondent in New Orleans informs me that a relative possesses a number in this condition, which were received many years ago as a gift from Mrs. Audubon. Mr. Charles E. Goodspeed, of Boston, was the recipient of the Painted Bunting plates, noticed above. 
by the "idle rascals" who were employed in filling orders in his shop, and who had so sadly mixed matters that no less than twelve numbers of his Birds had come back to him, some of them containing one, three, and five copies of the same plate, instead of a "Number," and mixtures of the most incongruous sort; he thought that "a clever young man as a clerk was worth a hundred thick heads," and begged Havell again to send him "a correct list of what he shipped to America on his account, and that list not made by any other person than either himself or Mrs. Havell." His next injunction, on May 4, was to insure his copper-plates of The Birds of America for $£ 5,000$, and to send them to either Victor Audubon or Mr. N. Berthoud, Number 2 Hanover Street, New York. At that moment Audubon was planning to return to America with his family by the Great Western on July 6. In writing again on June 30 , he remarked that he was not at all certain that Havell, who was then visiting at his native Reading, in Berkshire, would really sail on the 25th of July, since he had already postponed the journey so many times; he added that it would not even surprise him if his work on the Quadrupeds of America might not be out before they could fish and shoot together in his "native land."

Havell eventually came to America with his wife and daughter on the ship Wellington, in September, 1839; they landed at New York after the 15th of that month, and for a time were the guests of the Audubons at Number 86 White Street. His brother, Henry, ${ }^{13}$ who visited the United States in 1829, returned at about this time and established a print shop in Broadway, New York, but according to Robert's biographer,

${ }^{13}$ Henry Augustus Havell (1803-1840), painter, engraver, and at one time assistant to his elder brother, Robert Havell, Junior. 
his enterprise was ruined by a fire, when he went back to England and he died there about 1840. After a brief residence in Brooklyn, Robert Havell settled at Sing Sing, now Ossining, at a beautiful spot on the Hudson, overlooking the Palisades, which he named "Rocky Mount." There he devoted himself with characteristic energy to painting and sketching, but he also engraved and published a number of excellent views of his favorite river, the Hudson, as well as of New York and other American cities. In 1857 he established himself at Tarrytown, where he built a house and studio, and where in his later years he produced many meritorious works in oils. "He never tired," says his biographer, "of the great, broad, sweeping Hudson, and propped up in bed, that he might gaze at will on this mighty river," he died at the age of eighty-five, November $11,1878 .{ }^{14}$

Havell has been described as quite the opposite of Audubon in many of his characteristics, calm, deliberate, not easily discouraged, and fully his equal in industry, perseverance and determination. Audubon sometimes complained of his friend's lax business habits, but their long sustained and cordial relations were never broken during life, and their mutual debt was great. The engraver's first son, who lived but a year, was named Robert Audubon, and the naturalist, who was his godfather, held the child at its baptism at old St. James Church, Oxford Street, in 182\%. A descendant of Luke Havell, who was a drawing master at Reading, uncle of Robert the second, possesses a silver loving-cup which Audubon presented to his engraver upon the completion of the second volume of his illustrations; it is inscribed "To Robert Havell, from his friend J. J. A. 1834."

${ }^{14}$ George Alfred Williams (Bibl. No. 232), Print-Collectors Quarterly, vol. vi, p. 225 (1916). 
When we consider the size of Audubon's plates, which required for the portrayal of his largest subjects, such as the Whooping Crane or Wild Turkey, an area of no less than five square feet, it will be seen that his engraver was compelled to adopt the most expeditious methods. This and kindred difficulties were overcome by Havell's skillful union of aquatint with etching and line engraving, but some of his smaller figures, as the Snow Birds (Plate 13), appear to have been etched in the usual way, with but slight use of either aquatint, dry-point or burin. In aquatinting the plate was usually bitten to the desired depth for the softer shading of feathers or foliage, or for the entire expression of sky, water or landscape. Says George Alfred Williams: ${ }^{15}$

Aquatint proper consists entirely of gradations of tone produced by biting with aquafortis into the copper through a resinous ground broken into a multitude of fine granules, that render the personal touch practically negligible, and in consideration of this we can appreciate the exceptionally skillful use Havell, Junior, made of the difficult process. The graining of the aquatint grounds is produced by allowing fine dust particles to settle upon the freshly prepared plate. It is to these grainings of different degrees of fineness that the engraver must look for the subtlety of the tonal surfaces, but strength is obtained usually through the use of the etched line. The chief limitation of the aquatint process lies in the great difficulty of getting more than a few differences of shade, as the ground goes to pieces rather rapidly under successive bitings, and the transitions from one tone to another are very few, so that half tones are not readily obtainable. It is in the economical use of these half tones that Havell, Junior, achieved so much and thereby produced a chiaroscuro seldom, if ever, equaled in aquatint. 
Artists have sometimes frowned upon this combination of aquatint with other forms of engraving, especially when executed with the burin, for "like the permanent misery of a quarrelling married couple, they may ruin everything with discord"; but any such lack of harmony, when not overcome by Havell's skill, was usually completely subdued by the color which was subsequently applied to the printed sheet. This is seen by a comparison of the plain proof of such an elaborate plate as that of the rattlesnake attacking the mocking birds (Plate xxi) with the result attained in the finished impression. In replying to a criticism of Havell's work in 1830, Audubon expressed his conviction that "no birds were ever so beautifully and softly represented on copper," and any hardness, which his plates rarely showed, was not due to aquatinting, the inherent quality of which is softness. To quote our authority again:

In Havell's hands aquatint gave the essential structure of forms by a judicious use of the process called "feathering." This he often did upon the bare copper plate without a ground, allowing the acid to bite its own granular surface. In this way he produced the soft gradations and telling accents so necessary to the portrayal of birds, but by a further judicious use of line the accurate forms of both bird and plant life were given with great force and delicacy.

When Audubon first proposed to present the Congressional Library at Washington with a copy of his Birds, he asked Havell to do all the coloring himself; Havell

colored his prints in the usual manner by flowing washes of pure water-color tints over the monochrome proof which was printed from the copper plate. In this phase of the process the great charm of his genuine talent for water-color painting 


\section{AUDUBON'S GREATEST TRIUMPH 195}

asserted itself. Aside from the first crude washes, put on by artists or colorists employed for the purpose, he himself applied the salient tones and all the more delicate tints.

Much misunderstanding has arisen in regard to the engraving and publication of Audubon's earlier plates owing to the complex relations which existed between Lizars, the two Havells of the same name, and the naturalist himself; this involved the reissue of the first two numbers of the work, and a confusing series of legends upon the plates themselves, occasioned partly by a division of labor between father and son, and by the death of Robert Havell, Senior, in 1832. The errors into which some commentators have fallen, however, are due to their examination of but one set of plates. The account which follows is based upon a collation of complete copies at the British Museum, the Radcliffe Library, Oxford, the Jardin des Plantes, Paris, and the Boston Society of Natural History, and of numerous scattered plates. Lizars engraved the first ten plates only of the large folio, but before the summer of 1827 a considerable number of these early impressions had been distributed. The Havells, as we have seen, started the work anew, and Robert, the younger, retouched the greater part of Lizars' plates, so that their reissue in London constitutes for the bibliophile a second, and in some cases a third, edition. Moreover, the plates which were eventually executed by the younger Havell, to the number of 425 , were repeatedly printed from to meet the requirements of new subscribers; on such occasions errors were corrected, minor changes in the artist's or engraver's name introduced, and the nomenclature of the birds and plants more or less completely revised. Frequently the Whatman water-marks, or, indirectly, 
Audubon's titles, postdate the year of publication as printed on the plate itself. Conflicting legends, particularly on the earlier plates, which have often puzzled collectors, are mainly due to one or another of the conditions named. Nearly every plate underwent alterations of some sort, but the various legends show conclusively whether the print belongs to a first or a subsequent impression. In the British Museum copy, the younger Havell's first independent legend appears on Plate lxxvi (Virginia Partridge), as "Engraved, Printed, \& Coloured by R. Havell Jun ${ }^{\mathrm{r}}$. 1830." The word "London" was later added, but was eventually discarded. After the senior Havell's death in 1832, the son naturally dropped the suffix from his own name; thereafter his brief designation of name and date became gradually stereotyped. It should be noticed, however, that when Robert Havell needed to reprint from plates which were executed before his father's death, he would frequently remove only the "Junior," and let the original date stand, so that legends like the following are not uncommon: "Engraved, Printed, \& Coloured by R. Havell, London-1831"; to avoid the lacuna, designation of place and date were, at times, erased also. The naturalist's name underwent a different evolution on the plates, but after 1830, the date of his election to membership in the Royal Society, his designation gradually settled into the phrase: "Drawn from nature by J.J. Audubon, F. L. S. F. R. S.” (as in Plate lxxxi, 1830); accordingly, all plates which bear these titles, but an earlier date, are second or later editions. The previous hints, with examples to be given presently, will enable collectors to determine whether a given plate is a first or subsequent impression.

Lizars' first edition of plates, Numbers i to $\mathrm{x}$, bore 


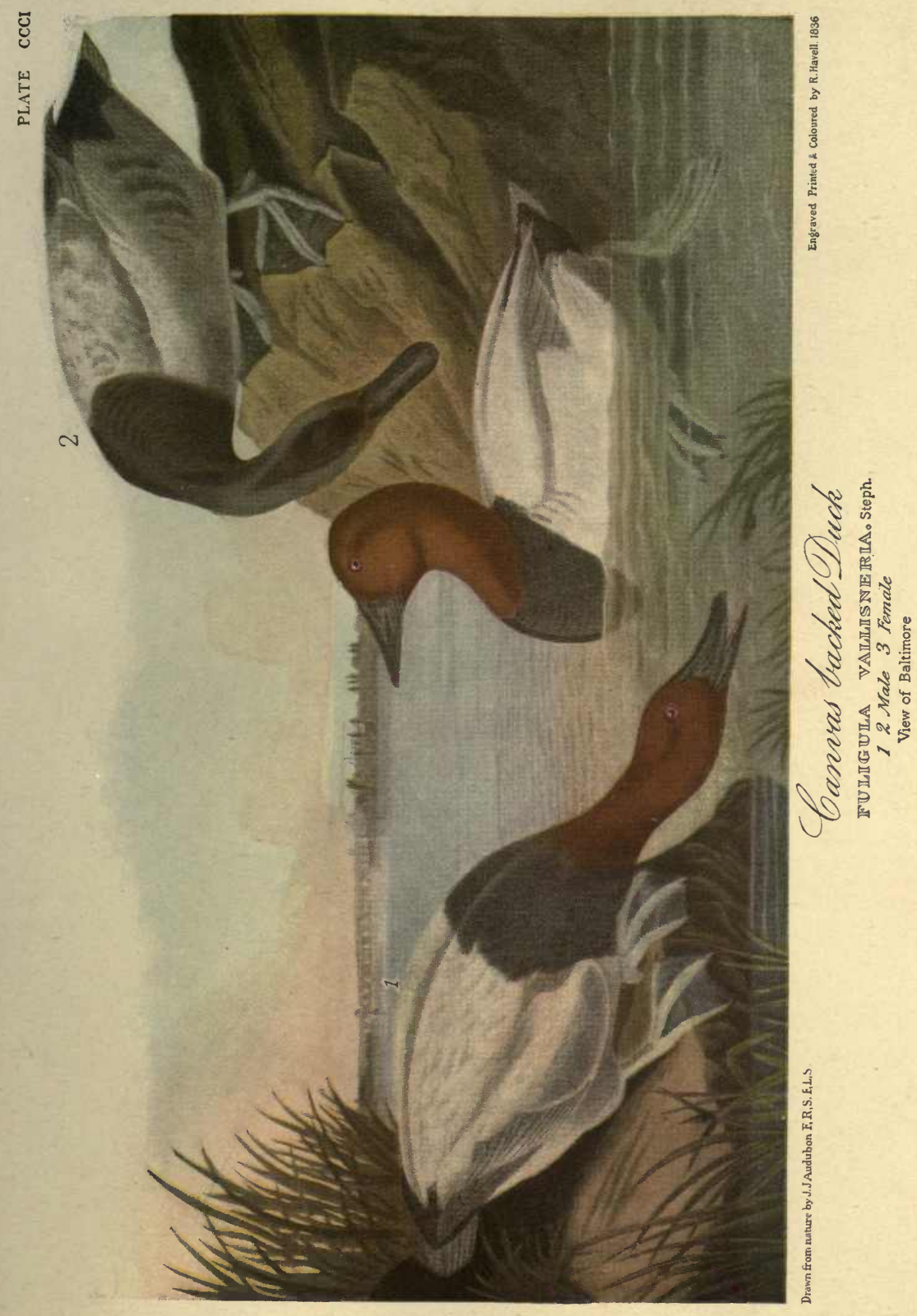



no dates, and, so far as known, the first date of the entire series was "1828," which was added to Plate 31 (the White-headed Eagle), but was erased from later issues. When Robert Havell, Junior, retouched Lizar's engraving of the Turkey Hen (No. II, Plate vi), he added the date "1829," but in a third or later edition the name was changed and the date removed. This same date appears also on the retouched Plate ii, of the Yellow-billed Cuckoo, and on that of the Purple Grackle or Crow Blackbird (Plate vii). A curious error crept into the first impressions of the former plate, which was mislabeled "Black-billed Cuckoo," a bird then recognized as quite distinct. ${ }^{16}$ Plates xxxi to lxxv (182829) were all dated in the first issue, and bore the names of both Havells; the legends are: "Engraved, Printed \& Coloured by R. Havell \& Son, London, 1828," and "Engraved by Robt. Havell, Jun ${ }^{\mathrm{r}}$. Printed \& Coloured by R. Havell Sen". London, 1828," or "1829" (British Museum copy), but when later printed by Robert, the younger, the dates were erased. All subsequent dating of the plates was somewhat irregular until 1834 (Plate ccii), but from that point to the end of the series, the year of issue was consistently added to each plate. Ornithologists are specially interested in the time of publication, since forty-seven new specific names occur on Audubon's large plates, and should date from them and not from the letterpress which followed.

To illustrate what has been said of successive editions of Audubon's plates, we shall give the legends of two or three of the most famous, taken from copies in

${ }^{16}$ In 1914 Dr. Samuel Henshaw showed me an impression of this suppressed plate, and also a large printed label, cut from a board backing, which bore within an ornamental border the title "Audubon's Birds of America-Engraved, printed, and colored by Lizars \&c. \&c." This suggests that Lizars may have issued the first two numbers, which he engraved, in portfolio. 
the British Museum and Boston Society of Natural History libraries or from detached plates obtained in London, in 1903:

Plate i (1st edit., Lizars; Brit. Mus.).-_"Great American Cock Male-Vulgo (Wild Turkey) Meleagris Gallopavo. Drawn by J. J. Audubon, M. W. S. Engraved by W. H. Lizars Edin'"."

Plate i (2nd or later edit., Havell; Boston Soc. Nat. Hist.)."Wild Turkey. Meleagris Gallopavo. Linn. Male American Cane. Miegia macrosperma. Drawn from nature by J. J. Audubon F, R, S. F, L, S. Engraved by W. H. Lizars Edin ${ }^{r}$. Retouched by R. Havell Jun ${ }^{r}$."

Plate vi (1st edit., Lizars; Brit. Mus.).- "Great American Hen \& Young, Vulgo, Female Wild Turkey-Meleagris Gallopavo. Drawn from Nature by John J. Audubon F.R.S.E. M.W.S. Engraved by W. H. Lizars Edinr."

Plate vi (2nd or later edit., Havell; detached plate).-The same with the exception of "F.L.S.," added to Audubon's name, and "Retouched by R. Havell. Junr. London, 1829."

Plate vi (3rd or later edit., Havell; Bost. Soc. Nat. Hist.)."Wild Turkey, Meleagris Gallopavo. Linn Female and Young." (Artist's name apparently cut off by binder.) "Engraved by W. H. Lizars. Retouched by R. Havell. Jun ${ }^{r}$."

Plate 31. (1st edit., Havell. Brit. Mus.).- "White-headed Eagle, male. Falco Leucocephalus. Fish Fulgo-Yellow mud Cat. Drawn from Nature \& Published by John J. Audubon, F.R.S.E., F.L.S., M.W.S. Engraved, Printed \& Coloured by R. Havell \& Son, London, 1828."

Plate xxxi (2nd or later edit., Havell; Bost. Soc. Nat. Hist). - "White-headed Eagle, Falco Leucocephalus. Linn, Male. Yellow Cat-fish. Drawn from Nature and Published by John J. Audubon. F,R,S. F,L,S. Engraved, Printed \& Coloured, by R. Havell." 


\section{AUDUBON'S GREATEST TRIUMPH 199}

Plates which were wholly the work of Lizars have naturally become extremely rare; they were evidently disregarded by Audubon when he recorded on July 2, 1827, that he had given Mr. Children a proof of his first number, which he called "the first in existence," and declared that the two guineas then received was the first money that had been returned to his hands. Lizars' initial number had actually been finished in the previous winter, and a copy of this is recorded as having been given to the daughter of Sir Walter Scott on the 9th of March, $182 \%$.

When Audubon had finally closed all his business affairs in Edinburgh and London, late in the summer of 1839, he returned to America, with the remaining members of his family, and settled in New York, where he purchased a house at Number 84. White Street, then in the uptown district.

An anonymous writer in the London Athenceum ${ }^{17}$ in giving a final review of Audubon's labors in 1839, paid this interesting tribute:

It seems but as yesterday that we were walking about with a transatlantic stranger, picturesque enough in his appearance and garb, to arrest the eye of every passing gazer; a tall stalwart man, with hair sufficiently long to qualify him to serve as a model to Gray's "Bard," and trousers ample almost as petticoats of "good Harmony cloth," so absorbed in the enthusiastic prosecution of his gigantic plan-a life's labouras to be heedless of the singularity of those meteoric locks, and those liberal nether garments. Some dozen of years, however, have elapsed since that day; the American Woodsman's hairlong since cut short-has grown white; his magnificent undertaking is completed, and he is now on the point of quitting England, to settle himself for the remainder of his days whether

${ }^{17}$ See Bibliography, No. 142. 
by the side of a bayou, in some forest clearing, or as an inhabitant of one of the American cities which have learned to know his value, report saith not.

We shake hands with the author, tendering him our hearty congratulations on the completion of a task almost as arduous as has ever been proposed to a literary man. . . .

The confidential simplicity of Mr. Audubon's own prefaces would make yet more personal leave-takings and farewells, on the critic's part, natural and graceful,-but it must suffice to say, that few have quitted England, carrying with them a larger portion of honest regard and sincere good wishes.

Possibly it was the same writer who gave this striking picture of Audubon in the pages of the same journal, thirty years later: ${ }^{18}$

We can remember when his portfolio excited delight in Edinburgh, London, and Paris, rivalling in smaller circles a new Waverley novel. The man also was not a man to be seen and forgotten, or passed on the pavement without glances of surprise and scrutiny. The tall and somewhat stooping form, the clothes not made by a West-end but by a Far West tailor, the steady, rapid, springing step, the long hair, the aquiline features, and the glowing angry eyes,-the expression of a handsome man conscious of ceasing to be young, and an air and manner which told you that whoever you might be he was John Audubon, will never be forgotten by anyone who knew or saw him.

We will add to this the musings of an anonymous American writer ${ }^{19}$ in the North American Review for the following year (1840):

It must have been with mingled and varied feelings that Audubon published his concluding volume. He was sure then

${ }^{18}$ See Bibliography, No. 152.

${ }^{10}$ W. B. O. Peabody; see Bibliography, No. 143. 


\section{AUDUBON'S GREATEST TRIUMPH 201 .}

that he had raised an imperishable monument to commemorate his own renown. All anxieties and fears which overshadowed his work in its beginning had passed away. The prophecies of kind but overprudent friends, who did not understand his selfsustaining energy, had proved untrue; the malicious hope of his enemies, for even the gentle lover of nature has enemies, had been disappointed; he had secured a commanding place in the respect and gratitude of men; he had secured a treasure of rich and glowing recollections, to warm his own heart in his declining years, and to kindle enthusiasm in his children's children....

On the other hand he had lost an employment which for years had kept all the powers of body and mind in healthy though intense exertion; whatever else he might do, the great work of his intellectual life was finished. . . His trumpet of victory at the result must have given an uncertain sound, partly exulting in his success, and partly lamenting that his great work was finished.

It has often been asked, how many complete sets of Audubon's folio of The Birds of America were distributed, and how many are in existence today. No definite answer can be given to either question. His final lists, appended to the last volume of his "Biographies" in 1839, and reproduced in Appendix III to the present work, gave the number of standing names as 161 (calling for 166 copies), of which 79 (with 84 copies) pertained to Europe, and 82 were American; inasmuch as 118 subscribers had dropped off, with incompleted sets on their hands, this brought the total number of original patrons at that time to 279 , and the number of copies which had been originally ordered to 284. On the other hand, the following advertisement, evidently from the hand of Audubon himself, appeared in The Athenceum, under date of "London, November 
1, 1837," and was reprinted in America a few weeks later: ${ }^{20}$

The number of perfect copies at present subscribed for does not exceed 190, of which upwards of 80 are subscribed for in America; and the expense of getting them up is so great, that not more than ten or fifteen copies, above the number subscribed for, will be prepared.

The Establishment necessary for its publication will be broken up when the last Number is coloured; and any applicacation for the Work must be made to the Author, 4, Wimpole - street, London; or Mr. R. Havell, Engraver, 77 Oxfordstreet, before the first of May next, as after that time no subscription can be received.

Assuming that Audubon's final published lists, calling for 166 copies, were correct, and that ten additional sets were prepared, this would bring the total original number known to have been complete to 176, which agrees with an estimate attributed to Victor Audubon, who once expressed the belief that "about 175 copies" were in existence, of which about 80 were in America. ${ }^{21}$ It is probable, however, that of the $\mathbf{1 1 8}$ persons who allowed their subscriptions to lapse, a number completed their sets from the residual stock, which must have been great, though the later plates would be the hardest to obtain; in this event the number of perfect sets of Audubon's Birds probably never exceeded 190 or 200.

${ }^{20}$ See Samuel N. Rhoads (Bibl. No. 231) The Auk, vol. xxxiii, p. 130 (1916); transcript of a clipping which apparently had been taken from a New York newspaper of January, 1838; the reading of the American notice is the same, excepting the statement that applications in this country should be made to "N. Berthoud, Esq., New York; Dr. George Parkman, Boston; Rev. Jno. Bachman, Charleston, S. C.; James Grimshaw, Esq., New Orleans, or W. G. Bakewell, Esq., Louisville." It is dated "New York, 11 Jan, 1838."

${ }^{21}$ Maria R. Audubon, Audubon and his Journals (Bibl. No. 86), vol. i, p. 71 . 
The proprietor of a well known Philadelphia bookshop ${ }^{22}$ has stated that during his experience as an antiquary, he has had personal knowledge of forty or fifty copies of the folio edition of Audubon's Birds in America, and he thought it probable that a single New England print dealer, in the course of twenty years, had broken up thirty or forty volumes for the purpose of selling the plates. This is not surprising, since from the sale of a single volume upwards of $\$ 1,500$ might be realized in this way, but no reputable dealer would now think of breaking up an unimpaired set.

Mr. Ruthven Deane, who has compiled a careful record of copies of The Birds of America known to exist in the United States, recorded in 1908 that he had ascertained the resting-place of seventy-five sets which, with few exceptions, were complete and in good condition. "A set in the library of the Mechanics-Mercantile Institute, San Francisco, California, which had been there for some thirty years, and another set in the San Francisco Art Association, presented in 1894 by Mr. Edward F. Searles, Methuen, Massachusetts, were both destroyed by the disastrous earthquake and fire which visited that city April 18, 1906." ${ }^{23}$

Audubon's own copy of his Birds, the plates of which werenaturally selected with the greatest care, was sold by Mrs. Audubon after the death of her last surviving son, in 1862, to John T. Johnson, of New York, for $\$ 1,200$; the subsequent history of these volumes has not been traced. Havell brought with him to America a copy, every plate of which is said to have been selected by himself, and it is undoubtedly one of the finest sets in existence. It passed from the family's possession to the

See Rhoads (Bibl. No. 231), loc. cit.

${ }^{23}$ Ruthven Deane (Bibl. No. 225), The $A u k$, vol. xxv, p. 401 (1908). 
hands of the publishers and booksellers, Messrs. C. S. Francis \& Company, of 554 Broadway, New York, who in $\mathbf{1 8 5 6}$ had charge of the sale of all of Audubon's works, ${ }^{24}$ and was later purchased by Dr. W. Gurdon Russell, of Hartford, Connecticut, who presented it to Trinity College, July 10, 1900. ${ }^{25}$

After recording the facts of the case, so far as they have been ascertained, the following extract from the minutes of a meeting of the New York Historical Society, held October 3,1865 , will be read with interest: ${ }^{26}$

The Librarian presented the following copy of a manuscript memorandum preserved in the first volume of Audubon's Ornithological Biography, formerly belonging to the late J. Prescott Hall, ${ }^{27}$ and now in possession of David G. Francis, Esq.:

${ }^{24}$ Eight in number, the aggregate cost of which was then $\$ 1,624$ : The Birds of America, with its letterpress, was offered at $\$ 1,000$; library, or octavo edition, with reduced plates, in $100 \mathrm{Parts,}$ at $\$ 100$; The Quadrupeds of North America, 2 vols., folio, with 3 vols. text, in $8 v 0 ., \$ 300$; text of the same, according to binding, from $\$ 31$ (paper) to $\$ 40$ (full Turkey mor.); Birds and Quadrupeds, library ed., 10 vols., 650 plates, $\$ 150$ to $\$ 160$, according to style; Synopsis of Birds of America, \$4; The Viviparous Quadrupeds of North America, 3 vols., text only, \$9. See Mrs. Horace St. John, Life of Audubon (Bibl. No. 71), in advertisement inserted in volume. These prices were similar to those that prevailed during the lifetime of the naturalist.

According to Mr. Ruthven Deane, Audubon's account books show that on January 8, 1840, a box was sent to Dr. George Parkman, of Boston, containing a set of The Birds of America, in full binding, at $\$ 1,075$; a set of the same, half bound, at $\$ 950$; and the "Biographies" at $\$ 27$.

The highest recorded price of The Birds of America is believed to be $\$ 4,350$, which the Kemble set brought at auction at Philadelphia, in 1906 (See Prices Current for 1906); the highest price paid for a single plate, that of the Turkey Cock (Plate No. 1) upwards of $\$ 140$; and the highest price asked for the octavo edition of the Birds (in original parts), $\$ 750$. The Quadrupeds in 2 vols., original folio, now brings about $\$ 500$.

${ }^{25}$ Ruthven Deane (Bibl. No. 225), loc. cit.

${ }^{26}$ For a copy of this minute, the substance of which was published in 1877 (See Bibliography, No. 179), I am indebted to the present librarian, Mr. Kelby.

${ }^{n}$ Jonathan Prescott Hall (1796-1862), eminent lawyer and jurist, was at one time district attorney for the southern district of New York, and author of Reports of Cases in the Supreme Court of City of New York- 


\section{AUDUBON'S GREATEST TRIUMPH 205}

"This work is presented to J. Prescott Hall by his poor Friend and sincerely attached servant

"New York April 4, 1844."

John J. Audubon"

"Mr Audubon told me in the year 184 - that he did not sell more than 40 copies of his great work in England, Ireland, Scotland, and France, of which Louis Phillippe took 10.

"The following received their copies but never paid for them: George IV., Dutchess of Clarence, Marquis of Londonderry, Princess of Hesse Homburg.

"An Irish lord whose name he would not give, took two copies and paid for neither. Rothschild paid for his copy, but with great reluctance.

"He further said that he sold 75 copies in America, 26 in New York and 24 in Boston; that the work cost him $£ 27,000$ and that he lost $\$ 25,000$ by it.

"He said that Louis Phillippe offerred to subscribe for 100 copies if he would publish the work in Paris. This he found could not be done, as it would have required 40 years to finish it as things were then in Paris. Of this conversation I made a memorandum at the time which I read over to Mr. Audubon and he pronounced it correct. "J. Prescott Hall."

As regards the subscription of Rothschild the following account of his interview with the famous banker has been recorded by Audubon himself. ${ }^{28}$ The naturalist, it appears, received a letter to Baron Rothschild from the American banking-house of Prime, Ward \& King, and presented it in the summer of 1834. The banker was

1828-29 (2 vols., New York, 1831-33). Mr. Hall was a subscriber to the octavo editions of Audubon's Birds and Quadrupeds.

${ }^{28}$ According to Lucy B. Audubon, ed., The Life of John James Audubon (Bibl. No. 73), from which we have drawn numerous extracts from his journals; see p. 381, under date of May 12,1834 . 
not in when Audubon and his son, Victor, called upon him, but "soon a corpulent man appeared, hitching up his trousers, and a face red with the exertion of walking, and without noticing any one present, dropped his fat body into a comfortable chair, as if caring for no one else in this wide world but himself." When Audubon presented his credentials, the banker asked: "Is this a letter of business, or is it a mere letter of introduction?" " As Audubon had not read the letter, he was obliged to answer rather awkwardly that he could not tell. "The banker then opened the letter, read it with the manner of one who was looking only at the temporal side of things, and after reading it said, 'This is only a letter of introduction, and I expect from its contents that you are the publisher of some book or other and need my subscription." Audubon continues:

Had a man the size of a mountain spoken to me in that arrogant style in America I should have indignantly resented it; but where $I$ then was it seemed best to swallow and digest it as well as I could. So in reply . . . I said I should be honored by his subscription to the "Birds of America." "Sir," he said, "I never sign my name to any subscription list, but you may send in your work and I will pay for a copy of it. Gentlemen, I am busy, I wish you good morning." We were busy men, too, and so bowing respectfully, we retired, pretty well satisfied with the small slice of his opulence which our labor was likely to obtain.

A few days afterwards $I$ sent the first volume of my work half bound, and all the numbers besides, then published. On

- seeing them we were told that he ordered the bearer to take them to his house, which was done directly. Number after number was sent and delivered to the Baron, and after eight or ten months my son made out his account and sent it by Mr. Havell, my engraver, to his banking-house. The Baron looked at it with amazement, and cried out, "What, a hundred 


\section{AUDUBON'S GREATEST TRIUMPH 207}

pounds for birds! Why, sir, I will give you five pounds, and not a farthing more!" Representations were made to him of the magnificence and expense of the work, and how pleased his Baroness and wealthy children would be to have a copy; but the great financier was unrelenting. The copy of the work was actually sent back to Mr. Havell's shop, and as I found that instituting legal proceedings against him would cost more than it would come to, I kept the work, and afterwards sold it to a man with less money but a nobler heart, What a distance there is between two such men as Baron Rothschild of London and the merchant of Savannah! 


\section{CHAPTER XXXIII}

\section{NEW ENTERPRISES AND LIFE AT “MINNIE'S LAND"}

Settlement in New York-The Birds in miniature, and work on the Quadrupeds-Marriage of Victor Audubon-Coöperation of Bachman in the Quadrupeds secured-Prospectuses-History of the octavo edition of the Birds-Baird's enthusiasm and efficient aid-Parkman's wren-Baird's visit to Audubon in New York-"Look out for Martens!" and wildcats-New home on the Hudson-Godwin's pilgrimage to "Minnie's Land" in 1842.

After thirteen years of unmitigated labor, Audubon could have basked in a fame already secure, and could have enjoyed, for a time at least, a leisure handsomely earned. But no sooner had he settled in New York than he entered upon two formidable tasks: one of these was the complete revision of his Birds of America, to be issued with its text in "miniature," as its reduced form was sometimes described; the other, which he did not live to see brought to completion, was an elaborate work on the Quadrupeds of North America, eventually carried forward in collaboration with the Reverend John Bachman.

In his confident and characteristic manner, Audubon at once issued a "Prospectus" of both these undertakings. The more cautious Bachman, in writing on September 13, 1839, to congratulate him upon their safe return, "in spite of storms, calms, and hurricane," said:

I am glad that you are about to do something with regard to the "Small Edition of Birds." But are you not too fast in issuing your prospectus of The Birds and Quadrupeds, with- 
out having numbers of both works, by which the public can judge of their merits? My idea, in regard to the latter, is that you should carefully get up, in your best style, a volume about the size of "Holbrook's Reptiles." This would enable you to decide on the terms of the book, I think that two thousand subscribers at $\$ 1.00$ for each number, might be obtained. But it must be no half-way aff air.

The animals have never been carefully described, and you will find difficulties at every step. Books cannot aid you much. Long journeys will have to be undertaken. Several species remain to be added and their habits ascertained. The drawings you can easily make, if you can procure the specimens. I wish I had you here, if only for two days. I think that I have studied the subject more than you have. You will be bothered with the Wolves and the Foxes, to begin with. I have two new species of Bats and Shrews to add. The Western Deer are no joke, and the ever varying Squirrels seem sent by Satan himself, to puzzle the Naturalists.

It is evident from this letter that Audubon was then intending to proceed with the work on the Quadrupeds alone and that Bachman's active coöperation was secured later. On September 15, shortly after his return to America, he wrote to Thomas M. Brewer on this subject as follows: ${ }^{1}$

Now that I am about to commence the publication of the Quadrupeds of North America, I will expect your assistance in the procuring for me of all such subjects as may easily be obtained around you. John Bachman is about to give the whole of his collections and his notes to me; and as I intend to open a pretty general correspondence in different parts of the Union, I trust to be enabled to proceed roundly on this fresh undertaking.

${ }^{1}$ See Thomas M. Brewer (Bibl. No. 79), Harper's New Monthly Magazine, vol. lxi, p. 666 (1880). 
Victor Gifford Audubon, who had preceded his father to America early in 1839, was married in that year to Mary Eliza, second daughter of John and Harriet Bachman. 'This double union of the two naturalists' families called forth mutual congratulations, but Bachman, who was inconsolable at the departure of his children, preferred to talk of birds: "By that time," said he, "four or five numbers [of the "Small Edition of the Birds'] are published, you may turn over the work to your sons; but, till then, you should carefully review every page and plate. The next thing will be to get subscribers. This would be purgatory to me; but it is necessary to success. While drumming up subscribers, you may obtain specimens for the Quadrupeds." When writing again January 13, 1840, Bachman, whose cooperation in the proposed work had been sought, continued:

The descriptions in the "Small Edition of Birds" will have to be abridged-your "roorthy friend" and other humbugs may be left out to advantage. I am not at all surprised at your success at getting subscribers; but let me say, cities are not the only places to obtain them. Birds sing and nestle among the groves of the country - The planters and farmers are the men to become subscribers. An intelligent planter from the up country said, a few days ago, that if the right person would thoroughly canvass the whole State of South Carolina, he would insure three hundred subscribers to the "Small Work." Old Jostle would be the man, and when his legs failed, the Young Jostle should go forward. Get the Editors to notice your work-this is a puffing world-from the porpoise to the steamboat.

When we meet, we shall talk about the partnership in the quadrupeds. I am willing to have my name stand with yours, if it will help the sale of the book. The expenses and the profits 

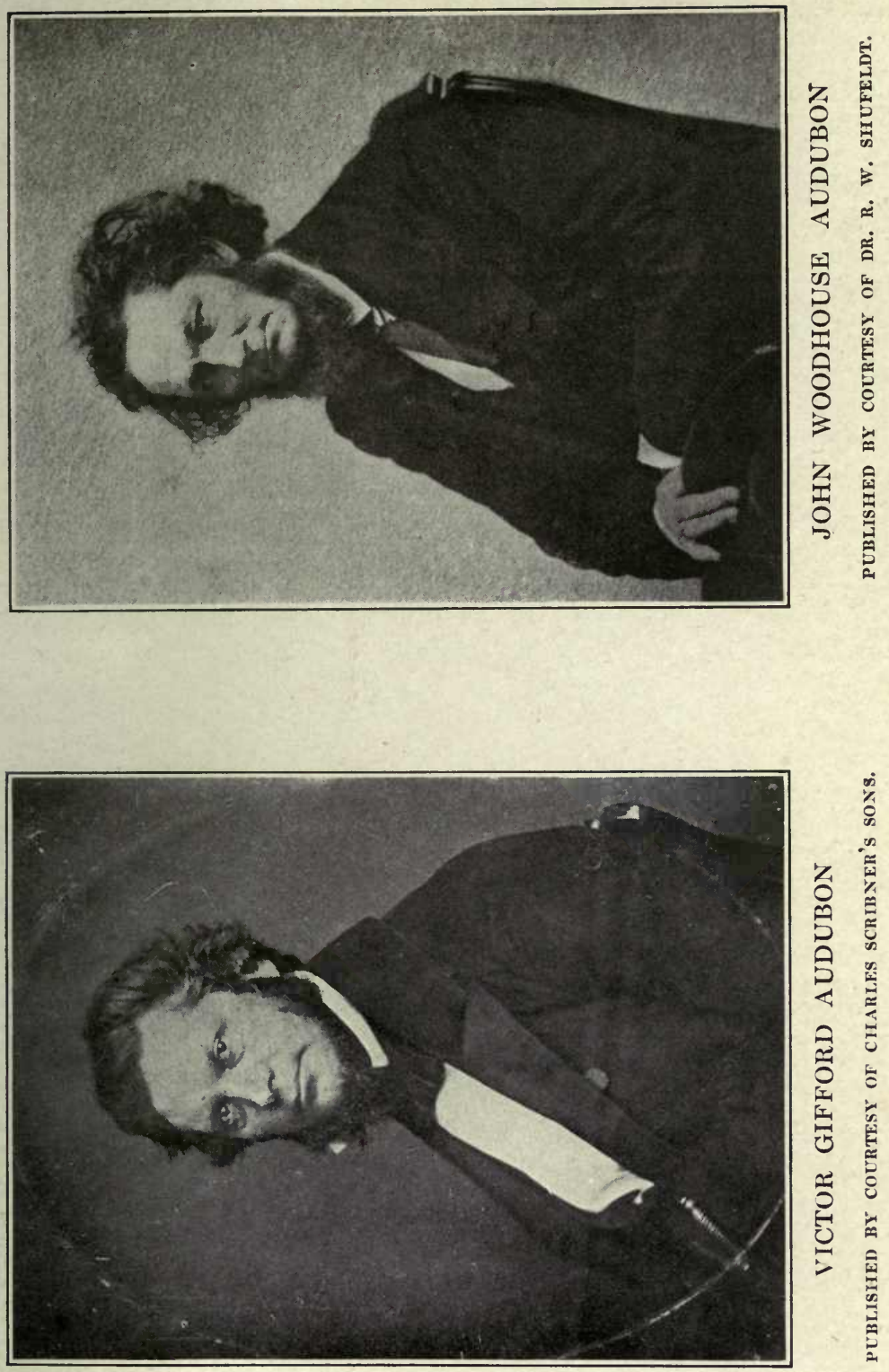

shall be yours or the boys'. I am anxious to do something for the benefit of Victor and John, in addition to the treasures I have given them-and this is all I can do. . . Employ yourself now in drawing every quadruped you can lay your hands upon. If you can find me a live Ermine, buy it in New York. I must once more examine and study its change of pilage.

Don't flatter yourself that the quadrupeds will be child's play. I have studied them all my life. We have much, both in Europe and America, to learn on this subject. The skulls and the teeth must be studied, and color is as variable as the wind; down, down in the earth they grovel, while we, in digging and studying, may grow old and cross. Our work must be thorough. I would as soon stick my name to a forged Bank Note as to a mess of soupmaigre.

The "Prospectus" of Audubon's "miniature" edition of the Birds was as follows: ${ }^{2}$

${ }^{2}$ From last page of paper covers, in which parts of the work were originally issued.

Below are the following notices:

"Persons desirous of subscribing to the above work are respectfully requested to apply to $J$. J.Audubon, 86 White street, Henderson Greene, 377 Broadway, or W. A. Colman, Broadway, New York; to J. B. Chevalier, 70 Dock street, or Orrin Rogers, 67 South Second street, Philadelphia; C. C. Little or James Brown, Boston; J. P. Beile, or Geo. Oates, Charleston, S. C.; Gideon B. Smith, Baltimore; David Ridgely, Annapolis, Md.; J. S. Kellogg \& Co., Mobile, Ala."

"S. H. Stevenson, Travelling Agent for Kentucky and Virginia; and William A. Pierce for Pennsylvania."

This first octavo edition of Audubon's Birds was issued by J. J. Audubon, and J. B. Chevalier, Philadelphia, in 100 parts, of five plates each, to be bound in 7 volumes, 1840-44. Complete sets in parts are now very rare; previous to 1907 a set is said to have been sold for $\$ 500$; in 1914 one was offered in Philadelphia for $\$ 750$. The introduction to No 1 , is dated "New York, Nov. 1839," and the fifteenth number, beginning volume ii, "N. Y., Aug., 1840." The first five volumes (1840-42) were issued with the coöperation of J. B. Chevalier, lithographer, 70 Dock Street, Philadelphia, but, according to Mr. Ruthven Deane, he was an agent who received a commission on sales, and, for a time, a share in the profits, but not a co-publisher with Audubon; it is also stated that when misfortune visited Chevalier in later life, he was cared for by Audubon or his sons, up to the time of his death. For fuller details, see Bibliography, No. 4. 
To those who have not seen any portion of Mr. Audubon's Original Drawings, it may be proper to state, that their superiority consists in the accuracy as to proportion and outline, and the variety and truth of the attitudes and positions of the figures, resulting from peculiar means discovered and employed by him, and his attentive examination of the objects portrayed, during a long series of years. Mr. Audubon has not contented himself with single profile views, but in many instances has grouped his figures, so as to represent the originals in their natural avocations, and has placed them on branches of trees decorated with foliage, blossoms and fruits, or amidst plants of numerous species-some are seen pursuing their prey in the air, searching for food amongst the leaves and herbage, sitting on their nests, or feeding their young; whilst others, of a different nature, swim, wade, or glide in or over their allotted element. The insects, reptiles and fishes that form the food of some of the birds, have now and then been introduced in the drawings. In nearly every instance where a difference of plumage exists between the sexes, both male and female have been represented, and the extraordinary changes which some species undergo in their progress from youth to maturity, have been depicted.

The plants are all copied from nature, and as many are remarkable for their beauty, their usefulness, or their rarity, the Botanist cannot fail to look upon them with delight.

The particulars of the plan of the work can be reduced to the following heads:

1. The size of the work is royal octavo, the paper being of the finest quality.

2. The Plates representing the Birds are correctly reduced from the original drawings, and are coloured in the most careful manner.

3. The work will appear in numbers, on the first and fifteenth of every month.

4. Each number will consist of Five Plates, accompanied with full descriptions of the habits and localities of the birds, their anatomy and digestive organs, (with occasionally wood 


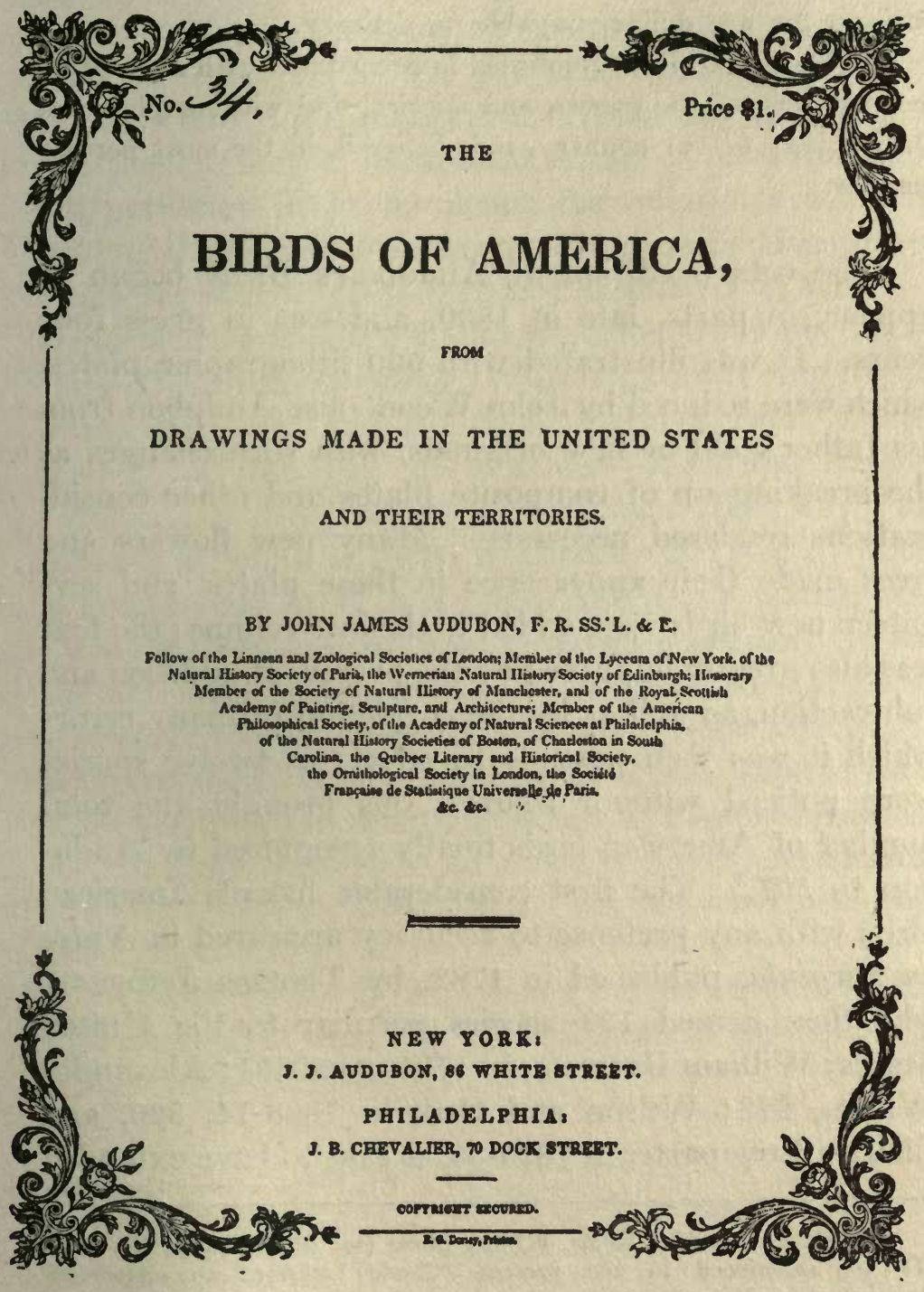

TITLE PAGE OF PAPER COVERS IN WHICH PARTS OF THE FIRST AMERICAN (OCTAVO) EDITION OF "THE BIRDS. OF AMERICA" WERE ORIGINALLY ISSUED. 
cuts representing the latter,) and will be furnished to subscribers for one dollar, payable on delivery.

5. The work will be published in accordance with a scientific arrangement of the genera and species, and will complete the Ornithology of our country, it is believed, in the most perfect manner.

The octavo edition of Audubon's Birds began to appear, in parts, late in 1839, and was in press four years. It was illustrated with 500 lithographic plates, which were reduced by John Woodhouse Audubon from his father's old or new originals, with such changes as the breaking up of composite plates and other considerations rendered necessary. Many new flowers and trees made their appearance in these plates, and seventeen new birds were added to the last volume; the text was also greatly improved by the process of addition and subtraction, as well as by the correction of many errors which it was then possible to effect: as twelve species were noticed without figures, this brought the total number of American birds finally recognized by Audubon to $507 .^{3}$ The first considerable list of American birds with any pretense to accuracy appeared in Notes on Virginia, published in 1782, by Thomas Jefferson, who then named 109 species peculiar to the United States; William Bartram, in 1791, gave 191; Alexander Wilson, 278; Wilson and Ord, in 1808-14, 320, and Charles Bonaparte, in 1825-33, is said to have extended

'Of these, according to Mr. Witmer Stone (see Bibliography, No. 221), 474 are sanctioned in the present "Check List" of the American Ornithologists' Union; seventeen have proved to be identical with others; ten are extra-limital; two are hybrids; and five have never been found since; of Audubon's suppressed species, two have been resuscitated. Audubon is thought to have been personally acquainted with 385 American species, others being known to him only through specimens sent by collectors, or discovered in museums. 
the number to 382 . The present number of North American birds, omitting sub-species, admitted to the third revised edition of the "Check-List," prepared by a Committee of the American Ornithologists' Union and published in New York in 1910, is 768. To this is added a hypothetical list of 26 names, the validity of which is still in doubt; these embrace Townsend's Bunting Spiza townsendi (Audubon); Carbonated WarblerDendroica carbonata (Audubon), Blue Mountain Warbler-Dendroica montana (Wilson), known only in the works of Wilson and Audubon; the mysterious Smallheaded "Flycatcher," or Warbler-Musicapa minuta (Wilson) or Wilsonia (?) microcephala (Ridgway), an account of which is given in Chapter XIV and which is known only in Wilson's and Audubon's works; and Cuvier's Regulus-Regulus cuvieri (Audubon), which has never been seen beyond the covers of The Birds of America, and its descriptive text: "I shot this bird," said Audubon, "on my father-in-law's plantation of Fatland Ford, on the Skuylkill River in Pennsylvania, on the 8th June 1812, while on a visit to my honoured relative Mr. William Bakewell ... I have not seen another since."

Audubon was soon canvassing the principal cities for this work, with what success is shown by the following letter ${ }^{4}$ to his family:

\section{Audubon to his Family}

Baltimore, Feb. 21. 1840.

11 o'clock at night.

MY DEAR FRIENDS

So far so good, but alas! I am now out of numbers to deliver to my subscribers here. Here! where I expected to pro-

'First published by Ruthven Deane (Bibl. No. 48b), The Auk, vol. xxv (1908). 
cure a good number more. This list is composed of excellent men and all good pay. I have in my pocket upwards of one hundred names, whom I am assured are likely to subscribe. Therefor I will not leave Baltimore for some days to come at least. I forward a copy of this list to Chevalier by the same mail and yet you may as well inquire if he has received it. More numbers I must have as soon as possible as all my subscribers here are anxious about receiving their copies, unfortunately I had only 90 No. 2. I look upon this list as a capital list. I have sent Mr. Ridgley of Annapolis a No. 1 and a prospectus, and expect some names tomorrow evening from that quarter.

I will remit money to Phila. and let you know how much as soon as I can. The box has arrived here safely and tomorrow or Monday I will deliver Biographies \&c. D. Potter is very ill and poor and yet I hope to get his note before I leave here.

I received a note from dear Jonny dated at Norfolk, all well and going on. I expect they are at this moment at John Bachman's. I am fatigued beyond description and had the misfortune last evening of skinning my shin bones, they bled profusely however, and I hope will soon get well, though feel rather sore at this very moment, but I will take care of them.

The amount of attention which $I$ have received here is quite bewildering, the very streets resound with my name, and I feel quite alarmed and queer, as I trudge along. Mess. Meckle, Oldfield and the Brune family have all assisted me in the most kind and brotherly manner, indeed I may say that my success is mostly derived from these excellent persons.

I have written to Mr. Mifflins. I feel that Theodore Anderson will not live long. Mr. Morris has not yet returned from Annapolis. See that the notice in the Baltimore Patriot which I sent you yesterday is inserted in the Albion, the Nerw York Gazette and if possible in the Courrier and Enquirer.

I have sent one to Chevalier and another to Dr. Parkman. I ought to have at this moment 300 copies Nos. 1, 2, 3, 4, for Washington City and really I think it would be better to stop the publication of the work for one month to effect this. There- 
for loose no time in urging Mr. Bowen (write to him) and Chevalier also on this all important subject.

If ever I was in want of assistance it is at this moment and you my dear Victor must be on the alert and second my endeavors to render you all Happy! I would be delighted to have a few lines from Mamma and Eliza at the end of your next letter, which I hope to receive in immediate answer to this, Here. I have marked all your items in your last letter. Call from time to time at the Mercantile Library. I am glad you have remitted to the Rathbone's. Do write to Mr. Hoppenstall and see the daughter of Capt. Brittan. I was invited last evening to a great ball, and should have gone had not my accident of shin bones prevented me. I am told that I would have had some 20 names there.

Recollect that our agents name is Gideon B. Smith and a most worthy man he is, highly recommended by Robert Gilmor and others.

[No signature]

To the gratification of Audubon and his friends, the octavo edition of his Birds of America was an immediate and great success. Only 300 copies of the plates of the first number, which was ready on December 3, 1839, were printed, but in little more than a month 300 more were demanded, and the number of plates required rose steadily until January 9,1841 , when it stood at 1,475 copies. ${ }^{5}$ The total number of subscribers given

"See "Original Account Book of J. J. Audubon" (Bibl. No. 223), The Nation, vol. lxxxiv, from which the following data regarding issues and sales of this work are drawn. The total edition of the plates for No. 2 was 1,345 , and of No. $3,1,339$. No. 11 of the plates was the first to run to 1,000 copies in the first printing, and this issue was continued to No. 50 , inclusive, excepting Nos. $3,28,29$, and 30 , of which 1,500 seem to have been printed; the plates of these numbers were done at the lithographic establishment of Endicotts, New York, all others being the work of J. T. Bowen, Philadelphia. When subscriptions began to fall off with No. 51, the edition was reduced to 1,150 , and again with No. 57, to 1,050, which remained constant to No. 84, or as far as this record goes. Of the text, printed by E. G. Dorsey, 1,200 copies formed the first edition of No. 1, 
in Audubon's published lists was 1,198, of which 198 are credited to Boston, 164 to Baltimore, 141 to New York, sixty-five to Philadelphia, and forty-three to foreign countries, ten of which went to England; Mr. George Oates of Charleston subscribed for seven copies. Such a reception for an expensive work on natural history was unprecedented in the United States, and has had few parallels in any country.

At the very beginning of this new undertaking, the hand of disease and bereavement rested heavily on the Audubon and Bachman families; they were obliged to see first one and then another of their daughters swept by the same terrible malady, tuberculosis, to an early grave. Mrs. John Woodhouse Audubon died at her old home in Charleston, whither she had gone for the benefit of her health in the previous winter, on September 23, 1840, at the age of twenty-three; and Mrs. Victor Audubon, after a long sojourn in Cuba, and shortly after returning to her home in New York, died there on May 25, 1841, at the age of twenty-two. Audubon was very fond of his daughters-in-law, and his "beloved Rosy," as Victor's wife was familiarly called, is said to have been a particular favorite and the life of his family circle. If work at this time brought no pleasure, it at least afforded him relief from painful thoughts.

In June, 1840, a boy who lived in Carlisle, Pennsylvania, mustered up courage to write to the naturalist and give him an account of a new bird, the Yellowbellied Flycatcher, which he and his brother had dis-

1,000 copies that of No. 2, and of successive numbers to No. 23. With No. 24, the edition was increased to 2,000, and in February, 1841, the earlier numbers were reprinted, thus forming a second edition of these parts, and affording a chance for correction of errors. (See Audubon's letter quoted above.) 
covered, under the very noses, as it were, of all the ornithologists in America. With that fine sense of modesty which characterized the man in after life, for his name was Spencer Fullerton Baird, he wrote: ${ }^{6}$ "You see Sir that I have taken (after much hesitation) the liberty of writing you. I am but a boy, and very inexperienced, as you no doubt will observe from my description of the Flycatcher."

Audubon, who had just returned from the sick-bed of his daughter-in-law, replied promptly as follows:

\section{Audubon to Spencer Fullerton Baird}

DeAR SIR,

NEw York, June 13, 1840.

On my return home from Charleston S. C. yesterday, I found your kind favor of the 4th inst. in which you have the goodness to inform me that you have discovered a new species of fly-catcher, and which, if the bird corresponds to your description, is, indeed, likely to prove itself hitherto undescribed, for although you speak of yourself as being a youth, your style and the descriptions you have sent me prove that an old head may from time to time be found on young shoulders!

I wish you would send me one of the stuffed specimens as well as the one preserved in spirits, and wish you also to rest assured that if the little Muscicapa stands as a nondescript that I shall feel pleased to name it after your friend.

I have never seen a male of the Cape May warbler with the upper part of the head pure black. Have you compared the Regulus with the description of Regulus Curieri? Could you not send me your bird to look at? Being on the eve of publishing the Quadrupeds of our Country, I have thought that you might have it in your power to procure several of the

- See Ruthven Deane (Bibl. Nos. 47 and 49-51), The Auk, rols. xxi, xxiii, and xxiv (1904-7), Passim; and William H. Dall, Spencer Fullerton Baird, a Biography (Bibl. No. 52) (1915); to these admirable accounts I am indebted for such abstracts of this correspondence as are here reproduced. 
smaller species for me, and thereby assist me considerably. Please write to me again soon, as I must resume my travels in 8 or 10 days. Have you seen a copy of the small edition of The Birds of America which I am now publishing? Believe me, dear sir,

With good wishes, your obt. sert.,

\section{JoHN J. AUduBon}

Thus began a correspondence between the youth of fifteen and the veteran of fifty-five, which led to an intimate friendship that lasted during Audubon's active career, and was an undoubted stimulus to young Baird, whose talents, enthusiasm and industry were quickly appreciated by the older naturalist. Baird answered Audubon's letter on June 20, and proffered his services in collecting mammals, saying that while they were more difficult to find than birds, he hoped "by increased exertion to make up the difference"; he also added: "I have seen some numbers of your work now publishing, and admire them very much. I have no doubt that it will do more to spread a love of Natural history, than any work ever published. For my part I read the description of birds and the episodes in your Ornithological Biography with the same motive of pleasure as I used to read a favorite novel." In Audubon's immediate reply of the 22nd, he said:

It is impossible at present for me to give you any precise idea of the work on our quadrupeds which $I$ have in contemplation to publish, any further than to say to you, that it is my intention, as well as that of my friend, the Rev ${ }^{\mathrm{d}} \mathrm{John}$ Bachman, of Charleston, S. C., assisted by several others of our best naturalists, to issue a work on the Mammalia of North America worthy of the naturalist's attention, both at home and abroad.-Through our joint efforts, and assisted as we hope and trust to be, by numerous friends and acquaintances in 
different portions of our Wide Union, we expect to collect, not only new species, but much of valuable matter connected with their geographical range, and particular habits. For instance, in your assistance in this department as well as in ornithology, you may be able to send us valuable intelligence respecting the Shrews, Mice, Rats, Squirrels, etc., found in your immediate vicinity \&c.- -and by saving and forwarding specimens to us, be able also, in all probability, to place into our hands, objects never before known to the World of Science. Whatever information we thus receive is sacredly published under the name of the friend from whom we receive the information, etc. I have sent you the Zoological report of Docr. De Kay. His Corvus cocolotle [cacolotl] is really our Raven. Supposed by some inexperienced European naturalists to be distinct from the Raven of Europe, which, however, is a gross error. $^{7}$. . .

The thrush which you have described, and which you kindly offer to send me, may be new, but perhaps you are not acquainted with the Turdus Nanus of my work, to which it appears, if not the same, probably a new variety! Nous verrons.....

Please to collect all the Shrews, Mice, (field or wood), rats, bats, Squirrels, etc., and put them in a jar in common Rum, not whiskey, brandy or alcohol. All of the latter spirits are sure to injure the subjects.

Audubon, who was now "killing two birds with one stone"-collecting subscribers for one work and mammals for another, had found a strong and willing helper in the young naturalist of Carlisle. On December 10 of the same year Baird wrote that he had discovered another Flycatcher, as well as a small Woodpecker, which was apparently new, and had shot a "Bay Lynx or Wild Cat a mile \& a quarter from Carlisle; the cat ... was $21 / 2$ feet long \& weighed $121 / 2$ pounds. . . . It was a

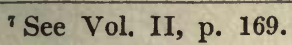


source of great regret," said Baird, "that I was not able to meet you in Philadelphia when I was there during the latter part of September. I saw Mr. Chevalier ${ }^{8}$ several times, and found him a very agreeable gentleman." Audubon replied to this letter on Christmas Day, as follows:

\section{Audubon to Spencer Fullerton Baird}

New YoRK, December 25, 1840.

MY DEAR SIR,

On my return yesterday from a tour of a month, I found your kind favor of the 10th inst. at my house. I regret exceedingly that you and I should not have met at Philadelphia, as I feel sure by the style and contents of your letters to me that you are fond of the study of natural objects, as much as I am.

I have no doubt that your journey during the last summer and autumn was a pleasing one to you, as I can well conceive from the fresh recollections of my many rambles.

You would oblige me much by sending me (through Mr. Chevelier) the Muscicapa you obtained Oct. 12th, and also the small woodpecker "with the very broad bill" I am anxious to see those birds, and will take especial care of them, and also return them to you, free of all expense.

I cannot at this moment return to the specimens you have already sent me, but in my next letter, I will assure you of the names of the subjects. I wish I could see your Bay Lynx, as I feel somewhat confident that we have more than two species within our limits.

Your anecdote connected with the sagacity of the Weasel is quite pleasing to me, and will appear in my biographies of quadrupeds bye and bye. I cannot, as yet, give you any estimate of my work on the Quadrupeds of our Country but will do so as soon as possible. With my best wishes, for your health

${ }^{8}$ See Note, Vol. II, p. 211. 
and prosperity, I pray you to consider me as your friend and obt. servant,

John J. Audubon.

In the following letter by William Yarrell, ${ }^{9}$ English naturalist and sportsman, are interesting references to Audubon's smaller edition of The Birds of America as well as to the writer's History of British Birds, which later became the standard work on the ornithology of Great Britain:

\section{William Yarrell to Audubon}

[Addressed] J. J. Auduвon Esq ${ }^{\mathrm{r}}$

No. 86 White Street

New York.

[Superscribed by Audubon] March 10. 1841.

\section{[English postmark] D \\ Paid \\ 4. MR 4 \\ 1841}

My dear Sir,

Your letter, and also that of your son, are now-before me, both received so long ago as the middle of last year-how time flies with those who are fully occupied-I reproach myself for having allowed them to remain so long unansweredand hope my numerous avocations, which absorb my whole time, will be admitted as my excuse. I see $\mathbf{M}^{\mathrm{r}}$. B. Phillips every now and then, we meet only to talk about you-I have received from his hands the first 17 Nos of your smaller American Birds and like them much - as I could not afford to have the large

- William Yarrell (1784-1856) was the author of A History of British Fishes (1835-36), and $A$ History of British Birds (1839-43) in three volumes; the latter has passed through several editions, the fourth and best being by Alfred Newton in four volumes (1871-85). For the favor of reproducing this letter, and another by Yarrell given in Chapter XXXIV, I am indebted to Mr. Ruthven Deane. 


\section{AUDUBON, THE NATURALIST}

work I make myself content with the small one, and shall be happy to receive the continuation-pray tell me to whom shall I make payment for them, shall it be to $\mathbf{M}^{\mathbf{r}}$. Phillips if so, let me or him know, and it shall be done immediately-I am quite of your opinion that there would be some sale for it here-if it was advertised and made known, but a commission of 10 . p cent will not tempt any London Bookseller who is sufficiently known and influential to be of any service to you-I exhibited my numbers at the meetings of the Linnean and Zoological Socities and gave the loose plates between them to lay on the table, but without the name of a London Bookseller on the cover no one knows where to get the work if Desirous of buying it.

I will now answer your inquiries for English Friends. Earl Derby remains much the same-very well in health, but deprived of the use of one side entirely, limbs as well as bodyunable to attend to other things, he appears to devote himself almost entirely to Zoology-Thomson his Superintendent of the Aviary is at this time in London buying some new or rare pheasants lately arrived here from China-and will have a valuable addition to the stock to take back with him-Lord Derby came to London by the Rail Road last March (1840) and Thomson tells me, his Lordship means to come up again this Spring. The Prince of Musignano now P. of Canino I hear of by report from others-He is quite well, continually publishing, and we hear that he means to visit London in the course of the present year- of $\mathrm{M}^{\mathrm{r}}$. Lear we hear the most satisfactory accounts-generally through $\mathbf{M}^{\mathbf{r}}$. Hullmandill-he is greatly improved in health and finances-a favorite with every body, patronized by all who go there-and he too, we hear, means to visit England in the course of the present year. Mr. Gould returned safe to England in August last, after an absence of two years and 8 months - Two years of the time were passed on Van Diemans land and various parts of New Holland - he did not go to New Zealand-He has brought home a very large collection of Birds, with, in many cases, the eggs and nests-He has commenced the publication of the Birds on the 
same scale as his Birds of Europe, but improved in execution -two parts are out: it is to be published every three months. I sent off a letter this day to your Edinburgh friend $\mathrm{M}^{\mathrm{r}}$. MacGillivray - he is a candidate for the Professorship of Natural History in the Marischall College of Aberdeen and wrote to ask me for a testimonial of recommendation-this was the object of my letter to him.-My second volume of the British Birds will be complete in July next, I will send it to you in one lump. Pray remember me to your good lady and thank your son Victoire for me for his letter. I hope you are all well, and with best wishes for a continuance to you of all that is good-I remain very sincerely yours

\section{J. J. Audubon Esq ${ }^{\mathrm{r}}$}

Wm. YARRELL.

\section{New York-}

Spencer Baird and his brother, William, were soon able to announce another discovery, now well known the country over as the Least Flycatcher, and in some sections by the onomatopoic name of Chebec. In referring to it in his letter of June 21, 1841, Baird wrote:

There is one flycatcher respecting which we are in doubt, and which was very abundant this spring. It is the one we had considered M. Pusilla but a thorough examination of the Biography, has thrown doubt on this supposition, it agrees pretty well with the M. Acadica of Nuttall, but not with the Acadica, of the Synopsis. I will send you one as soon as possible, as there is no set of Plates in Carlisle to which we might refer.

In conclusion Baird added: "May we not expect to see you in Carlisle before a great while? It would give us very great pleasure indeed."

Though Audubon gladly admitted this new-found species of bird at a later day, he was not at first dis- 
posed to accept its validity, as will appear in the following interesting letter which he sent to his young friend:

\section{Audubon to Spencer Fullerton Baird}

My deAr Sir, -

$$
\text { NEw YoRK, July 29, } 1841 .
$$

I have not had time to answer your interesting favor of the 21st until this morning, being now constantly engaged in the figuring, \&c., of the Quadrupeds of Our Country; by which I mean that I actually work from daylight every day until I retire to my necessary repose at night.

Your observations upon the birds of passage the last spring are what they have been almost throughout the U. S. The very backward spring which we have experienced this year did no doubt retard the coming into the States the millions of passenger birds that come to us from beyond our limits. The Fly-catcher of which you are in doubt is nevertheless the M. Pusilla, and you must not be surprised to find perhaps some discrepancy between the specimens you have procured and the descriptions you may have read, as among mine these differences are quite obvious and belonging to either sex or age, as is indeed the case with most of our birds as well as among many of our quadrupeds. ...

I cannot at present tell you when I may have the pleasure of meeting you at your own domicile, and yet this may happen quite unexpectedly.

Do you pay attention to the quadrupeds around you? If not, I wish you would!-and moreover I should be highly pleased to hear of your procuring for us all such as may be found in your vicinity. You have Bats, Wood Rats, \& Mice, Weasels, \&c., \&c., all of which I should like to possess specimens at your hands. Could you not save all that you come across with in this way, place them in common good Rum, and forward them to me at once or as soon as you have some 2 or three species. I will most cheerfully pay all expenses to Philadelphia addressed to J. B. Chevalier, No. 70 Dock Street. 


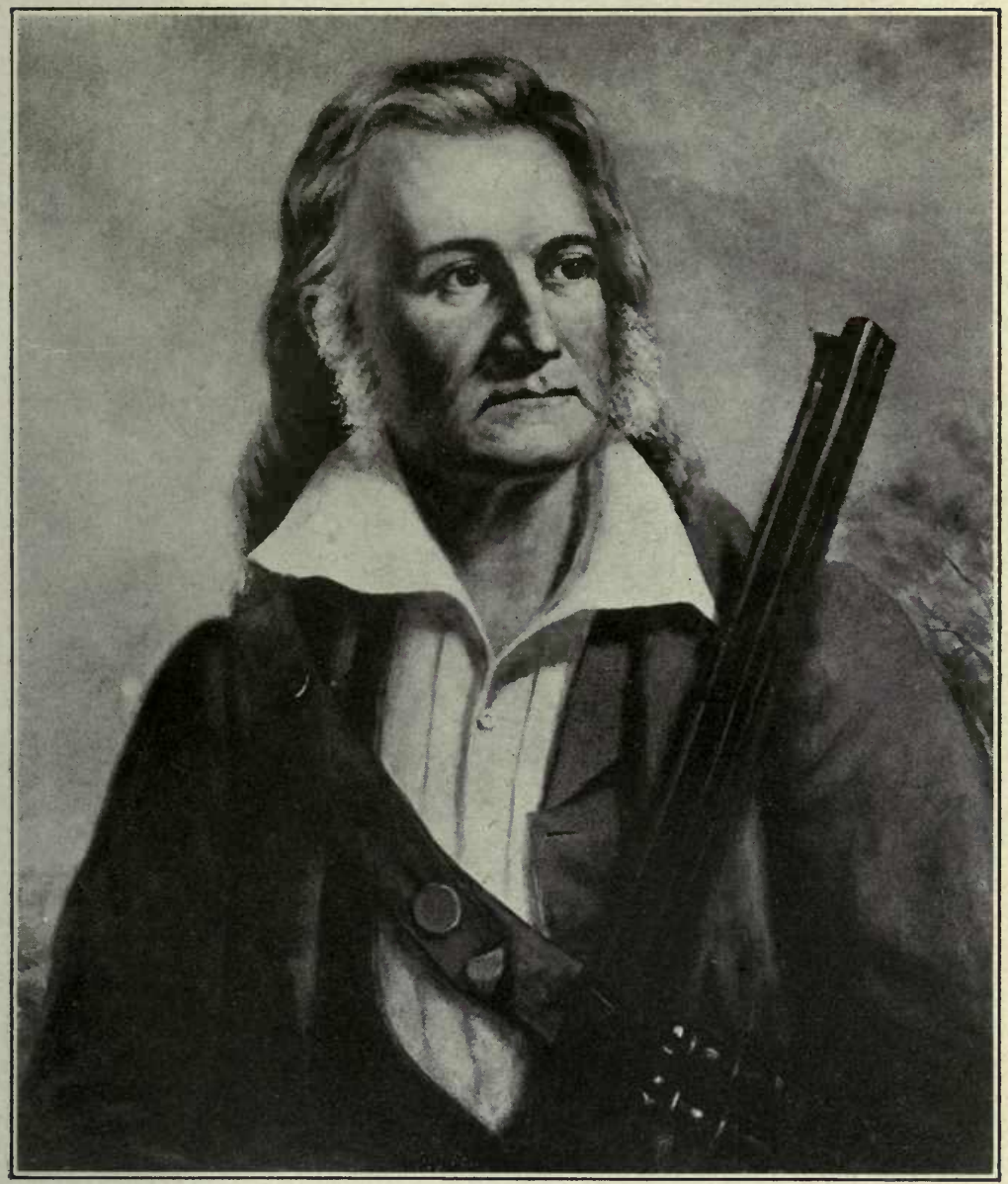

\section{AUDUBON}

AFTER A PORTRAIT PAINTED BY JOHN WOODHOUSE AND VICTOR GIFFORD AUDUBON AIBOUT 1841, NOW IN POSSESSION OF THE AMFRICAN MUSEUM OF NATURAT. HISTORY, NEW YORK. PUBLISHED BY COURTESY OF THE AMERICAN MIUSEUM OF NATURAL IISTORY. 

I am now as anxious about the publication of the Quadrupeds as I ever was in the procuring of our Birds, indeed my present interest in Zoology is altogether bent toward the Completion of this department of Natural Science.

Do please write to me often as I am always glad to hear from you, and when I am somewhat slow in answering your letters, be assured that it is altogether on a/c of the excess of Labour that I have to go through.

Believe me with sincere good wishes

Your friend and servant,

John J. Audubon.

Although Audubon never went to Carlisle, young Baird, as we shall see, repeatedly visited him in New York and became a favorite with his family. A description of the new Flycatchers was published by the Baird brothers in 1843, and represented Spencer's first contribution to his favorite science; Audubon included their discovery in the Appendix to the seventh and last volume of The Birds of America in 1844.

Audubon's occupations in the summer of this year are clearly reflected in the following letter: ${ }^{9}$

\section{Audubon to Dr. George Parkman}

New York, June 20th 1841

My Dear Friend.-

I intended having written to you yesterday by Miss Shatuck, who was good enough to spend the day with us, but I was so deeply engaged on a drawing of Rocky Mountain Flying Squirrels, that the time of her departure came suddenly and I could merely ask of her to say to you, that your last letter and remittance had reached us in safety, and with the

'See John E. Thayer (Bibl. No. 53), The Auk, vol. xxxiii (1916). Mr. Thayer's Ornithological Museum now contains the original specimen of Parkman's Wren, to which Audubon refers; it is "mounted on a twig, in a paper box with a glass front," and is "in excellent condition." 
unexampled promptness shewn by you on the three occasions you have been troubled with the delivery of 46 parts of our work to 46 of our Boston subscribers; and for which as I have said before I am very sorry to have nought but our sincerest thanks and gratitude to you for this, so remarkable proceeding. May God reward you and yours for all your generous actions.

I thank you also for your memorandums about the quadrupeds in the Boston Museum as I see that our animal there may save me the trouble of going to the State of Maine for it. When I was last under the hospitable roof of our Friend Docr Shattuck, I saw in George's room a No. of the "Penny Magazine" in which there is a plate representing a family of Beavers at work, that reminded me greatly of what $I$ have seen in the ponds of Indiana some thirty years ago, and which I should like to have for a few days to assist in part in the making of the background to my Drawing of these animals, drawn from the Individual you procured for me. I will take good care of the $N^{0}$ and will return it safely very soon.

Should George Shattuck have forwarded that $\mathrm{N}^{0}$. to $\mathrm{M}^{\mathrm{r}}$. B. of Baltimore, pray ask him to write to the later to send it to me as soon as convenient. If per chance you could procure for me a live Hare in the Summer dress (It is pure white in winter) pray do so and do not mind the price or the cost of its conveyance to me. This animal is abundant in the northern portions of your State and is fully double the size of the common Hare called the "Rabbit."

With sincerest regards and kindest remembrances to all around you and our mutual Friends,

believe [me] yours always

John J. Audubon.

The "Parkman Wren"

well mounted will soon be

on your chimney mantle!

The unique specimen of the little Wren, referred to in the postscript of this letter, had been discovered on 
the Columbia River by Dr. Townsend some years before, and though Audubon had described it in 1839, his figure of it had but just appeared; this was doubtless included, as Mr. Thayer remarks, in the parts of the octavo edition of The Birds of America, which Dr. Parkman distributed at Boston in the summer of this year.

As an indication of the zeal and energy with which Audubon undertook his work on the quadrupeds, the following letter (dated "New York, August 15, 1841," 'and addressed to "W. O. Ayres, ${ }^{10}$ Esq., Miller's Place, Suffolk county, Long Island, New York") will be read with interest:

\section{Audubon to W. O. Ayres}

I am now closely engaged in conjunction with my friend the Revd. John Bachman - of Charleston, S. C., in the preparing of a work on the viviparous quadrupeds of North America, and I have already drawn about one hundred figures of these, including thirty-six species.

Now knowing the interest you feel towards the advancement of Natural Science, in every department, I have thought that should you assist us in the procuring specimens, whether in the flesh or skin, dead or alive; that we would be much benefitted by such aid.-Long Island possesses rare and valuable species, and although many of them are plentiful they are rarely procured unless accidentally as it were. In your Rambles after the feathered Tribe, you surely come across at times with quadrupeds, and if you were good enough to shoot them or to catch them and send them to me in the manner mentioned below, I personally would feel extremely obliged to you.

Bats, Wood Rats and Wood Mice, Shrews, Shrew Moles

${ }^{10}$ Baird wrote to Audubon, November 4, 1846: "Please tell me the address of your friend Ayres. I have been collecting fishes for some weeks, and wish to correspond \& exchange with him on this subject." A woodpecker, Colaptes ayresii, was named after this friend by Audubon, in The Birds of America, vol. vii, in 1843. 
and all the smaller animals can be forwarded in an earthern jar immersed in good Yankee Rum.-The larger kinds can be skinned, preserving the skull entire, and also the legbone and the clavicles. One fore $\&$ one hind foot ought to be pinned on a board or cork until perfectly dried, and actual measurements and weights forwarded with the specimens. Nos. accordingly with the notes of localities and dates. Young and old are wanted. The Cat Squirrel is now and then procured about you of a very large size-the Woodchuck \&c. but it is unnecessary for me to give you a list as we are anxious to procure every thing we can from every portion of the Union with the view to ascertain their geographical range.

The expense involved in producing the early numbers of the small edition of his Birds must have been great, and Audubon was feeling the strain, when the letter, ${ }^{11}$ dated "New York-April 29, 1841," from which the following extract is taken, was sent to his Boston agent: "I doubt much if you are actually aware that we have at this moment in this city and at Philadelphia upwards of Seventy persons employed upon the present work, and that all these ... are to be paid regularly each Saturday evening, and that when we are out of temper it is not without cause."

When Baird visited the Audubons, in New York, in January, 1842, he was fascinated by the masterly drawings of birds and quadrupeds which were then being produced, and was determined to pay more attention himself to an art for which presumably he had little natural aptitude; he seems also to have received a hint for the improvement of his somewhat loose chirography. Upon leaving, Audubon presented his pupil with a copy of the Biography of Birds. After returning to his

${ }^{11}$ Addressed to Messrs. Little \& Brown, booksellers, acknowledging the receipt of a check for $\$ 214.20$. 
nome, Baird wrote from Carlisle, on February 8 of that year:

\section{Spencer Fullerton Baird to Audubon}

After a trial of two weeks I begin to find that I am getting over the shock caused by the sudden transition from the bustle of Broadway to the lifelessness of Carlisle, and hope that by the application of the proper means I may in time perfectly recover. Philadelphia seemed dull but Carlisle was death itself. My visit now however seems but as a dream, and I have settled down into my old regular monotonous life as if I had never been absent a day. When I arrived my friends had a great many questions to ask of course, but almost the first ones on every lip were about Mr. Audubon,- -how he looked? What was his age, whether the idea they had formed of him from his writings was correct, many queries also were respecting Mrs. A. and her sons; and they all said that they would be ever grateful to them for their kindness, to one away from home. ...

For want of other objects I have commenced to draw the sternal and shoulder apparatus of our birds, a pretty large collection of which $I$ have been making for a year past. . . . Have you heard from Mr. Lyon of Bedford yet about the money he owes you? I was asking about him the other day, of an acquaintance of his, who told me that he was as good as gold in all his debts, \& expressed some surprise at his not having paid, as he generaly is very punctual. . . . Last week I walked up to Pinegrove an iron works about sixteen miles in the mountains where resides the Mr. Ege I have so often spoken about as the mighty Nimrod of our county. On my arrival I found a fine wild cat hanging in the stable which had been killed a few days before. On returning the next day I took the cat with me slung across my shoulders, and on reaching home after measuring \& weighing it skinned it. I am in hopes of getting some more from here, as they promised to catch all they could for me. 
Baird signed himself "Your affectionate pupil," and added in a postscript: "I forgot to say that I had a fine steak of the wild cat broiled and it tasted like a tender piece of fresh pork. I will certainly eat the whole of the next one obtained. I intend to taste all the Quadrupeds inhabiting this part of the country."

Audubon's interesting reply was in part as follows:

\section{Audubon to Spencer Fullerton Baird}

\section{My dear young Friend.}

\section{New York, Feby. 10, 1842.}

It is about half an hour since $I$ had the real pleasure of receiving your letter of the 8 th inst. and my earnest thanks to you for it and its contents; to all of which I will try to answer at your request.

That beautiful Carlisle, its surrounding hills bordering its valleys, all within the bosom of quiet nature should appear to you as a small aff air when compared to our largest city in the Union, is not at all remarkable, but let me ask you the following questions. Did you meet all your dear Parents and Friends quite well? Did they not receive you with the kindest of welcomes? Were not their hearts and feelings towards you the same as ever? Surely all this was fact, and being so, would you not after all prefer Little Carlisle than Great Nere York with all its humbug, rascality, and immorality? Surely or do I mistake your nature sadly, you do! It is now a good long time since I was young, and resided near Norristown in Pennsylvania. It was then and is now a very indifferent place as compared with New York; but still my heart and mind oftentime dwell in the pleasure that I felt there, and it always reminds me that within a few miles of that village, my Mother ${ }^{12}$ did live, and it was there also that my good fortune led me to know and to marry the excellent Wife $I$ have yet, at whose hands yourself have tried to be rendered comfortable. Say

${ }^{12}$ See Vol. I, p. 103. 
what you will. "there is nothing like home" . . I I wish I could be with you, if only for one week, for then I imagine that between your friends of the mountains, yourself, and myself, we could Tree a "Catamount" and soon untree him. The tugging part of that far-famed animal, I would cheerfully give up to your youthful shoulders, but not so with the figuring of it, yet for a while. Is there such a Beast in existence? Do let me know as soon as you can. I am heartily glad that you have procured a wild cat from the mountainous part of Pennsylvania, and that you have preserved its skin, which I beg you to forward as soon as you please, along with whatever other quadrupeds you may have in hand, that we may say more on those Beasts of the Central States, than has ever been before told. . . .

Look out for Martens, and try to find me some youself! I am glad that you find wild cat meat pretty good, as it corroborates the sayings of many others, who pronounce it equal to young veal.

Let me say to you ("en passant") that your handwriting is considerably improved, and depend upon it that your attention to Drarwing will soon enable you as of "copper plate." Go ahead!

I now wish you earnestly to offer our joint respects, regards, and best wishes to all your family and friends, and to believe me always,

\section{Yours most truly, \\ Jomn J. Audubon. \\ 86 White Street.}

P. S. Thank you for what you say of the Bedford gentleman. When I write next, I will mention him at greater length. I wish you could let me know whether we could procure first rate peach trees from your vicinity, and how much 50 of them would cost. I should like to have them assorted, soft, and clings yellow, or red, or blood-red. We wish to plant these as early in March as possible, if young trees, two years old could be had, we might, perhaps, have fruit on some of them during the 
next summer? Try what you can do for your New York friend. [The following on outside of letter-sheet] I will make up a box for you in a few days, and send it to you through Mr. Chevalier.

Audubon, who ever found city life irksome, as early as 1841 had begun to look about for a farm, or some retired spot within easy access to New York, where he could establish the families of himself, of his two sons, and have about him many of the animals which he then wished to study and depict for his new work. Edward Harris would have been glad to have had him for a neighbor, and wrote from Moorestown, New Jersey, on July 5, 1841, suggesting that he examine "a small farm close to his village, containing about 25 acres of very good land," which the owner was then willing to sell for $\$ 3,500$, though, added Harris, "when Mr. Havell was here, he asked $\$ 5,000$ for it." A spot more to his liking, however, was found on the Hudson River, in Carmansville, later known as Washington Heights, where he purchased from thirty to forty acres of land which had a river frontage of a thousand feet, from the present One Hundred and Fifty-fifth to One Hundred and Fifty-eighth Streets, and extended to the easterly limits of the village at the old Bloomingdale Road, near the present Amsterdam Avenue. This tract was well wooded, and among the grand forest trees on the place a large tulip or white wood attracted general attention from its great girth and commanding height. Audubon decided to place his house at the foot of the river bluff, amid a cluster of fine oaks, chestnuts and evergreens, and a clearing had to be made before the site could be laid off; it was some years before the railroad came to mar his river view and interrupt access to the 
beach. Audubon began to build in 1841, and on February 24, 1842, Victor wrote to Edward Harris: "Our house in the country is going on well, and will probably be ready for us in about two months. John is at work out there every day"; they were planning, he said, to raise pigs and poultry, and he inquired after "draining tiles, such as are made near Philadelphia."

Audubon named his new estate "Minnie's Land," in honor of his wife, Lucy, to whom he deeded the property, the Scotch form of her name having no doubt come into familiar use during their residence abroad. In April, 1842, they turned their backs on the city and occupied their new home. Spencer Baird, when writing on May 3 of that year, said:

I have been in some doubt where this letter should be addressed, since " 86 White St." will not reach you, and you must by this time be snugly fixed $I$ hope in your beautiful place up the River. Do not laugh therefore if I prefix "Formerly" to the old superscription. . . .

I suppose that the First Number of the "Quadrupeds of North America" is out by this time, I hope that it will be hailed by a large list of subscribers, and will do what I can for this desirable end.

Submerged as Audubon was, with painting the Quadrupeds, keeping the small edition of his Birds in motion, and canvassing for subscribers to both works, which he published himself, he nevertheless found time for an extraordinary number of letters, which were written with an elegance of chirography that diverts our attention from their orthographic defects. In the labor of drawing and in all his business affairs he was constantly aided by his sons.

In Audubon's time the center of Carmansville was 
a quarter of a mile to the east of his house, while at a short distance below, on the river, lay Manhattanville, at the present One Hundred and Twenty-fifth Street, from which men frequently came on summer evenings to help handle the seine, fish then being plentiful in that part of the Hudson. The place came to possess a good garden and orchard, with stable, dairy, and poultry yards; enclosures also were made for deer, elk, wolves, foxes and other wild animals. The old barn of the Audubon place stood higher on the slope where the naturalist built his studio or painting house, but no traces of either now exist. Though standing low, the house commanded a wide sweep of the river with the Palisades on its opposite shore, and such attractive surroundings were a never failing source of delight and inspiration to the naturalist to his dying day.

In describing Audubon's activities, Parke Godwin made this note in the spring of $1842:^{13}$

During the last winter, which he spent in this city, he has worked on an average fourteen hours a day, preparing a work on the Quadrupeds of America, similar to his work on the Birds. The drawings already finished, of the size of life, are master-pieces in their way, surpassing if that be possible, in fidelity and brilliancy, all that he has done before. Early in the summer he will depart to continue his labors in the woods.

Before we glance at the half-submerged relic of Audubon's old house as it stands today in upper New York, ${ }^{14}$ we shall follow the same writer in a visit which he made to "Minnie's Land" in the summer of 1842 but did not describe until eleven years later $;^{15}$ we will only

${ }^{13}$ See Bibliography, No. 60.

${ }^{14}$ See Chapter XXXVI. (1853).

${ }^{15}$ Parke Godwin, The Homes of American Authors (Bibl. No. 68) 


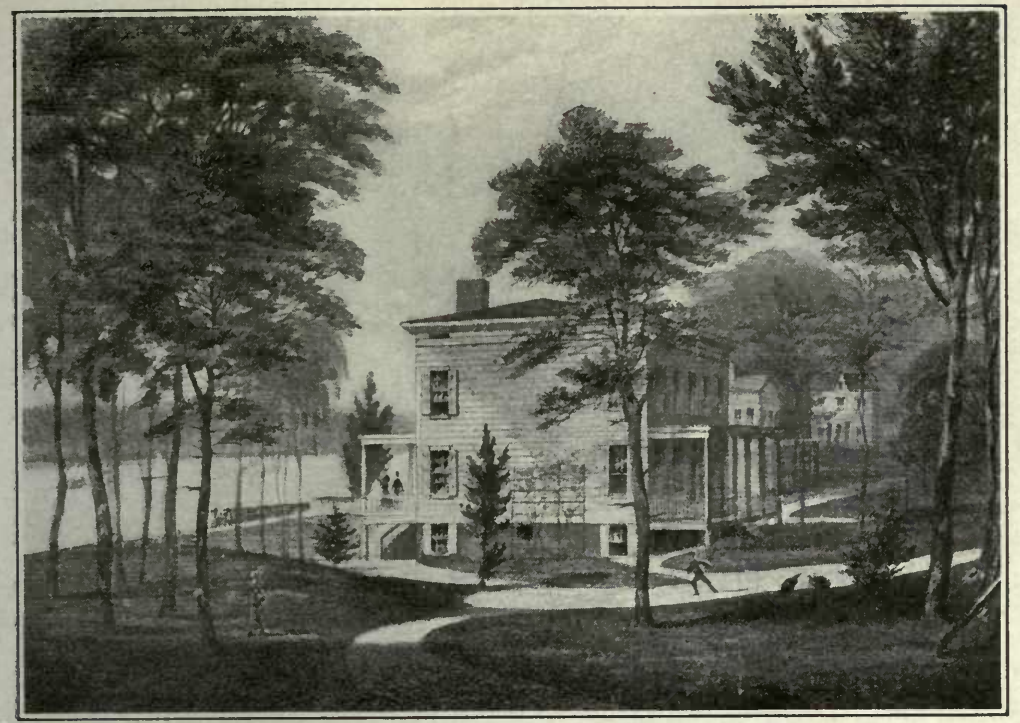

"MINNIE'S IAAN" AS IT APPEARED IN 1865.

After a lithograph published in D. T. Valentine's Manual of the Council of the City of New York.

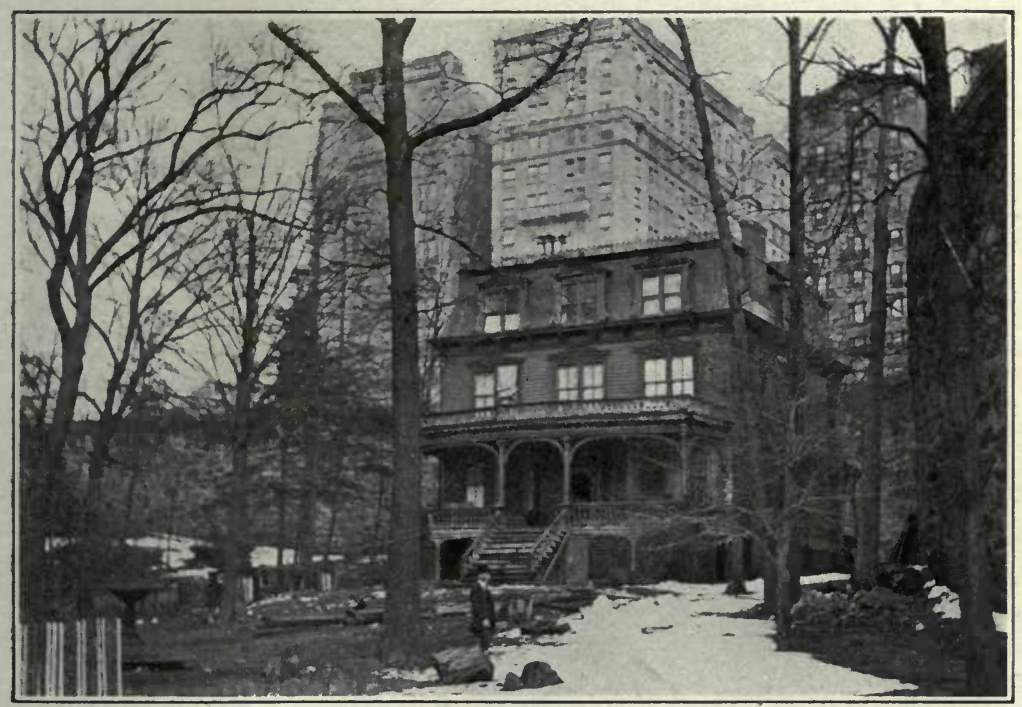

"MINNIE'S LAND" AS IT APPEARS TO-DAY FROM THE RIVER FRONT, POCKETED BY THE RETAINING WALI, OF RIVERSIDE DRIVE. 

add that at this time Audubon was in his fifty-eighth year, and not over sixty, as this writer surmised. After passing beyond the outposts of the city of that day, and turning into a rustic road which led directly to the river, his walk

soon brought a secluded country house into view,- - a house not entirely adapted to the nature of the scenery, yet simple and unpretending in its architecture, and beautifully embowered amid elms and oaks. Several graceful fawns and noble elk were stalking in the shade of the trees, apparently unconscious of the presence of a few dogs, and not caring for the numerous turkeys, geese, and other domestic animals that gabbled and screamed among them. ...

"Is the master at home?" I asked of the pretty maid-servant who answered my tap at the door, and who after informing me that he was, led me into a room on the left side of the broad hall. It was not, however, a parlor, or any ordinary reception-room that I entered, but evidently a room for work. In one corner stood a painter's easel, with a half-finished sketch of a beaver on paper; in the other lay the skin of an American panther. The antlers of elks hung upon the walls, stuffed birds of every description of gay plumage ornamented the mantle-piece; and exquisite drawings of field-mice, orioles, and woodpeckers were scattered promiscuously in other parts of the room, across one end of which a long rude table was stretched to hold artist materials, scraps of drawing paper and immense folio volumes filled with the delicious paintings of birds taken in their haunts.

\section{The master, who soon appeared,}

was a tall, thin man, with a high arched and serene forehead, and a bright penetrating gray eye; his white locks fell in clusters upon his shoulders, but were the only signs of age, for his form was erect, and his step as light as that of a deer. The expression of his face was sharp, but noble and commanding, 


\section{8}

and there was something in it, partly derived from the aquiline nose and partly from the shutting of the mouth, which made you think of the imperial eagle.

His greeting, as he entered, was at once frank and cordial, and showed you the sincere and true man. "How kind it is," he said with a slight French accent, and in a pensive tone, "to come and see me; and how wise, too, to leave that crazy city!" He then shook me warmly by the hand. "Do you know," he continued, "how I wonder that men can consent to swelter and fret their lives away amid those hot bricks and pestilent vapors, when the woods and fields are all so near?"

When writing in 1845, Godwin gave further intimations of the naturalist's appearance: "His forehead [was] high, arched, and unclouded; the hairs of the brow prominent, particularly at the root of the nose, which was long and aquiline; chin prominent, and mouth characterized by energy and determination. The eyes were deep-gray, set deeply in the head, and as restless as the glance of an eagle." 


\section{CHAPTER XXXIV}

\section{EXPEDITION TO THE UPPER MISSOURI}

Ambitions at fifty-seven-Plans his last expedition in the rôle of naturalist-Credentials from public men-Canvassing tour in Canada described-Baird's plans to accompany Audubon west frustratedWestern expedition begun-Ascent of the Missouri and YellowstoneDiscoveries of new birds-A wilderness that howls-Buffalo huntingPassing of the great herds-Return from Fort Union-Incident on the canal boat-Completion of the octavo edition of the Birds.

In the summer of 1842 , when his two new undertakings were well in hand, Audubon was planning a journey which he felt would help them both, his long cherished but ever deferred expedition to the Far West; in the dim perspective his mind's eye could trace the snowy summits of the Rocky Mountains, a promised land he was never destined to see, though, with true poetic justice, one of those grand peaks now bears his name. At this time he was in his fifty-eighth year, and although his family thought him too old for so arduous a journey, he would not be thwarted, for his eye was undimmed and his natural force unabated.

The letters which passed between Audubon and Baird at this time show how eager was his young friend to attach himself to the party. While in Washington, July 27, 1842, Baird wrote:

After making several unsuccessful efforts to get a second sight of you day before yesterday, I was obliged to give up the attempt in despair. I went to the Capitol at half past twelve and wandered over the whole building, Library, Senate 
Chamber and House, without being able to see or hear anything of your excellency. In the evening as in the morning I was again at Fuller's without avail, went up the street, listened awhile to the Circus music, came back, you were in bed.

One thing I wanted to ask you about, was respecting your proposed trip next spring. ... Nothing would delight me more than to go, if I can afford it. Next what preparation would I have to make to fit myself to accompany you. The journey ought to be a sort of "Humboldt \& Bonpland" one, for the purpose of increasing the general sum of knowledge in every department of science, physical as well as natural. ... If there is anything I can do for you here, do not hesitate to command me.

Audubon's interesting reply to this letter will be given in full:

\section{Audubon to Spencer Fullerton Baird}

NEW YoRK, July 30, 1842.

\section{My Dear Young Friend, -}

Your letter of the 27th Inst. reached me yesterday. I am truly vexed that I should have missed you at the Library or the Congress Chambers, where I went (perhaps too late) between 3 and 4 o'clock of the afternoon, having been detained at the different Departments of State where it was my duty to call, preparatory to the next coming Great Western Journey.

Now it proves by your letter that you feel favorably disposed to accompany me on this long thought-of and contemplated Tour, and wish me to give you some idea of the expenses, attached to such an undertaking; but to this question $I$ am quite unable to reply at present, although I may do so in a few weeks, and which I shall do, provided you write to me again on the subject.

I have no very particular desire to embark as deep in the Cause of Science as the great Humboldt has done; and that, simply because $I$ am too poor in pecuniary means and too in- 
competent; but I wish nevertheless to attempt to open the Eyes of naturalists to Riches untold, and facts hitherto untold. The portions of the country through which it is my intention to pass, never having been trodden by white Man previously.

I have some very strong doubts whether the results of the Antarctic Expedition will be published for some time yet; for, alas, our Government has not the means, at present, of paying some half a Million of Dollars to produce publications such as they should publish, and connected with the vast stores of Information, collected by so many Scientific Men in no less than Four Years of Constant Toil and privation, and which ought to come to the World of Science at least as brightly as the brightest rays of the Orb of Day during the Mid-summer Solstice. Oh, my dear young friend, that I did possess the wealth of the Emperor of Russia, or of the King of the French; then, indeed, I would address the Congress of our Country, ask of them to throw open these stores of Natural Curiosities, and Comply with mine every wish to publish, and to Give arway Copies of the invaluable Works thus produced to every Scientific Institution throughout our Country, and throughout the World.

As you however appear desirous to present my thoughts of your capabilities as one of the assistants in that Stupendous undertaking, I send you enclosed what I hope most sincerely may prove beneficial for such purposes.

Now as you have been kind enough to offer me your services at Washington, I ask you to call upon Mr. Cushing, M. C., of Mass.tts, and to ask him to have the goodness to forward me the Letter promised me by the President of the U. S., for, as I have not yet had it, I somewhat fear that it has been missent.

Write me at once, and believe me,

Your friend, John J. Audubon.

Audubon enclosed with this letter a warm recommendation of his friend for the position of curator of 
the rich collections made by the United States Exploring Expedition to the Antarctic, under command of Lieutenant Charles Wilkes, then stored at the Patent Office and National Institute, but nothing came of it and Baird went away disappointed.

During the summer, in accordance with his usual custom, Audubon had taken pains to fortify himself with credentials from the Government, and had obtained excellent letters from President John Tyler, Daniel Webster, Secretary of State, General Winfield Scott, who then held the highest commission in the Army, John C. Spencer, Secretary of War, and Lord Ashburton, a member of a special commission to settle the disputed boundary between Maine and the British provinces. The letters given him by Daniel Webster and President Tyler were as follows: ${ }^{1}$

\section{Daniel Webster to Whom it May Concern}

\section{United States of America,} Department of State.

To ALL TO WHOM THESE PRESENTS SHALL COME-GREETING.

Know Ye, that the bearer hereof, John James Audubon, a distinguished naturalist and native citizen of the United States, has made known to me his intention of travelling on the continent with the view principally of aiding the cause of science by extending his researches and explorations in natural history, and as he is known to me to be a man of character and honor and worthy of all friendly offices and of all personal regard, these are therefore to request all whom it may concern, to permit him to pass freely, without let or molestation, and to extend to him all such aid and protection as he may need, and which becomes the hospitality of civilized and friendly nations.

In testimony whereof I, Daniel Webster, Secretary of State of the United States, have hereunto set my hand and caused

${ }^{1}$ See Ruthven Deane (Bibl. No. 224), The $A u k$, vol. xxv (1908). 
the seal of this department to be affixed at the City of Washington, this the 24 th day of July, A. D. 1842.

[Signed] Daniel Webster

\section{President John Tyler to Whom it May Concern}

United States of America, WashingtoN, 28 th July 1842.

The bearer of this, John James Audubon, is a native citizen of the United States, who has informed me of his intention of travelling on the continent of America, chiefly to promote the cause of science by researches in natural history. $\mathrm{He}$ is known to me to be a naturalist of eminent acquirements and estimation, a man of character and honor and worthy of all personal respect and regard. I recommend him to my countrymen abroad and to the authorities and inhabitants of other countries that he may receive the friendly offices, aid and countenance which are due to the interests of science and the rites of hospitality among civilized nations.

JoHN TYLer, President of the U. States.

John Bachman, who had agreed to be responsible for the letterpress of the Quadrupeds, was already at work, as shown by the following note ${ }^{2}$ sent to Audubon at this time:

\section{John Bachman to Audubon}

My Dear Friend:

Charleston, August, 1842.

I have just returned from a visit to the country, where I left Mrs. Bachman for the benefit of her health. I have a season ticket on the railroad, and, on my weekly visits, I do much of my writing on Natural History. The moment the

'See C. L. Bachman, John Bachman, D.D., LL.D., Ph.D. (Bibl. No. 191), p. 199. 
clock strikes four I am up, and soon at work. From this hour until seven, I have no interruptions. I hope in this way to steal time to write about Quadrupeds. When I get fairly under way, as I am now, I am not easily diverted from the object before me, and nothing but ill health or domestic affliction will keep me back.

J. B.

On September 12 Audubon set out on a canvassing tour of Canada, on which he went as far north as Quebec; as he passed his home, he hailed his sons, who were sailing on the river, and the sight of them at this moment brought tears to his eyes. Whitehall, New York, was reached on September 13, St. Johns, Canada, on the following day, and on the 15th he was in Montreal; three days were spent at Quebec (September 16-18), where, as at other points, he met with the most gratifying success. After reaching home in October, the following glowing account of this tour and of the attractions of his new estate on the Hudson was given in a letter to Dr. Benjamin Phillips of London, ${ }^{3}$ dated from "New York, 7th Nov., 1842":

\section{Audubon to Dr. Benjamin Phillips}

I went on a tramp to the Canadas, leaving our comfortable abode on the 12th of Sepr. last and was absent for a whole month. My Journey extended to something like 1500 miles: during which I visited for the first time, the North-American Gibralter [Quebec], the sight of which was as new to me as it was wonderful in the days of old. The views (for I must speak in the plural) from the Citadel, are as far as I have seen the grandest and the most sublime I ever gazed upon. The St. Laurence River, is noble indeed, and when we know that that stream carried forth to the Atlantic the congregating

'See Vol. II, p. 144. 


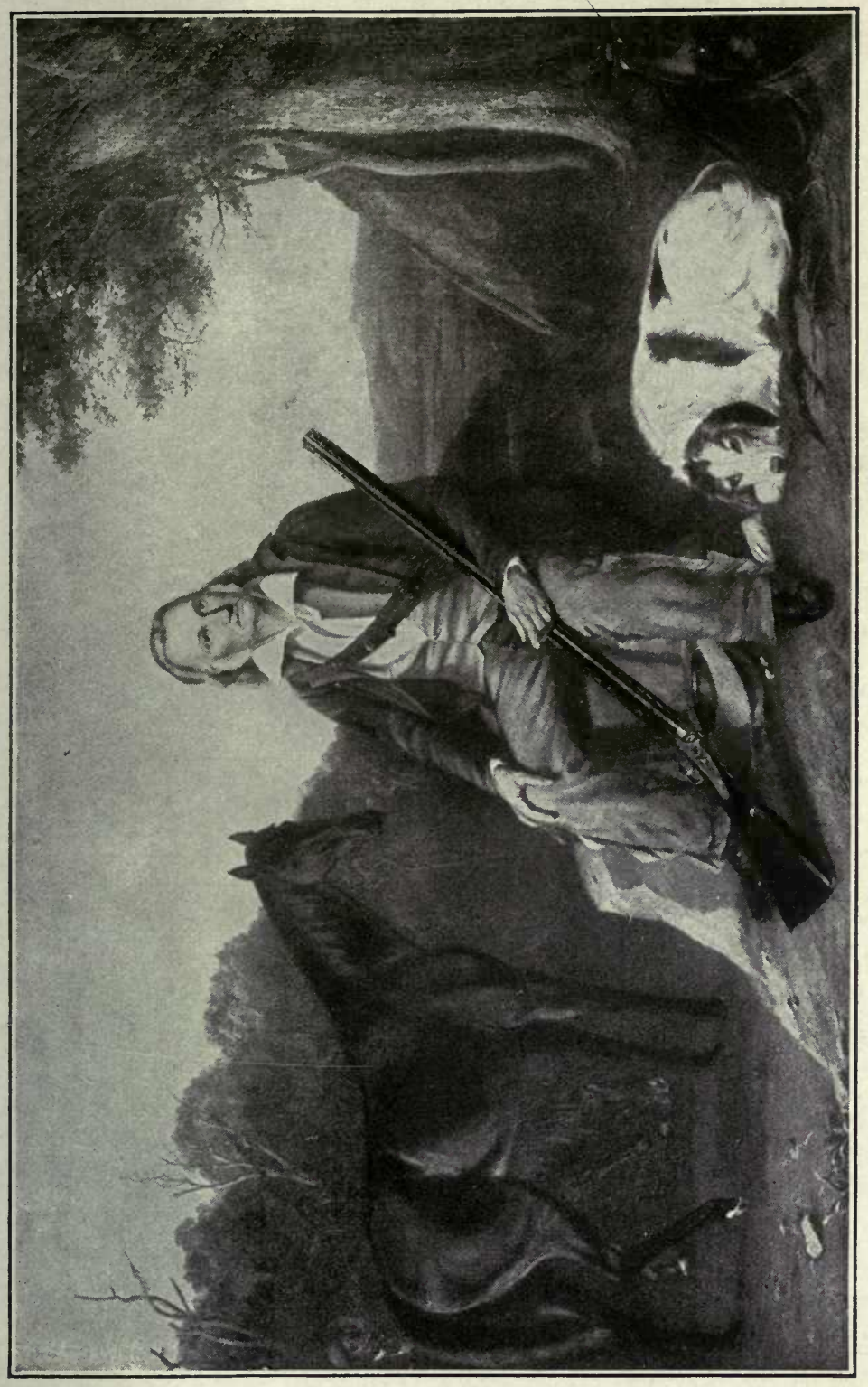

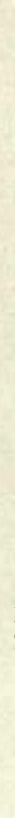

告

댕

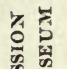

米?

그

넌

춘

4

車

긍

द दे

今 厸

4 幽

40

봏

号:

ธิ :

$\geqslant$

증

은

空

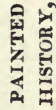

눈

ํํㄴ

4

뜔 

waters of all our sea-lakes, we must not be astonished at her great breadth, depth, and strength of current to about 60 miles below Montreal. About the latter city that noble stream is intercepted by many rapids and a vast number of Islands, the latter of which so intersect the view that in some instances it would prove quite out of the question to discover with certainty either of the main shores. I visited the falls of Montmorency, those of the Rivierre Serria and of La Chan[u]diere. I besides made many an acquaintance and a few very valuable friends. At Quebec I sold a copy of our large Work to the Earl of Caledon who also subscribed to our quadrupeds. At Montreal I sold several Copies of our Small Edition of the Birds of America and procured several good names to the quadrupeds. At Kingston where $I$ had the pleasure of becoming acquainted with Sir Charles Bagot and family (all delightful persons) I sold two copies of the large work to both Houses of Parliament, and also procured their double subscriptions to the Animals. Thus I returned home highly pleased with all that I had done and seen. The more perhaps because I procured in the meantime most valuable specimens of rare quadrupeds and a fund of information that can never be met with unless on the ground of action....

Our dear "Minnie's Land" is improving as fast as our poor pecuniary means will allow. We have done a good deal since our purchase of it, in a wild state as it was, and next spring we will have a good garden and probably some fruit from our own young trees, of which we have planted nearly 200 of the very best description, including pears, aples, quinces, apricote, plumbs, vines, nectarines, apricotes, etc., etc. ... We have fish whenever we draw the seine, and this summer we have caught one sturgeon that measured upwards of 8 feet ... weight more than 200 pounds . . . The "Boys" take a sailing pretty frequently in their sail boat, but I never join them in that, for attempts I have crossed the Atlantic pretty frequently I have an inward dislike to the water, after it is more than 2 or 3 fathoms deep! We have now been enjoying that delightful season, which our Americans call the "Indian Summer" and not 
a drop of rain have we had for several weeks. ... Would that you all were here at this moment, at my elbow, from which by a peep at the window, I gaze on the "Pallisades" and the breath of the Hudson, between the trunks of the many trees that stand at rest at present awaiting the return of spring for a renewal of fragrant verdure, and fruits innumerable. ...

We would be glad if you would ascertain whether a good agent can be had to procure subscribers in England for it [the Quadrupeds], or whether a responsible bookseller would buy the copyright, \& a certain number of plates either coloured or plain.

A few weeks later Audubon wrote also to William Yarrell, hoping to interest him in the foreign sale of his new publication, but as will be seen by his friend's reply, now to be given, with indifferent success:

\section{William Yarrell to Audubon}

[Superscribed by Audubon] Rec 28 Jany

1843

[Addressed] J. J. Audubon Esq ${ }^{\text {r. }}$

77 William Street

New York

[Superscribed by Yarrell]

single letter.

P. Paid, W.Y.

RYDer Street ST JAMES

London 17th Decr. 1842.

My dear Mr. Audubon,

I have this morning received your letter of the $28^{\text {th. }}$ Novr. last, and as it is strictly a letter of business, I reply to its various parts immediately.

About a month ago I received a note from $\mathrm{M}^{\mathrm{r}}$. Phillips to say that he had received the Plates of the first number of your work on the Quadrupeds of America-would I come and look at them, and would $I$ exhibit them at the meetings of the 
Societies I belonged to for the promotion of Natural History. I went to see them, and have with pleasure exhibited them at the Linnean Society on the third Tuesday in Novr. and at the Scientific evening, as well as the monthly general, meeting of the Zoological Society, both of which occurred early in Dec ${ }^{r}$. and $I$ then returned the 5 Plates to $\mathrm{M}^{\mathrm{r}}$. Phillips-They were very much admired but I did not obtain any request for a supply.

In reference to your next request, I must decline any connection with the sale or publication of this, or indeed any other foreign work, in this country. The truth is, that having now been in the business nearly forty years, $I$ begin to be tired of work; the last part of my History of British Birds will be published on the $1^{\text {st }}$ of June 1843 ; with that part I shall give up my pen, and write for money no more.

You are kind enough to give me some credit for experience as a publisher, and some knowledge of the persons who are likely to be purchasers of works on Natural History hereMy conviction is that you would gain more by paying full commission to an established Bookseller in London who would by advertising make your works known, and where they might be obtained-than you will by the best efforts of any private friend, even though his kindness should induce him to take all the trouble for nothing.

You say nothing about your family. I hope they are all well.

$$
\begin{aligned}
& \text { I remain, Dear Sir, } \\
& \text { Yours very truly } \\
& \qquad \text { W }^{\mathrm{m}} \text { Y YRRELL. }
\end{aligned}
$$

J. J. Audubon Esq.

77 William Street.

New York.

In the following letter to Spencer Baird Audubon was able to outline more fully his final plans for the western journey: 


\section{Audubon to Spencer Fullerton Baird}

New Yonk, Nov. 29, 1842.

\section{My dear Young Friend,}

It seems to me as if an age had already elapsed since I have heard from you or your whereabouts. Neither do I know clearly whether in the way of correspondence, you are in my debt, or I am in yours. Nevertheless I now write to you, and request you to read this letter more than once, and think deeply on the purport of its contents that you may be the [more] able to form a true Idea of what I intend to say [to] you, and for yourself to give me a true answer, on which I can depend, no matter whether it is to my liking or not.

It is now determined that I shall go towards the Rocky Mountains at least to the Yellowstone River, and up the latter Stream four hundred miles, and perhaps go across the Rocky Mountains. I have it in my power to proceed to the Yellowstone by Steamer from St. Louis on the 1st day of April next; or to go to the "Mountains of the Wind" in the very heart and bosom of the Rocky Mountains in the company of Sir William Drommond Stewart, Baronet who will leave on the 1st of May next also from St. Louis.

It has occurred to me that perchance you would like to spare a few months of your life, to visit the great Western Wilderness, and perhaps again prefer going in my Company in preference to that of any other person? Of this of course I cannot Judge without your answer to this. I thought that you would have been in New York long ere this, but not a Word of you has reached any friend of yours here for several months. I have had an abundance of applications from different sections of the country, from Young Gents who proffer much efficiency, etc., but I do not know them as I know you, and if the terms which I am about to propose to you will answer your own views, I wish you to write to me at once so that I may know how to prepare myself for such a Journey, and under such circumstances.

Would you like to go with me at any rate? By which I 
mean, whether by Land, or by Water, and undertake, besides acting towards me as a friend, to prepare whatever skins of Birds or Quadrupeds, I may think fit for us to bring home. The Birds, you might have one half as your own, the Quadrupeds, (should you wish it) you might have a $4^{\text {th }}$ or every $4^{\text {th }}$ specimen of the same species, reserving to myself all that is new or exceedingly rare.

I will procure and furnish all the materials for skinning, preparing, and saving whatever we may find in Ornithology and in Mammalia, and in all probability (if you think it absolutely necessary) pay one half your expenses from the time we leave St. Louis until our return to that city. You will have to work hard, of course, but then I trust to that the knowledge alone which you must acquire would prove a sufficient compensation, and as you already know me pretty well, I need not say to you that I am not "hard on the trigger."

It will be necessary for you to provide a good double barrelled Gun, and an excellent Rifle, Shot bag, powder flask, \&c, a good hatchet, and a sufficiency of clothes for something like a 12 month's Campaign. But if you will write me at once upon the subject, I can give you a more and a better a/c of all my intentions, than is at present necessary.

If all goes on as I trust it will go on, we may be back home by Octr. or Novr. next, 1843.

Do not lose a moment in writing to me in answer to this after you have thought deeply upon the matter.

Remember me kindly to all your friends, and believe me,

Yours Always,

John J. Audubon.

77 Williams Street, New York.

Baird was unable to reach a decision in the matter, and Audubon actually wrote five more letters on the subject and kept a place open for his young friend for nearly three months. On January 2, 1843, he said that while it was impossible to determine with any degree of 
accuracy the amount of money the journey might require, he could "safely say that the sum of $\$ 500$. would prove all sufficient, as our passages to the Yellow Stone will be granted us free; and the expenses from here or from Carlisle cannot exceed $50 \$$ to St. Louis, and may be less." "I have given up," he added, "all Idea of going South this season, being determined to draw quadrupeds until a few days of my leaving home for this grand and Last Journey, I intend to make as a Naturalist." Again, on January 31, he wrote:

It appears from the whole tenure of your letter, that that rascally article cash is the cause which prevents you from going along with me to the Yellowstone River and back. Now, it happens that although we are far from being rich, we are all desirous that you should go along with me, because we all know you, and I particularly so. Therefore, if you will go with me, and assist me all you can, in the way of hunting, measuring and dissecting Specimens when I am otherwise engaged, etc. etc. I will furnish you with all that may be necessary for your expenses, excepting your clothing and your gun or guns, as you may have them.

\section{In still another letter, of February 10, Audubon said:}

That your kind mother should feel great reluctance in the premises, does not astonish me, as my own good Wife was much against my going on so long a Journey; but her Strong Sense of what is best for us all, and as well as in myself, the perfect confidence that our Maker's Will will be done, she has now no Scruples of any kind, and as for myself I rely as much as I ever have done in the Support of the Almighty Being who has supported and secured me against evils of all sorts in my Various undertakings, and with this Idea at my heart, I feel confident that although an Old Man, I could undertake any Journey whatever, and no matter of their lengths or difficulties. 


\section{Mydeav}

\section{Monutbown Said $31^{\circ} 1840$}

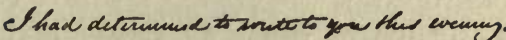

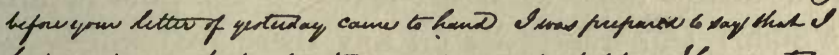

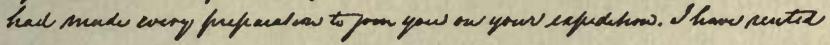

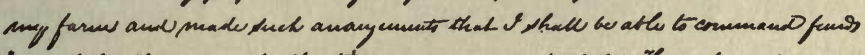

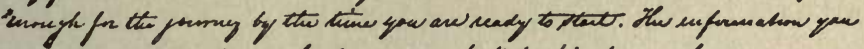

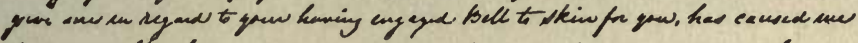

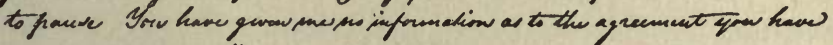

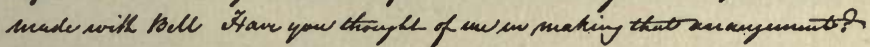

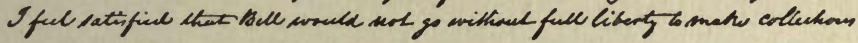

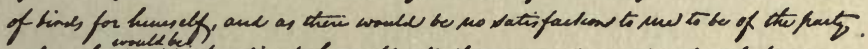

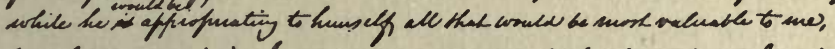

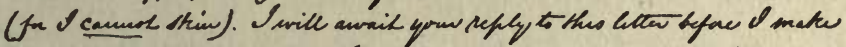

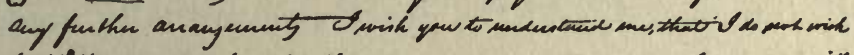

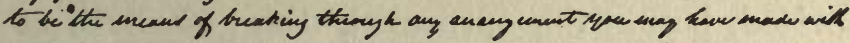

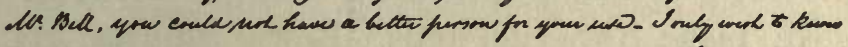

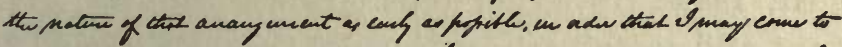

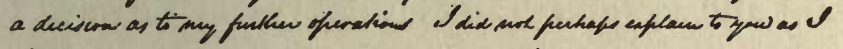

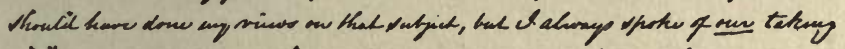

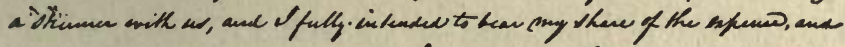

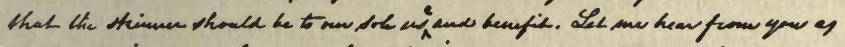

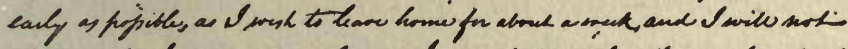

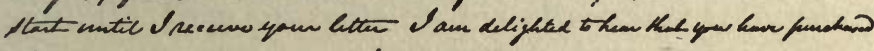

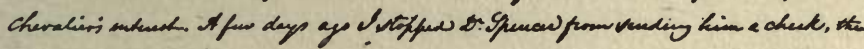

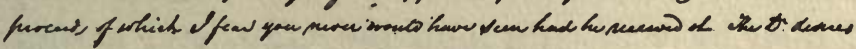

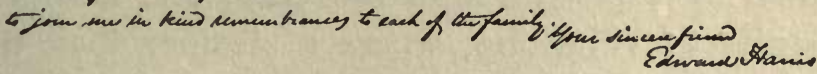

LETTER OF EDWARD HARRIS TO AUDUBON, REGARDING HIS INTENTION OF JOINING THE EXPEDITION TO THE UPPER MISSOURI, JANUARY 31, 1843. From the Deane MSS. 
But I wish you would assure your good mother that to go to Yellow Stone River, in a good Steamer, as passengers by the courteous offers of the President of the American Fur Company who himself will go along with us, that the difficulties that existed some 30 years ago in such undertakings are now rendered as Smooth and easy as it is to go to Carlisle and return to N. Y. as many times as would make up the Sum in Miles of about 3000: Our difficulties (if any there are) will be felt on our return; when we must come back to St. Louis in one or 2 open boats in Sep ${ }^{\mathbf{r}}$ and part of Oct ${ }^{\mathbf{r}}$ next. The passage being longer or shorter accordingly with the state of the Missouri at that Season.4

Young Baird would gladly have accompanied Audubon, but the fears of his friends for his health and safety interposed, and the party as eventually made up comprised, beside the naturalist, John G. Bell, as taxidermist, Isaac Sprague, artist, Lewis Squires, general assistant and secretary, and his old friend Edward Harris.

Audubon left his home on March 11, 1843, with Victor, who accompanied him as far as Philadelphia, where a rendezvous was made before starting west. The party went first to Baltimore, and by steam cars to Cumberland, then by coach through the Gap, and across the Alleghanies to Wheeling, where a steamer took them down river to Cincinnati. On March 19 they reached Louisville, where Audubon spent four days with his brother-in-law, William G. Bakewell, and on the 28th they arrived at St. Louis, where the party completed their outfit. On April 25 they began their ascent to the Missouri, in the steamer Magnet, a small vessel belong-

- See William H. Dall, Spencer Fullerton Baird, a Biography (Bibl. No. 52), pp. 88-91, for the complete letters from which the preceding extracts have been taken. 
ing to the American Fur Company, with a motley crowd of trappers, employed by the Company, representing French creoles, Canadian French, Indians, and other nationalities.

During this journey, which lasted eight months, Audubon kept a voluminous journal, which was written in a fine hand on large sheets of linen paper that could be easily rolled and carried in his pocket; this was afterwards sent to Bachman, was returned, and was lost for fifty years, or until 1896, when it was recovered from an old secretary by Audubon's granddaughters, one of whom published it in $1898 . .^{5}$ It is a highly interesting and spirited narrative from beginning to end, and abounds in graphic pictures of the Indians and trappers, the military posts and pioneer settlements, the abundant bird life and big game, the biggest of which, the buffalo, was then seen by Audubon in a state of nature for the first time, the grand and turbulent rivers, and the smiling or frowning face of the great wilderness so soon to be changed by the devastating hands of civilized man.

What Audubon thought to be a new finch, discovered near the Snake Hills in Missouri, was named for Edward Harris, and though it proved to have been previously described, the bird is still known as "Harris' Finch"; a few days later a new vireo, Vireo bellii, received the name of John G. Bell, his taxidermist, and similar honors were passed to artist Isaac Sprague, to whom was dedicated the little titlark, Alauda spragueii, now Anthus spraguei:

In those days of river navigation, the frequent tying up for fuel or necessary repairs, not to speak of ground-

'See Maria R. Audubon, Audubon and his Journals (Bibl. No. 86), vol. i, pp. 453-532, and vol. ii, pp. 1-196. 
ing in a treacherous channel, gave almost daily opportunities for the hunters to go ashore, and these occasions seldom failed to produce something interesting, new, or rare. In the Indian country, at Bellevue, Nebraska, where they touched to land a part of their cargo, Audubon "saw a trick of the trade, which made him laugh. Eight cords of wood were paid for with five tin cups of sugar and three of coffee-value at St. Louis about twenty-five cents."

They began to meet with buffalo about the mouth of the James River, in South Dakota, on May 20; the ground, said Audubon, was literally covered with their tracks, and the bushes with their hair. On the same day they discovered "Meadow Larks whose songs and single notes were quite different from those of the Eastern States," and this proved to be the first notice of the Western Meadow Lark, which later appeared as the Sturnella neglecta in the small edition of his Birds of America, then in course of publication.

Audubon's opinion of the Indian was modified considerably after having seen him in the western wilderness, and his confidence in George Catlin's descriptions was completely shattered; "His book," he said, "must, after all, be .altogether a humbug. Poor devil! I pity him from the bottom of my soul; had he studied, and kept up to the old French proverb that says, 'Bon Renommé vaut mieux que ceinture doré,' he might have become an honest man-the quintessence of God's works."

After forty-eight days and seven hours out of St. Louis, on the 12th of June, they reached Fort Union, at the mouth of the Yellowstone, where the Omega left them and returned down river. The country proved so interesting that the naturalist remained two months at 
the fort, where he occupied the room which had been used by Maximilian, Prince of Neuwied, when traveling through the western parts of America ten years before; here Audubon made many drawings. Buffalo were abundant on all sides, and a favorite occupation was shooting wolves from the ramparts of the fort. On June 18 they killed two antelope and two deer before noon, and "immediately after dinner," he said, "the head of the old male was cut off, and I went to work outlining it; first small, with the camera lucida, and then by squares." On the 30th he wrote: "I began drawing at five this morning, and worked almost without cessation till after three, when becoming fatigued for want of practice, I took a short walk, regretting that I could no longer draw twelve or fourteen hours without a pause, or thought of weariness."

On the 15th of July they started up the shore of the Yellowstone in a cart. The party soon had had enough of buffalo hunting, and on one day the naturalist was nearly speared by a charging bull that had been wounded. "What a terrible destruction of life," he says, "as it were for nothing, or next to it, as the tongues only were brought in, and the flesh of these fine animals was left to beasts and birds of prey, or to rot on the spots where they fell. The prairies are literally covered with the skulls of the victims, and the roads the Buffalo make in crossing the prairies have all the appearance of heavy wagon tracks." Foreseeing the departure of the buffalo, he wrote:

One can hardly concelve how it happens, notwithstanding these many deaths and the immense numbers that are murdered almost daily on these boundless wastes called prairies, besides the hosts that are drowned in the freshets, and the hun- 
dreds of young calves who die in early spring, so many are yet to be found. Daily we see so many that we hardly notice them more than the cattle in our pastures about our homes. But this cannot last; even now there is a perceptible difference in the size of the herds, and before many years the Buffalo, like the Great Auk, will have disappeared.

On the 9th of August he added: "I have scarcely done anything but write this day, and my memorandum books are now crowded with sketches, measurements, and descriptions." Those who maintain that a "howling wilderness" is a place that never howls, should read his note for August 19: "Wolves howling, and bulls roaring, just like the long continued roll of a hundred drums"; or this for the 21st: "Buffaloes all over the bars and prairies, and many swimming; the roaring can be heard for miles."

At Fort Union they built a Mackinaw barge forty feet long, which they christened the "Union," and on the 16th of August they started for St. Louis, which was reached in safety on the 19 th of October. There they unloaded, and "sent all things to Nicholas Berthoud's warehouse." "Reached home," said Audubon, "at 3 p. m., November 6 th, 1843, and thank God, found all my family quite well."

When Audubon was returning by the canal route from Pittsburgh to Philadelphia, he was sought out by a young traveler, who afterwards related the following incident. ${ }^{6}$ The naturalist, he was told, was under "a huge pile of green blankets and fur," which he had already noticed on one of the benches, and had taken for the fat pile of some western trader. Having waived

- Charles Winterfield (Bibl. No. 149), The American Review, vol. i (1845); see also Charles W. Webber, Romance of Natural History (Bibl. No. 173) (1852). 
his choice of a berth in Audubon's favor, he observed that "the green bale stirred a little,-half turned upon its narrow resting place, and after a while sat erect, and showed us, to our no small surprise, that a man was inside of it. A patriarchal beard fell white and wavy down his breast; a pair of hawk-like eyes glanced sharply out of a fuzzy shroud of cap and collar." When this stranger, drawn by a sense of irrepressible curiosity, had ventured near enough to recognize the "noble Roman countenance" thus obscured, he saw that it was Audubon in his wilderness dress; he was "hale and erect, with sixty winters upon his shoulders, and like one of his old eagles, feathered to the heel." Audubon's conversation, said this writer, was impulsive and fragmentary, but he showed him with pleasure some of his original drawings of animals, as well as a living collection of foxes, badgers and Rocky Mountain deer, which he was bringing home.

To follow this narrator further:

The confinement we were subjected to on board the canalboat was very tiresome to his habits of freedom. We used to get ashore and walk for hours along the tow-path ahead of the boat; and I observed with astonishment that, though over sixty, he could walk us down with ease. . . . His physical energies seemed to be entirely unimpaired. . . . Another striking evidence of this he gave us. A number of us were standing grouped around him on the top of the hoat, one clear sunshiny morning; we were at the time passing through a broken and very picturesque region; his keen eyes, with an abstracted, intense expression, peculiar to them, were glancing over the scenery we were gliding through, when suddenly he pointed with his finger towards the fence of a field, about two hundred yards off. "See! Yonder is a Fox Squirrel, running along the top rail. It is not often I have seen them in Pennsylvania." Now 
his power of vision must have been singularly acute, to have distinguished that it was a Fox Squirrel; for only one other person ... detected the creature at all.

The second Mrs. Victor G. Audubon ${ }^{7}$ said that on the day the naturalist returned, "the whole family, with his old friend, Captain Cummings, were on the piazza waiting for the carriage to come from Harlem ... He had on a green blanket coat with fur collar and cuffs; his hair and beard were very long, and he made a fine striking appearance. In this dress his son John painted his portrait." 8 This interesting portrait, which is still in possession of the family, and which is reproduced by his granddaughter in the work from which we have just quoted, shows a man whose apparent age, as suggested by his flowing white hair and grayish white beard, overshoots the clearer testimony of his smooth face and bright eye; as already noticed, Audubon had not then attained his sixtieth year.

Upon his return at this time Audubon is said to have been mistaken for a Dunker, or member of a sect of Quakers noted for their ample beards. On November 29 Bachman wrote: "I am glad to hear that your great beard is now cut off. I pictured you to myself, as I saw you in my home, when you came from Florida, via Savannah. You jumped down from the top of the stage. Your beard, two months old, was as gray as a Badger's. I think a grizzly-bear, forty-seven years old, would have claimed you as 'par nobile fratrum.' " Bachman was apparently disturbed about Audubon's personal habits at this time, for he added in the letter just quoted: "I am a teatotaler. I drink no roine, and do not

'See Vol. II, p. 294.

${ }^{8}$ See Maria R. Audubon, op. cit., vol. ii, Note on pp. 175-6. 
use snuff. I hope that you are able to say the same." 9

Spencer Baird wrote to Audubon from Washington, November 24, 1843, to congratulate him upon the safe return of his western party, saying: "From time to time short notices of your whereabouts and doings appeared in the newspaper and a thousand times I wished that the fears of my friends had not prevented me from accompanying you to the scenes of action." Audubon thought that he might well regret the difficulties that had stood in his way; in replying he said that he had seen "not one Rattlesnake and heard not a Word of bilious fever, or [experienced] anything more troublesome than Moschitoes and of these by no means many"; they had brought home a Swift Fox, an American Badger, and a live Deer, which they thought might prove to be new, fifteen new birds, as well as a certain number of quadrupeds, besides "many of the Birds procured on the Western side of the Big Rocky Hills by Nuttall and Townsend." He felt that much still remained to be done, his only regret being that he was not what he "was 25 Years ago, Strong and Active, for willing he was as much as ever."

In 1844 Audubon brought to a close his octavo edition of the Birds by adding seventeen species, eleven of which were new and represented his discoveries on the Upper Missouri of the previous year. The 500th plate, and last of the series which marked the end of Audubon's life-long labors in ornithology, was dedicated to "Baird's Bunting," Emberiza bairdii. "If a trace of sentiment be permissible in bibliography," said Elliott

'At the close of the Civil War, Bachman wrote to a friend: "I had been a snuff-taker for forty years, and I had tried three times to wean myself from the vice. I have done it effectually now. ..." 
Coues, ${ }^{10}$ "I should say that the completion of that splendid series of plates with the name bairdii was significant; the glorious Audubonian sun had set indeed, but in the dedicating of the species to his young friend Spencer F. Baird the scepter was handed to one who was to wield it with a force that no other ornithologist of America has ever exercised."

${ }^{10}$ Bibliographical Appendix to Birds of the Colorado Valley (Bibl. No. 181). 


\section{CHAPTER XXXV}

\section{FINAL WORK DAYS}

Painting the Quadrupeds-Assistance of Bachman and Audubon's sonsCopper plates of the Birds go through the fire in New York-Audubon a spectator at the ruins-Bachman's ultimatum-Success of the illustrations of the Quadrupeds-Bachman's letterpress-Recommendation of Baird-John W. Audubon in London-Bachman's assistants-His life and labors-Decline of Audubon's powers-Dr. Brewer's visit-Audubon's last letters-His death at "Minnie's Land."

After 1844 Audubon's remaining energies were devoted exclusively to his work on the Quadrupeds, in which it is necessary to discriminate between the large folio of illustrations, which began to appear, in parts, as early as 1842 and which was completed in 1846; the text, of which he lived to see but one volume finished; and lastly, the first and only composite edition of both text and plates, which was published by Victor Audubon in 1854. ${ }^{1}$ This series of works, as already noticed, was produced in collaboration with the Reverend John Bachman, of Charleston, South Carolina; Bachman assumed entire responsibility for the text, but owing to his comparative isolation from large libraries, and to the demands of professional duties, he depended on the Audubons to supply him with specimens and books.

Honest John Bachman, whose motto was, "Nature, Truth, and no Humbug," was suffering sadly, he said, from lack of tools, when he wrote to Victor Audubon in November, 1844: ${ }^{2}$

${ }^{1}$ See Bibliography, Nos. 5-7. 191).

'See C. L. Bachman, John Bachman, D.D., LL.D., Ph.D. (Bibl. No. 
The books are to be found in New York and Philadelphia, but are expensive. I would not have you buy them; but could you not copy for me such articles as we need?

I enclose my plan. I wish always, a month before the time, that you would give me notice of the species you intend to put into the hands of the engraver, and send me, at the same time, the specimen. I cannot describe without it; I will guess at nothing.

I find the labor greater than I expected, and fear that I may break down and, therefore, cry in time, "Help me Cassius or I sink!" Writing descriptions is slow and fatiguing work. I cannot, in the careful manner that I am doing them write more than three in a week. My son-in-law, Haskell, has copied forty-two closely written pages for me. I cannot shorten the articles, many of them $I$ ought rather to lengthen. With patience and the help of all, I hope, however, to get onthe work may be lighter as we proceed.

The following is my daily practice: I am up at 4 A. M., and work till breakfast, and recently, when parochial duties would permit, have kept on until 3 P. M.

The brush of my old friend, Audubon, is a truth-teller. I regard his drawings as the best in the world. Let us be very careful to correct any errors of description that have crept in on the plates-I see a few in the lettering-they can be corrected in the letter-press; and let us be so cautious as to have nothing in the future to correct. There is but one principle on which a just man can act; that is, always to seek the truth and to abide by it.

\section{Bachman wrote again on the 29th of that month:}

About the little mouse-I cannot see a needle in a haystack; or give it a name without knowing what it is. Friend, descriptions cannot be written, as a man works at making Jews-harps - so many a dozen in a given time. My credit, as well as your father's, is so deeply concerned, that $I$ will not publish a day before I am ready. ... 


\section{FINAL WORK DAYS}

I have such confidence in you, that I believe that you will do all that I wish. In doing this, however, you will have your hands full. Mine are so-God knows! Will not my old friend, Audubon, wake up, and work as he used to do, when we banged at the Herons and the fresh water Marsh-hens?

Bachman explained that he was the "schoolmaster," and when the boys were a little lazy, he would have to apply the whip.

In March, 1844, Spencer Baird sent Audubon a live Pennant's Marten or Fisher, a rather rare animal even at that time, and now all but extinct. Said Baird: ${ }^{3}$

It was found in company with an older one, in Peter's mountain, six miles above Harrisburg about five weeks ago. After a most desperate resistance the old one was killed, having beaten off a large pack of dogs, to whose assistance the hunters were obliged to run. This individual ran up a tree, and being stoned by the men, jumped off to a distance of forty feet! when being a little stunned by the leap they ran up quickly and threw their coats over it, and then secured it. The old one measured three feet and a half from nose to end of tail, and was about one third larger than this. . . . It seems to be in very good health, and is without exception the most unmitigatedly savage beast I ever saw. The Royal Bengal Tiger, or the Laughing Hyena are neither of them circumstances to it.

Audubon used this marten as the model for his illustration of the species (shown in natural size, Plate xli of the Quadrupeds); in noticing its habits later, he said: ${ }^{4}$

${ }^{3}$ See Ruthven Deane (Bibl. No. 51), The $A u k$, vol. xxiv (1907). To Mr. Deane I am indebted for Audubon's copy of a letter to John Bachman, soon to follow; this was written on several blank sheets at the end of his "Copy of my Journal from Fort Union homeward. Commencing (Sunday) Aug. $16^{\text {th }}$ (1843) at 12 o'clock, the moment of our departure."

The Viviparous Quadrupeds of North America (Bibl. No. 6), vol. i, p. 312 (London, 1847). 
We kept this individual alive for some days, feeding it on raw meat, pieces of chicken, and now and then a bird. It was voracious, and very spiteful, growling, snarling and spitting when approached, but did not appear to suffer much uneasiness from being held in captivity, as, like many other predacious quadrupeds it grew fat, being better supplied with food than when it had been obliged to cater for itself in the woods.

Baird also tried to secure for Audubon the "farfamed catamount" alive, which, from stories related by hunters, he thought might be different from the young of the panther or puma, and also a specimen of the true black fox in the flesh; though unsuccessful in either quest, his efficient aid was greatly appreciated by his friend. In February, 1845, Baird paid a visit to the Audubons at their Hudson River home, where he was warmly received; as his biographer relates, ${ }^{5}$ upon leaving he was invited to select any duplicate bird skins he desired from the naturalist's collection, then at John G. Bell's taxidermist shop in New York; he accepted this generous offer, and chose about forty specimens.

It is evident that some trouble-maker had disturbed the serenity of John Bachman's mind when the following interesting letter was written by Audubon to balm the feelings of his old friend. It is evident that Audubon at this time expected to collaborate in the letterpress of their work, but that plan, according to Bachman's own statement, was never carried out:

\section{Audubon to John Bachman}

\section{MY DEAR FRIEND}

[MINNIE's LAND] Jan. 8, 1845.

Never have I been so much astonished as I have been at reading your letter to Victor, and to which I feel myself bound to answer at once.

William H. Dall, Spencer Fullerton Baird, a Biography (Bibl. No. 52), p. 121. 


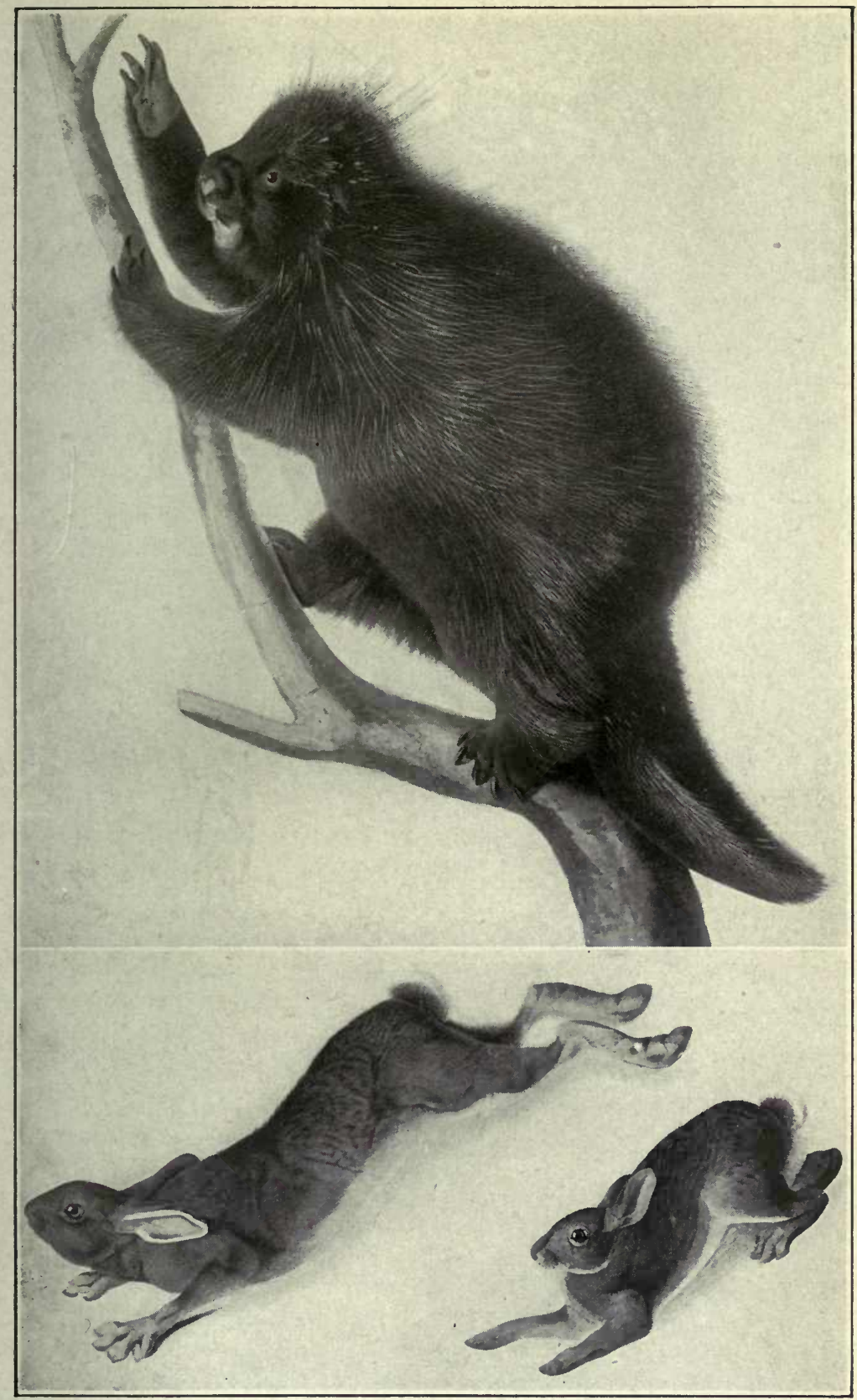

DRAWINGS FOR "THE VIVIPAROUS QUADRUPEDS OF NORTH AMERICA": ABOVE, AMERICAN PORCUPINE, DATED "NFW YORK, MARCH 6, 1842," AND PUBLISHED IN 1844; BELOW, RABBITS.

After the originals in water color in possession of the American Museum of Natural History, New York.

Published by courtesy of the American Museum of Natural History. 

In the first place you must have been most unmercifully misled by the "mutual friend" of whom you speak, when saying that through that individual you did understand that I never used your name as a coadjutor in the work, which is now publishing on the Quadrupeds of North America under the names of both I and you - Why you should have taken such a report or saying as truth is actually beyond my most remote thought, and again, why did you not long ago, write to me at once on this mysterious subject.

But to put an end to all this stuff, let me assure you that nothing of the kind has ever taken place, and this I could well prove by upwards of one hundred of our last subscribers, all of whom would be ready to testify that before receiving their names on my list, I always mentioned your name to each of them, and many that know you were glad that $I$ had so good and so learned a man at my elbow-I should amazingly be glad to know who the "mutual friend" is, as I think I could give him a lesson on propriety, being a mutual friend, that would serve that kind gentleman for the residue of his life-But enough of this, and all that I am sorry for is that you should not have answered "my short letters," in some of which I particularly requested you to forward me a fine black bear and one or two wolves, by which you would have saved me fully fifty dollars as I have had to pay sixty dollars for two of these vile rascals, and two hundred dollars for a pair of Elks. besides paying the highest of prices to draw other animals-

Now my friend I wish you would set in real earnest, and whenever it is convenient to you in preparing the letter-press for our work. I have made a beginning and have written Ten articles already in days, to wit all the plates of $N^{\circ} 1$, and the first of $\mathrm{N}^{\circ} 2$ which are as follows-

Lynx Rufus-Wild-Cat

Arctomys monax-Maryland Marmot

Lepus Townsendii

Neotoma Floridana

Sciurus Richardsonii

Canis (Vulpes) fulvus 


\section{The Beaver \\ The history of the Bison 28 pages \\ and Fiber Zybethicus (muskrat) 12 pages, \\ Tamias quadrivittatus}

This will shew you that I have not been very Idle since I began and I should like to know from you, whether you would like to see what I have said of these, as if you do, I will have them copied as soon as I receive your letter, and will forward the whole, and the additional written in the interim, at the same time. I have a beautiful drawing of a fine male moose, that of the Elk is already engraved, and next week we will forward to the engraver no less than five or six drawings of the best quality. by the way I am sorry that you should look upon the Texan Skunk as a bad figure. The animal is an ungraceful one in its Singular Colouring, but it is nevertheless quite true to nature, with all its specific characters to a $T$.

Victor wrote to you that I was anxious to have your opinion about the Title page and I hope you will send me your ideas forthwith on that subject. I send you now by mail a long article about our work which I conceive and hope will prove to you that the "mutual friend" knew but very little of my feelings or actions or sayings as regards you-

I really $\&$ most truly regret that you should have been put out, and mis-led about this our work by a third party, who must to say the least of it [have] abused your credulity to the very extreme.

However, the sooner forgotten, the sooner mended. it is with deeply felt regret from every one of my Family that we read the account in your letter of the condition of your dear wife, but hope that she will accompany you early next spring to visit our humble but comfortable residence. Now do Come! Present our joint regards to every one of your family, and believe me when I say that none will ever feel more delighted than I, to hear of the welfare of the beautiful "Rabbit" -

And now that I am exceedingly fatigued, having been writing for upwards of seven hours, I will wish you good night \& all the blessings that God may grant to [the] good man and 
to every member of his family-Do not forget me near your Sweet heart.

Ycur ever faithfully attached \&

Sincere friend

$$
\text { J. J. A. }
$$

In July, 1845, a destructive fire devastated a large section of the city of New York, including the warehouse in which the copperplates of Audubon's Birds were stored; many believed that the plates had been ruined, and one of these was the writer who after witnessing the event gave the following dramatic account: ${ }^{6}$

But who had lost most of all that pale crowd that hung like ghosts around the scene, and gazed with watery eyes, and blue compressed lips, over the ruin? An erect old man, with long white hair, glanced his strong bright eye as coldly over the glowing, smoking desolation, as an eagle would, who watched the sunrise chasing mists up from the valley. J. J. Audubon looks over the grave of the labor of forty years!

The Plates of the Birds of America are buried beneath those smoldering piles! Ye money changers dare not break the stillness with a sob, though the last cent of your sordid hoards be gone!... go away! Ye have lost nothing! . . . Yet that dauntless old man is not dismayed; he and Fate knew each other's faces in battle long ago. Let those who know how to love and venerate such labors - to sympathize with such grievous calamities, exhibit it in their prompt patronage of the new work now issuing-The Quadrupeds of America-and in the care which shall be taken to preserve the volumes of the Plates of the Birds, now in existence- the value of which will be fivefold increased!

When Baird heard the untoward news, he wrote from Carlisle, August 4, 1845: "It is with sincerest re-

- Charles Winterfield (Bibl. No. 150), The American Review, vol. ii (1845). 


\section{AUDUBON, THE NATURALIST}

gret that I see by the papers that your copper plates were injured or perhaps ruined by the fire which occurred a few weeks ago. Various reports are circulated respecting your loss, and among so many contradictory ones it is difficult to get at the truth of the case. Might I ask you to let me know the truth of the matter." In a postscript to this letter he added: "I forgot to say that I have been elected professor of Natural History in Dickinson College. The situation is entirely nominal, nothing to do \& no salary whatever." Audubon replied promptly on the 7th of August: ${ }^{7}$ "You have been too well-informed about the plates of our large work. They have indeed passed through the great fire of the $19 \mathrm{ul}^{\circ}$; but we are now engaged in trying to restore them to their wonted former existence; although a few of them will have to be reingraved for use, if ever that work is republished in its original size at all."

Bachman, who paid a long visit to the Audubons in the late summer or early autumn of 1845, said that while he was at "Minnie's Land," Audubon painted "Le Conte's Pine Mouse" with his usual facility and skill, but he detected a change in his mental powers. For a long time Bachman had complained of the want of books, which the younger Audubons failed to supply, and of lack of specimens, which no doubt their father wished to retain for use in his own studies, until at length his patience was gone and he tried another form of appeal. The following letter ${ }^{8}$ to their mutual friend, Edward Harris, shows that he was then determined to throw up the responsibility which had been assumed in the Quadrupeds unless what he regarded as "reasonable requests" were complied with forthwith:

William H. Dall, op. cit., p. 124.

- Jeanes MSS. See Note, Vol. I, p. 180. 


\section{John Bachman to Edward Harris}

Cifarleston, Decem. 24, 1845.

Friend Harris, you can be of service to me, to the Audubons $\&$ the cause of science. I will tell you how.

I find the Audubons are not aware of what is wanted in the publication of the Quadrupeds. All they care about is to get out a No. of engravings in two months. They have not sent me one single book out of a list of $100 \mathrm{I}$ gave them and only 6 lines copied from a book after having written for them for 4 years. When he published his birds he collected hundreds of thousands of specimens. In his Quadrupeds-tell it not in Gath-He never collected or sent me one skin from New York to Louisiana along the whole of the Atlantic States. Now he is clamorous for the letter press - on many of the Quadrupeds he has not sent me one line $\&$ and on others he has omitted even the geographical range-I know nothing of what he did in the West having never received his journal \& not twenty lines on the subject. I am to write a book without the information he promised to give-without books of reference \& above all what is a sine qua non to me without specimens. In the meantime my name is attached to the book, and the public look to us to settle our American species, and alas I have not the materials to do so.

Now this you can do for me. I am willing to write every description and every line of the book. I do it without fee or reward. But-1. Books of reference or copies of them he must obtain. 2. He must publish no species without my approbation. He has made some sad mistakes already. 3. He must procure such information as I shall write for. 4. He must send some person-say when John returns-to make a tour for collecting specimens through the states of the reest especially. I find the smaller Rodentia differing every 600 miles. Richardson's species differ from those of New York-ours are once more different from those of N. Y. Leib [?] found a number of new species in Illinois. The New Orleans squirrels differ from ours-California once more new. Now on this last par- 
ticular - the necessity of giving me specimens to describe from I wish you to speak to Audubon. I cannot consent to impose on the public. I cannot settle the species without specimens. [Tell] him what I have written and [of what I have] complained. Show him this letter if you should [think] it will accomplish the end. I shall soon have the volume finished as well as I am able from the scanty materials with which I am furnished. Then they will be clamorous for the second volume. Now I do not like to make any threats, but if my reasonable requests are not complied with I have made up my mind not to write another line at the end of the first volume. I have not made up my mind hastily. It is the result of four years remonstrance, mortification, and disappointment. Once and for nearly a year I gave up the matter in hopeless despair. I again resumed it on the solemn promise of Victor to do all I wished. Three months have since gone round and not one book sent-only ten lines copied-and a constant clamor for the letter press. But I am called off.

If Audubon was remiss in supplying the necessary materials, it is possible that Bachman, in turn, may have failed to appreciate the load which his friend's shoulders had carried for the five years then past. To Bachman specimens and books were, of course, absolutely essential, but Audubon needed them also, as well as subscribers and the large sums of money necessary to keep his great enterprises in orderly movement. At all events, Bachman's ultimatum brought immediate results, and it might not be wide of the mark to affirm that to the tactful Harris we virtually owe the completion of that admirable work, The Viviparous Quadrupeds of North America. It should be noticed that at the time the complaining letter was sent, John W. Audubon was in Texas, engaged in making collections, though, as it proved, with little success; Victor searched the country 
for the needed books, and his father's Missouri River journal was despatched to Charleston, without delay.

On New Year's Day, 1846, Bachman wrote to his friend:

As I do not like to disappoint you in anything, I send you one of the articles. It is about a fair sample of the whole. . . . I try to incorporate as much as I can of your own, but, in most cases, your notes have come too late.

You see how plain Haskell writes: I should think that by this time, he has copied three hundred pages as correctly as the inclosed.

\section{In his letter of March 6 he said:}

For the last four nights, I have been reading your journal. I am much interested, though I find less about the quadrupeds than I expected. The narratives are particularly spirited, and often instructive, as well as amusing. All that you write on the spot, I can depend on, but I never trust to the memory of others, any more than to my own. . . .

To return to your Journal. I am afraid that the shadows of the Elk, Buffalo, and Bighorn hid the little Marmots, Squirrels and Jumping Mice. I wish you had engaged some of the hunters to set traps. I should like to get the Rabbit that led you so weary a chase. Write to $S^{9}{ }^{9}$ and find out some way of getting - not his princess brain-eating, horse-straddling squaw,

?For "C," meaning Alexander Culbertson, a young Englishman, famous rider and shot, then in charge of Fort Union at the mouth of the Yellowstone. Audubon, with the assistance of Sprague, painted his portrait and that of his wife, a Blackfoot Indian princess, who also was noted for her skill in horsemanship. "I lost the head of my first [buffalo] bull head," said Audubon, "because I forgot to tell Mrs. Culbertson that I wished to save it, and the princess had its skull broken open to enjoy its brains. Handsome, and really courteous and refined in many ways, I cannot reconcile myself to the fact that she partakes of raw animal food, with such evident relish." (Maria R. Audubon, Audubon and his Journals, vol. ii, p. 111). p. 208.

For previous and following extracts, see C. L. Bachman, op. cit., 
but what is better than such a specimen from the Blackfoot country-1st. The Skunk; 2nd, Hares, in Winter colors; and $3 r d$, the Rabbit that you chased. In your Journal your descriptions of Buffalo hunts are first rate. I don't like my article on the "Beaver"; I shall have to write it over again. If I could only borrow Temminck's large work. Every library here is open to me, and you would be astonished to see the number of books in my own library; but the scientific works of close comparison are not among them. I had written letter after letter, but might have saved ten dollars postage.

Audubon wrote to Baird on February 2, 1846, to remind him of the Catamount, which was thought not to be "the Cougar," and of the Black Fox: "for the latter," he said, "I do give you my word that I would willingly pay you Twenty Dollars by a draft upon us at Sight." In another letter from "Minnie's Land, N. Y.," of March 14, he said: ${ }^{10}$

Could you procure a black and a Silver Fox for us, we will be willing to give a good price for either in the flesh, and preserved in common New England Rum, and forwarded by express to 78 John St, N.Y.

We expect to see John at home in about Six or Seven weeks. He has made a very poor Journey of this one, and will have to go to Europe this summer, I have no doubt.

Concerning his son's journey to Texas, Audubon had written Spencer Baird, September 30, 1845: ${ }^{11}$

My son John will leave this for the West and South-West, as far as the confines of Texas, about the last of next month, and intends being absent until the first of March. Would you like to go with him provided you can pay your own expenses?

${ }^{10}$ See William H. Dall, op. cit., pp. 130-2.

${ }^{11}$ Ibid., p. 126. 
He will take one of our Servant men along to help him in the procuring of Quadrupeds and Birds, of which he hopes to procure some, if not a good number of new Species.

As Baird gave no reply, Audubon sat down on Christmas Day, 1845, and wrote again to his young friend: ${ }^{12}$

I hope and trust that you were not offended at my letter, when I wrote you on the Subject of accompanying our son John to Texas where he is now I hope safe and sound, and I believe at Corpus Christi. . . .

... I have at last received a fine Red Fox from our Friend Ed. Harris, who although he did not kill it, obtained the Cunning Animal very shortly after its death. I have drawn it to the size of life, and I think made a good figure of it.

I have been drawing pretty constantly these last past weeks and have finished 6 plates for the Engravers. .... We are all hard at Work preparing the letterpress for the 1 st Vol. of the Quadrupeds, a copy of which I hope to send to you about the beginning of April.

Audubon's prediction in regard to his son was correct, and after John's return from Texas, in April, 1846, he started for England on June 10, with his wife and family; he remained in Europe until May, 1847, engaged, as his father said, "in making figures of those arctic animals, of which accessible specimens exist only in the museums of that quarter of the globe."

The Audubons, as we have seen, now tried to keep John Bachman better supplied, and in the spring of 1846 sent him several boxes of skins, with the urgent request that all which pertained to animals that had not been figured be returned as soon as possible. On March 13 Victor wrote that Temminck's monograph could not be found in all America, not in Boston, or Philadelphia, 
but that a copy would be ordered from Europe at once. In those days Charleston was farther removed in time from New York than California is now from Boston; two weeks was required for a letter of one naturalist to reach the other, and the difficulties of coöperation were correspondingly great. On May 31 Audubon acknowledged the return of the skins, but said: "Judge of my astonishment, when I could not find a single one of the small animals, Shrews, and Scalops argentatus, the latter of which I am anxious to draw at once."

The summer and autumn of 1846 bore heavily on John Bachman, subject as he then was to a "thousand calls and interruptions," and "bowed down, and almost distracted, with anxieties and grief." 13 But the first volume of the letterpress which had given him so much trouble was finished in November, and was published by Audubon at the close of this year. It was at once recognized as a standard and authoritative work, which was then without a competitor in America, and as Louis Agassiz affirmed, without an equal in Europe. At the time of its issue the twentieth number of the folio illustrations was nearly ready; the text itself had 271 subscribers, calling for 281 copies, ${ }^{14}$ though only the eastern cities had then been canvassed.

Early in 1846 Baird wrote to Audubon: ${ }^{15}$ "I have made drawings of the sculls of our quadrupeds which are at your service if you want them. They are Mink,

${ }^{13}$ Mrs. Harriet Bachman died in July, 1846, and almost immediately a daughter was stricken with a fatal disease; "It seizes," said the father, "with a deadly hold, weakens the cords of life; and only relinquishes its fatal grasp, when life is extinct." (See C. L. Bachman, op. cit.)

${ }^{14}$ New York City furnished (for vol. i) 82 subscribers, who took 86 copies; Philadelphia, 33; Boston, 27 (28 copies); and Baltimore, 15. In 1854 Victor Audubon obtained 129 subscribers for the second edition (published with reduced plates) in three days.

${ }^{16}$ For this and the following extract, see Ruthren Deane (Bibl. No. 51), loc. cit., p. 65. 


\title{
VIVIPAROUS QUADRUPEDS
}

\author{
o) \\ NORTH AMERICA.
}

B8

JOHA JAMES AUDUBON, F.R.S.. ETC. ETC.

$\triangle N D$

THE REV. JOHN BACHNAN, D.D. ETc ETc.

\author{
VOL. I.
}

LONDON:

WILEY AXD POTNAM

$\overline{1848 .}$

TITLE PAGE OF VOLUME I OF THE ENGLISH EDITION OF THE TEXT OF

"THE VIVIPAROUS QUADRUPEDS OF NORTH AMERICA." 


\section{Wild Cat, Ground Hog, Lepus Sylvaticus, Neotoma} Floridana and others. I have got a Camera Lucida now and intend trying to draw with it. Anything I can do for you in this way will be cheerfully done." When he wrote again, towards the close of this year, some important events had happened, as shown by this letter:

\section{Spencer Fullerton Baird to Audubon}

\section{Dear Mr. Audubon}

Caruste Nov. 4, 1846.

I have been intending to write for a long time, to find out how you all are at Minnie's Landing, and how yourself is particularly, but have put it off from time to time for various reasons. I can do so no longer, and must beg you to let me know these particulars.

Since my last visit to you, two pretty important events have happened to me. The first was getting married, the second, settling down steadily in my Professional chair. ${ }^{16} \mathrm{My}$ wife is the only daughter of Col. Churchill Inspector Gen. of the Army, now with Gen. Wool in Mexico. She suits me exactly, being as fond of birds \& snakes \& fishes etc. as myself. I have even given her a lesson or two in taxidermy.

My duties as professor consist in teaching Animal Physiology, Natural Theology \& Mathematics. My salary is small $\$ 400$ but I hope will be larger hereafter. I have to work hard, but that is good for me.

Please let me know how the quadrupeds get along. Is the first vol. published? How does John get along in England? What has become of his Texas birds?

Please to tell me the address of your friend Ayres. I have been collecting fishes for some weeks, and wish to corre-

${ }^{10}$ In the summer of 1846 Baird's nominal position in Dickinson College had been changed to an active one by his election to a professorship of chemistry and natural history, and his marriage had followed in August. The college had about one hundred students enrolled at that time, and the grammar, or preparatory, school attached to it, about half as many more. See Ruthven Deane (Bibl. No. 51), The Auk, vol. xxir, p. 65 (1907). 
spond \& exchange with him on this subject. I can send him a good many species.

Please give my love to all your kind family. My wife (to whom two years ago I gave a picture of yourself, as the most acceptable present) sends hers also, and desires exceedingly to see one to whom her husband owes so many obligations of every kind. Believe to be as ever

Yours most affectionately

Spencer F. Baird.

Audubon's immediate reply was as follows: ${ }^{17}$

Audubon to Spencer Fullerton Baird

Minniestand.

Nov. $8 t h, 1846$.

My dear Friend,

We were very happy to hear of your Success in obtaining a Professorship. I wish you had been more minute as to the amount of your Salary as I consider $400 \$$ as a very small sum. If you have not a house, fuel, and furniture, \&c \&c \&c to compensate for so small a sum, and having so much to perform for it. We are all glad that you have a good helpmate in the shape of a wife, and we would be very glad to have you under our roof, even now ; but as the winter is now fast approaching we hope to see you certainly some time next spring, or during the summer, as you know that then our place is worthy to reside at. The fishing is then Capital. The residence of our Friend, W. O. Ayers, is on Long Island, and I think that a letter addressed to him at Sag-Harbor, will be sure to be received by that good Friend of ours.

He will be glad to receive the collection of fishes which you have procured for him, and I know will be most happy to exchange for other fishes or subjects if you should desire any at his hands. Please to give your Dear Lady our best love, and congratulations on her having such a capitally perfect

${ }^{17}$ For this and the two following letters, see ibid., pp. 66-69. 
husband. We are all well at present. I have not done anything with the Birds which, indeed, my son Victor has sent to the Academy of Philadelphia. I suppose I need not look any more for a Black Fox in the flesh from you during the next winter.

Consider me always my Dear Friend,

Your most sincerely attached, John J. Audubon.

Should you procure a black fox, be sure to forward him uncut to our office New York 78 John Street. Adieu, and God bless both you and your Dear Wife.

This is a mistake, I brought them back, V. G. A:

The letter press will be ready in a few days. I will forward a Copy to you to Philada. from whence you can no doubt easily get it. I will join my Father, dear Mr. Baird, in congratulations, and in sincere wishes for your happiness \& welfare.

\section{Yours faithfully, \\ V. G. Audubon.}

Victor Audubon's gift of the volume was acknowledged by Baird on January 19, 1847, when he said:

I have been trying for some time past to find time for writing and thanking you for the copy of the Viviparous text. Never had mortal man such a feast as $I$ in turning over the pages and reading the interesting and copious accounts of the habits of animals, many of which were unknown to me beyond the name. I was exceedingly gratified by the kind terms I found myself mentioned throughout the book, more so than I deserve. Be assured that no effort of mine however humble shall be spared to assist in the perfecting a labor so stupendous and important as that in which you are engaged. Would that I could be of more substantial aid by sending half a dozen subscribers, I may do so yet, who knows. 
There was soon another matter of vital importance which Baird wished to announce to his friend, and, on February 8, he wrote Audubon:

Very much to my astonishment I received last Saturday a letter from Mr. Dana saying that he had written to Dr. Pickering that I would make a good curator of the Smithsonian institute, and advising me if I wished the place to write immediately to Prof. Henry and enclose my credentials. Now I would like the situation amazingly and write to ask you to make out a flaming recommendation for the place \& send me as soon as possible. Say what you please about qualification \&c. I would be obliged to you for the exertion of any personal influence you may have on the board of Regents. When there I would hope to be materially useful to you in your labors.

This was followed, on February 11, by a cordial letter from Audubon, in which he said:

I am quite convinced myself that no one can easily be found so well adapted for such a trust as yourself and if my testimoney as to your knowledge and high character and industry, and your zeal in seeking a perfect acquaintance with the various branches of Natural History, and all the scientific and literary pursuits which have heretofore occupied you, may be of any service, please present this note to the Honorable Board of Regents, who I trust will receive it as an evidence of my ardent desire for your success, the more readily as $I$ have the honor, I think, of knowing some of the Board personally.

Spencer Fullerton Baird's subsequent career, following his appointment as Assistant Secretary of the Smithsonian Institution in July, 1850, as successor to Professor Henry, its first Secretary, as the organizer of the United States National Museum and the Fish 
Commission, now the Bureau of Fisheries, as one of the ablest students of birds and fishes which the country has ever produced, as well as the friend of science and scientific men everywhere, is now well known, and has been ably set forth by his most recent biographer. ${ }^{18}$

John W. Audubon spent the winter of 1846-47 in London, where he was engaged in painting subjects for his father's work on the Quadrupeds. While he was

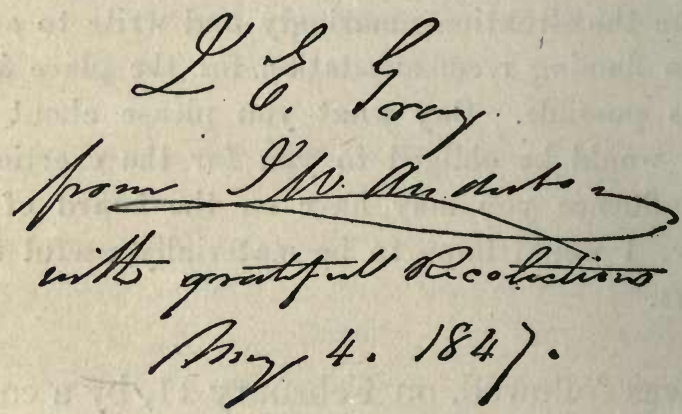

JOHN W. AUDUBON'S INSCRIPTION IN A COPY OF VOLUME I OF THE TEXT OF THE "QUADRUPED" (ENGLISH EDITION) PRESENTED TO JOHN E. GRAY.

there, arrangements were made for the publication in that city of the first volume of the letterpress; this appeared in May, 1847, ${ }^{19}$ closely following the American edition of the previous year, and it was the only European issue of the text of that work. At this time also John Audubon made the acquaintance of the distinguished zoölogist, John Edward Gray, then in charge of the great collections which were being brought together under his direction at the British Museum. Gray was asked to furnish descriptions of the animals which the younger Audubon had painted, but, as will appear from the following letter, he declined: ${ }^{20}$

${ }^{18}$ William H. Dall, op. cit., which see also for preceding extract.

${ }^{10}$ See Vol. II, p. 275; and Bibliography, No. 6.

${ }^{20}$ This hastily written note, possibly a duplicate of the one actually sent, was inserted in a copy of The Viviparous Quadrupeds of North 


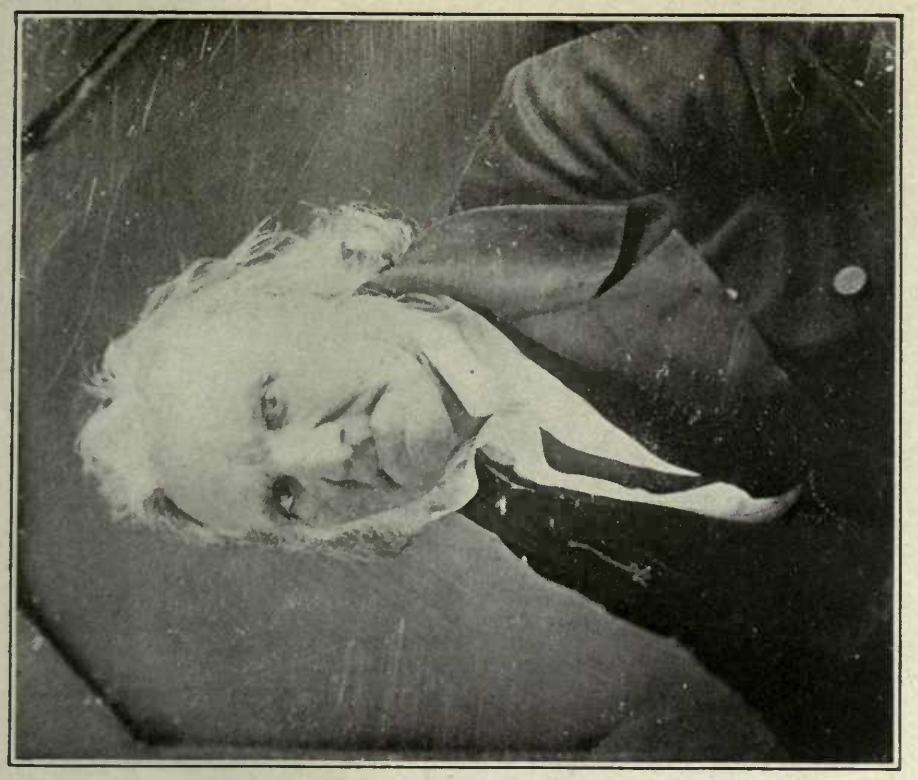

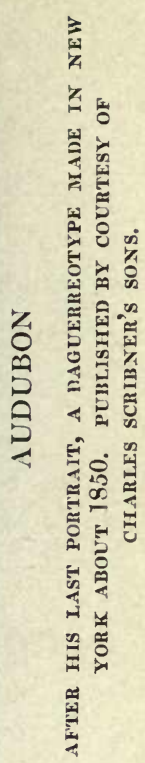

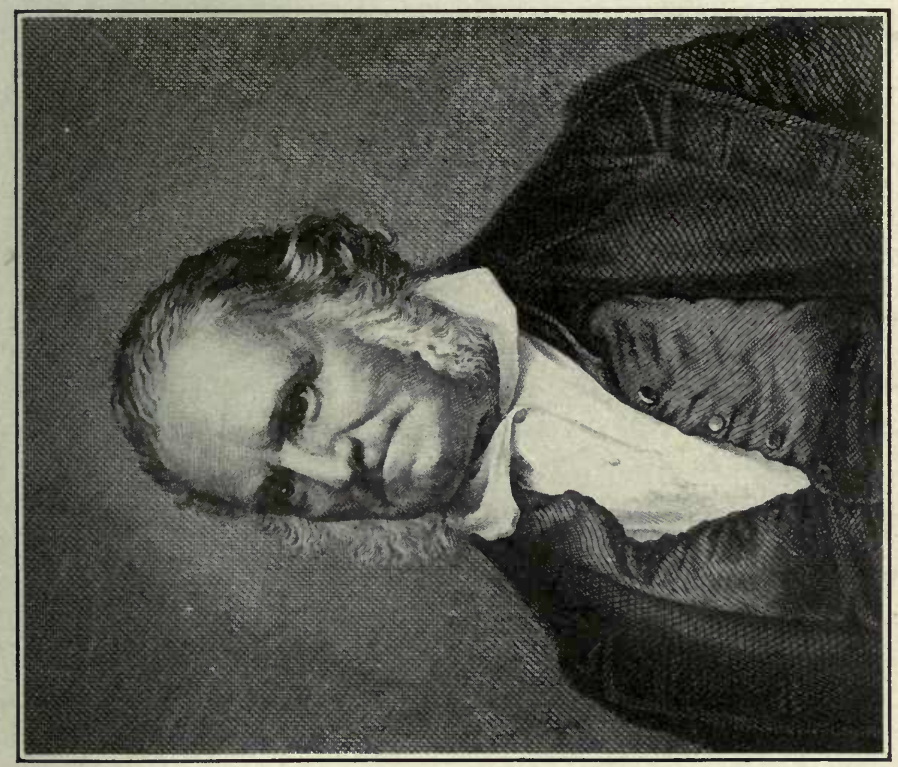

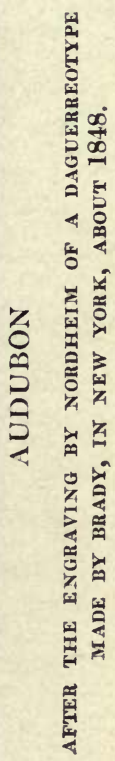





\section{John Edreard Gray to John Woodhouse Audubon}

4 May 1847

Brit. Museum

My DEAR Srr

I am very sorry that I am so occupied that I cannot undertake to furnish you with the descriptions of the American Mammalia which you have figured here but I think you will find that Dr Richardsons descriptions are so accurate and detailed that you had better copy them for the work than have more imperfect descriptions by a less experienced and minute describer.

at the same time should Dr Bachman on composing the Work want any note or the distinction between any two species or the description of any one wh have not contained in Richardson Work \& he will write to me I shall have great pleasure in immediately replying to his request-

Wishing you and your family a pleasant voyage believe me

Yours truly

J. E. GraY

Bachman was married in $\mathbf{1 8 4 9}$ to Maria Martin, ${ }^{21}$ his former wife's sister, who had aided Audubon in drawing the accessories of his large plates. While engaged upon the Quadrupeds, he wrote to Victor Audubon, from Madison Springs, Georgia, on June 30 of that year, as follows: ${ }^{22}$

I began working four hours a day, now I can work for twelve. I shall lessen the hours, should I find my strength fail-

America (vol. i, London, 1847) which I purchased in London, August, 1913, and which bore this inscription, in autograph, on the title:

\section{J. E. Gray.}

from $J$ W. Audubor

with grateful Recolections

May 4. 1847.

${ }^{21} \mathrm{Her}$ assistance to Audubon was recognized in his dedication to her of "Maria's Woodpecker," Picus martince (see Ornithological Biography vol. v, p. 181).

${ }^{22}$ See C. L. Bachman, op. cit., p. 270. 
Dear Siz,

In lookeng suer. my flater of and quactruffer Ifiud of hace ufte to to 16 flate 80 \& thay got ite 19 cupto q5 -

Dewo henaleorer

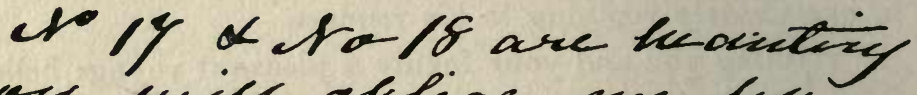
ypu usich ollige ne Ky sendeng then by the levot froven of to 90 melurese 4 oblije Ifotsoum

Saty yotare 1646

IETTER OF JOHN BACHMAN, NOVEMBER 7, 1846, ADDRESSED TO MR. GEORGE OATES, CHARLESTON, SOUTH CAROLINA. From the Jeanes MSS.

282 
ing. This is my tenth working-day. I have finished seventeen articles, and arranged notes for another. I have used as many of your notes as I could. Maria copies carefully. She lops off to the right and the left with your notes and mine: she corrects, criticizes, abuses, and praises us by turns. Your father's notes, copied from his journal, are valuable- they contain real information; some of the others are humbug and rigmarole; but you have done so well as to surprise us. . . .

I hope that if nothing untoward happens, the Second Volume will be finished in a month, and the Third Volume next winter.

About thirty years later, when Victor Audubon's sister-in-law ${ }^{23}$ was making a disposition of his literary effects, a bundle of manuscripts was saved and given to Mr. George Bird Grinnell. Included in it were a number of Audubon's letters, which are now reproduced, as well as a considerable section of the printer's copy of The Viviparous Quadrupeds of North America, Volume $\mathrm{I}$; this was in various handwritings, including little of Bachman's himself, much of Victor's and of John G. Bell's; a little of this copy also was made by the second Mrs. Bachman and by other and unknown hands, possibly those of one of Bachman's daughters and of his son-in-law, Reverend John Haskell, all of whom are known to have assisted in this labor.

When we recall the disadvantages under which $\mathrm{John}$ Bachman worked, it must be acknowledged that he was deserving of all the credit which he received. Born of Swiss and German stock at Rheinbeck, New York, in 1790, he clearly remembered walking in the mock funeral procession that was held in his village when the country was mourning the death of Washington in 1799.

${ }^{23}$ Miss Eliza Mallory, who in 1874 was living in the Victor Audubon house. 
From early boyhood he was an ardent enthusiast in the study of nature, at a time when such studies were generally frowned upon in country districts as not only idle but positively harmful. He trapped the beaver, and from the sale of its skins was able to make his first purchase of books on natural history. While a young man he became acquainted with Alexander Wilson and learned to know him well, having joined him in field excursions and collected birds for him in northern New York; on Wilson's recommendation he succeeded both him and his nephew, William Duncan, in the Elwood School, at Milestown, Pennsylvania, where he taught for a year. While there, a youth of barely fifteen, he was invited, no doubt through the influence of Wilson, to meet Alexander von Humboldt at a dinner given in honor of the great traveler at Philadelphia in 1804 . From a pastorate in Shagticoke, New York, Bachman in 1815 went to Charleston, South Carolina, where he presided over the Lutheran church for nearly sixty years, and became thoroughly identified with the South. Beloved as few men ever are in their community, he was widely honored for his attainments in natural science.

In an address on Humboldt, dictated by Bachman when in his eightieth year, and too feeble to deliver it himself, he alluded to the event noticed above to show "how scanty, in those days, was the material in natural science." Among the few naturalists who were present on the occasion of the dinner, which was held in Peale's Museum, were, he said: ${ }^{24}$

the two Bartrams, Wilson, the ornithologist, Lawson, his engraver, George Ord and a few others..... Few speeches were

${ }^{24}$ See C. L. Bachman, op. cit., p. 391. John Bachman died at Charleston, February 24, 1874. 
made and those were short-there was no formality. ... Humboldt was then, as he was afterwards, in every society, "the observed of all observers" ... I saw him every day during the few days he remained in Philadelphia. He inserted my name in his note-book, and for the last sixty years we corresponded at long intervals. . . . It would be very gratifying to me, and interesting to your societies, if I could have exhibited to you his autograph in some of his letters; but, alas! my whole library and all my collections in Natural History, the accumulation of the labors of a long life, were burnt by Sherman's vandal army, and, with the exception of a single letter, which, by accident, fell into the hands of another member of my family, I possess no memorials of one who condescended to speak of me as a friend.

As we have noticed, Audubon's large illustrations of the Quadrupeds were completed in 1846; this marked the ebb tide of his powers, and his son, John, who had painted nearly one-half of the originals of the large plates, like Victor, continued to aid Bachman in the prosecution of that work. The first number of this lithographic series was introduced by the common American wildcat, or Lynx rufus, in three-quarters natural size, followed by the proverbial ground hog, "Maryland marmot," or woodchuck, shown in both young and adult state, in the size of life. Plate No. 4 reproduced an exquisite drawing of four Florida rats climbing over a pine branch. Some of the elder Audubon's plates of squirrels are particularly fine and recall the best of his more famous bird pictures; the gray fox (No. 3, Plate xxi) is sniffing at a feather blown from a farmer's yard; in another drawing a rascally old black rat and its three young ones are robbing a hen's nest and breaking up the eggs; Hudson Bay squirrels reach after hazel nuts which hang in clusters from green boughs above; 
opossums, with sardonic grin, are making for the ripe, orange fruits of the persimmon, holding to the branch with their rat-like, coiled tails; the swift fox (Vulpes velox) sits on the ground, barking like a dog, with head up-turned, while the better known red fox (No. 18, Plate lxxxvii) struggles in an old-fashioned steel trap, the toothed jaws of which have gripped a paw above the heel, and you observe that his tail is where, in the circumstances, it is bound to be-between his legs. While many of these plates are of the highest degree of excellence, the colors are apt to be too vivid and the execution is far from uniform.

Thomas M. Brewer, a valued friend and correspondent, ${ }^{25}$ in response to an urgent request, "ere it be too late," paid a visit to the famous naturalist on the Fourth of July, 1846, of which he has given this record: ${ }^{26}$

I found him in a retreat well worthy of so true a lover of nature. It was a lovely spot, on a well-wooded point running out in the river. His dwelling was a large old-fashioned wooden house, from the veranda of which was a fine view, looking both up and down the stream, and around the dwelling were grouped several fine old forest trees of beech and oak. The grounds were well stocked with pets of various kinds, both birds and beasts, while his wild feathered favorites, hardly less confiding, had their nests over his very doorway. Through the grounds ran a small rivulet, over which was a picturesque rural bridge.

The patriarch ... had greatly changed since I had last seen him. He wore his hair longer, and it now hung in locks of snowy whiteness over his shoulders. His once piercing gray eyes, though still bright, had already begun to fail him. He could no longer paint with his wonted accuracy, and had at last, most reluctantly, been forced to surrender to his sons the task of completing his Quadrupeds of North America. Sur-

${ }^{25}$ See Vol. I, p. 150.

${ }^{2}$ See Bibliography, No. 79. 


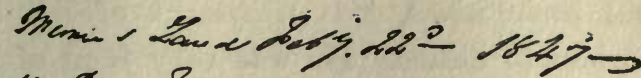

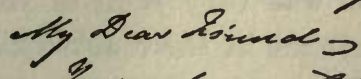

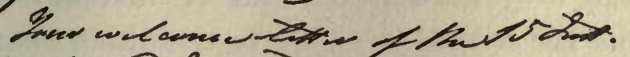

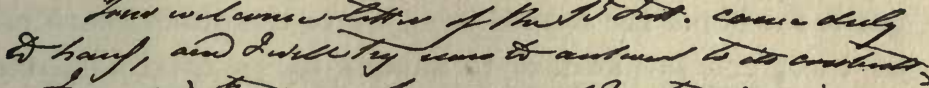

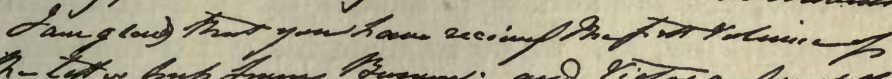

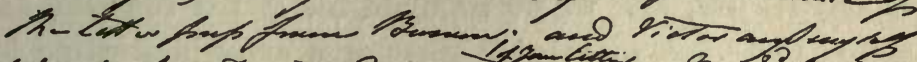

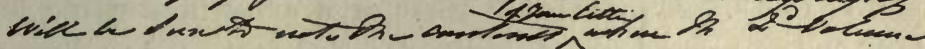

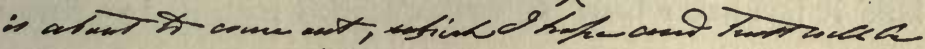
dima, tiene thin flate.

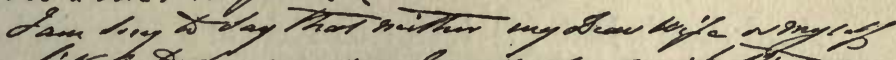

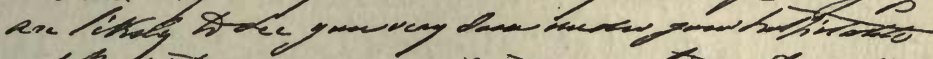

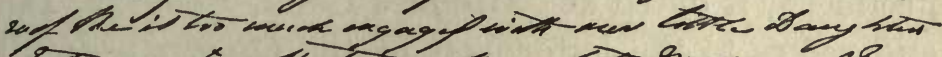

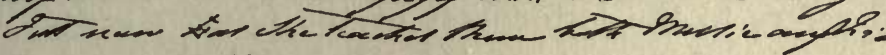
ency ocay fthements

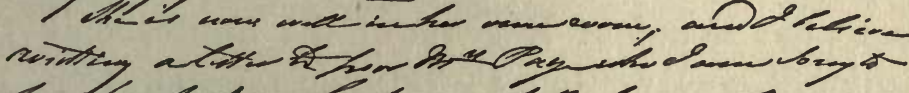

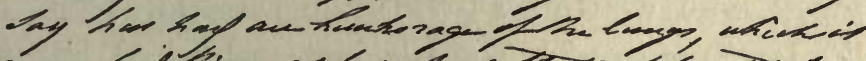

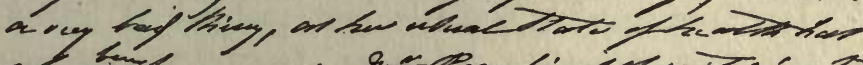

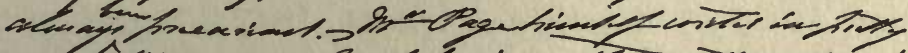

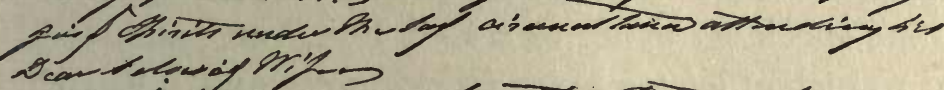

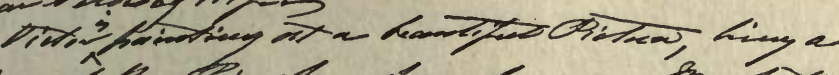

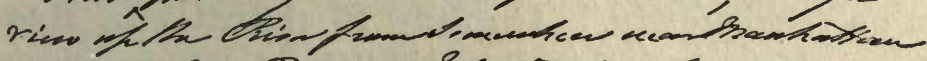

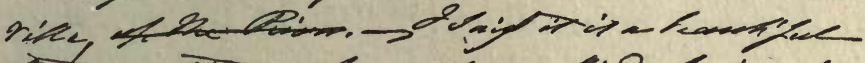

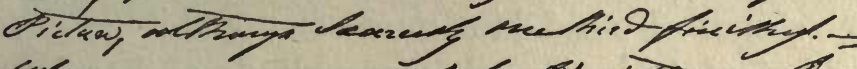

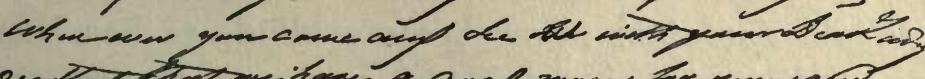

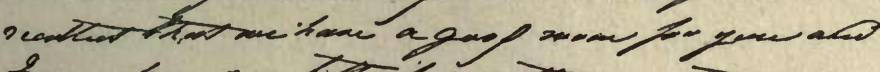

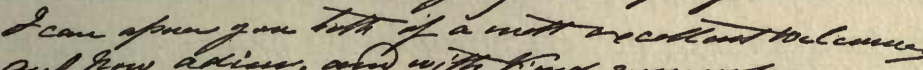

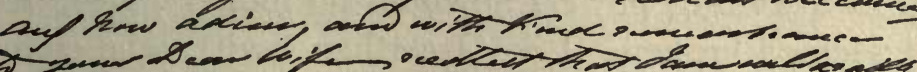

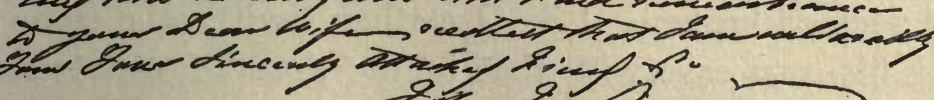

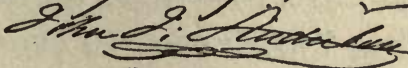
AUDUBON's LAST (?) IFTTER To EDWARD HARRIS, FEBRUARY 22, 1847.
From the Jeanes MSS. 
rounded by his large family, including his devoted wife, his two sons, and their wives, his enjoyment of life seemed to leave little to him to desire. He was very fond of the rising generation, and they were as devoted in their affectionate regards for him. He seemed to enjoy to the utmost each moment of time, content at last to submit to an inevitable and well earned leisure, and to throw upon his gifted sons his uncompleted tasks. A pleasanter scene or a more interesting household it has never been the writer's good fortune to witness.

Audubon's last (?) letter to Edward Harris, here reproduced, is dated at "Minnie's Land, Feby 22, 1487," and refers to the letterpress of the Quadrupeds. His last published letter to Baird, in which he recommended him to the Board of Regents of the Smithsonian Institution, ${ }^{27}$ was written at "Minnie's Land, Feb. 11, 1847." In Spencer F. Baird's last published letter ${ }^{28}$ to him, dated at "Carlisle April 24, 1847," he refers to "a fine specimen living of a Red Fox," and added: "If you want him let me know immediately and I will send him on immediately." On July 16 of that year Baird entered this note in his diary: "Went to Mr. Audubon's by stage. Found him much changed."

While Audubon never became blind, as has been erroneously stated, it troubled him to use glasses, and when from failing powers he could no longer paint, his heart seemed broken. Like Jonathan Swift, who compared his own case with that of the proud forest tree whose withering top showed to every passerby the first sign of decrepitude, so the mind of Audubon gave way. before his splendid physique utterly broke down.

Bachman, who visited his old friend in the spring of

${ }^{27}$ See Vol. II, p. 279.

${ }^{28}$ See Ruthven Deane, loc. cit., p. 70.

${ }^{20}$ See William H. Dall, op. cit., p. 155. 
1848, has given this picture of the naturalist's household in a letter ${ }^{30}$ from "Minnie's Land, May 11, 1848":

I found all well here, as far as health is concerned. Mrs. Audubon is straight as an arrow, and in fine health, but sadly worried. John has just come in from feeding his dogs. Audubon has heard his little song sung in French, and has gone to bed. Alas, my poor friend, Audubon, the outlines of his countenance and his form are there, but his noble mind is all in ruins.

The following letter was written by Victor Audubon to his father-in-law, John Bachman, before February 8,1849 , when his brother started on the ill-fated expedition to which he refers:

My brother will leave in a few days for California, he will be absent, perhaps for eighteen months.

This journey is undertaken with the hope that he may be able to get gold. What may be the result, God only knows. John will be accompanied by Col. H. L. Webb, as military leader; the party consists of about eighty picked men. One of Dr. Mayer's sons wished to go with John, but unluckily; his application came after the party was made up, so they could not take him.

I should like much to see you all, but now it will be impossible for me to go so far from home.

My dear old father is apparently comfortable, and enjoys his little notions; but requires constant care and attendance; the rest are well. Your granddaughters are growing finely, and are well educated; soon we shall call in a "Maitre de danse," to polish them up and improve their understanding.

I am just about to start for Washington, to get letters from the President for John and I will try and see the collection brought back by the exploring expedition, including the p. 274 .

${ }^{30}$ For this and the following letter, see C. L. Bachman, op. cit., 
famous Black-tail Deer. I am in a great bustle, the office is full of Californians.

The California party, which eventually consisted of nearly one hundred young men, sought to reach the goldfields by way of Texas, Mexico and Arizona; attacked by cholera in the valley of the Rio Grande and deserted by their leader, a remnant of the company chose in his stead young Audubon, who bravely conducted them to their destination. John Audubon returned in the following year, after thirteen of the members of the party and $\$ 27,000$ had been lost in the venture.

Like a patriarch of old, as a friend had once pictured him, Audubon passed the end of his days surrounded by loving and able retainers, who, like "ministers of state," were only too glad to execute his every wish. Distinguished and handsome in age, appearing to many older than he actually was, for years his snowy locks and benign countenance attracted every passer on the street, and for each he had a friendly look, word, or greeting, until in him were fulfilled the words of the Psalmist: "When thou art young thou goest whither thou willest, but when thou art old another shall lead thee, and thou shalt go whither thou willest not." On the 27th of January, 1851, Jean Jacques Fougère Audubon died, before attaining his sixty-seventh year, "as gently as a child composing himself for his beautiful sleep." 


\section{CHAPTER XXXVI}

\section{AFTERWORD: AUDUBON'S FAMILY IN AMERICA}

Bachman completes his text on the Quadrupeds-Victor Audubon's success in canvassing-John Woodhouse Audubon's family-New houses at "Minnie's Land"-Second octavo edition of the Birds-Victor Audubon's illness and death-Attempt to reissue The Birds of America in America-The residual stock of this imperfect edition-Death of John Woodhouse Audubon-His career and work as an artist and field collector-Mrs. Audubon resumes her old vocation-Fate of "Minnie's Land"-Death of Mrs. Audubon-Her share in her husband's fameStory written on Audubon's original drawings-Fate of the original copper plates of the Birds-A boy comes to the rescue-"Minnie's Land" today-The "Cave"-A real "Audubon Park."

After the death of the elder Audubon, his sons, under the leadership of Bachman, continued the work on the Quadrupeds until the third and last volume of the letterpress was completed in 1852. On March 13 of that year Bachman wrote to Edward Harris: ${ }^{1}$

Rejoice with me, the book is finished. I did not expect to have lived to complete it. But Victor Audubon came on, and I made him hold the pen, while I dictated with specimens and books before me, and we went on rapidly; we worked hard, and now we are at the end of our labors. I have, at last, prevailed on them to give the Bats. At the end of the work, I intend to give a synopsis and scientific arrangement of all our American species, including seals, whales and porpoises.

${ }^{1}$ See C. L. Bachman, John Bachman, D.D., LL.D., Ph.D. (Bibl. No. 191), p. 276. The suggestion made to Mr. Harris was adopted, which accounts for the six colored plates inserted in the third volume of the text; the "Large Work" referred to the folio plates with accompanying text, the "Small," to the first composite edition of both text and plates; see Bibliography, Nos. 5-7. 
This will be included in the letter-press of the Third Volume.

Here I will venture to consult you in regard to the publication of additional plates of species, not figured in the Large Work. A very small Arvicola and Shrews, we may not obtain, and they cannot be figured; but nearly all are within our reach. Some of the subscribers have bound up their plates, and there cannot be a sufficient number to make even half of another Volume. I propose, as all these figures will be contained in the Small Work, that they should be inserted in the letter-press of the Large Work, so that subscribers, by merely paying the cost of the small plates, would have the work complete-what do you think of this?

What do you think of Victor's obtaining one hundred and twenty-nine subscribers in about three days, and I think he will double the number next week; so, if the "Large Work" will not pay, the "Small" one, and this is large enough, is sure to do it.

When Victor was canvassing the South for the second or composite edition of this work, Bachman wrote to a friend in Savannah, on March 25, 1852: ${ }^{2}$

My son-in-law, Victor G. Audubon, is on a rapid visit to the South, and has a week or two to spare, which he is desirous of devoting to the obtaining of subscribers to the "American Quadrupeds." The Work (Miniature) will be complete in about thirty numbers, furnished monthly at $\$ 1.00$ per number.

The figures were made by the Audubons, and the descriptions and letter-press were prepared by myself.

I have no pecuniary interest in this work, as I have cheerfully given my own labors without any other reward than the hope of having contributed something toward the advancement of the cause of Natural History in our country. I am, however, anxious that the Audubons should, by a liberal sub-

${ }^{2}$ See C. L. Bachman, op. cit., p. 278. 


\section{AUDUBON'S FAMILY IN AMERICA 293}

scription, receive some remuneration for the labors and heavy expenses incurred in getting up this work. Of the character of the work it does not become me to say much. I will only add that in my department is summed up the result of investigations pursued through a long life, and, I think, the figures have never been equalled in any publication either in Europe or America.

May I bespeak from you a little aid to my esteemed son-inlaw, Mr. Audubon, in assisting him to procure subscribers. $\mathrm{He}$ is a stranger in your city; his time is limited, and his stay among you will necessarily be short.

By the aid of two friends here, he obtained two hundred and fifty subscribers in a few days.

On the 9th of April Bachman wrote to his son-inlaw: "Will you not return to New York by the way of Charleston and sail from here, take a manuscript volume in your pocket, and four hundred good and true names on your list?"

The reception accorded to the illustrations and text of this work had encouraged the brothers to do for the Quadrupeds what their father, with their aid, had so successfully accomplished for the Birds, by presenting text and plates, as Bachman said, in "Miniature." In this they succeeded as admirably as before, John reducing all the large plates, by the aid of the camera lucida, for the octavo edition which was published in $\mathbf{1 8 5 4}$.

The following historical evidence of the appreciation which Audubon's works have received at the hands of the National Government I owe to Mr. Ruthven Deane, to whom the reader of these pages is already indebted for many illuminating facts. Dr. Theodore S. Palmer was recently inspecting governmental records at Washington, when he accidentally came upon the following entry: 
Chap. CXXIX.-AN act making appropriations for certain Civil Expenses of the Government for the Year ending the thirtieth of June, eighteen hundred and fifty-seven.

To enable the Secretary of State to purchase one hundred copies, each, of Audubon's "Birds of America" and "Quadrupeds of America," for presentation to foreign governments, in return for valuable works sent by them to the Government of the United States, sixteen thousand dollars. [Act of August 18, 1858 (LL State., 90).]

In John Woodhouse Audubon's family there were two sets of children, two by his former wife, Maria $\mathbf{R}$. Bachman, and seven by Caroline Hall, to whom he was married on October 2, 1841. Victor Gifford Audubon, who had no children by his first wife, May Eliza Bachman, was married on March 2, 1843, to Georgiana Richards Mallory, an Englishwoman, and six children were born to them between 1845 and 1854. Of the naturalist's fifteen grandchildren, six are believed to be now living (1917). $0^{3}$

In 1852-3 Audubon's sons built houses for their

John W. Audubon's children by Maria Bachman were: (1) Lucy Audubon (Mrs. De Lancey Barclay Williams), 1838-1909; (2) Harriet Bachman Audubon, 1839- ; by Caroline Hall, who died in 1899: (3) John James Audubon, 1842 (lived one day); (4) Maria Rebecca Audubon, 1843- ; (5) John James Audubon, 1845-1893; (6) William Bakewell Audubon, 1847- , who emigrated to Australia, where he engaged in sheepraising, and has two children, Leonard Benjamin and Eleanor Caroline Audubon; Leonard Audubon, who is twenty-nine, is now fighting for France in the 55th Battalion of the Australian contingent; as I have been recently informed by his aunt, he has been almost constantly on the fighting front since August, 1916, and in the spring of 1917 he was promoted from the ranks "on account of great bravery under unusual conditions;" if still living, William Audubon and his son are the sole male representatives of the American branch of the Audubon family; (7) Jane Audubon, 1849-1853; (8) Florence Audubon, 1853- ; (9) Benjamin Phillips Audubon, 18551886.

Victor G. Audubon had six children by his second wife, Georgiana R. Mallory, who died in 1882; (1) Mary Eliza Audubon, 1845- ; (2) Rose Audubon, 1846-1879; (3) Victor Gifford Audubon, 1847-1915; (4) Delia Talman (Mrs. Morris Frank Tyler), 1849- ; (5) Lucy Bakewell Audubon, 1851-1898; and (6) Anne Gordon Audubon, 1854-1907. 


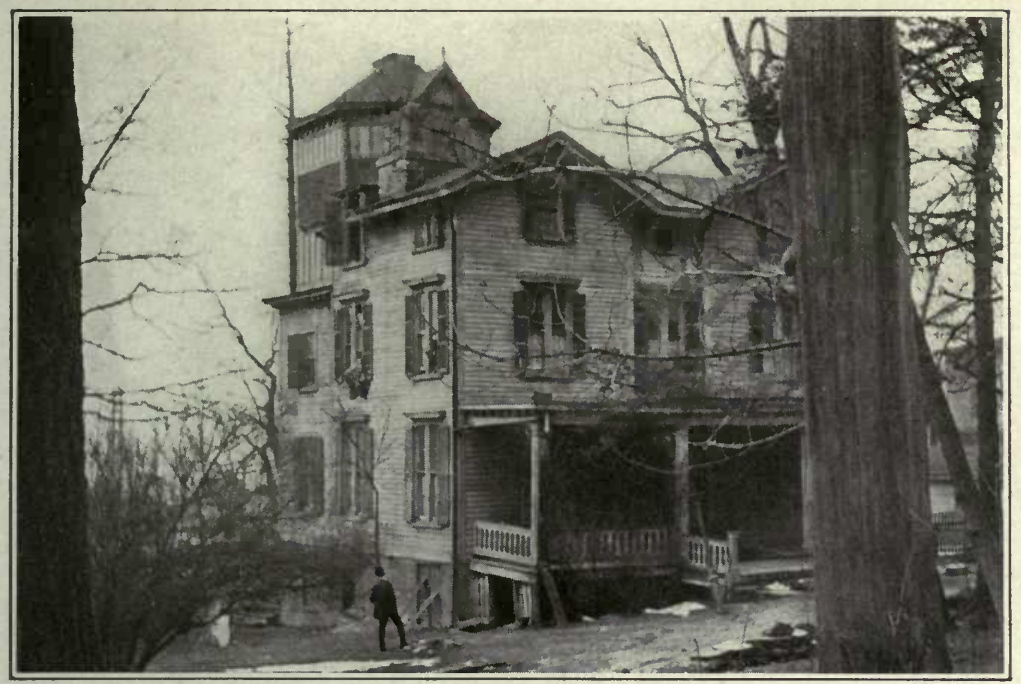

HOUSE FORMERLY BELONGING TO VICTOR GIFFORD AUDUBON, EAST FRONT, AS IT APPEARS TO-DAY; MRS. JOHN JAMES AUDUBON KEPT HER PRIVATE SCHOOL. IN THE CORNER ROON ON THE SECOND FLOOR.

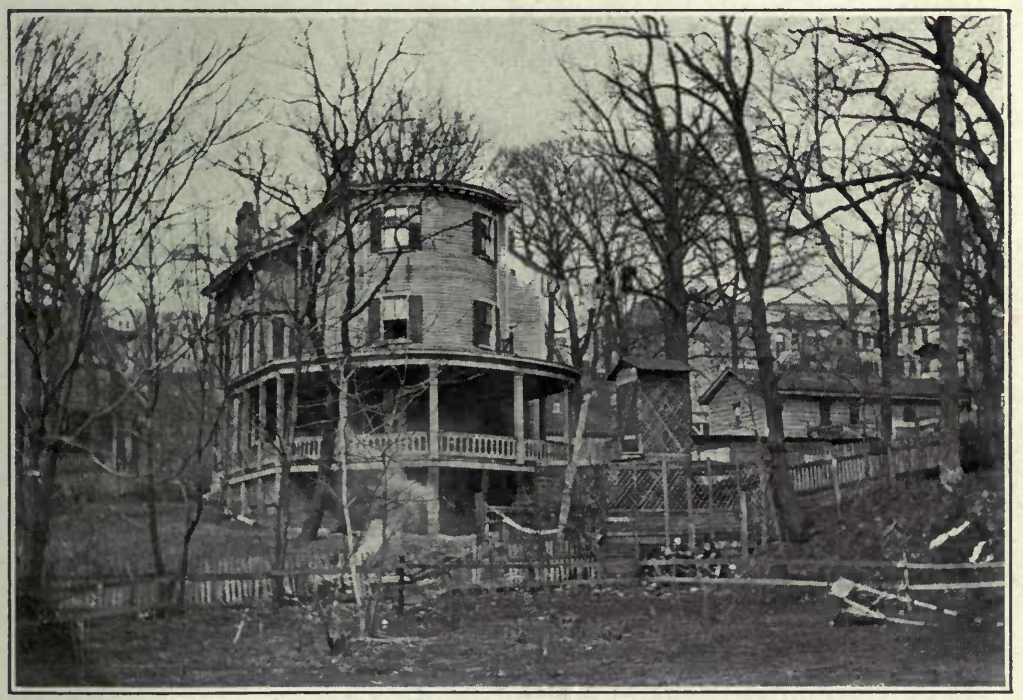

HOUSE FORMERLY BELONGING TO JOHN WOODHOUSE AUDUBON, SOUTH FRONT, AS IT APPEARS TO-DAY; AT THE RIGHT IS "THE CAVE," WHERE THE COPPER PLATES OF "THE BIRDS OF AMERICA" WREE STORED. 

growing families on their mother's estate; Victor's was placed just north of the original homestead, and John's not far away. On the slope behind John Audubon's house, a small building, later known as the "Cave," was specially constructed for the safer keeping of the famous copper plates, which had already passed through fire, and not wholly unscathed. Mr. John Hardin, now (1915) a serene and clear-eyed man of eighty-four, who settled in that neighborhood in 1852 and who was intermittently employed by the younger Audubons for a decade, has told me that he boxed with his own hands all of the copper plates, after wrapping each in tissue paper, and stored them in that building; whenever John Audubon wanted a plate, John Hardin would go to the "Cave" and get it for him.

In 1856 Victor Audubon published a second reduced edition of his father's Birds of America, in which the text and plates of the first octavo were reproduced with little or no change. At about that time Victor suffered an jury to the spine, ${ }^{5}$ and after $\mathbf{1 8 5 7}$ he was completely invalided; he died in his own home, August 18, 1860.

\section{To quote the daughter of John W. Audubon: ${ }^{\circ}$}

During this long period of my uncle's illness all the care of both families devolved on my father. Never a "business man," saddened by his brother's condition, and utterly unable to manage, at the same time, a fairly large estate, the publication of two illustrated works, every plate of which he felt he

See Vol. II, p. 267.

"Due, it was believed, to a fall into the "well" (now guarded by an iron rail), which led to a basement window of his house, though one who knew John W. Audubon well, said that Victor's illness resulted from a fall from a railroad train; see Jacob Pentz (Bibl. No. 81), Shooting and Fishing, May 11, 1893.

- Maria R. Audubon, in biographical memoir of her father in Audubon's Western Journal, 1849-1850 (Bibl. No. 219). 
must personally examine, the securing of subscribers and the financial condition of everything - what wonder that he rapidly aged, what wonder that the burden was overwhelming! After my uncle's death matters became still more difficult to handle, owing to the unsettled condition of the southern states where most of the subscribers to Audubon's books resided, and when the open rupture came between north and south, the condition of affairs can hardly be imagined, except by those who lived through similar bitter and painful experiences.

In 1858 or 1859 John W. Audubon entered upon an ambitious project, which the outbreak of the Civil War, aided, it is believed, by the unscrupulous dealings of business partners, rendered disastrous. In association with Messrs. Roe Lockwood, \& Son, New York, and the lithographers, Messrs. J. Bien \& Company, Number 180 Broadway, with whom considerable money had been invested, a second and American edition of his father's great folio on The Birds of America was attempted. An atlas of 106 double elephant plates, reproduced in colors on stone with slight but numerous changes from the original copper plates, was completed as Volume $I$ in $1860 ;^{7}$ the war, which broke immediately afterwards, completely ruined the enterprise, so that but few copies of the work were dispersed and an immense stock of plates was rendered useless; the burden of debt was undoubtedly increased by the issue of seven octavo volumes of text. ${ }^{8}$

Many years later, hundreds of persons who knew of Audubon's work only through its great reputation, and

${ }^{7}$ For fuller details, see Bibliography, No. 9, and for Prospectus of this work, Appendix III, No. 3.

${ }^{8}$ For conflicting accounts of this text, see Bibliography, No. 10, and for a definitive statement, Appendix III, No. 3. Miss Maria R. Audubon has told me that during the War, the Bien firm issued a patriotic poster, showing an eagle, taken from one of her grandfather's original drawings, and the American flag; it was thought that a large number of copies were sold. 


\section{AUDUBON'S FAMILY IN AMERICA 297.}

who had never learned to discriminate between a handcolored copper-plate engraving and a lithograph, were deceived by an adroit, but essentially spurious advertisement of these inferior reproductions when they were being exploited by a firm of Boston book dealers. The original bulk of these large lithographs must have been vast indeed, if the following story, which was attributed to a member of the firm in question, be true: "We bought the entire stock of those plates, many years ago," so this man is reported to have said, "and, though the sales of every succeeding year since have been sufficient to cover the original cost, the number of plates has not appreciably diminished."

When this larger venture failed, one of the publishers, who was not satisfied with the surplusage of books and plates left on his hands, is said to have placed encumbrances upon the Audubon estate. At about this time John W. Audubon's health broke down; "Worn out," as his daughter has said, "in body and spirit, overburdened with anxieties, saddened by the condition of his country, it is no matter of surprise that my father could not throw off a heavy cold which attacked him early in 1862." He died at the age of forty-nine, on the 18th of February of that year.

John Woodhouse Audubon, like his brother, Victor, had inherited decided artistic abilities, and from a youth had been his father's assistant, field companion and friend. Victor Audubon, on the other hand, was never a field collector, but aided his father more in a financial and secretarial capacity. Both in adult life were fond of music and good cheer, and at one time John was probably as devoted to adventure and sport as his father had ever been in his palmiest days. One of his youthful

- Maria R. Audubon, op. cit. 
pranks is thus guardedly referred to by the senior Audubon when writing at American Harbor, on the coast of Labrador, June 25, 1833: ${ }^{10}$ "The young men, who are always ready for sport, caught a hundred codfish in half an hour, and somerohere secured three fine salmon, one of which was sent to the "Gulnare' with some cod." Whether the fishermen at American Harbor, who had obstinately refused to sell, ever missed those fine salmon from their pounds, is not recorded. Another adventure has been related by $\mathrm{Mr}$. Fraser, ${ }^{11}$ whose family was on intimate terms with the Audubons and MacGillivrays at Edinburgh, when John Audubon, John MacGillivray (William MacGillivray's eldest son), and himself were caught in the Ravelston woods while shooting birds; the boys, he said "were rather roughly handled," but got off by giving up their guns.

Under his father's tuition John Audubon became an observant and self-reliant collector in the field, and an animal painter and draughtsman of no mean powers. At twenty-one, as we have seen, he accompanied his father's expedition to Labrador, was with him and Harris in Florida and Texas in 1837, made successive visits to England, and traveled again in Texas and in Mexico, all in the interests of his father's works. He painted nearly one-half of the large plates of the Quadrupeds of North America, besides reducing all the drawings for the smaller editions of the Birds and Quadrupeds, an enormous labor in itself, representing the redrawing, with numerous alterations, of 655 elaborate octavo plates. After his return from California in 1850, he began to bring out an account of his western travels,

${ }^{20}$ Maria R. Audubon, Audubon and his Journals (Bibl. No. 86), vol. i, p. 380 .

${ }^{11}$ See William MacGillivray, A Memorial Tribute to William MacGillivray (Bibl. No. 211), p. 40. 


\section{AUDUBON'S FAMILY IN AMERICA 299}

projected for ten monthly numbers, but this never advanced beyond the first part. ${ }^{12}$

If not a "business man" by instinct or training, John Audubon in emergencies could turn his hand to many things. For a time he superintended the building of houses, including his own and Victor's, which were completed in 1853, as well as another that was built on the Audubon estate for Mr. Hall, a brother-in-law; he also took charge of lighting the streets, and at another time was superintendent of a quarry in Vermont. "He was a bluff, gruff, but friendly man," writes George Bird Grinnell, ${ }^{13}$ and was always willing to talk about birds, mammals, or, indeed, any natural history object, to any boy who asked him questions." On the other hand, an ardent sportsman, who had lived with the family for years, ${ }^{14}$ has described him as a lovable companion, "genial in speech, full of anecdote, and a capital conversationalist ... ; in person of more than median height, and of commanding appearance, his face told plainly of the humanity of the man; he was as tender-hearted as a girl, and his expressive voice could command any key of which the vocal organs were capable; to the last he retained the Southern habit of softly clipping the ends of words."

John Woodhouse Audubon will be remembered chiefly as his father's aid and companion, although in his Western Journal, ${ }^{15}$ written in his thirty-eighth year but not published until forty-two years after his death, he has left a record of which anyone could be rightfully proud.

Mrs. John James Audubon was very active in body

${ }^{12}$ See Bibliography, Nos. 174 and 219.

${ }^{13}$ See Bibliography, No. 54.

${ }^{14} \mathrm{Jacob}$ Pentz (Bibl. No. 81), loc. cit.

${ }^{15}$ See Bibliography, No. 219. 
and mind for a long period after her husband's death, and in 185\%, when in her seventieth year, she returned in a degree to her old vocation of school teaching, which had been so successfully followed in Ohio and Louisiana when her husband was on the threshold of his extraordinary career. Her pupils now consisted of some of her numerous grandchildren and a few others drawn from the neighborhood; among the latter was the well known writer and father of the original Audubon Society, George Bird Grinnell, who pointed out to me the room in Victor Audubon's old house where his revered and venerable teacher had gathered her little flock. "She loved to read, to study, and to teach," said one who had known her, and "she knew how to gain the attention of the young, and to fix knowledge in their minds. 'If I can hold the mind of a child to a subject for five minutes, he will never forget what I teach him,' she once remarked; and, acting upon this principle, she was as successful, at three score and ten years, in imparting knowledge, as she had been in early life when she taught in Louisiana."

Mrs. Audubon's own house was rented and eventually sold. Meanwhile, it seems, she lived for a number of years with the family of her eldest son, and it was at Victor's house, as just noticed, that she started a small school. Finally, in 1863, at the age of seventy-five, bereft of children and fortune, she left the scenes of her once happy home, then "Minnie's Land" no longer, and for a considerable period lived with a granddaughter at Washington Heights, as that section on the river, including Carmansville, came to be called, and a little later at Manhattanville, a short distance below; there at the home of the Reverend Charles Coffin Adams, who prepared the original draft of the Life of her husband, the 


\section{AUDUBON'S FAMILY IN AMERICA 301}

history of which has been given, ${ }^{16}$ she passed a number of years after 1865 .

In a letter written to a relative from "Washington Heights, N. Y., July 11, 1865," Mrs. Audubon spoke thus of the present, while memories, not untinged with sorrow, filled the retrospect:

We have passed through a very cold winter which tried both my Granddaughter ... a and myself much. I have hoped until I almost despair that [she] would have a short Holiday so that we could go up to Hudson for a week and see you all and mingle with those who sympathize and care for us, but in a Boarding house, one seems a stranger in the world, and as I pass my days alone generally from breakfast till our dinner hour six o'clock evening when [my granddaughter] comes home from her music Pupils of whom she has now ten, and from that time I am glad when she is invited out to refresh her mind.

I seldom leave home but to go up to see my other Grand Daughter Lucy Williams, but being sixteen miles off we do not go there often....

I have heard from my Sister Gordon lately of Orleans, she has her Son at home! but they are likely to lose all their Property on account of Sister's Son having been engaged in the Confederate War. It does seem to me ... as if we were a doomed family for all of us are in pecuniary difficulty more or less. As to myself $I$ find it hard to look back patiently upon my great ignorance of business and the want of a wise adviser who I now find could have saved me half the property I have under errour and ignorance sacrificed and have just enough left to keep us but not enjoy life by any travelling about in this beautiful. World. I sat on Sunday night after Church on the Piazza contemplating the beautiful Moon \& its Creator, and I cannot yet say I wish to leave it, notwithstanding all my disappointments and mortifications. Excuse this

${ }^{16}$ See Chapter I. 
long detail about myself. I cannot help looking back as well as to the present and future.

After Mrs. Audubon had passed her eightieth year she left New York and again made her home in the West. In 1874, when with a granddaughter at Louisville, she dictated and signed the following letter to a gentleman who had asked for an autograph of her husband:

\section{Mrs. Audubon to William R. Dorlan}

LouisviLre Jan. 30

1874

Mr. WM. R. Dorlan

Dear Sir

I regret that your letter of Jan. 10th has remained so long unanswered, but my granddaughter who usually writes for me, is so constantly occupied with her pupils that until to-day she has not been able to find time to write to you. I regret that I cannot give you a letter of my husband John James Audubon with the autograph attached.

The enclosed, the best I have to send you is one from which the autograph and a portion of the letter were cut off many years ago.

With many regrets that I cannot more fully grant your request

\section{I am dear Sir}

Yours respectfully,

\section{Lucy Audubon}

Mrs. Audubon's closing days were spent at the home of her sister-in-law, Mrs. William G. Bakewell, at Shelbyville, Kentucky, where she died, with her mental faculties unimpaired, at the age of eighty-six, June 13, 1874, having outlived this sister-in-law and her younger sisters, Mrs. Alexander Gordon, of New Orleans, 


\section{AUDUBON'S FAMILY IN AMERICA 303}

and Mrs. Nicholas Augustus Berthoud, of St. Louis.

Not long after John W. Audubon's death, his family disposed of their house on what had been the "Minnie's Land" estate, and lived successively at Harlem, New Haven, Connecticut, and Salem, New York, where Mrs. John W. Audubon died, and where her daughter, Maria Rebecca, the biographer of her father and grandfather, with a sister, still resides. Victor Audubon's family, with some of their kinsfolk, remained at the Hudson River place, which was included in the section known as "Audubon Park," until May, 1878, when they took a house in New York, where Mrs. Victor Audubon died in 1882.

A brother of Mrs. Victor Audubon, Mr. E. Mallory, in writing to a friend in Buffalo from "Audubon Park, August 31, 1874," said that it was a source of deep regret to Mrs. John James Audubon that her last years were not passed with them, under the shadow of her old home on the Hudson; and he continued: "She was a kind and good friend, very intelligent, and much beloved here; I remember her telling a young lady, who asked her if she had read some fashionable novel, that she had no time; 'at my age,' said she, 'I must make the most of my time.' As she was a wide reader, it was a great trial when, in age, her eyesight completely failed her. The minister who pronounced her eulogy ${ }^{17}$ said:

Many of you can recall that aged form and benignant countenance, as she moved along these streets upon errands of usefulness and benevolence, with benedictions on her tongue, and smiles that were a blessing to all who met her.

${ }^{17}$ Charles Augustus Stoddard; for his memorial sermon, see Bibliography, No. 178. In the absence of the rector of the Church of the Intercession, the pastor of the Washington Heights Presbyterian Church was called to officiate at the funeral of Mrs. J. J. Audubon, June 22, 1874. 
Madame Audubon interested herself in all that pertained to the welfare of the neighborhood where she lived. Although it was not without a pang that she saw her sylvan home invaded by the growth of the city, and all old associations broken up, she did not treat those who came to live near her as strangers. She had a large and generous heart, and with her husband had always exercised a liberal hospitality and hearty kindness towards all. In prosperity and adversity she was equally sincere and humble, a friend of all worthy people....

Mrs. Audubon, during the period of her husband's greatest activity, had traveled much and met people distinguished in every walk of life. If, as some have thought, when Audubon was struggling for recognition, he was somewhat oblivious of the privations which his wife endured, in the sunshine of later years, when fame and fortune had smiled upon him, he showed by every token of affection how fully he realized his debt. Let it also be remembered that the monument by which Americans have signalized their appreciation of his labors, is honored by the ashes of his beloved Lucy, which rest by his side.

The original drawings of the plates of The Birds of America were sold by Mrs. Audubon on June 2, 1863, to the Historical Society of New York, ${ }^{18}$ and a few of them are now displayed in its building in that city; it is still hoped that a fire-proof and adequately lighted hall can be constructed so that the whole of this great series of pictures may be exhibited under more perfect conditions. The artistic beauty and historical value of these drawings, with the added charm which personal association has so richly supplied, would render Audubon's "Book of Nature" one of the most unique and interest-

${ }^{19}$ For the privilege of examining this unique collection $I$ am indebted to the courtesy of the Society, and of its librarian, Mr. Kelby. 


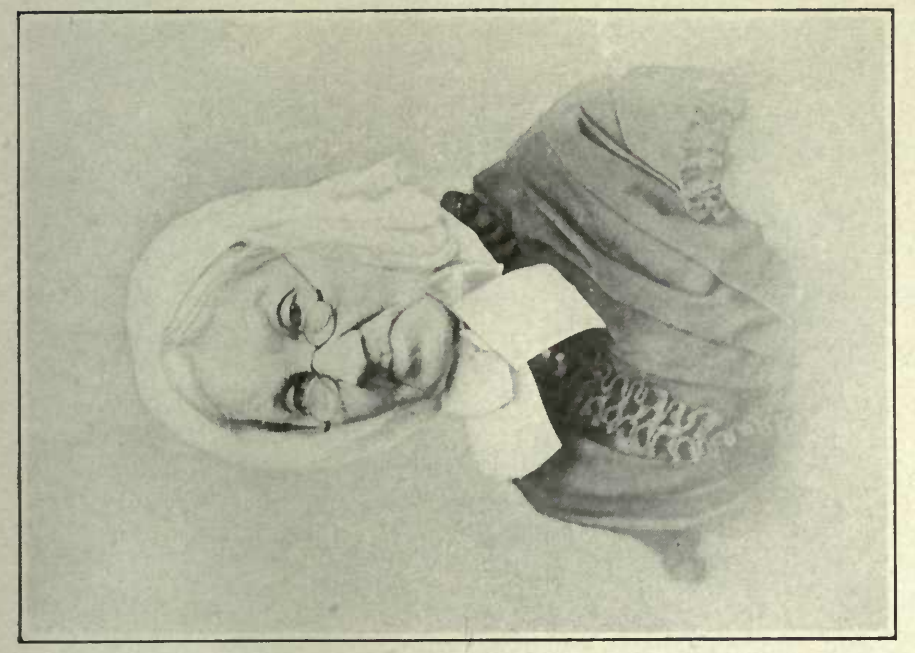

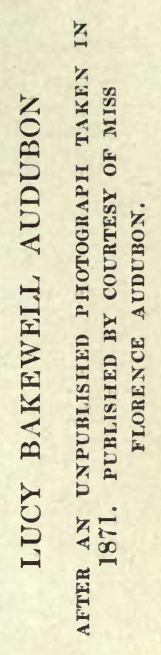
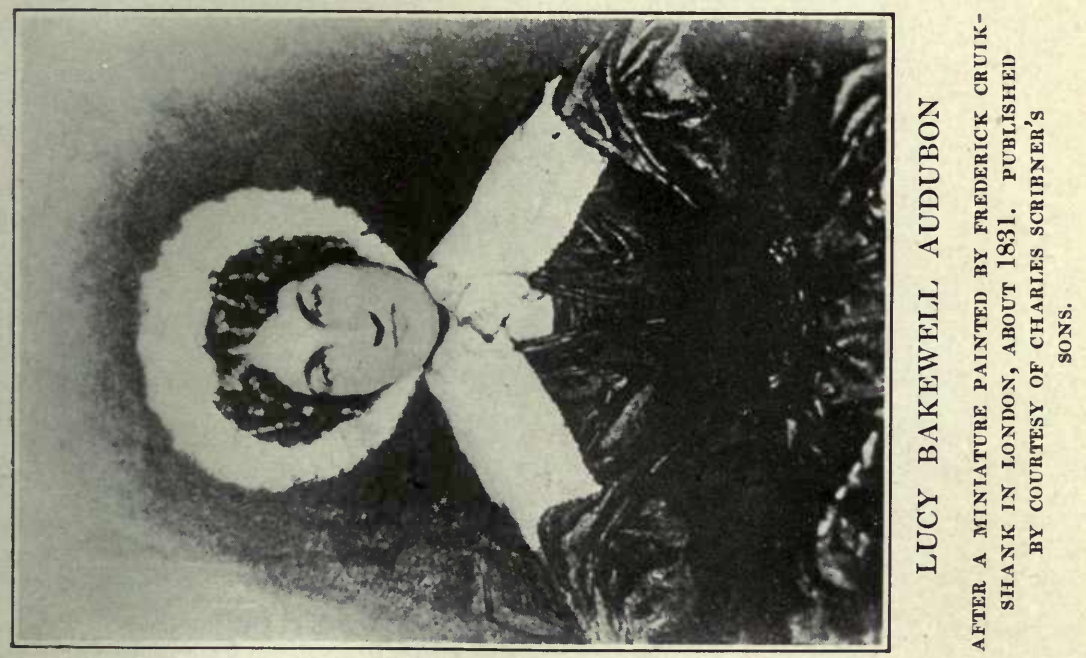

ing exhibits in the New World. The collection appears to be nearly complete, although some notable pieces, such as the Wild Turkeys, are lacking, but there are other drawings, and some of early date, which were never reproduced; all are inclosed in the original portfolios, scarred by hard knocks and the tooth of time, massive, leather-bound containers, which two strong arms would raise with difficulty from the ground. Most of these originals are mounted on a gray backing, with plate margins in each case indicated by ink lines. As was noticed in an earlier chapter, many original legends and notes written by Audubon's pencil or pen still remain on the drawings, though many have been trimmed off or erased; these include names of localities and dates, and directions to the engraver for changes in the background and composition or for any improvement of the whole or a part.

As a further illustration of the care which Audubon exercised over the minute details of his great undertaking, we will reproduce the penciled orders on the drawing of the Great White Heron (Plate cclxxxi), which shows an adult male performing the gymnastic feat of seizing a large striped fish, a view of Key West forming the background: "Keep closely to the sky in depth \& colouring! have the water a Pea-green tint. Keep the division of the scales on the leg in fact white in your engraving-The colouring over these will subdue them enough! finish the houses better from the original which you have; have the upper back portion very mellowing in the outline." Again, on the drawing of the Great Cinereous Owl (Plate cccli), we read: "Raise the bird about 4 inches on the copper-higher than in the Drawing, and put in a landscape below of Wild Mountains," a direction which in this instance was not followed, for 
the bird was eventually shown on a branch against the sky.

In many instances towards the end of his work, Audubon furnished Havell with drawings of the birds only, with directions to supply "an old rotten stick" for perch, or to "amend this rascally sky and water"; as we have already seen, he often depended upon him to combine several detached pictures into one plate, but not always with happy results. The following note was written on a drawing of the Carolina Parrot, reproduced in a very striking plate (No. xxvi), in which seven gaudy individuals of this nearly extinct species are represented feeding on a favorite weed, the cockle-bur: "The upper specimen was shot near Bayou Sarah, and appeared as very uncommon having 14 . Tail feathers all very distinct-uniformly affixed in 14 distinct receptacles that I drew it more to exhibit one of those astonishing fits of nature than anything else-it was a female. - The Green headed is also a Singular although not so uncommon a variety as the above one. LouisianaDecember (1821?) J. J. Audubon." The upper bird, which is here referred to, is noticed in his "Biography" of the species as "a kind of occasional variety."

On the drawing of the Swamp Sparrow (Plate lxiv), which was published in 1829, Audubon wrote, evidently with the wish of having his wife's name appear: "Drawn from Nature by Lucy Audubon, Mr. Havell will please have Lucy Audubon name on this plate instead of mine ...!"

Vandalism is always short-sighted, but seldom has its vision been more myopic and sinister than in the case of the copper plates of The Birds of America, most of which were sold for old metal and converted into copper bars. Had they been preserved to this day, their value 


\section{AUDUBON'S FAMILY IN AMERICA 307}

would have been an hundred-fold greater than that of the few paltry tons of metallic copper which they were supposed to represent. Mr. Ruthven Deane, whose researches in the field of "Auduboniana" have added greatly to this subject, has given a history of these plates, ${ }^{19}$ and of the interesting way in which a remnant came to be snatched, as it were, from the very mouth of the furnace, through the persistence and enthusiasm of a lad of fourteen. To follow this writer's account, it seems that shortly after the death of her son John, Mrs. Audubon sold the copper plates to a firm in New York, where they remained until about 1865, stored in the warehouse of Messrs. Phelps, Dodge \& Company. Not far from that time the plates were sorted and a few were given away; the large remainder was sent to a brass and copper company, of which William E. Dodge was president, at Ansonia, Connecticut. How some of these were fortunately rescued, in about the year 1873, is told in a letter to Mr. Deane from Mr. Charles A. Cowles, of Ansonia:

At that time I was about fourteen years old. I was beginning the study of taxidermy, and was naturally deeply interested in birds. I happened to be at the refinery watching the process of loading one of the furnaces, and noticed on one of the sheets of copper that a man was throwing into the furnace, what appeared to me to be the picture of a bird's foot. I took the plate from him, cleaned it with acid, and thereupon discovered the engraving, or as I termed it, the picture, of a bird (Plate cvi, Black Vulture), I made an immediate but unsuccessful request to the foreman of the furnace not to melt the plates; and then I appealed to the superintendent, but without avail. I next brought the matter to the general manager of the concern, my father, from whom I re-

${ }^{10}$ Ruthven Deane (Bibl. No. 225), The Auk, vol. xxv (1908). 
ceived no encouragement. This sort of treatment was evidently what I needed, for I hastened back to the works in a state of mind so determined that I succeeded in having all the plates, that had not been melted, removed to a place of safety. This occurred in the spring of that year; and the plates remained undisturbed until the annual inventory was taken the first of the following year. At that time the disposition of the plates was taken up. I appealed to my mother and interested her to such an extent that she drove to the factory and looked at one of the plates. She of course recognized that they were Audubon plates; and instructions were given by my father to keep them intact. The plates were subsequently submitted to a treatment which removed all oxidation and then taken to the main office of the company, and to the best of my recollection, distributed as follows: Mr. Wm. E. Dodge, president of the company, had a few plates sent to the American Museum of Natural History, New York City, and a few plates to the Smithsonian Institution, Washington, D. C., and I think he retained one or two for himself. The remainder of them, with the exception of two, my father kept; and they have since come into my possession by purchase from the estate. The two plates just excepted were Nos. xxii and lxxxii [Purple Martin and Whippoorwill], and they particularly struck my fancy, so much that when the plates were first discovered I managed to secure them on the quiet, cleaned them myself and hid them; and when the plates were distributed no one knew of the existence of these two and they later became my property.

It was thought possible that some of these plates had been sold in New York City before the bulk of them were condemned as junk and sent to Connecticut, but in $1898 \mathrm{Mr}$. Deane was able to give the designation and resting place of only thirty-seven; ${ }^{20}$ among these, how-

${ }^{20}$ At that time the American Museum of Natural History, New York, possessed nine; the Smithsonian Institution, six; Princeton University, four; Wesleyan University, Middletown, Connecticut, one, while the remainder were in private hands. 
ever, were the Wild Turkeys, Canada Goose, Great Northern Diver, Raven, American Robin, and Rubythroated Hummingbird, all among the finest of the original 435.

Under the guidance of Mr. George Bird Grinnell, on April 6, 1916, I paid a visit to "Audubon Park," now "Minnie's Land" no longer, where country roads have given way to business streets and forests to subways and skyscraper apartment houses. Notwithstanding the momentous changes which the extension of upper New York City has effected both above and below ground during the recent era of rapid transportation, the old Audubon houses still remain, like boulders amid stream, the impact of the city which has flowed around and beyond them being checked for the moment by a rampart of solid masonry, the retaining wall of the farfamed Riverside Drive, which rises above Audubon's old house close to its rear veranda and there makes a wide turn. For Mr. Grinnell this was a return to the scenes of his boyhood; the home of his father, Mr. George Blake Grinnell, stood on the hill just above the Audubon house, not far from the present "Riviera" building at One Hundred and Fifty-Seventh Street; the Grinnell apartment house which towers aloft close at hand stands in their old cow pasture, while their garden site is marked by the present entrance to the subway station on Broadway.

The first part of Audubon's original tract to be sold was the easterly section, extending from what is now the east side of Broadway to the Bloomingdale Road, and between the present One Hundred and Fifty-sixth and One Hundred and Fifty-seventh Streets; on that portion John Woodhouse Audubon built a large frame structure which, for a number of years, served as a 
boarding house for workmen employed in the sugar refinery of Messrs. Plume \& Lamont that stood on the river-bank, at the foot of the present One Hundred and Sixtieth Street. Victor and John W. Audubon also built three houses on the hill, one of which, between One Hundred and Fifty-sixth and One Hundred and Fifty-seventh Streets, was occupied by Mr. Grinnell; another, at one time the dwelling of Henry A. Smythe, a former Collector of the Port of New York, was on land now covered by the Numismatic Building, while a third, which was occupied by Wellington Clapp, was on a part of the Archer M. Huntington estate, south of One Hundred and Fifty-sixth Street, and stood a little easterly of the present Riverside Drive; all of these houses have disappeared. In September, 1842, the Corporation of Trinity Parish acquired from Richard F. Carman, in Carmansville, the tract of land later known as "Trinity Cemetery"; this extended from Bloomingdale Road to the River, and between the present One Hundred and Fifty-third and One Hundred and Fiftyfifth Streets. ${ }^{21}$

The original Audubon house, standing in the angle nearly opposite One Hundred and Fifty-fifth Street, is all but concealed, except from the river side, but may be approached by a lane which leads off from One Hundred and Fifty-eighth Street. In 1913, when this old landmark was in imminent danger of demolition, the Commissioner of Public Parks made an eloquent plea for its preservation to the Audubon Societies and to lovers of birds and nature everywhere. It was then suggested that instead of permitting the historic structure to be destroyed, the city should acquire it, float it

\footnotetext{
${ }^{21}$ For the substance of this paragraph, I am indebted to the Report of the American Scenic and Historic Preservation Society, New York, 1913.
} 


\section{AUDUBON'S FAMILY IN AMERICA 311}

up the Hudson River to Fort Washington Park, and reestablish it there as a permanent memorial to the naturalist; it was also noticed that the public interest was enhanced by the fact that the father of telegraphy, Samuel F. B. Morse, had worked upon his invention while Audubon's guest, and that the first message to be received from Philadelphia came over a wire which entered his room at the northwest corner of the building.

An early engraving ${ }^{22}$ represents the naturalist's house essentially as it appeared during his lifetime, surrounded by goodly forest trees of oak and chestnut, but these, when standing at all, are now reduced to gaunt and scarred remnants. A later print ${ }^{23}$ shows the three Audubon houses, the river, and between it and the lawn "that eye-sore of a railroad," ${ }^{24}$ which was built not long after Audubon settled upon his estate. The original house was sold before $1862,{ }^{25}$ and about eight years later its new owner occupied it, after having given it a mansard roof and made numerous changes which were sanctioned by an era of bad taste. The naturalist's house overlooked the river and commanded a grand view from its high veranda on the front, while Victor's, which later adjoined it to the north, owing probably to the encroachments of the railroad, was built to face the hillslope opposite; a top studio, at a corner of its roof, is an addition of a later purchaser. ${ }^{26}$

Adjoining Victor's house on the north was that of his

${ }^{22}$ See Mrs. Horace St. John, Audubon, the Naturalist of the New World (Bibl. No. 71), New York, 1856.

${ }^{23}$ See Valentine's Manual of the City of New York, New York, 1865.

${ }^{24}$ On October 30, 1847, Bachman wrote John and Victor Audubon that he proposed to visit them in the following May, when he would leave his two daughters with them awhile, "to hear you and Victor grumble about that eye-sore of a railroad, and to enjoy your good company, and your fish and shrimps.".

${ }^{25}$ To Mr. Jesse Benedict.

${ }^{20} \mathrm{Mr}$. Charles F. Stone, whose sister was an artist. 


\section{AUDUBON, THE NATURALIST}

brother, John, and on the east side of this was built the "Cave" and a barn since converted into a dwelling; at one time the loft of this barn was piled with boxes of bird skins and the surplus stock of the Ornithological Biography, good copies of which now bring from $\$ 30$ to $\$ 50$.

The three houses which were built and occupied by the great nature lover and his two sons, though in dire neglect, are not beyond repair; if such a project were practicable, they should be converted into a museum, and their walls once more ornamented with those beautiful pictures of birds and beasts which father and sons united to create. The triangle of ground between Riverside Drive and the Hudson River should be spared by the proud city that for years was the home of America's pioneer naturalist and animal painter, as well as the scene of his youthful experiments in trade, and converted into a true "Audubon Park." Such a memorial would contribute to the instruction and pleasure of all the people, for every generation of Americans that is to come. 


\section{APPENDICES}

APPENDIX I

Original Documents 
1. Copy of the original bill rendered by Doctor Sanson, physician at Les Cayes, Santo Domingo, to Jean Audubon, containing the only record known to exist of the birth of his son, Jean Jacques Fougère Audubon (see entry for April 26, 1785). Les Cayes, December 29, 1783-October 19, 1785; paid, June 7, $178 \%$.

\section{DOIT Mr. AUDUBON ngt. A SANSON}

Chirurgien aux Cayes

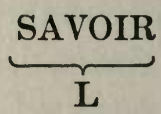

$1783 \mathrm{X}^{\text {bre }}$

" 29 " ipecacuanha pour un nègre Bossal ...... $66 \quad 6666$ " 31 " ipecacuanha pour un nègre Bossal.....6 66 $6^{66}$ 66 1784 janvier " 3 " une medecine pour un nègre Bossal ....6" $66^{666}$

"6 5 " une medecine pour un nègre Bossal ..... "6 6 "66

" 7 " une medecine pour un nègre Bossal $\ldots \ldots$ 6 $\quad 6^{66}$ "6

" 9 " une medecine pour un Bossal .........6" $6^{66}$ "6

"6 10 " une medecine pour un Bossal ..........6" 6 66

" $14^{\text {"6 }}$ une medecine pour le mulâtre joue ....... $666^{666}$

" 26 " une medecine pour $\mathrm{M}^{\mathrm{r}}$ audubon ........6" 10 " "6 mars " 27 " inoculé cezard 30 " inoculé jupiter 30 inoculé Rose 30 "... " 90 " " 


\section{ORIGINAL DOCUMENTS}

1a. Translation of the Sanson bill. (For comment, see Chapter IV.)

M. AUDUBON, merchant, to SANSON,

Physician at Cayes

$$
\underbrace{\begin{array}{c}
\text { Dr. } \\
\text { TO WIT }
\end{array}}_{\text {Francs }}
$$

1783 December " 29 "Ipecacuanha for a negro Bossal ....... " 6 " "

" 31 "Ipecacuanha for a negro Bossal ....... "6 6 " "

1784 January " 3 "A medicine for a negro Bossal ......... 6 " $\%$

“ 5 " A medicine for a negro Bossal .......... " 6 " "

" 7 " A medicine for a negro Bossal .......... " 6 " "

" 9 " A medicine for a Bossal " 6 " “

“ 10 " A medicine for a Bossal " 6 “ “

"14" A medicine for the mulatto Joue ${ }^{1}$..... "6 6 " "

" 26 " A medicine for M. Audubon ........... " 10 " "

March " 27 "Inoculated Cæsar, 30f; inoculated Jupiter, $30^{\mathrm{f}}$; inoculated Rose, $30^{f} \ldots \ldots \ldots \ldots \ldots$ \% 90 " $\%$

${ }^{1}$ For probable meaning of this term, see Note, Vol. I, p. 54. 
1. The original Sanson bill-Continued.

avril

66 1 "6 apozême purgatif pour joue mulâtre ...... $66 \quad 6^{66} 66$

66 $3^{\text {66 }}$ une medecine pour le mulâtre joue .....6" $66^{66}$ "6

" 8 " apozême purgatif pour

le nègre Dominique. "6 $\quad 6^{66} 66$

"6 10 " une medecine pour

Dominique .......6" $66^{66} 6$

" 15 " une medecine pour

Zemire .........6" 6 "6 6

" 20 " une medecine pour Rose " 6 "6

66 apozême purgatif pour jupiter $\ldots \ldots \ldots 6^{66} \quad 6^{66} 66$

21 " une medecine pour

Dominique ....... *6 6 "6 6

may " 2 " une medecine pour la negresse therese... "6 $6^{66} 66$

66 11 " pour soins, visites et remedes pendant la petite verole du mulâtre joue........ " 66 " "6

" 21 "Liqueur $\mathrm{mine} \mathrm{rale}$ d'hoffman pour $\mathrm{m}^{\text {lle. }}$ Rabin .........6" $6^{666}$

juin $\quad 200$ inoculé un petit nègre Bossal nommé joue. " " 30 " "6 juillet " 20 "Remis a $\mathrm{m}^{\mathrm{r}}$ audubon le compte du traitement de la galle de marianne et de sa fille, tout acquité... « $36^{66}$ 66 
1a. Translation of the Sanson bill-Continued.

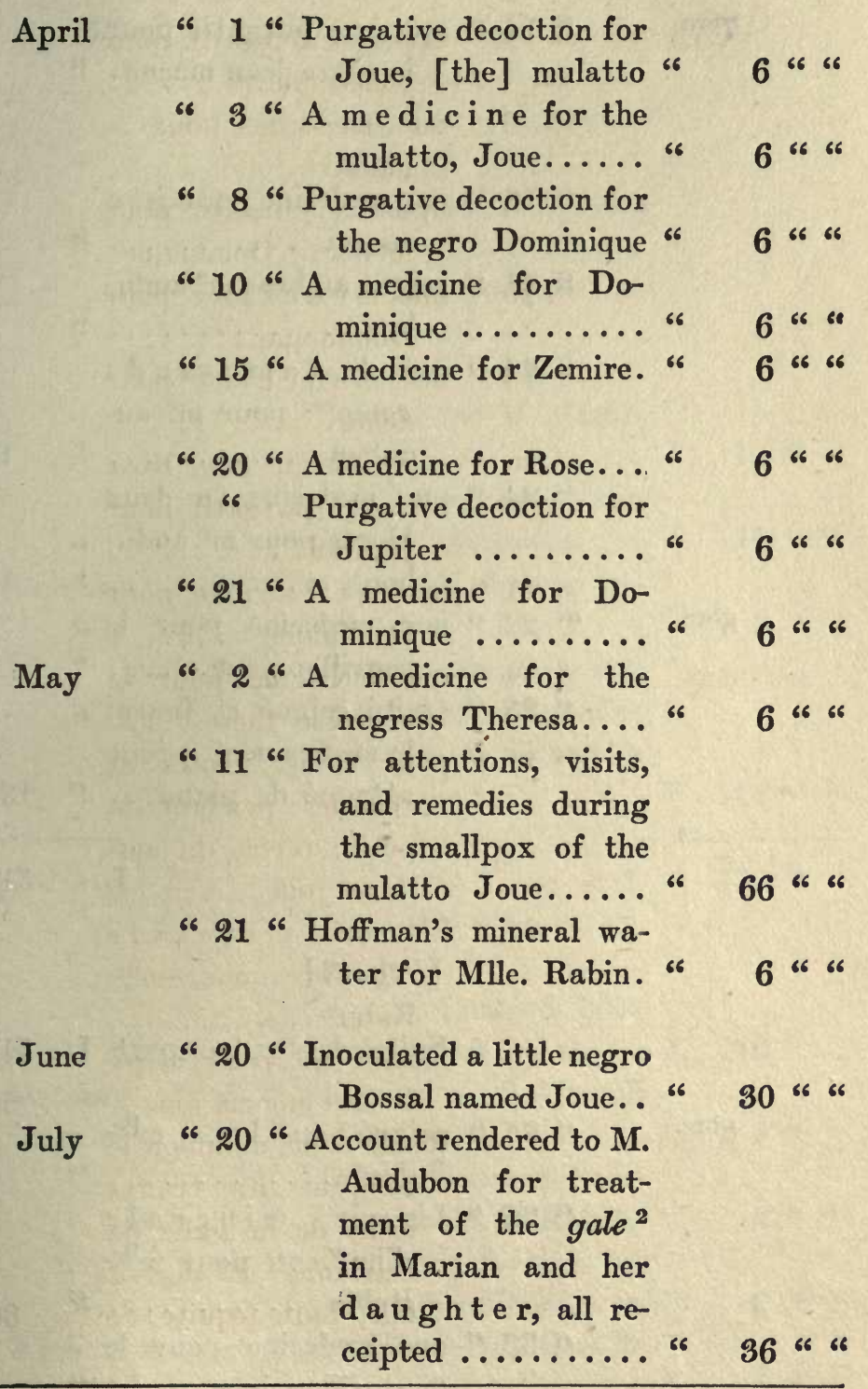

'Or acariasis, an affection of the skin caused by the mange-mite, Demodex folliculorum, a microscopic arachnid parasite found in the sebaceous glands of dog and man. 
1. The original Sanson bill-Continued.

ybre

" 14 " apozême purgatif pour

le nègre jean maçon. " $\quad 6^{\text {" }}$ "6

"6 16 une medecine pour jean maçon...$\ldots \ldots$ $66 \quad 666$

" 21 " saigné au bras $\mathrm{m}^{\mathrm{r}}$ audubon ............. $6 \quad 3$ "6

"23 " eau de tamarinds

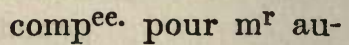
dubon........

66 24 "6 une medecine en deux

Dozes pour $\mathrm{m}^{\mathrm{r}}$ audubon .......... " 10 " * $8^{\text {bre. }} \quad$ "6 22 " une medecine pour le negrillon joue...... "6 $6^{66}$ "6

" 23 " traité soigné et fourni le medicament a joue attaqué de piano... " 132 " "6

L $\quad 5136666$

\section{[Page 2]}

Suite de l'autre part L 513 " "

$8^{\text {bre. }}$

" 25 " saigné au bras m me. Rabin .........." 3 " "

" 26 " Liqueur $\mathrm{m}$ in er a le d'hoffman pour mlle. Rabin ...........

" 30 " une medecine pour le negrillon joue...... * 6 " 6 $9^{\text {bre }}$ " 15 " une medecine pour le negrillon joue...... $6 \quad 6 \% 6$ 


\section{ORIGINAL DOCUMENTS}

1a. Translation of the Sanson bill-Continued.

September " 14 "Purgative decoction for the negro, John Mason [or John, ma$\operatorname{son}(?)] \ldots . . .$.

" 16 " A medicine for John Mason ......... " 6 " "

" 21 " Bled M. Audubon at the arm......... " 3 " "

" 23 "Tamarind water compound for M. Audubon...$\cdots \cdots \cdots$

"24 "A medicine in two doses for M. Audubon.... * 10 * *

October " 22 "A medicine for the little negro Joue..... * $\quad 6^{* 6}$

" 23 "Treated, attended, and furnished remedies for Joue attacked by the pian $^{3}$..........

\section{513 “}

\section{[Page 2]}

Brought forward from other part........ I 513 "6

October " 25 "Bled Mlle. Rabin at the arm......... " 3 " 6

" 26 " Hoffman's mineral water for Mlle. Rabin. " 6 " 6 " 30 "A medicine for the little negro Joue..... " 6 " 6 "

November " 15 "A medicine for the little negro Joue..... \& 6 " 6

${ }^{8}$ A skin disease to which negroes in Central America are specially prone. 
1. The original Sanson bill-Continued.

$\mathrm{X}^{\mathrm{bre}}$

1785 janvier

fevrier

mars

avril
" 8 " une medecine pour joue " 6 " "

" 18 " une medecine pour $\mathrm{m}^{\mathrm{r}}$ audubon .............

" 21 " une medecine pour le negrillon joue....... " 6 "6

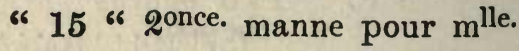

Rabin .............

66 366

" 18 " une medecine pour le tonneliere $\ldots . \ldots \ldots$ 6 6 " 6

" 6 " une medecine pour le tonneliere $\ldots \ldots \ldots$ 6 $\quad 6^{66}$ "

" 10 " une medecine pour le tonneliere ...... "6 6 "66

" 11 "trois Dozes de kina pour le tonneliere..

" 12 " trois Dozes de kina

pour le tonneliere.. " 9 66 66

" 13 " trois Dozes de kina

pour le tonneliere.. " 9 "6

"14 "trois Dozes de kina

pour le tonneliere.. " 9 " 6

" 2 " une visite de nuit pour

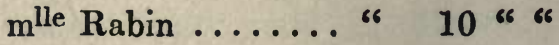

" 3 " une Lotion pour un

Erésipèle, que $\mathrm{m}^{\text {lle. }}$

Rabin a à la jambe. "6 $\quad 6$ "6 66

" 5 " une Lotion pour m $m^{\text {lle. }}$

Rabin

" 7 " une Lotion pour mlle.

Rabin ..........

" 8 " une medecine pour le tonneliere .......
9 "6 6 $6^{66} 6^{66} 66$ $66 \quad 6 \% 66$ $66 \quad 6^{666}$ 


\section{ORIGINAL DOCUMENTS}

1a. Translation of the Sanson bill-Continued.

December " 8 " A medicine for Joue... " 6 " 6 " 1785 January " 18 "A medicine for M. Audubon $\ldots . . . \ldots . . .6 \%$

" 21 "A medicine for the little negro Joue.....

February " 15 "Two ounces of manna for Mlle. Rabin...." $36 \%$

"6 18 " A medicine for the cooper ............ $66 \quad 6$ "6

March "6 6 A medicine for the cooper .........6" $66^{66}$

" 10 "A medicine for the cooper .........6" 6 "6

" 11 "Three doses of kino 4 for the cooper..... * 9 " 6

" 12 "Three doses of kino for the cooper ........

" 13 "Three doses of kino for the cooper ........ 66 966

" 14 "Three doses of kino for the cooper ........ * 9 " 6 April " 2 "A night visit for Mlle. Rabin .......... * 10 * "

" 3 "A lotion for an erysipelas which Mlle. Rabin has on the leg "6 $\quad 6$ "6 6 " A lotion for Mlle. Rabin .......... *6 6 "6 " 7 "A lotion for Mlle. Rabin ..........6" 6 " "6 " 8 "A medicine for the cooper ........... 66 $\quad 6^{66} 66$ 
1. The original Sanson bill-Continued.

" 9 " trois Dozes de kina pour le tonneliere...

" 10 " trois Dozes de kina pour le tonneliere... * 9 * *

66 11 "trois Dozes de kina pour le tonneliere... $66 \quad 9666$

" 12 "trois Dozes de kina pour le tonneliere... *6 9 " 66 " 24 " Passé la nuit pres de mlle. Rabin. en mal d enfant ........6 $66^{66}$ "66

66 25 " Passé la nuit pres de

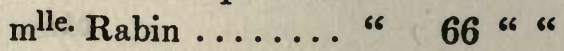

" 26 " mlle. $\mathrm{R}$ a bin est accouchée ......... .. *6 s6

may " 2 " une visite de nuit et Liqueur $\mathrm{m}$ in e r a le

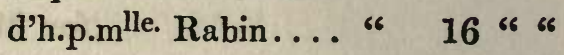

" 3 " Liqueur $\mathrm{m}$ in er ale d'hoffman p.mlle. Rabin ............ $66^{66}$ "6

"4 six Bouteilles d'eau blanche pour les cataplasmes nécessaires au mal de sein de mlle. Rabin..... "6 18 "6 66

juin

6 19 " ouvert un abcès au sein de mlle. Rabin soins et pour pansements. "6 36 \&6 6

" 26 " une medecine pour augustin negrillon.... 6 $\quad 6$ "6 
1a. Translation of the Sanson bill-Continued.

" 9 " Three doses of kino for the cooper ........

" 10 " Three doses of kino for the cooper .........

" 11 " Three doses of kino for the cooper ........ " 9 " “

" 12 " Three doses of kino for the cooper ........ " 9 " "

" 24 " Passed the night with Mlle. Rabin [who was] in child-birth.. " 66 " "

" 25 " Passed the night with Mlle. Rabin ...... " 66 " “ " 26 " Mlle. Rabin is delivered " . " "

May

“ 2 " A night visit and Hoffman's mineral water for Mlle. Rabin.... " 16 " "

" 3 "Hoffman's mineral water for Mlle. Rabin. " 6 “ “

"4 "Six bottles of eau blanche for poultices needed in an affection of the breast of Mlle. Rabin ....... " 18 " " June " 19 "Opened an abscess in the breast of Mlle. $R$ a b in ; for attentions and dressings. " 36 " " " 26 " A medicine for the little negro Augustine. “ 6 “ “ 
1. The original Sanson bill-Continued.

\section{[Page 3]}

Suite de l'autre part. . L 897 "

juin

juillet

aout

ybre.

$8^{\text {bre }}$

"6 30 "6 une medecine pour au-

gustin .......... L $\quad 6^{6 / 6}$

66 1 "6 une medecine pour la vielle jeanne....... * 6 " "

" 16 " une medecine pour $m$ [lle.] Rabin....... * 10 "6 "6

"6 15 " une medecine pour mlle.

Rabin ......... * 10 " *6

6 eau blanche pour $\mathrm{m}^{\mathrm{r}}$ audubon...$\ldots \ldots$ ss 3 " "

" 20 " une medecine pour $\mathrm{m}^{\mathrm{r}}$ aubinais commis.... " 10 "6

" 22 " une medecine pour $\mathrm{m}^{\mathrm{r}}$ aubinais ......... " 10 "6

"6 24 " tinture de Rhubarbe pour $\mathrm{m}^{\mathrm{r}}$ aubinais... * 6 " 6

" 26 "tinture de Rhubarbe pour $\mathrm{m}^{\mathrm{r}}$ aubinais... * $\quad 6$ * " 23 " une bouteille vin medicinal pour le nègre enflé ........... 66 15 "6 66

" 27 " une medecine pour la vielle jeanne....... * 6 \% 6 66 7 " une medecine pour le nègre enflé ........

" 11 " une medecine pour le nègre enflé..$\ldots \ldots 66^{6} \quad 6^{66}$ " 16 " une medecine pour thérése .......... 6 6 แ 6 


\section{ORIGINAL DOCUMENTS}

1a. Translation of the Sanson bill-Continued.

\section{[Page 3]}

Brought forward from the other part...... L 897 " " June " 30 "A medicine for Augustine ............ " 6 " " July « 1 " A medicine for old Jane " 6 “ "

" 16 " A medicine for M[1le.] Rabin .......... " 10 " " August " 15 " A medicine for Mlle. Rabin .......... " 10 " "

" Eau blanche for M. Audubon........ " 3 " "

" 20 "A medicine for M. Aubinais, clerk....." 10 " "

" 22 "A medicine for $M$. Aubinais ........ " 10 " "6

" 24, "Tincture of rhubarb for M. Aubinais.... " 6 " "

" 26 " Tincture of rhubarb for M. Aubinais.... " 6 " "

September " 23 " A bottle of medicinal wine for a swollen negro ............

"27 "A medicine for old Jane " 6 " "

October " 7 "A medicine for the swollen negro...... " 6 " "

"11"A medicine for the swollen negro..... " 6 " " " 16 " A medicine for Theresa " 6 " " 
1. The original Sanson bill-Continued.

" 19 " une medecine pour therese ......... " 6 " * acceptée apercu [?] Le 12 octob L 1009 "6 "6 1786 Audubon 330 1339 "6

Pour acquit aux cayes ce 7 juin 1787 Danson

\section{Recu de $\mathbf{M}^{\mathbf{r}}$ \\ Sanson \\ 7. Juin 1787.}

1784 janvier traité $\mathrm{m}^{\mathrm{r}} \ldots$. soins et fourni services... 330 " 


\section{ORIGINAL DOCUMENTS}

1a. Translation of the Sanson bill-Continued.

" 19 " A medicine for Theresa " 6 " "

Accepted viséd [?] October 12 L 1009 “ “

1786

Audubon 330

1339 “ “

Paid at Les Cayes this 7th June, 1787

SANSON

M. Sanson's receipt

June 7, $178 \%$.

1784 January Treated

M....For care and serv-

ices rendered ......... 330 " 
2. Copy of the Act of Adoption of Fougère (John James Audubon) and Muguet (Rosa Audubon). Nantes, March 7, 1794. (For translation, see Chapter IV.)

Extrait des registres des naissances des sections de la Halle et de Jean-Jacques de la commune de Nantes, département de la Loire-Inférieure, le 17 Ventose, an 2 de la République, une et indivisible, 10 heures du matin.

Devant moi Joseph Theulier, officier public élu pour constater l'état-civil des citoyens, ont comparu en la maison commune Jean Audubon, commandant la corvette "le Cerbère," bâtiment de la République, âgé de 49 ans, natif des Sablesd'Olonne, département de la Vendée et Anne Moinet son épouse, agée de 58 ans, native de la ci-devant paroisse de Saint-Léonard, de cette commune, lesquels assistés de René Toussaint Julien Beuscher, fabricant, âgé de 25 ans demeurant section de la Halle rue Rubens et de Julien Pierre Beuscher, chirurgien marin, âgé de 24 ans, demeurant section de la Fraternité, rue du Marchix, et employé par continuation sur la dite corvette le Cerbère, m'ont déclaré adopter et reconnaître dès ce moment comme leurs propres enfants savoir:

Un enfant mâle nommé Fougère, issu depuis le mariage d'eux comparant contrôlé le 24: Août 1772 dans la commune de Paimboeuf en ce département de lui Jean Audubon avec une habitante de l'Amérique morte il y a environ huit ans et une enfant femelle nommée Muguet issue aussi depuis le mariage sus dit de lui Jean Audubon d'une autre habitant de l'Amérique nommée Catherine Bouffard dont il ignore le sort.

Les deux enfants ci-présents, âgés le premier de 9 ans qui échoieront le 3 Floréal prochain, le second de 7 ans que échoieront aussi au 7 Floréal prochain tous deux nés en Amérique d'après cette déclaration que les témoins ci-dessus ont certifié véritable, 'j'ai rédigé le présent acte que le père naturel et la mère adoptive ainsi que leurs témoins ont signé avec moi les dits jour et an.

Signé au registre: Audubon Citoyenne Arse Mornet Jean Audubon, Beuscher \& Beuscher Jeune. 


\section{ORIGINAL DOCUMENTS}

3. Copy of the Act of Baptism of Jean Jacques Fougère Audubon. Nantes, October 23, 1800. (For translation, see Chapter IV.)

Premier brumaire, an neuvième.

Nous soussignés certifions avoir baptisé ce jour, premier brumaire, an 9 de la République, Jean Jacques Fougère Audubon fils adoptif de Jean Audubon lieutenant de vaisseau de la République et d'Anne Moinet sa légitime épouse, présents et certifiant l'adoption qu'ils ont fait du dit Fougère ainsi et de la même manière qu'il est porté dans l'acte ci-dessus.

Signé: Tardivead, prêtre de SaintSimilien de la Ville de Nantes. 
4. Copy of a bill of sale of Negroes rendered by Monsieur Ollivier to Monsieur Audubon. Les Cayes, Santo Domingo, 1785.

1785.-M. Audubon doit à Ollivier ce qui suit:

$$
\begin{aligned}
& \text { Juillet pour 4 négresses à } 1750 \quad 7.000 \\
& \text { - }-1 \text { " } 161750 \quad 1.750 \\
& \text { - - } 1 \text { négresse borgne } \quad 1.600 \\
& \text { - - } 1 \text { négritte } \quad 1.200 \\
& 11.590
\end{aligned}
$$

Pour acquit en compte et billet à mon ordre sous la réserve d'une augmentation de cent livres sur la négritte si elle vit au delà de six mois.

Aux Cayes, le 25 Juillet 1785.

Signé: Ollivier. 


\section{ORIGINAL DOCUMENTS}

5. Statement of Accounts of Messrs. Audubon, Lacroix, Formon, \& Jacques in the purchase of negroes from M. Th. Johnston, Les Cayes, Santo Domingo, 1785. (For comment, see Chapter III.)

Compte de vente frais et net produit de quarante nègres achetés de Monsieur Th. JOHNSTON, de compte à demi entre MM. AUDUBON LACROIX FORMON \& JACQUES, pour prix la somme de soixante mille livres, payée au dit sieurs la dite somme comme suit:

Par Monsieur Audubon

Par Lacroix Formon \& Jacques

$\left.\begin{array}{l}20.000 \\ 40.000\end{array}\right\}$

60.000

1785 Vendu par Monsieur AUDUBON, dont il se charge:

\begin{tabular}{|c|c|c|c|c|}
\hline Févriel & 11 & 1 & à..Reynaud Chateaudun & f 1650 \\
\hline - & 12 & 1 & - Garreau & 2100 \\
\hline - & 12 & 3 & - Bourseret & 6000 \\
\hline - & 12 & 1 & — Lui-même & 1500 \\
\hline - & 14 & 2 & - Cossard & 3564 \\
\hline - & 15 & 1 & -1 Lenoir & 1782 \\
\hline - & 18 & 1 & - Blanchet & 1782 \\
\hline - & 19 & 3 & - Jacques Bourry & 6000 \\
\hline Mars & 24 & 3 & - Bouffard & 4950 \\
\hline - & 24 & 1 & — Lui-même & 1500 \\
\hline - & 24 & 1 & - Ch. Gettée & 1800 \\
\hline - & 24 & 1 & - Bouffard & 1650 \\
\hline
\end{tabular}

19 têtes

34.278 
Vendu par Lacroix Formon \& Jacques dont il se charge:

Février $12 \quad 3$ à. Bourseret

6000

121 - Menard

2000

- 122 - Reynaud fils

3780

- 132 - Peridigon

3800

- 133 - Maillet Lacoste

- 151 - Dugay

- 193 - Jacques Bourry

- 191 - Lui-même

- 191 - Eux-mêmes

- 191 - Begon M.

- 192 - Millet

Mars 2 A. 1 de mort chez Villeneuve chirurgien pour mémoire.............

37.274

$$
\text { f... } 71.552
$$

Trais à deduire payés par Lacroix

Formon \& Jacques

Pour 80 régimes de bannanes 15

- 8 têtes de boeuf

Payé à Villeneuve chirurgien pour le traitement du nègre mort

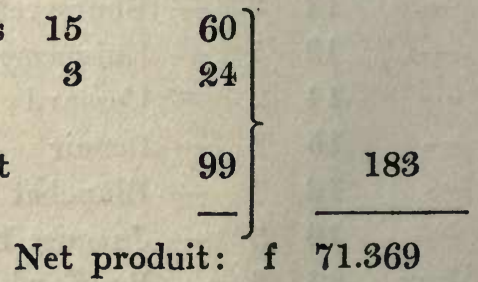

La demi de Monsieur Audubon

35.684 .10

Il a reçu en les reprises dont il se charge:

34.278 .6

Il lui est dû pour Lacroix Formon \& Jacques 


\section{ORIGINAL DOCUMENTS}

Clos et arrêté le présent compte en double par lequel il résulte que M. Audubon doit à Lacroix Formon \& Jacques dix mille livres pour sa demi du payement des dits nègres dont il les débite au compte courant arrêté ce jour en double, et les dits Lacroix Formon \& Jacques devant au dit Sieur Audubon celle de cent six livres dix pour sa demi qui lui revient du net produit de la vente des dits nègres, lesquels portés au crédit des deux comptes courant, dont quitté aux Cayes, le plus porté au crédit de M. Audubon la somme de dix sept cent quatrevingt deux livres pour la demi du billet du sieur Collard qui nous reste aux Cayes le 16 Septembre 1785.

Pour MM. Lacroix Formon \& Jacques

Signé: Clerc

Nous avons reçu de $\mathbf{M}$. 'Audubon la somme de trente mille livres pour la portion d'achat des dits nègres au-dessus. Aux Cayes, le 16 Septembre 1785.

Pour MM. Lacroix Formon \& Jacques

Signé: Clerc. 
6. Copy of bill of sale of Negroes to Monsieur Audubon, and a statement of his account with Messrs. Lucas Brothers \& Constant. Les Cayes, Santo Domingo, August 7, 1785June 9, 1788. (For comment, see Chapter III.)

Nous soussignés déclarons avoir vendu et livré à Monsieur Audubon, négociant de cette ville les nègres ci-après, nation Hibo et Canga...

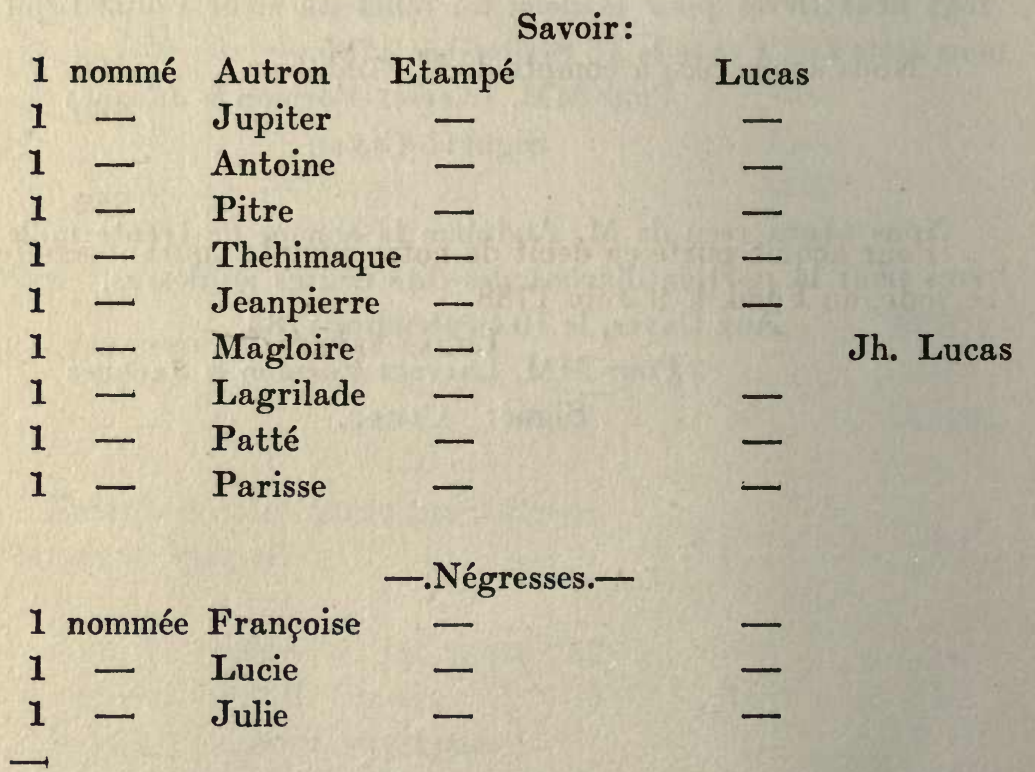

13 Ensemble treize nègres ou négresses à deux mille livres chaque formant la somme de vingt six mille livres sur laquelle somme nous avons reçu vingt-quatre mille livres comme suit:

16.000 en un mandat en sucre sur MM. Lacroix Formon \& Jacques.

$7.100-17-8$ en un billet de Formon Plumardière. $889-24$ en son billet.

24.000 pour payement et à compte des treize nègres 


\section{ORIGINAL DOCUMENTS}

ci-dessus détaillés, dans le nombre desquels le nommé Patté pour engagement de le livrer à $M$. Audubon dès qu'il sera en état de se rendre aux Cayes. Le dit sieur Audubon se réservant vue dessus quand nous lui en ferons la remise pour le prix de la somme de deux mille livres en argent comptant et moi Audubon accepte le dit marché et déclare avoir reçu livraison des douze têtes de nègres ou négresses que $\mathrm{j}$ 'ai bien vus et visités et desquels je suis satisfait, aux Cayes, le 7 Août 1785.

Signé: Audubon-Lucas frères.

Nous avons reçu à compte de M. Audubon

162

660

882

Pour acquit porté en debit de notre compte courant arrêté ce jour, au Fond, le 9 Juin 1788.

LuCAs Frères \& Constant. 
7. Accounts of William Bakewell, of "Fatland Ford," as protégé of his future son-in-laze and as attorney or agent for Audubon \& Rozier, giving certain exact indications

Mess $^{\text {rs }}$ Audubon \& Rozier

1805

Jan

4 Cash for sundries

11.25

12

$\mathrm{d}^{\mathrm{o}}$

$1 . \ldots$.

18 Brother

$150 . \ldots$

1807

Apl

22

Cash Mr Rozier

$66 . . .$.

Advertis'ts in Philad $^{\text {a } ~ \& ~ N o r r i s t o w n ~ . . ~}$

Cash $\mathrm{p}^{\mathrm{d}} \mathrm{M}$ Fishe

7......

$\mathrm{d}^{\mathrm{o}}$ paid Vendreman

$40 . \ldots$

3......

1808

Adv ${ }^{\text {ts }} \&$ hand bills............ 3.75

Cash Mr Pears .............. 14.50

May 3 Exps of Horses to Philad ${ }^{a} \ldots \ldots \ldots \ldots \quad 4.76$

20 Sundries $\ldots \ldots \ldots \ldots \ldots \ldots \ldots \ldots . \ldots \ldots$

June 8 Cash ....................... 3.18

17 Smith's work .............. 5.00

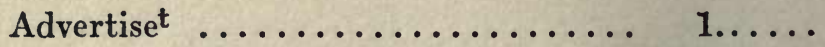

Oct 10 Exchange of Horse .................

Keep of Horses 23 weeks ........ 42.50

Dec $^{\mathrm{r}} 31$ Cash $\mathrm{p}^{\mathrm{d}} \mathrm{M}^{\mathrm{r}}$ Pears ............. 18.92

Note BY THE Autror. This record proves that Audubon upon his first return to France from the United States, must have left "Mill Grove" on the 12th of January, 1805, or not more than a day later; three days were required to walk to New York, which could not have been reached later than the 15th, and probably as many more were needed for a letter to go to "Fatland Ford." He probably sailed for Nantes shortly before January 


\section{ORIGINAL DOCUMENTS}

of the naturalist's movements and personal relations, before and after finally leaving "Mill Grove." January 4, 1805A pril 9, 1810. (For further reference, see Chapter VIII.)

in a/c with $\mathrm{W}^{\mathrm{m}}$ Bakewell

1805

March 18

Cash

5......

180 '

Apl

1 Cash of Miller ............. 150....

$\mathrm{d}^{\mathrm{o}}$ of Jackson .............. $50 . \ldots \ldots$

1808

Jan $8 \mathrm{~d}^{0}$ of Longacre ............. 50....

Apl $2 \mathrm{~d}^{0}$ of Longacre ............ $50 \ldots \ldots$

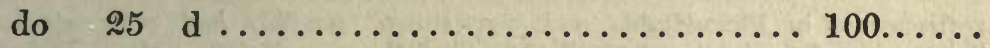

May $12 \mathrm{~d}^{0}$ formon $\ldots \ldots \ldots \ldots \ldots \ldots \ldots \ldots . \ldots \ldots$

Dec 20 Cash of Longacre ............ 30.....

18, the day when William Bakewell recorded that he had sent his "brother," Benjamin Bakewell, commission merchant in New York, \$150; this was undoubtedly in payment of the loan which the brother in New York had made to young Audubon for his passage to France. The next item, of April 22, 1807, was for money advanced to Ferdinand Rozier, probably when he was acting as clerk to Laurence Huron, in Philadelphia; "ad- 
7. Accounts of William Bakewell, of "Fatland Ford," as protégé of his future son-in-law and as attorney or agent for Audubon \& Rozier, giving certain exact indications

Mess $^{\text {rs }}$ Audubon \& Rozier

1809

\begin{tabular}{|c|c|c|}
\hline \multirow{3}{*}{25} & Advertise $^{t s} \&$ Vendue Exps $\ldots . . \ldots$. & 12.82 \\
\hline & Bills payable to W. Thomas ........ & $60 \% .10$ \\
\hline & Cash $\mathrm{p}^{\mathrm{d}} \mathbf{M}^{\mathrm{r}}$ Page for pow ${ }^{r}$ of Attorney & 1.37 \\
\hline 13 & Paid Attachment fees . . . . . . . . . . & 9.28 \\
\hline & Cash paid for $\operatorname{tax} \ldots \ldots \ldots$ & 2.91 \\
\hline & mortes $[?]$ \& half taxes............ & 7... \\
\hline
\end{tabular}

Commission 7998 a 1 1-2 per Cent .... 119.97

Jany 23 omitted Exps at Vendue........ 3.77

vertisements in Philadelphia and Norristown" possibly had reference to the lease and final sale of "Mill Grove" of the year before. Miers Fisher was the Quaker merchant, who for many years served as Lieutenant Audubon's American agent and attorney, and who was later the adviser of his son and Ferdinand Rozier. Thomas W. Pears, a relative by marriage of the Bakewells, was with Audubon in Benjamin Bakewell's office in New York, and afterwards associated with him and Thomas W. Bakewell in their disastrous mill experiment at Henderson, Kentucky. The bill of William Thomas, former Quaker tenant of "Mill Grove," was possibly in liquidation of his claim against Lieutenant Audubon and Dacosta in their mining operations at this farm (see the letters to Dacosta, Vol. I, p. 117). The credit entry under May 12, 1808, "formon-31.84," may represent interest collected on an unsettled claim of Lieutenant Audubon against Mr. Formon, a former partner in Santo Domingo, in relation to the sale of the ships, the Count of Artois and the Annette (see Chapter II, p. 33). Dacosta had been urged to apply to Mr. Formon's son-in-law, who appears to have lived at Philadelphia, but was unable to obtain anything from the Formon estate. The "Cash of Dacosta 299.44" possibly represented interest on the mortgage which we have assumed was given to Audubon and Rozier when Dacosta and his mining company came into possession of "Mill Grove," September 15, 1806 (see Chapter XI, p. 148). 


\section{ORIGINAL DOCUMENTS}

of the naturalist's movements and personal relations, before and after finally leaving "Mill Grove." January 4, 1805A April 9, 1810. Continued.

in a/c with $\mathrm{W}^{\mathrm{m}}$ Bakewell

1809

Apl 18 Clennell $\ldots \ldots \ldots \ldots \ldots \ldots \ldots \ldots . . \ldots . \ldots$

Sept 30 Kymar $\ldots \ldots \ldots \ldots \ldots \ldots \ldots \ldots . \ldots \ldots$

Oct 27 d $\ldots \ldots \ldots \ldots \ldots \ldots \ldots \ldots . \ldots . \ldots . \ldots$

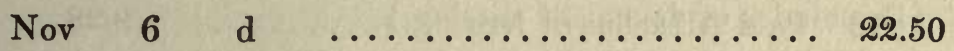

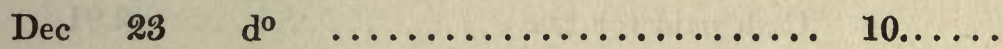

1810

Jan 23 Cash of Dacosta ............. 299.44

Feb $13 \mathrm{~d}^{\mathrm{o}}$ of Miller ......................

Balle of Neckland............. 237.32

Apl $\quad 3$ Miller $\ldots \ldots \ldots \ldots \ldots \ldots \ldots \ldots . .6 . \ldots$

9 do $\quad \ldots \ldots \ldots \ldots \ldots \ldots \ldots \ldots, 6.121 / 2$

$\$ 1159.221 / 2$ 
8. Concerning a Power of Attorney issued by Lieutenant Audubon and Anne Moynet Audubon to Ferdinand Rozier and John Audubon, the Younger, at Couëron, France, in 1805; parts in French translated by a Philadelphia notary; signatures of original document authenticated by the Mayor of Couëron, October 21, 1805; his attest of the legality of Anne Moynet Audubon's signature, at Couëron, October 27, 1805; authentification of the signature of the Mayor of Couerron by the Subprefect of Savenay, November 27, 1805; attest of the Subprefect's signature by the Prefect. (Remainder of document missing.)

Commonwealth of Pennsylvania ss:

I, Peter Stephan Du Ponceau, notary public \& Sworn Interpreter of foreign Languages for the Commonwealth aforesaid, residing in the City of Philadelphia, do hereby certify that I have carefully translated into English so much of the Instrument of writing hereunto annexed as is written in the French language, as follows, to wit:

At the bottom of the Deed [act] and immediately after the Signatures of the Witnesses, there is a Certificate in France [French], which being translated, is as follows:

Seen by us, the Mayor of the commune of Coueron, who attest the above Signatures of G. Loyen, assistant mayor, C. D'orbigny, Doctor of medicine, Audubon, \& Anne Moynet Audubon, to which full faith and credit is to be given, whereever it may be necessary-Done in our Office at Coueron, the thirtieth of yendemiaire fourteenth year of the French Empire [sic].

G. VALIIN, mayor.

[Mayor's seal] 
And on the back of the said Deed [Act] is written in French what follows.

We, Germain Vallin, Mayor of the commune of Coueron in the Department of Lower Loire in the French Empire, certify to all whom it may concern, that on this day, personally appeared before me John Audubon and Anne Moynette, his wife, both now residing in this said commune, and represented to us, That in order to give its full force \& effect to the Instrument written on the other side hereof, in the English language, which they have declared to be a letter of attorney in favor of Messieurs Ferdinand Rozier, \& John Audubon, junior for the purposes therein mentioned, it was necessary that the said Instrument be by them acknowledged before us, according to the forms prescribed by the Laws of the State of Pennsylvania, and that the said Anne Moynette Audubon should be examined by us separate from her said husband, in order to declare that she has signed and executed the said Deed [Act] of her own free will and accord, and without being compelled thereto by her husband; That this formality is rigorously required by the Laws of the State of Pennsylvania, and no other act, not even a notarial Instrument, can in any manner Supply the same.

In consideration thereof, we have received the acknowledgment which the said appearers have made before us, by which they have declared and acknowledged that the said Instrument, written in the English Language on the other sides hereof is their own Act and Deed, and that they desire that it may be recorded as such, whenever it may be necessary.

And the said John Audubon having withdrawn, we have examined the said Anne Moynette Audubon separately and apart from her said husband, and She declared to us, That She knows \& perfectly understands the contents of the said Deed [Act], and that She has Signed, Sealed, and declared [deliv- 
ered] the same, of her own free will and accord, without being compelled thereto by her said husband, either by threats or by any other means of compulsion whatever. In faith whereof, we the Mayor aforesaid, have Signed the present Certificate, and have caused the Seal of this mayoralty to be thereunto affixed-Given at Couëron the thirtieth of vendemiaire fourteenth year of the French Empire [sic]

G. VALIIN.

[Seal of the mayoralty

of Couëron.]

(Afterwards is written also in the French Language, as follows :)

I have seen the above and attest the Signature of G. Vallin, mayor of the commune of Couëron, above and on the other side affixed.

Done in the Subprefect's office, at Savenay, the fifth Brumaire fourteenth year.

The Subprefect of the first District. Magonet Tremelotrie

[Seal of the District of Savenay] 


\section{ORIGINAL DOCUMENTS}

I attest the above Signature of Magonet Tremelotrie.-

Nantz, the $7^{\text {th }}$. Frimaire $14^{\text {th }}$ year

The Prefect

Belleville

which [remainder wanting.] 
9. Articles of Association of Jean Audubon and Ferdinand Rozier to govern their partnership in business; drawn up at Nantes, March 23, 1806. (See Chapter IX.)

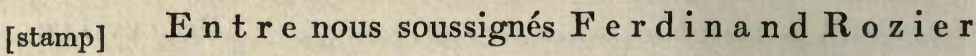
REP. FRA. et J e a n A u d u b o n, nous proposant de passer 50 aux états Unis sommes Convenus de former une cen société de Commerce aux Conditions Suivantes.

\section{Article Premier.}

L a s o c i été sera régie sous les noms Collectifs de Ferdinand Rozier et Jean Audubon et chacun de nous aura la Signature pour toute affaire.de notre Commerce seulement.

$$
\text { Art. 2. }
$$

a Notre arrivée nous prendrons possession de La terre de Mill-Grove, et nous ferons rendre Compte a $\mathbf{M r}^{\mathrm{r}}$. D a c o s t a qui a la procuration $\mathbf{d} \mathbf{M r}^{\mathbf{r}}$. A u d u b o n pére . nous nous occuperons des moyens de faire valoir cet établissement ou prendre Connoissance de La mine de Plomb Découverte, et avant d'y continuer les travaux Commencés, nous Examinerons si les dépenses faites par le $\mathrm{Sr}$. $\mathrm{D}$ a c o s $\mathrm{t}$ a ont été et peuvent nous etre utiles. enfin nous fairons où fairons faire des devis Estimatifs des frais et des produits qui peuvent en résulter. et nous n'entreprendrons rien que nous ne soyons tous deux parfaitement d'accord sur le principe en Conséquence nous signerons l'un et l'autre le projet que nous en arrêterons afin que l'un de nous ne s'en écarte, et il en sera de meme pour toute les nouvelles Dépences qui changeraient les profits arrêtes.

\section{Art. 3.}

Il est convenu que la Moitié du produit de cette habitation seront entre nous par Moitié et pour en Connoitre ainsi 
9a. Translation of the Articles of Association of John Audu bon and Ferdinand Rozier.

[stamp] We, the undersigned, Ferdinand Rozier and John REP. FRA. Audubon, who are intending to go to the United 50 States, are agreed to form a partnership in business cen upon the following conditions:

\section{Article First.}

The partnership will be administered under the joint names of Ferdinand Rozier and John Audubon, and each of us will have the power of signature for all matters of our business only.

\section{A r t. 2.}

Upon our arrival we will take possession of the farm of Mill-Grove, and we will call to account Mr. Dacosta, who has the power of attorney of Mr. Audubon, Senior. We shall take measures to improve the establishment, or make an investigation of the lead mine discovered [on the property], and before continuing the work already begun we will ascertain whether the expenditures made by $\mathbf{S}^{r}$. Dacosta, have been, and can still be, advantageous to us. Finally we shall prepare, or attempt to prepare, estimates of the expenses and the products which accrue from these, and we shall undertake nothing upon which we are not both perfectly agreed in principle; consequently we shall both subscribe to the project which we shall decide upon, in order that neither of us may depart from it, and it will be the same for all new expenses which might alter the plans that are reached.

$$
\text { A r't. } 3 .
$$

It is agreed that half the product of this plantation shall be divided between us on a one half basis, and in order to 
que la perte, nous aurons un Livre particulier pour cet Objet, d'un Coté seront Inséres les articles de dépences par Jour, et au moment que nous en fairons, de l'autre Coté les ventes et Produits des fermes et de tout ce qui pourra résulter de cette Opération en sorte que le Bénéfice se verra tous les jours par l'addition des articles qui Composeront le débit et le Crédit.

\section{A r t. 4 .}

La Maison cy dessus sera un objet distinct. de tout Commerce afin de pouvoir régler cette propriété tant et tant de fois que Nous le désirerons. il est même Convenu que joindrons aux frais de cette Exploitation ceux nécessaires pour la vie et autres dépences communes tant qu'il nous Conviendra de vivre et d'habiter ensemble.

\section{A r t. 5 .}

Il ne peut nous etre interdit de faire tout autre Commerce, mais avant d'en entreprendre nous resterons six mois a prendre des Informations aux pays de ce qui pourroit nous etre avantageux, alors nous nous livrerions à quelque opération de commerce ou Intérieur ou Maritime.

\section{A r t. 6.}

Nous pourrons l'un et l'autre faire quelque voyage a l'effet de nous procurer des Connoissances, et s'il arrivait que nous decidions quelque Négociants a envoyer des Marchandises à la vente ou à la Consignation de $\mathbf{M}^{\mathrm{r}}$. Rozier pére nous fairions la Condition que le Bénéfice qui resulteroit de ces Consignations seroit partages entre nous et le $S^{u r}$. F. Rozier pere.

\section{'Ár. $\%$.}

Tous les bénéfices comme les pertes résultant de nos Opérations Commerciales seront partagées Egalement entre les associes. 
recognize this [profit], as well as the loss, we shall keep a special book for the purpose; on one side shall be entered the items of expense, day by day, and, at the moment this is done, on the other side [shall also be given] the sales and products of the farms, and of all that can result from this business, in such a way that the profit shall be always apparent by the addition of the items which compose the debit and the credit.

\section{A r t. 4.}

The house above mentioned [Mill-Grove farmhouse] shall be an object separate from all business, in order that we may settle matters as completely as we desire. It is agreed that we shall add to the expenses of this exploitation, those necessary for life, and others of a common character, so long as it shall suit us to live and dwell together.

\section{A r t. 5 .}

We cannot be prevented from engaging in any other kind of business, but before undertaking it we shall remain six months in order to gather from the country information of a kind that would be advantageous to us; we shall then apply ourselves to some commercial occupation, whether inland or maritime.

\section{A r t. 6 .}

We are both at liberty to make any journey in order to procure information, and should it happen that we persuade any merchants to send goods to Mr. Rozier, Senior, we would establish the condition that the benefit which might result from these consignments would be divided between us and the $\mathbf{M}^{\mathbf{r}}$. F. Rozier, Senior.

\section{Art. $\%$.}

All the benefits as well as the losses resulting from our commercial transactions shall be divided equally between the partners. 


\section{A r t. 8.}

Les frais de Passage et autre communs entre nous fairont le premier article de nos dépences sociales....

\section{Art. 9.}

Nous nous promettons l'un et l'autre a mitié et In-$\mathrm{t} \mathrm{e} 11 \mathrm{i} \mathrm{g}$ e $\mathrm{n} \mathrm{e}$, et convenons très expressement qua la moindre difficulté, nous prendrons chacun un arbitre qui sera authorisé a se choisir un troisieme et nous engageons sur notre honneur a en passer par tout ce qui sera décidé, sans que jamais nous puissions en faire appel devant aucuns tribunaux.

\section{Art. 10.}

En cas de mort de l'un ou l'autre (ce qu'a Dieu ne plaise) le survivant sera seul charge de la Liquidation pour en tenir Compte à qui de droit, c'est a dire aux héritiers du Déffunt, mais la societé ne pourra etre dissoute que neuf années à Compter du Jour de la Datte du présent. ce Cas seulement arrivant, il sera alloué au survivant une Commission sur les produits de l'Etablissement fixe à Dix pour Cent.

Fait double et de bonne foy entre nous.

Nantes ce 23 Mars 1806.

$$
\begin{aligned}
& \text { TERDINAND ROZIER } \\
& \text { JEA AUDBON }
\end{aligned}
$$




\section{ORIGINAL DOCUMENTS}

\section{A rt. 8.}

The expenses of the journey and others of a common nature shall make the first item of our social expenses. ...

\section{A r t. 9.}

We both resolve to maintain friendship and mutual understanding, and we agree very expressly that, upon the least difficulty, we shall each select one arbitrator, who will be authorized to choose a third, and we promise upon our honor to fully accept the decision that shall be reached, without ever having it in our power to make an appeal from it before any courts.

$$
\text { Art. } 10 .
$$

In case of the death of one or the other (which, God forbid), the survivor shall have sole charge of making a settlement, in order to give an accounting to those entitled to it by law, that is to say to the heirs of the deceased, but the partnership cannot be dissolved until after nine years, counting from the day of the date of the present [instrument]. Only in this event, the survivor will be allowed a commission upon the products of the establishment fixed at ten per cent.

Done in duplicate and in good faith between us.

Nantes this 23 March 1806.

John Audubon FERDINAND ROZIER 
10. Power of Attorney issued by Lieutenant Jean Audubon, Anne Moynet Audubon, and Claude François Rozier to their respective sons, Jean Audubon and Ferdinand Rozier, at Nantes, France, April 4, 1806, eight days before the latter embarked to America to enter upon their partnership in business.

[stamp] Par devant Royer et Son Collégue, notaires à la REP. FRA. résidence de Nantes, département de la Loire-incen férieure soussignés, - ont comparu le Sieur Jean Audubon, rentier, et dame Anne Moinet, son épouse qu'il autorise, demeurants rue Rubens, No. 39, et monsieur Claudefrançois Rozier, négociant, rue de la fosse, tous trois commune de nantes, Les quels constituent pour leurs Procureurs généraux et spéciaux Jean Audubon, fils, et ferdinand Rozier, fils, aux quels, l'un en l'absence de l'autre, ils donnent pouvoir et procuration de faire, pour et au mieux de l'intérêt de Constituants, tous réglements de comptes, éligements de crédits, recovrements, payements, et autres actes analogues avec tous fermiers, correspondants, débiteurs et créanciers des Constituants aux Etats-unis d'Amérique; plaider, constituer, transiger, recevoir, donner quittances, renouveler, prendre termes, expedier et géréralement faire pour leur utilité, tout ce qui leur semblera le plus convenable; le tout, d'après les renseignements, pieces et documents relatifs, qui leur ont été, leur sont ou leur seront fournis tant par les constituants que par autres leurs précédents chargés d'affaires et fondés de pouvoirs aux dits Etatsunis de régir, gérer et administrer la moitié appartenante aux constituants de la terre de Mill Grove en Pensylvania même d'exploiter ou faire exploiter la mine de plomb récemment découverte sur la dite terre: consulter dans tous les cas importants, monsieur Miers fisher,-négociant à Philadelphie, comme ami commun et bon conseil; tenir tous livres et registres nécessaires, faire à la fin de chaque année ou plutôt, la balance de la recette et dépense pour la régie de la dite terre et l'exploitation de la mine, s'il y a lieu; vendre aux prix, charges, clauses 
10a. Translation of the Power of Attorney issued by Jean Audubon, Anne Moinet Audubon, and Claude François Rozier to Jean Audubon and Ferdinand Rozier, April 4, 1806.

[stamp] In presence of Royer and his colleague, notaries,

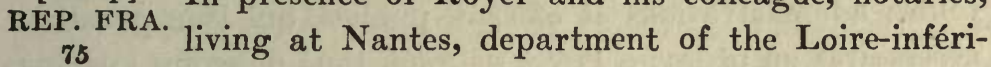
cen eure, undersigned, have appeared Sieur Jean Audubon, capitalist, and Madame Anne Moinet, his wife, whom he authorizes [to act], living at Number 39, rue Rubens, and Monsieur Claude François Rozier, of rue de la Fosse, all three of the commune of Nantes: who empower, to act as their general and special attorneys, Jean Audubon, the younger, and Ferdinand Rozier, the son, to whom, jointly and severally, they give authority and warrant of attorney to make, for and in the best interest of the grantors, all settlements of accounts, assignments of credits, recoveries of debts, payments, and other analogous acts with all tenants, representatives, debtors and creditors of the grantors in the United States of America; to go into court, settle, compromise, receive, to give receipts, to renew [loans or notes], to grant time, to expedite, and in general to do for their benefit all that shall seem to them most fitting; the whole, according to the instructions, papers, and documents relating thereto, which have been, are, or shall be furnished them, as well by the grantors as by their previous agents and attorneys in the aforesaid United States, to govern, conduct, and administer the half, belonging to the grantors, of the farm of Mill Grove in Pennsylvania, as well as to exploit, or cause to be exploited the lead mine recently discovered on the said farm; to consult, in every important matter, Mr. Miers Fisher,-merchant at Philadelphia, as a common friend and good counsellor; to keep all necessary books and registers; at the end of each year, or sooner, to strike the balance of receipts and expenses for the control of the said farm and the exploitation of the mine, should there be reason for it; to sell at prices, charges, stipulations, and conditions, 
et conditions dont il conviendront, mais d'accord avec monsieur Dacosta, propriétaire de l'autre moitie, la moitié de la dite terre de Mill grove, appartenante aux constituants, en toucher le prix, en donner quittances, faire tous partages, accepter tout lot et généralement faire pour l'intérêt des constituants tous actes conservatoires et definitifs en tous tribunaux, devant toutes administrations et officiers publics, qui leur paraitront nécessaires ou utiles; à l'effet de quoi, tous pouvoirs analogues exprimés ou non exprimés pour tous cas prévus ou imprévus, même de substituer en tout ou partie des dits pourvoirs, qui bon leur semblera et de le revoquer, leur sont donnés par la présente procuration qui ne sera pas sujette à surannation.

fait et passé en l'étude et au rapport de Royer, l'un de nous, sous les seings des comparants, après lecture, ce jour trois avril mil-huit-cent six. la minute est signée des parties et des Notaires soussignés; elle est restée à Royer, l'un d'eux, enregistrée à nantes le trcis avril mil-huit-cent-six par Dufau, qui a reçu un franc dix centimes.

VA R S A V A U X

J. $N$ OY E R

vu par nous président du tribunal de première instance séant à nantes, pour légalisation des Signatures varsavaux et Noyer apposées ci-dessus.

Ce jour trois avril mil huit cent six

$\operatorname{ca}_{\mathrm{A}} \mathrm{N}$ O N

Commercial Agency of the United

States of America

I William D. Patterson Commercial agent of the United States of America for the Port and District of Nantes do hereby certify that the Signatures affixed to the foregoing Document are those of Mess ${ }^{r s} \mathbf{J}$ Royer and Varsavaux both Notaries publick for the City of Nantes and of $M^{r}$ Gandon 
upon which they shall agree, but in accord with Monsieur Dacosta, owner of the other half, the half of the said farm of Mill Grove, belonging to the grantors; to receive the price thereof, to give receipt for it, to make all divisions, to receive all allotments, and in general to perform for the interest of the grantors all conservative and final acts in every court of justice before all jurisdictions and public officers, which shall seem to them necessary or useful : to the effect of which all analogous powers, expressed or unexpressed, foreseen or unforeseen, even of substituting in whole or in part of the aforesaid powers, whosoever shall seem good to them, and of revoking him, are given to them by the present bill of attorney, which will not be subject to expiration.

Done and granted in the office and on the report of Royer, one of us, under the signatures of the persons in appearance, after reading, this third day of April, one thousand eight hundred and six. The minute is signed by the parties and the undersigned notaries; it remains with Royer, one of us, recorded at Nantes the third of April one thousand eight hundred and six, by Dufau, who has received one franc, ten centimes.

VarsavaUX

J. ROYER

[S e a l] Examined by us, judge of the Court of the First Instance, sitting at Nantes, for the authentication of the signatures Varsavaux and Royer, affixed above, this third day of April, one thousand eight hundred and six.

Gandon

President of the Tribunal of premiere Instance at the said City and that to their Signatures and Ads as such, full faith and Credit is and ought to be due and given

[S e a l] In testimony whereof I have hereunto Set my Hand \& affixed my Seal of Office at Nantes this $4^{\text {th }}$. of april 1806.

W D PATTERSON 
11. Account Current of John Audubon and Ferdinand Rozier with the estate of Benjamin Bakewell, late commission merchant in New York, showing their dealings and standing with this house during the first sixteen months of their

1807

Augt 1 To Sundry Merchdize $\mathrm{p}^{\mathrm{r}}$ Invoice......\$2482 35

31 "Cash sundry expences on the above.. 644

Septr $29 \quad$ "Merchdize Powder Horns shot bags \&c 57

Nov 13 " W Taylor $\exp ^{\mathrm{s}}$ on $\mathrm{D}^{\circ}$ to Pittsburgh

" Cash certificate property $\mathrm{p}^{\mathrm{r}}$ Mentor to Nantes ............... 2

30 " $\mathrm{D}^{\circ}$ postage sundry french letters.. 314

Decer 31 " $\mathrm{Adv}^{\mathrm{t}} \mathrm{p}^{\mathrm{r}}$ Jane \# for Indigo \& expences ............... 151643

1808

Jany 29 "Cash frt $^{\mathrm{t}}$ \& cartge Oil from Philad ${ }^{\mathrm{a}}$.. 1245

30 " $D^{o} p^{d}$ Hislop for breast pins on your a $/$ c................... 9

Balance.............. 69512

1808

March 1 To Merche $\mathrm{p}^{\mathrm{r}}$ Bill @6 mo $\ldots . . . . . . . \$ 161$

April 7 " your note due this day......... 3647 29

"R. Henderson $\mathrm{am}^{\mathrm{t}}$ due him by you.. $\quad 7212$

June 27 "Cash cartge \& Lighterage on tobacco 750

"6 Freight \& primage- "6 $\mathrm{D}^{\circ} \ldots .105$

July 28 " your note due this day......... 78773 Septr 23 "Mdse 1 doz sans paraitres........ 24. 24.

$\$ 4804,90$

Dec $^{r} 13$ To Balance $\ldots \ldots \ldots \ldots \ldots \ldots \ldots \ldots \ldots \$ 92449$

Note bY The Author. For brig Mentor, see Chapter XI, Vol. I, p. 163, and for the ship Jane, Captain Sammis, ibid., p. 158. For Messrs. Robert 
business experience in the West. Covers the period, August 1, $180^{7}$ to December 13, 1808. (Statement accompanying the letter of Thomas Bakewell, reproduced in Vol. I, p. 196.)

in Account Current with Benj ${ }^{\text {n }}$ Bakewell Crs.

\section{7}

Augt. $\quad 4 \quad$ By your note at $8 \mathrm{mo}^{\mathrm{s}} \ldots \ldots \ldots \ldots \ldots 364729$

Dec ${ }^{\mathrm{r}}$. 31 " net proceeds sales on

your a/c .......... $319.35 \quad 32385$

“Francis Rozier balance his a/c... 81656

1808

Feby 1 By Balance as $\mathrm{p}^{\mathrm{r}}$ a/c rendered......\$ 69512 March 1 " your dft on U S Bank Philada.... 2000 " commission on goods al-

lowed you ........ \$118.20 [paper torn] deduct $1 / 3$ profit on

french goods ....... 24.26 [ 93.94]

25 “ $\mathrm{R}$ Kinder \& $\mathrm{C}^{\mathrm{o}^{\prime} \mathrm{s}}$ accept $\mathrm{e}\left(\overline{\mathrm{m}} \mathrm{o}^{\mathrm{s}}\right.$. [paper torn]

"L Huron's note - "9 days.[ " ]

"your note @ $4 \mathrm{mo}^{\mathrm{s}}$ for balance..[ “] ]

Balance.............. [ 924.49$]$

New York Decem ${ }^{\mathrm{r}}$. 13 $3^{\text {th }} .1808$

for the Assignees of the [estate of Benjamin

Bakewell]

Th[omas Bakewell]

Kinder \& Company, see accompanying letter of Thomas Bakewell, Vol. I, p. 196, and letter of William Bakewell, his uncle, ibid., p. 199. Laurence Huron was a French importer, resident in Philadelphia; for his award in the disputed Dacosta claim, see Vol. I, p. 168. At this time Benjamin Bakewell's importing business was in the hands of his creditors, but his son, Thomas Bakewell, was still employed in the office. 
11a. Final Account of Francis Dacosta, rendered July 25, 1807, to Lieutenant Jean Audubon, his vartner in the unfortunate

Dr. Mill Grove Farm-in account

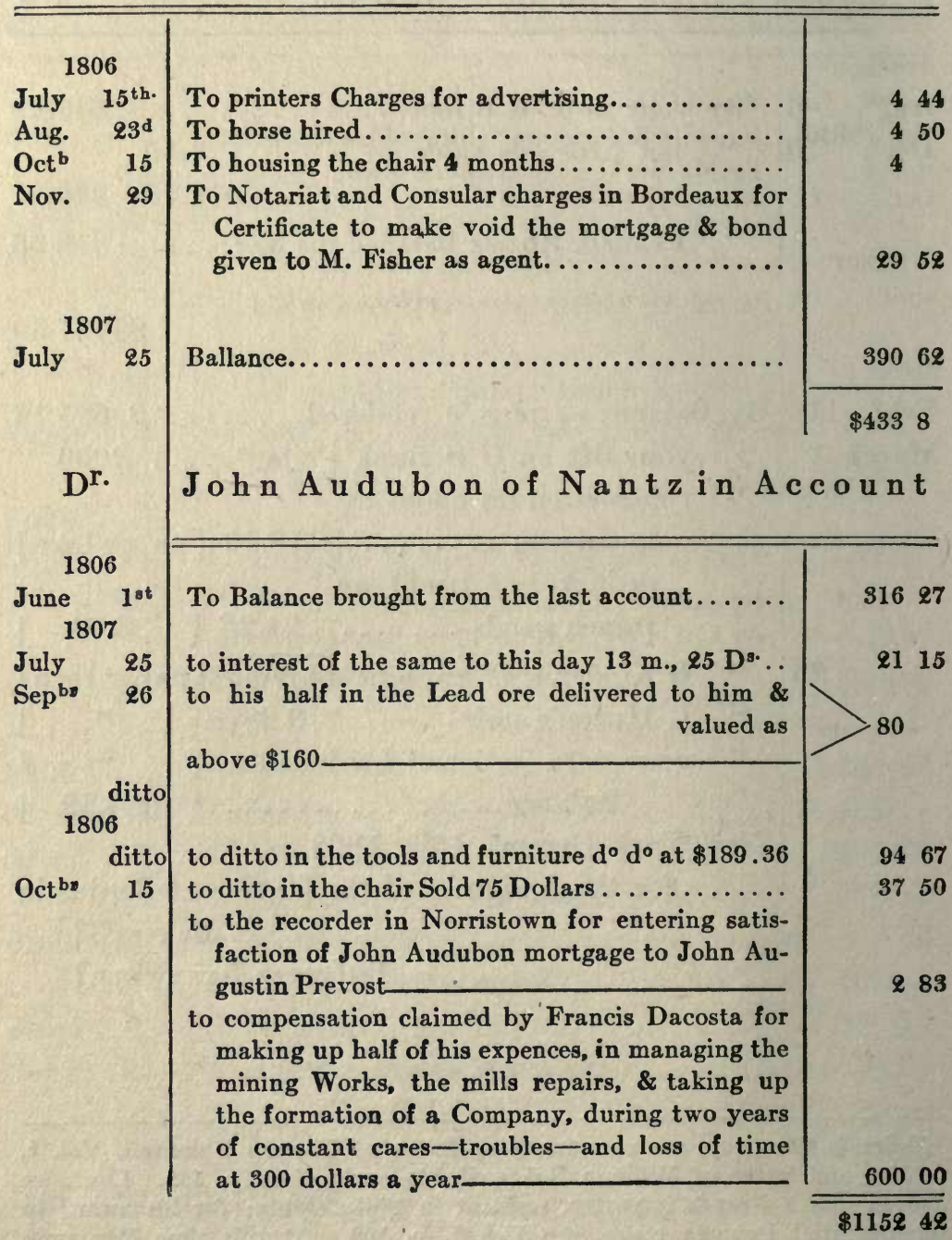


mining enterprise at "Mill Grove"; later contested and settled by arbitration. (For comment, see Vol. I, p. 168.)

with Francis Dacosta Cr.

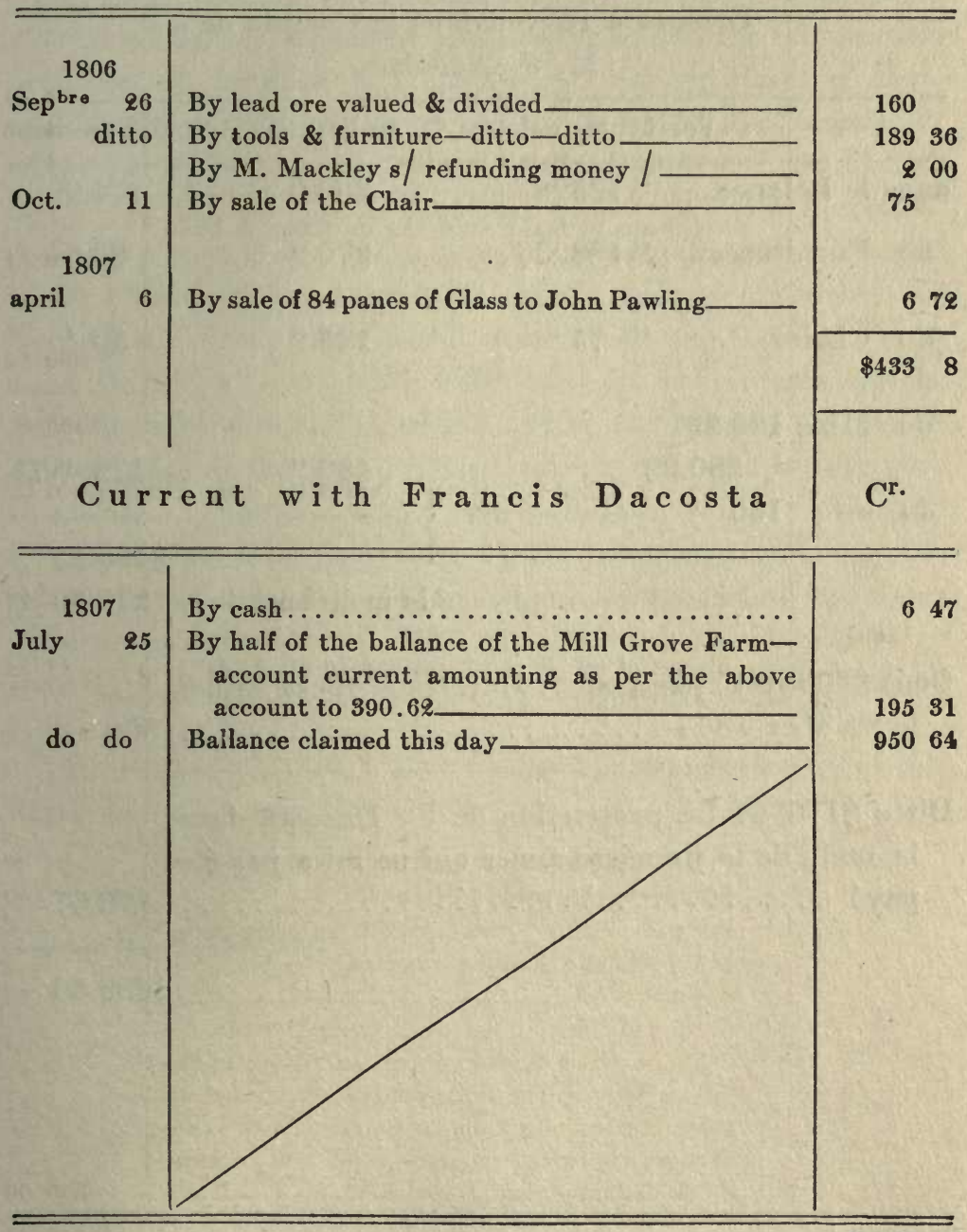

$\$ 115242$

E. E. Philadelphia the $25^{\text {th }}$ July 1807

[Signed] Francis Dacosta. 
11a. Final Account of Francis Dacosta, rendered July 25, 1807, to Lieutenant Jean Audubon, his partner in the unfortunate mining enterprise at "Mill Grove"; later contested and settled by arbitration.-Continued.

Erreurs à réléver dans le Compte de M. J. Audubon

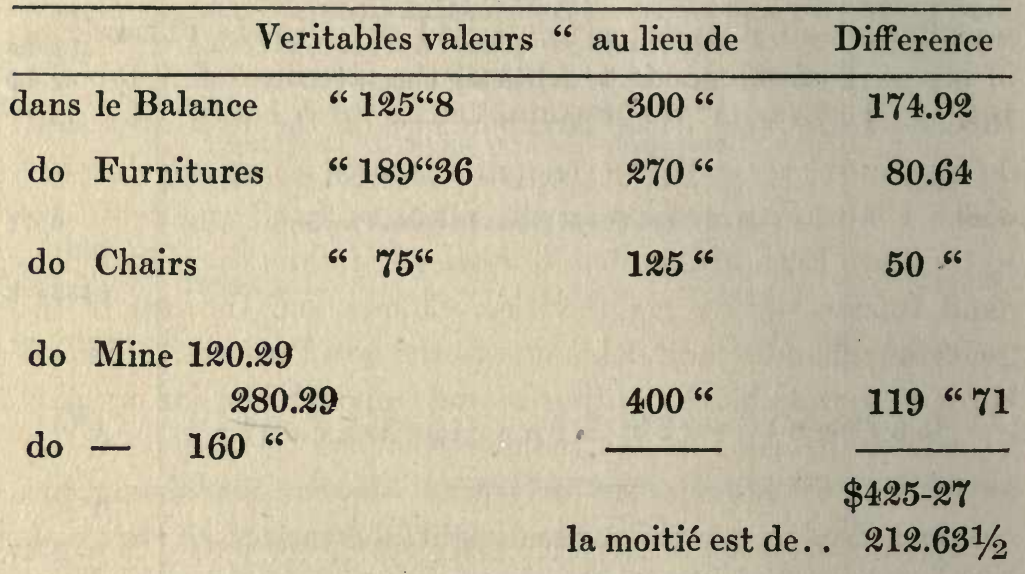

Omis $\$ 300$ payé par francis Dacosta à Miers Fisher le 24 May 1803 .................. 300

Ditto $\$ 176 “ 67$ La proportion de Fis Dacosta dans la rente de la premiere annee qui ne lui a pas été payé ....................... 176.67 
12. Quit Claim or Release given by John James Audubon to Ferdinand Rozier on the Dissolution of their Partnership in Business at Sainte Generiève, Upper Louisiana (Missouri), April 6, 1811.

I John Audibon having this day by mutual Consent with Ferdinand Rozier, dissolved and forever closed the partnership and firm of Audibon \& Rozier,-and having Received from said Ferdinand Rozier, payments and notes to the full amount of my part of the goods \& debts of the late firm of Audibon \& Rozier-I the said John Audibon one of the firm aforesaid, do hereby release and forever quit Claim to all or any Interest which I have or may have in the Stock on hand and debts due to the Late Firm of Audibon \& Rozier unto him the said Ferdinand Rozier, all my rights titles, claimes and Interest in the goods merchandise and debts due to the late Firm of Audibon \& Rozier-and do hereby authorize and empower him for my part to collect the same in any manner whatseer . either privately or by suit or suits in law or equity-hereby acclaiming him sole and absolute proprietor and rightful owner of all the goods merchandises \& debts of the firm aforesaid, as completely as they were the goods and property of the Late firm of Audibon \& Rozier-

In witness whereof $I$ have hereto Set my hand \& Seal this Sixth day of April 1811

[Seal]

Ed D. De Villmonte

John Audubon

Note BY THE AUTHor. It will be noticed that the naturalist writes his name seven times as "Audibon," in this document, but signs in the way usual with him at the period. See Vol. I, p. 24. 
13. Copy of a portion of the first Will of Lieutenant Jean Audubon. Couëron, May 20, 1812. (For comment on this and documents Nos. 14 to 18, see Chapter IV.)

Jean AUDUBON, propriétaire demeurant à sa maison de la Gerbetière commune de Couëron, lequel sain d'esprit a fait son testament comme suit:

Par les présentes mon testament.

Je donne et lègue à dame Anne Moinette mon épouse, la part et portion disponible en usufruit à raison de ce que j'aurai ou non de descendants de généralement tous les biens meubles et immeubles qui m'appartiendront à l'instant de mon décès.

Je donne et lègue à Monsieur Jean Audubon que je crois actuellement aux Etats-Unis sans cependant en être sûr, la moitié en toute propriété de généralement tous les biens meubles et immeubles qui m'appartiendront à l'instant de mon décès pour par lui en faire et disposer en toute propriété et à sa volonté à la charge toutefois par lui de laisser dame Anne Moinette mon épouse jouir sur iceux du legs fait ci-dessus en sa faveur.

Je donne et lègue à dame Rose Bouffard épouse de Monsieur Gabriel Loyen du Puigaudeau, demeurant actuellement au Port-Launay en Couëron, la moitié en propre de généralement tous les biens meubles et immeubles qui m'appartiendront à l'instant de mon décès pour par lui en faire et disposer en toute propriété et à sa volonté à la charge toutefois par elle de laisser dame Anne Moinette mon épouse, jouir sur iceux du legs que je fais ci-dessus en sa faveur.

Je veux et entends qu'en cas de mort de Monsieur Audubon ou de madame Puigaudeau, mes deux derniers légataires aux présentes ou même de tous les deux, les héritiers en ligne directe de l'un ou de l'autre recueillent entr'eux le legs fait en leur faveur, c'est-à-dire que les héritiers de M. Audubon recueilleront le legs qui lui est fait et ceux de Madame Puigaudeau celui fait à la dite; en cas toutefois que les sieurs Audubon et la dame Puigaudeau ne recueilleraient pas eux-mêmes le legs, soit parce qu'ils précéderaient moi le testateur, ou autrement, ... 


\section{Copy of the second and last Will of Lieutenant Jean. Audubon. March 15, 1816.}

Moi, soussigné, Jean AUDUBON, demeurant à la Gerbetière en la commune de Couëron, département de la LoireInférieure.

Par les présentes mon testament.

Je donne et lègue à dame Anne MOINETTE, mon épouse la part et portion disponible en usufruit à raison de ce que j'aurai de descendants de généralement tous les biens meubles et immeubles qui m'appartiendront à l'instant de mon décès.

Je donne et lègue à Monsieur Jean RABAIN créole de SaintDomingue, que je crois actuellement aux Etats-Unis, sans cependant en être sûr, époux de Mademoiselle Lucy BACKWELL, la moitié en toute propriété de généralement tous les biens meubles et immeubles qui m'appartiendront à l'instant de mon décès pour par lui en faire et disposer en toute propriété et à sa voionté, à la charge toutefois par lui de laisser dame Anne Moinette, mon épouse jouir sur iceux du legs fait ci-dessus en sa faveur.

Je donne et lègue à dame Rose BOUFFARD, créole de Saint-Domingue épouse de M. Gabriel Loyen du Puigaudeau, demeurant actuellement au Port-Launay en Couëron, la moitié en propre de généralement tous les biens meubles qui m'appartiendront à l'instant de mon décès pour par elle en faire et disposer en toute propriété et à sa volonté, à la charge toutefois par elle de laisser à dame Anne Moinette, mon épouse jouir sur iceux du legs fait ci-dessus en sa faveur.

Je veux et entends qu'en cas de mort de M. RABAIN ou Madame Puigaudeau, mes deux derniers légataires aux présentes, ou même de tous les deux, les héritiers en ligne directe de l'un ou de l'autre recueillent entr'eux le legs fait en leur faveur.

Cela dit, que les héritiers de M. RABAIN recueilleront le legs qu'il lui est fait et ceux de dame Puigaudeau celui fait à la dite dame en cas toutefois que les dits sieurs Rabain et dame 
Puigaudeau ne recueilleront pas eux-mêmes les legs faits, parce qu'ils précéderaient moi le testataire, ou autrement et dans le cas ou par quelque motif que ce puisse être les présentes dispositions en faveur de Jean Rabain et Rose Bouffard épouse Loyen du Puigaudeau seraient attaquées et annulées, je déclare donner mes biens meubles et immeubles sans exception quelconque à la dame Anne Moinette mon épouse en toute propriété. Fait dans ma demeure susdite à la Gerbetière en Couëron le 15 Mars 1816. Vive le Roi!

Signé: Audubon. 


\section{Copy of a portion of the first Will of Madame Anne Moynet, reife of Lieutenant Audubon. December 4, 1814.}

Par les présentes mon testament.

Je donne et lègue à Monsieur Jean AUDUBON, mon mari, la jouissance en toute propriété des biens meubles et celle en usufruit des biens immeubles qui m'appartiendront à l'instant de mon décès, pour qu'à l'un et l'autre titre de cette epoque, il en jouisse fasse et dispose comme de tous ses autres biens sans être tenu d'en donner caution, voulant et entendant qu'il puisse faire sur les immeubles tous changements, coupes de bois et autres qu'il lui plaira, le tout avec dispense des dommages et intérêts.

Je donne et lègue en toute propriété à Monsieur Jean Audubon fils et à dame Rose Bouffard, épouse de Monsieur Gabriel Loyen du Puigaudeau à chacun par moitié, la totalité de tous les biens qui composeront ma succession immobilière à l'instant de mon décès, duquel néanmoins par suite du legs fait ci-dessus en faveur de mon mari, ils ne pourront se mettre en possession qu'a sa mort.

Arrivant que mon mari fut mort avant moi, je veux et entends que M. Jean AUDUBON fils et la dame Rose Bouffard, épouse Puigaudeau, recueillent aussi ma sucession mobilière à l'effet de quoi le cas arrivant, je leur lègue et donne en toute propriété.

Mes intentions que si M. Jean Audubon fils ou la dite dame Puigaudeau étaient morts l'un ou l'autre avant moi ou même tous les deux, leurs enfants soient mes légataires, c'est-à-dire que les enfants de M. Audubon recueilleraient entr'eux ce que celui-ci doit avoir et que ceux de Madame Puigaudeau recueilleraient aussi entr'eux ce que celle-ci doit avoir à l'eff et de quoi je les donne et lègue aux dits enfants.

Si à ma mort l'un ou l'autre de M. Audubon fils ou de Madame Puigaudeau étaient eux-mêmes morts sans enfants, je veux que ce soit alors les survivants d'eux deux ou ses enfants qui recueillent ma succession entière, pourquoi à cette cause, je lègue la totalité de mes biens meubles et immeubles, . . . 
16. Copy of a portion of the second Will of Madame Jean Audubon. May 10, 1816.

..... Je donne et lègue à Monsieur Jean AUDUBON, mon époux, la part et portion disponible en usufruit à raison de ce que j'aurai ou non d'enfants de généralement tous les biens meubles et immeubles qui m'appartiendront à l'instant de mon décès pour par lui en jouir sa vie durant, sans pouvoir être tenu à en fournir caution et à ma mort mes héritiers les prendre dans l'état où ils seront.

Je donne et lègue en toute propriété à $\mathbf{M}$. Jean RABIN, créole de Saint-Domingue, époux de demoiselle Lucy BACHWELL, laquelle je crois aux Etats-Unis d'Amérique, sans cependant en être sûre et à dame Rose Bouffard, créole de Saint-Domingue, épouse de Monsieur Gabriel Loyen du Puigaudeau, demeurant au Plessis commune de Couëron, la généralité de tous les biens meubles et immeubles qui m'appartiendront à l'instant de mon décès, pour par eux s'en mettre en possession, les partager par moitié et chacun jouir faire et disposer de ceux qui lui échoieront comme de ses autres biens propres de ce jour. Si M. Jean Audubon mon époux, est mort avant moi, mais seulement du jour de sa mort s'il me survit parce que je veux expressément que le legs fait ci-dessus en sa faveur ait sa pleine et entière exécution de préférence et avant tout.

Je veux et entends qu'en cas de mort de Monsieur RABIN ou de Madame Puigaudeau mes deux derniers légataires ou même de tous les deux, les héritiers en ligne directe de l'un ou de l'autre réunis recueillent le légs fait en faveur de leur auteur, c'est-à-dire que les héritiers de M. RABIN recueuilleraient le legs à lui fait et ceux de Madame PUIGAUDEAU ce que celle-ci aurait recueilli.

Arrivant que les libéralités faites en faveur de Monsieur Rabin ou celles faites en fabeur de Madame Puigaudeau ou même toutes les deux par quelles causes ou raisons que ce soit viendraient à être déclarées nulles, je veux que Monsieur Audubon, mon époux recueille en toute propriété les biens meubles 


\section{ORIGINAL DOCUMENTS}

et immeubles qui en font l'objet et auraient passé aux mains de celui ou ceux qui ne pourraient les faire à l'effet de quoi je l'institue mon héritier en droits, fonds et propriétés pour les biens que mes autres autres légataires ci-dessus ou l'un d'eux seulement ne recueilleraient pas, ..... 
17. Copy of the third Will-"No 169-of Madame Anne Moynet, widow of M. Jean Audubon, living at his house of La Gerbetière, situated near the village of PortLaunay, not far from Couëron." December 26, 1819.

Par les présentes mon testament;

Je donne et lègue en toute propriété à Monsieur Jean RABIN époux de dame Lucy BACKWELL, que je crois présentement aux Etats-Units d'Amérique et à dame Rose BOUFFARD, épouse de M. Gabriel Loyen du Puigaudeau aîné la généralité de tous les biens meubles et immeubles de toute espèce et nature qui m'appartiendront à l'instant de mon décès en quelles mains et lieux qu'ils soient et par quelques personnes qu'ils soient dûs ou possédés pour par eux deux en jouir faire et disposer en toute propriété comme de leurs autres biens, et ainsi qu'ils le jugeront convenable, sauf à les partager par égale portion s'ils le trouvent à propos et nécessaire et sans que qui que ce soit étant ou se prétendant mes héritiers, puissent y apporter aucune opposition, parce que par ces mêmes présentes, j'institue le dit M. Rabin et la dame Puigaudeau, mes seuls et uniques héritiers.

Je veux que dans le cas de mort de M. Rabin, ses enfants recueillent entr'eux le legs fait en sa faveur, je veux également qu'en cas de mort de Madame Loyen du Puigaudeau, ses enfants recueillent entr'eux le legs fait en faveur de la dite leur mère.

'Te veux également qu'en cas de mort de M. Rabin sans enfants, Madame Loyen du Puigaudeau ou ses enfants, recueillent seuls la totalité de ma fortune et par ces mêmes raisons, qu'en cas de mort de Mme Loyen du Puigaudeau sans enfants, Jean Rabin ou ses enfants recueillent seuls la totalité de ma dite fortune. 
18. Copy of a portion of the fourth and last Will of "Madame Jean Audubon, living at the house of Les Tourterelles ('The Turtle Doves') at Couëron." July 16, 1821.

Par les présentes, mon testament,

Je donne et lègue en toute propriété à Monsieur Jean AUDUBON, dit Jean RABIN, époux de dame Lucy BACKWELL, et que je crois présentement aux Etats-Unis d'Amérique et à dame Rose BOUFFARD, épouse de Monsieur Gabriel Loyen du Puigaudeau aîné, demeurant à Couëron. Je leur donne et lègue, dis-je la généralité de tous biens meubles et immeubles de toute espèce et nature que je laisserai et qui m'appartiendront à l'instant de mon décès, en quelques mains et lieux qu'ils soient et par quelques personnes qu'ils soient dûs ou possédés pour par eux deux en jouir, faire et disposer comme de leurs autres biens et ainsi qu'il le jugeront convenables, sauf à les partager par égale portion quand et comme ils le voudront sans que qui que ce soit se disant ou prétendant les héritiers puissent y apporter aucune opposition parce que pár les dites présentes, j'institue les dịts M. Jean Audubon, dit Jean Rabin et la dame Rose Bouffard, épouse Loyen du Puigaudeau, les deux seuls et uniques héritiers de mes droits, actions, possessions et généralement tous autres, sans exception pas même pour les prétentions.

Je veux et entends que dans le cas où l'un ou l'autre ou même tous les deux ne pourraient pas recueillir les effets de ma libéralité, soit parce que je leur survivrais ou par toute autre raison, les enfants qu'ils laisseraient soient mes héritiers et légataires, c'est-à-dire que les enfants de Monsieur Jean Audubon dit Rabin, recueilleraient entr'eux la moitié de ma succession que je leur lègue et ceux de dame Rose Bouffard, épouse Loyen du Puigaudeau, recueilleraient aussi ensemble l'autre moitié que je leur lègue également.

Je veux et entends qu'avant de mort avant moi de Monsieur Jean Audubon, dit Jean Rabin sans enfants, Madame Rose Bouffard épouse Loyen du Puigaudeau ou ses enfants re- 
cueillent seuls la totalité de ma fortune, et par même raison qu'en cas de mort avant moi de Madame Rose Bouffard, épouse Loyen du Puigaudeau; sans enfants, Monsieur Jean Audubon, dit Jean Rabin ou ses enfants recueillent seuls cette totalité,... 


\section{ORIGINAL DOCUMENTS}

19. Notice of the Death of Lieutenant Jean Audubon, from the Official Registry of Nantes. Nantes, February 19, 1818. (For translation, see Chapter V.)

Extrait du registre des actes de décès des $3^{\circ} \& 4^{\circ}$ cantons de la Ville de Nantes, département de la Loire-Inférieure.

L'an 1818, le 19 Février à 11 heures du matin, devant nous soussignés, adjoints et officiers de l'état civil, délégués de $\mathbf{M}$. le Maire de Nantes, chevalier de Saint-Louis, ont comparu les sieurs Gabriel Loyen du Puigaudeau rentier, gendre du défunt ci-après demeurant à Couëron et François Guillet, épicier demeurant quai de la Fosse, majeurs, lesquels nous ont déclaré que ce jour à six heures du matin, Jean Audubon, ancien capitaine de navire, pensionnaire de l'Etat, né aux Sables d'Olonne département de la Vendée, époux de dame Anne Moinet, est décédé en la demeure de demoiselle Berthier, située chaussée de la Madeleine, $\mathrm{N}^{\circ} 24,4^{\circ}$ canton.

Les déclarants ont signé avec nous le présent acte, d'après lecture leur faite. Le dit défunt âgé de 74 ans.

Signé au registre: Gabriel Loyen du Puigaudeau, Gillet et Joseph de la Tullaye, adjoint. 
20. Letter of Lieutenant Jean Audubon to Francis Dacosta, his American agent and attorney, relating to the conduct of his son and to the lead mine at "Mill Grove" farm; transliterated from photographic copy of duplicate (Letter No 4) in Jean Audubon's letter-book. Nantes, March 10, 1805. (For translation, see Chapter VIII.)

Nantes Le 19 ventose an 13, 10 mars 1805

$M^{r} D_{A c o s t a}$

a phyladelphie

p Duplicata.

Je viens de recevoir dans ce moment votre duplicata du 12. $9^{\text {bre }}$ \& la votre du 5. Decembre, qui n'est pas aussi avantageuse, Sous plusiers rapports que votre précédente, mais enfin il faut esperer que l'item vous prouvera que votre dernier sillon ne sera point déserteur, et que les occides de fer qui se trouvent se dissiperont en fouillant plus avant, au moins c'est ce que je désire. vous faites bien de faire tous vos efforts pour avoir des associés \& Si cela ne reussit pas, \& que vous vouliez travailler pour notre compte Je trouverai toujours bon, tout ce que vous ferez, puisque vous avez ma confiance dans ce cas je crois que vous s... igé [?], de faire faire des reparations les plus urgentes Surtout à la maison principale, Devant vous y loger. Quand à $\mathrm{M}^{\mathrm{r}} \mathrm{W}$. Thomas, vous ferez bien de vous le garder, pour toutes les raisons, que vous me dites \& Je crois qu'il ne doit pas sopiniatrer à se retirer, qu'il ne sache, s'il à mérité, oui ou non, sa récompense.

Je suis $M^{r}$. on ne peut plus faché de ce que vous ayez à vous plaindre, de la conduite de mon fils, car le tout, bien considéré n'est occasionné, que par de mauvais conseils \& un deffaut d'usage on a aiguillonné son amour propre, et peut être avait-il été assez jeune pour se vanter, dans la maison ou il va que cette plantation devait lui echoir, à lui seul; vous avez tous les moyens de detruire cette présomption, on n' ignore point a philadelphie, que vous avez autant de droits que moi \& que vous ne faites rien que pour notre mutuel avantage. 
Je lui ecris a ce sujet, car il ne men parle point, et je lui donne la cémonce que mérite son indiscrétion; vous lirez cette lettre et voudrez bien avoir la complaisance de la cacheter avant de lui remettre. Vous me dites que je puis m'en rapporter sur son compte au rapport que m'en fait $\mathrm{M}^{\mathrm{r}}$. Meyers fisher, dans sa longue lettre du mois de Septembre que Malheureusement je n'ai pas reçu, car $\mathbf{M}^{\mathbf{r}}$ fisher, ne me parle point de lui, ni en bien, ni en mal. Quand à venir dans le pays, cela me parraît presqu'impossible, rappeller mon fils nest pas plus aisé, les raisons qui me l'en fait l'envoyer existent toujours; il ne faut qu'un instant pour le faire changer du mal au bien, sa grande jeunesse et sa petulance sont tous ses torts et si vous avez la Bonté de lui donner l'indispensable, il sentira bientot la Nécessité de se rapprocher de vous et pourra vous être d'une grande utilité, si vous exploitez par vous même.

Il faut donc Mon cher monsieur, que nous tachions de le ramener par la douceur à son Devoir. Si vous avez de l'indulgence pour lui ce sera moi qui vous en aurai toute l'aubligation; j'espere que la lettre cy-jointe operera chez lui un changement. C'est mon seul fils, mon heritier, \& je suis vieux. Quand $M^{r}$ Meiers fisher aura montré ma lettre au prétendu beaupere, il verra qu'il s'est trompé dans son calcul sur le prétendu Mariage de sa fille, car s'il avait lieu sans mon consentement tout secours de ma part cesserait des cet instant; et c'est ce que vous pouvez bien si vous voulez avoir cette bonté, dire au prétendu beau pere, ne voulant pas que mon fils se marie aussi jeune; vos lettres du 28 Octobre \& 12 Novembre sont à la campagne. Je ne puis point répondre categoriquement sur leurs contents; Je les examinerai \& vous dirai par ma prochaine ce que J'en pense. Votre famille que J'ai vu se porte bien. Nos dames vous rémercient de votre bon souvenir. Je suis \& .

[Jean Audubon.] 
21. Letters of John James Audubon to Claude François Rozier, father, and to Ferdinand Rozier, son, immediately preceding and following his active partnership in business with the latter: 180' and 1812. (For translations see Chapters XI and XV.)

[Letter No. 2, superscribed] Monsieur Fr. Rozier, Negociant

Nantes.

Loire inferieure.

NEw Yonk avril 24 1807-

Mr. Rozier Negociant

Nantes

Mon Cher Monsieur

Je profite d'une bonne occasion pour Bordeaux pour vous accuser reception d'un Duplicats des pouvoirs que nous vous demandai plusieurs mois passes. Vous saurez aussi que les vins consignes a M. L. Huron de Philadelphia sont arrives en cette ville et ont sauves les assurances; votre fils s'est transporte sur la place et par une de ses lettres m'apprend que les 60 caisses sont vendues il me dit que vous pouvez compter sur un profit net d'a peu pres 20 p. ct. s'il s'est trouve tres bons et le reste ne manquera de trouver acheteur: $\mathbf{M}^{\mathbf{r}}$. Le Ray est arrive et a apporte avec lui une petite Boite de dentelles pour M. Benjamin Bakewell d'icy elle doit arriver en peu de jours de Philadelphia. $\mathbf{M}^{\mathbf{r}}$. B. B. a paru satisfait de la vente de son Bois Futtie. il lui tarde seulement de voir les retours il est malheureux que le commerce de votre ville avec ce pays ne soye pas aussi regulierement suivi qu'a Bordeaux d'ou nous avons des Batiments tous les mois et par plusieurs. Comme notre ami Ferdinand vous ecriva de Philadelphia concernant $\mathrm{M}^{\mathrm{r}}$. Huron je ne m'ettendray pas sur son compte: dans plusieurs de vos Lettres que si nous nous decidions obtenir un magasin de detail que vous pourriez nous tenir constamment employe nos idees sur ce sujet sont par faitement d'accord et ce serait avec bien du plaisir que nous commenserions sous auspices et les bons 
avis de Mr. Bakewell ici; les objects bien choisis bien achette et envoye avec soins sont toujours sur de rencontrer un bon marche: j'ose esperer que le Navire la Jeanne Capt Sammis sera arrive a votre port et que les Indigos charges par M. B. Bakewell pourront y etre venu en temp de vente de cette marchandise dont $j$ 'ai neanmoins quelque crainte vu le prix qu'ils lui avaient coute. Nous vous remercions sincerement pour le prix courant que vous nous avez envoye, dans une de mes dernieres ecrite par voye de Bordeaux je vous priais de demander a Mr. Fleury Emery une boite de graines de la Martinique et de se pays cy. nous esperons sous peu vous envoyer quelque marchandises et peut etre $\mathrm{M}^{\mathrm{r}}$. Bakewell profitera d'une occasion que nous allons avoir en peu de jour pour votre port. A peu plus trois semaines passees Je fus a Mill Grove et l'affermais pour un an ne pouvant faire mieux pour le present. Votre fils a Philadelphia a present va essayer de terminer les comptes de mon pere avec $\mathrm{M}^{\mathrm{r}}$. Dacotta [Dacosta] qui n'oublie pas aisement d'etre chicanneur.... presentez Je vous prie mes respects et amities a votre bonne famille et epouse et croyez en moi comme votre devoue

et constant

serviteur

J. J. Audubon

Ayez la complaisance de faire parvenie l'incluse a mon bon pere.

[Superscribed] $\mathrm{Mr}^{\mathrm{s}}$ F. RozIER ${ }^{\mathrm{s}}$

$\mathrm{Merch}^{\mathrm{t}}$

St Genevieve

u. $\mathbf{L}$.

Mon CHER Rozier:-

SHIPPINGPORT • 10th. Augst. 1812

Come il est presque probable que l'occasion que je trouve est sur, je suis avec elle le plaisir de t'écrire quelque mots-

Je reçus en temps ta lettre envoyé a $\mathrm{Phil}^{\mathrm{a}}$ a lequelle je repondis alors; depuis je n'ai entendu de tes nouvelles que par 
voies très indirectes, je serais bien content si tu peux donner quelques instants a tes amis que tu me compte aux nombre et m'écrire par temps; je partis avec ma femme et mon fils de Phil $^{\mathrm{a}}$ au mois passé, la plus grande parties de ce temps a été à descendre L'Ohio qui est actuellement très bas nous avons eu la Barge et L'Equipage du $G^{l}$ Clark, avec la compagnie de $\mathbf{M}^{\mathbf{r}}$ R. A. Maupin et de $\mathbf{M}^{\text {de }}$ Galt qui avaient rester plusieurs mois a New York \& a Phila. Je vais probablement descendre a la $\mathrm{N}$. Orléans cet autumn avec $\mathbf{N}$. Berthoud, les merchandizes sont extremement rare et très chere, partout, mais plus encore les gros Lainages que l'on ne trouve du tout.

Je n'ai pas de doute que ton plomb ne se vende tres bien cet article ayant augmenté considerablement depuis la guerre.dans les derniers jours que j'etais dans l'Est j'ai recu une lettre de mon père et une de ton frère toute ta famille se portait alors bien dit 4 mois passés, ton frère désire beaucoup entendre de toi, si la paix vient un jour non bien loin (ce qu'à Dieu plaise) 'j'espere entrer en liaison avec lui.

Je lui est écrit et l'engage a faire de même tes lettres pouront se rendre si envoyers a $\mathbf{N}$. York et de la dans la Cartel. Ma femme se porte bien et mon fils sois de même et compte au nombre de tes amis est ce que dison celui qui t'estimera toujours.

Adieu

J. Audubois 


\section{APPENDIX II}

\section{Audubon's Early Dated Drawings Made in France and America}

Drareings now in the Collections of Mr. Joseph $Y$. Jeanes, of Philadelphia, and formerly belonging to Mr. Edward Harris, of Moorestozen, Nero Jersey; of Mr. John E. Thayer, Lancaster, Massachusetts; and of Harvard University. (See Chapter XII.)

In addition to the serial numbers, here given, the drawings usually bear French and English names, with various notes in French relating to weights and measurements, and rarely with sketches of detail.

Mr. Jeanes' collection contains the following:

No. $\quad 5$. Long-tailed Mountain Tit, 22 January, 1805

13. Sedge Sparrow, near

Nantes,

22. Reed S parrow, near

Nantes,

78 . Hawk's E y e,-Spotted

Plover,-France,

97. The Creeper, France,

86 . Shrike, near Nantes,

93 . Nuthatch, near Nantes,

Terns, France,

50 . The Redstart, near
Nantes,
1805

1805

18 March, 1805 [?]

June 7, 1805

July, $\quad 1805$

July 9, $\quad 1805$

July 12, 1805

August,

1805 
No. 61. The Great Swallow (Le martin noir), near Nantes,

65. The Wagtail, near Nantes, Dec. 22,

69. The Green Finch, near

Nantes,

Dec.,

1805

92. L'Ecorcheur à tête rouge, near Nantes,

1805

6. "Grosbec," near Nantes, 1806 [?]

94. Woodpecker, near Nantes, March 8, 1806 Fish Hawk, Perkioming

Creek,

1806

209 . Wood Thrush, Mill Grove, August 14, 1806 145. Long-tailed Duck, New York,

Dec. 17, 1806

Golden Eye, New York, Dec. 28, 1806

153. American Widgeon, New

York,

Dec. 28,

1806

102. Robin (eggs dated May 8th), New York,

Jany. 4,

1807

156 . Shelldrake, New York,

Jany. 28, 1807

143 . Widgeon, New York, Feby. 23, 1807

146. Canvasback, New York, March 22, 1807

163 . Shoveller, New York, April 3, 1807

163. Sprig-tail, New York,

Feby. 22, 1807 Wood Duck,

48 . Orchard Oriole, Falls of the Ohio,

June 5 ,

1808

214. Chimney Swallow, Falls of the Ohio,

July 2\%, 1808

188 . Kentucky W a r b l e r, 20 miles from Philadelphia, (June?), 1809

109 . Passenger Pigeon, Falls of the Ohio,

Dec. 11,

1809

Hooded Merganser, Falls of the Ohio,

March \%, 1810 


\section{ORIGINAL DOCUMENTS}

No. 41 . Catbird, Red Banks, June, 1810

105. Red-wing Blackbird,

June,

1810

81. The Frog-eater (Hawk),

Red Banks,

Nov. 29, 1810

186 . Killdeer,

200, 201 . Pewit, and G re a t-

crested Flycatcher,

Henderson,

May 22, 1811

207. Carolina Parrot, Hender-

son,

June 9,

1811

49. Swamp Sparrow, Pennsylvania,

March 12, 1812

6 . Spotted Sandpiper, Pennsylvania,

April 22, 1812

11. Whippoorwill, Pennsylvania,

May 7, 1812

10. Nighthawk,

May 8,

1812

58. Great American Shrike,

Henderson,

Nov. 30, 1812

76 . Red-crowned black Woodpecker, Henderson,

Oct. 15, 1814

66. Black-capped Nuthatch,

Henderson,

Feby. 16, 1815

Willet, Henderson,

May 8, 1815

Snipe, Henderson,

March 17, 1816

300 . Yellow-billed Rail, Henderson,

Oct. 9,

1816

Purple Gallinule, New Orleans,

April 23, 1821

Chuck Wills Widow, Red River,

June, 
The Harvard University collections contain the following:

No. 91 . L'Ecorcheur,

42. The $S$ e d g e - b i r d, near

Nantes,

1805

43. The Nightingale, n e a $\mathbf{r}$

Nantes,

July 6,

1805

57. Brown Thrush, near New

York,

May 10, 1807

Excellent examples of Audubon's early work in the collection of Mr. John E. Thayer are:

No. 96 . Woodpecker: prior to

1803 (see note, vol. $i$, p.

178).

112. Water Thrush, Mill

Grove, Pennsylvania, Aug. 2,

1806

144 . 64. Malaga Shell Drake.

Goosander, M e r gu s

Merganser A. W. Chute de L'Ohio

17 December, 1809

175. Crested Titmouse, Redbanks,

July 1,

1810

71 . 44. The Spirit or Butterball-Bufflehead, Henderson,

Mar. 19,

1815

154. Golden Crested Wren A. W., S y lvi a Regulus, Shippingport, Kentucky; drawn by J. J. Audubon - Mistletoe on Black Walnut. Jany. 28, 1820 Hermit Thrush, opposite Fredericksburg, Ky., Oct. 16, $\quad 1820$

315 . Rose-breasted Grosbeak (on spray of dogwood). 


\section{ORIGINAL DOCUMENTS}

Among the drawings of the Harris-Jeanes collection which may be earlier than 1805 , though they bear no date, are "The Black Crow of Buffon, Corneille noire," also the head of a Jackdaw wholly in crayon and pastel: "No. 160, Le grand Duc, âgé vingt un an, Buff on,- the large horned owl, Eagle owl. J. J. L. Audubon," a crayon sketch on paper measuring eighteen by twenty-six inches, and water-marked "J. Kool"; also "No. 164. La corneille mantelle de Buffon, Royalton crow, Sea crane, hooded crow, crow-British,-J. J. L. Audubon," a crude sketch in pastels of the same size as the last.

The following legends appear on the drawing of the Canvasback Duck: "Cet Oiseau est nommé Canvas Back Canard very much esteemed par les Americans and very rare ici [c]elui est male et étais beau"; "New York le 22 Mars 1807J. J. L. Audubon" "No. 146." 


\section{APPENDIX III}

\section{"The Birds of America"}

1. Final Lists of Subscribers to "The Birds of America," folio edition, as published by Audubon in 1839. (See Ornithological Biography, vol. v, pp. 647-651.)

\section{List of American Subscribers}

1. Library of Congress of the United States, Washington City.

2. State Departments, Washington City.

3. Library of the General Court of Massachusetts.

4. Legislature of South Carolina, for the Columbia College.

5. Legislature of Louisiana.

6. Legislature of Maryland.

7. Legislature of New York.

8. Legislature of Michigan.

9. Boston Athenæum.

10. Harvard University, Cambridge, Massachusetts.

11. Providence Atheneum, Rhode Island.

12. Salem Atheneum, Salem, Massachusetts.

13. American Philosophical Society, Philadelphia.

14. Academy of Natural Sciences, do.

15. Columbia College of New York.

16. Boston Natural History Society.

17. Charleston Library, South Carolina.

18. Charleston Natural History Society, South Carolina.

19. Charleston Citizens' Library, do

20. Richard Harlaw [Harlan], Esq., M.D., Philadelphia. 
21. John P. Wetherell, Esq. Philadelphia.

22. Mrs. Ford, do.

23. Mrs. Douglas Cruger, New York.

24. Edward Prime Esq., banker, New York.

25. James G. King, Esq. do. do.

26. Cornelius C. Low, Esq. do.

27. P. J. Stuyvesant, Esq., M.D. do.

28. Robert Ray, Esq. do.

29. J. L. Joseph, Esq. do.

30. Richard N. Carman, Esq. do.

31. Mrs. Bailey, do.

32. Stephen Van Rensselaer, Esq., Albany, New York.

33. Hogden Haggerty, Esq. do.

34. W. L. Colman, Esq. do.

35. Samuel Swartout, Esq. do.

36. James Watson Webb, Esq. do.

37. Thomas H. Faile, Esq. do.

38. Lewis Rogers, Esq. do.

39. Jer. Van Rensselaer, Esq. M.D. do.

40. H. C. De Rham, junior, Esq. do.

41. Stephen A. Halsey, Esq. Long Island, do.

42. Edward Harris, Esq. Moorestown, New Jersey.

43. Thomas H. Perkins, Esq. Boston.

44. J. G. Cushing, Esq. do.

45. Samuel Appleton, Esq. do.

46. George C. Shattuck, Esq. M.D. Boston.

47. P. J. Jackson, Esq. do.

48. James Brown, Esq. do.

49. Frederick Tudor, Esq. do.

50. The Honourable Daniel Webster, do.

51. Augustus Thorndike, Esq. do.

52. L. Baldwin, Esq. Civil Engineer, do.

53. E. Greenwood, Esq. Museum, do.

54. George Pratt, Esq. do.

55. William Sturges, Esq. do.

56. Robert Gilmor, Esq. Baltimore.

57. John B. Morris, Esq. do. 
58. — Smith, Esq.

Baltimore.

59. Thomas Edmonston, jun. Esq. do.

60. William Gaston, Esq. Savannah, Georgia.

61. James Potter, Esq. do. do.

62. Alexander Telfair, Esq. do. do.

63. Thomas Young, Esq. do. do.

64. John David Mongin, Esq. do. do.

65. Daniel Blake, Esq. do. do.

66. Thomas Butler King, Esq. St. Simon Island, Georgia.

67. Thomas Metcalf, Esq. Augusta, Georgia.

68. E. Geddings, Esq. M.D., Charleston, South Carolina.

69. William J. Rees, Esq. Stateburgh, do.

70. R. O. Anderson, Esq. Georgetown, do.

71. Miss Burley, Salem, Massachusetts.

72. Miss Elizabeth L. Pickman, Salem, Massachusetts.

73. William Oakes, Esq. Ipswich, do.

74. James Arnold, Esq. New Bedford, Rhode Island.

75. Garnet Duncan, Esq. Louisville, Kentucky.

76. John Croghan, Esq. M.D. do. do.

7\%. Henry Clay, jun. Esq. Ashland, do.

78. James Grimshaw, Esq. New Orleans.

79. Gustavus Schmidt, Esq. do.

80. J. J. Hughes, Esq. Manchester, Mississippi.

81. John Hunt, Esq. Mobile, Alabama.

82. Henry Hunt, Esq. Mobile, Alabama.

\section{Europe}

1. Her Most Excellent Majesty, Queen Adelaide, England.

2. (His Most Christian Majesty, Charles X).

3. His Majesty Philippe I. King of the French.

4. Her Royal Highness Mademoiselle d'Orleans.

5. Prince Massena, Paris.

6. His Grace the Duke of Rutland, London.

7. The Honourable W. C. Wentworth Fitzwilliam, London.

8. The Right Honourable the Countess of Ravensworth, Ravensworth Castle. 
9. The University of Edinburgh.

10. The Society of Writers to her Majesty's Signet, Edinburgh.

11. Henry Witham, Esq. of Lartington, Durham.

12. John Rutter, Esq., M.D., Liverpool.

13. Doctor Bickersteth, Liverpool.

14. Armorer Donkin, Esq. Newcastle-upon-Tyne.

15. Yorkshire Philosophical Society, York.

16. John Clough, Esq., Oxton Hall, Yorkshire.

17. Jos. S. Crompton, jun., Esq., Eshott Hall, Bradford, Yorkshire.

18. Thomas Walker, Esq. Killinbeck, near Leeds.

19. Leeds Philosophical and Literary Society.

20. John Marshall, jun. Esq., Headlinglay, Leeds.

21. Samuel Greg [Gregg], Esq., Quarry Bank, near Manchester.

22. Edward Lloyd, Esq., Greenhill, near Manchester.

23. The Manchester Society for the promotion of Natural History.

24. The Reverend Peter Horden, M.A., for the Cheetham Library, Manchester.

25. G. W. Wood, Esq., Manchester.

26. Mrs. Rattsbone [Rathbone], Greenbank, Liverpool.

27. J. G. Children, Esq., British Museum, London.

28. The Right Honourable the Earl of Caernarvon, London.

29. S. P. Atkins, Esq., Walbrook, London.

30. The Right Honourable the Earl of Derby, P. Z. S.

[President of the Zoological Society], \&c. \&c. \&c.

31. The Right Honourable Earl Spencer, London.

32. John Heathcote, Esq., London.

33. Joseph John Gurney, Esq. Earlham Hall, Norfolk.

34. James Darbyshire, Esq., Manchester.

35. John Blackwell, Esq., Manchester.

36. A. J. Cresswell Baker, Esq., Prowin Park.

37. Reverend Edward Craig, Edinburgh.

38. The College of Glasgow, as Trustees of the Hunterian Museum. 
39. John Buddle, Esq., Newcastle-upon-Tyne.

40. The York Subscription Library, York.

41. Kirk Patrick, Esq., London.

42. T. B. L. L. Baker, Esq. Christ Church, Oxford.

43. Doctor Lodge, for the University Library, Cambridge.

44. George Thackeray, D.D., Provost of King's College, Cambridge.

45. The Cambridge Philosophical Society.

46. The Fitzwilliam Museum, by M. Davy, Vice Chancellor.

47. Dr. Kidd, for the Anatomical School, Christ Church, Oxford.

48. Doctor Williams, for the Radcliffe Library, Oxford.

49. James Pickering Ord, Esq., Hedge Hill, near Derby.

50. The Right Honourable Viscount Milton, London.

51. M. Feuillet, for the Library of the Royal Institute of France.

52. Vicounte [Viscount] Simeon, for the Ministry of the Interior, 6 copies.

53. M. Pitois, Paris.

54. Mrs. Warden, London.

55. Mr. Hearne, bookseller, London.

56. Henry Ellisan, Esq., Beverly, Yorkshire.

57. Benjamin Smith, Esq. M. P., London.

58. The Right Honourable the Earl of Bradford, London.

59. Thomas Frost, Esq., Gorton Hall, near Manchester.

60. John G. Reeves, Esq., Birmingham.

61. Birmingham Old Library, by Beilby, Knott, and Beilby.

62. Joseph C. Dyer, Esq., Manchester.

63. Thomas Walker, Esq., Ravensfield, near Doncaster.

64. George Lamb Fox, Esq., Yorkshire.

65. Haarlem Library, Holland.

66. Mrs. [Miss] Euphemia Gifford, Duffield Bank, Derby.

67. Charles Fox, Esq., Perrair, near Truro, England.

68. George Lane Fox, Esq., Yorkshire.

69. Sir John Tobin, Liverpool.

70. His Grace the Duke of Buccleuch, Dalkeith Palace, Scotland. 
71. His Imperial and Royal Highness the Grand Duke of Tuscany, \&c. \&c. \&c.

72. London Institution, by Mr. Bradley, Librarian.

73. Benjamin Phillips, Esq., F. R. S. L., \&c. \&c. \&c. 17 Wimpole Street, London.

74. Henry G. Bohn, Esq., London.

75. Charles J. Warde, Esq. Welcomb, near Stratford-onAvon.

76. The British Museum, London (in part).

77. His Grace the Duke of Northumberland, \&c. \&c. \&c.

78. Earl Hardwicke, \&c. \&c. \&c. Wimpole, Arrington, Cambridge.

79. Sir Jacob Hastley, Bart, \&c. \&c. \&c., Cavendish Square, London. 
2. Prospectus of "The Birds of America," as issued in 1828, when ten Numbers of the original folio were engraved. (Compare Ornithological Biography, vol. i, pp. 1-16, as supplementary text, at the end.)

Under the Particular Patronage and Approbation of

His Most Gracious Majesty

\section{BIRDS OF AMERICA}

from

Dr aw ings

made

During a Residence of Twenty-five Years

in

The United States and its Territories,

by

John James Audubon,

Citizen of the United States.

Member of the Lyceum of New York; Fellow of the Royal Society of Edinburgh; of the Linnean Society of London; Member of the Wernerian Natural History Society of Ecinburgh; of the Zoölogical Society, London; Fellow of the Society of Scottish Antiquaries; Member of the Society for promoting the useful Arts of Scotland; of the Literary and Philosophical Societies of Cambridge, Liverpool, and Newcastle-uponTyne; of the Horticultural Society of Edinburgh; of the Natural History Society of Manchester; of the Scottish Academy of Painting, Sculpture and Architecture, \&c., \&c.

\section{PROSPECTUS.}

To those who have not seen any portion of the Author's splendid Collection of Original Drawings it may be proper to explain, that their superiority consists in every specimen being of the full size of life, portrayed with a degree of accuracy as to proportion and outline, the result of peculiar means dis- 
covered and employed by the Author, and lately exhibited to a meeting of the Wernerian Society. Besides, in every instance where a difference of plumage exists between the two sexes, both the Male and Female Birds have been represented. The Author has not contented himself with single profile views of the originals, but in very many instances he has grouped them, as it were, at their natural avocations, in all sorts of attitudes, either on branches of trees, or amidst plants and flowers: some are seen pursuing with avidity their prey through the air, or searching diligently their food amongst the fragrant foliage; whilst others of an aquatic nature swim, wade, or glide over their allotted element. The Insects, Reptiles, or Fishes, that form the food of the birds, have been introduced into the drawings; and the nests of the birds have been frequently represented. The Plants are all copied from Nature, and the Botanist, it is hoped, will look upon them with delight. The Eggs of most of the species will appear in the course of the publication.

The Particulars of the Plan of the Work will be found detailed below :-

1. The Engravings in every instance to be of the exact dimensions of the Drawings, which, without any exception, represent the Birds of their natural size.

2. The Plates will be Coloured, in the most careful manner, from the original Drawings.

3. The Size of the work will be Double Elephant, and printed on the finest Drawing Paper.

4. Five Plates will constitute a Number; one Plate from one of the largest Drawings, one from one of the second size, and three from the smaller Drawings.

5. There are 400 Drawings; and it is proposed that they shall comprise Three Volumes, each containing about 133 Plates, to which an Index will be given at the end of each, to be bound up with the Volume.

6. Five Numbers will come out annually.

7. The Price of each Number will be Two Guineas; payable on delivery. 
TEN Numbers being now completed, will give an exact idea of the nature and style of the Work. All the other Numbers will at least equal these in interest and execution. It would be advisable for the Subscribers to procure a Portfolio, to keep the Numbers till a Volume is completed.

** Persons desirous of becoming Subscribers are requested to apply to Mr. Audubon, or Mr. Robert Havell, Jun. (Engraver), 79, Newman Street, Oxford Street, London.

Where Specimens of the Work may be seen: or, to any of the following Agents:-Messrs. Treuttel, Würz \& Co., Soho Square, and Mr. S. Highly, Fleet Street, London; MM. Levrault and Pitois, Paris; Messrs. Robinsons, Liverpool; Mr. T. Sowler, Manchester; Mr. M. A. Barclay, York; Messrs. Hernaman and Robinson, Leeds; Mr. E. Charnley, Newcastle-uponTyne; and J. B. Kidd, Esq., Edinburgh.

Note BX тHe Author. Audubon's first Prospectus was issued on March 17, 1827, when two Numbers of his large work were ready, and the last which I have seen bears the date of 1831 , when one hundred plates had been published. The present citation is from a copy in possession of the Boston Public Library; it is printed on two sides of white paper, octavo, and bears the autograph of "Wm. Everett, Esq., Aug. 7, 1867." 
3. Prospectus of the Second (partial) Edition of "The Birds of America," issued by John Woodhouse Audubon, through Messrs. Trübner \& Company, London, 1859. (See Bibliography, Nos. 9 and 10.)

\section{A U D UBON'S}

Celebrated Work

\section{BIRDS OF NORTH AMERICA}

To be published in Numbers, by Subscription only, at one half the original price.

The undersigned proposes to publish, by Subscription, this well-known Work of his late Father, J. J. Audubon, F.R.SS.L.\&E., etc., from the original Copperplates transferred to stone.

This Edition, in softness, finish, and correctness of coloring, will be superior to the first, and every Plate will be colored from the original Drawings, still in possession of the family.

It will contain all the Plates and Text of the original Work, embracing more than one thousand figures of Birds, all of the size of nature, represented in action amid the scenes or on the plants most common to their habits,- together with seven volumes royal octavo, of Ornithological Biography.

The Work will be issued in forty-five numbers viz., fortyfour of Plates and one of Text, each number of Plates containing ten-printed on seven sheets double-elephant paper, of the best quality for the purpose, 27 by 40 inches, and will be delivered to Subscribers Monthly, at $£ 2,8 \mathrm{~s}$ per number; the last Number, comprising seven volumes of Text, to be delivered bound with the fifteenth number.

It is intended that each Number shall contain as follows: Viz. two large Plates, each occupying the whole sheet; two of a medium size, each occupying also the entire sheet; and six of the smaller size, two Plates on a sheet; thus presenting ten of the original Plates on seven sheets, giving a variety in 
each number. The text is properly and scientifically classified, and when the Work shall be completed the Plates can be placed and be bound corresponding with the order of the Text, in either three or four Volumes. The regular issue of the Numbers will commence so soon as the number of Subscribers will justify the undertaking.

As the Work will be published for Subscribers alone, few or none being printed beyond the number subscribed for, it is not possible that its pecuniary value can ever be much reduced; on the other hand, the probabilities are that it will rather be increased. Nor will there ever be a time when it can be published at a less price than the present; for in estimating the cost the mere expense of manufacturing has been taken into consideration, without reference to the original cost of the Copper-plates, which was nearly One hundred thousand Dollars; and a very small profit has been charged on the expense thus estimated.

The first Number is considered superior in many respects to the same Plates in the first Edition, and it is confidently hoped that subsequent Numbers will exhibit still greater superiority as the Artists gain experience. A full list of Subscribers will be published with the Work. The Numbers will not be sold separately, except the first, which will be sent, properly packed, as a Specimen, to any part of the country, free of expense, on the receipt of $£ 2,8 \mathrm{~s}$.

Orders or communications to Trübner \& Co., Booksellers, 60, Paternoster Row, London.

New York, March 31, 1859.

J. W. Audubon.

Trübner \& Co. also offer to the Trade and the Public the following Editions of Audubon's Birds and Quadrupeds of North America:

Birds of North America-Library Edition, 7 vols., royal 8vo., with 500 finely colored Plates, from Drawings made in the United States and their Territories. Price £25. 
Quadrupeds of North America,-By J. J. Audubon and Rev. John Bachman. Original Edition, 3 vols. imperial folio, bound in half russia. One hundred and fifty superbly colored Plates. With descriptive letter-press, in 3 vols., royal 8 vo. Price $£ 63$. The same work,-Library Edition, 3 vols. royal 8 vo. with one hundred and fifty-five finely colored Plates. Price $£ 9,9$ s.

NotE BY THE AUTHor. For the citation of this rare document, from the only copy known to exist, I am indebted to the kindness of Mr. Ruthren Deane, who writes: "I found this Prospectus bound in the first volume of The Ibis (1859). This copy was previously in possession of the late Pierre Verreaux, of Paris, France, and is now in the John Crerar Library, Chicago, Illinois."

Ornithologists will be pleased to find that it immediately sets at rest numerous disputed questions concerning the plates and text of this sole, but ill-fated, attempt at the republication of the original folio of The Birds of America in America. (See Bibliography, Nos. 9 and 10, and Chapter XXXVI, p. 296.)

Mr. Ruthven Deane has written me that an examination of the account books kept by the Audubons during the publication of the large and small editions of The Birds of America showed partial payments on the Folio by 23 subscribers; the only name among those not listed in the Ornithological Biography was that of J. R. Peters, who was credited with a payment of $\$ 412.00$. Mr. Deane adds: "I have a list of the subscribers to the 1840, 8vo., edition, of 1,095 names, New York, Baltimore and Boston taking 501; also a list of subscribers to the Quadrupeds of North America, 3 volume, 8 vo., edition, of 2,004 names, New York, Boston and Charleston, South Carolina, taking 1,102." 


\section{APPENDIX IV}

Authentic Likenesses of Jean Jacques Fougìre Audubon

1. 1824.-Oil portrait by himself; painted at "Beech Grove," William Garrett Johnson's plantation, West Feliciana, Louisiana; presented by Audubon to Mrs. Johnson; inherited by her daughter and granddaughter, and now in possession of Dr. D. G. Murrell, Paducah, Kentucky. Size of original, 12 by 9 inches. Reproduced in The Auk, vol. iii, 1886 (see Bibliography, No. 184).

2. 1826 (?).-Oil portrait by himself (?), 18 by 32 inches, West Feliciana; presented by Audubon to Col. Edwar' Durrive's father, later acquired by Mr. E. Curtis, and now in the possession of Mr. Thomas P. Thompson, New Orleans.

My information concerning this doubtful portrait has been derived entirely from Mr. Ruthven Deane, to whom its present owner recently wrote: "My Audubon, by himself, attracts much interest, and grows more real as time makes it familiar."

3. 1826.-Pencil sketch by himself; signed

"Audubon at Green Bank

Almost, Happy!!- Sepr 1826."

Made at the home of Mr. William Rathbone, Sr., and presented to Mrs. Rathbone; now in possession of Mr. Richard R. Rathbone, Glen$\mathrm{y}$-Menai, Anglesey; for reproduction see The Life and Adventures of John James Audubon, 
edited by Robert Buchanan, and Maria R. Audubon, Audubon and His Journals.

4. 1826 (?).-Oil portrait by W. H. Holmes, 36 by 28 inches; painted for Audubon's friend, Walter Horton Bentley, Manchester, England, and in possession of the Bentley family ever since. Audubon is represented in a green coat, a crimson cloak with deep fur edging thrown over one shoulder, and with portfolio in hand.

For information concerning this fine but little known portrait, as well as for the photograph reproduced in Vol. I, p. 416, I am indebted to Mr. Ruthven Deane. In 1913, Mr. John Conway Bentley, a grandson of the former owner, formerly of Glasgow, but then living in Cheshire, England, attempted to dispose of the Holmes portrait in this country.

5. 1826.-Oil portrait by John Syme; painted at Edinburgh, November, 1826; supposed to have been engraved by W. H. Lizars, but no trace of painting or engraving has been found. See Maria R. Audubon, op. cit., vol. i, pp. 157 and 165 .

On November 27, 1826, Audubon wrote: "At twelve I went to stand up for my picture, and sick enough I was of it by two; at the request of Mr. Lizars I wear my wolf-skin coat, and if the head is not a strong likeness, perhaps the coat may be." In writing to his son, Victor, in 1833 (see Chapter XXVII, p. 57), Audubon said: "I am glad to hear of Kidd \& Co.'s publication of Parrots, but I regret that my face should have been there from Syme's picture, which in my estimation is none of the best."

6. 1828.-Oil portrait painted in London by an American artist named Parker, in August, 1828; Parker subsequently accompanied Audubon and 
Swainson to Paris, where he is said to have executed portraits of Cuvier and Redouté. On August 25, a few days before starting on this journey, Audubon wrote: "Mr. Parker has nearly finished my portrait, which he considers a good one, and so do I" (Maria R. Audubon, op. cit., vol. i, p. 303). No further mention of this painting has been found.

7. 1830-31.-Miniature painted on ivory by Frederick Cruikshank, probably in London, and before Audubon's return to America on August 2, 1831. This portrait has become well known through the excellent engraving of it by $\mathrm{C}$. Turner, A.R.A., first published in London, "Jany. 12, 1835, for the Proprietor, by Robert Havell, Print-seller, 7\%, Oxford Street," with Audubon's characteristic autograph. Good copies of the original engraving have become very rare. (See Frontispiece, Vol. I.)

Miss Maria R. Audubon possesses a very faint water-color sketch of the original, which, as she has recently written me, "was destroyed by fire at Shelbyville, Kentucky, with many other rare and valuable belongings of my grandmother's, soon after her death [in 1874]."

8. 1833.-Portrait in oils by Henry Inman; half-length, natural size; in possession of Miss Harriet $B$. Audubon. "Mr. Inman has painted my Portrait in Oil, and $I$ say that it is a truer portrait of me than even the Miniature" (sce Chapter XXVII, p. 39). Engraved by H. B. Hall for the second Octavo Edition of The Birds of America, published in 1856, and the same engraving has appeared in later editions of The Life of John James Audubon, the Naturalist, edited by Lucy Audubon; for re- 
production of a photograph of the original portrait, see Maria R. Audubon, op. cit., vol. i, p. 206; and for reproduction of the Hall engraving, Vol. II, p. 130, of the present work.

This portrait, like the Cruikshank miniature, has become well known through frequent reproduction; both represent the naturalist at the full meridian of his working powers, and are among the finest likenesses of him extant.

9. 1834.- "John J. Audubon"; portrait drawn and engraved on steel by J. Brown; published by Geo. Henderson, 2, Old Bailey, Ludgate Hill, London, 1834. A poor drawing of Audubon, in hunting dress, published with a biographical sketch, in an English edition of Cuvier's $L e$ régne animal (see Bibliography, No. 56). This drawing served as the basis of a wood engraving, in which Audubon is represented as a much younger man, three-quarters length, gun in hand, with thumb on trigger, which appeared in Gleason's Pictorial for 1852 (see Bibliography, No. 67.).

10. (Before) 1839.-Life Mask, made in London by Robert Havell, Junior, and formerly in his possession; acquired from his daughters, Mrs. Amelia Jane Lockwood and Miss Marion Elington Havell, by Mr. John E. Thayer, and by him presented to Harvard University. For reproduction of the mask, for excellent photographs of which I am indebted to Dr. Samuel Henshaw, Director of the Museum of Comparative Zoölogy, Harvard University, see Vol. II, p. 188.

The original was made from a dark colored plaster (?), and has a decidedly coarse texture. Mr. Harry P. Havell, who possesses a replica of the original in wax, writes that he obtained from the Misses Havell, his cousins, the information 
that this mask was made while Audubon was at their home in London; the matter was treated in a jocular way, as Audubon lay upon a sofa with straws in his nose, while submitting to the rather unpleasant ordeal of having a mold made of his countenance. Mr. Havell, to whom I am indebted for the substance of this note, also possesses the silver loving cup, which Audubon presented to Robert Havell upon the completion of the second volume of his illustrations in 1834 (see Chapter XXXII, p. 192). For notice of another mask by O'Neill, Edinburgh, 182\%, see Maria R. Audubon, op. cit., vol. i, p. 205.

11. 1838.-Portrait in oils, three-quarters length, by George P. A. Healy; represents Audubon in hunting shirt, with flowing collar open at neck, knapsack at side and gun in hand (see Frontispiece, Vol. II) ; painted in London upon the initiative of the artist, still struggling for recognition.

This portrait, with a number of other paintings, was raffled at Boston, at a later day, when it was won by the artist, who then gave it to a former patron, Mr. Bradlee, by whom it was presented to the Boston Society of Natural History, and it now hangs in the library of that institution. The present reproduction is from a photograph received through the kindness of Mr. Ruthven Deane, who still owns the negative, which was reproduced in Mr. Healy's Reminiscences (see Bibliography, No. 197).

12. 1840-45 (?).-Cameo, by John C. King; original intaglio, in shell, a cast of which was given by the artist to Mr. Kennard, and is now in possession of Mr. Frederic H. Kennard, of Boston; cast first reproduced by C. Hart Merriam, in The Auk for 1908 (see Bibliography No. 226).

Mr. King was a Scotch artist and sculptor, who died at Boston, April 21, 1882.

13. 1841 (?).-Portrait in oils, full length and size, by John Woodhouse Audubon; figure seated, with land- 
scape background; gun resting on arm, and dog at side. For reproduction, see Maria R. Audubon, op. cit. This or the following used as the basis of a painting by Alonzo Chappel (see No. 23).

14. 1841 (?).-Half-length portrait in oils, natural size, by John Woodhouse and Victor Gifford Audubon. Original presented to the American Museum of Natural History by Mr. Fordham Morris in 1900 ; for reproduction, see Vol. II, p. 226.

15. 1841 (?).-Full-length portrait, in oils, by John Woodhouse Audubon; original now in possession of the American Museum of Natural History; for reproduction, see Vol. II, p. 250.

16. 1842.-Pencil sketch by Isaac Sprague (1811-1895), an artist noted for his paintings of plants and birds. Sprague accompanied Audubon on his expedition to the Missouri River in 1843. According to Miss Maria R. Audubon, the original drawing is still in possession of the Sprague family, Wellesley Hills, Massachusetts. For reproduction, see Maria R. Audubon, op. cit.

17. 1843.- Half-length portrait in oils, by John Woodhouse Audubon, representing the naturalist as he appeared when returning from his expedition to the Missouri River in November, 1843, with flowing white hair and beard; he wears a green overcoat, with fur collar, and with both hands holds a favorite gun. The original, which was never quite finished, is now in possession of his granddaughters, at Salem, New York. For reproduction, see Maria R. Audubon, op. cit., vol. i. frontispiece. 
18. 1844.-Cameo by John C. King, now known only from the photograph made from a cast of the original intaglio, which the artist presented to the father of Mr. O. A. Farwell, of Detroit, in 1871.

"My father and Mr. King were great friends, and on one occasion, when father dropped into Mr. King's studio, he found Mr. Audubon sitting for the cameo. Mr. King introduced the two gentlemen and asked them to start a conversation, which was continued during the sitting. The two men became so animated in their very interesting conversation that they forgot where they were, and thus the artist was enabled to catch the natural and striking expression of the great ornithologist." See "The King Cameos of Audubon," by C. Hart Merriam (Bibl. No. 226), who published the first account of this photograph, and of the previously mentioned Kennard cast, with reproductions, in 1908. No trace of the original cameos, which were cut in shell, has yet been found. The Farwell photograph has been reproduced as a medallion on the covers of the present work.

19. 1848-49 (?).-A daguerreotype made by Brady, in New York, probably before 1850 , since it was published in that year, and a considerable interval of time is clearly represented between this first camera likeness and the last which was ever made of the naturalist (see No. 20, and Vol. II, p. 280). This daguerreotype was first published as a steel engraving by D'Avignon, in Lester's Gallery of Illustrious Americans (for which it was, in all probability, originally made), in New York, 1850 (see Bibliography No. 62).

The same sun portrait was again engraved on steel (size $41 / 4$ by $31 / 4$ inches) by Nordheim, and published by Hermann J. Meyer, 164 William Street, New York. It also appeared as a 
wood engraving, brought out by M. P.-A. Cap, in Le Muséum D'Histoire Naturelle, p. 175, Paris, 1854: a better reproduction, by the same process, was given in Scribner's Magazine, vol. xiii, p. 275 (see “Audubon's Story of his Youth," by Maria R. Audubon, Bibl. No. 40), in 1893.

The original daguerreotype was finally discovered in the collections at the National Museum, at Washington, where it had been deposited by Mrs. Elizabeth Berthoud Grimshaw, a daughter of Mrs. Nicholas Berthoud, and niece of Mrs. Audubon; it was again published by Dr. R. W. Shufeldt, and Miss M. R. Audubon, in 1894 (see "The Last Portrait of Audubon," Bibl. No. 196). According to the writers just cited, the daguerreotype was formerly in possession of Mrs. Gordon, a sister of Mrs. J. J. Audubon, who gave it to the present owner.

20. 1850 (?).-A daguerreotype, representing Audubon as he appeared at the close of his career; original in possession of Miss Mary Eliza Audubon; for reproduction see Audubon and his Journals, vol. i, p. 74, and Vol. II, p. 280, of the present work. As to the probable date of this picture, see the preceding notice.

21. 1851.-Death mask; profile from original, since destroyed by fire, reproduced in Scribner's Magazine, vol. xiii, by Maria R. Audubon (Bibl. No. 40), March, 1893.

22. 1851.-Profile of head; pencil sketch, after death, made by John W. Audubon; reproduced by Maria R. Audubon, Audubon and his Journals, vol. ii, p. 526.

23. 1861.-Oil portrait by Alonzo Chappel, engraved on steel for Duyckinck's National Portrait Gallery of 
Eminent Americans (see Bibliography, No. 74), and published by Messrs. Johnson, Fry \& Company, New York, 1862.

The original of this portrait, which was evidently drawn, with slight changes, from the large painting of the same subject by John Woodhouse Audubon, executed about 1841 (see No. 13), is now in possession of Mr. Ruthven Deane, who has written me that it is done in black and white, like all of Chappel's work which was designed for the purposes of steel engraving, and measures 12 by 17 inches. Concerning this artist, Mr. Arthur Lumley wrote to Mr. Deane on April 26, 1905, as follows: "I knew Chappel in my boyhood days, when he ranked next to Felix O. C. Darley as an illustrator; at the same time he was a good portrait painter in oil. Chappel, in many ways, was a gifted man, and his historical pictures were fine in compositiun and color. He held a high rank, and had no occasion to seek orders, having all he could do, and at his own terms; most of his work was reproduced by steel-plate engravings": Chappel, he adds, who died about 1875, was "a quiet, genial gentleman who was ever ready to help and guide rising aspirants in the field of art."

24. $190 \%$ (unveiled).-Bust by William Couper; unveiled at the American Museum of Natural History, New York, December 29, 1906. Reproduced through courtesy of the Museum, at p. 160 of Vol. II of the present work.

25. 1910 (unveiled).-Statue, by Edward Virginius Valentine; unveiled in Audubon Park, New Orleans, November 26, 1910; reproduced at p. 14 of Vol. I of the present work. 


\section{APPENDIX V}

\section{Bibliography}

Besides the published writings of Audubon, I have included in this Bibliography such references to his life and times as occur in the text or which possess some degree of merit; all other important literary and historical authorities are cited in footnotes to the text. The titles appear in a single numerical series, but the arrangement under each head is strictly chronological. All references to this list in the text are indicated usually by title, with the name of the author, and always by Arabic numerals, in correspondence with the series which follows. If some chaff has been admitted to this garner, no corn, I hope, has been thrown into the fire.

\section{a. Principal Works}

1. Audubon, John James:

The Birds of America, from Original Drawings by John James Audubon, Fellow of the Royal Societies of London \& Edinburgh and of the Linnæan \& Zoölogical Societies of London, Member of the Natural History Society of Paris, of the Lyceum of New York, \&c. \&c. \&c. 4 vols. colored plates, double elephant folio. Published by the Author. London, 1827-1838.

Issued without text, titles excepted, to subscribers, in $\mathbf{8 7}$ Numbers of 5 plates each, or 435 copper-plate engravings, colored by hand, and representing 1,065 life-size figures of 489 supposedly distinct species of birds. Titles the same, except that in volumes II-IV, after "New York," in list of societies following author's name, is added, "of the Philosophical Society 
and the Academy of Natural Sciences of Philadelphia." Begun at Edinburgh in autumn of 1826, and completed in London, June 20, 1838.

A more detailed citation is:

Vol. I. Parts 1-22, pll.

Vol. II. Parts 23-44, pll.

i- $\quad c x, 1827-30$.

cxi- ccxx, 1831-34.

Vol. III. Parts 45-66, pll. ccxxi- ccexxx, 1834-35.

Vol. IV. Parts 67-87, pll. cccxxxi-ccccxxxv, 1835-38.

More exact data on publication of individual plates are:

$\begin{array}{lll}182 \% \ldots . . . \text { pll. } & 1-25 & 1833 \ldots \ldots \text { pll. } 156-185 \\ 1828 \ldots \ldots \text { pll. } & 26-50 & 1834 \ldots \ldots \text { pll. } 186-235 \\ 1829 \ldots \ldots \text { pll. } & 51-75 & 1835 \ldots \ldots \text { pll. } 236-285 \\ 1830 \ldots \ldots \text { pll. } \quad 76-100 & 1836 \ldots \ldots \text { pll. } 286-350 \\ 1831 \ldots \text { pll. } 101(\text { ? })-125 & 1837 \ldots \ldots \text { pll. } 351-400 \\ 1832 \ldots \text { pll. } 126-155(\text { ? }) & 1838 \ldots \text { pll. } 400[401]-435\end{array}$

The first ten plates were executed by William Home Lizars, Edinburgh, 1826-7, but were later retouched or reëngraved (?) by Robert Havell, Junior, who produced all the rest in London; printed on Whatman's drawing paper, size (untrimmed), $391 / 2 \times 291 / 2$ inches, and colored after the originals. A considerable number of the plain plates were dispersed, and at least one complete set exists in this state (see Note, Chapter XXVI, Vol. II, p. 7, and also Chapter XXXII, Vol. II, p. 190); scientific and common names, with legends of author and engraver, and eventually the date of publication, were given on each plate. Issued to subscribers at two guineas a Part, and sold in Europe at $£ 182,14 \mathrm{~s}$; in America, at $\$ 1,000$. The Turkey Cock (Plate No. 1) now brings upwards of $\$ 140$, and perfect sets upwards oi $\$ 4,000$, according to binding and state. Total number of original sets probably did not exceed 190 or 200 .

2. Audubon, John JAmes, F. R. SS. L. \& E. [with list of societies]:

Ornithological Biography, or an account of the habits of the Birds of the United States of America; accompanied by descriptions of the objects represented 
in the work entitled The Birds of America, and interspersed with delineations of American scenery and manners. 5 vols. roy. 8 vo. Edinburgh, 1831-1839.

Vol. I (original ed.). Preface dated "March 1831." Pp. i-xxiv, 1-512, and 1-16, including "Prospectus," "Contents" to Vol. I, and names of subscribers to The Birds of America. Text to accompany plates i-c of the large folio. Adam Black, 55 North Bridge (with names of agents; Neill \& Co. Printers, Old Fishmarket), Edinburgh, MDCCCXXXI.

Vol. I (American reprint). Pagination the same. Judah Dobson, Agent, 108 Chestnut St., and H. H. Porter, Literary Rooms, 121 Chestnut St., Philadelphia, MDCCCXXXI. Copyright by R. Harlan, M.D., 1831. Printed by James Kay, Jun. \& Co., Printers to the American Philosophical Society, No. 4 Minor St.

Vol. I (American reprint). The same, but bearing the imprint of E. L. Carey and A. Hart, Chestnut St., Philadelphia, MDCCCXXXV.

Vol. II (original ed.). Preface dated "1st December 1834." Pp. i-xxxii, 1-588. Text of plates ci-cc. Adam and Charles Black. Edinburgh, MDCCCXXXIV.

Vol. II (American reprint). The same, but with imprint of Hilliard, Gray, and Company. Boston, MDCCCXXXV.

Vol. III (original and only ed., as are IV and V). Preface dated "1st December 1835." Pp. i-xvi, 1-638, with 9 woodcuts. Text to plates cci-ccc. Same imprint as Vol. II. Edinburgh, MDCCCXXXV.

Vol. IV. Preface dated "1st November 1838." Pp. i-xxviii, 1-618. Text to plates ccci-ccclxxxvii. Imprint, the same. Edinburgh, MDCCCXXXVIII.

Vol. V. Preface dated "1st May 1839." Pp. i-xl, 1-664, with 98 woodcuts. Text to plates ccclxxxviii-ccccxxxv. Same imprint. Edinburgh, MDCCCXXXIX.

According to Stone, 5 species recognized in the folio are 
suppressed in the "Biography"; 26 new names are given, and 502 species are recognized, but as 11 were more or less hypothetical, 491 remain in supposedly good standing.

3. Audubon, John JAmes, F. R. SS. L. \& E. Member of various scientific associations in Europe and America:

A Synopsis of the Birds of North America. Pp. i-xi, 1-359. 8vo. Adam and Charles Black, Edinburgh; Longman, Rees, Brown, Green and Longman, London. MDCCCXXXIX.

A methodical index to the birds of America, with special reference to the large folio plates and Ornithological Biography; 45 families and 139 genera are defined; 5 new names are added, making the total number of recognized species 491 .

4. Audubon, John James, F. R. SS. L. \& E. (\&c., \&c.) :

The Birds of America from Drawings made in the United States and its Territories. 7 vols. of text and plates, roy. 8vo. Published by the Author and J. B. Chevalier. New York and Philadelphia, 1840-1844.

The "Birds in Miniature," or first octavo edition of text and plates combined; issued to subscribers in 100 Parts, each with 5 lithographic colored plates, at $\$ 1.00$ a Part.

Vol. I. Parts 1- 14; pll. 1- 70; pp. i-viii, 9-256. 1840.

Vol. II. Parts 15- 28; pll. 71-140; pp. i-viii, 9-206. 1841.

Vol. III. Parts 29- 42 ; pll. 141-210; pp. i-viii, 9-236. 1841.

Vol. IV. Parts 43- 56; pll. 211-280; pp. i-viii, 9-324. 1842.

Vol. V. Parts 5\%- 70; pll. 281-350; pp. i-viii, 9-348. 1842.

Vol. VI. Parts 71- 84; pll. 251-420; pp. i-viii, 9-460. 1843.

Vol. VII. Pts. 85-100; pll. 421-500; pp. i-x, 9[11]-374. 1844.

In this "miniature" edition, the "delineations of American scenery and manners" are omitted, the text revised, and the nomenclature made to conform with the Synopsis; the plates of the large folio were broken up, and their accessories reduced, so that but one species appears on each; 7 species, described in the Biography and Synopsis are figured for the first time in an 
Appendix, in which also appear 17 species that had been neither figured nor described before, thus bringing the total number of birds represented on the octavo plates to 500 ; four of the largest birds receive two plates each, thus leaving the number of distinct species figured at 496, while the 12 species herein described brings the total number of species recognized by Audubon in 1844 to 508 . The plates of this edition are rearranged and renumbered to conform with the new arrangement of the text, which was considerably improved. The series begins with the California Vulture, and ends with Baird's Bunting.

Vols. I-V were published by J. J. Audubon, New York, and simultaneously issued by J. B. Chevalier, Philadelphia; Vols. VI-VII, published by J. J. Audubon, 77 Williams St., New York, and 34 North First St., Philadelphia.

The Numbers or Parts were issued in blue paper covers, or drab when without plates $(7 \times 11$ inches $)$, on which were printed the "Prospectus," lists of subscribers and agents, besides other information which the author wished to convey to his patrons. The printer's legend at the right lower corner reads: "Lithd.

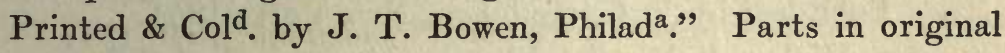
covers are extremely rare; a set in this condition was offered in 1914 at $\$ 750$.

5. Audubon, John James, and Bachman, Rev. John:

The Viviparous Quadrupeds of North America. 2 vols. of 150 lithographic, colored plates; imp. folio. Published by J. J. Audubon, New York, 1845-1846.

Vol. I. Parts 1-15, pll. 1- 75, 1845.

Vol. II. Parts 16-30, pll. 76-150, 1846.

Issued to subscribers in 30 Parts of 5 plates each, size $28 \times 22$ inches, at $\$ 10$ a part, or $\$ 300$, without text except titles, tables of contents, and names on plates; 76 of the originals by J. J. Audubon, and 74 by J. W. Audubon, assisted by V. G. Audubon. Author's and printer's legends read: "Drawn from Nature by J. J. Audubon, F. R. S. F. L. S.," and "Lith. Printed \& Cold. by J. T. Bowen, Phila. 1842 [-1845]." 
6. Audubon, John James, F. R. S. (\&c., \&c.), and Bachman, Rev. John, D. D. (\&c., \&c.) :

The Viviparous Quadrupeds of North America. 3 vols., roy. 8vo. Published by J. J. Audubon and V. G. Audubon, New York, 1846-1854.

Issued to subscribers, as text to foregoing:

Vol. I. Pp. i-xvi, 1-390. Text only. Published by J. J. Audubon, New York, 1846.

Vol. I (European ed.). The same as foregoing with imprint of Wiley \& Putnam, London, 184\%.

Vol. II. Pp. 1-336. Text only. Published by V. G. Audubon, 1851.

Vol. III. Pp. i-vi, 1-350. Text, with 6 colored plates. Published by V. G. Audubon, 1854.

7. Audubon, John James, F. R. S. (\&c., \&c.), and Bachman, REv. Јон,, D. D. (\&c., \&c.) :

The Quadrupeds of North America [in "Miniature"]. 3 vols., roy. 8vo., with 155 colored plates. Published by V. G. Audubon, New York, 1854.

Vol. I. Nos. 1-10, pll. i-1, pp. i-viii, 1-384.

Vol. II. Nos. 11-20, pll. li-c, pp. 1-334.

Vol. III. Nos. 21-31, pll. ci-clv, pp. i-vi, 1-348.

First and only edition of the text and plates reduced to octavo size; most of the plates lithographed, printed and colored by J. T. Bowen. In Vol. I the introduction is cut down, the list of subscribers omitted, and tables of contents and genera placed at end; Vol. II is same as first edition, with omission of subscribers' lists; Vol. III same as in first edition, except for omission of table of genera at back. All plates in Vol. I, and 28 in Vol. II, or 78 in all, are by J. J. Audubon, and 77 are by J. W. Audubon.

8. Audubon, John JAmes, F. R. S. (\&c., \&c.) :

The Birds of America, from Drawings made in the United States and their Territories. Vols. I-VII, roy. 8vo. Published by V. G. Audubon, New York, 1856. 
The second octavo edition of the Birds, with 500 plates, published without change, except in pagination. The portrait of Audubon, which appears in this or in some of the later editions, was engraved by H. B. Hall after the painting by Henry. Inman.

9. Audubon, John James:

The Birds of America; from Original Drawings by John James Audubon, Fellow of the Royal Societies of London \& Edinburgh, \&c., \&c., \&c. Reissued by J. W. Audubon. 1 vol. of 106 double elephant folio plates, in chromolithography, by J. Bien, 180 Broadway, representing 151 of the original copper plates. Roe Lockwood \& Son, Publishers. New York, 1860.

The only (and partial) reissue of the original folio; plates, in many instances double, renumbered to correspond with the octavo edition, with backgrounds often simplified or changed, and much inferior to the original hand-colored engravings; the plates are dated " 1858 " or "1859." Checked by the Civil War, the residual stock of plates found a ready sale thirty years later. Citation from copy in the Public Library, New York City. (See Appendix III, Document No. 3).

10. Audubon, John J AMes:

The Birds of America, from Drawings made in the United States and their Territories, by John James Audubon, F. R. S., \&c., \&c. Reissued by J. W. Audubon. Vols. I-VII, roy. 8vo. Text only. Roe Lockwood \& Son, Publishers. New York, 1861. Vol. I, pp. i-viii, 11-246; Vol. II, pp. i-viii, 11-200; Vol. III, pp. i-viii, 9-234; Vol. IV, pp. i-viii, 9-322 ; Vol. V, pp. 1-viii, 9-346; Vol. VI, pp. i-viii, 2-456; Vol. VII (not seen).

Issued as the letterpress of the imperfect folio (see No. 9) described above. According to Sabin, quoted by Coues (see No. 181 of this Bibliography), only 4 royal octavo volumes of this text was issued; the present citation is from the 6 volumes 
in the Public Library of New York; all are without plates, and it should be noted that Vols. I and II, and III and IV are bound as two volumes. In 1914 a set of this edition, in seven volumes, bound in cloth, was advertised by a bookseller in New York at \$40. (See Appendix III, Document No. 3).

\section{Audubon, John James:}

The Birds of America. ... Reissued by J. W. Audubon, in 7 vols., imper. 8vo., with 500 colored plates, $10 \times 7$ inches. Roe Lockwood \& Son. New York, 1861.

Third complete octavo edition, to be distinguished from the 7 vols. (No. 10) referred to above, and the V. G. Audubon reissue of 1856 (No. 8). Reference partly from Coues.

12. Audubon, John James:

The Birds of North America: a popular and scientific description of the Birds of the United States and their Territories. New edition. New York, 1863.

Not seen, but given on the authority of Coues.

13. Audubon, John James:

The Birds of America. .. 8 vols. 8vo. New York, 1865.

According to Coues, a later edition of J. W. Audubon's reissue of 1861 , but in 8 instead of $\%$ volumes.

14. Audubon, John James, F. R. S. (\&c., \&c.) :

The Birds of America, from drawings made in the United States and their Territories. Vols. I-VIII, imper. 8vo. George R. Lockwood, late Roe Lockwood \& Son, 812 Broadway, New York. No date. (1871.) Vol. I, pp. i-viii, i-xv (memoir), 11-246, pll. 1-70; Vol. II, pp. i-vii, 11-199, pll. 71-140; Vol. III, pp. i-viii, 9-233, pll. 141-210; Vol. IV, pp. i-viii, 9-321, pll. 211280; Vol. V, pp. i-viii, 9-346, pll. 281-250; Vol. VI, 
pp. i-vii, 9-298, pll. 351-394; Vol. VII, pp. i-vii, 9-285,

pll. 395-440; Vol. VIII, pp. i-viii, 9-256, pll. 441-500.

(Pagination taken from Coues.)

Sixth and last complete octavo edition of text and plates, being a reissue of the 1865 edition. In the biography, signed "G. R. L[ockwood]., 1870," it is stated that Jean Audubon died "at Rochefort on the Loire [sic], where he had ₹ large estate" at the age of ninety-five, and that J. J. Audubon was born on his father's plantation at New Orleans in 1780. This memoir was issued separately as an advertising pamphlet by J. L. Sibole ("Fine Book Dealer, 109 So. 15 th. Street, New York"), to exploit the octavo editions of the Birds and Quadrupeds (pp. 1-15, paper cover, no date).

\section{b. Minor Papers and Reprints}

15. Audubon, John James:

"On the Hirundo fulva of Vieillot." Annals of the Lyceum of Natural History of New York, vol. i, pp. 163-166. New York, 1824.

16. Audubon, John James:

"Facts and Observations connected with the permanent residence of swallows in the United States." Annals of the Lyceum of Natural History of Nere York, vol. i, pp. 166-168. New York, 1824.

17. Audubon, John James (a citizen of the United States):

"Account of the Habits of the Turkey Buzzard (Vultur aura) particularly with the view of exploding the opinion generally entertained of its extraordinary power of Smelling." In a letter to Professor Jameson. [Note.] This communication was originally intended to be sent to a friend unaquainted with the habits of birds-J. J. A. Edinburgh New Philosophical Journal, vol. 2 (Oct.-Apr.), pp. 172-184. Edinburgh, 18261827. Dated "Edinburgh, Dec. 7, 1826." 
18. Audubon, John James:

"Observations on the Natural History of the Alligator." In a letter to Sir William Jardine, Baronet, \&c. Edinburgh New Philosophical Journal, vol. 2, (Oct.-April), pp. 270-280. Edinburgh, 1826-182\%.

Gives the first account of the nesting habits of the American alligator.

19. Audubon, John James:

"Account of the Carrion Crow or Vultur atratus." Edinburgh Journal of Science, vol. vi (Nov.-April), pp. 156-161. Edinburgh, 1826-1827.

Notices the nesting and other habits, and maintains that this species, like the Turkey Buzzard, is guided to its food by sight and not by smell.

20. Audubon, John James:

"Notes on the Habits of the Wild Pigeon of America, Columba migratoria." Edinburgh Journal of Science, vol. vi (Nov.-April), pp. 256-265. Edinburgh, 1826$182 \%$.

Read before the Royal Society of Edinburgh, February 19, 1827.

21. Audubon, John James:

"Notes on the Rattlesnake (Crotalus horridus), in a letter addressed to Thomas Stuart Traill, M. D., \&c." Edinburgh New Philosophical Journal, vol. 3 (AprilOct.), pp. 21-30. Edinburgh, 182\%.

Read before the Wernerian Society of Natural History, February 24, 1827. Reproduced in Journal of the Franklin Institute and American Mechanics' Magazine, vol. ii, N. S., pp. 32-37. Philadelphia, 1828. Later repudiated by the editor; see Thomas P. Jones, "The Romance of the Rattlesnake," No. 93 of this Bibliography. 
22. Audubon, J. J.:

"Account of the Method of Drawing Birds employed by J. J. Audubon, Esq., F. R. S. E." In a letter to a friend. Edinburgh Journal of Science, vol. viii, pp. 48-54. Edinburgh, 1828.

'22a. Audubon, John James:

"Journey up the Mississippi." The Winter's Wreath for 1829, pp. 104-12\%. Liverpool and Philadelphia, 1828.

23. Audubon, John James:

"Notes on the Bird of Washington-(Falco Washingtonia) or Great American Sea Eagle" (with figure). Loudon's Magazine of Natural History, vol. i, pp. 115120. London, 1828-1829.

Dated "London, April, 1828."

24. Audubon, John J.:

"The Flood of the Mississippi." Edinburgh Literary Journal. February, 1831, pp. 140-142.

See "Episode" entitled "A Flood," Ornithological Biography, vol. i.

25. Audubon, J. J.:

"An Account of the Habits of the American Goshawk (Falco palumbarius, Wils.)." In a letter to Sir William Jardine, Bart. Edinburgh Journal of Natural and Geographical Science, vol. 3 (March), pp. 145-147. Edinburgh, 1831.

26. Audubon, John J JMes:

"Improvements in the Navigation of the Mississippi." Edinburgh Literary Journal, March 26, 1831, pp. 194-195.

See Ornithological Biography, vol. i. 
27. Audubon, John James:

"Hunting the Cougar, or the American Lion."

Edinburgh New Philosophical Journal, vol. 11, pp. 103115. Edinburgh, 1831.

See "The Cougar," Ornithological Biography, vol. i. "It having been remarked, and rather sharply, that in our article on 'Audubon's Ornithological Biography,' we have overrated that gentleman's talents, we, in our own vindication, and as proofs of Audubon's descriptive powers, submit to the judgment of our readers the above sketch, taken at random from his work." (Editor's note.)

28. Audubon, J. J.:

"Account of a Hurricane in North America." Edinburgh New Philosophical Journal, vol. 12 (Oct.-April), pp. 278-281. Edinburgh, 1831-1832.

See "The Hurricane," Ornithological Biography, vol. i.

29. Audubon, J. J.:

"The Ohio." Edinburgh New Philosophical Journal, vol. 12, pp. 122-126. Edinburgh, 1832. See the same, Ornithological Biography, vol. i.

30. Audubon, J. J., and Bachman, Rev. John, D. D. :

"Descriptions of New Species of Quadrupeds inhabiting North America." Journal of the Academy of Natural Sciences, vol. viii, pt. ii, pp. 280-329. Philadelphia, 1839-1842.

Read, Oct. 5, 1841.

31. Audubon, J. J., and Bachman, J.:

"Descriptions of New Species of Quadrupeds inhabiting North America." Proceedings of the Academy of Natural Sciences, vol. i (Oct., 1841), pp. 92-103. Philadelphia, 1843. 
32. Audubon, John James, and Bachman, John:

"Description of a new North American Fox, genus Vulpes, Cuv., (Utah)." Proceedings of the Academy of Natural Sciences, vol. vi, pp. 114-116. Philadelphia, 1852-1853.

33. Audubon, John James:

"Earthquake in Kentucky." Reproduced in Magazine of American History, vol. 16, pp. 342-344, with portrait. New York, 1886.

See "The Earthquake," Ornithological Biography, vol. i.

\section{c. Epistolary Articles}

34. Audubon, John James:

"Letter to the Editor" (No. 1). Dated "St. Augustine, East Florida, Dec. 7, 1831." Monthly American Journal of Geology and Natural Science, vol. i, pp. 358363. Philadelphia, 1832.

35. Audubon, J. J.:

"Letter from J. J. Audubon to the Editor" (No. 2). Dated "Bulowville, East Florida, December 31, 1831." Monthly American Journal of Geology and Natural Science, vol. i, pp. 407-414. Philadelphia, 1832.

36. Audubon, J. J.:

"Letter to the Editor" (No. 3). Monthly American Journal of Geology and Natural Science, vol. i (June), pp. 529-537. Philadelphia, 1832.

37. Adduвon, J. J.:

"Letter from J. J. Audubon to William MacGillivray." Edinburgh Journal of Natural History, vol. i (for Dec., 1838), p. 171. Edinburgh, 1835-1839.

Dated, "On board the Crusader, Cote Blanche, 18 April, 1837." 


\section{d. Translations}

38. B BZIN, Eugène:

Scènes de la Nature dans les Etats-Unis et le Nord de l'Amérique. Ouvrage traduit d'Audubon, avec Preface et Notes du Traducteur. T. 1-2, pp. 1-460, 1-512. 8vo. Paris, $185 \%$.

Selections from the Ornithological Biography, with Introduction; dedicated to Charles Lucien Bonaparte.

39. (ANon.):

"Drei Ziegenmelker Nordamerika's." Naumannia: Archiv für die Ornithologie, vorzugstweise Europas, herausg. von E. Baldamus, pp. 158-163. Stuttgart und Leipzig, 1858.

\section{e. Autobiography}

40. Audubon, Maria R.:

"Audubon's Story of his Youth." Scribner's Magazine, vol. xiii, pp. 267-287, illust. New York, 1893.

First appearance of autobiographical sketch, entitled, "Myself, J. J. Audubon." Reproduced also in Audubon and his Journals (see No. 86), vol. i.

\section{f. Journals}

41. Deane, Ruthven:

"Extracts from an Unpublished Journal of John James Audubon." The Auk, vol. xxi, pp. 334-338. Cambridge, 1904.

Including entries for fourteen days, extending from October 12, 1820, to November 25, 1821. 
42. (ANON.):

"A Story of Meadville from John J. Audubon, F. R. S., August 28, 1824." Pamphlet (in blue paper cover), pp. 1-4. Dated April 9th, 1846.

An early version, taken from the original journal, and probably given by Audubon himself to some of his friends, possibly Spencer F. Baird, who visited him in both early and late April of this year. For passages not since reproduced, see Vol. I, p. 341. Citation from copy in the Public Library, New York City.

For fuller journal records, see Audubon and his Journals (No. 86), including "European Journals," (1826-1827), vol. i, pp. 79-242; the "Labrador Journal," 1833, vol. i, pp. 343-446; and the "Missouri River Journals," 1843, vol. i, pp. 447-532, and vol. ii, pp. 1-196.

\section{g. Familiar Letters}

43. Coues, Elliott :

"Behind the Veil." Bulletin Nuttall Ornithological Ciub, vol. v, pp. 193-204. Cambridge, 1880.

Gives interesting letters by Audubon and MacGillivray, which are reproduced in the present work.

44. Gordon, Mrs.:

"Christopher North": A Memoir of John Wilson. New York, 1894.

For letter of J. J. Audubon to J. Wilson, no date [Jany. $1,1836]$, see pp. 363-364.

45. Shufeldt, R. W., and Audubon, M. R.:

"The Last Portrait of Audubon, together with a Letter to his Son." The Auk, vol. xi, pp. 309-313. New York, 1894. 
46. RHOADs, S. N.:

"Auduboniana," The Auk, vol. xx, pp. 377-383. Cambridge, 1903.

Gives three letters to Edward Harris, partly reproduced in the prisent work.

47. Deane, Ruthven:

"Unpublished Letters of John James Audubon and Spencer F. Baird," The Auk, vol. xxi, pp. 255-259. Cambridge, 1904.

First installment.

48. Deane, Ruthven:

(a) "A Hitherto Unpublished Letter of John James Audubon," The Auk, vol. xxii, pp. 170-171. Cambridge, 1905.

(b) See also "An Unpublished Letter of John James Audubon to his Family," The Auk, vol. xxv, pp. 166-169. Cambridge, 1908.

49. Deane, Ruthven:

"Unpublished Letters of John James Audubon and Spencer F. Baird," I, The Auk, vol. xxiii, pp. 194-209. Cambridge, 1906.

Second installment.

50. Deane, Ruthven:

"Unpublished Letters of John James Audubon and Spencer F. Baird," II, The Auk, vol. xxiii, pp. 318-334. Cambridge, 1906.

Third installment.

51. Deane, Ruthyen:

"Unpublished Letters of John James Audubon and Spencer F. Baird," III, The Auk, vol. xxiv, pp. 53-70. Cambridge, $190 \%$.

Fourth installment. 
52. Dali, William Healey:

Spencer Fullerton Baird: A Biography. Pp. i-xvi, 1-462. 8vo. 19 illust. Philadelphia and London, 1915.

Reproduces eighteen letters of Audubon to Baird, dating from June 13, 1840, to February 11, $184 \%$.

53. Thayer, John E.:

"Auduboniana," The Auk, vol. xxxiii, pp. 115-118,

4 plates. Cambridge, 1916.

Reproduces four original water-color drawings, and two letters addressed to Dr. George Parkman, dated "New York, June $20^{\text {th }}$," and "August $13^{\text {th }} 1841$. ."

54. Grinnelt, George Bird:

"Some Audubon Letters," The Auk, vol. xxxiii, pp. 119-130. Cambridge, 1916.

Gives two letters written to Victor G. Audubon from New York, April 28 and Sept. 9, 1833.

See also Caledonian Mercury, November 3, 1831, for letter to Joseph B. Kidd (No. 163), Brewer (No. 79), Bachman (No. 191), Günther (No. 204), Deane (No. 225), and Alexander Bliss, in Autograph Leaves of our Country's Authors, for facsimile letter of Audubon to Thomas Sully, dated "Manchester (England), Sept. 16, 1826" (Baltimore, 1864).

\section{h. Biographies}

55. Christopher North (John Wilson):

"Noctes Ambrosianae," No. XXX, Blackrwood's Edinburgh Magazine, vol. xxi (Jan.), pp. 112-105 (sic). Edinburgh, $182 \%$.

56. (ANon.):

"Biographical Sketch of John James Audubon," with portrait (drawn and engraved by J. Brown); in- 
sert in G. Cuvier and P. A. Latreille, The Animal Kingdom, vol. i, pp. 197*-204*. London, 1830.

57. Lander, Sir Thomas Dick, Bart., and Brown, Capt. THomas:

Biographical Sketch, with engravings by Joseph B. Kidd. Pp. i-x, 1-184, 16mo. Edinburgh, 1833.

Mainly extracted from vol. i of the Ornithological Biography; refers to the false rumor of Audubon's death in October, 1831, and to his plan of forming a Gallery of Paintings in Natural History, started in association with Kidd.

58. (ANon.) :

"Biographical Sketch of J. J. Audubon." Miscellany of Natural History, vol. i. 1833.

Not seen.

59. Dunlap, Winliam:

History of the Rise and Progress of the Arts of Design in the United States. 2 vols. New York, 1834. For John James Audubon, see vol. ii, pp. 402-408.

60. (Anon.) Godwin, Parke:

"John James Audubon." United States Magazine and Democratic Review, N. S., vol. x, pp. 436-450. New York, 1842.

See also Out of the Past; Critical and Literary Papers, pp. 89-110 (New York, 1870), and Homes of American Authors; for the last, see No. 68.

61. GRIswold, Rufus W.:

The Prose Writers of America, article "Audubon.". Philadelphia, 1847.

62. Lester, C. Edwards (editor):

The Gallery of Illustrious Americans, containing the Portraits and Biographical Sketches of Twenty- 
four of the most eminent Citizens of the American Republic since the death of Washington. Plates from daguerreotypes by Brady; engraved by D'Avignon. Published from 205 Broadway, New York, by G. P. Putnam, D. Appleton \& Company, and C. S. Francis \& Company. New York, 1850.

Issued in 24 Parts. For John James Audubon, see Part No. 7; reproduced in Spooner's Biographical History of the Fine Arts, vol. i, pp. 53-55 (New York, 1867). See also No. 196.

63. Phillarète-Chasles:

Etudes sur la Littérature et les Moeurs des AngloAméricains au xix siècle. Pp. i-viii, 1-516. Paris, 1851. See "Audubon. Le Voyageur et le Naturaliste," pp. 68-106.

An excellent review by an experienced French critic and author, who appears to have met Audubon and to have attended one of his exhibitions in Edinburgh.

64. (Anon.) Thorpe, Col. Thomas B.:

"Incidents in the Life of Audubon," Godey's Lady's Book, vol. xlii, pp. 306-309, with portrait. Philadelphia, 1851.

65. Griswold, Rufus W.:

"John James Audubon," International Monthly Magazine, vol. ii, pp. 469-474. New York, 1850-1851.

66. CAP, P. A.:

"Jean Jacques Audubon," L'Illustration, vol. xviii, pp. 70-71, illust. Paris, 1851.

67. (ANon.):

"Audubon, the Naturalist," Gleason's Pictorial, vol. iii, p. 196, with portrait of Audubon as a young man. Boston, Sept. 25, 1852. 
Audubon is said to have been born in New Orleans, May 4, 1780, and "in 1810 he embarked in a skiff with his wife and young child for his only companions, and with his gun and pencil for baggage, and commenced an adventurous and wandering life-the life of a hunter and naturalist, which he did not abandon until 1834."”

68. Godwin, PARKe:

"John James Audubon," in The Homes of American Authors. New York, 1853.

See also "The Home of Audubon," The Leisure Hour, vol. 2, pp. 300-303 (London, 1853), and Little Journeys to the Homes of American Authors, New York and London, 1896.

69. Smiles, Samuel:

Brief Biographies. Boston, 1861. See "Audubon the Ornithologist," pp. 171-197.

70. St. John, Mrs. Horace:

Life of Audubon, the Naturalist in the Nere World. His Adventures and Discoveries. Pp. i-xiv, 1-172. London, 1856.

71. St. John, Mrs. Horace:

Life of Audubon, the Naturalist of the Nere World. His Adventures and Discoveries. Revised and corrected, with additions, and illustrated with engravings by J. W. Orr from original designs. Pp. 1-24, 1-312. Boston, 1856.

First American edition, followed by others in 1861, 1864, 1870,1876 and later; citation from edition of 1864 .

72. Buchanan, Robert (editor):

The Life and Adventures of John James Audubon, the Naturalist. Edited from materials supplied by his widow. 8vo. Pp. i-viii, 1-366. Portrait and vignette on title. London, 1868. 
This was followed by a second and third English edition in 1869 , the latter without frontispiece, but with vignette stamped on cover. The editor assumed no responsibility for the fidelity of his record, which was based on a manuscript by the Rev. Charles Coffin Adams, of New York. Reproduced in "Everyman's Library," with an Introduction by John Burroughs (originally appearing as a review of Buchanan's work in 1869; see No. 153). 12mo. Pp. i-xx, 1-336. London and New York (no date).

73. Audubon, Lucy (editor):

The Life of John James Audubon, the Naturalist. Edited by his Widow. With an Introduction by James Grant Wilson. 8vo. Pp. i-x, 1-444. Portrait, and vignette on title. New York, 1869.

Reprinted at various times; citation from a copy bearing date of 1906. This work is a reproduction, with but slight changes, of Buchanan's rendering of the original Adams manuscript.

74. Duyckinck, Evert Augustus:

"John James Audubon," in the National Portrait Gallery of Eminent Americans, illustrated from paintings by Alonzo Chappel. 2 vols., 4to. New York, 1862. For Audubon, see vol. i, pp. 47-54.

75. Parton, James:

Peoples' Book of Biography, or Short Lives of the most interesting Persons of all Ages and Countries. Hartford, 1869. For Audubon, see pp. 163-16\%.

A second edition appeared under the title Illustrious Men and their Achievements, \&c. (New York, 1881).

76. (ANon.):

"Audubon," Chambers' Journal, vol. 46, pp. 85-89. London and Edinburgh, 1869.

A compilation from Buchanan's Life. 
77. (Anow.):

"The Life of John James Audubon, the Naturalist," Harpers' Nere Monthly Magazine, vol. xxxix, pp. 613614. New York, 1869.

78. Audubon, Maria R.:

"Reminiscences of Audubon by a Granddaughter," Scribner's Monthly Magazine, vol. xiii, pp. 333-336. New York, $18 \% 6$.

79. Brewer, Thomas M.:

"Reminiscences of John James Audubon," Harper's New Monthly Magazine, vol. lxi, pp. 666-675. New York, 1880.

Reproduces a number of interesting letters.

80. (Anon.) Larrabee, W. H.:

"Sketch of J. J. Audubon," Popular Science Monthly, vol. xxxi, pp. 687-697, with portrait. New York, $188 \%$.

See also reprint in Pioneers of Science in America. Sketches of their lives and Scientific Work. From the Popular Science Monthly, with additions. "John James Audubon, 1780-1851," pp. 152-156. New York, 1896.

81. Pentz, $\mathrm{J}_{\text {Aco }}$ :

"The Audubons." Shooting and Fishing, May 11, 1893, illust. New York.

Interesting reminiscences and portraits of John Woodhouse Audubon and his family, with whom the author lived for a number of years.

82. Elliot, Daniel Giraud :

"The Life and Services of John James Audubon," Transactions of the New York Academy of Sciences, vol. xiii, pp. 43-5\%. New York, 1893. 
An address delivered before the New York Academy of Sciences, April 26, 1893.

83. Godwin, Parke:

"John James Audubon," in Commemorative Addresses, pp. 149-192.

An interesting sketch by one who had known Audubon as early as 1842 , but replete with errors in dates and questions of fact; condensed from earlier papers. See Nos. 60 and 68.

84. Mitcheli, Donald G.:

American Lands and Letters. 2 vols. London, 1897, 1899. For Audubon, see vol. i, pp. 204-213.

85. Bradford, Mary FuUker:

Audubon. Pp. 1-72, illust. New Orleans, 1897.

Originally read before the Quarante Club, and privately printed in the interests of a fund for the erection of a monument to Audubon in New Orleans, a project which has since been realized (see Vol. I, p. 13).

86. Audubon, Maria R.:

Audubon and His Journals, with zoölogical and other notes by Elliott Coues. With 37 Illustrations, including 10 Portraits of Audubon, and 3 hitherto unpublished Bird Drawings. 2 vols., 8vo. Vol. i, pp. i-xiv, 1-532; vol. ii, pp. i-viii, 1-554. With reproduction of diplomas, etc. New York, 1898.

The first volume of this excellent work is devoted to a biography of the naturalist, pp. 1-78, and to his Journals (see No. 42); the second continues the Journals, and reproduces most of the "Episodes" from the Ornithological Biography.

87. Burrovghs, John:

John James Audubon. Pp. i-xviii, 1-144. With portrait. 16mo. and (large paper) 8vo. Boston. 1902. Citation from second edition of 1904. 
88. Merriam, C. Hart:

"John James Audubon," Popular Science Monthly, vol. 1xx, pp. 301-303, with portrait. New York, $190 \%$.

Deivered on the occasion of the unveiling of marble busts of ten eminent scientific men at the American Museum of Natural History, December 29, 1906.

89. Merriam C. Hart:

"John James Audubon," Bird Lore, vol. 9, pp. 3-5. New York, $190 \%$.

89a. Stone, Witmer :

"John James Audubon," in Leading American Men of Science, ed. by David Starr Jordan, pp. 71-87. New York, 1910.

90. Bakewell, Rev. Gordon:

"Reminiscences of John James Audubon." Publications of the Louisiana Historical Society, vol. v, pp. 31-41. New Orleans, 1911.

An address delivered before the Louisiana Historical Society, November 16, 1910. Affirms, on the testimony of Bernard de Marigny, that Audubon was a Louisianian by birth. See Vol. I, p. 69 of the present work.

\section{i. Revieres and Criticism}

91. (Anon.) Brewster, David:

"Mr. Audubon's Ornithology of the United States of America," Edinburgh Journal of Science, vol. vi, p. 184. Edinburgh, 1826-1827.

This highly commendatory paper by David Brewster, and that by Robert Jameson, which follows, gives the first formal announcement of Audubon's work in the scientific journals of the day. 
92. (ANon.) J JMeson, Robert:

"Mr. Audubon's great work on Birds of the United States of America," Edinburgh Nero Philosophical Journal, vol. 2, pp. 210-211. Edinburgh, 1826-1827.

The editor stated that Audubon had spent twenty-two years in the study of American birds, and that the engravings, of which several had already appeared, would be accompanied by a quarto volume of letterpress, containing all his observations on the natural history of the species, in the form of letters, an example of which was given in the paper on the Turkey Buzzard in the present number of that Journal (see No. 17).

93. (Anon.) Jones, Thomas P.:

"The Romance of the Rattlesnake," Franklin Journal and American 'Mechanics' Magazine, vol. ii (August), N. S., p. 144. Philadelphia, 1828.

This notorious attack upon Audubon's veracity was followed by Waterton (see No. 115), and referred to by Victor Audubon (see No. 118), in his reply. Audubon's original article (see No. 21) was published by this editor, who knew so little of its author that not even his name was given correctly.

93a. Cuvier, Georges:

"Rapport verbal fait à L'Académie Royale des Sciences, sur L'Histoire naturelle des Oiseaux de L'Amérique Septemtrionale, de M. Audubon," Le Moniteur, 1 re. octobre. Paris, 1828.

For extracts from Cuvier's report, see Chaptcr XXIII, p. 413.

94. (ANon.):

"Ueber die Abbildungen von Vögeln," in Froriep, Notizen, Bd. xxi, col. 49-54. Berlin, 1828.

95. W[ILLIAM]. S[waINSON].:

"Some Account of the Work now publishing by Mr. Audubon," Loudon's Magazine of Natural History, vol. i, pp. 43-52 (May). London, 1828-1829. 
Dated at "Tittenhanger Green. April 11, 1828." A highly laudatory article on Audubon's plates, quoted in his "Prospectus" of The Birds of, America.

96. (ANon.):

"Report of a committee appointed by the Lyceum of Natural History of New York to examine the splendid work of Mr. Audubon upon the Birds of North America; May, 1829," American Journal of Science and Arts, vol. xvi, pp. 353-354. New Haven, 1829.

Applauds The Birds of America, and recommends that the Lyceum become a subscriber.

97. "ORNITHOPHILUS":

"Remarks on Audubon's Birds of America, and Ornithological Biography," Edinburgh New Philosophical Journal, vol. 10, pp. 317-332. Edinburgh, 18301831.

A highly favorable and elaborate review, mistakenly attributel to Swainson. Reprinted in the National Gazette and Literary Register, vol. xii (June 10), Philadelphia, 1831. In - an editorial note it is said that the Ornithological Biography is about to be reprinted in Philadelphia by James Kay, Jr., \& Company.

98. Christopher North (John Wilson):

"Audubon's Ornithological Biography Introduction," Blackrood's Edinburgh Magazine, vol. xxx, pp. 1-16 (July). Edinburgh, 1831.

The second of Wilson's articles in praise of Audubon; reprinted with his later reviews of the same work in Critical and Miscellaneous Essays, vol. v, pp. 91-149.

99. Christopher North (John Wilson):

"Audubon's Ornithological Biography. Second Survey. Wilson's American Ornithology," Blackwood's 
Edinburgh Magazine, vol. $\mathrm{xxx}$, pp. 2417-280. Edinburgh, 1831.

100. (ANON.):

"Ornithological Biography...... By John James Audubon. \&c. \&c. Edinburgh, 1831," Edinburgh Literary Journal or Weekly Register of Criticism and Belles Lettres, April 16, 1831, pp. 248-249.

101. (Anon.) Featherstonhaugh, G. W.:

"Ornithological Biography. By John James Audubon, F. R. S. Published by Judah Dobson and H. H. Porter, Literary Rooms, Philadelphia," Monthly American Journal of Geology and Natural Science, vol. i, September, pp. 136-139. Philadelphia, 1831.

102. (ANON.):

"Ornithological Biography," American Quarterly Reviere, vol. x, pp. 245-258. Philadelphia, 1831.

103. (ANON.):

"The Birds of America. . . . By John James Audubon, F. R. S. . . . . . vol. i. folio. London, 1831. Ornithological Biography . . . . . 1 vol. 8vo. Edinburgh, 1831," Quarterly Reviere, vol. xlvii, pp. 332-366. London, 1832.

In the same article are reviewed Jameson's edition of Wilson's American Ornithology, and Part II of Swainson's and Richardson's Fauna Boreali-Americana.

104. Waterton, Charles:

"On the Faculty of Scent of the Vulture," Loudon's Magazine of Natural History, vol. v (April), pp. 233241. London, 1832.

Signed "Walton Hall, Dec. 21, 1831"; the first of nineteen critical and polemical articles extending over a period of five years, and directed against Audubon and his friends. 
105. (Anon.) Peabody, W. B. O.:

"Audubon's Biography of Birds. Ornithological Biography of Birds..... Philadelphia, 1831," North American Reviere, vol. xxxiv, pp. 364-405 (April). Boston, 1832.

The first of three able articles by the same anonymous writer which appeared in this Reviere. See Nos. 130 and 143.

106. (Anon.) Featherstonhaugh, G. W.:

"Audubon, Author of The Birds of America, and Ornithological Biography," Monthly American Journal of Geology and Natural Science, vol. i, pp. 456-468 (April). Philadelphia, 1832.

A laudatory review, in which the author professes to give "a true history of a conspiracy, got up to utterly break down and ruin the reputation of one of the most remarkable men America ever produced."

107. Abert, John :

"Habits of Climbing of the Rattle-snake. Extract of a letter from Col. Abert, of the U. S. Topographical Engineers, to Dr. Harlan of Philadelphia," Monthly American Journal of Geology and Natural Science, vol. i, pp. 221-223. Philadelphia, 1832.

Dated "Washington, Oct. 21, 1831." Supports Audubon's account of the climbing habits of the rattlesnake, which had become the subject of acrimonious dispute.

108. (ANON.):

"Audubon," The Athenaum, vol. for 1833, pp. 817818. London, 1833.

In number for November 23. An account, partly from private sources and partly from a New York newspaper, of Audubon's present researches and plans, with detailed comment on his Florida and Labrador expeditions. 
109. Hunter, Perceval:

"Means by which the Vulture (Vultur Aura, L.) traces its Food," Loudon's Magazine of Natural History, vol. vi, pp. 83-88. London, 1833.

Dated “Oxford, Jul. 2, 1832." Defends Audubon's account of lack of sense of smell in the Vulture, published in 1826 (see No. 17).

110. Waterton, Charles:

"The Means by which the Turkey Buzzard traces its Food," Loudon's Magazine of Natural History, vol. vi, pp. 162-163. London, 1833.

Signed "Walton Hall, Jany. 1, 1833." A caustic reply to the last. Reprinted in Essays in Natural History, chiefly Ornithology, First Series. London, 1838.

111. Waterton, Charles:

"Remarks on Mr. Audubon's Account of the 'Habits of the Turkey Buzzard (Vultur Aura), particularly with the View of exploding the Opinion generally entertained of its extraordinary Powers of Smelling," "Lou'don's Magazine of Natural History, vol. vi, pp. 163171. London, 1833.

A characteristically flippant article, ending thus: "But here I will stop: I have been too long on carrion,- "neque enim toluare vaporem ulterius potui' (Ovid Met., ii, 301)."

\section{Waterton, Charles:}

"The Gland on the Rump of Birds," Loudon's Magazine of Natural History, vol. vi, pp. 274-277. London, 1833.

Denial that birds ever oil their feathers in preening, as Audubon had maintained for the eagle. Reprinted, with many controversial articles, which follow, in Essays on Natural History, First Series, referred to above. 
113. Audubon, V. G.:

"[Mr. Audubon, Jr.] in Reply to Mr. Waterton's Remarks on Audubon's Biography of Birds," Loudon's Magazine of Natural History, vol. vi, p. 369. London, 1833.

Signed "121 Great Portland St., Jn. \%, 1833." Victor Audubon's defense of his father, who was then in America.

114. R[OBERT] B [AKEWELL]:

"Observations on Mr. Waterton's Attacks on Mr. Audubon," Loudon's Magazine of Natural History, vol. vi, pp. 369-372. London, 1833.

Signed "Hampstead, Jn. 10, 1833."

115. Waterton, Charles:

[Mr. Waterton in reply to Mr. Audubon, Jun.], Loudon's Magazine of Natural History, vol. vi, pp. 464-465. London, 1833.

Signed "Walton Hall, July 6, 1833"; Refers to Dr. Jones' "Romance of the Rattlesnake" (see No. 93), and quotes a letter by George Ord, in explaining why Swainson did not write the "Biography of Birds."

116. Waterton, Charles:

"Mr. Audubon again," Loudon's Magazine of Natural History, vol. vi, pp. 465-468. London, 1833.

A reply to Robert Bakewell, in which the author says that his only object in attacking Audubon was to defend his own account of the vulture.

117. Swainson, William:

"Mr. Audubon, and his Work, the "Biography of Birds': Mr. Swainson in reply to Mr. Waterton," Loudon's Magazine of Natural History, vol. vi, p. 550. London, 1833.

Dated Sept. 17, 1832. 
118. Audubon, V. G.:

"Mr. Audubon, and his Work, the 'Biography of Birds': Mr. Audubon, jun., in Reply to Mr. Waterton," Loudon's Magazine of Natural History, vol. vi, pp. 550-553. London, 1833.

Signed "121 Great Portland, Sept. 19, 1833." Quotes articles by Jones, Featherstonhaugh and Abert; see Nos. 93, 101, 106 and $10 \%$.

119. Waterton, Charles:

"Retrospective Criticism," embracing the following minor articles: "Mr. Audubon, and his Work, the Biography of Birds" (signed "Walton Hall, Nov. 7, 1833) ; "Mr. Audubon, jun."; "Aerial Encounter of the Eagle and the Vulture" (see the "Biography of Birds," vol. i, p. 163) (signed "Walton Hall, Nov. 7, 1833"); "Audubon's Humming-bird" (see the "Biography of Birds," vol. i, p. 248) ("Walton Hall, Nov. 19, 1833"); "The Virginian Partridge," Loudon's Magazine of Natural History, vol. vii, pp. 66-74. London, 1834.

The three last reprinted in Essays on Natural History, First Series, referred to above.

120. Waterton, Charles:

"Retrospective Criticism," embracing the following minor articles: "The Vulture's Nose" ("Walton Hall, March 6, 1834"); "Audubon's Claim to the Authorship of the Biography of Birds"; "Audubon and his Ornithology"; "The Passenger Pigeon" ("Walton Hall, Jany. 19, 1834"). Loudon's Magazine of Natural History, vol. vii, pp. 276-283. London, 1834.

The first and last articles reprinted in Essays on Natural History, First Series, referred to above.

121. (ANon.):

"The Birds of America. No. XXXVII. By J. J. Audubon, Esq. Coloured Plates. Elephant folio. Lon- 
don, Havell," Athencum, vol. for 1834, p. 350 (May 10). London, 1834.

fit the same time was also reviewed Part ii of $A$ Manual of: the Ornithology of the United States, by Thomas Nuttall.

122. (ANON.):

"The Birds of America. By J. J. Audubon, F.R.S., F.L.S. Parts XLI, XLII, XLIII. London, Havell," Athencum, vol. for 1834, pp. 653-654. London, 1834.

Describes the Wood Duck (Plate ccvi) as perfect, and compliments the engraver, Robert Havell, on "the accuracy with which he has appreciated and retained the spirit of the originals."

123. (AnoN.) HaLI, James:

"American Ornithology," The Western Monthly Magazine, vol. ii, .pp. 337-350 (July). Cincinnati, 1834.

A comparative review of the ornithological works of Alexander Wilson, Thomas Nuttall, and John James Audubon, very laudatory of the first two but condemnatory of the last, by Judge Hall, whose brother, Harrison Hall, was an interested publisher of Wilson's work. "How shall we venture to dissent from the almost unanimous expression of public sentiment, which has set him [Audubon] up as a sort of 'greatest and best,' against whom to speak in dispraise, would be a species of treason. Yet it must be done, and it is our vocation to do it: the critic must not be silent when the interests of science require, and the honor of his country demands, that he should proclaim the truth..... The exaggerations contained in these sketches ["Episodes"] are such as to weaken our confidence in the entire work."

\section{BaCHMAN, JoHN :}

"Retrospective Criticism. Remarks in defence of the Author of the Birds of America," Loudon's Maga- 
zine of Natural History, vol. vii, pp. 164-175. London, 1834.

A reply to Waterton, and an appeal for as much justice for Audubon as was shown to Wilson, his predecessor. Dated "Charleston, Dec. 31, 1833."

125. Bachman, JoHN :

"An account of some experiments made on the habits of the Vultures inhabiting Carolina,- the Turkey Buzzard and the Carrion Crow, particularly as it regards the extraordinary powers of smelling usually attributed to them," Journal of the Boston Society of Natural History, vol. i, pp. 15-31. Boston, 1834.

Bachman did not deny the power of smell to the vultures, but maintained that they were guided to their prey by sight alone.

126. (ANon.):

"Audubon's Birds of America and Ornithological Biography," Edinburgh Nerw Philosophical Journal, January, 1835.

"All is life, health, and beauty. Never before were birds so represented, and if ever again they will be, still Audubon will be the chief of a school, of whom it will be said that it studied nature. Turn now to any volume of plates that you can find, and what presents itself? not a bird surely, but an effigy stuffed with straw, and more worthy of being burnt, than that of a Tory statesman by a radical mob."

12\%. BaCHMAN, JoHN:

"Defence of Audubon," Bucks County Intelligencer, 1835.

Not seen.

128. (ANON.):

"Ornithological Biography .... . Volume ii, published at 25s.," Loudon's Magazine of Natural History, vol. viii, pp. 184-190. London, 1835. 
129. TAylor, Richard C.:

"On the Geology and Natural History of the NorthEastern Extremity of the Alleghany Mountain Range, in Pennsylvania, United States," Loudon's Magazine of Natural History, vol. viii, pp. 529-541. London, 1835. Confirms Audubon's account of the climbing habits of the rattlesnake.

130. (Anon.) Peabody, W. B. O.:

"Audubon's Biography of Birds; Ornithological Biography," North American Review, vol. xli, pp. 194231. Boston, 1835.

131. Christopher North (John Wilson):

"Audubon's Ornithological Biography," Blackrood's Edinburgh Magazine, vol. 37, pp. 107-124. Edinburgh, 1335.

132. Waterton, Charles:

"On Snakes, their Fangs, and their Mode of procuring Food," Loudon's Magazine of Natural History, vol. viii, pp. 663-668. London, 1835.

Reprinted in Essays on Natural History, First Series, referred to above.

133. Waterton, Charles, Esquire, of Walton-Hall :

"A Letter to James [Robert] Jameson, Esq." [followed by 21 lines of fine print, giving titles and membership in scientific societies]. Pp. 1-14. Wakefield, 1835.

Privately printed, and designed mainly to hit Audubon and his snake stories over Jameson's shoulders. Signed, "WaltonHall, January 27, 1835." "Should you honor me- with a reply, I promise you that I will take an immediate and dispassionate notice of it; and I will address to you a second, a third, and a fourth letter, and so on. As you have first 
attacked me through Audubon, through him I will continue to point my dart at you. ... This mode of carrying on the warfare will answer well my ends. It will give me an opportunity of again bringing on the stage certain individuals with whom I have not yet quite squared up accounts; and, at the same time, I trust it will be to you a kind ...... of hint, a warning-lest you make another false step in your exertions to sound again in the public ear, $O$ Candour! whither art thou fled? Certainly not to Walton Hall. ... Pray, sir, where were your brains (whither had they fled? Certainly not to Walton Hall) when you received, and approved of, a narrative at once so preposterous and so palpably fictitious?" Reprinted in Essays on Natural History, edited by Norman Moore (London, 1871). Citation from pamphlet in Library of British Museum.

134. Waterton, Charles, Esquire, of Walton-Hall:

"Second Letter to Robert Jameson, Esq." [with same titles as in last]. Pp. 1-16. Wakefield, 1835.

Ridicules in particular Audubon's accounts of the Vulture, the Passenger Pigeon, and a hurricane in North America. Signed "Walton-Hall. March 2nd, 1835."

135. Waterton, Charles:

"Audubon's Plates of the Birds of America," Loudon's Magazine of Natural History, vol. viii, pp. 236238. London, 1835.

Accuses Audubon of misrepresentation in his statements of the time required to produce his drawings.

136. (ANoN.):

"Ornithological Biogiaphy, or an Account of the Habits of the Birds of the United States of America. ..... By J. J. Audubon. vol. ii \&c. First Notice," Athenaum, London, January 3, 1835, pp. 5-7.

The same: "Second Notice," Athenaum, January 17, pp. 43-45. 
The same: "Third Notice," Athencum, January 31, pp. 87-89.

"There is amply sufficient remaining in Audubon's pages, for fully a dozen more notices, were we disposed to follow the exhausting system."

13\%. (ANon.):

"Ornithological Biography .... vol. iii, First Notice," Athenceum, pp. 41-42, January 16, 1836. London.

The same: "Second Notice," Athenaum, January 23, 1836, pp. 62-63.

138. Waterton, Charles, Esq., Walton-Hall :

"An Ornithological Letter to William Swainson, Esq., F.R.S. \&c. \&c." Pp. 1-16. Wakefield (Richard Nichols, Bookseller), $183 \%$.

Signed "Walton-Hall, March 10, 183\%," and reprinted in Moore's edition of Essays on Natural History, referred to above. A long and bitter tirade against both Swainson and Audubon. "You have seen fit to laud one man exceedingly, for his zoological acquirements, who to my certain knowledge, paid other people for the letterpress and drawings, which were to appear in his work." Citation from pamphlet in British Museum Library.

139. (ANoN.):

"Ornithological Biography .... by John James Audubon. vols. i-iii," Oken's Isis, Bd. xxx, pp. 922928. Leipzig, 1837.

140. Sells, W.:

"On the Habits of the Vultur aura, with notes on the dissections of the two heads of two specimens by $R$. Owen," Proceedings of the Zoölogical Society of London, Pt. v, pp. 33-35. London, $183 \%$. 
Favors the view that the vulture is guided to food by the sense of smell.

141. (ANON.):

"Ornithological Biography . . . . vol. iv . . . . " Athenaum, London, Dec. 1, 1838, pp. 849-852.

142. (ANon.):

"Ornithological Biography . . . . vol. v . . . . " Athenceum, London, vol. for 1839 , p. $7 \%$.

143. (Anon.) Peabody, W. B. O.:

"Audubon's Ornithological Biography," North American Reviere, vol. i, pp. 381-404 (April). Boston, 1840.

144. (ANon.):

"Audubon's Ornithology. A Synopsis of the Birds of North America. Edinburgh, 1839. The Birds of America. London and Edinburgh, vol. 1. New York, 1840," American Journal of Sciences and Arts, vol. xxxix, pp. 343-35\%. New Haven, 1840.

145. Ord, George:

[Reply to Audubon's charge against Wilson, and countercharge against Audubon.] Proceedings of the American Philosophical Society, vol. 1, pp. 272-273. Philadelphia, 1840.

Report of meeting held September 18, 1840.

146. (ANon.):

"The Birds of America ..... vol. ii, octavo edition ....... published by J. J. Audubon, and J. B. Chevalier," American Journal of Science and Arts, vol. xlii, pp. 130-136. New Haven, 1842.

"Mr. Audubon has now nearly a thousand subscribers to his work; an instance of liberal support of a work on natural his- 
tory certainly without a parallel in the New World, and hardly with one in the Old."

147. (ANon.):

"A Synopsis of the Birds of North America, by J. J. Audubon. London, 1839," Oken's Isis, Bd. xxxvii, pp. 713-718. Leipzig, 1844.

148. Winterfield, Charles:

"American Ornithology (The Birds of America and Ornithological Biography)," The American Reviere: A Whig Journal, vol. i, pp. 262-274. New York 1845.

149. Winterfield, Charles:

"About Birds and Audubon," The American Review: A Whig Journal, vol. i, pp. 371-383. New York, 1845.

Refers to a meeting with Audubon on a canal boat in Pennsylvania, when the latter was returning from his Missouri River expedition in 1843. See No. 173.

150. Winterfield, Charles:

"A Talk about Birds and Audubon," The American Reviere: A Whig Journal, vol. ii, pp. 279-287. New York, 1845.

Interesting reference to "the great fire [of July 19, 1845] which so lately devastated so large a part of this proud city [New York]," in which the copper plates of Audubon's Birds were thought to have been destroyed (see Chapter XXXV, p. 267).

151. (ANoN.):

"Audubon, the Naturalist," Athenceum, London, vol. for 1856, p. 283.

Review of Mrs. Horace St. John's Life of Audubon (see No. 71 ). 
152. (ANon.):

"The Life and Adventures of John James Audubon," Athenoum, London, vol. for 1868, pp. 833-834. Review of Buchanan's Life (see No. 72).

153. (ANon.) Burroughs, JoHN:

"The Life of Audubon . . . . . edited by Mrs. J. J. Audubon" [see No. 73], The Nation, vol. ix, pp. 13-14. New York, 1869.

Reprinted in Buchanan's Life of Audubon, "Everyman's Library" (see No. 72).

154. (ANon.):

"The Adventures of Audubon," .... Edinburgh Reviero, vol. cxxxii, pp. 250-275. Edinburgh, 1870. Review of Buchanan's Life.

155. SHUFELdT, R. W.:

"Shedding Horns of Antelope," Shooting and Fishing, New York, March, 1896.

For critical articles by the same author, see also the following: "On the Terrestrial Attitudes of Loons and Grebes," The Ibis, London, January, 1898; “Audubon's Figure of the Mountain Partridge," Field and Stream, New York, September 1899; "Scaup Duck," Shooting and Fishing, New York, November 26, 1903; and "The Nest of the Orchard Oriole," The Wilson Bulletin, Oberlin, June, 1903.

156. (ANoN.):

"A Great Naturalist," Blackroood's Edinburgh Magazine, vol. clxiv, pp. 58-69. Edinburgh, 1898.

Review of Audubon and his Journals.

15\%. (Anon.) Merriam, C. Hart:

"Audubon," The Nation, vol. LXVI, pp. 151-152. New York, 1898. 
See also Science, N. S., vol. VII, pp. 289-296, with plate. New York, 1898.

Reviews of Audubon and his Journals.

158. M[IALL], L. C. :

"Audubon," Nature, vol. Ivii, pp. 286-28\%. London, 1896-1898.

A dour review, in which the writer remarks that Audubon's Birds of America "has great artistic merit but less scientific value than a good series of photographs from life."

159. Hutт, W. N.:

"Audubon the Original Nature Fakir," Scientific American, vol. xcviii, p. 59. New York, 1908.

A feeble echo of the slanderous charges brought against Audubon by Thomas P. Jones in 1828 (see No. 93).

160. Colles, George W.:

"A Defense of Audubon," Scientific American, vol. xcviii, p. 311. New York, 1908.

An excellent rejoinder to the egregious article quoted above.

161. Burns, Frank L.:

"Alexander Wilson," Pts. I-VIII, The Wilson Bulletin, vols. xx-xxii. Oberlin, 1908-1910.

See particularly, I. "The Audubon Controversy," vol. xx, pp. 3-18, and II. "The Mystery of the Small-headed Flycatcher," vol. $\mathrm{xx}, \mathrm{pp}$. 63-79.

\section{j. Auduboniana and Miscellanea}

162. (ANon.) :

"Wilson the Ornithologist," The Literary Gazette, and Journal of Belles Lettres, Arts and Sciences, London, Saturday, September 3, 1831, p. 574.

A grotesque notice, based on a rumor, said to have originated in a Philadelphia newspaper, of the death of Audubon 
in America, but confounding his identity with that of Alexander Wilson, whose death had actually occurred at Philadelphia eighteen years before. In the issue of October 15, the editor acknowledged his error in resurrecting and then killing Wilson, but explained that the obituary was intended for Audubon.

163. Brown, Capt. Thomas:

"Mr. Audubon," Caledonian Mercury, Edinburgh, Thursday, November 3, 1831.

Quotes a letter written by Audubon, to Joseph B. Kidd and dated "New York, Sept. 7, 1831," four days after his death had been announced in England. In its issue of September 8, this paper had already corrected the London editor's error respecting Wilson.

164. (Anon.) Featherstonhaugh, G. W.:

"Audubon's Expedition to California and the Rocky Mountains," Monthly American Journal of Geology and Natural Science, vol. i, p. 229. (November.) Philadelphia, 1831.

165. (ANon.):

"Mr. Audubon," Nerw York Mirror, vol. 10, p. 325. New York, April 20, 1833.

166. (ANon.):

"Audubon and his Labrador Expedition." Editorial in the National Gazette and Literary Register, Philadelphia, vol. xiii, No. 3808, September 10, 1833.

"We wish him a degree of success and prolongation of vigor equal to his great merits; indeed, for the past at least, success is fully assured."

16\%. (ANon.):

"Mr. Audubon," National Gazette and Literary Register, Philadelphia (extracted from the Boston Patriot), vol. xiii, No. 3919, September 10, 1833. 
Welcomes Audubon on his return to Boston, and gives detailed account of his successful Labrador expedition.

168. MacGillivray, William:

A History of British Birds, indigenous and migratory, 5 vols., 8vo. Illust. London, 1837-1852.

See Practical Ornithology, 6th. Lesson: "Ornithologus [Audubon], and Physiophilus [MacGillivray]," pp. 462-474 (1839).

169. Swainson, William:

Taxidermy, Bibliography, and Biography. The Cabinet Cyclopadia, conducted by the Rev. Dionysius Lardner. 12mo. London, 1840. For "J. J. Audubon, Animal Painter," see pp. 116-117.

170. Freiligrath, F.:

"Epistel an Audubon nebst einer Antwort aus Amerika." Pp. 1-16, 18mo. Philadelphia, 1844.

This rare little pamphlet bears on its cover a woodcut of an Indian brandishing a gun and knife: the poem begins:

"Mann der Wälder, der Savannen!

Neben rother Indier Speer,

An des Mississippi Tannen

Lehntest du dein Jagdgewehr !"

and the response:

\section{"Audubon, den Vogelfänger \\ Sangst du an, mit Herzeleid; \\ Freiligrath, o grosser Sänger! \\ Deine Lieder fliegen weit."}

See also J. Bayard Taylor, "Audubon. From the German of Ferdinand Freiligrath," Graham's American Monthly Magazine, vol. xxvi, p. 264. This poem consists of twenty stanzas, the first four and best of which are: 


\section{BIBLIOGRAPHY}

Man of forests and savannas!

On the Mississippi's tide,

Leanest thou thy hunting-rifie

Oft the Indian spear beside;

With the forest's tawny chieftains

Thou the friendly pipe dost light-

Seest the wandering pigeon's journey

And the eagle's silent flight.

With thy shot thou lam'st his pinion;

And the trackless region through,

On the mighty river's mirror

Pliest thou thy swift canoe.

O'er the green and grassy prairie

Boldly flies thy fiery steed;

Deer and forest-fruits the manna

God has given thee in thy need!

Ferdinand Freiligrath (1810-1876), well known German lyric poet and apostle of democracy, was more than once forced to flee his native land on account of his political sentiments; he went to England seven years after Audubon had finally settled in America, and that country became his refuge for over twenty years; his translations from the English included Longfellow's poem of "Hiawatha."

171. (ANon.):

"Mort de Jean Jacques Audubon, célèbre naturaliste américain," illust., L'Illustration, Paris, vol. xvii, No. 416, February 28, 1851, p. 128.

172. (ANON.):

"John James Audubon," Harper's New Monthly Magazine, vol. ii, pp. 561-563 (March). New York, 1851. 
173. Webber, Charles Wilkins:

Romance of Natural History; or Wild Scenes and Wild Hunters. 8vo.; pp. 1-8, 17-610. Philadelphia, 1852.

An abridgment of the author's Wild Scenes and Wild Hunters, 1851, and also issued under the title The hunter naturalist; also published as The Romance of forest and prairie life; narrative of perilous adventures \& wild hunting scenes (H. Vizetelly. London, 1853). Gives an anecdote of meeting Audubon on a canal boat in Pennsylvania, when he was returning from the Upper Missouri in 1843 (see No. 149) and is quoted here for no other reason.

174. Audubon, John Woophouse:

Illustrated notes of an expedition through Mexico and California. Pp. 1-48, 4 plates, plain or colored. J. W. Audubon. New York, 1852. Reprinted as Extra Number 41 of The Magazine of History, with Notes and Queries. Pp. 1-83, 4 colored plates (including frontispiece). W. Abbatt. Tarrytown, 1915.

It was planned to issue this work monthly in ten numbers, if it should receive sufficient public support. The drawings are exquisitely reproduced, and as works of art are deserving of the highest praise. See No. 219.

175. $\mathrm{A}[\mathrm{NNA}] \cdot \mathrm{A}[\mathrm{TKINS}] .:$

Memoir of J.G. Children, Esq., including some unpublished poetry of his father and himself. Printed for private distribution. Pp. 1-314. Westminster, 1853.

Refers to Audubon's relations with Children, and to his naming of "Sylvia childreni," which later proved to be an error.

176. Nolte, Vincent:

Fifty Years in both Hemispheres: or Reminiscences of a Merchant's Life. London, 1854. 
English edition of a work originally published at Hamburg in the same year. See particularly his version of the meeting with Audubon in 1810, and of their descent of the Ohio in Nolte's flatboat to Louisville in the winter of that year.

177. WALLACE, W. Ross:

"Audubon's Hymn in the American Forests," Harper's Nere Monthly Magazine, vol. xix, p. 619 (October). New York, 1859.

178. Stoddard, Charles A[ugustus]:

“A Noble Woman's Life: A Memorial Sermon to the late Madame Audubon." Printed by request. Pp. 1-24, 18mo. Anson D. F. Randolph \& Co., 770 Broadway, cor. 9th St., New York, 1874.

179. $\mathrm{F}$.

"Audubon's Birds of America," Magazine of American History, vol. 1, pp. 252-253. New York and Chicago, 1877.

Reproduction of a note by J. Prescott Hall concerning Audubon's subscribers.

180. Lockwood, SAMUEL:

"Audubon's Lily Rediscovered," Popular Science Monthly, vol. x (April), pp. 675-678. New York, 1877.

Records the rediscovery of Audubon's long lost and discredited yellow water lily, Nymphaca flava, by Mrs. Mary Treat, in Florida, in the summer of 1876 . Originally figured by Audubon, with the Common American swan, on Plate cccexi, of The Birds of America, in 1838.

181. Coues, Elliott:

Birds of the Colorado Valley, Bibliographical Appendix: "List of Faunal Publications relating to North American Ornithology," pp. 567-746. 8vo. Washington, 1878. 
Gives full citations of the various editions of Audubon's works. "It takes an inspired idiot to be a good bibliographer" (Coues).

182. WADE, JosepH M.:

"Letter to J. M. Wade on Audubon's Mill," Ornithologist and Oölogist, vol. 8, p. 79. Boston, 1883.

183. Jordan, David Stark:

"Rafinesque," Popular Science Monthly, vol. xxix, pp. 212-221 (June). New York, 1886. Reproduced in Pioneers of Science in America, edited by William Jay Youmans (New York, 1896).

184. Shufeldt, R. W.:

"On an old Portrait of Audubon, painted by himself, and a word about some of his early Drawings," The $A u k$, vol. iii, pp. 418-430, with portrait. New York, 1886.

185. Saunders, Frederick:

The Story of Some Famous Books. For Audubon, see pp. 141-144. London, $188 \%$.

186. Starling, Edmund L.:

History of Henderson County, Kentucky. 8vo., pp. 1-832. Henderson, $188 \%$.

Gives an account of Audubon's mill and of his other business ventures at Henderson, but when departing from local records is inaccurate and unreliable.

18\%. Martin, D. S.:

"Audubon's Grave," Science, vol. x, pp. 68-69 (Aug. 5). New York, 1887.

Refers to the project set on foot to raise funds for erecting a monument to the naturalist. 
188. Shufeldt, R. W.:

"Audubon's Grave," Science, vol. x, p. 108 (Aug.

28). New York, 1887.

Proposes that the remains of Audubon should eventually rest in the crypt of the Cathedral of St. John the Divine, New York City.

189. (ANon.):

[Audubon's Grave], Science, vol. x, p. 205 (Oct. 28). New York, $188 \%$.

Announces the appointment of a committee by the New York Academy of Sciences to secure funds for the erection of the proposed monument.

See also the same, vol. x, p. 278 (Dec. 9).

190. ShUFELdT, R. W.:

"Audubonian Sketches," The Audubonian Magazine, published in the interests of the Audubon Society for the protection of birds, vol. i (January), pp. 267-271, illust., and vol. ii (February), pp. 3-6, illust. New York, 1888.

See files of the same magazine, vol. i, pp. i-xi, 1-288, February, 1887-January, 1888, and vol. ii, pp. i-vi, 1-264, February, 1888-January, 1889, New York, for various comments on Audubor's life and services.

191. Bachman, C. L.:

John Bachman, D.D., LL.D., Ph.D. 8vo, pp. i-xii, 1-436, with portrait. Charleston, 1888.

Reproduces numerous letters which passed between the Bachman and Audubon families.

192. Loomis, LEVERETT M.:

"A Forgotten Volume," The Auk, vol. viii, p. 230. New York, 1891. 
193. (ANon.) :

"Report of the Audubon Monument Committee of The New York Academy of Sciences," Transactions of the Academy, vol. xiii, pp. 23-69. New York, 1893.

194. Shufeldt, R. W.:

"Audubon the Naturalist," illust., The Great Divide, San Francisco, September, 1893.

"More about Audubon the Naturalist," ibid., February, 1894.

195. Duke, Basil W.:

"Audubon," Southern Magazine, vol. iii, August, 1893, pp. 3-19, portrait and illust. Louisville, 18931894.

196. Shufeldt, R. W., and Audubon, M. R.:

"The Last Portrait of Audubon, together with a letter to his son," The Auk, vol. xi, pp. 309-313, portrait. New York, 1894.

The original of D'Avignon's engraving, published in 1850; see No. 62.

197. Healy, George P. A.:

Reminiscences of a Portrait Painter. Chicago, 1894.

Gives an account of his successful manœuvres to obtain sittings for his portrait of Audubon in 1838.

198. Call, Richard Ellisworth:

The Life and Writings of Rafinesque. Filson Club Publications, No. 10. 4to. Pp. i-xii, 1-22\%. Louisville, 1895.

Takes Audzbon severely to task for his treatment of Rafinesque at Henderson in the summer of 1818 ; see pp. 2429. 
199. "Renignolds" (E. R. Shattuck):

"Audubon's Plates sold for Junk," Forest and Stream, New York, September 12, 1896.

200. BAKEWELL, W. G.:

Bakerwell-Page-Campbell. Being an account of the descendants of John Bakewell, of Castle Donnington, Leicestershire, England, born in 1638, \&c., \&c. Wm. H. Johnston \& Company. Pittsburgh, 1896.

Gives genealogy of the Bakewells, and of the families of J. J., J. W. and V. G. Audubon.

201. Coues, Elliott:

"Letter by Audubon to Charles Bonaparte, dated New York, May 1, 1833," The Osprey, vol. ii. Washington, $189 \%$.

202. Rozier, Firman A.:

Rozier's History of the early Settlement of the Mississippi Valley. 8vo., pp. 1-338. St. Louis, 1898.

See Part $\mathbf{X}$ for some account of the business relations of Audubon with the author's father, Ferdinand Rozier.

203. Coues, Elliott:

"William Swainson to John James Audubon, The Auk, vol. xv, pp. 11-13. Cambridge, 1898.

Letter dated "Tettenhanger Green, $2^{d}$ October 1830"; reprinted in The Osprey, vols. iv and v (Washington, 1900). ,

204. Günther, Albert :

"The unpublished correspondence of William Swainson with contemporary naturalists (1806-1840)," Proceedings of the Linncean Society, 112th session, pp. 14-24. London, 1900.

Lists twenty-four letters of Audubon to Swainson, dating from 1 May, 1828, to 11 Jany., 1838, with brief reference to 
their contents. For abstract of this paper see Theodore Gill, "Swainson's Correspondence." The Osprey, vol. v, pp. 29-30 (Washington, 1900).

205. Gill, Theodore :

"Correspondence of and about Audubon with Swainson," The Osprey, vol. v, pp. 23-25. Washington, 1900.

206. Gill, Theodore:

"William Swainson and his Times," The Osprey, vols. iv and v. Washington, 1900.

20\%. (Anon.) :

"Recent Sales of Audubon's Works," The Osprey, vol. v, pp. 31 and 63. Washington, 1900.

Copy of The Birds of America sold by Bangs, February 6, 1896 , for $\$ 1,250$, and another by Sotheran, London, 1892, for $£ 345$ (about $\$ 1,725$ ), the first with the Ornithological Biography included.

20\%. Bohemian (C. S. Boutcher):

"Early Days in the Lehigh Valley," Black Diamond Express, vol. iv, pp. 3-15. New York, 1900.

Describes Audubon's visit to Mauch Chunk in 1829, and gives also a detailed account of the copy of The Birds of America formerly the property of David Eckley, of Boston, and then in possession of Robert H. Sayre, of South Bethlehem, Pennsylvania (for which see Chapter XXVI, p. 7).

208. (ANoN.):

"Audubon in the [American] Museum [of Natural History]," with explanatory notes by Maria R. Audubon, The American Museum Journal, vol. 1, pp. 82-84, with portrait. New York, 1900-1901.

Describes portrait of Audubon painted by his sons towards the close of his life, and given to the Museum by Mr. Fordham 
Morris, of New York, an oil painting of wild turkeys, the original of which was made by Audubon in $\mathbf{1 8 2 6}$ for the Royal Institution of Liverpool, and several other paintings and plates. In vol. ii, page 42, of the same journal is reproduced an unpublished painting of the Red-eyed Vireo by Audubon.

209. Deane, Ruthven:

"Unpublished Letters of William MacGillivray to John James Audubon," The Auk, vol. xviii, pp. 239249. Cambridge, 1901.

210. Coues, Elliott:

"Auduboniana and Other Matters of Present Interest," Bird Lore, vol. iii, p. 9. New York, 1901.

210a. Clark, Edward B.:

"Relics of Audubon," Chicago Evening Post, February $7,1901$.

An account of Auduboniana and other literary rarities in possession of Mr. Ruthven Deane.

211. MacGillivray, William:

A Memorial Tribute to William MacGillivray, M.A., LL.D. Ornithologist; Professor of Natural History, Marischal College and University, Aberdeen. 4to, pp. i-xvi, 1-204, with illust. Edinburgh, 1901.

Contains sketch of MacGillivray's life and work, with an account of the monument placed over his grave, and of a beautiful memorial tablet inscribed to his memory at Marischal College, with an unpublished "Journal" by MacGillivray, and extracts from his other writings.

212. Butter worth, HezeKiah:

In the Days of Audubon; A Tale of the "Protector of Birds." Illustrated. Pp. x-xii, 1-236. New York, 1901. 
213. Job, Herbert K. :

"Following Audubon among the Florida Keys," Outing, vol. xliii, pp. 71-79, illust. New York, 1903.

214. Howe, Reginald Heber :

"Audubon's 'Ornithological Biography," The Auk, vol. xxi, p. 286. Cambridge, 1904.

Note on volume $i$ of the American edition, bearing the imprint: "Philadelphia: Judah Dobson, Agent, 108 Chestnut Street; and H. H. Porter, Literary Rooms, 121 Chestnut Street. MDCCCXXXI." See also Ruthven Deane, The Auk, vol. xxiv, 190\%, p. 111, and Nathaniel E. Janney, the same, p. 349 .

This writer at one time proposed to bring out a revised edition of the Ornithological Biography, but the project was abandoned from lack of support.

215. (ANoN.) :

"[John James Audubon]; Notice of the Commemoration of the one hundred and twenty-fifth anniversary of his birth," The Auk, vol. xxii, p. 334 (July). Cambridge, 1905.

See Chapter I, Note 6.

216. Deane, Ruthven:

"John James Abert to John James 'Audubon" (hitherto unpublished letters), The $A u k$, vol. xxii, pp. 172-175. Cambridge, 1905.

21\%. Deane, Ruthven:

"William Swainson to John James Audubon" (a hitherto unpublished letter), The Auk, vol. xxii, pp. 3134. Cambridge, 1905.

218. Deane, Ruthven:

"William Swainson to John James Audubon," The Auk, vol. xxii, pp. 248-258. Cambridge, 1905. 
219. Audubon, John W.:

Audubon's Western Journal: 1849-1850. Being the MS. record of a trip from New York to Texas, and an overland journey through Mexico and Arizona to the gold-fields of California. With a biographical memoir by Maria R. Audubon, and edited by Frank Heywood Hodder. Map, portrait, and original drawings. Pp. 1250, 8vo. Cleveland, 1906.

For the original edition of Part 1 of J. W. Audubon's Journal, see No. 174 of this Bibliography.

220. Clatborne, F.:

Simple Love and Occasional Pieces in Verse, with A Notice of Audubon. Pp. 1-60. New Orleans, 1906.

221. Stone, Witmer:

"A Bibliography and Nomenclator of John James Audubon," The Auk, vol. xxiii, pp. 298-312. Cambridge, 1906.

Most complete and accurate analysis of Audubon's ornithological works yet given.

222. (Anon.) :

"Abstract of Audubon's Account Books, kept at Philadelphia, while the Octavo edition of the Birds was being issued," Evening Post, New York, Saturday Supplement for December 29, 1906.

223. (ANON.):

"Original Account Book of J. J. Audubon," The Nation, vol. Ixxxiv, p. 12 (June 3). New York, 1907.

See the preceding; gives interesting data regarding the issue of the first octavo edition of The Birds of America in parts, at Philadelphia, 1840-1844. 
224. Deane, Ruthuen:

"Unpublished Letters of Introduction carried by John James Audubon on his Missouri River Expedition," The Auk, vol. xxv, pp. 170-173. Cambridge, 1908.

225. Deane, Ruthuen:

"The Copper-Plates of the Folio Edition of Audubon's 'Birds of America,' with a brief Sketch of the Engravers," The Auk, vol. xxv, pp. 401-413. Cambridge, 1908.

226. Merriam, C. $\mathrm{H}_{\text {ART }}$ :

"The King Cameos of Audubon," The Auk, vol. xxv, pp. 448-450, with plate. Cambridge, 1908.

226a. Merritt, Dixon L.:

"Audubon, the Ornithologist, in Kentucky," The Taylor-Trotwood Magazine, vol. 10, pp. 293-298. Nashville, 1909.

226b. Derby, EARL of:

In letter, to Audubon, dated January 17, 1835. Reproduction of "The Eagle and the Lamb." Forest and Stream, June 26, 1909, pp. 1011-1012. New York, 1909.

92\%. SHufeldT, R. W., M.D.:

"An hitherto unpublished painting by Audubon," The Wilson Bulletin, N. S., vol. xii, pp. 3-5, illust. Oberlin, 1910.

Oil painting of cock and hens, but original in poor state of preservation.

228. Fitzpatrick, T. J.:

Rafinesque. A Sketch of his Life roith Bibliography. 8vo., pp. 1-242, with portrait and reproductions of rare titles. Historical Department of Iowa, Des Moines, 1911. 
Cites 939 separate publications by Rafinesque, numerous manuscripts and 134 Rafinesquiana.

229. Arthur, Stanley Clisby:

"John James Audubon, and the Birds of Louisiana," Times-Picayune, New Orleans, May 2, 1915.

Gives an account, with illustrations, of "Fontainebleau," and of the house at Mandeville which is regarded as "the probable birthplace" of Audubon.

230. Arthur, Stanley Chisby:

"Audubon in West Feliciana," Times-Picayune, New Orleans, August 6, 1916.

Follows Audubon's footsteps in Louisiana, and gives an interesting account, with illustrations, of the plantation houses at which Mr. and Mrs. Audubon lived at various intervals from 1821 to 1829.

231. RhOAdS, SAMUEL N.:

"More Light on 'Audubon's Folio 'Birds of America," The Auk, vol. xxxiii, pp. 130-132. Cambridge, 1916.

232. Williams, George Alfred:

"Robert Havell, Junior, Engraver of Audubon's 'The Birds of America,'" Print-Collector's Quarterly, vol. 6 , No. 3 (October), pp. 225-25\%, illust. Boston, 1916.

Presents a genealogy of the Havell family, and gives an excellent analysis of the work of the eminent engraver.

233. (ANoN.):

"More Buried Treasure in a Noted Basement," Nerw York Tribune, Sunday, March 11, $191 \%$.

An appeal for a better treatment of the originals of Audubon's Birds of America. "The original charter of the New York Historical Society signifies that the organization was 
formed to preserve the history of the United States, and especially the history of the City of New York. If Audubon's wonderful drawings of the birds of America are not United States history and New York City history rolled into one, then what, in the name of Herodotus, Father of History, is?"

234. Townsend, Charles W.:

"In Audubon's Labrador," The Auk, vol. xxxiv, pp. 133-146, illust. Cambridge, $191 \%$. 


\section{INDEX}

Abert, John James, on Audubon's plans, ii, 3; his career and the rattlesnake episode, ii, 3, 77; “Abert's squirrel," ii, 4, 64, 155.

Abolitionists (Les Amis des Noirs), activity in France, $i, 43$; their opposition to white planters and fomenting of rebellion in Santo Domingo, i, 49.

Academy of Natural Sciences (Philadelphia), introduction of Audubon to, i, 328; foundation and work of, i, 333; notice of meeting of, $i, 333$; Waterton on rejection of Audubon by, ii, 87.

Accipiter cooperi, i, 330.

Adams, Rev. Charles Coffin, history of his manuscript on the Life of Audubon; his career and writings, i, 18; ii, 300 .

Adams, John Quincy, i, 396.

Adelaide, Queen of England, patronage of, $i, 391$.

Allston, Washington, i, 336.

American Ornithologists' Union, number of species of American birds recognized by (in 1910), ii, 215; doubtful species in "CheckList" of, ii, 215.

American Ornithology, story of the author, production and publication of, $i, 202-219$; original drawings for, $i, 213$; the engraver and publisher of, $i, 213,217$; the Prospectus and character of, $i, 217$; the issue and patronage of, i, 217; death of the author of, $i, 219$; publication of the last volume of, $i$, 223; second American edition of, $i$,
223; diary of the author of, i, 224; Audubon's charge against the author of, $i, 226$; counter charge of Ord in defense of the author of, i, 227.

American Philosophical Society, Audubon to Sully on his rejection by, i, 362; his later membership in, $i$, 363; Harlan on rejection of Abert by, ii, 3-4; 27.

Anthus spraguei, Sprague's Titlark, ii, 253.

Antonio de Sedella, Father, portrait of, i, 319, 321; Governor Claiborne on, i, 319.

"Ark." See Flatboats.

Arthur, Stanley Clisby, i, 314; on the bird-life of the St. Francisville region, i, 315 ; ii, 318 ; on Audubon and West Feliciana, i, 322-323; 338.

"Articles of Association" of Audubon and Ferdinand Rozier, description and reproduction of original of, i, 146-148; ii, 344-349.

Ashburton, Lord, Baron (Alexander) Baring, ii, 242.

“Astur (Falco) Stanleii," i, 354, 417. See "Stanley Hawk."

Athenceum (London), on Audubon, ii, 84-85, 140, 199-200; advertisement of The Birds of America, ii, 201.

Aubinais, M., i, 55.

Audibon (or Audubon?), Pierre, in the American Revolution, i, 24.

Audubon, Anne, suit by, i, 28, 263. Audubon, Catherine Françoise. See Mme. Jean Louis Lissabé. 
Audubon, Claude, and his family, i, 27.

Audubon, Dominica, suit by, i, 28, 263.

Audubon, Jean, his command at Yorktown and checkered career, $i$, 24; his parentage and father's family, i, 26-28; birth and baptism, i, 27; beginning of life at sea and capture at Louisburg, i, 28; a prisoner in England, i, 28; enters French Merchant marine and begins his voyages to New Foundland, i, 29; enlist's in French navy and appears at Nantes, i, 30; reënters merchant marine and begins voyages to Santo Domingo, i, 30 ; his ships and commands, i, 31 ; his marriage, i, 32; fight in $L_{e}$ Comte d'Artois and capture by the English, i, 32; prisoner in New York, and release, i, 32; joins the American Revolution and commands a ship at the siege of Yorktown, $i, 34$; later commands in the United States and fight with a British privateer, i, 34; residence in the West Indies, $i, 36$; travels in the United States and purchase of "Mill Grove," i, 36; joins the National Guard at Les Cayes, i, 37; epitome of Santo Domingo career, $i, 37$; engagement with Coirond Brothers with interests at Les Cayes and St. Louis, i, 38; rapid rise to wealth as planter, sugar refiner, and slave dealer, i, 39; light cast by his dealings in slaves, i, 39; ii, 330-335; his West Indian fortune and final settlement of estate, i, 40-41, 268; treatment of slaves and dependents, i, 41, 54; Santo Domingo experience compared with that of a contemporary planter at Jaquemel, i, 44-48; birth of his son at Les Cayes, i, 52, discovery of bill of his physician, $i$,
53; see also i, 54, and ii, 314-327; his son, Fougère, and daughter, Muguet, taken to France, i, 57; his reference to Audubon's mother, i, 59 ; designation of his children in his wills, i, 63, ii, 360-362; dual personality expressed by his son, $i, 63$; joins National Guard at Nantes, i, 74; possible refuge of his family during Revolution in France, i, 76; activities immediately before and during French Revolution, $i$, 77-82; Revolutionary offices, $i, 78$; report as Civil Commissioner, i, 78; mission to Pornic and Paimbœuf, $i, 79$; signature during Revolution, i, 79; mission to Les Sables d'Olonne, and letters to the Administration, $i$, 80 ; his reimbursement for services to the Republic, i, 81; operations as ensign commander, and encounter with the Brilliant, i, 82; his later commands and elevation to rank of lieutenant de vaisseau, i, 82; his financial losses in Santo Domingo, i, 82; indemnity from the French Government, i, 83; respective rank and service in the French merchant marine and navy, $i, 83$; his certificate of service, $i$, 83; retirement and pension, i, 83, 85; settlement and occupations at "La Gerbetière," i, 85; Santo Domingo interests described in power of attorney, i, 85; residences at Nantes, i, 86; see also i, 57, 58; his death, $i, 87$; his son's tribute, $i, 87$, 88; financial vicissitudes, $i, 88$; see also i, 85; habits, abilities and physical characteristics, $i, 88$; letter soliciting aid for his son, i, 100 ; interest in "Mill Grove" and the Prevost mortgage, i, 105; lease and inventory of the property, $i$, 105; portrait at age of forty-five (?), i, 106; mining project with 
Dacosta, i, 113; sale to Dacosta of a one-half interest in "Mill Grove," and its lead mine, $i, 114$; expectations for his son, i, 115; financial aid from Claude François Rozier, i, 115; correspondence with Dacosta, i, 116-123; instructions regarding his son's proposed marriage, $i$, 117; appeal in answer to Dacosta's complaints concerning his son, i, 118; instructions for settlement of claims against the Ross and Formon estates, $i, 121-123$; his uncanceled mortgage, i, 122; instructions concerning the farmhouse at "Mill Grove," i, 122; as grantor of powers of attorney, i, 131, 132-133, 153; see also i, 85-87; marriage of his daughter, i, 131; arranges a business partnership for his son, $i$, 132; his former country villa as it appears to-day, i, 135-14.5; division of the "Mill Grove" property and sale of his remaining interests, $i$, 149-150, 152-153; letters of his son, i, 159-161, 163; portrait at Couëron, i, 100; troubles with Dacosta and contest over his final accounts, i, 168; bequest of his property in usufruct to his wife, and testamentary designation of his children, $i, 262$; contest of relatives over wills, $i, 263$; unfounded statements of biographers of his son, $i$, 264; his claims against the RossFormon estates as a basis of fiction, $i, 265$; final settlement of his financial affairs, i, 268; his descendants in France and last of his name in America, i, 269, ii, 294. Audubon, Mme. Jean (Anne Moynet), her marriage and property at Paimbœuf, i, 32, 40, 57, 80; adoption of children by, i, 59 ; baptism of adopted son, i, 60-61 ; characterization of her son in wills, i, 62, 262-264; as grantor of powers of attorney, i, 131, 132133, 153; legal troubles and impoverishment, i, 263; removal from "La Gerbetière," i, 263, 268; her death at "Les Tourterelles," i, 263; disposition of her estate, $\mathbf{i}$, 266,269 ; break in relations of her adopted son with his family in France, i, 266-269; attack upon her husband's estate and its final settlement, i, 263, 268; her testaments, ii, 363-368.

Audubon, Jean Jacques Fougère (John James Audubon, see also Fougère and Jean Rabin), his masterpiece, i, 1; his greatest working period, $i, 2$; experience in Paris in 1828, i, 2; Cuvier's eulogy and patronage of the French Government, i, 3; rarity and cost of his publications, i, 4; personality and talents, i, 5; attacks upon his character, i, 6; his historical background and hitherto unwritten history, i, 7; his Americanism, i, 8; characteristics of his writings, $i$, 8-10; his Ornithological Biography, i, 9; drawings of birds and mammals, i, 10; influence on American ornithology, $i, 10$; honesty of purpose, $i, 11$; memories of him in London, $i$, 11; public monuments and other honors in America, i, 13; Societies and Clubs dedicated to his memory, i, 14; his bibliography, i, 15; attempt at autobiography, i, 16; first formal Life of, i, 17; true history of Buchanan's Life, i, 1822; Mrs. Audubon's revision of Buchanan's Life, i, 22; Miss Maria R. Audubon's Life and Journals, i, 22; accepted account of his birth and early life in light of new discoveries, i, 22; parentage and early names; a creole of Santo Domingo, i, 52; his baptismal name, i, 53; discovery of the bill rendered by 
the physician who assisted at his birth, i, 53; feeble health and death of his mother, $i, 56$; birth of his sister, creole of Santo Domingo, i, 56; taken with his sister to France, i, 57; his foster mother and home at Nantes and Couëron, i, 57; his adoption and text of act, i, 59; suppression of his mother's name, $i, 60$; his baptism and text of act, i, 60; assumed name of "La Forest," i, 61;

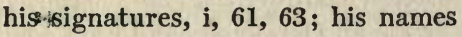
appearing in wills, $i, 62$; his dual personality in a power of attorney, $i, 64$; first date given in his autobiography, i, 65; record in his Ohio River journal, i, 66; his later autobiographic sketch, i, 66-68; traditional date of birth, i, 68; myth concerning birth in Louisiana, i, 68-72; account given by the Rev. Gordon Bakewell, i, 69; influence of environment on character, i, 90; his limited schooling, i, 91-93; the spur his ambition needed, $i, 91$; experience in the French navy, i, 92; early passion for nature and for drawing, i, 93; as truant, i, 94; his father intervenes and takes him to Rochefort, i, 94; return to Couëron, i, 96 ; baptized in the Catholic Church, i, 96; first return to the United States, i, 98; illness at Morristown, i, 99; befriended by his father's American agent, i, 99; his father's letter and intentions in sending him to America, i, 100; his settlement at "Mill Grove" farm, and period of stay there, $\mathbf{i}, 101-103$; begins his studies of American bird-life, i, 106; makes first "banding" experiment on young of a wild bird, i, 107; visit to "Fatland Ford," and choice of a wife, i, 110; his gayety and cxtravagance, i, 110; abstemi- ous habits in youth as regards food and drink, i, 111; his account of himself, i, 111; his accomplishments described by a future brother-in-law, i, 111; opposition to his marriage, i, 116; Dacosta's grievances, i, 116-119; quarrels with Dacosta and returns to France, $i$, 123-125; voyage on the Hope, i, 126; life at Couëron and friendship with D'Orbigny, i, 127; receives with Ferdinand Rozier a power of attorney from his parents, i, 131; attends the marriage of his sister and signs the record, i, 131 ; his relations with his brother-in-law, i, 132; his partnership with Rozier and second letter of attorney, i, 132; returns, with Rozier, to the United States, i, 134; voyage of the Polly, and receipt of Captain Sammis, i, 134; experience with British privateers, $i$, 134; boyhood home at Couëron, $i$, 136-145; his description of "La Gerbetière," i, 136; his abortive attempt, with Rozier, to administer the "Mill Grove" mine and farm, i, 146-148; their "Articles of Association," i, 146-148; ii, 344349 ; sale of remaining rights in "Mill Grove" to Dacosta and Company, $i, 148-149$; receives, with Rozier, new power of attorney, $i$, 153; enters business office of Benjamin Bakewell in New York, 1, 153; his associates and correspondence with the elder Rozier, i, 153166 ; letters to his father, $i, 159$ 161, 163-164; his use of English and French, i, 155; ii, 372-374; plans a retail business with Rozier, i, 157-158, 160-162, 165; dispatch of live birds, and other objects of natural history to France, i, 158$159,160,162,165-166$; conflicting references to "Mill Grove" ex- 
plained, i, 158-160, 162, 165-168; his drawings and preoccupation in New York, i, 170-172; works for Dr. Mitchell's collections in natural history, $i, 171$; term of service in the Bakewell office, i, 154-155, 171172; his account of himself, $i, 172$; his early drawings, ideals and perseverance, i, 173-174, 178-183; study under David in Paris, $i, 174$ $175,176-178$; cause of certain defects in his published work, i, 174; date of his Paris experience, $i, 174$ 175,177 ; encouragement from his father, i, 174; David's supposed influence on his style, i, 178; patronage of Edward Harris and history of the Harris-Jeanes collection of his early drawings, $i, 179$ 183; his drawing methods, i, 183185; his ambition, difficulties and defects, $i, 184$; purchases goods in New York, and with Rozier starts west, i, 186; Rozier's diary of their journey, i, 187-192; settles at Louisville, $i, 192$; venture in indigo and effect of the Embargo Act, i, 193; his marriage to Lucy Green Bakewell, and return to Louisville, $i, 194$; a later journey on the Ohio River, i, 195; occupations at Louisville, $i, 196,197-198$; business with assignees of the Bakewell firm, $i$, 196; birth of his elder son, i, 198; his drawings of birds and plants, i, 198; his wife receives a portion of her father's estate, $i, 198$; meeting with Alexander Wilson, and the troubles which ensued, i, 207; stories of Audubon and of his rival compared, i, 220-225; charges and counter charges, i, 226; his merits and demerits, i, 227-232; his cifficulties and pleasures as western trader, i, 232-236; moves with Rozier to Henderson, i, 236; again they move to Ste. Geneviève, i, 237-241; held up at Cash Creek, i, 238-240; experience at the Great Bend, i, 240; dissolution of his partnership with Rozier and return to Henderson, i, 241; after-relations with Rozier, $i$, 243; in troubled times, $i, 246$; befriended by Dr. Rankin, i, 248; birth of their younger son, $i, 248$; enters the commission business with a brother-in-law, i, 249; his visit to Ste. Geneviève, i, 249; reënters trade at Henderson and buys land, i, 250; town records of his purchases, i, 250, 252; his store and house of $\operatorname{logs}, i, 252$; his popularity, i, 252; Henderson gossip and anecdotes, $i, 253$; his second partnership with Thomas W. Bakewell, $i, 254$; they lease land and build a steam grist-, and lumbermill, i, 254; partnership of Thomas W. Pears, i, 254; the Henderson mill at a later day, $i, 254$; their mechanical difficulties, $i, 254$; lease of timber land and plunder of workmen, i, 255; bill of lumber rendered by J. J. Audubon \& Co.s i, 256; financial depression and failure of the mill, i, 257; quarrel over steamboat and encounter with Bowen, i, 257-259; legal history of the suit, i, 258; the opinion expressed to him by the judge, $i$, 259; goes to Louisville jail for debt, i, 260; declares himself a bankrupt and is released, i, 260; his walk to Louisville, i, 260; later account given to Bachman, i, 260; reflections on passing his old mill in $1820, i, 261$; light on his enigma, i, 262-272; his designations in wills, i, 262-264; probable history of a fictitious "bequest," i, 264266; his brother-in-law's letters, i, 266-269; attempt of relatives to break his father's will in France, 
and impoverishment of his stepmother, i, 263; his step-mother's death, i, 263; the last of his family in France, i, 269; his elder son's visit to Couëron, i, 269; his reference to "Audubon of La Rochelle," i, 270; h/s "Episodes" and methods of composition, $i, 273-284$; discrepancies and inaccuracies of some of his narratives, $i$, 273-274, 279291; his account of meeting Nolte and Nolte's account of meeting him, i, 274-279; on horseback from Henderson to Philadelphia, i, 275; description of the famous earthquakes and the hurricane, i, 279291; criticism of his account of Daniel Boone, i, 291 ; "Episode" of "The Prairie," i, 274, 282-284; answer to a criticism of, $i, 284$; his sketch of "The Eccentric Naturalist" and comment, $i, 285-300$; practical jokes, and cost to Zoölogy, i, 291; the "Scarlet-headed Swallow" and "Devil-Jack Diamond Fish," i, 291-293; his later relations with Rafinesque, i, 294; his Aneid, 1819-1824, i, 301-326; debt to his wife, i, 301; begins to work at portraiture at Shippingport, i, 303; removal to Cincinnati, i, 303; history of his engagement as taxidermist at the Western Museum, and friendship with Dr. Drake, i, 303-306; starts a drawing school and plans a journey through the West and South, i, 306; starts with Captain Cummings and Joseph R. Mason for New Orleans, i, 307; his Ohio and Mississippi Rivers journal, $i, 307$; experience at Natchez; boots and portraits, $i$, 308 ; loss and recovery of a portfolio, i, 309; stranded at New Orleans, i, 309; resorts to portraiture again, i, 311; his drawings of birds, i, 311; interview with Vanderlyn, i, 312; leaves New Orleans with Mason, i, 313; meeting with Mrs. Pirrie and engagement at "Oakley," i, 312; enchantments of the West Feliciana country and introduction to St. Francisville, i, 313-315; experience as tutor to "my lovely Miss Pirrie of Oakley," i, 315, 317-318; leaves abruptly and returns with Mason to New Orleans, i, 318; his industry and fruits, i, 318; joined by his family in New Orleans, $i, 319$; crisis in financial affairs and losses of drawings, i, 320; as teacher at Natchez and Washington, i, 321; parts with his pupil assistant, i, 321; his first lessons in the use of oil colors, $i, 321$; engagements of his wife at New Orleans, Natchez and St. Francisville, i, 322; his wife's "Beechwoods" school, i, 322; resolution to pursue his ornithological studies, i, 323; misadventure with Stein, i, 324; ill and adrift, i, 324; decides to visit Philadelphia to find a publisher for his drawings, i, 325; settles, with his elder son, at Shippingport, $i, 325$; experience in Philadelphia in 1824, $i, 327-335$; his exhibition at the Academy of Natural Sciences, i, 328; meeting with Bonaparte and Ord, i, 328; opposition encountered, $i, 328-330$; criticisms of Ord and Lawson, i, 329; his work for Bonaparte, i, 330; appreciation of Fairman and Harris, i, 331; assistance of Edward Harris and beginning of their friendship, $i, 331,333$; early letter to Harris, i, 332; Thomas Sully, as friend and teacher, i, 334; visit to "Mill Grove," i, 335; reception in New York and assistance of Samuel Latham Mitchell, i, 336; election to membership in the Ly- 
ceum of Natural History, i, 338; acts as model for Vanderlyn's portrait of Andrew Jackson, i, 338; to Thomas Sully, i, 339; visit to Albany and Niagara Falls, $i$, 339 ; misadventure at Presque Isle, i, 340; the Meadville "Episode," 1 , 341-343; residence at Pittsburgh, $i$, 343; journey to Lakes Ontario and Champlain, where plans of his publication are matured, i, 343; stranded at Cincinnati, i, 344; returns to St. Francisville, and resorts to teaching, i, 346; sails with his drawings from New Orleans, $i$, 347 ; journal of the voyage of the Delos, $i, 348-350$; lands in Liverpool, $i, 350$; his credentials, i, 351; introduction to Lafayette, i, 351; customs duties, i, 350; Nolte's letter to the Rathbones, i, 352; aid of the "Queen Bee" of "Greenbank," i, 353; his "observatory nerves," i, 353; ornithological dedications, i, 354; exhibition of his drawings at the Royal Institution, i, 354; appearance and habits, i, 354; paintings as gifts, and the Turkey Cock seal, i, 355; painting methods, i, 355; opens a subscription book of The Birds of America at Manchester, i, 356; plan of the work, $i, 356$; his life of contrasts, i, 357; journey to Edinburgh, i, 357 ; invitation to merge his work, i, 357; meeting with Lizars, who agrees to engrave his first number, i, 358; first proof of the Turkey Cock received, i, 358; publication of the first ten plates in Edinburgh, $i, 358$; success of his Edinburgh exhibition, i, 359; impressions of Philarète-Chasles, i, 359; Cap's hint taken, i, 360; cast of his head made and his portrait painted, i, 361; response at banquet of the Royal Institution, i,
361 ; society's tax on his strength, i, 361; contributions to journals, $i$, 362; blackballed by an American Society, i, 362; proposed gift to the Royal Institution, i, 363; visit to "Dalmahoy," i, 363; friendship of Basil Hall, i, 364; characterization of Francis Jeffrey, i, 365; first meeting with Scott, and his record of the interview, $i, 365$; exhibits his drawings at Sir Walter's home, i, 366; Scott, on Audubon, i, 367; papers on the Wild Pigeon and the Rattlesnake, i, 368; his painting of "Pheasants attacked by a fox," i, 369; Sidney Smith, i, 369; to his wife, i, 369-373; first meeting with Kidd, i, 373; issues his Prospectus, i, 373; visit to Selby at "Twizel House," 374; with Thomas Bewick at Newcastle-upon-Tyne, i, 375; success in canvassing, $i, 376$; in London, i, 377-410, 413-418; his credentials for the metropolis, $i$, 376-380; abandonment of his work by Lizars and discovery of Robert Havell, Junior, i, 380-384; his Birds of America fly to London, i, 384; painting his way to liberty, $i$, 388; canvassing experiences, $i, 388$; efforts to secure the patronage of the King, i, 390, 392; the Queen becomes his patroness, $i, 392$; visit to Glasgow, i, 393; difficulties with his publishers, i, 393; timely aid from Sir Thomas Lawrence, i, 398396 ; exhibition and sale of his paintings, $i, 394$; resolutions on snuff, i, 396; dislike of London, i, 397; his work and Selby's compared, i, 397; revision of his drawings, $i$, 398; calls by appointment upon an earl, i, 398; visits the great Universities, i, 399; solicitations of publishers and contributions to magazines, i, 399; friendship with Swainson, and original letters of 
their correspondence, i, 400-403; Swainson's review of his work, $i$, 403; visit at Tyttenhanger, i, 404; to Swainson, i, 405-407; request for further contributions to magazines refused, i, 407; visit to Paris with the Swainsons and Parker, i, 408413; his picture of Cuvier at fiftynine, $i, 411$; patronage of the Duke of Orleans, i, 411; exchange of works with Redouté, i, 412; with Cuvier at the Royal Academy, i, 412; Cuvier's report on his work, i, 413; correspondence with Swainson, i, 413-415; Bonaparte to, i, 416-419; first journey from England to America, i, 420-436; to his wife, i, 420; exhibition of drawings in New York, i, 421; painting at Camden and Great Egg Harbor, i, 421; Swainson to, i, 422; sojourn in the Great Pine Forest, i, 423, 425-426; to Victor Audubon, i, 424; "Episodes" and record of work, i, 425; visits his sons and joins his wife at "Beechgrove" (St. Francisville) in Louisiana, i, 427 ; to Harlan, i, 427430; Swainson to, i, 430; occupations at "Beechgrove," i, 432; preparations to return, with Mrs. Audubon, to England, i, 432; to Havell, i, 433; proposition for a successor to the position held by his wife, $i, 434$; reception at Washington, and accessions of subscribers, i, 435; aid of Edward Everett, i, 435; his letterpress and its rivals, $i, 437-451$; membership in the Royal Society, i, 437; settlement in Edinburgh and publication of the Ornithological Biography,i,437; engages William MacGillivray to assist him, i, 4.38; rival publications, i, 439, 442-44.5; issue of his first volume of letterpress, i, 439; Sir William Jardine to, i, 441; MacGil- livray as his reviewer, i, 445; undertakes a Natural History Gallery of paintings with Kidd, i, 446; notices and final abandonment of the enterprise, $\mathrm{i}, 446$; to London and Paris, i, 447; Edward Everett to, $i, 448-451$; financial difficulties overcome, i, 451; explorations in Florida and the South Atlantic, ii, 1-25; returns to America with his wife, and a taxidermist as assistant, ii, 1; to Kidd, ii, 1; his obituary in the London Literary Gazette, ii, 2; Abert and Featherstonhaugh announce his plans, ii, 3 ; promise of governmental aid at Washington, ii, 4 ; visits Charleston and meets John Bachman, ii, 5; sails from Charleston for Florida with two assistants, ii, 5; Bachman on, ii, 5 ; dedication to Bachman of a copy of his Birds, ii, 7; his Birds of America as gifts to others, ii, 7; his journey described in Featherstonhaugh's Journal, ii, 8-14; account of meeting with Bachman, ii, 9 ; hospitality of the Charlestonians, ii, 10; impressions of St. Augustine, ii, 12; methods of work, ii, 12; Harlan to his wife, ii, 14; misadventures at Bulowville, ii, 1520; shooting birds at Live Oak Landing, ii, 16; narrow escape from the marshes, ii, 17-19; as a prophet on the future of eastern Florida, ii, 20; the ibis of Orange Grove Island, ii, 21; his plans delayed, ii, 22-24; journey from St. Augustine to Key West, ii, 24; return to Savannah and Charleston, ii, 25; eastern visit and explorations in the North Atlantic, ii, 2666; settles again in Camden, ii, 26; an experiment in lithography, ii, 26; correspondence of Harlan, ii, 28; his welcome at Boston, ii, 29; to Edward Harris, ii, 29; journey to 
Maine coast and New Brunswick, ii, 30; winter and illness in Boston, ii, 31, 34-35; sends his son to England to take charge of his publications, and plans an expedition to Labrador, ii, 31; Bachman to, ii, 32; to Victor Audubon, ii, 33; drawing. of the Golden Eagle, ii, 34 ; to his son, ii, 35-40; financial affairs, ii, $37-38,65$; on his portrait by Inman, ii, 39; his American subscribers, ii, 39-41; letters to Harris, ii, 40; organization of his proposed expedition, ii, 42-44; George Parkman to, ii, 43; sails in the Ripley for Labrador, ii, 44; journal of his experiences, ii, 44-50; at Bird Rock, ii, 4.5; discovers a new finch, ii, 45; scenes of work at Wapitagun, ii, 46-48; his efforts and accomplishments, ii, 48; return to Eastport and Boston, ii, 49; editorial comment, ii, 50; letter from Havell; ii, 51; Thomas L. McKenney on, ii, 52; arrested in Philadelphia, ii, 52; Washington Irving's aid in Washington, ii, 53; itinerary from Richmond, ii, 53; winter at Bachman's, ii, 54; letter to his son, ii, 55-62; on Ord and Waterton, ii, 55, 61; on his buzzard experiments, ii, 55; on Syme's portrait, ii, 57; his family alliance, ii, 58 ; on his American subscribers, ii, 59, 62; on Robert Havell, ii, 59; on growing old, ii, 60 ; on self-improvement, ii, 61 ; on Kidd, ii, 57, 62; Bachman, on his working habits, ii, 62 ; to Harris, ii, 64 ; echo of his early business troubles, $\mathrm{ii}, 64$; his statement of the case, ii, 65; return to England, ii, 65; gratitude to Edward Harris, ii, 66; as target of critics and detractors, ii, 67-92; questionable essays, ii, 68; his reply to Sully, ii, 68-71; the rattlesnake controversy, ii, 71-80; charges of an editor, ii, 72; his original drawing and account of the rattlesnake, ii, 74-76; his errors and vindication, ii, 76-80; letter of Thomas Cooper, ii, 78; on the bend of the rattlesnake's fang, ii, 79; rediscovery of his discredited lily, ii, 80 ; on the buzzard's sense of smell, and present state of the controversy, ii, 81-84; his champions of the scientific and literary press, ii, 84; on his snake stories, ii, 85; his most persistent heckler, ii, 86-92; Waterton and Swainson, on the authorship of his Ornithological Biography, ii, 87; on the rivalries of contemporaries, ii, 93124; to Swainson, ii, 95-97, 99-100, 101-103, 112; Swainson to, ii, 9799, 103-108; his appeal to Swainson for assistance on his letterpress, ii, 94, 98, 102-103, 104-107; check in friendship and engagement of MacGillivray, ii, 108; resulting controversy over the authorship of the Ornithological Biography, ii, $87-88,109$; on the craze for describing new species, ii, 110; "Ornithophilus" on, ii, 111; Swainson as biographer of, ii, 113-115; his reference to Bonaparte resented, ii, 118; his letter to Bonaparte and their subsequent relations, ii, 119-121; comment on Gould, ii, 121-124; return to England in 1834, ii, 125; to Edward Harris, ii, 125; on his relations to William MacGillivray, ii, 125-138; MacGillivray to, ii, 126-128, 130132, 134; his ornithological collection, ii, 129; completion of the second volume of his letterpress, ii, 132; to Harris, on the alligator and the American edition of his Ornithological Biography, ii, 132, 134; MacGillivray's contract with, 
ii, 134; MacGillivray's assistance and friendship, ii, 134-137; his acknowledgments and dedication to MacGillivray, ii, 137; to John Wilson, ii, 139; on the effects of overwork, ii, 140; letters to Harris, ii, 141-144; on Alexander Wilson, $\mathrm{ii}, 143$; issue of his third volume of the Ornithological Biography, ii, 144; on his journey, il, 144; third American tour, ii, 146; landing in New York, ii, 146; efforts to secure the Nuttall-Townsend collection of western birds, ii, 147149, 153-154; thwarted in Philadelphia, ii, 149; in Boston and Salem, ii, 149-151; meets Brewer and Nuttall, ii, 150; friendship and recommendation of Daniel Webster, ii, 151; success of canvassing in New York, ii, 153; efforts to obtain the collections in Philadelphia renewed, ii, 153; rivalry of priority seekers, ii, 155; plans an expedition to Florida, and visits Washington for governmental aid, ii, 155; entertained at the White House, ii, 156; on Andrew Jackson, ii, 156; winter spent with Bachman, ii, 156; overland with Edward Harris and his younger son to New Orleans, ii, 157; experiences in the Gulf of Mexico and Texas, ii, 157-165; adventures with the Crusader, ii, 158-163; at Galveston Bay, $\mathrm{ii}, 163$; visit to Houston, ii, 164; his party disbands at Charleston, ii, 165; his son's marriage, and return to England, ii, 166; to Thomas Brewer, ii, 168; extension of his Birds and revolt of British patrons, ii, 170, 174; to Harris on Townsend's second collection of western birds, ii, 170 173; eagerness to render his work as complete as possible, ii, 173; on extra plates and partial sub- scribers, ii, 174; to William Swainson, ii, 176; his day of greatest triumph, ii, 177; return to Edinburgh and completion of his letterpress, ii, 178-186; to his son, ii, 178-181; at work with MacGillivray, ii, 178181 ; publication of the fourth volume of the Ornithological Biography, ii, 181; impairment of the health of his wife, $\mathrm{ii}, 181,183,186$; their tour in the Scottish Highlands, ii, 182; to Edward Harris, ii, 184-186; completion of his labors in England, ii, 186; number of American species of birds recognized in 1839, ii, 186; valedictory to the "gentle reader," ii, 187; prepares to return with his family to America; directions to Havell, ii, 188-191; intimate history of the work of his engraver, with manual for collectors, ii, 191-199; the Athenceum on, ii, 199; Peabody on, ii, 200; on the original and existing numbers of copies of his Birds, ii, 201-203; on his own and $\mathrm{Ha}$ vell's copy of The Birds of America, ii, 203; original and present prices of his works, ii, 204; singular attest of J.P. Hall regarding, ii, 205; Audubon's account of the Rothschild incident, ii, 206-208; settles in New York, and immediately undertakes two new works, ii, 208; Bachman to, on a revised edition of The Birds of America, and the Quadrupeds, ii, 208; to Brewer on the Quadrupeds of North America, ii, 209; marriage of his elder son, ii, 210 ; Bachman, on his coöperation in the Quadrupeds, ii, 210; prospectus of the octavo edition of the Birds, ii, 211-212, 214; its composition and number of American species of birds recognized, ii, 214215 ; to his family while canvassing 
in Baltimore, ii, 215-217; original account book of, ii, 217; extraordinary success of his Birds in "miniature," ii, 217 ; bereavements of his family, ii, 218; his friendship with a rising young naturalist, ii, 218; opening correspondence with Spencer Fullarton Baird, ii, 219223; William Yarrell to, ii, 223225; new birds from Baird, ii, 219, 225 ; their correspondence continued, ii, 226; letter to George Parkman, and the "Parkman Wren," ii, 227-229; to W. O. Ayres on collecting quadrupeds, ii, 229 ; on the expenses of his publication, ii, 230; Baird on his first visit to his friend, ii, 230-232 ; consolation and advice to his pupil, ii, 232; purchase of land and house-building, ii, 234; "Minnie's Land" on the Hudson, ii, 235; his activities, ii, 235; Parke Godwin on Audubon and "Minnie's Land," in 1842, ii, 236-238; in 1845, ii, 238; his expedition to the Upper Missouri, ii, 239-258; correspondence with Baird, ii, 239-241; credentials from the Government, ii, 242; Daniel Webster's letter, ii, 242; his letter from President Tyler, ii, 243; Bachman on the Quadrupeds, ii, 243; canvassing tour to Canada, ii, 244; description of Canadian visit in letter to Benjamin Phillips, ii, 244246; William Yarrell to, ii, 246; overtures to Baird to join his western expedition fail, ii, 248250, 252; Edward Harris to, ii, 251; his party, ii, 252; rendezvous at Philadelphia and beginning of journey, ii, 252; ascent of the Missouri in the Magnet, ii, 252; his journal of their experiences, it, 253; discovery of new birds, ii, 253; on George Catlin, ii, 254; at Fort Union, ii, 254-256; first ex- perience with buffalo, ii, 254; forecast of its fate, ii, 255 ; in a wilderness that howls, ii, 256; his return, ii, 256; on a canal boat homeward bound, ii, 257; mistaken for a Dunker, ii, 258; portrait by his son, ii, 258; to Baird, ii, 258; completion of his Birds in octavo, and dedication to Baird, ii, 259; his final work on the Quadrupeds, ii, 261; on Pennant's marten, ii, 263; to Bachman on mischief makers, and letterpress of the Quadrupeds, ii, 264-267; his copper-plates of The Birds of America pass through fire in New York, ii, 267; as a spectator at the ruins, ii, 267; reply to Baird on the results of the fire, ii, 268; Bachman's visit in 184.5, ii, 268; Bachman's complaints and ultimatum through Harris, ii, 269; Bachman on his Missouri River Journal, ii, 271; correspondence with Baird, ii, 272273, 275-278, 279; recommendation of Baird, ii, 279; his son visits England to paint for the Quadrupeds, ii, 280; manuscript of the Quadrupeds of North America, ii, 283; illustrations and completion of plates of the Quadrupeds, ii, 285; Brewer on a visit to "Minnie's Land" in 1846, ii, 286-288; letter to Harris in 1847, ii, 287; Baird's note of last visit in 1847 , ii, 288; Bachman on his visit of 1848 , ii, 288; last days and death at "Minnie's Land," ii, 290; work of his sons, and his family in America, ii, 291-312; appropriation by the Government to procure copies of Audubon's works for presentation to foreign countries, ii, 293; manuscript notes and legends on original drawings of the Birds, ii, 305.

Audubon, Mrs. John James, as edi- 
tor of a Life of her husband, i, 18, 22; her girlhood home, i, 108; Audubon's account of their meeting and his debt to, i, 109; her father and uncle as protégés of Audubon, i, 125; Audubon on, i, 160; her marriage and journey West, i, 194; her children, i, 198, 247 , 248; her realization in her father's estate, i, 198-200; her father and family, i, 199, 253-254; as spur and balance wheel, i, 301; at Cincinnati, i, 303, 306, 307, 320; the Western Museum incident, i, 304; at New Orleans, i, 320, 322; engagements at Natchez and St. Francisville, i, 322; her "Beechwoods" school, i, 322; Audubon to, i, 370-372, 420-421, 424, 428; at "Beechgrove," i, 431-435; accompanies her husband to England, i, 435-436; ii, 1; John Bachman to, ii, 5; Richard Harlan to, ii, 14; her activities and school at "Minnie's Land," ii, 299; breaking up of her home and the Life of her husband, ii, 300 ; to a relative on her family's affairs, ii, 301; to William R. Dorlan on her husband's autograph, ii, 302; her last years and death, ii, 302; a eulogy, ii, 303; disposal of the original drawings of The Birds of America, ii, 304; ascription of drawing to, ii, 306.

Audubon, John Woodhouse, his birth, ii, 248; 323, 371; his father to, ii, 373,390 ; ii, $43,44,54,56-57$, 156; marriage to Bachman's daughter, ii, 166; journey to Texas, ii, 272; goes to England to paint for the Quadrupeds, ii, 273, 280; dedication to John Edward Gray, ii, 280; J. E. Gray to, ii, 281; part in painting the originals of the folio plates of the Quadrupeds of North America, ii, 285; his unfor- tunate California venture, ii, 289, 290; his marriage to Caroline Hall, ii, 294; children and descendants, ii, 294; his house at "Minnie's Land," ii, 295, 311-312; his illness and death, ii, 295-296, 297; his project for reproducing the original folio of The Birds of America in America, checked by the War, ii, 296, 389-391; residual stock of the incomplete work, $\mathrm{ii}, 296$; as his father's aid, ii, 297, 299; activities and characteristics as boy and man, ii, 297-299, 309-310; his Western Journal, ii, 299; death of his second wife, ii, 303.

Audubon, Mrs. John Woodhouse (Maria Rebecca Bachman), her marriage, ii, 166; her death, ii, 218; her children, ii, 294.

Audubon, Mrs. John Woodhouse (Caroline Hall), her marriage, children and descendants, ii, 294; her death, ii, 294 .

Audubon, Lucy, death of, i, 247.

Audubon, Maria Rebecca, publication of Audubon's Autobiography by, i, 16; Audubon and his Journals by, i, 22, 28, 63, 66, 106, 153, 270, 369.

Audubon, Marie Rosa (Mme. de Vaugeon), i, 27; suit by, i, 28, 263.

Audubon, Pierre, service in the French merchant marine, i, 26; his son, Jean, and his family, $i, 27$; at siege of Louisburg, i, 28.

Audubon, Rosa (Mme. Gabriel Loyen du Puigaudeau, see Muguet), her birth, i, 56; taken to France, i, 57 ; act of adoption, $i, 59$; as godmother, i, 128; marriage contract and marriage of, $i, 131$; her home, children and death, i, 269.

Audubon, Rosa, i, 247.

Audubon, Victor Gifford, his birth, i, 198; 269, 325, 371, 396, 427; 
takes charge of his father's publications in England, ii, 31; his father to, ii, 33-40,43-44, 55-62; in his father's defense, ii, 55,$88 ; 65$, $81,119,178,189$; on the number of sets of The Birds of America issued, ii, 202; married to Mary Eliza Bachman, ii, 210; on "Minnie's Land," ii, 235; John Bachman to, ii, 261-263, 281-283; to Spencer F. Baird, ii, 278; Baird to, ii, 278; as amanuensis to Bachman, ii, 283, 291; to Bachman, ii, 289 ; success in canvassing, ii, 292; Bachman's recommendation, ii, 292; his issues of the Quadrupeds and Birds, ii, 293, 295; his second marriage and children, ii, 294; his house at "Minnie's Land," ii, 295, 311; his illness and death, ii, 295; death of his wife, ii, 303.

Audubon, Mrs. Victor Gifford (Mary Eliza Bachman), her marriage, ii, 210; her death, ii, 218. Audubon, Mrs. Victor Gifford (Georgianna Richards Mallory), ii, 258; her marriage and children, ii, 294; her death, ii, 294.

"Audubon of La Rochelle," i, 27, 270, 271.

Audubon (Montgomery County, Pennsylvania), i, 102.

Audubon and his Journals, i, 22. Audubon Association and Societies, history and aims of, i, 14.

Audubonian Epoch and Period in American ornithology, i, 10.

Aukland, Sir J. D., i, 377.

Ayres, W. O., Audubon, on collecting quadrupeds, to, ii, 229-230; $27 \%$.

Bachman, Rev. John, i, 291, 293; meeting and friendship with $\mathrm{Au}-$ dubon, ii, 5, 9; to Mrs. Audubon, ii, 5; Audubon's gift of his Birds of America to, ii, 7; as canvasser for Audubon, ii, 27; Audubon to, ii, 27; to Audubon, ii, 32-33, 51; buzzard experiments, ii, $55-56$; 57 , 59,61 ; publication of his paper on the Turkey Buzzard, ii, 56; on Audubon's working habits, ii, 6365; account of experiments on the sense of sight and smell in vultures, ii, 81-83; Audubon to, on the effects of overwork, ii, 14014.1; 146; on conditions in the South, ii, 148; Audubon's winter with, ii, 156; marriage of daughter of, ii, 166; in London, ii, 178, 179; 184; to Audubon on his "Small Edition of Birds" and Quadrupeds, ii, 208-209; marriage of the daughter of, ii, 210; on his cooperation with Audubon in the Quadrupeds, ii, 210-211; 216, 220; to Audubon on the Quadrupeds, ii, 243-244 ; 258-259; on the Quadrupeds of North America, ii, 261263, 269-272, 281-283; calls for help, ii, 262; Audubon to, on mischief-making of a "mutual friend," and the letterpress of the Quadrupeds, ii, 264-267; on Audubon in 1845, ii, 268; his ultimatum to Edward Harris as mediator, ii, 268-270; on Audubon's Missouri River Journal, ii, 271; difficulties of coöperation, ii, 273; domestic bereavement, ii, 274; his second marriage, ii, 281; working methods, ii, 281; facsimile letter, ii, 282; manuscript on the Quadrupeds, ii, 283; early life and career, ii, 284; on Alexander von Humboldt, ii, 284; on Audubon in 1848, ii, 288; completion of the text of the Quadrupeds, ii, 291; recommendation of Victor Audubon and statement of his part and interest in the work, ii, 292-293; 311.

Bachman, Mrs. John (Harriet Martin), death of, ii, 274 . 
Bachman, Mrs. John (Maria Martin), marriage of, ii, 281.

Bachman, Maria Rebecca. See Mrs. John Woodhouse Audubon.

Bachman, Mary Eliza. See Mrs. Victor Gifford Audubon.

Baco, mayor of Nantes, proclamation of, i, 74 .

Baird, Spencer Fullarton, his friendship with Audubon, ii, 218-220; Audubon to, ii, 219-222, 232-233; discovers new birds, ii, 219, 221 , 225 ; visits Audubon in New York, ii, 230; to Audubon, ii, 231-232, 235 ; correspondence with Audubon on the Missouri expedition, ii, 239241, 248-250, 252; 259; dedication of Audubon to, ii, 259-260; Coues on, ii, 260; correspondence with Audubon on quadrupeds, ii, 263, 264, 272-273, 274-278; on Pennant's marten, ii, 263; first visit to Audubon, ii, 264; on fate of Audubon's copper-plates, ii, 267; his marriage and appointment in Dickenson College, ii, 276; on Victor Audubon's gift, ii, 278; on the curatorship of the Smithsonian Institution, ii, 279; his recommendations by Audubon, ii, 279; last letter and visit to Audubon, ii, 288.

Bakewell, Benjamin, as protégé of young Audubon, i, 125; Audubon's engagement with, i, 153, 154-155, 171-172; his establishment, correspondents and clerks, i, 153-154; his residence and previous business career, i, 154; his New York business and correspondents, $i, 155$; dealings with Claude François Rozier, as told in Audubon's letters, i, 156$158,161-163$, 164-166; ruin of his trade by the Embargo Act, i, 172; his business dealings with Audubon and Rozier, i, 186, 193; emigration to America and establish- ment in New Haven, i, 201; Wilson at his glass works in Pittsburgh, i, 204.

Bakewell, Eliza. See Mrs. Nicholas Augustus Berthoud.

Bakewell, Rev. Gordon, on Audubon's birth, i, 69 ; Audubon's portrait of, i, 69 .

Bakewell, G. W., on William Bakewell, i, 99.

Bakewell, John, i, 200.

Bakewell, Joseph, i, 200.

Bakewell, Lucy Green. See Mrs. John James Audubon.

Bakewell, Robert, i, 200, 377.

Bakewell, Thomas Woodhouse (of Crith, Derbyshire), i, 200.

Bakewell, Thomas Woodhouse, i, 153; statement of accounts of Audubon \& Rozier with his uncle's estate, i, 193; see also ii, 354-355; letter to Audubon \& Rozier, i, 196; failure of his commission business with Audubon at New Orleans, i, 248; second partnership with Audubon, and history of their mill enterprise at Henderson, i, 254-255; 259 ; lease of land, $i, 254$; investment in mill, $i, 255$; withdrawal from business partnership, i, 256; subsequent successful career at Pittsburgh and Cincinnati, i, 259; his financial reverses, fortitude and death, i, 259.

Bakewell, William, his purchase of "Fatland Ford" and settlement upon this estate, i, 99, 108; his daughter, Lucy Green, i, 108-110; his private accounts and aid to Audubon and Rozier, i, 125; sale of a portion of his farm in the interests of his daughter, 1, 198; to Audubon and Rozier regarding the sale, i, 199; his family and history, i, 200; emigration to the United States and business at New Haven, i, 201; death of his first 
wife, i, 201; his second marriage, i, 201; his death, i, 201; death of his second wife, $i, 201$; financial assistance to son by, i, 255.

Bakewell, William Gifford, record of a visit to "Mill Grove," i, 111-112; 4.27; ii, 252.

Bakewell, Mrs. William Gifford, ii, 302.

Banks, Sir Joseph, ii, 117.

Barraband, Pierre Paul (1767-1809), his method of drawing birds, i, 184, 4.04.

Bartram, Anne, i, 215.

Bartram, John, and his Botanic Gardens, i, 215.

Bartram, William, as mentor to Alexander Wilson, $i, 212$; Wilson, in letter to, i, 213; his hospitality, i, 214, 216; his niece, and the Botanic Gardens of his father, $i, 215$; on numbers of American birds, ii, 214.

Bascanion. See Black snake.

Bayou Sara, introduction of Audubon to, i, 309; life of Audubon at, $i, 314-318$; village and origin of name of, i, 314.

Bazin, Eugène, translations by, i, 360.

Beates, Frederick, purchase and sale of "Mill Grove" by, i, 169.

Beer, William, i, 143, 155.

Bell, John, ii, 252; dedication of Audubon to, ii, 253.

Benedict, Jennett, Audubon's itinerant portrait of, i, 342.

Benedict, Jesse, ii, 311.

Berthoud, Mme., death of, i, 326.

Berthoud, Nicholas Augustus, i, 197, $256,303,309$; engagement of Victor G. Audubon with, i, 325; mother and family name of, $i, 326$; 427 ; ii, $27,28,33,36,37,38$, 130.

Berthoud, Mrs. Nicholas Augustus, i, 326; ii, 303.
Besant, Sir Walter, on London in 1837, i, 355, 395.

Best, Robert, and the Western Museum, i, 303, 306.

Bewick, Thomas, Audubon's visit to, i, 375 ; ii, 142.

Bibliography, i, 15; ii, 401-456.

Bien, J., and Company, ii, 396.

"Bird of Washington" ("Aquila washingtonii"), Audubon's supposed discovery of, i, 241, 400, 406; ii, 185.

Birds of America (folio), cost and rarity of, i, 4; defects in drawings of, $i, 174,184-185$; destruction of drawings designed for, i, 179, 320321 ; in embryo, i, 180-183; presentation copies of, $i, 356$; plans of publication, i, 343; first subscriber to, $i, 353$; first engraved plate of, $i, 359$; Lizars' part in engraving of, $i, 359$; issue of first number of, i, 362; first prospectus of, i, 373, see also ii, 386-388; title of, i, 381; the Havells in relation to, $i, 380$ 385 ; rebirth of, in London, $i, 384$; the singular history of plate No. iii, i, 384; d difficulties with colorists, i, 389; the Queen as patroness, $i, 392$; revision of drawings, i, 398; Swainson's review, i, 403; progress of, i, 4.05; Cuvier's report, i, 413; Bachman as canvasser for, ii, 27; Thomas H. Perkins' copy, ii, 29; Audubon's directions for dispatch of parts of, ii, 37; his financial accounts with, ii, 37; American subscribers, ii, $36-41$; insurance of drawings for, ii, 40; editorial comment, ii, 41 ; revolt of patrons at extension of plan, ii, 170, 174; Audubon on extra plates and partial subscribers to, ii, 174; completion of, ii, 177; Audubon on residual stock of plates, ii, 188-190; uncolored plates of, ii, 190; on insurance of cop- 
per-plates of, ii, 191; intimate history of the engravers and plates, with manual for collectors, ii, 191-199; story told in artists' and engravers' captions or legends, ii, 196-198; dates, errors and editions in plates, ii, 196-198; original and present known numbers of complete sets, ii, 201; Audubon's and Havell's copies of, ii, 204; original and present prices, ii, 204; curious attest of J. P. Hall, ii, 205 ; original drawings for plates, ii, 304; manuscript records and legends on original drawings, ii, 305 ; story of fate of original copper-plates of, ii, 295, 306-309; final lists of subscribers, ii, 380385 ; prospectus of 1828 , ii, 386388.

Birds of America (in octavo), prospectus, ii, 208-212, 214; agents' original and present prices of, ii, 211; titles on original parts, ii, 213; beginning of publication, ii, 214; number of birds and doubtful species, ii, 214; Audubon as canvasser for, ii, 215-217; remarkable success of, ii, 217; account-book of Audubon in business of, ii, 217; William Yarrell on, ii, 223; "Parkman's Wren" in, ii, 228; expense of publication of, ii, 230 .

Birds of America (partial American issue in folio), ii, 296; residual stock of plates of, ii, 297; original prospectus of, ii, 389-391.

Birds of Europe, ii, 122; anecdote of, ii, 123.

Blackbird, Red-winged (Angelaius phoeniceus), Ord's charge concerning Audubon's drawing of, i, 228.

Blackcocks (Tetrao tetrix), original painting of, i, 363, 366.

Black snake, "blue racer" (Bascanion constrictor), confused with rattlesnake, ii, 76 .
Blackwood's Magazine, John Wilson on Audubon and Kidd, i, 447; John Wilson on Audubon, ii, 139.

Blanchard, Jean François, as attorney of Jean Audubon at Les Cayes, i, 85.

Blue Jays (Cyanocitta cristata), painting of, $i, 397$.

Bohn, Henry G., on Audubon's drawings, i, 357.

Bonaparte, Charles Lucien, introduces Audubon at Philadelphia, i, 328; his career and work as an ornithologist, i, 329-331; his artist and engravers, i, 330; Audubon's contribution to his American Ornithology, i, 330; his account of the Wild Turkey, i, 331; characterization by a contemporary, $i$, 334; his subscription to The Birds of America, i, 380, 385; to Audubon, i, 416-419; 423; ii, 40, 49-50; $96,98,106,107,108,110,112,118$; Audubon to, ii, 119; his list of American birds, ii, 120; his comment on Audubon's work, ii, 120, 169; on publication of new species by, ii, 173; 176, 184, 214, 224.

Bonnabel, Antonio, acquisition of lands from, by Bernard Marigny, i, 70 .

Boone, Daniel, Audubon's characterization of, criticized, i, 281.

Bossals and creoles in Santo Domingo, i, 42, 47.

Boston Patriot, ii, 50.

Bouffard, Catharine, designation of, in legal documents, i, 56 ; mother of Muguet (Rosa Audubon), i, 56; her appearance in France, i, 56; mother of Louise, i, 56 .

Bouffard, Louise, inquiry concerning, i, 56; her birth, i, 57, 130.

Boulart (General), letter to Citizen Audubon, i, 80. 
Bowen, Samuel Adams, his steamboat at Henderson, i, 236; Audubon's encounter with, i, 257-259; suit against Audubon by, i, 258; conclusion of bench in action brought by, $i, 259$.

Bradford, Mrs. J. L., i, 13.

Bradford, Samuel F., as publisher of Wilson's American Ornithology, i, 217, 219.

Bragdon, Sam L., i, 348.

Braud, William, Audubon as teacher in family of, i, 318; Mrs. Audubon's engagement with family of, i, 322.

Brewer, Thomas Mayo, ii, 8; Audubon on the rattlesnake, ii, 79, 150; Audubon to, ii, 152-153, 165-166, $168-169,175,209$; on Audubon in 1846, ii, 286-288.

Brewster, Sir David, i, 362; ii, 84.

Brilliant, Jean Audubon's encounter with, i, 82.

Broadnax, Henry P., judge in case of Samuel Adams Bowen and others vs. Audubon, i, 258; his decision in a case of assault, $i, 259$.

Brown, Capt. Thomas, curious history of Illustrations of the American Ornithology by, i, 443-445; limited circulation, rarity and piratical character of the work, $i$, 443-445; his Illustrations of the Genera of Birds, i, 444; contemporary and later notices of his atlas, $i, 444$.

Buchanan, Robert Williams, true story of his Life of Audubon, i, 18-22; his struggles, talents, idiosyncrasies and death, i, 19, 21, 22.

Buckland, William, D.D., i, 377.

Buffalo (New York), Audubon's visit to, in $1824, \mathrm{i}, 340$.

Buffalo hunting on the Upper Missouri and Yellowstone in 1843, ii, 254-256.

Bullen, George E., i, 400, 403.
Bulow, John, welcome of Audubon and their adventures at his plantation, ii, 15-20.

Bunting, Henslow's (Passerherbulus henslowi), i, 354.

Burchell, William John, ii, 97, 105.

Bureau, Louis, i, 143, 149; manuscript letters of, i, 154.

Burns, Robert, relations of Alexander Wilson with, i, 208.

Butler, Benjamin F., ii, 153.

Butterflies, as food of birds, i, 358 .

Cabinet Cyclopadia, Swainson in, ii, 113.

Caire, Louis P., to Lafayette, i, 352.

Caledonian Mercury, Notice of Jameson's edition of Wilson and Bonaparte's Ornithology in, i, 442; notice of Jardine's edition in, $i$, 44.4-443, 446; Audubon to Kidd in, ii, 2; on the Wilson-Audubon obituary, ii, 3.

Call, Richard Ellsworth, i, 287, 299.

Camden (New Jersey), work of Audubon at, i, 421, 426; ii, 26-27, 30. Campbell, Sir Archibald, ii, 30.

Cap, P. A., i, 360.

Caporal, Le petit, date of original drawing of, i, 180.

Carolina Paroquet (Conuropsis carolinensis), early drawing of, i, 180. Carrier, Jean Baptiste, mission and infamy of, $i, 75$; denounced by $\mathrm{Ju}$ lien, $i, 76$; reign of terror at Nantes under, $i, 75$; recall of, $i$, 76.

Cass, Lewis, ii, 52.

Catlin, George, ii, 254.

Cayes (Les Cayes), delivery of slaves at, i, 31; Jean Audubon's business interests in, i, 39; its prerevolutionary importance, i, 38; corruption of its name, $\mathbf{i}, 38$; slave trade at, i, 39-41; first touched by the Revolution, i, 50; birth of Fougère (John James Audubon), and 
Muguet (Rosa Audubon), at, i, 52-53, 56; Jean Audubon's fortune and financial losses at, i, 82; final settlement of Jean Audubon's estate at, i, 268.

Cedar-bird (Bombycilla cedrorum), habits of, i, 423.

Central Committee (at Nantes), extract from register of, $i, 134$.

Century of Birds, ii, 121.

Cerberus, Jean Audubon's command of, and encounter in, i, 82.

Chapelain, Doctor, as witness, i, 153. Charette, siege of Nantes under, $i$, 74 ; execution of, $i, 76$.

Charles $\mathrm{X}$, patronage of, $\mathrm{i}, 3-4,27$. Charleston, meeting of Audubon and Bachman at, ii, 5, 9; Audubon's tribute to hospitality of people at, ii, 10; bird-hunting at, ii, 10; return of Audubon's party, ii, 25; Bachman's services at, ii, 284.

Chat, Yellow-breasted (Icteria virens), Audubon's original drawing of, $i, 425$.

Chevalier, J. B., ii, 211, 216, 222, 226, 234.

Children, John George, i, 377; his career and friendship with Audubon, i, $379-380,420$, 437; ii, $34,56,59$, 199.

Chouanerie, i, 27.

Chuck-will's-widow (Antrostomus carolinensis), Audubon's early drawing of, $i, 182$.

Cincinnati (Ohio), in 1810, i, 205; record of earthquakes at, i, 280; settlement of Audubon at, i, 303; Dr. Drake and the Western Museum, i, 303-306; early "Notice concerning," and activities of Dr. Drake, i, 304-306; organization of a college and medical school, $i$, 305; Audubon stranded at, i, 344. Cincinnati College, relations of Dr. Daniel Drake to, i, 304; foundation and first president of, $i, 305$.
Clapp, Wellington, ii, 310.

Clay, Henry, i, 307, 372, 378, 396.

Clifford, John O., i 290.

Clinton, De Witt, i, 2, 218, 339.

Cochereau, Matthew, painting of David's studio by, i, 177.

Coirond Brothers, i, 33, 38.

Coirond (Coyron), Mme., i, 86.

Coit, Rev. Dr. Henry Augustus, ii, 43.

Coit, Rev. Dr. Joseph, ii, 43.

Coleman, William A., Audubon to, ii, 174.

Colles, George W., on Audubon's account of the rattlesnake, $i$, 76.

Collett, Tobias, i, 103.

Colnaghi and Company, i, 383.

Colson, Augustus, i, 342.

Columbus, incident on voyage of, $i$, 312.

Combe, Andrew, i, 361.

Cook, Capt. James, i, $37 \%$.

Coolidge, Joseph, ii, 43, 50.

Cooper, Thomas, and the climbing habits of the rattlesnake, ii, 5354, 77-78; to Audubon, ii, 78.

Coot, Audubon's early drawing of, i, 178.

Couëron, discovery of documents at, i, 53; settlement of Jean Audubon at, i, 57, 83; condition in 1793, i, 80,137 ; the D'Orbignys at, $i, 127-$ 128, 130; history and characteristics of, 136-140; present industry and population of, 137 ; record of visit to, in 1913, $\mathrm{i}, 138-140$; grand calvaire at, i, 139; history of Audubon's boyhood home at, i, 14014.5.

Coues, Elliott, on Audubon, i, 110; on Alexander Wilson, i, 213; ii, 129.

Count of Artois (Le Comte d'Artois), encounter of Jean Audubon and his capture in, i, 32; armament and fate of, $i, 33$; bill of 
sale of, $i, 33$; unsettled claims concerning, i, 121, 265.

Couper, William, bust of Audubon, by, i, 13.

Cowles, Charles A., story of his rescue of a remnant of Audubon's copper-plates, ii, 307.

Crane, Whooping (Grus americana), i, 227.

Crosby, Fortunatus (Judge), court record under, i, 260.

Crusader, Audubon's adventures in, ii, 157-163.

Culbertson, Alexander, ii, 271.

Cummings, Capt. James, i, 307; ii, $69,258$.

Cushing, Caleb, ii, 241.

Cuvier, Baron Georges, his eulogy on Audubon's Birds, 1, 1; his patronage, i, 2; his death, i, 4; report at the Royal Academy of Sciences, i, 174, 412-413; Audubon's description of, i, 410-411; ii, 101, 142, 448.

Cyclopædia, New American, Wilson's editorial work on, i, 216-217, 219.

Dacosta, Francis, and the Prevost mortgage, i, 106; first appearance at "Mill Grove," and his interest in its mine, $i, 113$; early exploitation, i, 114; as Lieutenant Audubon's attorney and guardian of his son, i, 114; his purchase of a one-half interest, i, 114; his salary and grievances, i, 115; difficulties with young Audubon and with the mine, i, 115 ; correspondence of Lieutenant Audubon, i, 116-123; Lieutenant Audubon's appeal in answer to complaints, i, 118; instructions for settlement of claims, i, 121-123; rebellion of young Audubon, i, 123; his praise of Audubon's drawings, i, 124; succeeded by Audubon and Rozier, i, 132; called to account, $i, 146$; acquisition of the remaining Audubon and Rozier in- terests, i, 148-150; his "rôle of chicaner," i, 151, 158; his failure and disputed claim, i, 168; award of arbitrators in case, $i, 168$; reproduction of his contested accounts, ii, 355-358.

"Dalmahoy," Audubon's visit to, i, 363.

Darwin, Charles, i, 354, 399.

Darwin, Erasmus, i, 200.

David, Jacques Louis, i, 3, 174, 175, 176 ; his revolutionary ardor, patriotism and popularity, i, 174, 176; his exile and death, $i, 174$; his portrait of the mayor of Nantes, $i, 174$ 176; his reception at Nantes, i, 175; his address to the Municipal Assembly, i, 175; his studios and pupils at the Louvre, i, 177; his works and influence, i, 177; influence on Audubon's style, i, 178. Davis, Isaac P., ii, 151; on Webster's copy of The Birds of America, ii, 152.

Davy, Sir Humphry, i, 356, 377, 379.

Deane, Ruthven, i, 246, 444, 448; ii, 14, 188; on copies of The Birds of America in America, ii, 203, 204; 211, 263, 293; on the copper-plates of The Birds of America, ii, 307309.

Debtors, terrors of, in England, i, 395.

Declaration of Rights, voted by the National Assembly of France, and its effect upon Santo Domingo, i, $37,49$.

De Genlis, Stephanie-Felicité, i, 163.

De Kervegan, Daniel, popularity and portrait of, as mayor of Nantes, i, 175 .

De La Luzerne, his recommendation of Jean Audubon, i, 32, 34.

Delos, Audubon's voyage on, i, 347350 ; subsequent fate of, 348 .

De Marigny, Ecuyer Sieur, and his 
family, i, 69; true story of his family, and of "Fontainebleau," which has been erroneously attributed to him, $i, 69$; his summer house at Mandeville, $i, 71$.

Derby, Earl of, ii, 146.

De Vaugeon, Mme. Le Jeune, i, 28; suit by, i, 262.

De Vaugeon, Pierre, i, 27.

De Wimpffen, Baron. See Francis Alexander Stanilaus.

Dickenson College, Baird's appointment and position at, ii, 268, 276.

Dodge, William E., ii, 307 .

D'Orbigny, Alcide Charles Victor, i, 128.

D'Orbigny, Dr. Charles Marie, as friend of young Audubon, i, 120, 127-128; his family, i, 128; Audubon as godfather to son of, i, 128; financial troubles of, i, 128-130; Gabriel Loyen du Puigaudeau to, i, 129; as debtor to Lieutenant $\mathrm{Au}$ dubon's estate, i, 129; inquiries concerning, i, 130; as witness, i, 153; Audubon's correspondence with, i, 160, 163, 171.

D'Orbigny, Charles (the younger), i, 128.

D'Orbigny, Gaston Edouard, birth and baptism of, i, 128.

Dorlan, William R., ii, 302.

Drake, Dr. Daniel, and Alexander Wilson, i, 205; record of earthquakes at Cincinnati by, i, 280; his engagement of Audubon as taxidermist, $i, 303$; his foundation of the Western Museum and $\mathrm{Au}$ dubon's connection with it, i, 304306; his varied activities, i, 304; his early "Notice concerning Cincinnati," i, 304; his organization of the Cincinnati College and medical school, i, 305; his troubles with rivals, i, 306; his appointment at the Transylvania University, i, 306.
Duck, Labrador (Camptorhynchus labradorius), at Bradore Bay, ii, 48; extinction of, ii, 48, 152.

Duck, "Velvet," White-winged Scoter (Oidemia deglandi), Audubon's early drawing of, i, 182; description of, $i, 182$.

Duncan, William, i, 208; ii, 284.

Dunkin, Judge, i, 260; ii, 64 .

Dupré (Tête-Carée), raid of Nantes by, i, 77.

Du Puigaudeau, Gabriel Loyen, Audubon's power of attorney to, $i$, 64; to D'Orbigny, i, 128-130; to J. Cornet, i, 130; his marriage, i, 131; his family, occupation and residence, i, 132; to Audubon, i, 266269.

Du Puigaudeau, Mme. Gabriel Loyen. See Rosa Audubon.

Du Puigaudeau, Gabriel Loyen (the Second), death of at "Les Tourterelles," i, 269.

Eagle, "Brown." See "Bird of Washington."

Eagle, Golden (Aquila chrysaëtos), Audubon's drawing of, ii, 35.

Eagle, "Washington's." See "Bird of Washington."

Eagle, White-headed (Haliceetus leucocephalus), Audubon's original drawing of, $i, 310$.

Eagle and Lamb, original painting of, i, 394-396, 405, 406.

Earthquakes in the Ohio and Mississippi Valleys, 1811-1813; casual and exact records of, i, 279.

Eckley, David, dedication of copy of The Birds of America to, ii, 7 ; history of copy formerly owned by, ii, 7; ii, 150.

Ecton Consolidated Mining Company, i, 169.

Edinburgh, first visit and success of Audubon at, i, 357-373; beginning of The Birds of America at, i, 
358; exhibition of Audubon's drawings at, i, 359; meeting with Sir Walter Scott at, i, 365; issue of Audubon's Prospectus at, i, 373.

Edinburgh Literary Journal, notice of Brown's Illustrations of the American Ornithology in, i, 443.

Edinburgh New Philosophical Journal, ii, 111.

Edward (Ezekiel Edwards ?), unsettled claim of Jean Audubon against, i, 121.

Edwards, Bryan, on the products and wealth of French Santo Domingo, i, 30; on the Santo Domingo blacks, i, 43.

Edwards, Ezekiel, i, 121.

Eggleston, Thomas, i, 13.

Elaps. See Coral snake.

Embargo Act, of President Jefferson, effect of, on Audubon and Rozier, i, 193.

"Episodes." Seo Ornithological Biography.

Evans, Roland, acquisition of "Mill Grove" by, i, 105.

Everett, Edward, patronage and aid of, $i, 435$; letters of, $i, 436,448-$ 451; his efforts for the removal of import duties on The Birds of America, i, 4.48; his nomination of Audubon to fellowship in the American Academy of Arts and Sciences, i, 450; ii, 5, 23, 64 .

Falco Cooperii (Accipiter cooperi), i, 330, 417. See "Stanley Hawk." "Fatland Ford," William Bakewell's acquisition of, i, 98, 108, 201 ; mansion house and farm of, i, 108; Audubon's introduction to, i, 108; Generals Washington and Howe at, $i, 108$; marriage of Lucy Bakewell at, i, 194; realization of Mrs. Audubon in, i, 198.

Faxon Walter, i, 444.

Featherstonhaugh, G. W., Rafines- que's reply to, i, 294; on Audubon's plans, ii, 4; Audubon's Florida letters to, ii, 8-14, 15-22; suspension of Journal of, ii, 23, 28, 84.

Feliciana, West, characteristics of, i, 314-315; former prosperity of, $i$, 323.

Finch, MacGillivray's, MacGillivray's Seaside Sparrow (Passerhebulus maritimus macgillivraii), i, 354.

Fisher, Miers, as Jean Audubon's attorney and protégé of his son, $i$, 99 ; Jean Audubon to, i, 100; residence in Philadelphia, i, 106; and the Prevost mortgage, i, 106, 122; succeeded by Dacosta, i, 113-114; 120-122; as counselor of Audubon and Rozier, i, 148, 149, 160, 167; resumption of duties as agent and attorney by, i, 168.

Fitzpatrick, T. J., i, 287, 292, 299.

Flatboats, on the Ohio River in 1810, i, 234; convenience of, $i, 234$; cost of, at Pittsburgh, i, 235; time of passage of, from Pittsburgh to New Orleans, i, 235; floating trade of, i, 234.

Flicker (Colaptes auratus), original painting of, $i, 363$.

Florida, Audubon's explorations in, ii, 12-25; Audubon, on the future of the east coast of, ii, 20 .

Floyd, John, ii, 5.

Flycatcher, Least (Empidonax minimus), discovery by the Baird brothers, in 1843, ii, 225.

Flycatcher, "Selby's," i, 354.

Flycatcher, "Small Green-crested," i, 425.

Flycatcher, "Small-headed," curious history of, i, 218, 226-227; reference to, by Thomas Nuttal, i, 227; identifications of, by Cowes and Baird, i, 227; ii, 215.

Flycatcher, Traill's (Empidonax trailli), i, 354. 
"Fontainebleau," myth and true story of, $\mathrm{i}, 69,71$.

Formon de Boisclair, Jean Audubon's dealings with, and claims against, i, 33-34, 121, 265, 338. See Lacroix, Formon \& Jacques.

Fort Union, Audubon's experiences at, ii, 254-256.

Fougère, i, 53, 57, 59, 61 ; ii, 328, 329. See Jean Jacques Fougère Audubon.

Francis, C. S., and Company, ii, 203.

Francis, David G., ii, 204.

Franklin Journal, Audubon's article, and Jones" "Romance of the Rattlesnake" in, ii, 72.

Fulton, Robert, first steamer on the Ohio River, built by, i, 236.

Gallatin, Albert, i, 377; Audubon's interview with, $i, 390$.

Galt, W. C., i, 197.

Gannet Rock, Audubon's account of approach to, i, 9.

Gannets (Sula bassana), i, 10.

Gaston, William, aid rendered Audubon by, at Savannah, ii, 25, 59.

General Assembly (Santo Domingo), new Constitution of, i, 49.

Geoffroy Saint-Hilaire, i, 411.

George IV, Gallatin on, i, 390.

George Street (Edinburgh), Audubon's apartments in, i, 437.

Gill, Theodore, i, 444; ii, 113.

Girard, Stephen, his reputed interest in Dacosia's mining enterprises at "Mill Grove," i, 149.

Godwin, Parke, on Audubon's drawing of quadrupeds, ii, 236; on a visit to Audubon at "Minnie's Land," ii, 236-238; on Audubon in 184.5, ii, 238.

Goodspeed, Charles E., i, 384, ii, 26, 190.

Gordon, Mrs. Alexander, ii, 302.

Gould, John, Bonaparte on, ii, 121;
Audubon on, ii, 121; works of, il, 121 ; charges against, ii, 122; anecdote of, ii, 123; financial success of publications of, ii, 124; 224-225. Gould, Mrs. John, Audubon on, ii, 121.

Grackle, Boat-tailed (Megaquiscalus major), Audubon's drawing in Bonaparte's Ornithology, i, 330.

Gray, Asa, ii, 81.

Gray, John Edward, i, 354, 380, 444; dedication to, ii, 280 ; to J. W. Audubon, ii, 281.

Gray's Ferry (now Philadelphia), settlement of Alexander Wilson as teacher at, i, 210, 211, 212, 216.

Great Bend (of the Mississippi), Audubon's and Rozier's experience at, in 1810, i, 240.

Great Egg Harbor, work of Audubon at, i, 421, 424; visit of Wilson and Ord, i, 422; drawings of $\mathrm{Au}$ dubon, i, 425.

Great Pine Forest (Mauch Chunk), sojourn and work of Audubon at, i, 423, 425-426.

Great Russell Street (London), old print dealer of, i, 11-12, 377 .

Great Western, ii, 190.

Grinnell, George Bird, ii, 283, 299, 309.

Groundhog, Audubon's early drawing of, $i, 181$.

Guépin, M. A., i, 73, 77.

Günther, Albert, on Rafinesque's letters and character, i, 297; on Swainson and his correspondence, i, 400-403.

Hackberry, in the Ohio River basin, i, 188.

Haines, Reuben, visit of Audubon to "Mill Grove" with, i, 335, 339.

Haiti, i, 38, 52.

Hall, Capt. Basil, on the Leander, i, 364 ; as Audubon's friend, i, 365, 367 ; to John Murray, i, 378; re- 
turn to England from the United States, i, 407.

Hall, Harrison, publication of, i, 329; ii, 98.

Hall, James, notorious review of, i, 329 ; ii, 98.

Hall, J. Prescott, memorandum regarding The Birds of America, ii, 204.

Hardin, John, ii, 295.

Harlan, Richard, i, 328; on Ord, i, 328-329; 333, 334, 407, 439; ii, 9; on Abert, ii, 3; Audubon to, ii, 14; to Mrs. Audubon, ii, 14; to Audubon, ii, 28-29; 58.

Harris, Edward, meeting with Audubon, $i, 331$; his friendships and career, i, 331, 333; early letters to Audubon, i, 332, 344; Audubon to, i, 448; Audubon to, ii, 26-27, 30, $31,40-41$; memento to, ii, 49; $\mathrm{Au-}$ dubon to, ii, 64-66, 125, 132, 134, $141-144,147-148$; 149, 151, 155, 157, 165; Audubon to, ii, 170-173; 175; Audubon to, ii, 182, 184-186; 234; to Audubon, ii, 251; dedication to, ii, 253; Bachman's ultimatum to, ii, 268-270; in rôle of mediator, ii, 270; Audubon to, ii, 287; Bachman to, ii, 291.

Harrison, William Henry, i, 307.

Harvard University, drawings and manuscripts at, i, 180, 307-308.

Haskell, Rev. John, ii, 271, 283.

Hatch, Capt. Joseph E., i, 347.

Havell, Daniel, i, 382.

Havell, George, i, 382.

Havell Henry Augustus, i, 382; ii, 189, 190, 191-192.

Havell, Robert, Senior, his family, i, 381-383; his shop in Newman Street, i, 382; partnership with his son, $\mathrm{i}, 383$; their enterprise in undertaking The Birds of America, i, 384; his death, i, 384; their relationship as read in the legends of Audubon's plates, ii, 195-198.
Havell, Robert, Junior, i, 12 ; Audubon's discovery of, i, 382; a family of artists, i, 382; partnership with his father and rebirth of The Birds of America in London, i, 384; his "Zoölogical Gallery," i, 384 ; advertisement of his business, i, 386; story of the Prothonotary Warbler, i, 383-384, 405; Swainson on, i, 414; Audubon to, i, 433; ii, 33, 34, 35, 38; to Audubon, ii, $51,57,58,62,174,180,186$; Audubon on closing up his business, ii, 188-191; settlement in the United States, ii, 191-192; his work, characteristics and death, ii, 192; Audubon's memento to, ii, 192; his genius and mastery of aquatint, ii, 193-195; as Audubon's engraver, ii, 195; history of his engravings of Audubon's Birds, ii, 196-198; his copy of the work, ii, 203.

Havell, Robert, \& Son, i, 12.

Havell, William, i, 383.

Haverhill (New Hampshire), experience of Alexander Wilson at, $i$, 219.

Hawk, Cooper's. See Falco Cooperii. Hawk, Great-footed, Duck Hawk (Falco peregrinus anatum), original drawing of, $i, 311$.

Hawk, Harlan's (Buteo borealis harlani), i, 311.

Hay, Robert William, i, 377, 379.

Henderson (Kentucky), removal of Audubon and Rozier to, i, 236; settlement, early name and population of, $i, 236$; game and character of the country at, in 1810, $i$, 236; first Kentucky steamer built at, i, 236; Audubon's activities in 1810, i, 237; return of Audubon to, in 1811, i, 242; houses of Dr. Adam Rankin, i, 248; original plot of town, $i, 250,252$; his purchase of land at, $i, 250,252$; his $\log$ house and store, $i, 252$; town rec- 
ords, i, 252; record of earthquakes, i, 280; Rafinesque's visit, i, 285287.

Hendersonville. See Henderson.

Henry, Joseph, ii, 279.

Henshaw, Samuel, i, 308; ii, 197.

Henslow, John Stevens, i, 354, 399.

Heppenstall, John, i, 394.

Herschel, Sir William, i, 377.

"Highfield Hall," residence of William Swainson near Tyttenhanger Green, i, 403.

Hirundo serripennis (Stelgidopteryx serripennis), ii, 186.

Historical Society (New York), unpublished drawing in collections of, $i$, 228; original drawings of The Birds of America at, ii, 304306.

History of British Birds (MacGillivray), ii, 113, 114, 130, 135; (Yarrell), ii, 223; on his completion of, ii, 225.

Holden, Edward, to George Ramsden, $i, 351$.

Holland, Dr. Henry, i, 377.

Hollander, Edward, i, 276.

Hope, Audubon's voyage in, i, 125.

Hopkins, Rev. John Henry, Audubon's acquaintance with, at Pittsburgh, i, 343.

Hopkins, Samuel, i, 252; Audubon's purchase of land, i, 252.

Hopkinson, John, i, 400.

Houston, Sam, Audubon's visit to, ii, 163; his characterization of, ii, 164 . Howe, General William, visit at "Fatland Ford," i, 108.

Humboldt, Baron Alexander von, i, 356; and Bachman, ii, 284; Bachman's account of dinner to, ii, 284.

Huntington, Archer M., ii, 310.

Huron, Laurence, engagement of Ferdinand Rozier, with, i, 153; his business relations with the Bakewell firm and with Rozier, the eld- er, i, 156-157, 159-161, 165; his award in the settlement of the contested accounts of Francis Dacosta, i, 168; dealings of Audubon \& Rozier, i, 186.

Ingalls, William, Parkman's recommendation of, ii, 42 .

Indigo, history of Audubon's investment in, i, 193.

Indians (Shawnee), feather hunting of, i, 238; incident at camp of, i, 239 ; (Osage), Audubon's experience with, $i, 240$.

Irish, Jedediah, i, 425.

Irving, Washington, ii, 53, 153.

Jackson, Andrew, Audubon as model for portrait of, $i, 338$; 378 ; il, 155; Audubon on, ii, 156.

Jackson, Daydon, i, 400.

Jameson, Robert, i, 357; edition of Wilson's and Bonaparte's Ornithology, i, 439, 442; ii, 84 .

Jaquemel (Santo Domingo), planter's experience at, $i, 44-48$.

Jardine, Sir William, to Audubon, 440; edition of Wilson and Bonaparte's Ornithology, i, 442; ii, 102.

Jay, Harriet, on Robert Buchanan, i, 21.

Jeanes, Joseph Y., his collection of original Audubon drawings and manuscripts, i, 180, 181 ; ii, 50, 375 379.

Jefferson, Thomas, Embargo Act of, i, 193; on the numbers of species of American birds, ii, 214.

Jenner, Edward, announcement of discovery of vaccination, i, 55 ; account of behavior of young cuckoo (Cuculus canorus) discredited by Waterton, ii, 90.

Johnson, John, ii, 203.

Johnson, Samuel, on biography, i, 7.

Johnson, William Garrett, Audubon at home of, $i, 427,432$; engage- 
ment of Mrs. Audubon by, i, 431; authorization to fill position at home of, i, 434.

Jordan, David Starr, i, 287, 291.

Joue, i, 54.

Julien (of Paris), heroic conduct of, i, 76 .

Juniata River, i, 274, 277.

Keel boats, on the Ohio and Mississippi, i, 234; Audubon's journey by, in 1810, i, 238-241.

Kidd, Dr. John, i, 399.

Kidd, Joseph Bartholomew, i, 363, 373, 443; and the "Ornithological Gallery," i, 446; Audubon to, ii, 1 ; $35,57,61,62$.

Kinder, Robert \& Company, dealings of Audubon and Rozier with, $i$, 186, 197-19.9; ii, 355.

King, Thomas Butler, ii, 11-12, 14.

Kingfisher (Ceryle alcyon), Audubon's early drawing of, i, 180.

Kirtland, Dr. Jared P., i, 291; "Note Book" of, i, 292.

Kite, Mississippi (Ictinia mississip piensis), Ord's charge concerning, i, 228; similarity in one of Wilson's and Audubon's figures of, i, 228; misnaming of sex in, i, 229; $\mathrm{Au}-$ dubon's legends on original drawing of, i, 229; Wilson's and Audubon's first experience with, $i, 229$ 230 ; 316.

Knox, Dr. John, i, 358.

Koster, Henry, ii, 117.

Krudener, Baron, i, 436 ; ii, 38.

Labrador, Audubon's experiences in, ii, 45-49; expense and results of expedition to, ii, 50 .

La Caille, i, 29.

Lacroix, Formon de Boisclair \& Jacques, Jean Audubon's claims against, $i, 33$; bills of slaves of, ii, 331-333; 338.

La Dauphine, i, 31.
Lafayette, Marquis de, Louis P. Caire to, i, 351.

"La Gerbetière," i, 85, 96, 120, 126; as boyhood home of Audubon, i, 136-137, 144-14.5; Audubon's last visit to, $i, 137$; situation of, i, 136138; in 1913, $\mathrm{i}, 138-143$; Jean Audubon's restoration of, i, 143; description in old deed of, $i, 144$; changes of a century, $i, 144$.

Lake Champlain, tour of Audubon. to, in 1824, i, 343.

Lake Ontario, tour of Audubon to, in 1824, $\mathrm{i}, 343$.

Lamarck, Jean Baptiste Antoine de Monet, i, 13.

La Marianne, Jean Audubon as cabin boy in, i, 28; at Louisburg, i, 28; Jean Audubon as lieutenant of, i, 29.

Landsdowne, Marquis of, i, 398.

Landseer, Sir Edwin, criticism of painting by, i, 366.

Lanman, Charles, proposal of, i, 17. L'Annette, Jean Audubon's command of and interest in, i, 34; concerning sale and settlement of claims in, i, 121, 265.

La Rochelle, as port of Jean Audubon's ships, i, 29, 277. See "Audubon of."

Laval, John, award in the settlement of Dacosta's disputed accounts, $i$, 168.

Lavigne, L., i, 34, 46, 57, 83, 87, 116, 128, 144, 269.

Lavigne, Mme. L., i, 269.

Lawrence, Sir Thomas, i, 356, 377, 380, 393-394.

Lawson, Alexander, Wilson to, i, 212; Wilson's debt to, as the engraver of his Ornithology, i, 213; the daughter of, i, 219; his statement regarding the mysterious flycatcher, i, 227; as Bonaparte's engraver, $i, 330$; report of his interview with Audubon, i, 330. 
Lawson, Malvinia, on Wilson's publisher, i, 219.

Lea, Isaac, on Rafinesque, $\mathrm{i}, 297$; ii, $4,56,95,98,422$.

Leach, William Elford, i, 353.

Le Comte d'Artois. See Count of Artois.

Le Conte, Joseph, i, 171.

Lehman, George, ii, 2, 9, 12, 25.

Le Marquis de Lévy, Jean Audubon's command of, i, 31 .

Le Printemps, i, 29.

Le Propre, i, 30.

Les Sables d'Olonne, Pierre Audubon's family at, i, 26; its hostility to the Revolution, $i, 27$; as home port of Jean Audubon's ships, i, 28; mission of Jean Audubon to, i, 80-81; 83.

Leslie, Charles Robert, comment on the American Ornithology, i, 217.

"Les Tourterelles," death of Mme. Audubon at, i, 263; death of Rosa Audubon at, i, 269.

Le Sueur, Charles Alexandre, i, 294, 328 ; appearance of, i, 333; ii, 157 .

Letters in facsimile, "Audubon \& Bakewell" to Rozier, i, 251; Audubon to Edward Harris, i, 332; Samuel Latham Mitchell to Dr. Barnes, i, 337; William Swainson to Audubon, i, 402; Charles Lucien Bonaparte to Audubon, i, 417; George Parkman to Audubon, ii, 43; Robert Havell to Audubon, ii, 51 ; William MacGillivray to Audubon, ii, 132; Edward Harris to Audubon, ii, 251; John Bachman to George Oates, ii, 282; Audubon to Edward Harris, ii, 287.

L'Eveillé, Jean Audubon's command of, $i, 82$.

Lincoln, Thomas, ii, 43; "Lincoln's Finch," ii, 45, 50.

Linnæan Society, Audubon's election to, $i, 397$; manuscripts in possession of, $i, 400$.
L'Instituteur, Jean Audubon's command of, $i, 82$.

Lissabé, Mme. Jean Louis, suit by, i, 28, 263.

Literary Gazette (London), on Brown's Illustrations, i, 444; announcement of publication of the Ornithological Biography, i, 444; Audubon's premature obituary in, ii, 2.

Little and Brown, Messrs., ii, 230.

Liverpool, arrival of Audubon at, in 1826, i, 350; his reception and friends at, $i, 352-355$; exhibition of Audubon's drawings at, $i, 354$.

Livingston, Robert M., first steamer on the Ohio River, built by, i, 236 .

Lizars, Daniel, Audubon to, i, 385.

Lizars, William Home, as Audubon's engraver, i, 358-359, 361, 375, 384, 442-443; his plates of The Birds of America, i, 195-199.

Lockhart, John Gibson, i, 445.

London Colney, residence of William Swainson at, $i, 403$; death of Mrs. Swainson at, i, 403.

London, recollections of Audubon in, i, 11; site of Havell's engraving establishment in, i, 12; Audubon in, $i, 377-419$; his first impressions of, i, 377; rebirth of The Birds of America in, i, 384; his dislike of, i, 397; completion of his Birds in, ii, 177 .

Loon (Gavia immer), "Great Northern Diver," original drawing of, ii, 47 .

Loudon, John C., editorial enterprise of, i, 399.

Louisburg, Jean Audubon made prisoner at, $i, 28$.

Louisville (Kentucky), diary of a journey from Philadelphia to, in 1807, i, 187-192; establishment of Audubon \& Rozier at, i, 192; prospects and hospitality of the people, i, 196-198; birth of Victor 
Gifford Audubon at, i, 198; arrival of Alexander Wilson at, i, 205; a meeting of rivals at, $i, 220-226$; in 1810, i, 233; Audubon's legal troubles at, i, 260.

Lubbock, Sir John, baron Avebury, characteristics in youth of, i, 93.

Lyceum of Natural History (New York), activities of in 1817, i, 171; introduction of Audubon to, $i$, 336.

Macaulay, Thomas Babington, on Addison, i, 6.

MacGillivray, John, ii, 298.

MacGillivray, William, i, 12; ii, 108, 113-114; his assistance to Audubon, ii, 125-138; to Audubon, ii. 126-128, 130-132, 134; his methods of work, ii, 127-129; his History of British Birds, ii, 130, 135-136; his contract with Audubon, ii, 134; character and scholarship, ii, 134136; his writings, ii, 135; Audubon's acknowledgments to, ii, 137; his copy of the Ornithological Biography, ii, 138; Audubon at work with, ii, 178-180, 181; Audubon's tour with, ii, 182; Audubon's memorandum of account with, ii, 188.

MacLeay, William Sharp, ii, 94.

Magpie (Pica rustica), Audubon's early drawing of, $i, 178$.

Mallory, E., on Mrs. John James Audubon, ii, 303.

Mallory, Eliza, ii, 283.

Mallory, Georgianna Richards. See Mrs. Victor Gifford Audubon.

Manchester, visit of Audubon at, in 1826, i, 356; Audubon's success in canvassing at, i, 376.

Marigny, Bernard, his birth, i, 70; acquisition of "Fontainebleau," $\mathbf{i}$, 70 ; his service in France and return to the United States, i, 71; act of the Government to estab- lish his disputed claim to land, $\mathbf{i}$, 71 ; origin of "Fontainebleau," and description of his property, $i, 71$; foundation of Mandeville, i, 71; friendship with Audubon, i, 72; his death, $i, 72$.

Marigny myth, i, 68-71.

Mark, Edward L., i, 308.

Marten, Pennant's, Fisher (Mustela pennanti), Baird and Audubon on, ii, 263.

Martin, Catharine, i, 27.

Martin, Maria, ii, 6, 32, 61; Audubon to, ii, 65,156 ; marriage of, ii, 281; dedication to, ii, 281, 283. See Mrs. John Bachman.

Martin, Marie Anne, i, 26.

Martin, Pierre, Jean Audubon as sailor under, i, 30 .

Mason, Joseph R., as Audubon's assistant in 1820-1822, $i, 307,312$, 313-316; his return to Philadelphia, i, 321; ii, 69.

Mauch Chunk. See Great Pine Forest.

McKenney, Thomas L., on Audubon, ii, 52.

McLane, Louis, ii, 5 ; Levi Woodbury to, ii, 23.

Meadville (Pennsylvania), "Episode" of Audubon at, in 1824, i, 341-343; and itinerant portrait at, i, 342.

Mease, Dr. William, i, 327.

Merchant-traders, means of travel and hardships of, i, 234-236; their journeys by flatboat and horse to and from the West, i, 234-236.

Mill of Audubon, Bakewell and Pears, at Henderson (Kentucky), history of the building, operation and failure of, i, 254-257; lease of land for, i, 254; description of relic of, in 1879 and 1883, i, 254; difficulties with operation of, $i$, 255 ; cost, conversion and destruction of, $i, 255$; reorganization for working of, i, 256; bill rendered 
for products of, $i, 256$; final failure and closure of, i, 257; Audubon's financial and legal troubles following failure of, i, 257-261.

"Mill Grove," Jean Audubon's purchase, i, 37, 105; Audubon's arrival at, $i, 99-101$; tenant and rent of, i, 101; acquisition and preservation by the Wetherills, i, 102; situation and characteristics, i, 102; old conveyances and designation, i, 103; first miller and builder, i, 104; mills and farm house at, i, 104; the Prevost mortgage, i, 105, 122; Jean Audubon's lease and inventory, $\mathrm{i}, 105$; stay of $\mathrm{Au}$ dubon at, i, 106; Jean Audubon's portrait at, i, 106; bird studies at, i, 106; discovery of lead and arrival of Dacosta, i, 113; Dacosta's onehalf interest and exploitation of mine, i, 114; analysis of his lead ore, i, 114; Claude François Rozier's interest, $i, 115$; the Audubon, Dacosta, Rozier partnership and its difficulties, $i, 115$; instructions concerning farmhouse at, i, 118; Audubon and Rozier as agents for conduct and sale of, i, 132; $\mathrm{Au}$ dubon's and Rozier's duties at, $i$, 146; status of house in their "Articles," i, 147; story of later mining enterprises at, $i, 148-150,152-$ 153, 167-170; consideration for sale of remaining Audubon and Rozier interests to Dacosta and Company, i, 149; division of the property, and sale of the Audubon and Rozier rights, i, 150, 152-153; Audubon's conflicting references to sale of, i, 158, 159-160, 162, 165-168; difficulties over conditional sale of, i, 168; unraveling the tangle, i, 169; Dacosta's contested accounts, and award in their settlement, $i$, 168; sequel to story of mine at, $i$, 169 ; products of mine at, $i, 199$.
Milestown (Pennsylvania), Alexander Wilson, as teacher at, i, 212. Miller, Sarah, Wilson to, i, 206. "Minnie's Land," purchase of estate of, ii, 234; building of house at, ii, 234; Audubon at, ii, 236-238; Audubon's account of, ii, 245-246; houses of Audubon's sons at, ii, 294-295, 311-312; the "Cave" at, ii, 295, 312; departure of Mrs. John James Audubon from, ii, 300; building activities and changes at, ii, 309; present condition of original houses at, ii, 309-311; early representations of Audubon's house at, ii, 311.

Miquelon Island, voyage of Jean Audubon to, i, 29.

Mississippi River, Audubon's cruise on in 1820, $\mathrm{i}, 307$.

Missouri River, Audubon's experiences and discoveries on, in 1843, ii, 252-256.

Mitchell, Doctor Samuel Latham, his friendship with Audubon, i, 171; his repute and activities, $i, 171$; as friend of Rafinesque, $i, 290$; his introduction of Audubon and letter to Dr. Barnes, i, 336.

Mocquard, Françoise, i, 55, 86.

Morris, George Spencer, i, 331.

Morris, Samuel C., purchase of "Mill Grove" by, i, 105.

Morristown (New Jersey), stay of Audubon at, i, 99.

Morse, Samuel Finley Preese, as Audubon's guest, ii, 311.

Morton, Countess of, as patron and pupil of Audubon, i, 365.

Morton, Earl of, record of a visit to the home of, i, 363 .

Morton, Samuel George, ii, 154, 171, 172.

Moynet (Moynette, Moinet), Anne. See Mme. Jean Audubon.

Muguet, i, 56, 57, 59, 61. See Mme. Gabriel Loyen du Puigaudeau. 
Mulattoes, numbers and plight of, in Santo Domingo, i, 43; as slave holders, i, 44; revolt under Ogé, i, 50 ; first clash with whites at Les Cayes, i, 50; union with the blacks and beginning of general revolt, i, 51 .

Murray, John, i, 377; Basil Hall to, i, 378.

Nantes, Jean Audubon at, i, 30-32; his places of residence, $i, 36,57-58$, 86-87; in the Revolution, i, 59, 7374; Committee of Public Safety and National Guard of, i, 74; attack and siege of, i, 74; acceptance of republican constitution by, i, 75; reign of terror under Carrier at, $i, 75$; fate of Vendeans at, i, 75; savior of, $i, 76$; victims of Carrier and the plague at, i, 75; execution of Charette at, $i, 76$; raided by "Tête-Carée," i, 77; restoration of peace at, $i, 77$; revolutionary records of, $i$, 78; Jean Audubon's activities, i, 78-82; his death at, $i, 87$; his appreciation by, i, 83.

Natchez (Mississippi), visit of $\mathrm{Au}$ dubon, $i, 308$; loss of his portfolio at, i, 309; as teacher at, i, 321; his

first lessons in oils, i, 321 ; engagement of Mrs. Audubon, i, 322; illness of Audubon, i, 324.

National Assembly of Paris, Declaration of Rights, of, $i, 49$; vacillating policies of, $i, 51$.

National Gazette, on Audubon, ii, 41-42, 50-51.

Natural History of Deeside and Braemar, ii, 136.

Neuwied, Maximillian, ii, 255.

Newark (New Jersey), Alexander Wilson at, i, 210.

New Castle (Delaware), landing of Alexander Wilson at, i, 209.

New Haven (Connecticut), establish- ment of William and Benjamin Bakewell at, i, 201.

Newman Street, Havell's shop in, i, 12.

New Orleans (Louisiana), memorial to Audubon at, i, 13; Alexander Wilson at, i, 207; Audubon at, i, 306-310; his struggles to gain a footing at, i, 310-312; as teacher at, i, 318; settlement and financial difficulties at, i, 319; engagement of Mrs. Audubon at, i, 322; Audubon embarks for Liverpool at, $i$, 347; his observations at, $i, 348$.

Newton, Alfred, i, 444; ii, 223.

New York (New York), memorials to Audubon at, i, 13; Jean Audubon a prisoner at, $i, 32$; his release, $i, 32,34$; disbanding of the British army at, i, 35; Audubon's introduction to, $i, 99$; pestilencè at, i, 99; 135; Audubon's original drawings at, i, 228; Vanderlyn's portrait of Andrew Jackson in City Hall of, i, 338; Audubon's description of landing at, in 1836, ii, 146; his success in canvassing at, ii, 153; his old residence and estate, ii, 234-236, 310-312.

New York Herald, account of "Mill Grove" mine in, i, 114.

Niagara Falls (New York), Alexander Wilson at, $i, 216$; Audubon at, i, 340; ii, 167.

Nighthawk (Chordeiles virginianus), Audubon's early drawing of, i, 180. Nolte, Vincent, on Audubon in 1811, i, 277; his journey from Pittsburgh to Lexington, i, 276-279; 352.

Northumberland, Duke of, $i, 377$.

Nuttall, Thomas, collection of western birds of, ii, 147, 149, 153-154; 156; meeting with Audubon, ii, 150; career and writings, ii, 150.

Nymphaa. See Water-lily. 
"Oakley," plantation and house of, $i$, 313-315; Audubon's pupil and his life as tutor at, i, 315-318; his drawings at, i, 316; ii, 74 .

Oates, George, ii, 211, 218.

Ogé, James, rebellion and death of, i, 50; its effect upon the Santo Domingan whites, $\mathrm{i}, 50$.

Ohio River, Audubon's description of journey on, i, 195; Wilson's journey in 1810, $i, 205$; traffic of the "ark" and keel boat, in 1810, i, 234-236; first steamer, and steam traffic on, i, 236; Audubon's experience at the mouth of, $i, 238$; breaking up of the ice in, $i, 241$; Rafinesque on fishes of, $i, 292$; $\mathrm{Au}$ dubon's descent of, in 1820, i, 307. Ord, George, on Alexander Wilson, i, 211 ; as Wilson's editor and biographer, $i, 217$, 223-225; his octavo edition of Wilson, $i$, 223; defense of Wilson and charge against $\mathrm{Au}-$ dubon, i, 226-228; 230; basis of his attack on Audubon, i, 227, 231232; his opposition to Audubon, i, $328-329$; 333 , 339, 422; ii, 4, 27, 55, $61,72,80,83$; as Waterton's correspondent, ii, 87-88, 91; 98, 284.

Orleans, Duke of, as Audubon's patron, i, 3, 411-412.

Ornithological Biography, description of Bird Rock in, i, 9; story of the Pewee, i, 99, 106-107; on the Velvet Duck, i, 182; journey down the Ohio River, i, 195; Alexander Wilson's visit to Louisville, i, 220223; Wilson on the Whooping Crane, i, 227; discrepancies in "Episodes" in, i, 273; "Louisville in Kentucky," i, 274; "The Prairie," i, 274, 282-284; "A Wild Horse," i, 274-276; "The Eccentric Naturalist," i, 274, 285-300; "The Earthquake," i, 279; "The Hurricane," i, 280; "The Regulators," i, 281; "Colonel Boone," i, 281;
Natchez, i, 308; on The Birds of America, i, 343; publication of, $i$, 438; MacGillivray's assistance in, i, 438; rivals of, $i, 438-439$; 442445; American copyright of, i, 439; publisher's announcement, i, 44444.5, 448; the Athenaum on, ii, 84$85,140,142$; W. B. O. Peabody on, ii, 85; Featherstonhaugh on, ii, 85 ; on the authorship of, ii, 87-89, 102-103, 103-109; on new species in, ii, 109-111; "Ornithophilus" on, ii, 111, 112; Swainson on, ii, 113; and MacGillivray, ii, 125-138; $\mathrm{Au}-$ dubon on American Edition of, ii, 134, 141; MacGillivray's copy of, ii, 138; John Wilson on, ii, 139; third volume of, ii, 144, 178-180; fourth volume of, ii, 181 ; completion of, ii, 186; valedictory to reader, ii, 187; memorandum of accounts with MacGillivray for assistance in, ii, 188; Audubon on residual stock of, $\mathrm{ii}, 189$.

Ornithological Gallery, plan and abandonment of, by Audubon and Kidd, i, 446.

Orr, Charles, correspondence of Alexander Wilson, with, i, 210-212. Osprey, Fish Hawk (Pandion haliaëtus), early drawing by Audubon, i, 182.

Otter, original painting and exhibition of, i, 394.

Oven-bird (Seiurus aurocapillus), "Golden-crowned Thrush," Audubon's original drawing of, i, 425 .

Owen, David Dale, i, 294.

Owen, Sir Richard, i, 354.

Owensboro (Kentucky), i, 236.

Oxford Street (London), i, 11.

Page, Benjamin, i, 256.

Paimbœuf, i, 32, 80, 137.

Palmer, Sarah White, i, 124.

Palmer, Theodore Sherman, ii, 293.

Pamar, R., i, 318, 348. 
Paris, in 1828, i, 2; Audubon at, i, $74,408-413,448$; his reception and patronage at, $i, 410-413$.

Parkman, Dr. George, ii, 29, 35, 36; to Audubon, ii, $42-43 ; 57,59,134$, 141; Audubon to, ii, 227.

Patterson, W. D., i, 231; ii, 352.

Peabody, W. B. O., i, 231; ii, 200.

Peale, Rembrandt, i 328.

Peale, Robert, i, 328.

Peale, Titian R., his drawings of birds, i, 330.

Pears, Thomas W., i, 124; as partner of Audubon and Bakewell, $i$, 254; his withdrawal, i, 255, 426.

Peel, Sir Robert, i, 377.

Penal laws, in England, i, 395.

Penn, John, i, 105.

Penn, William, land purchase by, $i$, 103.

Percy, Capt. Robert, Mrs. Audubon's school at plantation of, $i$, 322; Audubon at plantation of, $i$, 324.

Perkins, Thomas H., ii, 28, 29, 39, 150.

Perkioming Consolidated Mining Company, i, 169.

Perkioming Creek, i, 103-104, 106.

Perrytown (Sutton, New Hampshire), i, 284.

Pewee, Phœbe (Sayornis phobe), Audubon on, i, 99; his first study of, $i, 106$; original drawing of, $i$, 180.

Pewee, Wood (Myiochanes virens), Audubon's original drawing of, i, 180, 425.

Philadelphia (Pennsylvania), reception of Audubon at, i, 327-335; a meeting of the Academy of Natural Sciences at, i, 333; ii, 154.

Philarète-Chasles, impressions of $\mathbf{A u}$ dubon's exhibition at Edinburgh, i, 359.

Phillips, Dr Benjamin, ii, 144-145, 223-224; Audubon to, ii, 244-246.
Phœbe, Say's (Sayornis sayus), i, 330.

Picus auduboni, ii, 113.

Pigeon, Passenger (Ectopistes migratorius), Audubon's original painting of, i, 363; Audubon on, i, 368 .

Pirrie, Eliza, as Audubon's pupil, and her romantic history, i, 315, 317-318.

Pirrie, James, i, 315; Audubon's drawings made at plantation of, $i$, 316.

Pirrie, Mrs. James, engagement of Audubon by, i, 313; her home and family, $i, 313-318$.

Pitois, M., i, 432.

Pittsburgh (Pennsylvania), record of journey from Philadelphia to, in 1807, $i, 187-191$; characterization, growth and population of, $i$, 191; Wilson's description of, in 1810, i, 204; 343, 344.

Plaisance, Samuel, i, 123, 265.

Planters (Santo Domingo), their prosperity and grievances, i, 4244; their morality and vicissitudes, i, 44-46; their revolt, i, 49-51.

Polly, Audubon's and Rozier's voyage on, i, 134-135, 187.

Pope, John, i, 237.

Pornic, mission of Citizen Audubon to, $i, 79$.

Porter, Dr. Edmund, to Dr. Thomas Miner, i, 333.

Posey, Fayette, i, 258.

Presque Isle, i, 340.

Priestley, Joseph, i, 154, 200-201.

Prospectus, of American Ornithology (Wilson), i, 217; of The Birds of America, i, 373; of first octavo edition, ii, 211-214; reproduction of (for 1828) for original folio, ii, 386-388; reproduction of (by J. W. Audubon), for second (partial) American edition of original folio, ii, 389-391. 
Provost, Henry Augustin, i, 105-106, 122.

Quadrupeds of North America, i, 17; Bachman to Audubon on, ii, 208; Audubon to Brewer on, ii, 209; on Bachman's coöperation in, ii, 210; Audubon to Baird on, ii, 219-221, 222, 226-227, 233; Audubon to Parkman, ii, 227; to W. O. Ayres, ii, 229; Parke Godwin on, ii, 236; editions of, ii, 261 ; Bachman on text of, ii, 261-263, 269272, 281-283; Baird on materials for, ii, 263, 264, 274, 276-277, 278; Audubon on letterpress of, ii, 265; Harris as mediator in difficulties with letterpress of, $\mathrm{ii}, 269$; coöperation of authors in, ii, 273; subscribers to, ii, 274; Louis Agassiz on, ii, 274; title of text of, ii, 275; English edition of first volume of text of, ii, 280 ; dedication copy of first volume of text of, ii, 280 ; J. E. Gray on, ii, 281; manuscript of text of, ii, 283; Illustrations of, ii, 285; in octavo, ii, 293.

Quebec, Audubon's visit and success in, ii, 244.

Queen, Jean Audubon's fight in, i, 35. Queen Charlotte (La Reine Charlotte), Captain Jean Audubon's command of, at Yorktown, i, 34.

Quinarianism, curious tenets and advocacy of, ii, 94, 95, 104, 109, 114, $116,117$.

Quincy, Josiah, ii, 29, 150.

Rabin, Mlle., birth of son of, $i, 52$; as characterized by Jean Audubon, i, 52; record of physician of, i, 53; her feeble health and death, $i$, 56 ; suppression of her name, $i, 60$; early and assumed names of her son, i, 62; as characterized by her son, $i, 63,66$; fictitious account of death of, $i, 67$.
Rabin, Jean, i, 53, 57, 61, 62, 63, 64, 263, 264; ii, 361, 362, 364. See Jean Jacques Fougère Audubon.

Rafinesque, Constantine Samuel (Schmaltz), i, 171; his travels, writings and career, i, 285-300; Audubon on, i, 285; and the bats, i, 286; his early life and precocity, i, 287; his bibliography, i, 287; visit to America, i, 288; life in Sicily, i, 288; marriage and embitterment, $\mathbf{i}, 289$; return to America and shipwreck, i, 290; visits Audubon, i, 290; his "scarlet-headed swallow" and fictitious fishes, $i$, 291; his Ichthyology of the Ohio River and "Devil-Jack Diamondfish," i, 292; at Transylvania University, $i, 294$; originality and independence, i, 295; impractical projects and inventions, $i, 295-296$, 298 ; troubles at Lexington and return to Philadelphia, i, 296; his mania for new species, $i, 296$; his letters, $i, 297$; his multifarious writings, final struggles and death, i, 297-299; his ardor and fatal versatility, i, 299; contemporary notice of, i, 333.

"Rafinesquiana," i, 287.

Rambler, i, \%.

Ramsden, George, Edward Holden to, i, 351.

Rankin, Dr. Adam, i, 238, 242; his "Meadow Brook Farm," i, 248; birth of John Woodhouse Audubon at home of, i, 248.

Rankin, William, i, 248.

Rathbone, Richard, introduction of Audubon to, i, 352.

Rathbone, William, Sr., assistance rendered Audubon by, i, 352.

Rathbone, Mrs. William, Sr., at "Greenbank," i, 353; gift to Audubon by, i, 355.

Rathbone, William, Jr., i, 352.

Rattlesnake, Audubon's account of 
drawing of, $i, 316$; climbing habits of, ii, 53-54, 64; Audubon on, ii, 71-76; Dr. Jones' charge concerning, ii, 72; Audubon's error in description of, ii, 76-78; vindication of Audubon's drawing and account of the fangs of, ii, 79 .

Rattlesnake, encounter of the Polly with, i, 134-135, 187.

Redbanks. See Henderson.

Redbird, Summer Tanager (Piranga rubra), Audubon's drawing of, i, 316.

Redouté, Pierre Joseph, works and friendship of, i, 411 .

Red River (Arkansas), drawing of the Chuck-will's-widow on, i, 182.

Redstart, American (Setophaga ruticilla), Audubon's early drawings of, i, 181, 316.

Rees, Abraham, i, 216.

Rees, William J., ii, 62.

"Regulus cuvieri," "Cuvier's Wren," i, 180, 354; ii, 215, 219.

Rhoads, Samuel N., i, 291; ii, 202.

Richardson, John, ii, 98, 105, 106.

Ricordel, Mme. See Mme. Jean Audubon.

Rider, Alexander, i, 331.

Ridgely, D., ii, 38.

Ripley, the voyage of, ii, 43-50.

Robertson, John Argyle, ii, 183.

Robin, American (Planesticus migratorius), Audubon's early drawing of, $i, 182$.

Rochambeau, Comte de, i, 34 .

Rochefort, i, 30, 83, 93, 94 .

Roe Lockwood \& Son, ii, 296.

Roget, Dr. Peter Mark, i, 377.

Roscoe, Edward, i, 352, 353, 354.

Roscoe, William, i, 218.

Ross, David (and Company), i, 57, 121-123, 265, 266.

Rothschild, Baron, Audubon's account of interview with, ii, 206.

Rowan, William, i, 400.

Roy, Constance (Rozier), i, 245.
Royal Society (London), Audubon's election to membership in, i, 437; William Swainson on his election, ii, 97.

Rozier, Charles A., i, 146.

Rozier, Claude François, i, 147; Ferdinand Rozier to, i, 149-152; his family, i, 152; his death, i, 152; and Benjamin Bakewell, i, 154; Audubon to, i, 154, 156-158, 161163, 164-166.

Rozier, Felix, i, 246.

Rozier, Ferdinand, i, 146; his "Articles," $i, 147$; to his father, i, 149152; at Philadelphia, i, 153; as attorney for Lieutenant Audubon and his wife, i, 153; his business plans, $i, 156-158,161-162,165$; his diary, i, 187-192; Thomas Bakewell to, i, 196; William Bakewell to, i, 199; removes from Louisville to Henderson, $i, 236$; removes with Audubon to Ste. Genevieve, i, 237-241; dissolves partnership with Audubon, i, 241; Audubon to, i, 243; career of, i, 244-246; his death, i, 246; "Audubon \& Bakewell" to, i, 251; ii, 359.

Rozier, Firman A., i, 246.

Rozier, François Denis, i, 154.

Rozier (Colas), Renée Angelique, death of, i, 152.

Rozier, Tom J., i, 196.

Rozier, Welton A., manuscripts in possession of, i, 149, 168, 187.

Rue de Crébillon, Jean Audubon's home in, i, 57.

Rush, Dr. Benjamin, i, 288.

Russell, W. Gurdon, ii, 204.

Saget (mayor of Nantes), $i, 77$.

St. Albans, i, 403.

St. Augustine, Audubon's description of, ii, 12; hunting birds at, ii, 12.

St. Francisville (Louisiana), engagement of Audubon at, i, 313; origin of name, $i, 314$; character 
of country and abundance of birds, i, 314; Audubon as tutor at, i, 315-318; Mrs. Audubon's school, i, 322; former wealth of country, i, 323, 345 .

Sainte Geneviève (Missouri), Audubon's journey to, i, 237-241; dissolution of partnership with Rozier at, $i, 241$; Audubon's subsequent visits, i, 242; Ferdinand Rozier's career at, i, 244-247.

St. John, Mrs. Horace Roscoe Stebbing, i, 17.

St. Johns, ii, 244.

Saint Louis (Santo Domingo), i, 39, 41.

Sammis, Capt. S., i, 131, 156, 158, 159, 164, 187.

Sandpiper, Spotted (Actitis macularia), Audubon's early drawing of, i, 249.

Sanson, Dr., as Jean Audubon's physician, $i, 53$; his bill of services, resources and favorite remedies, $i$, 53; his inoculations for smallpox, i, 55; his treatment of Audubon's mother, i, 56; for complete text of bill, with translation, see ii, 314327.

Santo Domingo, pre-revolutionary lure of, i, 36; Jean Audubon's career in, $i, 36-38$; effect of the Declaration of Rights on, i, 37; slave trade at, $i, 39-41$; cost of slaves at, i, 40; prosperity and praise of, $i, 42$; population of whites and blacks in $1790, i, 42$; plight of mulattoes and history of slavery in, i, 43; Baron de Wimpffen's experience with society and plantation life, i, 44-48; unjust taxation, $i, 44,46$; debasement of morals, i, 45; bossals, creoles and mulattoes, i, 44-47; outbreak and progress of the Revolution, i, 4951; the Revolution in relation to the history of Jean and Jean
Jacques Fougère Audubon, i, 50; Les Cayes first touched by Revolution of, i, 50; first blood drawn in the North, i, 50; Ogé's futile rebellion, i, 50; later events in rising of blacks and mulattoes against whites, i, 50; physicians and their remedies in, $i, 54$.

Sautron, i, 139.

Savenay, i, 78.

Say, Thomas, i, 294, 330, 333-334.

Sayornis saya, $\mathrm{i}, 330$.

Sayre, Robert H., ii, 7.

Scott, Sir Walter, on Audubon's exhibition, i, 359; Audubon on, 1, 365 ; on Audubon, i, 366-368; 370. Scott, Winfield, ii, 242.

Searles, Edward F., ii, 203.

Seaside Finch (Passerherbulus maritimus), original drawing of, i, 425. Sedgwick, Adam, i, 399.

Selby, Prideaux John, Audubon's visit to, i, 374; Illustrations of British Ornithology by, i, 375; to Audubon, i, 375; ii, 102.

Serinettes, i, 163.

Shannonville (Pennsylvania), i, 102. Sharp, William, i, 209.

Shattuck, Dr. George C., ii, 29, 35, $43,150,151$, 228.

Shattuck, Dr. George Cheyne, as Audubon's assistant, ii, 43; as philanthropist, ii, 43 ; 228.

Shippingport (Kentucky), Audubon as peripatetic portrait painter at, i, 303 ; 326,345 .

Slack, Elijah, on Audubon's term of service at the Western Museum, i, 304; as president of Cincinnati College, i, 305.

Slaves (in Santo Domingo), numbers delivered at Les Cayes, $i, 31$; as a basis of wealth, $i, 39$; trade in, $i$, $39-41$; numbers and mortality of, i, 42; management of, i, 43-47; diseases of, $i, 46$; cost and taxes of, $i, 46$; revolt of, $i, 49-51$. 
Smallpox, i, 55.

Smith, Rebecca (Bakewell), i, 201. Smith, Rev. Sidney, i, 369, 372.

Smythe, Henry A., ii, 310.

Sparrow, Baird's (Emberiza bairdii, Audubon, 1844; now Ammodramus bairdi), ii, 259.

Sparrow, Harris's (Zonotrichia querula), ii, 253.

Sparrow, Swamp (Melospiza georgiana), Audubon's early drawing of, i, 249.

Sparrow, Vesper (Poocetes gramineus), "Bay-winged Bunting," original drawing of, $i, 425$.

Spencer, John C., ii, 242.

Sprague, Isaac, ii, 252.

Stanilaus, Francis Alexander (Baron de Wimpffen), i, 44; his experiences and observations as planter in Santo Domingo, i, 44-48.

Stanley, Edward George Geoffrey Smith (fourteenth Earl of Derby), i, 354, 380, 437.

"Stanley Hawk" (Falco stanleyi, now Accipiter cooperi), Cooper's Hawk. See Falco.

Starling, Edmund L., i, 236, 250, 252, 256-257.

Sterling, Mrs. Frederick A., i, 342.

Stoddard, Rev. Charles Augustus, tribute to Mrs. John James Audubon, ii, 303.

Stone, Charles F., ii, 311.

Stone, Witmer, ii, 214.

Stuart, Gilbert, i, 336.

Sturnella neglecta, Western Meadow Lark, ii, 254.

Sully, Thomas, i, 2, 328; Audubon as pupil of, i, 334; to Audubon, i, 334; Audubon to, i, 339; ii, 68-71.

Sully, Mrs. Thomas, Audubon to, i, 389.

Swainson, William, on Rafinesque, i, $289,377,395$; correspondence of, i, 400; Audubon to, i, 400-401, 405$407,409-410$; ii, 95-97, 99, 101-103,
112, 176-177, 353; to Audubon, i, 402, 413-414, 422-423, 430-431; ii, 97-101, 103-108; characteristics, i, 402; on Audubon, i, 403; Audubon at home of, i, 404; with Audubon in Paris, i, 408-412; 415; ii, 84; in controversy over the Ornithological Biography, ii, 88, 93-109; as leader in the Quinarian movement, ii, 9395, 114, 116-117; Audubon's proposal for assistance of, ii, 102; his response and answer to a later letter, ii, 103-108; their subsequent relations, ii, 111-114; as biographer, ii, 113-116; Literary Gazette on, ii, 113; as the "British Cuvier," ii, 114; his career and adversities, ii, 117; his emigration and death, ii, 118; 173.

Sylvia (Helinaria) swainsonii, il, 113.

Syme, John, i, 361.

Synopsis of Birds of North America, publication of, ii, 186; number of species recognized in, 186.

Tawapatee Bottom, i, 240.

Taylor, Richard C., ii, 77.

Thayer, John E., i, 307, 363; ii, 227, 229.

Tête-Carée. See Dupré.

Texas, Audubon's visit to Republic of, ii, 163-165.

Thackeray, George, ii, 146.

The Foresters, i, 216.

Thomas, William, i, 101, 113, 115, $116,117,118,150,151$.

Thrush, Hermit (Hylocichla ustulata), i, 308.

Thrush, Wood (Hylocichla mustelina), Audubon's early drawing of, i, 180.

Title pages, in facsimile, The Birds of America, original folio, i, 381; prospectus of The Birds of America, i, 391; of covers of parts, of octavo (second) edition of the 
Birds, ii, 213; of English edition (Vol. I) of The Viviparous Quadrupeds of North America, i, 275.

Titmouse, Mountain, Audubon's early drawing of, $i, 181$.

Torrey, John, i, 171.

Townsend, Dr. John Kirk, ii, 147, 149, 153-154, 156, 170-173, 179.

Traill, Dr. Thomas S., i, 353.

Transportation by steam, in the Atlantic, i, 2; on the Ohio River, $i$, 236.

Transylvania Company, i, 252.

Transylvania University, i, 294-296, 306.

Treat, Mary, ii, 81.

Trinity Cemetery, i, 13.

Trudeau, James, ii, 184, 185, 186.

Turkey, Wild (Meleagris gallopavo), i, 311, 355, 358, 363; ii, 198.

"Twizel House," i, 374.

Tyler, John, Audubon's credentials from, ii, 242.

Tyttenhanger (or. Tittenhanger), Green, i, 403.

Valentine, Edward Virginius, i, 14. Valley Forge (Pennsylvania), i, 102. Van Buren, Martin, ii, 153, 166.

.Vanderlyn, John, i, 312, 338.

Vaux, James, i, 108.

Vendée, La, i, 24-27.

Vendeans, characteristics and revolt of, i, 26; Nantes besieged by, 1 , 74 ; defeat and fate of, $i, 75$; execution of leader of, $i, 76-77 ; 80$.

Vigors, Nathaniel Augustus, i, 377; to Audubon, i, $407-408$; 415 ; ii, 101, 107.

Vireo belli ( $V$. bellii, of Audubon, 1844), Bell's Vireo, ii, 253.

Vireo, Warbling (Vireosylva gilva), Audubon's original drawing of, $i$, 425.

Vireo, Yellow-throated (Lanivireo flavifrons), Audubon's original drawing of, i, 316.
Vulture, Turkey (Cathartes aura), and Black, or "Carrion Crow" (Catharista urubu), controversy over the sense of smell in, ii, 8184; experiments of Audubon and Bachman on, ii, 55-56, 61, 81-82; memorial of the faculty of the South Carolina Medical College on, ii, 83; present condition of the question, ii, 83.

Wade, Joseph M., i, 213, 254.

Wagtail, White (Motacilla alba), Audubon's early drawing of, i, 181.

Wainwright, Rev. Dr., Edward Everett to, i, 436.

Waller, Sir J. Walter, to Audubon, i, 392; 406.

Walton, Isaac, i, 206.

Warbler (Sylvia trochilus delicata, sylvia delicata), Audubon's unpublished drawing of, i, 228.

Warbler, Bay-breasted (Dendroica castanea), "Autumnal Warbler," Audubon's original drawing of, i, 426.

Warbler, Blackburnian (Dendroica fusca), "Hemlock Warbler," Audubon's original drawing of, $\mathrm{i}, 180$, 426.

Warbler, Black-poll (Dendroica striata), Audubon's original drawing of, i, 425; ii, 50.

Warbler, Black-throated Blue (Dendroica carulescens), "Pine Swamp Warbler," Audubon's original drawing of, i, 425.

Warbler, Canada (Wilsonia canadensis), "Canada Flycatcher," Audubon's original drawing of, i, 4.25 .

Warbler, Carbonated (Dendroica carbonata), Audubon's original drawing of, i, 180.

Warbler, Chestnut-sided (Dendroica pennsylvanica), Audubon's original drawing of, i, 180. 
Warbler, "Children's," Yellow Warbler (Dendroica astiva), i, 354.

Warbler, Connecticut (Oporornis agilis), Audubon's original drawing of, i, 426.

Warbler, Magnolia (Dendroica magnolia), "Black and Yellow Warbler," Audubon's original drawing of, i, 425.

Warbler, Pine-creeping (Dendroica vigorsi), Audubon's original drawing of, $i, 316$.

Warbler, Prairie (Dendroica discolor), Audubon's original drawing of, $i, 316$.

Warbler, "Rathbone," i, 180, 354.

Warbler, Tennessee (Vermivora peregrina), Audubon's original drawing of, $i, 316$.

Warbler, Yellow-rumped, Myrtle Warbler (Dendroica coronata), Audubon's original drawing of, $i$, 180.

Ward, Henry, ii, 2, 4, 9, 12, 25, 32, 59.

Washington, General George, at Valley Forge, i, 102; Polk's portrait of, i, 106; at "Fatland Ford," i, 108.

Water-lily, yellow (Nymphaea hutea), ii, 80 .

Waterton, Charles, i, 12, 224-232, 415; ii, 55, 61, 73; on Audubon's drawing of the rattlesnake, ii, 79; on the vulture's olfactory sense, ii, 82; to George Ord, ii, 83; his Wanderings, polemics and life at Walton Hall, ii, 86-92; on Alexander Wilson's diary, ii, 87; on the Ornithological Biography, ii, 87; on the young Cuckoo and Hummingbird's nest, ii, 90-91; 142.

Watty and Meg, i, 208.

Webster, Daniel, as Audubon's patron, ii, 151; his letter of recommendation and promise of ducks, ii, 152; Audubon's credentials from, ii, 242.

Wellington, ii, 189, 191.

Wernerian Society, i, 183; ii, 72.

Westerman, General, to Citizen Audubon, i, 80.

Western Journal, ii, 298.

Western Museum, Audubon as its taxidermist, and story of its foundation, i, 303-306.

Wetherill, Samuel, Junior, i, 102, 169 ; ii, 14.

Wetherill, Samuel Price, i, 102.

Wetherill, Dr. William, i, 201.

Wetherill, W. H., i, 99, 102, 149.

Wheelock, John, i, 218.

Whewell, William, i, 399.

Whip-poor-will (Antrostomus vociferus), Audubon's early drawings of, i, 180, 249.

Whitehall (New York), ii, 244.

White-throated Sparrow (Zonotrichia albicollis), Audubon's early drawing of, i, 249.

Wilkie, David, i, 377.

Williams, George Alfred, on the ancestry and achievements of Robert Havell, Junior, i, 382; ii, 193-195.

Wilson, Alexander, i, 107; his life and accomplishments, i, 202-220; his journey of $1810, i, 202$; his rebuke to a judge, i, 203; description of Pittsburgh, i, 204; descends the Ohio, i, 205; impressions of Cincinnati and Louisville, i, 205; success in New Orleans, i, 207; his meeting with Audubon, i, 207; early life and struggles, i, 208; success as a dialect poet, i, 208; champions the oppressed weavers, is fined and sent to jail, i, 208; emigrates to America, i, 209; unfortunate love affairs, i, 209, 212, 215, 216; to Charles Orr, i, 210 212; George Ord on, i, 211 ; friendship with Bartram and Lawson, i, 212; his poverty and thrift, i, 214- 
216; his talents and genius, i, 214; The Foresters, i, 216; his American Ornithology begun, i, 216; his prospectus and first volume, i, 217; canvasses New England, i, 218; journey South and extension of his work, i, 218; second New England tour, and his arrest as a spy, $i$, 219 ; completion of his seventh volume and his premature death, $i$, 219; his character, i, 219; Audubon's account of their meeting in Louisville, i, 220-223; Ord's revival of the incident, $i, 223$; his diary in light of later events, $i$, 224-232; his evasive flycatcher, $i$, 226; the "twin" Mississippi Kites, i, 227230 ; as a later "rival" of Audubon, i, 231-232, 234-235, 311, 422; mistaken obituary of, ii, 2; Audubon on, ii, 143; number of species of American birds recognized, ii, 214 ; and Bachman, ii, 284.

Wilson, James, i, 438.

Wilson, John, i, 362, 385, 447; ii, 84; Audubon to, ii, 139.

Winterfield, Charles, ii, 121, 256-258; on Audubon at the ruins of a fire, ii, 267.

Wollaston, Dr. William Hyde, i, 377.
Wood, Rev. J. G., on Waterton, ii, 89.

Woodbury, Levi, ii, 5; to Louis McLane, ii, 23.

Woodpecker, Green, Audubon's early drawing of, i, 178, 181.

Woodpecker, Red-cockaded (Dryobates borealis), Audubon's early drawing of, i, 316.

Wren, "Cuvier's." See "Regulus." Wren, Bewick's (Thryomanes bewicki), Audubon's original drawing of, $i, 180$.

Wren, Marsh (Telmatodytes palustris), original drawing of, $i, 425$.

Wren, Parkman's (Troglodytes ä̈don parkmani), original specimen, ii, 227.

Yarrell, William, ii, 58; to Audubon, ii, 223-225, 246-247.

Yellow-throat, "Roscoe's," Maryland Yellow-throat (Geothlypis trichas), i, 354.

Yorktown (Virginia), Jean Audubon's command at, i, 24 .

Zoölogical Gallery, i, 12, 382, 394.

Zoölogical Society (London), i, 398, 444. 


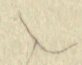




Q+S Riography 

